
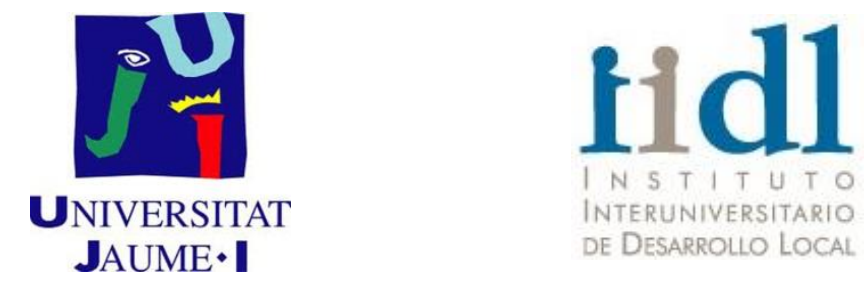

Doctorado en Cooperación al Desarrollo.

Instituto Interuniversitario de Desarrollo Local Universitat Jaume I

\title{
GESTIÓN ASOCIADA DEL TERRITORIO PARA LA CUALIFICACIÓN DE LA EVALUACIÓN Y EL CONTROL SOCIAL A POLÍTICAS PÚBLICAS LOCALES. UNA MIRADA A EXPERIENCIAS DE COLOMBIA Y BOLIVIA
}

\section{TESIS DOCTORAL}

\author{
Presentada por: \\ Martha Patricia Umbarila Laiton
}

\author{
Dirigida por: \\ Dra. Raquel Flores Buils \\ Dr. Antonio Caballer Miedes \\ Dra. Mar Valero Valero
}

Castellón de la Plana (España), mayo 2017 

"El adulto es verdaderamente ciego en lo que respecta al niño, y el niño tiene una visión genuina, una pequeña llama brillante y esclarecedora que nos trae de regalo" María Montessori.

A mí Cristopher.

Hijo me haces re-descubrir el multiverso, te amo con toda mi alma. 

Aquí está, creí que no iba a lograrlo, pero aquí está el producto de cuatro años de reflexión y de muchos años más de interés por el tema en cuestión.

Es mucho tiempo éste, en el que he decantado, reflexionado y re hecho no sólo párrafos, líneas y hasta capítulos enteros de esta tesis; también ha pasado con la vida misma, hecha y re hecha. Llena de nuevos comienzos y retos, migración a otro país y un hijo son también los saldos de este camino recorrido, en el aprender y desaprender...

En este tiempo y por él tengo que agradecer a mi familia, mis padres y hermana que nunca se han ido, que siempre están ahí, a pesar de la ausencia física, están conmigo en cada paso que doy porque son parte de mi alma y un gran trozo de mi corazón. A mi esposo Jheyson Aguilar, ese que la vida me regaló, aquel que se convirtió en compañero de vida y constructor de historias comunes, gracias por los años compartidos y la evidencia de que cada día es una oportunidad para hacerlo mejor, por permitirme evidenciar que todos los días son posibilidades para re encontrarnos y re hacernos en el amor y la familia; por apoyarme y animarme a continuar...

A mis amigas incondicionales Esperanza gracias por el ánimo y el apoyo con las transcripciones de entrevistas, a Tatiana Gutiérrez por creer siempre en mí y a Dianis por animarme a seguir...

Al OPSIDE, a Mar y Raquel por haber promovido la oportunidad de cursar este doctorado, por animarme a continuar y hacerlo posible. A José Manuel y Antonio mil gracias por leer y releer, por mostrarme caminos otros para el análisis, por acompañarme en la escritura. Al Centro de Planificación y Gestión CEPLAG de la Universidad Mayor de San Simón de Cochabamba, escenario en el que me fue posible presentar avances y retroalimentar mi investigación, gracias por escucharme y proporcionarme la información con la que se cuenta para enriquecer este trabajo. A la Doctora Carmen Ledo, por motivarme siempre a realizar esta tesis doctoral, por creer en ella y darme la oportunidad de continuar formándome y trabajar en su equipo. Al equipo CEPLAG por acogerme e interesarse en mi investigación, a Raúl Huaynoca por el apoyo en el trabajo de campo y la construcción de mapas. Laura Menéndez, gracias por el ánimo constante para continuar y por recordarme mi reto. Al PRIAC-Universidad Nacional de Colombia por la experiencia de trabajo y sustento empírico de este estudio.

Al Consejo de Coordinación de la Participación y el Control Social de Sacaba por permitirme acercarme a este espacio ciudadano y conocer su dinámica. 



\section{ÍNDICE}

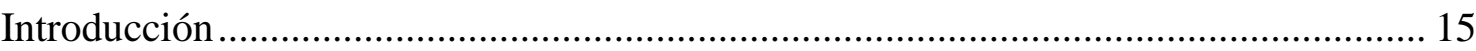

CAPÍTULO 1. GESTIÓN DEL TERRITORIO PARA LA PAZ, CERCAMIENTO A

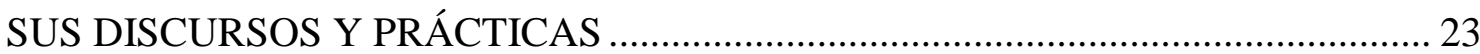

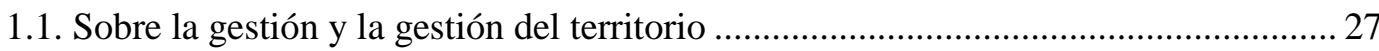

1.2. Sobre la paz y la construcción de paz .......................................................................... 33

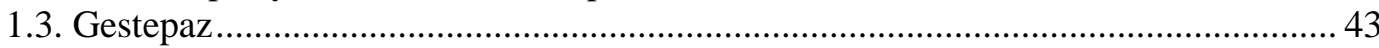

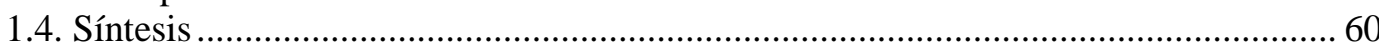

CAPÍTULO 2. PLANIFICACIÓN PARTICIPATIVA Y GESTIÓN ASOCIADA COMO MARCO DE ACCIÓN DE LAS POLÍTICAS PÚBLICAS: REPENSAR LO

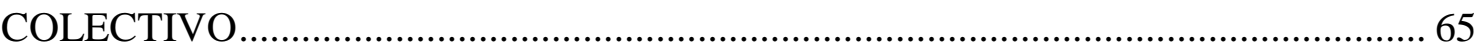

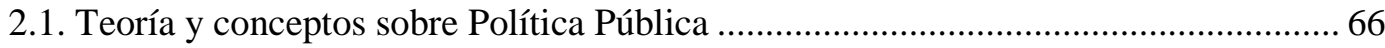

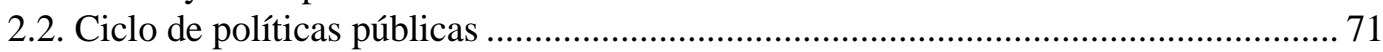

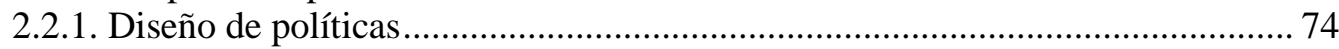

2.2.2. Implementación de políticas públicas ................................................................ 79

2.3. A propósito de la incidencia en política pública: la evaluación como aprendizaje

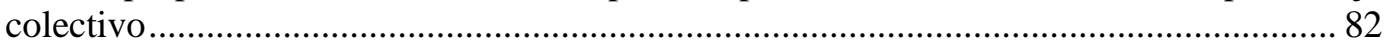

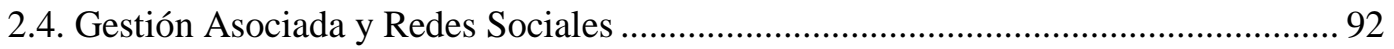

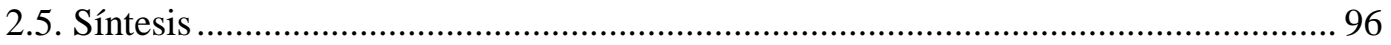

CAPÍTULO 3. EL CONTEXTO DE ESTUDIO. DOS REALIDADES

LATINOAMERICANAS: COLOMBIA Y BOLIVIA …............................................ 99

3.1. Colombia: Contexto y dinámica del conflicto armado .......................................... 102

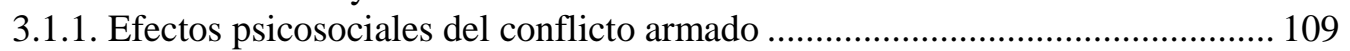

3.1.2. Condiciones de desigualdad e inequidad social.......................................... 112

3.1.3. El horizonte de la construcción de paz .......................................................... 116

3.2. Bogotá: Escenario de múltiples complejidades .................................................... 120

3.2.1. Contexto capitalino: construcción de sentido en el marco del Plan de Desarrollo

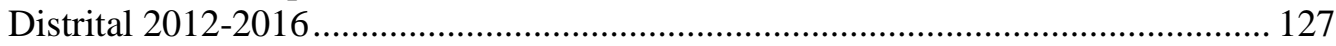

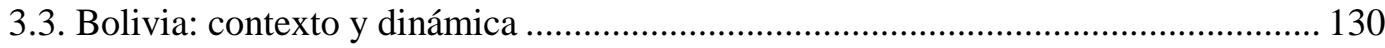

3.3.1. Cochabamba y municipio de Sacaba: Tensiones entre lo rural y lo urbano .... 136

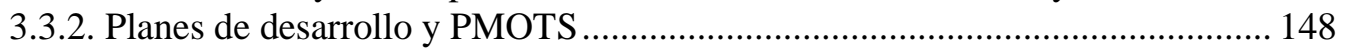

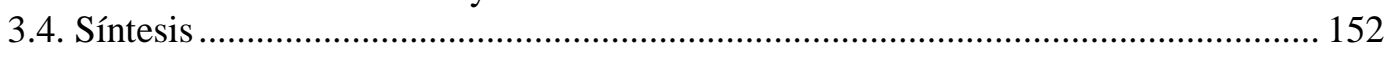

CAPÍTULO 4. ASPECTOS METODOLÓGICOS .................................................. 157

4.1. Disertación sobre paradigmas del conocimiento ...................................................... 158

4.2. Unidades de análisis y ordenadores epistemológicos ............................................. 161

4.3. Consideraciones metodológicas y técnicas de recolección de información............... 161

4.4. Abordaje metodológico de las fuentes: acercamiento conceptual a las técnicas

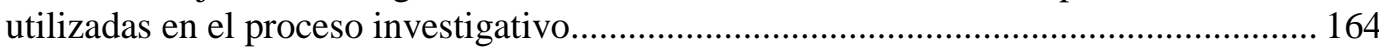

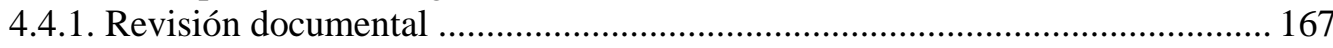

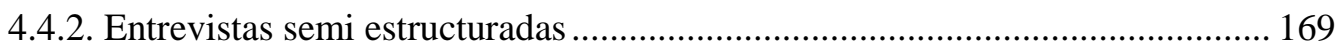

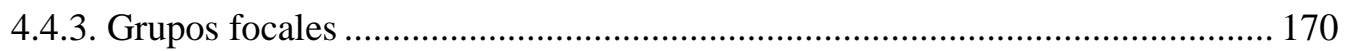

4.4.4. Observación participante y diario de campo...................................................... 172

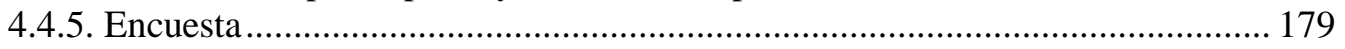

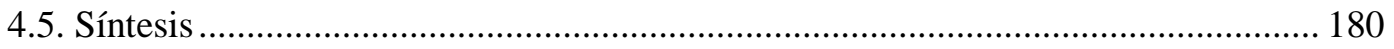


5.1. Objetivos de la investigación

5.2. Participantes, instrumentos, procedimientos y resultados

CAPÍTULO 6. EVALUACIÓN DE POLÍTICAS PÚBLICAS: POTENCIACIÓN DE ESCENARIOS DE GESTIÓN ASOCIADA DEL TERRITORIO EN BOGOTÁ Y EN

6.1. Evaluación y monitoreo: una aproximación a los antecedentes................................. 248

6.2. La evaluación desde la perspectiva de la Gestión Asociada del Territorio...............259

6.3. Aspectos de consideración experiencia control social en Bogotá: ISO/ IWA4 ....... 263

6.4. Experiencia de fortalecimiento de capacidades sociales para control social: Bogotá

266

6.5. Bogotá y los instrumentos de control social ...................................................... 271

6.6. Bogotá y la Descentralización............................................................................... 273

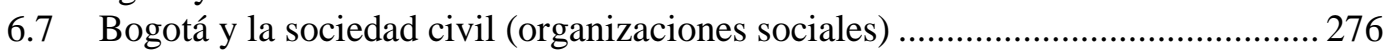

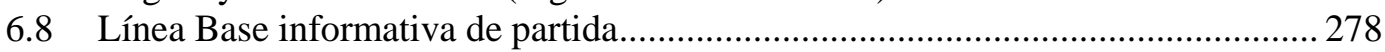

6.8.1 Composición por Géneros .......................................................................... 279

6.8.2 Experiencia previa de las organizaciones sociales en proyectos de Control

Social 281

6.8.3 Entidades de apoyo a los procesos de participación de las organizaciones: . 283

6.8.4 Escenarios de desempeño de las Organizaciones ........................................... 284

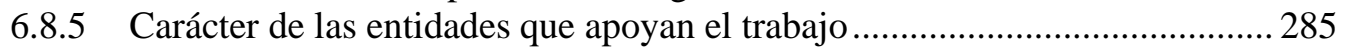

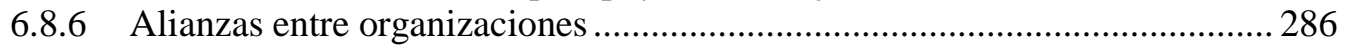

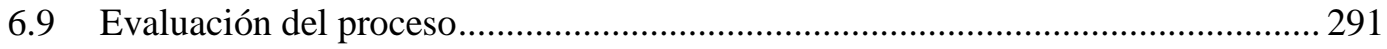

6.9.1 Componente Evaluativo Cualitativo de la Metodología IWA/ISO-4 y su

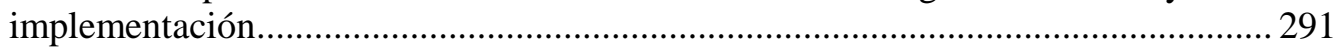

6.9.2 Percepciones generales de la Metodología IWA/ISO-4 .............................. 292

6.9.3 Percepción de Debilidades que los Actores Sociales y Delegados

Institucionales identificaron en la implementación de la Metodología IWA/ISO-4.. 293

6.9.4 Percepción de Fortalezas que los Actores Sociales y Delegados Institucionales identificaron en la implementación de la Metodología IWA/ISO-4 ........................... 294

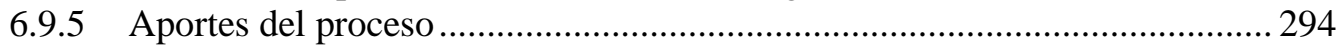

6.10 Aspectos a considerar control social en Cochabamba......................................295

6.11 Cochabamba-Sacaba y la descentralización .....................................................298

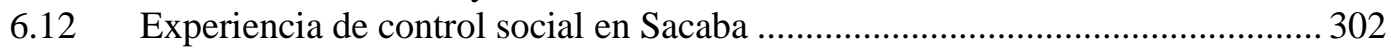

6.13 Sacaba y la Sociedad Civil (organización social)..................................................... 306

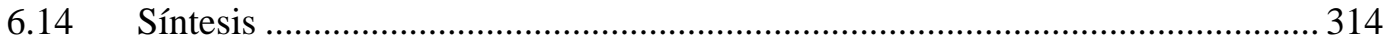

CAPÍTULO 7. PROPUESTA DE FORTALECIMIENTO DE LA INCIDENCIA

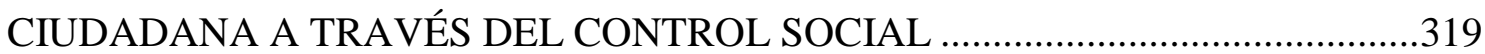

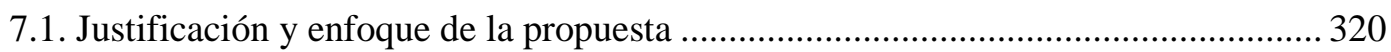

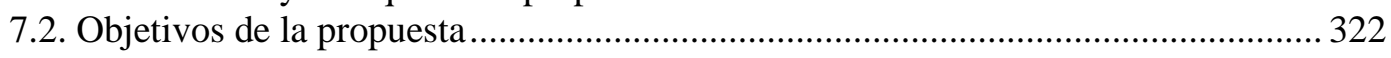

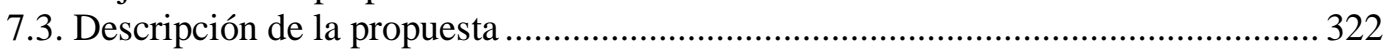

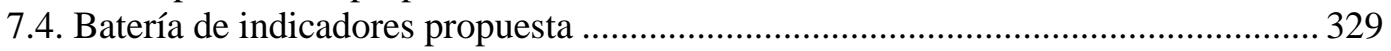

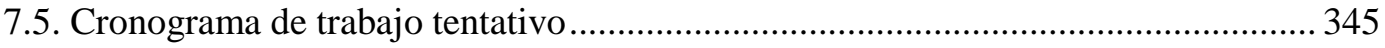

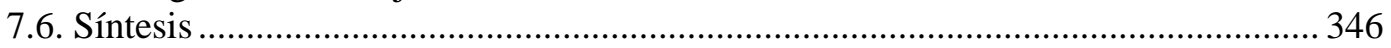

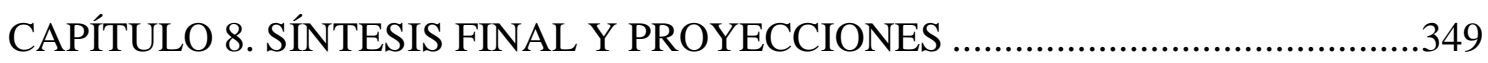

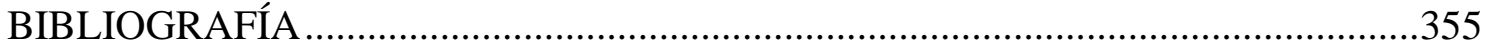


ANEXO 1. FICHA DE REVISIÓN BIBLIOGRÁFICA ....................................................... 377 ANEXO 2. ENCUESTA DE CAPACIDADES ORGANIZACIONES SOCIALES ECOS

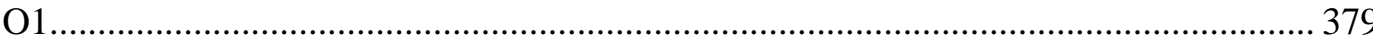
ANEXO 3. ENCUESTA PARA LA EVALUACIÓN DE LA PARTICIPACIÓN CIUDADANA EVAPACI 381 ANEXO 4. ENTREVISTA A PERSONAS VINCULADAS CON EXPERIENCIA IWA

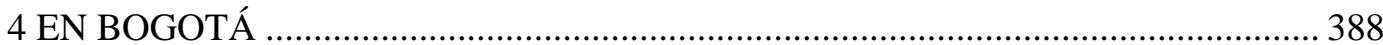
ANEXO 5. ENTREVISTA A PERSONAS QUE ACOMPAÑAN EL PROCESO DE IMPLEMENTACIÓN DE LA EVALUACIÓN EN BOGOTÁ............................................. 389 ANEXO 6. ENTREVISTA A LÍDERES SOCIALES QUE PARTICIPAN EN EL PROCESO DE IMPLEMENTACIÓN DE LA EVALUACIÓN EN BOGOTÁ.............. 390 ANEXO 7. ENTREVISTA LÍDERES SOCIALES CONTROL SOCIAL SACABA ... 391 ANEXO 8. ENTREVISTA UNIDAD DE TRANSPARENCIA SACABA ..................... 392 ANEXO 9. ENTREVISTA OBSERVATORIOS CIUDADANOS COCHABAMBA .. 393

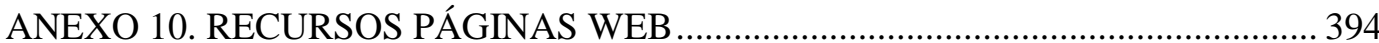

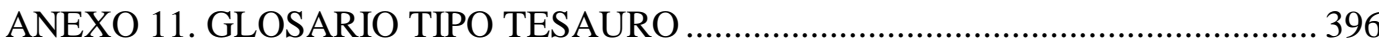
ANEXO 12. DIARIO DE CAMPO EN CLAVE DE GESTEPAZ …............................... 398 ANEXO 13. GLOSARIO DE TÉRMINOS ................................................................ 400

\section{ÍNDICE TABLAS}

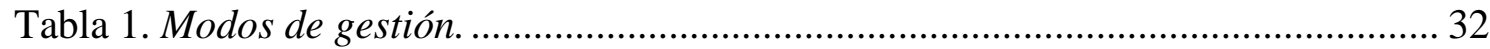

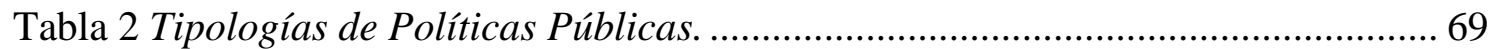

Tabla 3. Escuelas de la planificación .............................................................................. 74

Tabla 4 Aspectos a identificar en el análisis de políticas públicas ................................ 82

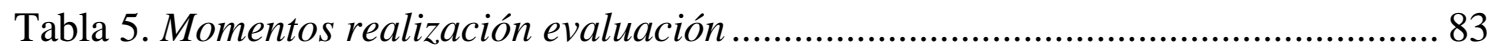

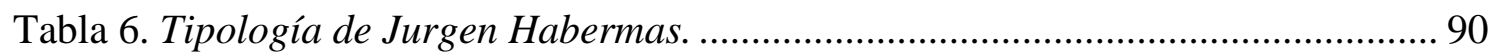

Tabla 7. Surgimiento de las guerrillas en Colombia................................................... 104

Tabla 8. Víctimas del conflicto armado Colombia, desagregado por hechos ............... 110

Tabla 9. Aspectos socioeconómicos Bogotá, por estratos de población años 2011 y 2014.

Tabla 10. Aspectos socioeconómicos de Bogotá, por estrato social según viviendas, hogares y personas, trayectoria histórica 2011-2014.

Tabla 11. Pobreza total y extrema total en Bogotá año 2014. 126

Tabla 12. Área Metropolitana de Cochabamba: Distribución de la población según municipio, fecha de realización de censos de población e índice de masculinidad..... 140 Tabla 13. Ejes, líneas de acción y componentes PMOT Sacaba, 2014 149

Tabla 14. Categorías abordadas en la investigación. 162 
Tabla 15. Caracterización de los grupos focales.

Tabla 16. Características del observador participante ….............................................173

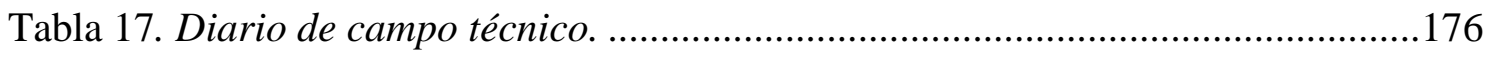

Tabla 18. Descriptores temáticos de búsqueda bibliográfica. .....................................187

Tabla 19. Textos por departamentos editoriales de organizaciones y de ONG............188

Tabla 20. Documentos académicos editados por centros de investigación o

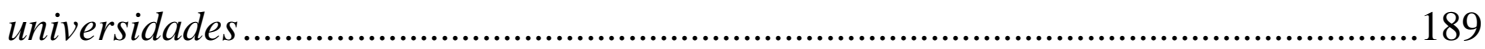

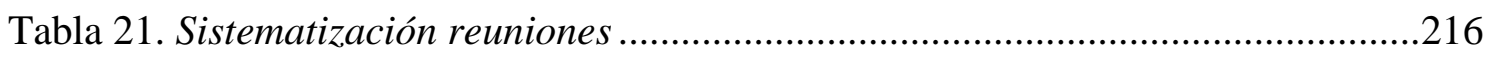

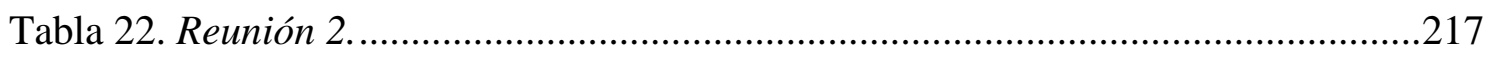

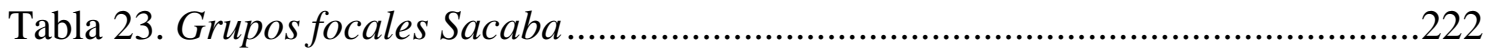

Tabla 24. Resultados grupos focales .........................................................................224

Tabla 25. Principales destinatarios de los resultados del monitoreo y la evaluación,

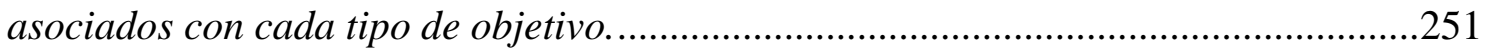

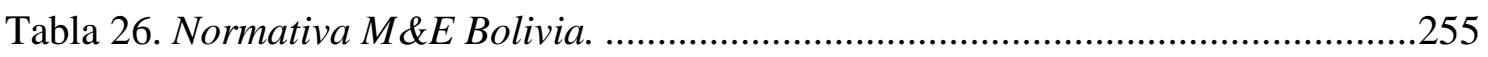

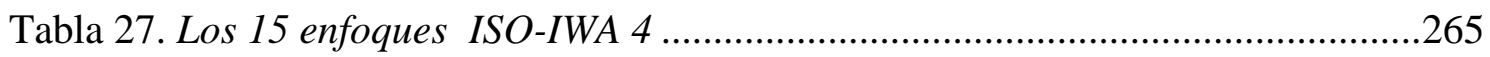

Tabla 28. Participación en proceso de diagnóstico y planeación ..................................309

Tabla 29. Participación en proceso de evaluación ......................................................... 310

Tabla 30. Iniciativa de Ciudades Emergentes y Sostenibles ICES-BID .........................330

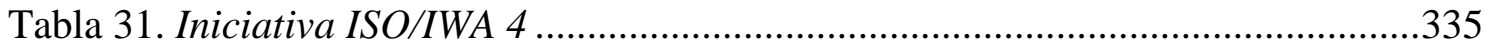

Tabla 32. Iniciativa de evaluación de la Red de Ciudades Cómo Vamos ......................338

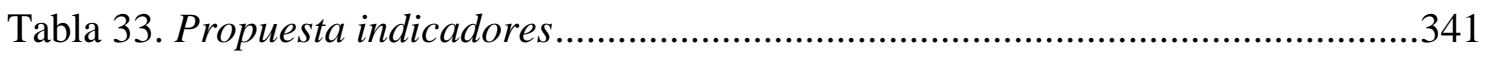

\section{ÍNDICE FIGURAS}

Figura 1. La gestión pública en las entidades territoriales. ..........................................31

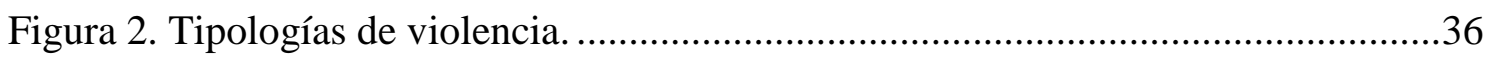

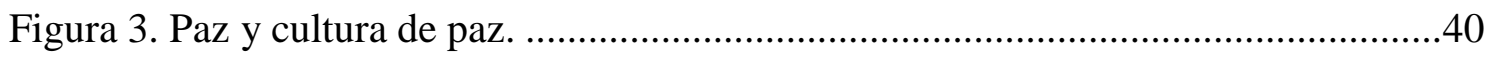

Figura 4. Triángulo proceso de construcción de paz en Galtung. ...................................42

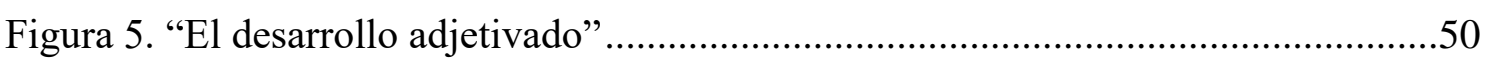

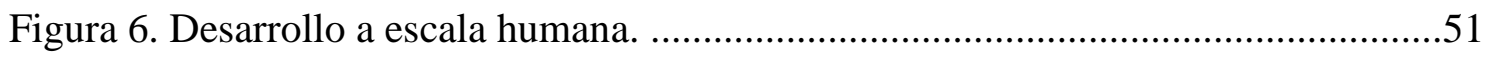

Figura 7. Dimensiones de análisis del desarrollo local. .................................................54

Figura 8. Factores que inciden en construcción de Políticas Públicas. ...........................70

Figura 9. Visión lineal de las políticas públicas......................................................72 


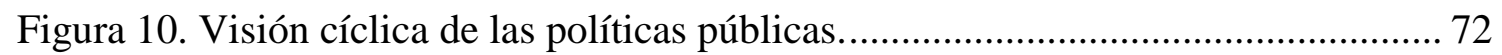

Figura 11. Proceso de estructuración de las Políticas Públicas. ...................................... 73

Figura 12. Identificación y construcción de problemas y agenda política .................... 78

Figura 13. Definición de ámbitos de intervención......................................................... 80

Figura 14. Factores de identificación intervención estatal y acción gubernamental ....... 81

Figura 15. Evaluación de políticas públicas por niveles............................................. 84

Figura 16. Factores de degradación del conflicto ..................................................... 111

Figura 17. Dimensiones de la ciudadanía ................................................................... 113

Figura 18. Evolución del IDH tradicional y el IDH* ajustado. 2000-2009................. 115

Figura 19. Evolución del IDH tradicional y el IDH* ajustado. 2000-2009................. 115

Figura 20. Acuerdos frente a la política de desarrollo agrario integral. ........................ 116

Figura 21. Acuerdos frente a la participación política.............................................. 117

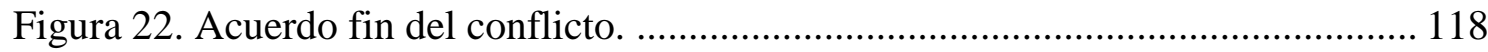

Figura 23. Acuerdos frente al problema de las drogas ilícitas.................................... 119

Figura 24. Acuerdos sobre el tema de víctimas....................................................... 120

Figura 25.. Bogotá D.C. Crecimiento poblacional-Bogotá 2011-2014 ...................... 122

Figura 26. Bogotá D.C. Pirámide poblacional-Bogotá 2011-2014 _........................... 123

Figura 27. Bogotá D.C. Crecimiento poblacional-Bogotá 2011-2014. EMPB 2014... 124

Fuente: DANE-SDP. Encuesta Multipropósito Bogotá, 2014 ................................... 125

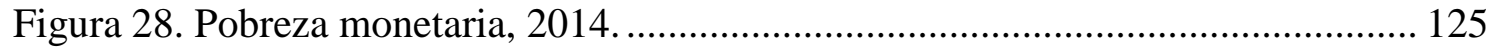

Figura 29. Ejes estratégicos del plan de desarrollo distrital 2012-2016 ...................... 128

Figura 30. Elementos que coadyuvan para la definición de la autonomía territorial

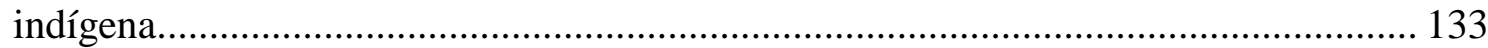

Figura 31. Evolución de la población de Bolivia, según departamentos (en porcentaje)

Figura 32. Bolivia. Evolución del desarrollo humano en las últimas dos décadas, 1992-

2013. 136

Figura 33. Región Metropolitana de Cochabamba. Crecimiento de la población 19922012 138

Figura 34. Sacaba: Estructura de la población por edad, sexo y grado de urbanización, 2012.

Figura 35 Área Metropolitana de Cochabamba y Sacaba: Distribución porcentual de dotación de principales Servicios básicos, 2012 144 
Figura 36. Sacaba: Distribución porcentual de hogares por tipo de Sistema de abastecimiento alternativos de agua, 2012.

Figura 37. Sacaba: Distribución porcentual de hogares por tipo de distribución del agua según grado de urbanización, 2012.

Figura 38. Procesos cognitivos de los métodos cualitativos de investigación. Integra los aspectos propuestos por Morse $(1994 ; 25)$ con los propuestos por Bonilla (2000). .....166 Figura 39. Diario de campo: Aspectos vinculados.......................................................174

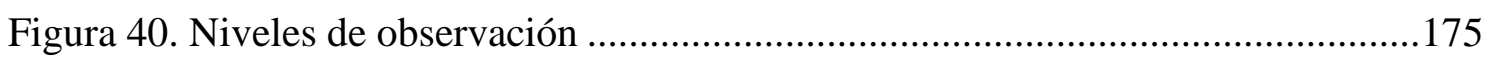

Figura 41. Lógicas de registro en el diario de campo intensivo..................................178

Figura 42. Estructura de un diario híbrido que combina dos lógicas, la de verificación y

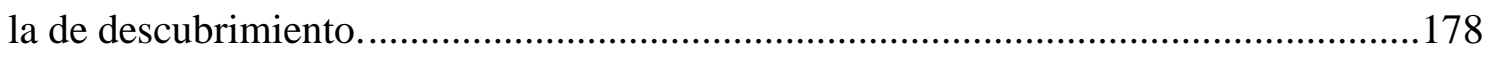

Figura 43. Producción bibliográfica: Análisis por países...........................................190

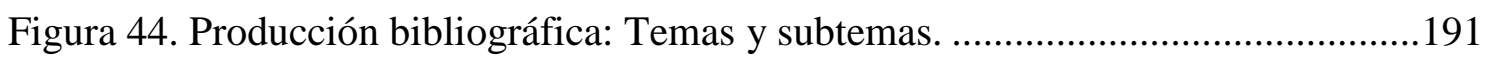

Figura 45. Textos sobre construcción de paz ..........................................................193

Figura 46. Textos sobre gestión del territorio. ........................................................... 195

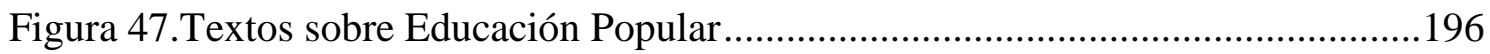

Figura 48. EStructructura física del grupo focal ..................................................222

Figura 49. Esquema organizacional del sistema de seguimiento a metas de Gobierno 252

Figura 50. Sistemas y Subsistemas de información para planificación y M\&E ...........254

Figura 51. Subsistemas del Sistema de Planificación Integral del Estado SPIE Bolivia

Figura 52. Esquema desarrollo y propuesta de evaluación Políticas Públicas ..............261

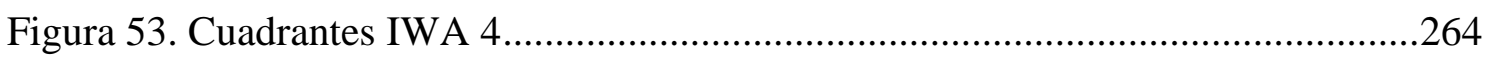

Figura 54. Fortalecimiento de veeduría ciudadana y construcción de confianza social en

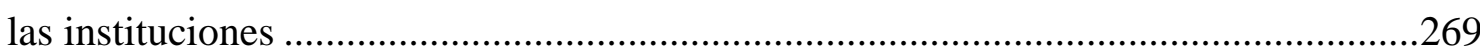

Figura 55. Consolidado distrital por rango de edad. ...............................................278

Figura 56. Participación de mujeres y hombres. Total miembros organizaciones........279

Figura 57. Sectores de trabajo organizaciones sociales. Consolidado Distrital ............281

Figura 58. Entidades que apoyan el trabajo de las organizaciones. Consolidado Distrital

Figura 59. Escenarios de trabajo privilegiados por las organizaciones. Consolidado

Distrital.

Figura 60. Carácter de las entidades que apoyan el trabajo de las organizaciones sociales. Niveles local, distrital y nacional. 


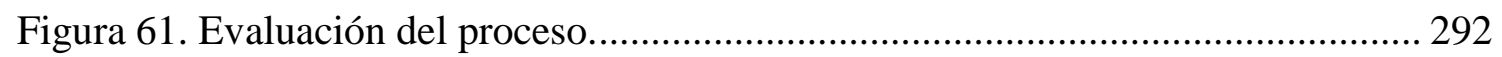

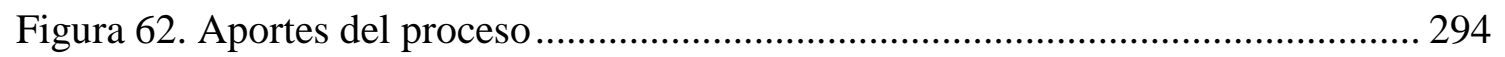

Figura 63. Actores de la participación y el control social .......................................... 305

Figura 64. Tipos de organización a la que pertenecen, según zonas. ........................... 307

Figura 65. Población encuestada EVAPACI ................................................................. 308

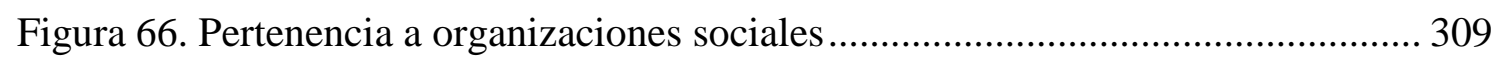

Figura 67. Participación de encuestados en procesos de evaluación a políticas públicas.

Figura 68. Principales obstáculos para participar en procesos de evlauación de políticas

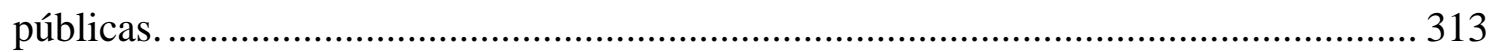

Figura 69 principales razones que lo motivarían a participar en procesos de evlauación de políticas públicas.

Figura 70. Componentes metodológicos sistema GAT aplicado a evaluación y control social de las políticas públicas..... 322

Figura 71. Momentos del proceso de construcción sistema GAT aplicado a evaluación y control social de las políticas públicas.................................................................... 324

Figura 72. Audiencia pública participativa, secuencia para su realización. .................. 327

Figura 73. Fuelle de bandoneón o Consejos Participativos de Políticas Públicas,

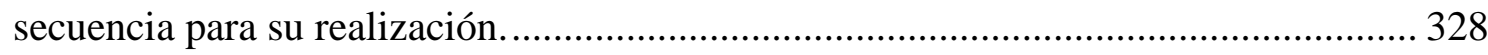

Figura 74. Estructura sistema de indicadores propuesta para evaluación y control social a la gestión pública municipal .................................................................................... 340

\section{ÍNDICE MAPAS}

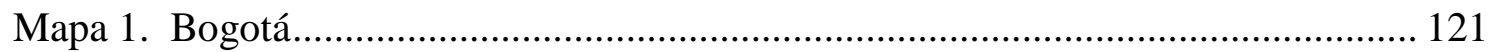

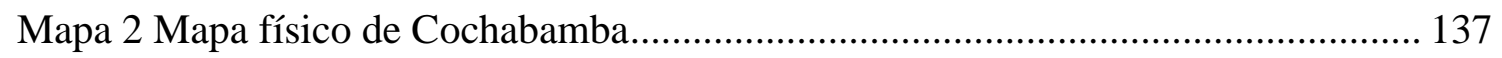

Mapa 3. Sacaba: Distribución de categorías de uso de suelo por distritos, 2014 ......... 139

Mapa 4. Distritos del Municipio de sacaba. .............................................................. 147

Mapa 5. Participación en proyectos de control social ............................................... 282

Mapa 6. Establecimiento de alianzas de las localidades............................................ 287

Mapa 7. Incidencia de la participación para aumentar la transferencia........................ 288

Mapa 8. Participación en evaluación de PP .................................................................... 289

Mapa 9. Participación con incidencia en evaluación de PP......................................... 290 



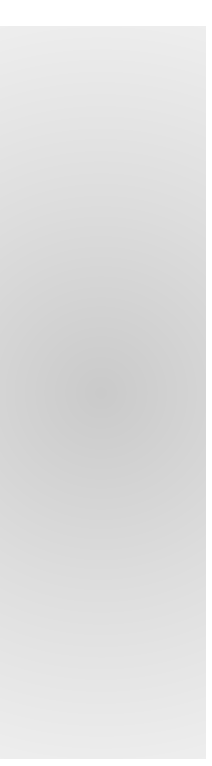

\section{INTRODUCCIÓN}

Esta investigación se propone analizar el sentido (concepción, formas de construcción, múltiples visiones) y el significado (implicaciones, aspectos subyacentes), así como aportes de la Gestión Asociada del Territorio para la paz en dos contextos latinoamericanos Colombia y Bolivia. Pensar en la gestión asociada del territorio, nos remite a interrogarnos por aspectos vinculados con el reconocimiento de derechos, la redistribución de la riqueza y la representación política desde la perspectiva democrática, en los diversos escenarios en que se sitúe; éstos, como elementos vinculados con la importancia del diseño, la formulación y la aplicación de políticas públicas que posibiliten la inclusión social y que fomenten la gestión democrática y competente del territorio, a partir de la promoción de procesos de equidad social y transparencia en las acciones ligadas con los procesos de toma de decisiones en los contextos colombiano y boliviano. Por otra parte, se involucra el desarrollo de capacidades sociales e institucionales, orientadas por la equidad y la convivencia como temas que apuntan a la reducción de las diversas modalidades de violencia, de allí la importancia de fortalecer la participación social en las diferentes instancias territoriales en las que se ordena la administración pública y el escenario político del país, tarea que está intrínsecamente vinculada con procesos sociales que trascienden las lógicas de exclusión social, urbana y territorial posibilitando la construcción de condiciones y oportunidades para la paz y superación de desigualdad e inequidad social.

El escenario local se convierte por tanto, en una instancia de construcción de paz, así como de gestión territorial ya que cumple con la tarea fundamental de trabajar en contextos micro sociales (organizaciones de base, sociales y populares), a partir de la transformación de actitudes promotoras de escenarios de conflictos y violencias, se 
parte de la reflexión individual y colectiva que logra amplias repercusiones en los ámbitos relacionales y de análisis crítico de la situación actual de construcción de paz y posconflicto en Colombia como de violencia estructural en Bolivia; fortaleciendo a la par prácticas sociales que promueven la inclusión social, la convivencia, la participación y el liderazgo, a partir de actividades educativas, de soberanía alimentaria, de movilización social, de evaluación y control social como modalidades de participación ciudadana en los asuntos públicos, entre otras.

En este sentido, las experiencias de trabajo desde el nivel local cuyo pilar orientador es la evaluación de políticas públicas y/o el control social, día a día generan aportes importantes a la construcción de paz y superación de la desigualdad social en países latinoamericanos. Partiendo de lo anterior, interesa analizar de forma exploratoria, cómo se construyen, agencian y desarrollan las iniciativas locales que se sitúan tanto en la ciudad de Bogotá, como en Cochabamba-Sacaba en cuanto a evaluación de políticas, evidenciando su trayectoria histórica, e identificando los aspectos fundamentales en el marco de la gestión asociada del territorio, desde esta perspectiva se hace énfasis en sí han generado escenarios de trabajo articulado y cooperativo entre actores y cómo se pueden fortalecer estos escenarios, en términos de propiciar la incidencia ciudadana en la toma de decisiones.

La Gestepaz involucra dos campos temáticos amplios, a saber, la gestión del territorio y la construcción de paz; sobre ellos la producción bibliográfica ha sido principalmente escrita desde la perspectiva de las ciencias sociales y humanas, por eso interesa recuperar dichos documentos y hacer análisis retrospectivos que permitan ampliar el panorama de construcción general sobre los temas implicados.

En este sentido, se encuentra que la gestión asociada del territorio aparece ligada estrechamente con los temas de administración, planificación y operacionalización de decisiones, situando con ello las anteriores como tareas fundamental y exclusivamente estatales y/o gubernamentales, así se restringe el espectro de participación, de forma que otros actores sociales tales como las organizaciones populares se ven invisibilizadas total o parcialmente en estos ámbitos. De allí que en esta investigación sea importante volver la mirada sobre estos escenarios sociales, que potencian procesos fundamentales para la transformación social de condiciones de inequidad y desigualdad social.

Sobre el tema de la construcción de paz, se encuentra una vasta bibliografía, así autores como Lederach, Galtung, Schirch, entre otros, han puesto de manifiesto importantes reflexiones sobre el origen, el sentido y el significado de este término, logrando así la mirada colectiva a temas como la paz positiva, los constructores de paz, los principios éticos, las rutas posibles, la transformación de conflictos, el enfoque de sensibilidad al conflicto, entre otros. Con estas construcciones se ponen en evidencia principios éticos, como preceptos que deben guiar las acciones encaminadas al objetivo de lograr la paz en un territorio específico, proceso social que a su vez demanda de la participación activa de diversos actores sociales que interactúan en él, a saber: actores institucionales, 
sociales, comunitarios, estatales, gubernamentales. Todo ello, en aras de procurar una coordinación conjunta de escenarios que promuevan la convivencia y la equidad social; teniendo en cuenta el carácter de corresponsabilidad que resulta inherente a los procesos vinculados con el tema de la construcción y mantenimiento de la paz en un sentido amplio.

De esta forma, tomando como referente los aspectos mencionados anteriormente, encontramos diversidad de formas de acercamiento a los orígenes y fundamentos conceptuales, éticos, metodológicos de la gestión asociada del territorio; planteamientos derivados de determinadas corrientes de pensamiento, cuya comprensión y aprehensión permite develar el devenir histórico y los por qué de construcciones sociales materializadas en el empleo de un tipo de lenguaje para signar un campo específico del conocimiento. Nos referimos así, a la importancia de esta investigación, que tiene su fundamento en la necesidad de desentrañar las tramas sociales, culturales, políticas e incluso económicas que se hallan estrechamente vinculadas con constructos legales, morales y de actuación sobre la gestión del territorio y la construcción de paz respectivamente.

Sin lugar a dudas, el tránsito investigativo por los temas en cuestión, implica el análisis prospectivo y retrospectivo desde sus concepciones a su devenir histórico; realizando un recorrido por los significados construidos. El estudio que se presenta, es relevante por su innovación investigativa sobre el tema Gestión Asociada del Territorio, ya que si bien hay publicaciones que tratan sus ámbitos temáticos de forma particular, no se encuentran elaboraciones que articulen desde la perspectiva temática, analítica y reflexiva los dos campos de investigación implicados.

Desde esta perspectiva, el análisis sistemático de la información y la exploración a profundidad de los discursos y prácticas desarrolladas en el contexto local, se articulan con la urgencia de dar cuenta sobre las construcciones académicas y empíricas con relación al tema. Por lo tanto, elaboraciones como el estado de la cuestión desarrollado en este trabajo, brindan la posibilidad de leer los textos en su contexto y derivar reflexiones que contribuyan a impulsar líneas de investigación sobre el tema, generar reflexiones amplias y centradas en la Gestión Asociada del Territorio en contextos de posconflicto y construcción de paz, así como de superación de condiciones de desigualdad y exclusión social, con ello contribuir a los desarrollos investigativos del grupo de investigación de Educación Popular y Procesos Comunitarios de la Universidad Nacional de Colombia y ampliar las perspectivas de investigación del equipo OPSIDE (Observatorio Psicosocial de Recursos en Situaciones de Desastre de la Oficina de Cooperación al Desarrollo y Solidaridad) de la Universitat Jaume I en España.

Allí es donde la investigación adviene como actividad clave para el quehacer de profesionales de diversas áreas del conocimiento, posicionándose como un camino para el abordaje de la cuestión social, con amplias repercusiones en los marcos de indagación 
y acción. Como parte del ejercicio académico de reflexión, surge la iniciativa de indagar por temáticas determinadas en contextos específicos; teniendo como punto de partida intereses académicos y personales, que innegablemente están vinculados con la práctica profesional como Trabajadora Social y especialista en Análisis de Políticas Públicas, en el campo de las ciencias sociales y humanas.

El interés por este tema de investigación tiene dos vertientes claras, surge por una parte de las inquietudes, reflexiones personales e intereses temáticos suscitados a partir del trabajo adelantado como consultora e investigadora en el proceso de "Fortalecimiento del control social en la gestión pública de Bogotá" adelantado por el grupo de investigación del Programa Interdisciplinario de Apoyo a la Comunidad (PRIAC) de la Universidad Nacional de Colombia. En este grupo de investigación y a partir del trabajo llevado a cabo con organizaciones sociales cuyo pilar de acción es la evaluación a políticas públicas y control social, surgieron inquietudes sobre la contribución de dichas experiencias desde sus discursos y prácticas a la construcción de paz y superación de desigualdad social, en dos contextos específicos por una parte en Colombia que en la época actual transita por los caminos del posconflicto y la construcción de paz y en Bolivia cuya trayectoria histórica en temas de movimientos sociales es significativa.

Por otra parte, otro de los factores que motiva la realización de esta investigación y los intereses temáticos que subyacen a la misma, está vinculado con el trabajo desarrollado como profesional de Trabajo Social y Analista de Políticas Públicas en el Centro de Planificación y Gestión (CEPLAG) de la Universidad Mayor de San Simón en Cochabamba, allí tuve la oportunidad de apoyar procesos de construcción y planteamiento de alternativas de cualificación de procesos de planificación participativa y Gestión del Territorio. En este escenario, la interacción permanente con docentes expertos en los temas eje de la Gestepaz, la asistencia a disertaciones académicas, la interacción con la teoría sobre el tema y la formación permanente; fueron elementos que contribuyeron a fomentar en mí el interés por plantear y desarrollar una investigación que vinculará a las organizaciones sociales y de evaluación de políticas públicas y control social, con la gestión del territorio y la construcción de paz respectivamente.

Teniendo en cuenta lo anterior, la presente tesis de doctorado se ha estructurado en siete capítulos que dan cuenta del recorrido investigativo emprendido con el fin de optar al título de Doctorado en Cooperación al Desarrollo. Así tenemos:

El primer capítulo "Gestión del territorio para la paz, acercamiento a sus discursos y prácticas", corresponde a la gestión del territorio para la paz como innovación investigativa, como campo de conocimiento que establece múltiples relaciones con otros temas en el contexto de diversidad de disciplinas y áreas dentro de las Ciencias Humanas y Sociales. Como concepto y práctica se reivindica la participación social como principio y fundamento de la gestión pública en aras de fomentar la equidad y la convivencia en el marco de una gestión democrática y competente. También se realiza un recorrido por los avatares conceptuales del término territorio como entramado 
simbólico de sentidos y significados, que ha sido objeto de atención de ámbitos de conocimiento que van desde las Ciencias Naturales hasta las Ciencias Políticas pasando por la Geografía, la Sociología y la Antropología. En este capítulo se construye la noción de gestión del territorio para la paz a partir de los análisis realizados en la producción bibliográfica recopilada y estudiada, incorporando elementos como el desarrollo en su multiplicidad de acepciones: local, comunitario, sostenible, humano etc., el control social para la transparencia, las sinergias entre los diferentes actores sociales que interactúan en este escenario; de igual manera se alude a mencionar los enfoques que deben sustentar la puesta en marcha de las políticas públicas.

El segundo capítulo "Planificación participativa y gestión asociada como marco de acción de las políticas públicas: repensar lo colectivo", aborda el paradigma de la Planificación Participativa y Gestión Asociada del Territorio entendiéndola como marco de acción que permite repensar lo colectivo, construir escenarios cooperativos, colectivos y de cogestión del desarrollo social en cualquier contexto territorial. Sitúa a las metodologías de Planificación Participativa como un escenario de potenciación de lo común, de aquello que en la administración pública tiende puentes y cualifica las relaciones entre estado y sociedad en aras de propiciar espacios significativos de incidencia en la toma de decisiones.

El tercer capítulo "El contexto de estudio. Dos realidades latinoamericanas: Colombia y Bolivia”, desarrolla la parte contextual del estudio, se hace un recorrido por el devenir histórico colombiano y boliviano marcados uno por el conflicto armado y los efectos de las modalidades de violencia sobre los Derechos Humanos de los diferentes colectivos de población; y el otro por la pervivencia en el tiempo de condiciones de desigualdad e inequidad social, respectivamente. En este sentido, en el caso colombiano se habla de las lógicas que permiten hablar de la degradación del conflicto armado vinculadas con el rentismo, la territorialización, el terror, la criminalización y la vinculación apolítica como aspectos que dan cuenta de la barbarie del conflicto en el país y de los impactos psicosociales que éste causa. Por otra parte, en este apartado del estudio y en el caso boliviano, se da cuenta de los factores que están vinculados con la desigualdad social, aspectos que dilucidan las dificultades contextuales para lograr la redistribución, la representación y el reconocimiento de los derechos, menoscabando con ello el ejercicio de la ciudadanía en sus registros legal, social y político.

El cuarto capítulo "Aspectos metodológicos", desarrolla los aspectos metodológicos de este estudio. Se hace un análisis de la investigación social cualitativa y cuantitativa, desentrañando sus implicaciones metodológicas, a la luz de los planteamientos teóricos que las sustentan. Se dilucida la importancia que adquiere la subjetividad como un factor preponderante, en tanto que aporta en gran medida a estos procesos, dando la palabra a aquellos y aquellas que interactúan en las realidades sociales plurales en las que se sitúa el estudio. 
En el quinto capítulo "Desarrollo de la investigación", se exponen los aspectos vinculados con el desarrollo de la investigación, tales como los objetivos que orientaron el estudio, los instrumentos que se construyen atendiendo a las particularidades de los sujetos y a los ordenadores epistemológicos planteados en el tránsito que conduce del planteamiento del tema al problema de investigación. Se da cuenta de la muestra y de los resultados obtenidos, para ello se construyen matrices sintéticas y de análisis de la información recolectada con las diversas técnicas empleadas a saber las entrevistas, la observación participante y los grupos de discusión. Posteriormente se hace un balance analítico de los resultados obtenidos con la parte empírica del estudio, aspectos consignados en el análisis y las inferencias al final del capítulo.

El sexto capítulo "Evaluación de políticas públicas: potenciación de escenarios de gestión asociada del territorio en Bogotá y en Sacaba", analiza la evaluación de políticas públicas como un escenario potencial de prácticas y discursos de Gestión Asociada del Territorio tanto en Bogotá como en Cochabamba-Sacaba, ello a partir de la identificación de sistemas categoriales que se construyen en los discursos y prácticas cotidianas de los diversos grupos poblacionales que forman parte de dichas iniciativas. Se caracterizan con mayor nivel de profundidad los aspectos vinculados con la concepción de sujeto, de evaluación y monitoreo, la noción-significado y matrices definitorias de la Gestión Asociada del Territorio como corriente de pensamiento, discurso y práctica, en el marco del análisis de su ligazón y contribución a la construcción de paz y superación de condiciones de desigualdad e inequidad social.

El séptimo capítulo "Propuesta de fortalecimiento de la incidencia ciudadana a través del control social", presenta reflexiones sobre la propuesta de fortalecimiento de la incidencia ciudadana a través del control social en el municipio de Sacaba que se ubica en Cochabamba-Bolivia. Dicha propuesta se construye a partir de los aprendizajes que subyacen al proceso que se adelantó en Bogotá a través de la construcción de observatorios ciudadanos de control social; se propone la creación de un sistema de trabajo y articulación permanente entre los diversos actores sociales que se sitúan en el territorio municipal y también se proponen unos indicadores para la evaluación de políticas públicas que han sido diseñados a partir de extensivas revisiones sobre sistemas internacionales. Dichos indicadores se proponen a partir de retomar las áreas vigentes en el Plan Departamental de Cochabamba para vivir bien.

El capítulo final de síntesis y proyecciones, contiene un análisis de los aportes de este estudio a la comunidad científica, destacando las elaboraciones propias, los instrumentos de recolección de información construidos, las articulaciones temáticas y la construcción de teorías sociales sobre un tema incipientemente estudiado en el campo de las Ciencias Humanas y Sociales. Este apartado se dirige a la síntesis y reflexión sobre los resultados del proceso investigativo y las proyecciones de trabajo desde esta perspectiva, para el fortalecimiento de líneas de investigación y caminos a recorrer en el campo de la Gestión Asociada del territorio al futuro. 
Igualmente se encontrará la bibliografía y webgrafía que sirvió de insumo fundamental para la realización de la investigación tanto teórica como empírica, de forma que se convierte en herramienta de trabajo para aquellas y aquellos que estén interesados en profundizar la temática en cuestión, analizando los diferentes aspectos involucrados en ella. Por otro lado, presentamos un apartado con los anexos en el que se adjuntan a la investigación las propuestas metodológicas para recolección y análisis de la información tales como base de datos bibliográfica, guías de entrevista semiestructurada, la propuesta de diario de campo en clave de paz, entre otros.

Así mismo se incluye un $\mathrm{CD}$ en el que podemos encontrar todo el proyecto de investigación que presentamos, así como los insumos de dicha investigación, a saber la versión digital de las bases de datos bibliográficas, la base de datos de referencia a páginas web sobre los temas de gestión del territorio y construcción de paz tanto en Colombia como a nivel general y algunas publicaciones de interés para la comunidad científica que estudie uno o varios de los temas tratados en esta investigación.

Finalmente, se destaca que se han mantenido los sentidos y significados de la diversidad cultural del lenguaje colombiano, por ello se conservan algunos términos derivados de la cultura del país. 



\section{CAPÍTULO 1. GESTIÓN DEL TERRITORIO PARA LA PAZ, CERCAMIENTO A SUS DISCURSOS Y PRÁCTICAS}

La gestión del territorio para la paz representa un campo de innovación investigativa en tanto no ha sido profundamente explorado desde la perspectiva bibliográfica y de construcción académica, es un campo de análisis que involucra dos ejes temáticos (gestión del territorio y construcción de paz), pero que por su naturaleza interdisciplinaria establece relaciones temáticas con otros ámbitos del saber, en tanto se nutre de ellos y les permite consolidar reflexiones, discursos y prácticas vinculadas con el quehacer institucional y social en las esferas nacional, regional y local respectivamente. La gestión como concepto y práctica ha sido construida socialmente como una tarea propia de los organismos estatales y/o gubernamentales en un Estado, pareciese que las actividades involucradas en este campo de acción fueran socio históricamente atribuidas a este espacio; sin embargo, es necesario ampliar el espectro de análisis sobre el tema, ya que existen otros actores sociales cuyo quehacer y cuya cotidianidad están directamente vinculados con la gestión del territorio y que sus acciones y discursos tienen grandes repercusiones en la construcción de condiciones de paz; en tanto que se promueve desde estas iniciativas la equidad y la convivencia en el nivel local, lo cual según la perspectiva de análisis de varios autores como Lederach (2009) tiene un grado importante de repercusión en los niveles globales.

En este capítulo, se abordarán los planteamientos derivados de la revisión de un corpus teórico amplio, dando cuenta de aquellos aspectos vinculados con el estado actual del conocimiento sobre los temas de la gestión del territorio y la construcción de paz. Por 
supuesto, se hará referencia desde el ámbito teórico a aquellos elementos ligados con la materialización tanto de la gestión del territorio como categoría conceptual y como eje transversal a lo territorial, como con la construcción de paz también desde un abordaje de lo conceptual, lo metodológico y lo ético.

Es importante mencionar que la categoría Gestión del Territorio para la Paz que se construye a lo largo de este capítulo no es aplicable solamente en contextos en los que como Colombia se identifica violencia política, como se verá más adelante resulta ser un concepto mucho más amplio y que recoge y busca hacer frente a los tres tipos de violencia mencionada por los teóricos de la paz la violencia cultural, la estructural y la política. Es por ello que como concepto también resulta interesante para las condiciones actuales del territorio boliviano que es el otro análisis de caso que se realizó en este estudio.

Así mismo hay que considerar la o las nociones de territorio que podemos encontrar, ya que así también tendremos una perspectiva integrada para analizar los avatares de las prácticas y discursos de la gestión del territorio. En esta perspectiva, encontramos diversidad de definiciones para este término. En primera instancia diremos que constituye uno de los elementos fundamentales de existencia del Estado en el ámbito del Derecho Internacional, campo en el que su connotación es más amplia ya que trasciende su consideración física para dar cuenta de su significado como elemento de la soberanía nacional, lo que nos remite a pensar en áreas terrestres y subterráneas, así como el espacio aéreo de un país.

Sí pensamos en la función legal que cumple el territorio tendremos que en primera medida está vinculada con la mirada desde la perspectiva patrimonial en la que es concebido como objeto en el que el Estado despliega su autoridad en ejercicio del derecho real de propiedad. En contraste encontramos también la teoría del territorio entendido como sujeto (Gerber, Kauffamann, entre otros) aquí se considera como una parte integrante de la personalidad del Estado, en esta noción también podríamos incluir el hecho de que el territorio significado ya no solo como espacio físico, sino como entramado simbólico en el que interactúan los individuos, se convierte en sujeto en tanto hay un proceso de apropiación socio-cultural del mismo y de igual manera cumple con la función de ser escenario de la interacción social y construcción de tejido social.

La teoría pura del derecho desde la óptica de autores como Rosseau, ve el territorio como área de jurisdicción estatal o contexto dentro del que el Estado ejerce competencias territoriales, de manera que ésta acepción está ligada con los elementos que permiten hablar de su configuración como base física en la que el Estado desarrolla en ejercicio de su soberanía, las funciones asignadas por el Derecho Internacional.

Así se observa cómo desde diferentes campos del conocimiento es posible analizar los elementos que convergen en la o las definiciones de la palabra territorio, que fue inicialmente abordado desde las ciencias naturales en razón de la relación que se 
establece entre los seres vivos animales o vegetales y la determinada área física en la que habitan. Posteriormente la geografía jugó un papel definitivo ya que estableció la relación entre espacio, recursos naturales, sociedad y poder para atribuirle un significado; en este sentido, se dilucida que luego múltiples disciplinas se insertan en el debate epistemológico sobre el territorio, entre ellas destacamos la Sociología, la Antropología y las Ciencias Políticas.

Para efectos de esta investigación el territorio se concibió como construcción social con un componente fundamental a saber la identidad cultural. Diremos que el espacio constituye el medio natural existente en determinada área geográfica, por su parte "el concepto de territorio incorpora la apropiación del espacio por la acción social de diferentes actores" (Flores, 2007, p. 36) en un escenario marcado por la existencia de relaciones de poder, así "surge por tanto como resultado de la acción social, que en forma concreta y abstracta se apropia de un espacio tanto física como simbólicamente" (ibíd. 36). En el pensamiento antropológico constituye un ambiente de vida, de acción así como pensamiento de una comunidad, vinculado a procesos de construcción de identidad. En la llamada Sociología del desarrollo siguiendo las palabras de Abramovay (1998) decimos que "el territorio representa una trama de relaciones con raíces históricas, configuraciones políticas e identidades que ejercen un papel poco conocido en el propio desarrollo económico".

Pecqueur (2000), citado por Flores (2007), menciona que existen dos tipos de territorios. El primero definido por una decisión político-administrativa, en la que convergen unos intereses vinculados en la mayoría de las veces con establecimiento de políticas de desarrollo en una región. Por otra parte, está el territorio construido o llamado también espacio-territorio que se forma a partir de un encuentro de actores sociales en un espacio geográfico dado, con el fin de identificar y resolver un problema común. Así el territorio construido como espacio de relaciones vislumbra también la importancia de tomar en cuenta el sentido de pertenencia de los actores locales, en relación con la identidad construida y la acción colectiva y de apropiación que se despliegan en este escenario y que tienen que ver con el sentido y el significado del término en cuestión. Dicha pertenencia sumada a las actuaciones en el espacio geográfico, implica la referencia a la noción de territorialidad en la cual las relaciones sociales y el espacio local aparecen interconectados promoviendo el fortalecimiento de la identidad.

Es importante destacar que al hablar de la construcción social del territorio, se puede hacer alusión a su consideración de que el espacio-lugar como escenario que soporta las actividades económicas "es sustituido por la idea del espacio-territorio, cargado de vida y de cultura, como también de desarrollo potencial" (Lacour, 1985, citado en Flores, 2007), lo cual implica valorar tanto las posibilidades de construcción de conocimiento como el hacer y el saber hacer local que se convierten en factores promotores del desarrollo endógeno desde el sentido de territorialidad; estos aspectos dan cuenta del capital cultural y social existente en un territorio. 
En definitiva, en palabras de Velásquez (2011) el territorio es un sujeto construido como producto de la interacción social, caracterizado porque en él se dan tipologías de producción que trascienden el escenario meramente económico para involucrar otras dimensiones de la vida social. Así se encuentra que hay una producción material (construcción física del territorio: vivienda); producción social (interacción entre grupos sociales con recursos e intereses distintos en ese espacio); producción simbólica (elemento de referencia para la construcción de la identidad individual y colectiva, la construcción de un nos-otros que implica la distinción con otros colectivos sociales para la estructuración de una idea de comunidad y/o colectividad) y producción política (como aquellos aspectos que nos permiten la acción conjunta en escenarios de toma de decisiones, la participación es referente fundamental).

En este escenario, la Gestepaz se sitúa como referente de acción que se propone encauzar aquellos elementos involucrados con la gestión pública, la descentralización, el desarrollo local, en el caso que nos ocupa en este trabajo doctoral la evaluación de políticas públicas y el control social de los recursos públicos; así como la participación, hacia contextos en los que primen el reconocimiento (de derechos), la redistribución (de ingresos representada en niveles de inclusión y equidad social) y la representación (política y democrática de las y los ciudadanos), como referentes indispensables para la superación de conflictos sociales que han acompañado el devenir de los contextos, sucesos históricos que como el conflicto armado (en el que se conjugan la violencia estructural y la violencia política) o la violencia estructural han permeado las diferentes dimensiones de la vida social, logrando un alto nivel de incidencia en aspectos de orden colectivo e individual, en las dimensiones objetiva y subjetiva; en las relaciones sociales, en los niveles nacional, regional y local, en la construcción de tejido social y hasta en la relación que se establece con el territorio como expresión de la construcción simbólica, la producción material, la producción social y política.

Trabajar desde la Gestepaz implica la inmersión y asunción de los enfoques de derechos, donde encontramos la perspectiva diferencial o poblacional (donde se promueve la inclusión por género, generación y etnia), la mirada territorial (de procesos de planeación y de realización de derechos), y el análisis sectorial (educación, salud, ambiental etc.). Por otra parte, el quehacer debe estar orientado por un enfoque que pretenda contribuir en mayor medida a fomentar la participación, la convivencia y la equidad, tratando en lo posible de no causar ningún daño a los colectivos de población involucrados en cada uno de los ámbitos en los que se materializa la gestión del territorio para la paz; por tanto el análisis del contexto global es un factor con gran preponderancia, así como la posibilidad de comprensión de las dinámicas sociales, políticas, económicas y culturales de los escenarios sociales en donde se desarrolla la Gestepaz.

Sobre los anteriores planteamientos se encuentran varias disertaciones que logran aproximarse a la reflexión a profundidad sobre cada uno de los temas mencionados, 
algunas producciones escritas los articulan destacando los principios, imperativos éticos y valores que los caracterizan. El objeto fundamental de esta investigación es precisamente visibilizar una de las prácticas que potencian una gestión del territorio más holística, se busca evidenciar que la evaluación, es un momento clave dentro del ciclo de las políticas públicas, se tiene como hipótesis que sí se generan cambios en esta fase del ciclo, ello podría repercutir positivamente en los demás momentos, de manera que los actores sociales involucrados re-pensaran la lógica que tradicionalmente han seguido para la construcción de planes, programas y proyectos desde un paradigma más participativo y construccionista, uno que le dé cuerpo y sentido a la palabra gobernanza como un escenario en el que ciudadanía y gobierno son agentes activos con posibilidad de incidencia en la toma de decisiones.

La pregunta por la gestión del territorio y por la construcción de paz, involucra el análisis de la producción escrita construida en espacios y tiempos específicos. En este sentido, a continuación, se desarrolla la aproximación teórica sobre el tema en cuestión, retomando los hallazgos del análisis retrospectivo de la producción escrita. El mencionado análisis y sus respectivos resultados son fruto de la lectura rigurosa de documentos generales sobre el tema a saber, compilados conceptuales y metodológicos que abordan los entramados simbólicos de la gestión del territorio y la construcción de paz respectivamente.

\subsection{Sobre la gestión y la gestión del territorio}

El tema de gestión del territorio para la paz, está siendo recientemente explorado en el ámbito de las Ciencias Sociales; en la revisión documental se evidencia que la articulación gestión territorial vs construcción de paz, si bien es implícitamente abordada en algunos de los documentos teóricos y de sistematización de experiencias, no es trabajada a profundidad, de manera que son escasos los referentes que desentrañan sus elementos, valores y fundamentos; así como su relación con el tema de la paz y los aportes locales a este proceso. En este sentido, se presentará a continuación el balance general de la gestión territorial para dar paso posteriormente a la articulación con las otras categorías de investigación propuestas.

La gestión del territorio está estrechamente ligada con las prácticas democráticas y competentes en un escenario social determinado, involucra la promoción de procesos de inclusión, equidad social y transparencia en las acciones ligadas con la gestión territorial de las políticas en los procesos de toma de decisiones. Por ende, las dimensiones de análisis de la noción comprenden el acercamiento al territorio como concepto, entendiéndolo como entramado simbólico y cultural que sustenta la construcción de tejido social, las formas organizativas, la propia identidad y las dinámicas que allí se desarrollan. El territorio así visto constituye el lugar "es el local de la actividad acción - inmediata del sujeto, (...) es el local de identidades significativas. De esa 
manera, este lugar tiene relación con el espacio de la vivencia y de la convivencia, y posee como punto de referencia lo cotidiano que es imprescindible para la comprensión de la sociedad" (Scheineider y Tartaruga, 2006:11).

En este contexto, la redistribución, el reconocimiento y la representación se convierten en condiciones "sine qua non" para la gestión del territorio, así como para la construcción de paz. Cuando hablamos de gestión, es inevitable pensar en la distribución de competencias territoriales y asociar el término con responsabilidades estatales y gubernamentales de acción en un país, estableciendo una relación casi que automática con el ámbito administrativo, directivo y de toma de decisiones; como ejemplos de esta perspectiva de análisis encontramos definiciones como: "la gestión territorial es el conjunto de decisiones administrativas, organizativas y operacionales, desarrolladas por la sociedad para implementar políticas, estrategias y fortalecer sus capacidades orientadas al uso planificado del territorio". (Vides, Villalobos y Lobo, 2010, p. 5)

En otros documentos se expone la relación que se establece entre gestión y territorio mediada por el ámbito económico "la discusión sobre el territorio y su gestión tiene en la economía un nodo muy importante en el concepto de economías externas. Este debe ser entendido a partir de los postulados de Marshall (1920) y se ha unido al de competencia imperfecta, así como al de los rendimientos crecientes para explicar las aglomeraciones, las ciudades industriales como fenómenos de crecimiento y desarrollo". (Rendon, 2009, p. 21)

Respecto a este punto se observa que en palabras de Ortún (1995) la gestión como concepto puede ser analizada desde dos puntos de vista como práctica y como conjunto de disciplinas, con particular atención al papel de la economía en este escenario. Como práctica está vinculada con términos como la creación y mantenimiento de un medio laboral y la coordinación y motivación de las personas de una organización para conseguir unos objetivos; como disciplina aparece conformada por varias teorías, en este ámbito se dice que gestión es economía, se afirma que ésta última debería ser por naturaleza la integradora de la gestión. En esta perspectiva, se identifican dos contextos: El organizacional y el de la economía, en el que se integra la visión micro y la lectura macro.

En este sentido se encuentra que "es objeto de discusión el que la gestión puede ser considerada una ciencia en el sentido de ofrecer proposiciones contrastables de validez universal sobre qué determina el éxito de las organizaciones. Parece más prudente partir de la base que la gestión como objeto de estudio recibe atención por una serie de disciplinas (psicología, economía) lo que permite referirse, sin excesivo riesgo, a un conjunto de ciencias de la Gestión: Aquellas disciplinas que toman como objeto de estudio algún aspecto de las actividades de coordinación y motivación de las personas que componen las organizaciones" (Ortún, 1995, p. 6) (El subrayado es aportación de la autora del presente estudio). 
Desde nuestra perspectiva la afirmación de Ortún (1995) es acertada en mencionar que la gestión es un campo objeto de estudio de varias disciplinas, sin embargo, es importante tomar en cuenta que además de los ámbitos organizacionales, empresariales y meramente económicos es posible ubicarla en otros, tales como el público, el de los recursos y el escenario local, de manera que encontramos términos como gestión pública, gestión de recursos, gestión local que dan cuenta de la diversidad conceptual de la palabra y sus implicaciones en variedad de esferas de la vida social. De esta manera, se evidencia que se debe establecer un espectro de análisis mucho más amplio y que no esté restringido únicamente a una dimensión a la que se supeditan también las actuaciones y discursos que derivan de ella.

Se observa que reiteradamente aparecen los conceptos económicos complejos para mostrar que un territorio indudablemente está vinculado con mecanismos de gestión, lo cual implica hacer determinadas tareas para alcanzar unos fines. Al buscar tanto en bases de datos bibliográficas como en la web artículos, publicaciones y documentos que aborden el tema de la gestión, aparecen referencias a los proyectos (económicos, de desarrollo social, de infraestructura, incluso a gestión de derechos), así como a la estrategia requerida para llevar a cabo una tarea que coadyuve a cumplir unos objetivos, la estrategia entendida como conjunto de fases que permiten poner en marcha una acción para alcanzar un fin determinado. Así identificamos en este punto varios factores vinculados con la acción de gestionar, a saber: la existencia de un fin específico, de una estrategia y de unas dimensiones (económica, política, social, ambiental) en las que se materializan dichas actividades.

Respecto a los documentos escritos desde la perspectiva de la geografía son algunos de los que más abordan el tema de gestión del territorio asociada a la georeferenciación, ya que ésta disciplina al considerarse una ciencia social del territorio tiene una relación directa con perspectivas metodológicas integradoras así como técnicas avanzadas, tales como los Sistemas de Información Geográfica (SIG) y la teledetección entre otras, que aseguran el abordaje de los problemas territoriales en la actualidad respecto a: sostenibilidad de recursos, urbanización, desequilibrios y desarrollo territorial, de esta forma se indica su orientación encaminada hacia la ordenación, la planificación y la aplicación de todas las técnicas propias de su campo. A este conjunto de metodologías desde este ámbito de estudio se le denomina gestión territorial.

Asimismo, se observa que indiscutiblemente la gestión del territorio está vinculada con la gestión pública en las entidades territoriales, teniendo en cuenta que esta investigación se realiza tomando como casos de estudio dos contextos Bogotá y Cochabamba, diremos que para efectos de este estudio entendemos:

la gestión pública como la organización y el manejo por parte de las autoridades en un contexto institucional dado, de los recursos (humanos, jurídicos, tecnológicos y financieros) a su disposición, para proporcionar a los distintos sectores de la población, en los campos 
de su competencia, los satisfactores de sus necesidades individuales y colectivas. Para tal efecto, ponen en marcha programas de desarrollo y buscan alcanzar objetivos de bienestar colectivo consignados en programas de gobierno, en los planes de desarrollo y de ordenamiento territorial. (Velásquez et al. 2009, p. 188)

Resulta importante destacar en cuanto a la mencionada definición, el hecho que la gestión pública, involucra un campo de acción que trasciende la mera satisfacción de necesidades y se inscribe en la potenciación del ser político de los ciudadanos, en tanto éstos como integrantes de una determinada comunidad deben ser considerados como activos participantes de ella, ello implica el vincularse en procesos de toma de decisiones. Como se mencionó anteriormente retomando a Scheineider y Tartaruga (2006) en tanto el territorio es el cotidiano del sujeto, el lugar de su convivencia, hablamos que su participación en los asuntos públicos cuyo radio de acción se sitúa allí, debe indispensablemente considerarlo como sujeto político a partir de su papel activo en la creación y recreación de la vida social, política, económica y cultural que le es inherente.

En este sentido vemos que la gestión definida así incluye dos tipos de acciones (véase Figura 1): las primeras orientadas a fortalecer la capacidad de las entidades territoriales y de los funcionarios en términos de planificar, diseñar políticas públicas, programar proyectos de inversión pública, así como acciones para su ejecución, gestión de recursos financieros y ejecución de programas y proyectos subyacentes a los planes, conocida como gestión institucional. Las segundas conformadas por el conjunto de acciones dirigidas a garantizar las condiciones adecuadas (dimensiones económica, institucional y política) para operar los recursos necesarios con el fin de prestar los servicios a su cargo y de este modo asegurar a la población el pleno ejercicio de sus derechos en el territorio, estas acciones se denominan gestión del desarrollo humano. (Velásquez et al., 2009, p. 189)

Vista como se menciona, la gestión en el ámbito público requiere una lectura con cierto grado de complejidad y continuidad respecto a la toma de decisiones, ya que desde allí se observa que se derivan un conjunto de modelos de gestionar el territorio, éstos como escenarios que dan cuenta de planteamientos que van desde el carácter técnico pasando por la priorización de los intereses sociales y políticos de las estrategias y actores involucrados, hasta racionalidades centradas en la importancia de fomentar la participación ciudadana como pilar fundamental en los procesos de toma de decisiones. En esta perspectiva, se observa que la gestión aparece definida como eje transversal de varios ámbitos, en donde se dice que expresa múltiples racionalidades (técnicas, económicas, sociales, políticas, burocráticas entre otras) en escalas temporales diferenciadas a largo, mediano o corto plazo. 


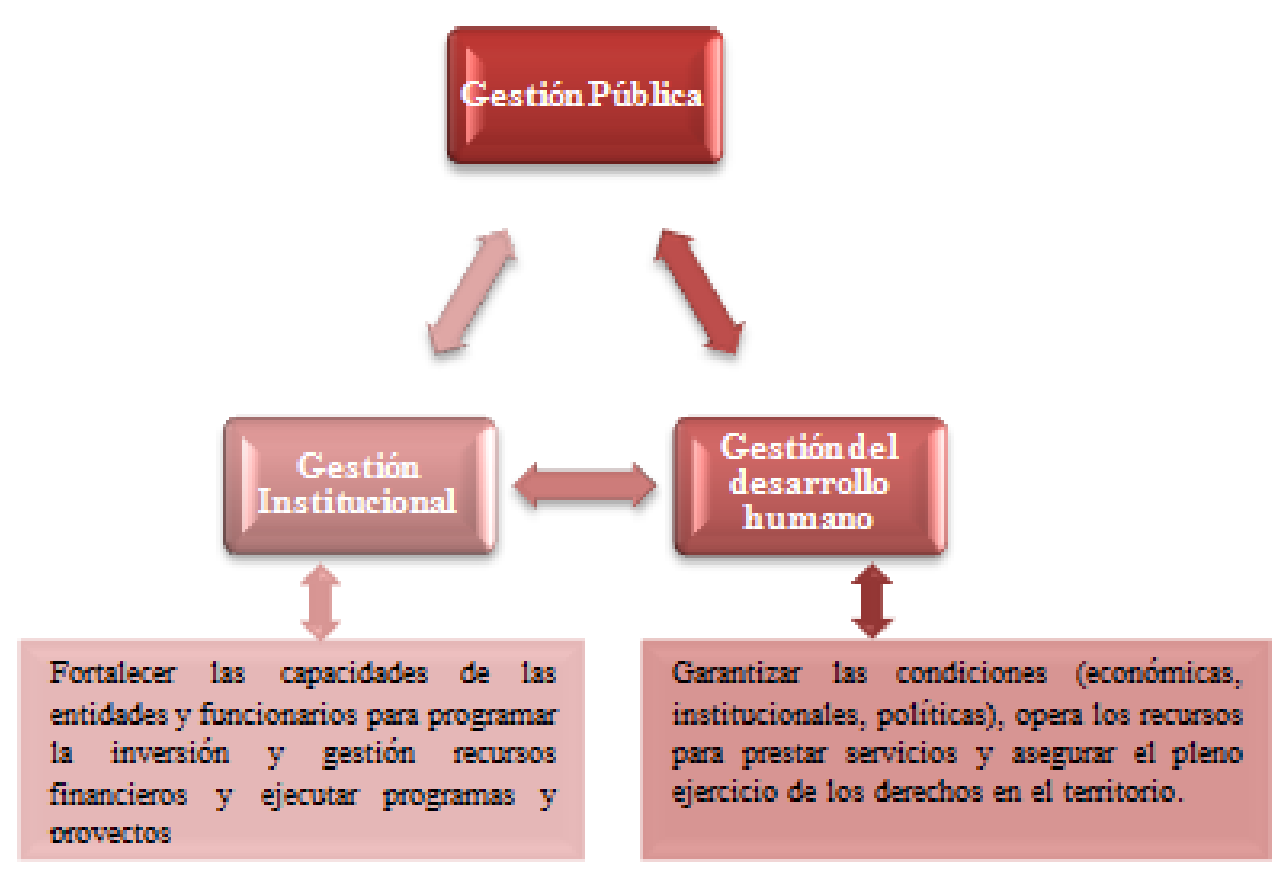

Fuente: Elaboración propia, con base en Velásquez et al., 2009; 188-189.

Figura 1. La gestión pública en las entidades territoriales.

Así, atendiendo a las dimensiones técnicas y políticas de la gestión territorial vemos que se adoptan diversidad de formas y modos de gestión. Escenarios que resultan de la interacción entre racionalidades, actores involucrados e intereses específicos en relación con los bienes y servicios. Dichas modalidades de gestión dan cuenta de una forma relacional que se establece entre los actores locales y externos a éste ámbito en el contexto de la toma de decisiones. Como se observa en la tabla 1 dichos modos de gestión retomando las palabras de Velásquez et al (2009), pueden ser caracterizados desde cuatro variables:

1. El control técnico del proceso: Que expresa la coherencia entre las fases de la gestión (definición de políticas, programas y proyectos, financiamiento de la inversión, ejecución, operación, seguimiento y evaluación). Escenario de interrelación de actores que implica la confrontación de intereses, empleo de recursos.

2. La focalización: Se refiere al grado en que la gestión consigue satisfacer las demandas de la población y de otro a la pertinencia de las decisiones en materia de ampliación y mejoramiento de los servicios. Los aspectos de eficiencia, eficacia y efectividad juegan un rol preponderante, a través de ellas es posible valorar qué tanto las autoridades locales y sus equipos administrativos operan en el campo de sus competencias y logran atender los segmentos poblacionales que más requieren de la acción del Estado.

3. La capacidad de innovación: Indica el esfuerzo de renovación y cambio que le imprimen al proceso de gestión las autoridades locales en la mira de mejorar el proceso y sus resultados, tanto desde el punto de vista cuantitativo como 
cualitativo. Se refiere a las dimensiones técnico-administrativas (planeación, gestión financiera, manejo del personal, incorporación de tecnologías, gestión de proyectos) y a las socio-políticas (nuevas formas de relación política en el seno de la administración municipal, apertura a la participación ciudadana, incorporación de nuevos modelos para la construcción de acuerdos políticos y para el manejo de conflictos).

4. La relación entre las autoridades públicas y los ciudadanos: Considera las distintas vías de contacto, de diálogo y participación, tanto en términos operativos (prestación de servicios, atención al ciudadano) como políticos (participación en la toma de decisiones, control social de la gestión pública). Escenario de participación y diálogo entre los actores sociales en el contexto de la toma de decisiones en la gestión pública

Tabla 1. Modos de gestión.

\begin{tabular}{|c|c|c|c|c|}
\hline \multicolumn{2}{|c|}{ Modelos } & $\begin{array}{l}\text { Racionalidad en la } \\
\text { gestión pública }\end{array}$ & Rasgos fundamentales & $\begin{array}{c}\text { Participación de la } \\
\text { sociedad }\end{array}$ \\
\hline \multicolumn{2}{|c|}{ Modo tecnocrático } & $\begin{array}{l}\text { Predominio } \\
\text { racionalidad técnica } \\
\text { en el ciclo de la } \\
\text { gestión pública }\end{array}$ & $\begin{array}{l}\text { La lógica gira sobre ideas } \\
\text { de eficiencia en el uso de } \\
\text { recursos y eficacia y } \\
\text { productividad } \\
\text { prestación de servicios, } \\
\text { pragmatismo en las } \\
\text { decisiones. El proceso de } \\
\text { gestión en manos de } \\
\text { "especialistas" }\end{array}$ & \multirow{3}{*}{$\begin{array}{l}\text { Baja presencia de la } \\
\text { sociedad en las } \\
\text { decisiones públicas. } \\
\text { Existen mecanismos y } \\
\text { espacios institucionales } \\
\text { de participación } \\
\text { ciudadana pero con un } \\
\text { bajo nivel de incidencia } \\
\text { de la población en las } \\
\text { decisiones. }\end{array}$} \\
\hline \multirow{2}{*}{ 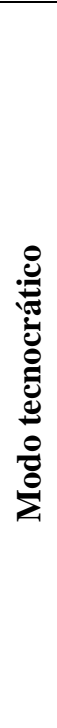 } & $\begin{array}{l}\text { Modalidad } \\
\text { técnico } \\
\text { empresarial }\end{array}$ & $\begin{array}{l}\text { Una línea de gestión } \\
\text { que traslada al sector } \\
\text { público los principios } \\
\text { de la administración } \\
\text { privada. }\end{array}$ & $\begin{array}{l}\text { Se habla de la gerencia } \\
\text { pública como estilo ideal } \\
\text { de administración; se hace } \\
\text { uso de la planeación } \\
\text { estratégica y otras } \\
\text { metodologías "importadas" } \\
\text { del ámbito empresarial. }\end{array}$ & \\
\hline & $\begin{array}{l}\text { Modalidad } \\
\text { tecno- } \\
\text { burocrática }\end{array}$ & $\begin{array}{l}\text { Introducción de un } \\
\text { sesgo en algunos } \\
\text { momentos del ciclo } \\
\text { de la gestión. } \\
\text { Racionalidad técnica } \\
\text { predominante aunada } \\
\text { a una burocracia } \\
\text { estatal. }\end{array}$ & $\begin{array}{l}\text { Los objetivos de eficiencia } \\
\text { y productividad económica } \\
\text { son complementados con } \\
\text { una política de gasto } \\
\text { público con criterios de } \\
\text { manejo burocrático }\end{array}$ & \\
\hline
\end{tabular}


Tabla 2. Modos de gestión (continuación)

\begin{tabular}{|c|c|c|c|}
\hline $\begin{array}{l}\text { Modelo de } \\
\text { control } \\
\text { político }\end{array}$ & $\begin{array}{l}\text { Búsqueda de } \\
\text { acumulación } \\
\text { política por parte } \\
\text { de autoridades } \\
\text { locales }\end{array}$ & $\begin{array}{l}\text { Busca subordinar los principios } \\
\text { tecnocráticos de organización } \\
\text { de la gestión. Busca reportar un } \\
\text { rendimiento político } \\
\text { independientemente de la } \\
\text { satisfacción de necesidades de } \\
\text { la población }\end{array}$ & $\begin{array}{l}\text { La incorporación de la } \\
\text { población depende } \\
\text { funcionamiento de redes de } \\
\text { clientela política. } \\
\text { participación ciudadana tiene } \\
\text { cabida cuando puede ser } \\
\text { controlada desde arriba por las } \\
\text { autoridades públicas. }\end{array}$ \\
\hline $\begin{array}{l}\text { Modelo } \\
\text { participativo }\end{array}$ & 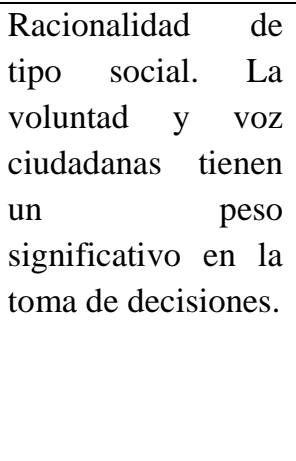 & $\begin{array}{l}\text { La gestión se atiene a una } \\
\text { especie de mandato ciudadano } \\
\text { permanente, persigue el } \\
\text { mejoramiento de la calidad de } \\
\text { vida de la población y busca } \\
\text { asegurar su incorporación a la } \\
\text { toma de decisiones. }\end{array}$ & $\begin{array}{l}\text { Peso importante a la } \\
\text { participación ciudadana y las } \\
\text { formas de movilización en } \\
\text { ámbitos públicos (planeación } \\
\text { participativa, presupuestos } \\
\text { participativos, apertura al } \\
\text { diálogo con la ciudadanía). La } \\
\text { participación como ingrediente } \\
\text { necesario en la toma de } \\
\text { decisiones }\end{array}$ \\
\hline
\end{tabular}

Fuente: Elaboración propia con base en los planteamientos de Velásquez et al (2009).

Vemos representadas en la anterior tabla las modalidades de la gestión, que se encuentran ligadas con un conjunto de pilares en función de la racionalidad que se otorgue a la gestión pública. En un modelo que podríamos llamar básico se sitúan las acciones técnicas en el ciclo de la gestión, en dónde la sociedad no participa mucho en las decisiones públicas a pesar de la existencia de los mecanismos para ello. Luego en un modelo de control político vemos la preponderancia que se otorga a la acumulación política que incide negativamente en la incorporación de la población a las instancias de toma de decisiones, ya que ésta solo es posible a través de las redes del clientelismo político. Finalmente, y como un deber ser está ubicado el modelo participativo cuya lógica social se caracteriza porque la participación ciudadana se convierte en un imperativo en la escena social, de manera que aspectos vinculados por ejemplo con la movilización social son relevantes en el contexto.

\subsection{Sobre la paz y la construcción de paz}

Con el ánimo de continuar con el hilo conductor que orienta el abordaje de los temas en esta tesis, ahora se realizará un recorrido por el tema de la paz, sin embargo "La primera definición está orientada hacia la violencia, siendo la paz su negación. Para conocer la paz tenemos que conocer la violencia" (Galtung, 2003, p. 31). En este sentido se observa que existen diversidad de conceptos sobre violencia y referencias a una tipología de la misma, algunos autores mencionan que avizorar definiciones sobre la violencia resulta un ejercicio ambiguo y en ocasiones contradictorio por la naturaleza misma de la iniciativa. 
Así, vemos que si hablamos desde la perspectiva etimológica violencia proviene de la raíz vis cuyo significado está vinculado a la fuerza entre tanto se podría considerar que la violencia significaría entonces un uso excesivo de dicha fuerza. A continuación, se presentarán dos definiciones del término en cuestión, para hacer un análisis de los elementos que están implicados en dicha noción:

- María Moliner en el diccionario de uso de español la define como "utilización de fuerza en cualquier operación y la manera de proceder, particularmente un gobierno, en que se hace uso exclusivo o excesivo de la fuerza" (1998, p. 1405)

- Esperanza Hernández la entiende como "la fuerza y la acción destinada a hacer daño o causar perjuicio a las personas o las propiedades y del otro como aquella que impide a los seres humanos la satisfacción de sus necesidades esenciales" (2002, p. 108)

- La Comisión de Estudios sobre Violencia dice que "violencia serán todas aquellas actuaciones de individuos o grupos que ocasionan la muerte de otros o lesionan su integridad fisica o moral... la violencia se puede ver como algo que impide la realización de los derechos humanos, comenzando por el fundamental: el derecho a la vida" (1997, p. 17)

- Fisas (1998) y Javier Urra mencionan que "la violencia es siempre un ejercicio de poder, sean o no visibles sus efectos como tal, puede manifestarse en cualquier esfera de nuestra vida, en lo cultural, lo económico, lo político o lo doméstico. La violencia puede ser considerada como la forma más burda de la agresión. En este sentido, es una fuerza exclusivamente humana que aspira a ser la solución que excluya a todas las demás, por lo que también es una censura totalitaria”.

En las definiciones retomadas de diversos autores y autoras se identifica que como elementos vinculados con la violencia se encuentran: el uso de la fuerza excesiva, la intencionalidad de hacer daño al otro y a sus propiedades, la imposibilidad para la realización de Derechos Humanos, la existencia de relaciones de poder y la materialización de dichos actos violentos en diferentes dimensiones de la vida social tales como la económica, política, cultural. Entonces se vislumbran unas características, unos desencadenantes y unos efectos.

Retomando las palabras de Zapata (2009), diremos que autores como el sociólogo noruego Johan Galtung hacen una distinción de diversos tipos de violencia en razón de sus particularidades en términos de las dimensiones implicadas y los agentes externos que perpetran los actos violentos, en este sentido se dilucidan:

- Violencia directa: Se refiere a los actos que tienen incidencia directa y visible sobre el bienestar físico y/o mental de las personas, la muerte sería la expresión extrema de esta tipología. Según afirma Galtung para que hablemos de este tipo de violencia debe existir la participación de un actor que es quien ocasiona el daño, así como otro quien es el afectado por esta agresión a saber la víctima y el agresor $(1969,1996)$ 
- Violencia indirecta o estructural: Es la que está originada por factores vinculados con estructuras económicas, sociales y políticas que dificultan el pleno desarrollo de los colectivos de población en la sociedad. Puede vislumbrarse en políticas públicas, instituciones y sistemas que priorizan las necesidades de unos grupos de población sobre otros. En este sentido, encontramos la desigualdad social, la pobreza, la explotación, la hambruna entre otros: se menciona que es indirecta en tanto no es posible identificar el actor concreto que ocasiona el daño ya que son actores que bien podríamos llamar colectivos (Galtung, 1969, 1998).

- Violencia cultural: Hace referencia a aquellos factores de la cultura tales como la religión, el lenguaje, la educación, las artes entre otros que justifican y legitiman el uso de la violencia directa y la violencia estructural. Algunos ejemplos de esta tipología pueden ser: los himnos, banderas, marchas militares, discursos incendiarios, racistas y sexistas entre otros (Galtung, 1990). Este autor enfatiza en mencionar que la violencia cultural se vale de ciertos aspectos de la cultura, pero no de ésta en su totalidad.

Se observa que desde la perspectiva académica y teórica dichas tipologías de violencia pueden ser analizadas individualmente. En el campo de lo práctico se observa que aparecen interconectadas y que diversas modalidades pueden afectar a la población. Así, se observa cómo en comunidades se dilucida la presencia de factores derivados de la violencia estructural que se conjugan con la violencia directa ocasionando fuertes efectos a nivel psicosocial en la población, tal es el caso de la violencia sociopolítica en donde se observa la interacción entre la violencia estructural y el conflicto armado. En la figura 2 se muestra una síntesis de las diversas tipologías de la violencia presentadas, añadiendo la violencia sociopolítica como concepto acuñado por el CINEP.

De acuerdo a los planteamientos de Zapata (2009), Federación colombiana de municipios y el Diccionario de Acción Humanitaria y Cooperación al Desarrollo Hegoa (2000) haremos un recorrido sucinto por los avatares conceptuales del conflicto teniendo en cuenta que éste puede materializarse en actos violentos y que resulta importante al momento de analizar el tema de la paz. 


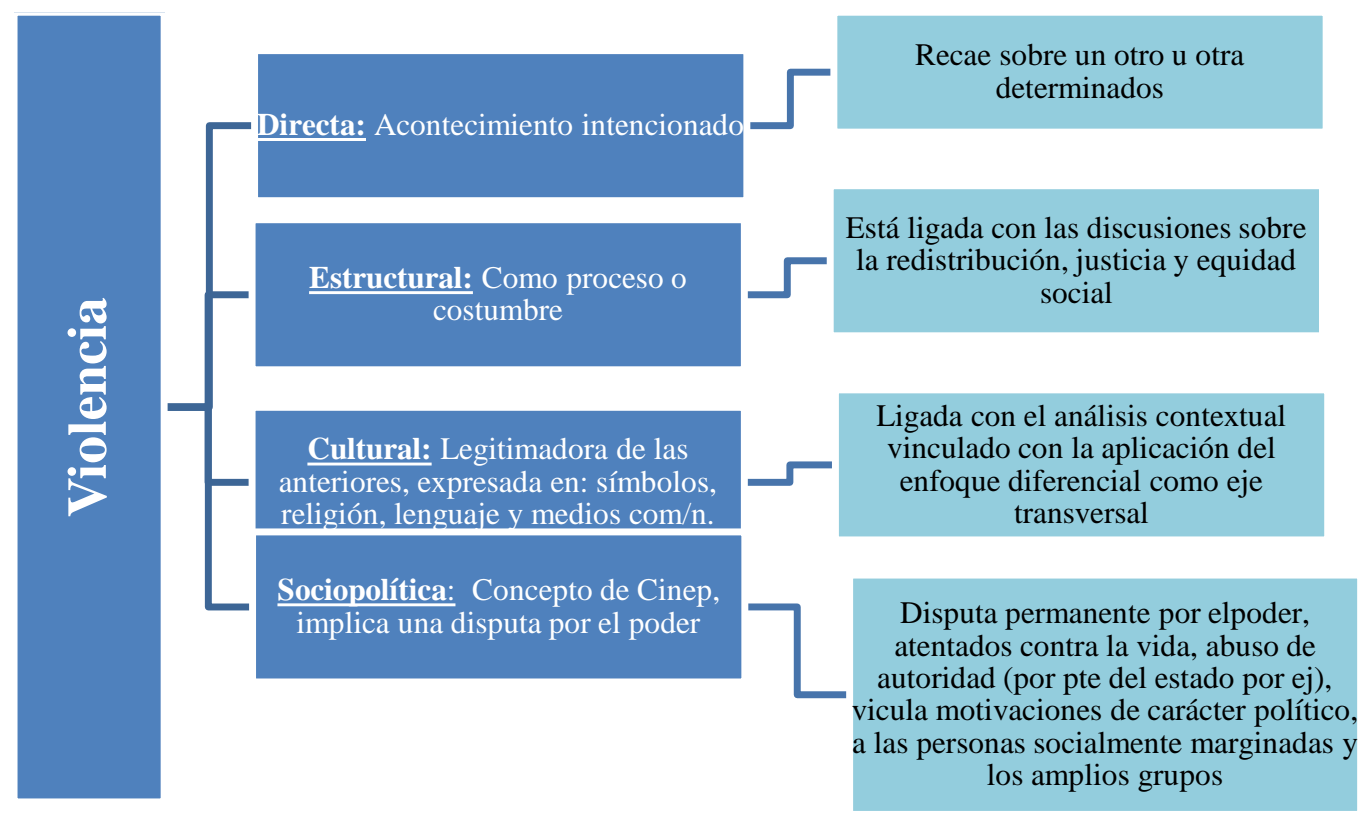

Fuente: Elaboración propia con base en la revisión de textos sobre tipologías de la violencia. 2012.

Figura 2. Tipologías de violencia.

Según afirma Zapata el interés por el estudio del tema del conflicto subyace a la Segunda Guerra Mundial y adquiere auge durante la década del setenta cuando los estudios sobre la paz se establecen como una disciplina independiente, escenario en el que Galtung resulta figura preponderante. Si hacemos una búsqueda general sobre los autores que reflexionan sobre el tema del conflicto, nos encontramos con variedad de escritos, aspecto que evidencia que realmente el conflicto ha sido un tema ampliamente abordado en el discurso de las Ciencias Sociales y Humanas, de acuerdo al campo de conocimiento y al contexto cultural desde el que éste sea analizado es posible identificar variaciones en su conceptualización.

Desde la perspectiva clásica de estudio del conflicto se vislumbran los planteamientos de Lewis Coser en su libro "Las funciones sociales del conflicto social", este autor define el conflicto como "lucha por los valores y el estatus, el poder o los recursos escasos, en el curso del cual los oponentes desean neutralizar, dañar o eliminar a sus rivales" (1956, p. 8) Coser no analiza el conflicto considerándolo como negativo sino por el contrario lo concibe como generador potencial del mantenimiento de la cohesión grupal.

Hocker y Wilmot desde un análisis del conflicto interpersonal, definen conflicto como: "Contienda manifiesta entre por lo menos dos personas interdependientes que perciben metas incompatibles, recursos escasos e interferencia de otros para alcanzar sus propias metas" (1953, p. 40). Por su parte, Lederach (2009) hace énfasis en la fluidez del conflicto señalándolo como proceso interactivo que incluye los contextos social y cultural, así como las características de orden más subjetivo entre las que se destacan: 
intenciones, percepciones, expresiones e interpretaciones subyacentes; de manera que el conflicto no sería visto como negativo o positivo sino que sería analizado desde la forma como las personas lo manejen. También es importante destacar el carácter dinámico del conflicto, asumiéndolo como algo inherente a la convivencia humana, teniendo en cuenta que su asunción y tramitación constituyen factores que están asociados con aquellos elementos que lo harían potencial de cambios positivos en las comunidades, en las personas y por ende en la sociedad.

Desde esta perspectiva analítica se observa que las principales diferencias entre violencia y conflicto están ligadas con:

a) La posibilidad de evitar uno y otro: El conflicto al ser connatural a la convivencia humana resulta inevitable. Entre tanto la violencia es evitable en cuanto hace parte de una decisión consciente de las personas, ya que no es un factor inherente al ser humano ni elemento propio de la cultura.

b) La naturaleza de su existencia: Es posible que exista conflicto sin violencia, pero ésta siempre tendrá de telón de fondo un conflicto, la violencia existe en la vida cotidiana pero no se constituye en elemento fundamental del conflicto.

c) La consideración que se le atribuye: El conflicto puede considerarse constructivo o destructivo, la violencia es arbitraria e instrumental.

d) Los efectos: De acuerdo a cómo se maneje el conflicto puede llegar a considerarse motor de cambio positivo tanto para los individuos como para la sociedad. Los individuos pueden verse vinculados en relaciones de violencia mostrando mensajes repetitivos y rígidos, las diferencias no son aceptadas ni comprendidas, situación que obstaculiza la construcción de iniciativas de cambio y/o desarrollo.

Por otra parte, pero conservando el hilo conductor propuesto para este análisis se observa que según el Diccionario de Acción Humanitaria y Cooperación al Desarrollo Hegoa (2000), el conflicto armado es concebido como:

Aquellos conflictos en los que la colectividad no puede gestionar y confrontar sus diferentes intereses de forma creativa, lo que degenera en un ciclo de violencia física. La dinámica del conflicto, por tanto, puede implicar que un conflicto o desacuerdo entre varias partes se convierta en un conflicto armado, que puede ser de baja intensidad, como suelen serlo la mayoría, pero que puede adquirir mayores dimensiones convirtiéndose en un conflicto de alta intensidad, cuando acarrea más de 1000 víctimas anuales (HEGOA, 2000)

En palabras de la Federación Colombiana de Municipios es posible afirmar que la definición de conflicto armado involucra la existencia de una confrontación armada que se desarrolla dentro de las fronteras de un país a diferencia de la guerra que se da entre países o estados, en dicha confrontación las personas se ven involucradas de forma polarizada. "Se trata de un conflicto armado interno (inmerso en un potencial conflicto 
regional complejo), irregular, prolongado, con raíces ideológicas, de baja intensidad en el cual las principales víctimas son la población civil y cuyo combustible principal son las drogas ilícitas" (Pizarro, 2004, citado en Federación Colombiana de Municipios, sf, p. 7)

Se evidencia que el conflicto armado colombiano se nutre de otros conflictos tales como los sociales, económicos y políticos aspecto que dificulta la tramitación no violenta del mismo. En este escenario todos los niveles y dimensiones de la sociedad se ven afectados de una u otra manera, esta afectación también deriva de factores ligados con los conflictos sociales que surgen por la fragilidad del Estado, la cultura de la violencia, la desigualdad e inequidad sociales, las dificultades de gobernabilidad, la corrupción y las violaciones masivas a los Derechos Humanos. Así, se evidencia la multiplicidad de factores que adquieren expresión en los escenarios locales.

Desde esta óptica de análisis se observa que es necesario aunar esfuerzos en torno a la comprensión y reflexión sobre las expresiones de los conflictos y las relaciones que establecen con aspectos territoriales, institucionales, económicos, sociales y políticos ya que hablar en clave de paz implica incidir en estos focos que perpetúan el conflicto.

\begin{abstract}
Es necesario contribuir a afectar las condiciones estructurales del conflicto para avanzar en la construcción de paz. Aunque sea un camino largo, avanzar en las formas de fortalecer el Estado Social de Derecho, hacer efectivos y ciertos los mecanismos de participación existentes, ejercer una democracia real, avanzar en la gobernabilidad y en la exigibilidad de los Derechos Humanos son múltiples vías necesarias y fundamentales para el logro de la paz (Pizarro, 2004, citado en Federación Colombiana de Municipios, sf, p. 7).
\end{abstract}

Hablar de la construcción de paz nos remite a pensar ¿De qué tipo de paz estamos hablando? Nos ubicamos entonces en un ámbito epistemológico que implica desentrañar los elementos vinculados con la conceptualización y el devenir teórico del concepto. Al igual que sobre el concepto de violencia y conflicto sobre la noción de paz se han planteado diversidad de acepciones que están vinculadas con momentos históricos determinados y determinantes en un periodo y tiempo específicos; este término abarca varios niveles y sentidos.

En la revisión documental que se realizó para este trabajo se encuentra que al igual que sobre la violencia se han construido tres niveles de análisis, la paz según la perspectiva de varios autores también puede expresarse en estos mismos niveles. En primera instancia es importante mencionar que se entiende el concepto de paz de forma holística, trascendiendo el mero hecho de culminación de la guerra materializado en el cese de hostilidades o acciones violentas, aspectos que permiten hablar de la llamada paz negativa. Se hablará entonces de la paz sostenible entendiéndola como un concepto complejo, que se concibe como una tarea inmersa en las discusiones que involucran el desarrollo, así como la superación de condiciones vinculadas con las violencias directa, 
estructural y cultural, lo que denominaríamos la paz positiva, esta visión de la paz nos permite dilucidar que concibe al conflicto como potencialidad y motor de crecimiento y transformación; en este sentido, nos situamos en el ámbito del ejercicio pleno de derechos fundamentales de los individuos al interior de la sociedad.

Este concepto de paz positiva fue propuesto en la década del sesenta por Galtung en el marco de la Investigación para la Paz, como complemento a la paz negativa entendida como alternativa a la violencia directa. "En sentido amplio la paz sería el resultado de la conjunción de aspectos que garanticen la vida con dignidad para todos, en medio de la diversidad a través de la justicia social, satisfacción de necesidades básicas, autonomía, desarrollo, identidad, diálogo, integración y equidad para los miembros de una sociedad" (Fed. Colombiana de municipios sf, p. 9)

La paz positiva va más allá de la ausencia de violencia directa y enfatiza en la presencia de justicia social. Esta visión exige la existencia de estructuras políticas, sociales y económicas que permitan una distribución equitativa del poder y acceso a recursos. Igualmente, esta visión no rechaza el conflicto. Por el contrario, entiende su potencialidad como motor de crecimiento y transformación e insiste en su resolución pacifica. (Zapata, 2009, p. 13)

Por otra parte, encontramos el concepto de paz neutra, siguiendo los planteamientos que se hallan en la Enciclopedia de paz y conflictos del Instituto de la Paz y los conflictos de la Universidad de Granada se observa que esta tipología implica la participación activa de todos los seres humanos para reducir la violencia cultural. Es la dimensión de la paz que involucra la denominada cultura de la paz

Como conjunto de valores, actitudes y comportamientos que reflejan el respeto a la vida, de la persona humana y de su dignidad, de todos los derechos humanos; el rechazo de la violencia en todas sus formas y la adhesión a los principios de libertad, justicia, tolerancia y solidaridad, así como la comprensión tanto entre los pueblos como entre los grupos y personas. (Universidad de Granada, 2004, p. 909)

La cultura de la paz entonces estaría vinculada en este sentido con los tres tipos de violencia mencionados anteriormente, de manera que establece una interacción dialéctica entre sus componentes y características, véase Figura 3. La gráfica mostrada a continuación surge como resultado de la abstracción de conceptos sobre paz y cultura de paz, teniendo en cuenta que los investigadores para la paz suelen utilizar el triángulo de la no violencia para reconstruir el concepto de paz, aquí se retoma la imagen mental del triángulo, para mostrar las relaciones que se establecen entre las diversas acepciones de paz con las de violencia y cómo éstas y aquellas convergen para estructurar la cultura de paz. 


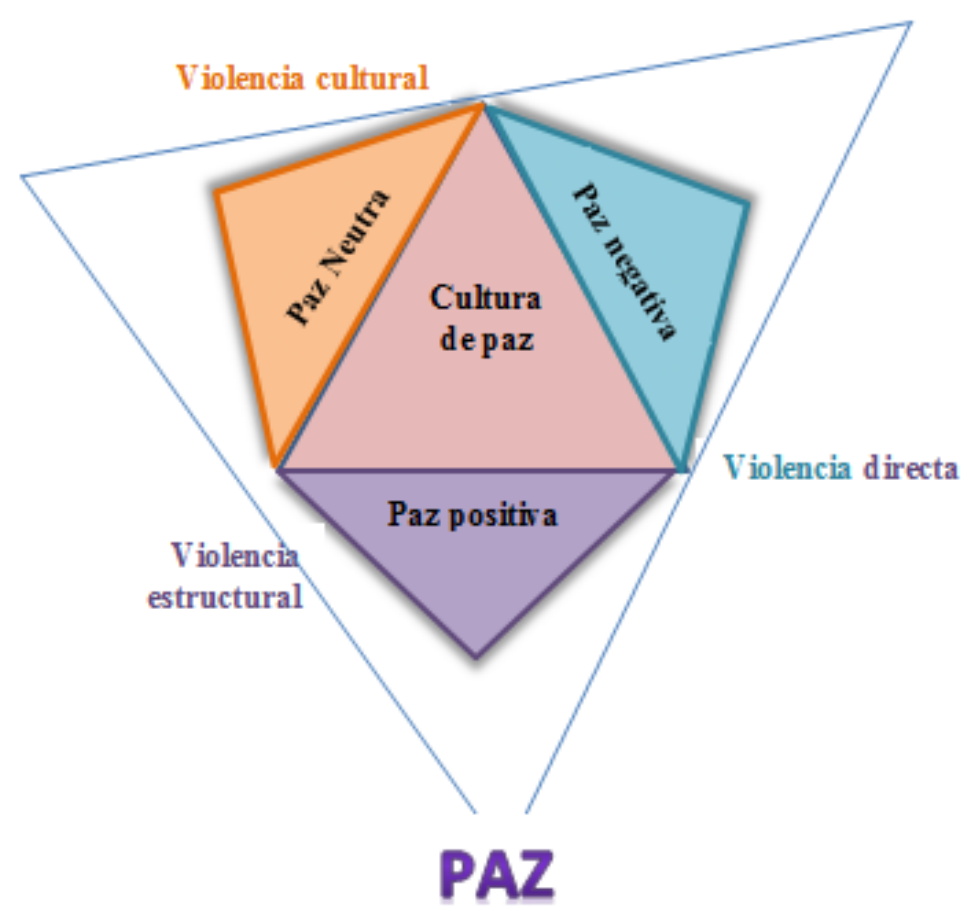

Fuente: Elaboración propia, 2012.

Figura 3. Paz y cultura de paz.

La paz neutra implica en este sentido la redefinición de un modelo antropológico de la cultura de la paz a través del análisis y diagnóstico de los discursos y prácticas de la política tanto cultural como económica. Los avatares históricos del concepto mismo de paz nos llevan a transitar de una concepción negativa hasta una acepción positiva del término vinculada con el desarrollo humano (sustentable y justo), en aras de fomentar la satisfacción de las necesidades y las condiciones requeridas para que el ser humano desarrolle su potencial en la sociedad y ejerza plenamente sus derechos.

La referencia a la paz positiva nos lleva entonces a situarnos en una perspectiva más holística del término, en donde se identifican elementos vinculados tanto con el imperativo de modificación de condiciones estructurales, como con aquellas otras imbricadas con el conflicto armado. Nos situamos en el terreno del fomento de aspectos que promuevan por una parte la transformación de condiciones de inequidad y desigualdad social y por la otra de solución pacífica de la confrontación armada; llegamos entonces al tema de la construcción de paz o peacebuilding como escenario cuyo objetivo fundamental expresa un vínculo intrínseco con el conjunto de actividades, que persiguen el mejoramiento y reforzamiento de las perspectivas de paz en un territorio, aunado a la disminución de la posibilidad de conflictos violentos en el mismo.

Desde el análisis retrospectivo de la producción bibliográfica, se evidencia que el concepto en la mayoría de textos aparece vinculado con las sociedades en proceso de reconstrucción post-conflicto, así las cosas siguiendo los planteamientos de la Universidad de Granada (2004) se dilucida que autores como Bavly asocian peacebuilding con los intentos por la paz realizados por iniciativas ciudadanas con el fin 
último de tener injerencia en las decisiones de los líderes políticos, por su parte Ronald J. Fisher lo concibe como "el conjunto de esfuerzos orientados a mejorar la relación entre adversarios, alcanzar mayores cuotas de confianza y cooperación, establecer nuevas actitudes y percepciones más precisas respecto a la otra parte, creando un clima más positivo comprometido con una sólida voluntad política para la resolución constructiva de las diferencias". (Fisher, 1997, Citado en Universidad de Granada, 2004, p. 920)

La construcción de paz cobra auge desde 1992 cuando el Secretario General de las Naciones Unidas en la Agenda para la Paz le otorga un sentido y significado diciendo que:

Es una actividad post conflicto orientada a fortalecer y solidificar la paz y el orden en un territorio para evitar nuevas situaciones de violencia, debiendo reconstruir las instituciones e infraestructuras de naciones desgarradas por guerras civiles $y$ disensiones destructivas y creando lazos de paz entre naciones en guerra. (Fisher, 1997, citado en Universidad de Granada, 2004, p. 920)

Es a partir de este acontecimiento, que el término entra en vigor asociándose a procesos de gran envergadura como el desarrollo a largo plazo, la construcción y consolidación de estructuras e instituciones legales de Derechos Humanos, los sistemas y procesos de gobierno y la resolución de disputas hasta llegar al peacemaking y peacebuilding. En este contexto, vemos que la construcción de paz involucra procesos antes, durante y después de la confrontación armada, por ende en escenarios de conflicto armado de larga duración como en el caso colombiano, es indispensable identificar las capacidades locales para la paz y aunar esfuerzos en torno a su promoción, caracterización y consolidación en tanto se consideran aportes desde un enfoque de abajo a arriba (bottom-up) que coadyuvaría a prevenir los conflictos violentos atendiendo a causas radicales que producen la violencia estructural, como la pobreza, la represión política y la desigual distribución de los recursos (Knight, 2003, citado en Martínez, 2008, p. 8).

En el sentido mencionado anteriormente se vislumbra que como precedente de las propuestas de construcción de paz que ocupan la atención de diversas instancias en la década de los noventa, se encuentran los aportes de Johan Galtung quien desde los sesenta estudió el triángulo conformado por el establecimiento de paz o pacificación (peacemaking) que debía ser abordado para transformar actitudes y percepciones de las partes en conflicto con miras a mantener la paz (peacekeeping) en donde estarían incluidas las formas de abordaje de las conductas violentas y la facilidad de la pacificación, así como la consolidación o construcción de paz (peacebuilding) que se refiere a las maneras de afrontar las causas de los conflictos (Ver Figura 4). 


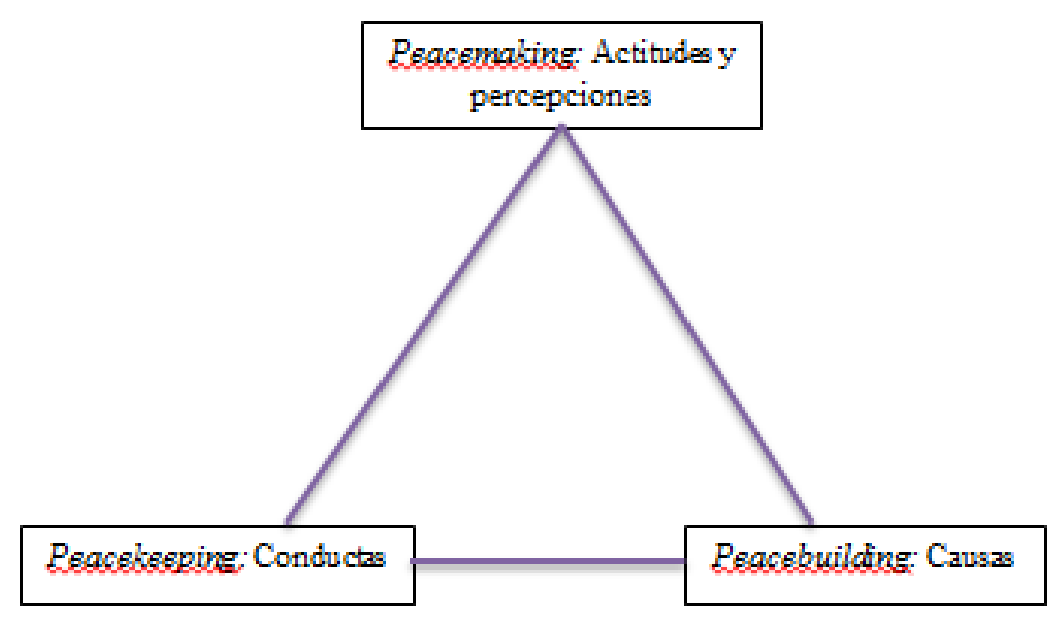

Fuente: Elaboración Propia con base en planteamientos de Galtung, 2012.

Figura 4. Triángulo proceso de construcción de paz en Galtung.

Se evidencia en este escenario que no existe un único concepto de construcción de paz. Lederach menciona "construcción de paz constituye los esfuerzos, actividades y estructuras para reducir y acabar con la violencia y construir relaciones saludables entre individuos, comunidades y naciones" (2007). A la par identifica los principios fundamentales de la construcción de paz (mencionadas en Zapata, 2009, pp. 19-20), que para efectos de esta tesis son incorporados en la perspectiva analítica que ésta sigue:

- Globalizante: Donde se menciona que para lograr una paz duradera se requiere un abordaje del conflicto en los diferentes niveles de la sociedad involucrando a todos los actores sociales, desde las comunidades de base hasta los líderes que toman decisiones. De manera que para esto se requiere el desarrollo de habilidades que permitan identificar las necesidades de las personas, la visión de largo plazo y el o los planes y acciones concretas para lograr la meta que se desea.

- Interdependiente: Todas las personas y las actividades de las sociedades tienen una interconexión. Quienes están en el campo de la construcción de paz deben tener la capacidad de fortalecer relaciones entre los individuos, fomentando la interacción entre las distintas actividades para propiciar un cambio sostenible.

- Sostenible: Partiendo de considerar que los conflictos se inscriben en varias generaciones es importante fomentar el fortalecimiento de los recursos y actividades propias del contexto local con la visión de largo plazo.

- Estratégico: Incluye el diseño e implementación de acciones concretas con una visión de cambio deseado. Se desarrollan habilidades para responder a las necesidades inmediatas sin perder la vista al futuro. "Para ser estratégicos los constructores de paz deben adoptar múltiples roles, trabajar con diferentes actores $y$ desarrollar múltiples actividades”. (Schirch, 2004) 
- Infraestructura: Bases de apoyo a los procesos de cambio a largo plazo. Está conformada por las personas, las relaciones, así como los contextos sociales e institucionales que desarrollan.

Knight (2003) citado en Martínez (2008, p. 11) da cuenta de varias dimensiones en las que se materializaría la construcción de paz a saber: la perspectiva política debido principalmente a la naturaleza de los conflictos, hace referencia a la creación o reconstrucción de instituciones de gobernanza, de manera que se desarrollen medios que permitan la lucha por el poder a través de canales pacíficos. Así se observa que se recupera la concepción política centrada en la democratización como objetivo fundamental de la construcción de paz. En el ámbito económico se dilucida que se incluyen aspectos tales como el fomento de oportunidades en los ámbitos de generación de micro créditos, creación de empleo, mejora de los servicios de salud y educación entre los fundamentales.

Se habla entonces de la importancia que adquiere la inclusión de mecanismos eficaces y eficientes de gobernación o gobernanza, de manera que se propenda por la ampliación de la concepción de seguridad humana. "La buena gobernanza sería la que contribuyera al bienestar global de una sociedad mediante el refuerzo de las instituciones y el equilibrio entre la sociedad civil, el mercado y el Estado" La gobernanza entonces se materializa en un conjunto de pilares que incluyen la participación política, la equidad, la tolerancia, la eficiencia y la efectividad gubernamental; en síntesis la gestión del territorio democrática y competente, que promueva la equidad y justicia social junto a la convivencia como sus piedras angulares.

Hoy el enfoque de paz es un enfoque de construcción del desarrollo con la vinculación de todas las fuerzas sociales y políticas del país; es decir, es un concepto mucho más macro, más integral, más influyente de la paz, que plantea que la paz es un bien colectivo necesario que sólo se logra tocando múltiples dimensiones de la vida social y no solamente la dimensión del conflicto especificamente (...) Entonces construir paz no es simplemente eliminar el conflicto, sino que construir paz es generar convivencia, es generar desarrollo, es generar posibilidades de fortalecimiento de la democracia, etc. Así lo menciona el profesor Velásquez en la entrevista realizada en 2011 (Velásquez, 2011)

\subsection{Gestepaz}

La gestión del territorio para la paz es resultado de la integración de los objetivos de desarrollo, justicia y equidad social a partir de la gestión democrática y competente; se vincula con el desarrollo de capacidades sociales e institucionales, orientadas a fortalecer la equidad y la convivencia como temas que apuntan tanto a la reducción del conflicto y la construcción de la paz que sería el caso de Colombia, como en lo 
concerniente a la creación y mantenimiento de condiciones de calidad de vida, equidad y transparencia en el caso de Bolivia. Este proceso está orientado a fortalecer una gestión competente de las políticas públicas y la participación social en las diferentes instancias territoriales en que se ordena la administración pública y política de los contextos; tareas que plantean como trasfondo la posibilidad de enfrentar las lógicas de exclusión social, urbana y territorial, fomentando la construcción de condiciones y oportunidades para la inclusión, el desarrollo de las libertades humanas, el reconocimiento, la redistribución y la representación, necesarias para la ampliación del mapa político y de gestión territorial en estos países.

En esta perspectiva, leer el territorio desde una lógica física (material), social y cultural, implica que los enfoques diferenciales basados en el reconocimiento de las diversidades culturales, étnicas, de género, de edad y de clase, así como la participación social y política, forman parte de los procesos de planeación urbana; transformándose en instrumentos de aporte a la construcción de capacidades sociales e institucionales a nivel territorial, tal como lo menciona el profesor Velásquez en la entrevista realizada en 2011:

Cuando hablamos de gestión del territorio y perspectivas de paz, significa pensar la paz como un objetivo estructurante y pensar el territorio y su gestión como tareas en las que están involucrados muy diversos actores, pero que pueden conducir a señalar e identificar una serie de rutas que nos permitan esa construcción de convivencia pacífica. (El subrayado y la negrilla son aportación de la autora)

Como se observa en las anteriores líneas Gestepaz implica entonces la paz estructurante desde la idea de considerar el territorio como sujeto fundamental, cuyos discursos y prácticas de gestión estarán ligados con pautas éticas, metodológicas y conceptuales que promocionen las rutas para la construcción de convivencia pacífica, a la par de la generación de lo que llamaremos el "desarrollo adjetivado" aquel que sea susceptible de lograrse contando con la participación activa de los individuos y comunidades que se inscriben en determinado espacio social, se identifican entonces multiplicidad de actores intervinientes en este sentido así como aspectos subyacentes que coadyuvan a ampliar el sentido y significado de la Gestepaz tanto en Colombia como en Bolivia. Escenario en el que la sociedad civil y sus iniciativas organizativas juegan un rol preponderante e imperativo como parte de la creación de caminos que en un mediano y largo plazo, contribuirán al logro de la paz, pues aúnan esfuerzos en torno a la disminución y eliminación progresiva de condiciones de inequidad, desigualdad e injusticia social, a partir de la reivindicación de derechos, el ejercicio pleno de la ciudadanía y como estrategias de evaluación y control social para la transparencia de las acciones de la administración y gestión pública.

Tal como se evidenció en líneas anteriores Gestepaz involucra discusiones vinculadas con lo que llamaremos "el desarrollo adjetivado", se emplea este término ya que el 
estudio de los avatares del desarrollo como construcción conceptual, nos remiten a hacer referencia a varias dimensiones que se han dado en la historia a esta palabra. Encontramos referencias al desarrollo económico, desarrollo local, desarrollo rural, desarrollo social, desarrollo sostenible, desarrollo humano (en el que hablamos también del Índice de Desarrollo Humano -IDH-) entre otros. En este sentido, una de las primeras premisas a tener en cuenta a la hora de abordar el tema del desarrollo es que éste no puede verse de forma atemporal, por el contrario, debe analizarse a la luz de un momento histórico cuyas características darán cuenta de una forma específica de comprensión del término en cuestión.

En general vemos que el desarrollo es concebido como proceso de cambio social (referido) a un proceso deliberado que persigue como finalidad última la igualación de las oportunidades sociales, políticas y económicas, tanto en el plano nacional como en relación con sociedades que poseen patrones más elevados de bienestar material. Sin embargo, esto no significa que dicho proceso tenga que seguir la misma trayectoria, ni deba conducir necesariamente a formas de organización social y política similares a las que prevalecen en los países actualmente industrializados o desarrollados (Sunkel y Paz, 1986, Citado por Ramos, 2012).

Autores como Hissong Robin (1996) hacen referencia a la modernidad entendida como proyecto cultural con unos valores y principios establecidos, esta alusión se menciona como necesaria para hacer referencia a las tendencias y contratendencias del desarrollo. Se dice que a éste proyecto subyacen los planteamientos teóricos y las proposiciones prácticas sobre el desarrollo y las instituciones responsables de la difusión y reproducción del mismo. Tomando estos aspectos como antecedentes que dan cuenta del devenir histórico del desarrollo se observa que:

a) En la década del cuarenta se inician las reflexiones, análisis y discusiones sobre desarrollo a través del Plan Marshall, como conjunto de estrategias que ponen en función del desarrollo a la industrialización entendida como motor de crecimiento, que se materializa en cuestiones técnicas que harían que los países pobres llegaran a desarrollarse.

b) En la década del sesenta se establece una relación directa entre el concepto de desarrollo y el de planificación, que materializada en planes, programas y proyectos busca promover políticas; se entiende entonces la planificación estatal como herramienta fundamental para el análisis, diagnóstico y formulación de propuestas de cambio, así como para legitimar acciones de intervención estatal.

c) A finales de la década del setenta se cuestiona el concepto de desarrollo fomentado hasta entonces. Se demanda de una noción más vinculada con los seres humanos y que no ponga tanto énfasis en el crecimiento económico, se habla entonces del Desarrollo Humano y del Índice de Desarrollo Humano IDH. 
d) En la década del ochenta según Alcañiz (2008), surge la perspectiva del desarrollo local como respuesta al proceso de globalización, dados los vacíos evidenciados en las políticas macroeconómicas para la resolución de problemas asociados con la creación de empleo y la mejora del bienestar. Esta perspectiva se centrará en darle una mayor presencia a los niveles locales y regionales en la planeación del desarrollo.

A la luz de los planteamientos de autores como Arturo Escobar (1996) también es posible realizar un análisis del desarrollo desde la perspectiva discursiva, donde se destaca que en el devenir histórico de este término se hallan imbricadas las razones de algunos países para reconocerse y ser llamados "subdesarrollados" desde comienzos de la segunda posguerra, escenario en el que este aspecto empieza a posicionarse como problemático, dando paso a estrategias, planes y tareas tendientes a salir de dicho subdesarrollo haciendo que estas sociedades pasasen por intervenciones sistemáticas, detalladas y extensas. En palabras de Escobar (1996) a medida que los expertos y políticos occidentales empezaron a ver como problemáticas ciertas condiciones de Asia, África y América Latina (condiciones vinculadas con pobreza y "atraso") se inscribe en la escena social un nuevo campo del pensamiento y de la acción denominado desarrollo, esto deriva en un conjunto de estrategias construidas con el fin de hacer frente a los mencionados problemas. Dicha estrategia de afrontamiento fue configurada en un inicio por Estados Unidos y Europa Occidental, se convirtió a través de los años en una fuerza poderosa en el llamado Tercer Mundo.

En este contexto se habla del desarrollo entendido como práctica singular históricamente constituida, en el marco de un escenario marcado por el dominio del pensamiento y la acción, aspectos que permiten analizar las características e interrelaciones de los ejes que subyacen a su definición: 1) Las formas de conocimiento que a éste se refieren y a través de las que se materializa en objetos, conceptos y teorías. 2) Las relaciones de poder que se movilizan en su práctica, discursos y las subjetividades que construye en este espacio, las mismas que hacen que las personas se autodenominen "subdesarrolladas" o "desarrolladas". 3) Las formas que en los ejes mencionados hacen que el desarrollo se constituya en una construcción discursiva, que origina aparatos eficientes en relación con las relaciones de poder y las formas de conocimiento.

Otra de las reflexiones aplicables sobre la noción de desarrollo tiene que ver con la identificación y aplicación de términos específicos a los países del sur, en donde se observa una heterodesignación y una taxonomía que dan cuenta de elementos que dejan entrever una posición de inferioridad respecto a aquellos que son nombrados como países desarrollados. Así, se asignan conceptos que están estrechamente relacionados con elementos derivados de la universalización de paradigmas occidentales que denotan una separación tajante entre los principios de la modernidad y la modernización, aspecto en el que se dilucida que las bases conceptuales del desarrollo están inscritas en 
corrientes de pensamiento específicas que dan cuenta de su construcción como término con sentido y significado en un momento específico de la historia. En palabras de Hissong (1996) las bases conceptuales de las diferentes nociones de desarrollo se asentarían en los pilares promovidos por:

- Positivismo lógico: Donde se observa que los efectos de la dominación y el poder son aspectos ignorados al no tener en cuenta el rol de las instituciones sociales y políticas. En este contexto, se considera la intervención estatal como innecesaria ya que es el mercado el que aparece como medio que asegura el equilibrio en las dimensiones espacial y sectorial, haciendo una división entre esferas políticas y económicas de manera que lo político se restringe a la implementación de medidas necesarias para mantener las condiciones del mercado. Frente a las desigualdades que afectan el funcionamiento del mercado se dice que es aconsejable el uso de instrumentos para remover los obstáculos en determinadas áreas así encontramos un principio de eficiencia con redistribución de manera que se mantiene un equilibrio y un orden vigente.

- El estructural funcionalismo: Donde se incluyen conceptos vinculados con la dominación, el poder, la accesibilidad y la participación ya que admite el rol de las instituciones y los diversos actores de la escena social, los procesos sociales no aparecen separados de los espacios y modos de producción que organizan y estructuran acuerdos en relación a sus necesidades, entendiendo en este contexto el espacio como relacional y categoría constitutiva del modo de producción; se otorga un énfasis importante a la intervención estatal en los procesos de desarrollo de manera que se posibilita la escogencia de alternativas que propendan por el cambio de procesos sociales y se logre así la corrección de los desequilibrios sin cambiar las estructuras readecuando con ello el orden vigente a un sentido mucho más funcional.

- El materialismo dialéctico: Propende por la desmitificación de los valores y principios modernos que son adoptados por la burguesía como fundamentos de los procesos de modernización capitalista, en segunda instancia comprende el orden social como producido por los seres humanos de acuerdo a las condiciones y circunstancias históricas existentes, ya que rechaza la neutralidad de la ciencia y la concepción del ser humano como individuo. Propone el análisis de todos los aspectos de una realidad y todas las interrelaciones entre éstos. Por otra parte, considera las relaciones entre sujeto-objeto, así como aquellas otras que se dan entre teoría y práctica.

Como se observa en los planteamientos anteriores las diversas corrientes de pensamiento referenciadas darán cuenta de formas específicas de nombrar el desarrollo en un momento y tiempo determinados, otorgándole unas características especiales en razón de las relaciones que se establecen entre los actores involucrados, los objetivos que se persigan, la naturaleza de las instituciones y la función que se le asigna al Estado. 
Dichas corrientes de pensamiento convergen para estructurar una determinada forma de entender el desarrollo y se encuentran acompañadas por diversidad de teorías que también permiten identificar el énfasis que se pone en una o varias dimensiones de la vida social al hablar de desarrollo, entre dichas teorías encontramos la contribución de las escuelas neoclásica y keynesiana que están imbricadas en el marco positivista; la contribución de las teorías del crecimiento por etapas; la contribución de las teorías del crecimiento polarizado que están derivadas del pensamiento estructural-funcionalista; la contribución del paradigma centro-periferia derivado del pensamiento estructuralista latinoamericano; la contribución de los enfoques de la economía dual; de los modelos dependentistas y el pensamiento neoliberal.

Así, desentrañando los avatares históricos y conceptuales del desarrollo llegamos a la relación que se establece entre éste y la llamada planificación del desarrollo que es concebida como el principal instrumento para generar, lograr, orientar, evaluar y predecir sus procesos. En este sentido, el Estado se entiende como actor que es el responsable de abanderar los procesos de desarrollo reconociendo a la planificación como herramienta fundamental en el análisis, diagnóstico y formulación de propuestas de cambio y para dar legitimidad a las acciones de intervención estatal. En este punto, se considera importante hacer referencia a algunos planteamientos de fondo sobre el tema de la planificación que dan cuenta de sus recorridos en el contexto Latinoamericano, lo cual resulta interesante de referenciar teniendo en cuenta la naturaleza de esta investigación.

En América Latina se observa que desde la década del 40 adquiere importancia la intervención del Estado en el sector privado, desde una perspectiva de racionalización. En este escenario la planeación aparece concebida como proceso necesario para el logro del desarrollo de un país, dicho proceso debe ser liderado por el sector público. Ya en la década del sesenta se observa que la planificación está definida como práctica institucional estandarizada en gran parte de los países de Latinoamérica ya que en el nivel externo se dilucida un condicionamiento de la asistencia bajo los parámetros incluidos en la estrategia de desarrollo promocionada a través de la Alianza para el Progreso, en donde se vislumbra el requerimiento de la creación y consolidación de estructuras de planificación y promoción de planes, programas y proyectos. En el nivel interno encontramos el aumento de la intervención estatal en escenarios marcados por la industrialización y la urbanización, acá se evidencia la aparición de movimientos sociales y su promoción por parte de entidades como la Comisión Económica para América Latina CEPAL.

La promoción de modelos de desarrollo afincados en los parámetros mencionados no trajo consigo los resultados que se querían, principalmente por el estilo de planificación adoptado, así como por los efectos de la importación de modelos de desarrollo de otros países denominados "avanzados", lo cual tiene repercusión en el no fomento de la creación de modelos endógenos de promoción del desarrollo. El modelo de planificación que cobra auge por esta época es el normativo (plan libro) que privilegia 
el deber ser y los aspectos legislativos necesarios para el alcance de los objetivos, está fundamentado en la racionalidad técnica de manera que se desarrollan actividades más tendientes a la formulación, dejando de lado la frecuencia de la fase de ejecución y asignando recursos con eficiencia en donde se obtiene un mayor nivel de rentabilidad.

En el contexto internacional se da el auge de la importancia del desarrollo económico y social, se hace expresa la necesidad de “... la colaboración más completa posible entre todas las naciones en el campo económico, con el fin de asegurar para todos, mejores condiciones de trabajo, adelanto económico y seguridad social" (Uricoechea, 1968, p. 26). Es en este escenario, en donde bajo la inspiración del presidente Kennedy la década del sesenta fue nombrada como la década del desarrollo, cuyo objetivo era que los países se comprometieran y aunaran esfuerzos en aras de superar el "subdesarrollo".

El mencionado ideal de desarrollo, aparece ligado con los parámetros asociados con la modernización de las estructuras sociales de los países, con miras a propiciar la participación de las comunidades y los individuos; participación entendida como la integración de grupos sociales a la vida moderna de los países desarrollados, para esto se procuran diversas facilidades institucionales para los grupos marginados; como aspectos que dan cuenta de la diversificación de los mecanismos de bienestar social. Es "entendida entonces la modernización como un proceso de apertura del sistema social para brindar a los diversos estratos y clases sociales oportunidades institucionales nuevas o mayores, la idea o el hecho mismo de modernizarse una sociedad implica la extensión y diversificación de su sistema institucional" (Uricoechea, 1968, p. 13)

En suma, se observa que una de las grandes contradicciones entre la teoría del desarrollo y el proyecto de la modernidad está vinculada con la importancia y ubicación que se le da al ser humano. Ya que la mayoría de enfoques del desarrollo lo ignoran privilegiando otras dimensiones de la vida social, en esta perspectiva encontramos que éste es concebido como un insumo más dentro del proceso de producción, es decir como fuerza de trabajo, de manera que son clasificados en razón de diversas variables. Este énfasis en el ser humano o en otras dimensiones tales como la económica dará cuenta de la construcción de diversos "adjetivos" otorgados al desarrollo (Ver Figura 5)

A finales de la década de los setenta se inicia la crítica al concepto de desarrollo, desde este momento se encauzan esfuerzos para impulsar y visibilizar una concepción de desarrollo centrada en las personas y que no ponga tanto énfasis en el ámbito económico, dicha corriente de trabajo gira en torno a la noción de desarrollo humano "Fue Amartya Sen quien argumenta a favor tanto del reconocimiento de las cualidades humanas como de la -capacidad humana-como expresión de la libertad, es decir, la propia capacidad que las personas tienen para hacer uso de sus capacidades adquiridas" (Stein, 2003, p. 3, Citado en Alcañiz, 2008, p. 32).

Allí, se inscribe la importancia de la construcción de vías alternativas que permitieran que aquellos países subdesarrollados, re-surgieran como países independientes con la 
capacidad para la construcción de vías alternativas a las promovidas por las grandes potencias mundiales; esto es, la identificación de los sentidos, significados, y escenarios demandantes de un nivel de desarrollo mayor.
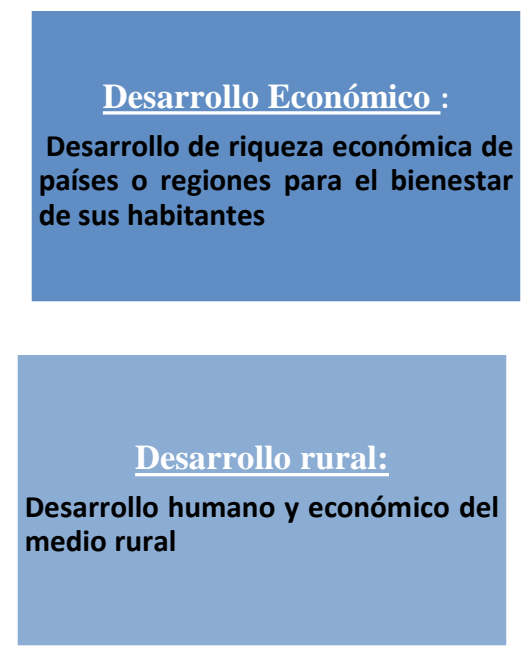

Desarrollo humano: Conclusión de capacidades que permitan a las instituciones y personas ser protagonistas de su bienestar
Desarrollo local: Aprovechamiento de los recursos y potencialidades endógenos de una comunidad.

Fuente: Elaboración propia con base en los planteamientos de Ramos Ana. Asignatura Teorías y conceptos de desarrollo. Máster en Cooperación al Desarrollo. Universitat Jaume I, 2012.

Figura 5. "El desarrollo adjetivado"

Se identifican en este sentido, propuestas como la hecha por Manfred Max-Neef y su equipo de trabajo en 1986. En donde el desarrollo a escala humana sería el objetivo y el principio orientador de la creación de procesos endógenos, o de desarrollo propio de los países Latinoamericanos. Esta propuesta está ligada con la importancia que se otorga a la provisión de recursos para que los individuos satisfagan sus necesidades humanas fundamentales, con el fin último de fomentar niveles crecientes de auto dependencia y una articulación llamada "orgánica" entre: seres humanos-naturaleza; tecnología de los procesos globales-comportamientos locales; personal- social; planificación-autonomía y sociedad civil-Estado (Ver Figura 6).

En este contexto se considera el aporte que puede brindar la CEPAL como comisión regional especializada de las Naciones Unidas para América Latina, que es un mecanismo a través del que se encauzan las recomendaciones y la asistencia del Consejo Económico y social, de la Comisión de Asuntos Sociales y de la Comisión de la población de la ONU. Puede contribuir para el fomento de procesos sociales endógenos de los países del llamado tercer mundo, ya que su propósito es ayudar a los gobiernos latinoamericanos a fomentar el desarrollo de sus países y elevar el nivel de vida de los pueblos. "Entre otras de sus actividades, la CEPAL entra a apoyar los servicios de asesoramiento a diferentes gobiernos en áreas como el desarrollo comunal, los servicios sociales de salud y vivienda..." (Saboyá, 1981, p. 121). 


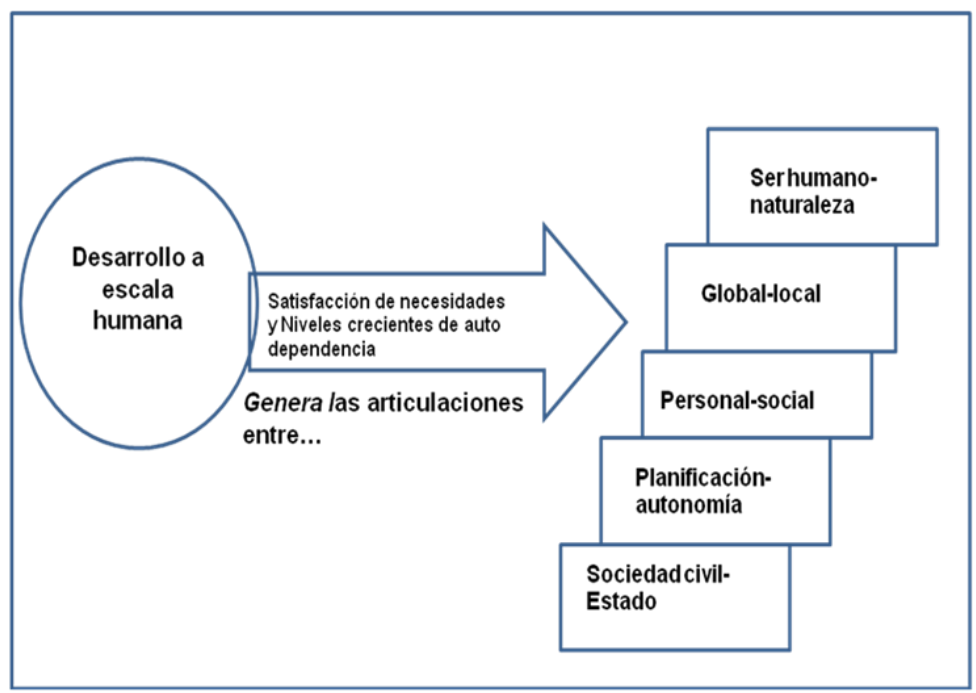

Elaboración propia a partir de Max-Neef Manfred. Desarrollo a escala humana: Una opción para el futuro. Bogotá, 2003

Figura 6. Desarrollo a escala humana.

Como se ha evidenciado en líneas anteriores, en varias de las elaboraciones consultadas para el estado de la cuestión, se identifica la concepción de desarrollo afincada en principios económicos, sin embargo, el análisis a profundidad de los contextos locales y globales da cuenta de procesos sociales que, como alternativas democratizadoras, permiten una concepción sistémica y construccionista de otras realidades sociales. Cuando se habla de desarrollismo, históricamente el discurso social ha puesto un énfasis particular en lo económico y en las relaciones de dependencia que estructuran determinados ideales, en este sentido, vemos cómo al hacer referencia a los postulados y pilares de mecanismos como la Alianza para el Progreso, nos ubicamos en un contexto temporal signado por el impulso de ideales desarrollistas, que hacen que países como los Latinoamericanos inscriban planes de desarrollo económico y social, que les permitan trascender el umbral del subdesarrollo.

De igual manera se dilucidan planteamientos como los de Amartya Sen donde se visibiliza el reconocimiento de las cualidades humanas. Desde el enfoque de este economista el desarrollo es un proceso de expansión de las libertades reales de las que disfrutan los individuos, los sujetos son concebidos como agentes con posibilidades de debatir y en general participar activamente en la definición de aspectos inherentes al desarrollo que desean.

El enfoque de Amartya Sen ya mencionado en líneas anteriores favorece una visión amplia de desarrollo, que es articulada en la definición de Desarrollo Humano asumida por el PNUD. Esta definición concibe el desarrollo como proceso a través del cual se amplían las oportunidades de los individuos, entre ellas, una vida prolongada y saludable, acceso a la educación y a los recursos indispensables para un nivel de vida 
digno (...) el PNUD al instituir el IDH en 1990, posibilita el despertar de la conciencia global, ya que evidencia las múltiples y complejas dimensiones de las capacidades humanas y señala que el desarrollo humano proviene de una acción pública deliberada y efectiva para permitir a las personas participar en el proceso de desarrollo y beneficiarse de él. (Alcañiz, 2008, p. 34)

Frente al IDH se observa que se inscriben en esta escena las preguntas por la desigualdad social sobre ¿Cómo acabarla? y ¿Qué políticas se pueden diseñar para evitar su transmisión intergeneracional? ¿Por qué los sistemas políticos y los mecanismos de redistribución no son eficaces? Como respuesta a dichos interrogantes aparece en primera instancia el hecho de que en la medición del IDH no se incorpora la desigualdad, cuyas causas explicativas se situarían en varias dimensiones a saber la económica por la correlación de niveles de actuación; la política-social vinculada con factores históricos y de desigualdad de oportunidades y accesos al poder en un contexto de exclusión y la económica-política por un acceso inequitativo a la representación institucional y a los escenarios de incidencia en toma de decisiones.

Las limitaciones de la medición del IDH se evidencian en el hecho de que a pesar de considerar las tres dimensiones fundamentales como salud, educación e ingreso solo se expresa el logro promedio alcanzado por una población determinada en cada dimensión, esto imposibilita la observación sobre cómo se distribuyen los logros individuales entre los diferentes colectivos de población, de allí que surjan alternativas como la propuesta por el PNUD en 2010 y que aparece en su informe regional de desarrollo humano en América Latina y el Caribe, en donde se propone el IDH ajustado por desigualdad de manera que se propenda por la evaluación de los logros individuales en relación con las dimensiones macro (salud, educación e ingreso).

Cabe destacar que el IDH mide el nivel de bienestar alcanzado por la población en los ámbitos de educación, salud e ingreso, tomando en cuenta las características de los logros individuales; éste indicador disminuiría considerablemente al dilucidar las diferencias en los niveles de desigualdad y sus avances en las diferentes dimensiones del desarrollo individual, por ende, se evidenciaría un menor nivel de desarrollo humano. Lo anterior implica que, para capturar la desigualdad en los indicadores de bienestar, se necesita mejorar la forma en que se miden, monitorean y evalúan las condiciones de vida de las personas.

Igualmente se observa que otros factores externos tales como la violencia o conflicto armado tienen gran incidencia en el IDH y por ende en el bienestar de la población. De allí que en el informe de desarrollo humano de 2011 en Colombia se incluyeran indicadores como la concentración de la propiedad y el conflicto armado a través de un IDH ajustado, dicho indicador ajustado evidencia una disminución considerable del bienestar y calidad de vida de la población. La comparación del IDH 
convencional y el ajustado muestra el deterioro que estos fenómenos tienen sobre el desarrollo humano de los colombianos y las colombianas.

Los factores externos que inciden en el desarrollo y que debiesen ser considerados en la medición del IDH tienen que ver tanto con la desigualdad como con la exclusión social (que son evidentes en los dos estudios de caso: Bolivia y Colombia), ya que se evidencia la aparición de aspectos que dan cuenta de sus mecanismos que como menciona García Roca se materializan en la sociedad del desempleo, el desmantelamiento de lo público a través de las lógicas que vehicula el mercado capitalista, haciendo que las crisis se naturalicen, promoviendo de esta manera la enajenación de los sujetos y fomentando un concepto de asistencia que no propende por enfatizar, rescatar, visibilizar y poner en acción las capacidades y habilidades de los contextos locales y los diferentes colectivos de población en este escenario.

\section{La búsqueda obsesiva de beneficios ha roto el principio básico de una sociedad inclusiva: crecer para ampliar el nosotros humano. Lo que es bueno para el capital ha dejado de ser bueno para el trabajo. La exclusión se ha instalado en el corazón mismo de la sociedad hasta invertir su orientación inclusiva (García, sf, p. 32).}

En este contexto se observa que la gestión del territorio para la paz se convierte en una de las vías alternativas a la situación mencionada, ya que involucra la promoción de estrategias que reivindican y fomentan condiciones para la redistribución (de la riqueza), la representación (materializada en la incidencia en la toma de decisiones y la participación social, ciudadana y comunitaria), el reconocimiento (de derechos y ejercicio pleno de ciudadanía). En el escenario de la Gestepaz hablamos de un desarrollo local y comunitario que propende por reivindicar la identidad y el territorio como generadores y potenciadores de dinámicas económicas, sociales y culturales cuyo pilar fundamental es la participación de los agentes, sectores y fuerzas que interactúan en un territorio, los cuales a partir de un proyecto común combinan la generación de crecimiento económico, equidad, cambio social y cultural, sustentabilidad ecológica, enfoque de género, calidad y equilibrio espacial y territorial con la finalidad de elevar la calidad de vida y el bienestar de sus pobladores. (Casanova, 2004, Citado en Alcañiz, 2008, p. 35)

Cabe destacar que "también el desarrollo local es entendido como un proceso endógeno registrado en pequeñas unidades territoriales y asentamientos humanos capaz de promover dinámicas económicas y el mejoramiento de la calidad de vida de la población" (Jiménez, 2007, p. 301). El expresar el desarrollo como endógeno nos remite a pensar en el reconocimiento, la visibilización y la importancia de aprovechar las potencialidades de los individuos y comunidades del contexto local, considerándolos como agentes activos cuya voz participa de los procesos de toma de decisiones y que en articulación con otros actores, coadyuva a generar procesos sociales que promuevan la convivencia, la equidad y la transparencia en la gestión pública; en suma, deben 
considerarse como sujetos de derechos y activos participantes de la gestión democrática y competente del territorio.

Posicionándonos en el enfoque ${ }^{1}$ del desarrollo local en consonancia con los anteriores planteamientos, se observa que podemos hablar de diversos aspectos que permitirían caracterizarlo, siguiendo las palabras de Jiménez (2007) encontramos las dimensiones: económica, sociocultural, político-administrativa (Ver Figura 7).

Como se observa interactúan las dimensiones propuestas en lo que dijéramos constituye una relación dialéctica, en la que el contexto local y las comunidades se consideran agentes activos y actores sociales desde dos perspectivas: 1) La participación directa en procesos de toma de decisiones, gestión pública, control social para la transparencia o 2) Desde su participación indirecta - pero no menos importante o incidente- a través de iniciativas como las organizaciones sociales o las estrategias propias que de igual manera, contribuyen a enriquecer los mecanismos que se despliegan en cada uno de los escenarios citados en la figura anterior. Las comunidades deben generar sinergias con otros agentes sociales (institucionales, Estado, ONG, otras comunidades y organizaciones sociales) en aras de fomentar la convivencia pacífica, la inclusión, la equidad y la gestión democrática y competente como aspectos vinculados directamente con la Gestepaz.

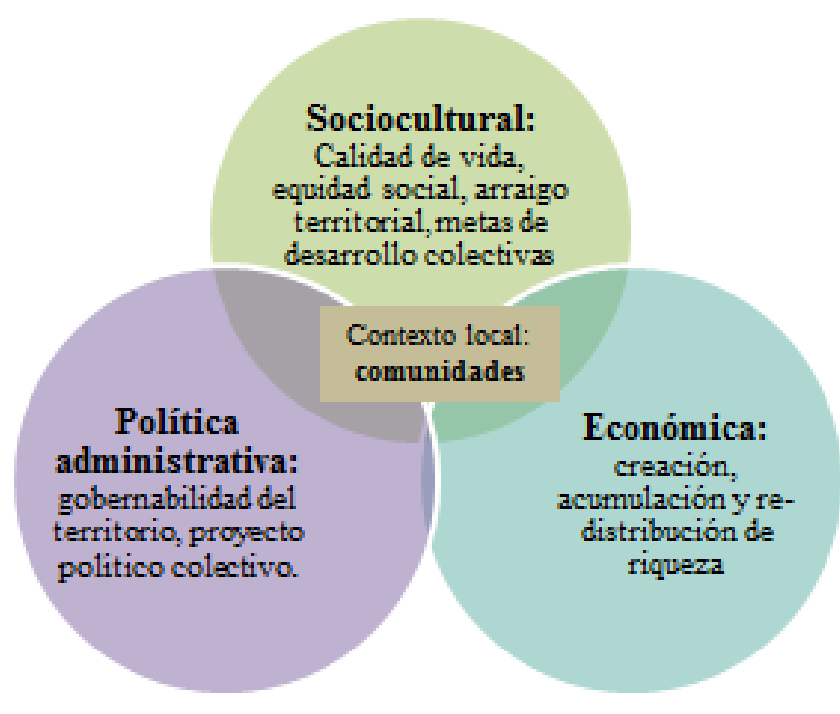

Fuente: Elaboración propia con base en los planteamientos de Jiménez 2007. Jiménez propone en la dimensión económica hablar de distribución, desde mi elaboración propongo el uso del término redistribución en esta dimensión del desarrollo local.

Figura 7. Dimensiones de análisis del desarrollo local.

\footnotetext{
${ }^{1}$ Se menciona la noción de enfoque al estar respaldado por un planteamiento teórico mínimo sobre la manera fenomenológica como debería presentarse o implementarse el desarrollo local.
} 
En este sentido, temas como la descentralización y la gestión pública nos remiten a pensar en el concepto, sentido y significado de la gobernanza, el escenario propuesto por la Gestepaz implica una nueva perspectiva de comprensión y aprehensión de este tema de manera que

el nuevo escenario implica emprender una nueva forma de gobernación (ejercicio del gobierno) y también nuevos objetivos para la gestión del desarrollo; liderazgo de redes, gestión estratégica, gestión relacional, corresponsabilidad públicoprivada-comunitaria, concertación y visión compartida son algunos de los nuevos elementos que materializan la gobernanza moderna para la gestión del desarrollo. (Jiménez, 2007, p. 317)

Así, la gobernanza para el desarrollo local demanda de unos aspectos que le son inherentes y en los cuales los gobiernos en este contexto deben asumir una coordinación social, de manera que se develan:

i) La corresponsabilidad que a su vez implica un conjunto de aspectos tales como la identificación de objetivos comunes, de manera que se propenda por desdibujar la barrera existente entre sociedad civil y gobierno local fomentando una actitud de diálogo y cooperación. La participación se inscribe entonces como legítima y como un objetivo importante. Se deslindan los obstáculos de la relación escenario públicoescenario privado.

En segunda instancia la corresponsabilidad implica la asunción de responsabilidades para cada actor; se trata de establecer los sentidos y las lógicas de integración, coordinación y gestión multinivel y multisectorial para la prestación y provisión de servicios públicos en un territorio determinado. Finalmente, un tercer escenario que se devela en el análisis de la corresponsabilidad en contextos de gobernanza para el desarrollo está representado por la articulación y coordinación de los anteriores puntos de manera que el gobierno local juega un papel preponderante en términos de coordinación social y de integración de los agentes vinculados en este escenario (administraciones locales, comunidades locales, ONG'S y empresas locales).

ii) La definición y establecimiento de mecanismos de cooperación entre los sectores público y privado de forma que se instauren relaciones caracterizadas por el trabajo conjunto tendiente a la satisfacción de problemas locales que desbordan la actuación unidireccional o fragmentada del gobierno local. En este escenario aspectos como la demanda de soluciones que integren conocimiento, información, experiencia y recursos económicos, que con la acción únicamente del sector público no se pueden solventar.

iii) La eficacia representada en la identificación de sinergias entre los recursos, los conocimientos y las capacidades que subyacen a las relaciones que se establecen entre actores y agentes territoriales. 
La gobernanza exige una sociedad civil fuerte o al menos activa e interesada en lo público, pues es la contrapartida necesaria para que el gobierno encuentre un "partenaire" o socio en su gestión. De lo contrario, seguiremos con formas jerárquicas e impositivas de gobierno. Sobre este punto es necesario trabajar en la cultura política participativa y en la formación de ciudadanía. (Jiménez, 2007, p. 323)

En este escenario se encuentra que la participación se convierte en una piedra angular de la gestión territorial en dos sentidos "la creación de capacidades en las personas para su desempeño en la "cosa pública” (desarrollo de ciudadanías) y sus logros en la profundización de los procesos de inclusión y equidad social y territorial" (Niño, 2007, p. 183). En este contexto la participación es entendida en dos acepciones a saber: como principio y como derecho, de manera que se encuentra estrechamente vinculada con la formulación de políticas, a través de iniciativas que buscan fortalecer los procesos democráticos en los territorios, así como la construcción y fomento de las ciudadanías propositivas en el marco del Estado Social de Derecho. De manera que

En el marco del proceso descentralizador, orientado a fortalecer la capacidad institucional y de la gestión pública de los municipios, la participación adquiere carácter político en la lógica de desarrollar mecanismos de inclusión social, y de vigilancia y control de las políticas públicas. Las autonomías territoriales y la autodeterminación de actores locales adquieren sentido en las apuestas participativas como formas de acercamiento a las identidades, intereses y características múltiples de lo local en el escenario público y colectivo. (Niño, 2007, p. 186).

Como lo evidencian Velásquez y González (2003) en su libro ¿Qué ha pasado con la participación ciudadana en Colombia? la institucionalización de los espacios de participación ciudadana de la mano de las políticas descentralizadoras de la década del ochenta generan cambios fundamentales en la arquitectura del sistema político, de manera que los colectivos de población tienen la posibilidad de intervenir de forma directa en la discusión sobre políticas y programas gubernamentales en el ámbito local, así se evidencia una ruptura con el monopolio de las élites políticas en las decisiones públicas. Con el advenimiento de la constitución Política de Colombia en 1991 dichos mecanismos de participación avanzan en términos de procurar por una parte, el reconocimiento de la actuación de las personas en diversas instancias de la vida política y en el escenario de la gestión pública y por la otra la configuración de una infraestructura legislativa e institucional que privilegia la acción en las entidades territoriales municipales, se abre un inmenso abanico de posibilidades en términos de la oferta estatal de participación; sin embargo, dichos mecanismos no se encuentran en correspondencia con las bases sociales e iniciativas ciudadanas que le darían total legitimidad.

En Bolivia con el advenimiento del Estado Plurinacional y la asunción del poder por la llamada izquierda en el país, se observa una apertura política y cultural que da cuenta del reconocimiento de derechos a pueblos originarios campesinos e indígenas (mayoritarios en el país) que anteriormente eran invisibles jurídicamente y pretendían 
ser negados en escenarios políticos, sociales, económicos y culturales. Dejamos en el pasado el Estado colonial, republicano y neoliberal. Asumimos el reto histórico de construir colectivamente el Estado Unitario Social de Derecho Plurinacional Comunitario, que integra y articula los propósitos de avanzar hacia una Bolivia democrática, productiva, portadora e inspiradora de la paz, comprometida con el desarrollo integral y con la libre determinación de los pueblos (CPE, 2008, p. 2).

El caso boliviano representa un importante hito histórico en Latinoamérica dadas las condiciones que enmarcan su cambio renovador democrático a partir de que un candidato de origen indígena asume las riendas del país como presidente, lo que incide positivamente en el fortalecimiento del reconocimiento y visibilización de actores y movimientos sociales que en adelante son considerados como parte en la toma de decisiones y ejercen su derecho a la participación.

Retomando las palabras de Niño (2007) diremos que, así como la participación comparte escenario con la descentralización y los propósitos subyacentes a un Estado Social de Derecho, también lo hace con la globalización que encuentra sinergias con los aspectos mencionados, así como con la participación y el fortalecimiento de los contextos locales y regionales. Es desde allí desde donde se dilucida el carácter político en la lógica de inclusión social, vigilancia y control de las políticas públicas; contexto en el que los diversos grupos poblacionales tienen un papel preponderante ligado con la creación de iniciativas que permiten ubicar las prácticas participativas que emergen en los contextos locales y su vínculo con el reconocimiento del territorio, como un entramado de universos culturales y políticos. El mencionado conjunto de alternativas juega un papel importante en tanto permite vislumbrar las lógicas de exclusión concomitantes a las dinámicas del mercado, con una incidencia considerable en procesos de producción y reproducción de la vida social, simbólica y material de los pueblos.

De allí que Gestepaz se conciba como proceso democrático de gestión y promoción de condiciones de equidad, convivencia y construcción de paz, que contribuye a encauzar los proyectos democratizadores y la acción competente en el territorio, desde una perspectiva de inclusión a partir de los enfoques diferenciales y de derechos, en contextos en los que se propende por el bienestar de la población sin causar daño. A esta concepción se vinculan aspectos fundamentales como se ha venido mostrando en esta tesis, tales como la participación, la descentralización en su sentido originario de "buscar el equilibrio democrático entre los poderes existentes en el interior de cada Estado con el fin de potenciar el desarrollo y la calidad de vida de la población”. (Carrión, 2007, p. 77)

A través de la asignación de recursos a entidades territoriales municipales y regionales y con la distribución de competencias se buscó promover a los contextos locales como autónomos, la descentralización con el tiempo también fue víctima de la influencia de diversos factores tales como en Colombia lo es la inserción de actores armados y en éste 
y otros contextos, la aparición y mantenimiento de fenómenos como la corrupción; a la que se atribuye la culpa de los déficits fiscales en varias esferas nacionales dada la transferencia de recursos a departamentos y municipios

Lo que no se dijo en su momento, ni tampoco ahora, es que el gran responsable del déficit fiscal es el Estado central, que ha mantenido un elevado y creciente volumen de gasto, en ocasiones no justificado, y en otras, sometido a prácticas corruptas. El resultado lógico de la descentralización de competencias a municipios y departamentos debió haber sido la de un Estado central más pequeño, sin embargo, no fue así y muchas actividades se duplicaron. (Serpa Uribe, 2007, p. 148)

Por otra parte, aparecen referencias a aspectos positivos de la descentralización tales como los aspectos vinculados con el ejercicio de la ciudadanía, en éstas se afirma que a partir de la Constitución Política de 1991 en Colombia y con la Constitución Política del Estado Plurinacional en Bolivia, se fortalece el empoderamiento ciudadano frente al ejercicio de derechos. La participación ciudadana se promueve en los municipios pequeños, reconociendo a las comunidades y sus demandas. En escenarios como estos se inscribe la participación en su dimensión sociopolítica que deja entrever las prácticas participativas que surgen desde el contexto local, se desarrollan iniciativas tales como las experiencias organizativas que a través de sus discursos y prácticas ponen en la escena pública los problemas del contexto actual, haciendo visibles los mecanismos de exclusión social son

apuestas desde la subalternidad social y política nacidas de las identidades, los territorios y lo local, como posturas epistémicas fronterizas que confrontan las condiciones y los constructos mismos de la modernidad (...) son apuestas por consolidar en la periferia modos particulares de alimentación, cultivo, consumo, propiedad etc... (Niño, 2007, p. 194)

Iniciativas tales como las emprendidas por las organizaciones y movimientos sociales, logran aportar tanto a la visibilización de los problemas como a la creación y desarrollo de estrategias (económicas, sociales, ambientales, culturales) para hacer frente y eliminar progresivamente condiciones de desigualdad, inequidad y exclusión social, contribuyendo con ello a fortalecer la conciencia crítica; promover prácticas de fortalecimiento de identidades territoriales desde los escenarios individuales aunando esfuerzos para la convivencia pacífica en el ámbito colectivo; procesos que aportan progresivamente a la reconstrucción y fortalecimiento del tejido social.

Todo lo anterior en el marco de la promoción de prácticas y discursos inmersos en enfoques diferenciales y de derechos, de forma que los problemas y necesidades son leídos desde la comprensión de su impacto diferenciado sobre los colectivos de población en razón del género, la generación y la etnia. Así las cosas "el enfoque diferencial de género, edad y etnia parte de los principios básicos del libre ejercicio de los derechos, de la equidad, y del reconocimiento de las diferencias entre los grupos poblacionales" (Meertens, sf, p. 2). Dicho enfoque diferencial también puede considerarse en perspectiva territorial afirmando que resulta fundamental 
partir de que los territorios no son homogéneos, cada escenario cuenta con unas características sociales, culturales, ambientales, políticas y económicas que dan cuenta de su particularidad así como de la constitución de una determinada "identidad territorial”, así mismo deben leerse las necesidades y construirse las políticas públicas sociales, tomando en cuenta la importancia de realizar análisis contextuales que propendan por la identificación de estas características particulares y con ello de las necesidades, demandas, potencialidades y recursos con los que se cuenta.

Donny Meertens plantea varios puntos de análisis en relación con los aspectos que deben incluir las políticas de atención a víctimas del desplazamiento forzado desde una perspectiva centrada en el enfoque diferencial, premisas que se consideran aplicables para reflexionar sobre el trabajo que desarrollan las organizaciones sociales que participan en ejercicios de control social y/o evaluación de políticas públicas, como alternativas democratizadoras en el escenario de la gestión asociada del territorio. Entre ellas encontramos:

- El desarrollo de procesos que promuevan la no-discriminación en el ejercicio de los derechos, la inclusión social y el acceso equitativo a los recursos y servicios del Estado. En los grupos organizados en la sociedad civil se parte de la articulación de acciones y esfuerzos que vinculan la preocupación por lo colectivo que es común a los individuos que integran los grupos sociales, se desarrollan acciones vinculantes que justamente intentan hacer ruptura con los paradigmas de subordinación que tradicionalmente se instauran en los escenarios públicos.

- Reconocimiento de las vulnerabilidades y necesidades particulares de cada grupo particularmente mujeres, niños y niñas y minorías étnicas. Haciendo una reflexión retrospectiva que articula el trabajo empírico llevado a cabo en este estudio con los planteamientos subyacentes al campo teórico, se haya que una de las premisas que motivan la acción colectiva de los grupos de población que se organizan con el objetivo de incidir en las políticas públicas a partir de desarrollar un rol importante en procesos de valoración de la gestión pública es justamente el interés de luchar contra las vulnerabilidades a las que son expuestos los diversos integrantes de las comunidades.

- Promover el acceso en forma equitativa a la toma de decisiones, a la participación y a la organización. El interés de las personas por participar en uno, en varios o en todos los momentos del ciclo de las políticas públicas está motivado principalmente por lograr incidencia en los procesos de toma de decisión en las administraciones públicas de los diferentes niveles territoriales: municipal, distrital e incluso nacional. 
- Realizar acciones positivas para desarrollar la autoestima y la autonomía de las personas, con particular énfasis en aquellas que pertenecen a los grupos tradicionalmente subordinados. En este escenario se observa cómo se aúnan esfuerzos en torno al papel de las organizaciones sociales en la promoción del empoderamiento de los colectivos de población, concibiendo dicho empoderamiento como "proceso o mecanismo a través del cual personas, organizaciones o comunidades adquieren control o dominio sobre los asuntos o temas de interés que les son propios" (Rappaport, 1987,1993, Citado en Agost, 2011, p. 155). En sus dos dimensiones, tanto en la capacidad individual de determinación de la propia vida o autodeterminación personal, así como en la participación democrática en la vida en comunidad a través de escuelas, comunidades, organizaciones sociales, se evidencia el empoderamiento como objetivo, logro y resultado del quehacer de los colectivos de población inmersos en la organización social.

- Eliminar los estereotipos culturales que obstaculizan el libre ejercicio de los derechos y la inclusión social. Se promueve el reconocimiento de las identidades individuales y colectivas en los procesos de intercambio relacional, concibiéndolos como potenciadores de reivindicación social, así como de procesos que en sí mismos constituyan iniciativas de transformación social de condiciones de violencia, inequidad y desigualdad social. A través de la promoción de lo que podríamos llamar relaciones sociales igualitarias, en medio de las diferencias poblacionales mencionadas en líneas anteriores, se busca lograr una ruptura con los estereotipos promovidos por ejemplo por el consumismo y las lógicas mercantiles.

De lo expuesto anteriormente se destaca que las iniciativas, experiencias, organizaciones sociales que se vinculan con el control social y/o evaluación de políticas públicas, cobran gran relevancia en procesos vinculados con la gestión asociada del territorio, configurándose como actores sociales de gran importancia para el fomento de condiciones que propendan por la equidad, la igualdad y la transformación social. Por lo tanto, se evidencian sus aportes en los dos ejes fundamentales planteados como categorías gruesas de esta investigación: la gestión del territorio y el ejercicio asociado de transformación de la lógica tradicional con que opera la administración pública, concebida esta última en perspectiva amplia involucrando la creación de escenarios en los que se propenda también por la eliminación de los efectos y causas de la violencia estructural y cultural como diría Johan Galtung.

\subsection{Síntesis}

La gestión del territorio para la paz y dentro de ella la gestión asociada del territorio, como campos de innovación investigativa involucran dos ejes temáticos fundamentales (gestión del territorio y construcción de paz) que a su vez establecen relaciones con 
otros temas en el contexto de diversidad de disciplinas y áreas dentro de las Ciencias Sociales y Humanas. Como discurso y práctica han sido construidas socio históricamente como una labor asignada a organismos o instituciones estatales y/o gubernamentales, sin embargo se dilucida que este campo de actuación y producción de conocimiento involucra diversidad de actores sociales cuyas acciones y elaboraciones están vinculadas con la construcción de condiciones de paz, ya que contribuyen en su cotidianidad a fomentar la equidad y la convivencia enmarcadas en la gestión democrática y competente del territorio.

Hacer un análisis a profundidad de los aspectos que están imbricados en la Gestepaz, demanda del estudio de términos y entramados simbólicos y contextuales tales como el territorio, se observa que se encuentran diversidad de nociones sobre esta palabra unas que lo asocian con la perspectiva socio-jurídica en donde aparece concebido como un ámbito fundamental para el Derecho Internacional, ya que su sentido está ligado con la definición de la soberanía de los estados, vemos en esta lógica un territorio significado en razón de su aspecto físico. Por otra parte, se evidencia una acepción legal en donde el territorio está vinculado con la perspectiva patrimonial, en una noción más objetivizada, encontramos entonces el territorio como objeto, que también es concebido desde la óptica de la jurisdicción estatal en términos de la asignación de competencias territoriales.

Diversidad de campos del conocimiento han hecho un acercamiento al territorio, logrando dar cuenta de su sentido y significado en un espacio y tiempo determinados; de manera que recorremos el camino que inicia en las Ciencias Naturales pasando por la Geografía, la Sociología, la Antropología hasta llegar a las Ciencias Políticas, en el estudio de estas elaboraciones se vislumbran los avatares conceptuales y éticos vinculados tanto con las lógicas territoriales como con la producción que subyace a éste en las dimensiones material, simbólica, política y social, de manera que se afirma que el territorio constituye un referente de construcción de identidad individual y comunitaria; en suma, se dilucida que entre la construcción de identidad individual y la comunitaria existe una relación dialéctica lo que representa un proceso interactivo de constitución de referentes simbólicos para el nosotros.

La Gestepaz como referente de acción busca encauzar los elementos asociados con la gestión pública, la descentralización, el desarrollo local, el control social de los recursos públicos y la participación a escenarios en los que se propenda por el reconocimiento (de derechos), la redistribución (de ingresos representada en niveles de inclusión y equidad social) y la representación (política y democrática de las y los ciudadanos) en el marco tanto de contextos caracterizados por la pervivencia del conflicto armado como el colombiano, donde se deben aunar esfuerzos y procurar sinergias en aras de fomentar la convivencia pacífica y la gestión democrática y competente del territorio así como aquellos otros escenarios en los que sí bien no se sitúa la violencia política como problema fundamental, sí se observan otros factores que promueven la desigualdad e inequidad social como el boliviano. 
Por su parte, el concepto de gestión aparece vinculado con la existencia de un fin específico, de una estrategia y unas dimensiones (económica, política, social, ambiental) en las que se materializan un conjunto de actividades que subyacen a un objetivo específico; el contexto social se inscribe como sujeto susceptible de análisis en términos de identificación de necesidades, actores involucrados, demandas y posibilidades de actuación. Esta perspectiva deja entrever dos acciones concretas desarrolladas en el ámbito de la gestión; en primera instancia encontramos aquellas orientadas al fortalecimiento de las capacidades territoriales y de los funcionarios en el campo de la política e inversión pública; en segundo lugar se hallan aquellas otras tendientes a garantizar condiciones adecuadas para operar los recursos en función de la garantía de los derechos de la población en el territorio, hablamos así de gestión del desarrollo humano. En razón de las dimensiones técnicas y políticas de la gestión se observa la adopción de diversidad de formas y modos de gestión, como resultantes de la interacción de racionalidades, actores e intereses enmarcados en la consecución y provisión de bienes y servicios, estos modelos de gestión pueden ser caracterizados desde cuatro ámbitos: el control técnico del proceso, la focalización, la capacidad de innovación, la relación entre las autoridades públicas y los ciudadanos.

Según la línea discursiva que orienta la elaboración de esta tesis doctoral, es importante remitirse a abordar la paz concibiéndola como una noción holística que va más allá del cese de hostilidades por parte de los grupos armados, se trasciende el objetivo de acabar con la violencia directa por ser un escenario de paz negativa, trasladando los esfuerzos al logro de la paz positiva que involucra la concepción del conflicto como potenciador de transformaciones, enfatizando con ello la presencia de la justicia social, esta perspectiva implica la existencia de estructuras políticas, sociales y económicas que propendan por la equidad y acceso a recursos e instancias de poder. En este sentido, el fomento de la cultura de paz se convierte en una piedra angular de la construcción de paz, en tanto vincula el abordaje de los tres tipos de violencia (directa, cultural y estructural) estableciendo una relación dialéctica entre sus componentes y características, de modo que

El proyecto de cultura de paz, en definitiva, sólo alcanza sentido en la medida que sea un instrumento útil para movilizar a la gente, para su propia transformación y la de su entorno. Frente a la violencia y el terror, además el discurso de la cultura de paz habría de ser como una batería para cargar pilas a la sociedad civil, a sus conciencias y a sus posibilidades de actuación, y (...) para rebelarse, conquistar el alma y derrotar cultural y espiritualmente a la violencia, redefiniendo la democracia, la civilidad y la esfera de lo sacro. (Fisas, 1998, p. 14)

Es en este contexto en donde la construcción de paz o peacebuilding cobra relevancia como proceso integral que incluye tanto la necesidad de eliminación de la violencia directa, como los esfuerzos que deben hacerse para derribar definitivamente los mecanismos de exclusión vinculados con las violencias cultural y estructural. La 
literatura consultada pone en evidencia una producción escrita afincada en la concepción de construcción de paz como proceso postconflicto, sin embargo, también se dilucida que es fundamental concebirlo holísticamente como generador de condiciones antes, durante y después de un posible periodo posterior al conflicto. En esta perspectiva se involucra la buena gobernanza entendida como pilar promotor de la participación política, la equidad, la tolerancia, la eficiencia y la efectividad gubernamental, a saber una gestión democrática y competente que fomente la equidad y justicia social.

El desarrollo se convierte en uno de los preceptos que promueven la Gestepaz, debe ser visto desde una lectura temporal y contextual en razón de identificar sus sentidos y significados a la luz de los acontecimientos y condiciones de la esfera social en un momento y tiempo determinados. De igual manera, influyen en la conceptualización de desarrollo diferentes corrientes de pensamiento, así como teorías como la escuela neoclásica keynesiana, la positivista, la del crecimiento por etapas, el crecimiento polarizado, el estructural funcionalismo entre otras, para finalmente hablar de la planificación del desarrollo como instrumento de análisis, diagnóstico y formulación de propuestas de cambio.

Las nociones de desarrollo transitan desde concepciones economicistas hasta aquellas otras ligadas con el desarrollo humano como aspecto fundamental. Con el advenimiento de los planteamientos de Amartya Sen sobre la importancia de partir de las capacidades humanas como expresión de la libertad, se estructura una nueva forma de pensamiento sobre el desarrollo, centrada en el reconocimiento de recursos, potencialidades y habilidades de los individuos para emplear sus capacidades adquiridas. Con Max Neef hablamos del desarrollo a escala humana cuyo objetivo es la promoción de procesos endógenos o propios, vinculados con la necesidad e importancia de que se inscriba en este escenario la satisfacción de necesidades humanas para aumentar progresivamente la auto dependencia que evidencia las relaciones entre ser humano-naturaleza, ámbito personal-social, tecnología-procesos globales, planificación-autonomía y Sociedad Civil-Estado. En este punto se habla del IDH y la necesidad de afinar sus indicadores en términos de vincular los logros individuales en relación a las variables de salud, educación e ingreso; igualmente es importante tener en cuenta la incidencia que sobre éste tienen factores externos como el conflicto armado y la concentración de la propiedad, lo cual se ve reflejado en la propuesta de medición hecha por el PNUD en el Informe de Desarrollo Humano, Colombia 2011, un IDH ajustado que incluye los mencionados factores externos, como variables de incidencia en el desarrollo humano de la población.

El escenario del desarrollo local y comunitario que propende por reivindicar la identidad y el territorio como generadores y potenciadores de dinámicas económicas, sociales y culturales, está inscrito en la Gestepaz en donde la participación se convierte en su insumo fundamental. En él convergen las dimensiones: sociocultural, política administrativa y económica en las que se despliega una relación dialéctica entre el 
contexto local y las comunidades, como actores a través de la participación directa o indirecta en iniciativas de promoción de espacios de incidencia en toma de decisiones, así como en escenarios de gestión pública y control social para la transparencia. Todo lo anterior incorporando el enfoque diferencial que busca leer los problemas sociales desde su impacto diferenciado sobre los colectivos de población, poniendo en evidencia la importancia de estructuras políticas que estén acorde con las realidades sociales locales, enfoque que también puede aplicarse al ámbito territorial en tanto los territorios no son homogéneos, sino que por el contrario poseen particularidades en razón de características sociales, culturales, ambientales, económicas y políticas que le son inherentes.

La aplicación del enfoque diferencial en el espacio territorial nos remite a identificar los importantes aportes de las organizaciones sociales a la Gestepaz fundamentalmente en: el desarrollo de procesos que promueven la no discriminación en el ejercicio de derechos, la inclusión social y el acceso equitativo a los recursos y servicios del Estado; el reconocimiento de las vulnerabilidades y necesidades particulares de cada grupo poblacional; la promoción del acceso en forma equitativa a la toma de decisiones, la participación y la organización social; la realización de acciones positivas para desarrollar la autoestima y la autonomía de las personas, particularmente aquellas que pertenecen a comunidades históricamente excluidas y la eliminación de estereotipos culturales que obstaculizan el libre ejercicio de los derechos y la inclusión social, aspectos que serán abordados con mayor profundidad en los siguientes capítulos. 


\section{CAPÍTULO 2. PLANIFICACIÓN PARTICIPATIVA Y GESTIÓN ASOCIADA COMO MARCO DE ACCIÓN DE LAS POLÍTICAS PÚBLICAS: REPENSAR LO COLECTIVO}

El estudio de las políticas públicas implica el acercamiento a dinámicas de orden teórico-conceptual, metodológico e incluso ético-político para su estructuración, definición y concreción; así como el conocimiento y análisis crítico de las dimensiones sociales, políticas y económicas que enmarcan la discusión sobre el quehacer de las Ciencias Sociales y Humanas en este campo; dichos escenarios constituyen el pre-texto y contexto para la previsión, la decisión y la acción a través de planes, programas y proyectos para transformar las realidades sociales de exclusión y desigualdad, en las que se reproduce la cuestión social. Pensar las políticas públicas implica realizar un recorrido por el devenir histórico de la acción sobre lo público, implica desentrañar las fuerzas y vicisitudes de la definición de iniciativas, acciones y decisiones, frente a la solución de situaciones socialmente problemáticas, que afectan la calidad de vida de los colectivos de población y que a su vez interrogan las posibilidades de respuesta frente a dichas situaciones problema, iniciativas en las que a su vez retomando planteamientos de varios teóricos como Oszlak (1994) se expresa la oportunidad de analizar el curso del Estado en acción.

Por otra parte, resulta importante realizar un balance retrospectivo y prospectivo sobre las posibilidades de construcción de los planes, programas y proyectos de política pública, en el sentido de potenciar la reflexión de cada uno de los momentos de lo que se ha llamado el ciclo de las políticas, que a grandes rasgos aparece constituido por las etapas de: planeación-formulación-diseño; implementación o ejecución y 
seguimiento/evaluación. Momentos que no pueden concebirse como compartimentados o como lineales, sino que devienen como apuestas de estructuración y de re contextualización a la luz de los cambios de contextos de aplicación de las políticas públicas.

\subsection{Teoría y conceptos sobre Política Pública}

Cuando se habla de política pública es necesario hacer una alusión a la concepción sobre lo público, en tanto es lo que permite definir los sentidos y contenidos de este conjunto de iniciativas, pero también representa la posibilidad de reflexionar sobre un escenario ampliado y de interacción-participación de múltiples actores sociales que convergen en la previsión, decisión y acción pública. Lo político y lo público no es algo que compete única y exclusivamente al Estado como ha sido considerado históricamente, aludir a lo político y lo público es destacar un escenario multiactoral en el que se piensa un proyecto de sociedad colectivo, de interés general.

Este planteamiento está por demás alejado de concebir actores sociales homogéneos que piensan igual y que no dan lugar a la pugna y contradicción de intereses, es una apuesta por la reinvención democrática de las relaciones entre Estado-Sociedad así como gobierno-sociedad, se parte de la premisa que menciona la importancia de construir un escenario multipropósito de planificación-gestión, en donde las lógicas de colectividad, articulación de actores-intereses-escenarios, constituye la configuración por consenso de procesos de toma de decisión en donde los actores son concebidos como legítimos otros y construyen participativa y colectivamente las políticas públicas. Pensar un escenario con estas características, implica la transformación de las lógicas tradicionales de planeación de programas y proyectos, en donde la construcción se asigna a los expertos, a los gobiernos o a los estados como únicos actores; implica apuestas políticas por la articulación y metodologías adecuadas para construir un escenario con estas características.

En este marco conceptual re-pensar lo público es un elemento ineludible para conceptualizar o reflexionar sobre la política pública. En primer lugar, se dilucida la autonomía de las esferas estatal y público social, entendiendo que lo público no solo obedece al Estado, sino que se enraíza en todas las discusiones que son de interés común, involucrando tanto al estado como a la sociedad. Así se vislumbra la reflexión sobre autonomía toda vez que las dos esferas (estado-sociedad) tienen sus propias lógicas de configuración, consolidación y fortalecimiento, pero deberían establecer sinergias frente a la toma de decisiones, la definición de agendas y la estructuración de políticas y acciones públicas.

Retomando la idea según la cual -igualdad política, pluralismo político y deliberacióncorresponden a lo público y configuran claves para los procesos de participación, se halla también que en ellas están inmersos los procesos de construcción de políticas públicas de la mano de reflexiones profundas sobre los sentidos (lógicas), contenidos y significados (implicaciones) de la participación sustantiva, que en términos de la 
relación pública estatal aparece vinculada con la construcción de escenarios de debate colectivo en la cosa pública en general. Sí se realizara el análisis de los elementos anteriormente mencionados en el marco de un contexto neoliberal, se lograría vislumbrar que asimismo la relación entre el ámbito privado estatal, está ligada con el posicionamiento de este ente como integrante de intereses privados, agente de la acción a partir de la sumatoria de intereses heterogéneos que persiguen el alcance de objetivos determinados que en este escenario perpetuarían la individualidad por encima de lo colectivo, la organización social y los intereses comunes.

Sin pretender hacer una referencia exhaustiva a las discusiones que desde el ámbito académico abordan el tema de "lo público", en este punto de la disertación sí vale la pena hacer alusión a algunos elementos importantes para situar el lugar que ocupa ésta, en términos de construcción de otros escenarios epistémicos reflexivos, como la ciudadanía y los derechos o la construcción y/o fortalecimiento de capacidades. En este sentido, dicho espacio permite trascender la reflexión, para desentrañar los límites de inscripción entre la vida social y la vida política, de forma que lo público representa entonces "el ámbito de la ciudadanía libre para el tratamiento debatido de los asuntos comunes" (Garay, 2000: 15)2. En tanto hablamos de una relación bidireccional y de coconstrucción entre estado y sociedad, hablamos de lo accesible y concerniente a toda la gente y lo pertinente al bien común o al interés compartido (Ibíd.)

Siguiendo los aportes de Arendt (citada por Cunill, 1997) se dilucida que la existencia de esta instancia -lo público-, posibilita a su vez la emergencia de un espacio social privilegiado, que fomenta la interacción de diversos actores en escenarios de deliberación, dando paso con ello a alternativas de discusión conjunta sobre los elementos definitorios de la identidad, la pertenencia y la diferencia en grupos de población que a través de su acción articulada, amplían la conciencia sobre aspectos de corresponsabilidad frente a lo colectivo, favoreciendo así las condiciones de comunicación, e intercambio relacional como posibilidades de instauración progresiva de escenarios de diálogo de saberes o negociación cultural, con miras a lograr el funcionamiento armónico, transparente, vinculante e inclusivo de la cosa pública. Aparece buscando cabida y oportunidades de consolidación, la conciencia colectiva como ámbito de creación de actores sociales, cuya acción permea e incide en escenarios de toma de decisiones desde un llamado a lo colectivo como posibilidad de resurgimiento democrático de la participación.

Entre tanto y tomando como referente básico la reflexión suscitada hasta aquí la construcción de políticas públicas demanda insistentemente la motivación, promoción y aseguramiento de garantías de participación política, en procesos cuyo producto es la toma de decisiones y en virtud de ello -desde lo ético- los asuntos de interés general o colectivo. Así se da paso al reconocimiento de la necesidad de fortalecer el escenario público social por medio de dos formas a saber: el asociacionismo crítico como espacio en el que la ciudadanía en general conforma un tejido que se dispone a propender por la

2Garay Luis Jorge. "Algunas concepciones teóricas sobre lo público: una aproximación básica" En: Ciudadanía, lo público, democracia. Textos y notas. Bogotá, 2000. P. 15 
democracia, la construcción de valores y de formas de vida que generen relaciones en lo social, cada vez más igualitarias.

En segunda instancia, se habla de la creación de una comunidad crítica, donde no solo se transforman las relaciones en lo social, sino que además de ello se vehiculan procesos de seguimiento y control al ejercicio estatal, en virtud de procesos de democratización social. Respecto a la esfera pública social se habla de un fortalecimiento que lleva consigo la resignificación de la cultura pública y social como conjunto de perspectivas, creencias, actitudes y valores sobre el sistema político y el rol determinante de los individuos en dicho sistema, pero también y como aspecto importante se alude al reconocimiento de la esfera pública social como actor político significante y significativo en las dinámicas estatales.

Además de lo anterior, es importante resaltar lo fundamental de aunar esfuerzos en torno a la transformación de la esfera pública estatal, donde se deben procurar acciones tendientes a cambiar las dinámicas actuales, de manera que se de paso con ello a la democratización social de escenarios estatales, a partir de dinámicas de regulación y no de constitución, por lo cual es fundamental que el control social a la gestión pública no sea una mera delegación de funciones propias del Estado a las organizaciones, sino que verdaderamente las experiencias de veeduría constituyan escenarios de integración Estado-sociedad que expresen la trascendencia de los intereses particulares a la opción por lo colectivo, a partir de ámbitos de inscripción del pluralismo en la representación social.

La definición de políticas públicas aparece articulada con la definición de términos del inglés como politics: que implica consenso y policy: que expresa lo que el gobierno hace o no. Al hacer un estado de la cuestión sobre el tema se encuentran nociones como: "Forma particular de decidir y ejecutar acciones de gobierno" (Gault y Blanco, 2013); "Tipo de actividad del gobierno, aquella que se encamina a estimular la colaboración social o inhibir el conflicto... cauce que determina y orienta el curso a seguir por la actividad gubernamental" (Guerrero, 1993). Y otras como la de Vargas Alejo que expresa que son un "Conjunto de sucesivas iniciativas, decisiones y acciones del régimen político frente a situaciones socialmente problemáticas, que buscan la resolución de las mismas o llevarlas a niveles manejables" (Vargas, 1999: 58) en estas definiciones se encuentran como elementos comunes la alusión a dinámicas de previsión, decisión y acción como elementos constitutivos de las políticas públicas.

Entendidas como proceso de toma de decisiones emergentes de la compleja relación entre Estado, Sociedad y mercado, y del escenario público ${ }^{3}$ y político que involucra disputas de poder y ventajas en función de incidir sobre y desde intereses, se trasciende su comprensión como meras respuestas que el Estado da a las demandas de una sociedad, en forma de leyes, instituciones o servicios. La Política Pública emanada del Estado, es un resultado de la conjunción de propósitos, lineamientos, oposiciones,

3 Estado, Gobierno. 
enfrentamientos, coaliciones y compromisos, que configuran los contenidos, los sentidos y los alcances de las mismas.

Desde perspectivas como la de Oszlak (1994) también las políticas públicas son vistas como conjunto de sucesivas tomas de posición de los diversos actores frente a situaciones socialmente problemáticas en el marco de una particular arena de conflicto político, que permite observar patrones de diferenciación, integración e interdependencia entre los actores sociales.

En tanto actividad de comunicación pública, las políticas públicas juegan un papel de ordenador de las simbólicas que definen la relación y lugar de los sujetos con las instituciones, entendiéndolos como actores sociales de Derechos que son promovidos desde su lugar de agencia, incidencia y participación en los procesos implicados en las mismas. En la lógica de análisis de la ciencia política tradicional se encuentran aportes como los de J. Lowi, en donde se señala que de acuerdo al carácter de aplicabilidad y a la extensión social de las políticas, éstas se pueden clasificar como regulatorias ${ }^{4}$, distributivas y redistributivas. En donde la clasificación, está vinculada con el parámetro de coerción que representarían. De esta forma se halla que las distributivas corresponden a suministros directos de servicios públicos a los ciudadanos; las regulatorias, de la economía y los mercados y las redistributivas conciernen a las transferencias de ingresos a ciudadanos, empresas, asociaciones o colectividades.

Tabla 3 Tipologías de Políticas Públicas.

\begin{tabular}{|c|l|l|}
\hline \multirow{2}{*}{ Probabilidad de coerción } & \multicolumn{2}{|c|}{ Aplicabilidad de la coerción } \\
\cline { 2 - 3 } & Comportamiento de individuos & \multicolumn{2}{|c|}{ Medio ambiente/entorno } \\
\hline Débil & Políticas distributivas & $\begin{array}{l}\text { Políticas de gasto público } \\
\text { (infraestructura) }\end{array}$ \\
\hline Fuerte & Políticas regulatorias & Políticas redistributivas. \\
\hline
\end{tabular}

Fuente: Vargas Alejo. Notas sobre Estado y políticas públicas. Almudena. Bogotá, 1999

Sí la clasificación estuviese orientada en función de la incidencia de los actores y colectivos sociales sobre las mismas, estas podrían ser de carácter directivo, jerárquicas o participativas. Ello quiere decir, que más que una acción neutra, la Política Pública es un ejercicio intencionado de decisiones, que encuadra un proceso y una pregunta. Un proceso que cobra relevancia en el terreno de verificar que tanto se van modificando objetivamente las condiciones incidentes en los procesos de inclusión, equidad y realización de derechos ${ }^{5}$. Una pregunta que interroga sobre ¿Quién toma las decisiones?, ¿Para qué se toman? Y ¿Sobre quién o qué se toman?

\footnotetext{
${ }^{4}$ De la economía y los mercados

${ }^{5}$ Estrechamente vinculados con la dignidad humana y el respeto por la vida individual y colectiva.
} 
Pregunta que permite entender el marco de relaciones sociales existentes ${ }^{6}$ detrás de los procesos de cristalización de los arreglos político-institucionales (O’Donell y Schmitt, 1988) a los que se lleguen.

Es importante destacar que la construcción de política pública está influenciada por diversos factores, unos vinculados con el contexto internacional en tanto que las coyunturas y temas-problema abordados desde este ámbito externo, determinan la entrada de una situación problemática nacional en la agenda pública. De igual manera, el régimen político incide en la inserción de un tema en agenda para la posterior estructuración de políticas públicas, la naturaleza específica de un régimen político determina, de manera crucial, la estructuración de las políticas públicas; no solo se pregunta ¿Quién? Y ¿Cómo? Sino sobre las formas de gobernar (formas institucionales) y modos de gobierno (prácticas culturales) como dos escenarios en permanente tensión, en este sentido se halla que el régimen político en el ciclo de políticas públicas:

a) Se convierte en el ordenamiento que da identidad a la idea de Estado: la forma de aparato estatal, define instituciones y contenidos

b) Confiere organicidad y orden a las relaciones entre Estado-Sociedad. Imprime sentido normativo y contenido valorativo a las relaciones sociales.

c) Permite que el Estado tenga orden interno (unidad instituciones estatales) y externo (factor de cohesión de estructuras y principios de la vida en sociedad)

d) Constituye un ordenamiento mediante el cual el Estado confiere poder y autoridad a los gobernantes para toma de decisiones (asigna competencias, establece controles, caminos de participación decisional)

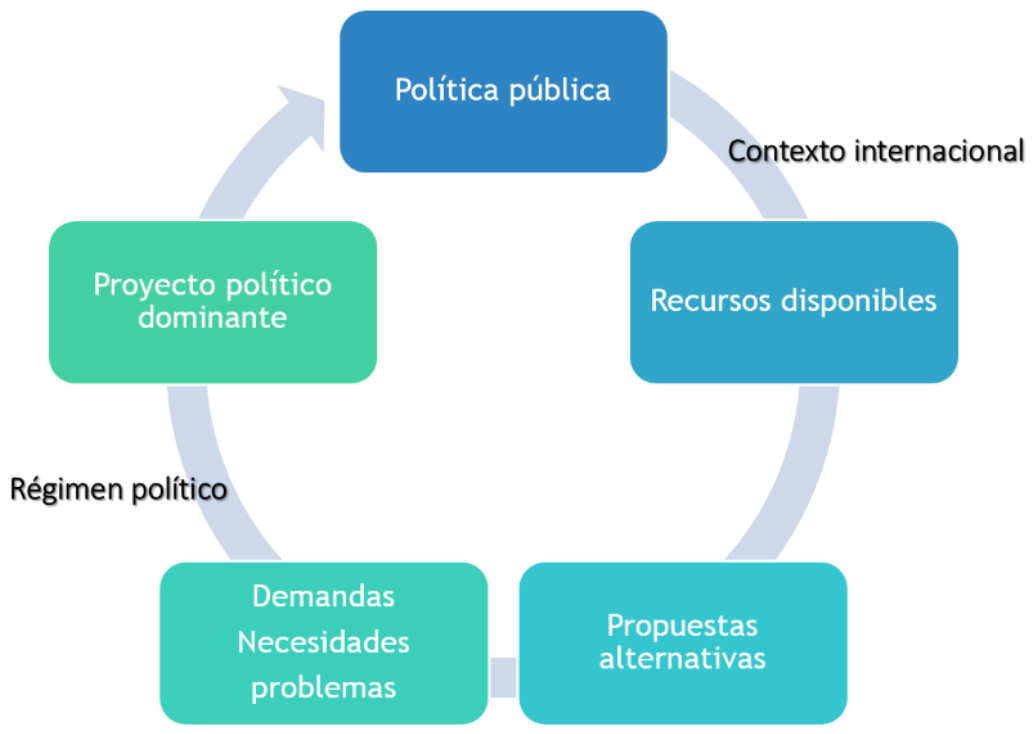

Fuente: Vargas (1999). Notas sobre Estado y políticas públicas. Almudena. Bogotá.

Figura 8. Factores que inciden en construcción de Políticas Públicas.

\footnotetext{
${ }^{6}$ Acciones colectivas, movimientos sociales que influyen desde la sociedad en su diseño, decisión e implementación. (en Acuña, Camou, Jordana, Moe, y Tsebellis).
} 
De manera que resulta indispensable desentrañar el ordenamiento constitucional: principios, códigos y normas específicas que ordenan y regulan la lógica de operación y concreción del Estado en acción, así como identificar la especialización funcional: estructuración jerárquica del poder que rige y regula la acción, al caracterizar estos aspectos se estará realizando a la par una caracterización de las estructuras y caminos institucionales que implementan la política pública y que constituyen elementos de incidencia en el proceso de construcción de este conjunto de iniciativas, acciones y decisiones.

\subsection{Ciclo de políticas públicas}

Hablar del ciclo de las políticas públicas implica aludir a momentos específicos en los que se materializa la acción de estado. Las formas de concebir las políticas, determinan en definitiva un modo de operación en cuanto a su implementación y por supuesto seguimiento y evaluación, ello evidencia el conjunto de discursos y prácticas que forman parte del proceso de concreción y tránsito del tema-problema a la acción. De manera que se destacan dos posibilidades la primera de ellas en donde la política pública se concibe linealmente como un conjunto de fases ordenadas desde el inicio hasta la evaluación, la sucesión expresa una consecución de etapas y dicha visión etapista establece procesos jerárquicos y objetivos.

Mientras que la visión de las políticas como cíclicas aporta la concepción de éstas como momentos parte de un ciclo que interactúa permanentemente y no se identifica fácilmente su inicio y su fin, dada la situación de interdependencia. Justamente la noción de las políticas como ciclo y como proceso conformado por momentos particulares, es la que se retoma para orientar el presente trabajo de investigación, puesto que una de las hipótesis que resultan de allí es que sí se generan cambios en uno de los momentos del ciclo, dígase por ejemplo la evaluación se estará influenciando todos los demás momentos de los que éste se conforma, dicha influencia se menciona en varios sentidos el primero en cuanto a la forma en que se concibe la participación ciudadana, otro en cuanto a la parte de operativización de las políticas es decir cómo se llevan a cabo las acciones y tres la incidencia que puedan o no puedan tener los ciudadanos en todo el proceso.

Ahora conservando como punto constitutivo del análisis, esa visión cíclica de la que se viene hablando se aludirán a algunas particularidades del ciclo de la política retomando los planteamientos de Medellín (2004) que parecen generar aportes importantes en cuanto a aspectos de caracterización de los momentos por los que el llamado ciclo transita.

Se menciona el inicio y surgimiento en donde se configura el problema social y transita a convertirse en situación socialmente problemática. Posteriormente se habla de un escenario de formulación o toma de decisión en el que las instituciones estatales o el sistema político institucional valora las alternativas de solución para elegir la mejor. Igualmente se ubica una etapa denominada como de ejecución o implementación en 
donde se da la materialización de decisiones que involucra instituciones estatales y participación privada o ciudadana etc. La etapa de evaluación se convierte en la posibilidad de valorar los resultados, efectos o impactos de la política pública para reformular o modificar las acciones que así lo requieran.

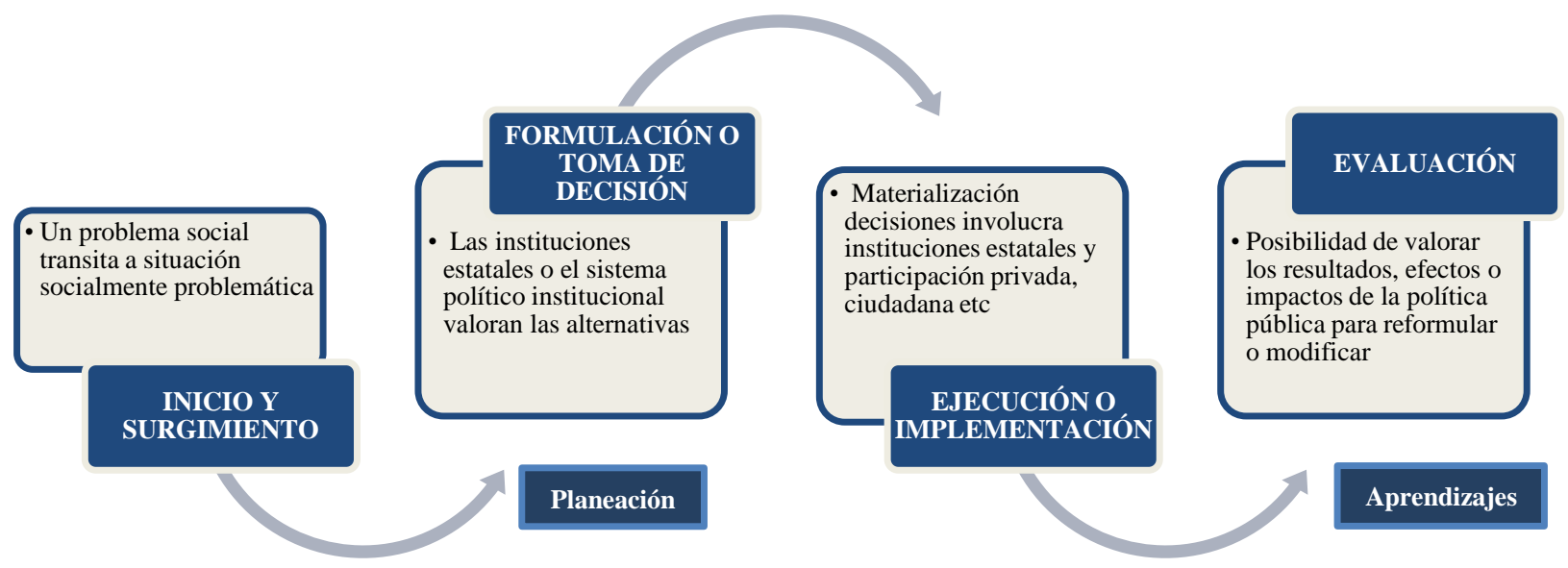

Fuente: Elaboración propia, 2014.

Figura 9. Visión lineal de las políticas públicas.

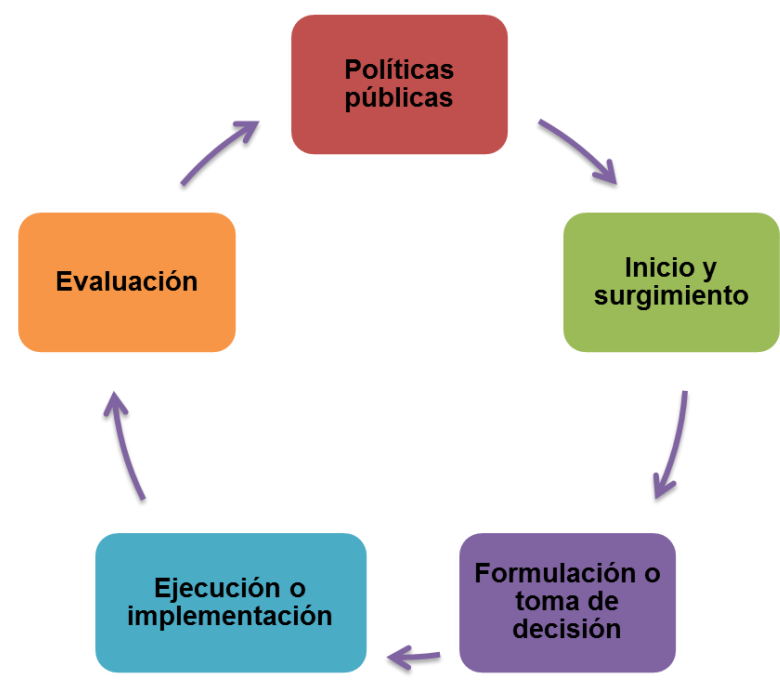

Fuente: Elaboración propia, 2014.

Figura 10. Visión cíclica de las políticas públicas.

Como se evidencia en el anterior gráfico el ciclo de la política pública está conformado por 4 momentos clave para la estructuración de planes, programas y proyectos. Entendemos a la estructuración como: "el producto de un intenso proceso político a través del cual emergen y toman forma los proyectos e intereses de agentes (individuos), agencias (instituciones) y discursos (sintesis de la interacción entre agentes y agencias) en pugna por imponer un determinado proyecto de dirección 
política y de dirección ideológica sobre la sociedad y el estado que son gobernados" (Medellín, 2004: 26), es el proceso que atraviesa una política pública para la toma de decisiones y puesta en marcha de planes, programas y proyectos. Intervienen allí múltiples factores, al igual que múltiples tomas de postura y decisión que requerirían en estricto sentido la participación y vinculación temprana de todos los sectores y actores que de alguna u otra forma tienen que ver con la definición de la situación socialmente problemática y la respectiva estructuración de acciones e iniciativas para resolverla.

Es importante considerar que en el ciclo de política pública intervienen múltiples factores incidentes en el proceso de diseño y formulación, pugnas de intereses y fuerzas; tensiones y conflictos que se activan, equilibran y reactivan en la dinámica de estructuración. En este sentido, el reconocimiento de estos factores de convergencia genera una posibilidad de ampliación del panorama de análisis de los momentos que subyacen a dicho ciclo de políticas, desde esta perspectiva la propuesta de Pedro Medellín (2004) al respecto resulta interesante ya que se plantea una etapa de reconocimiento de dichas divergencias.

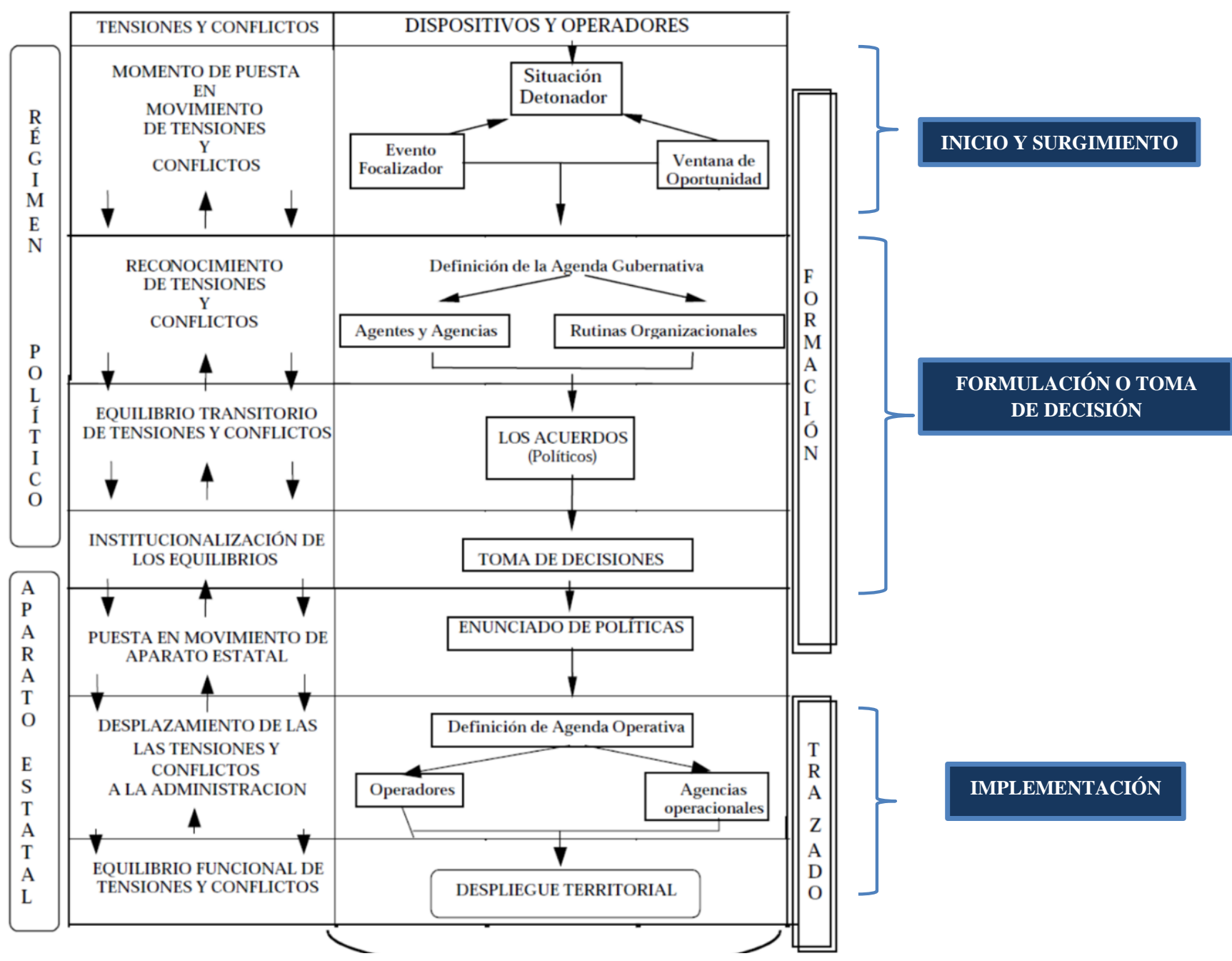

Fuente: Medellín, Pedro. CEPAL, 2004.

Figura 11. Proceso de estructuración de las Políticas Públicas. 


\subsubsection{Diseño de políticas}

Pensar momentos como la formulación de políticas públicas o la toma de decisiones, implica a su vez pensar en los sentidos y significados de la planificación social ya que en ello consiste el ejercicio de proyectar alternativas y/o estrategias que materializadas en planes, programas y/o proyectos contribuyan a mejorar el desarrollo o solucionar la situación socialmente problemática. Este proceso de planeación u ejercicio prospectivo desde el deber ser incluye una opción política, por fomentar la participación de la sociedad civil como forma de anticipación a la toma de decisiones y a la construcción de proyectos colectivos, impulsando así las dinámicas de fortalecimiento de lo público para la ciudadanía.

Cuando se hace referencia a procesos de planeación de planes, programas y proyectos por ende de políticas públicas, es posible hallar diversas escuelas de planificación en América Latina, a través de las cuales se han desarrollado diversas metodologías para orientar los procesos de estructuración, entre ellas se destacan las que son consignadas en la siguiente matriz analítica:

Tabla 4. Escuelas de la planificación

\begin{tabular}{|c|c|c|c|c|}
\hline \multicolumn{5}{|c|}{ Planificación tradicional-normativa } \\
\hline Características & $\begin{array}{l}\text { Cómo se } \\
\text { entiende } \\
\text { planificar }\end{array}$ & Paradigmas & $\begin{array}{l}\text { El proceso de } \\
\text { planificar }\end{array}$ & Críticas \\
\hline $\begin{array}{l}\text { Formaliza la } \\
\text { intervención } \\
\text { pública para } \\
\text { asegurar } \\
\text { coherencia, } \\
\text { eficacia } \\
\text { eficiencia. y } \\
\text { Estructuración } \\
\text { total de } \\
\text { problemas }\end{array}$ & $\begin{array}{l}\text { Actividad } \\
\text { técnico-política } \\
\text { para verificar el } \\
\text { grado de alcance } \\
\text { de objetivos } \\
\text { propuestos. } \\
\text { No se refiere al } \\
\text { qué hacer sino al } \\
\text { cómo hacerlo }\end{array}$ & $\begin{array}{l}\text { Objetivo: } \\
\text { división sujeto de } \\
\text { la planificación y } \\
\text { objeto de } \\
\text { intervención. } \\
\text { Método } \\
\text { científico- } \\
\text { positivista. } \\
\text { El marco teórico } \\
\text { de orientación es } \\
\text { funcional a } \\
\text { intereses de } \\
\text { proyecto político. }\end{array}$ & 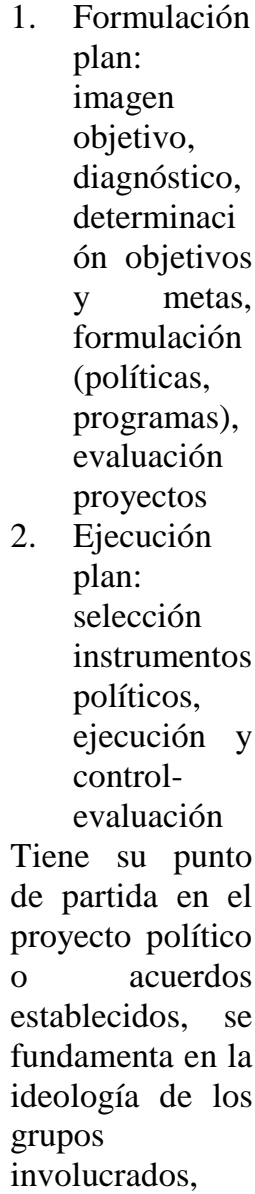 & $\begin{array}{l}\text { - Visiones únicas. } \\
\text { Sistema que sigue } \\
\text { leyes. Certidumbre } \\
\text { Al servicio de } \\
\text { proyectos políticos } \\
\text { dominantes } \\
\text { - Priman los factores } \\
\text { económicos para } \\
\text { proyectar la imagen } \\
\text { objetivo y ejecutar. } \\
\text { Cálculo económico } \\
\text { del ser } \\
\text { Restringida a los } \\
\text { actores } \\
\text { gubernamentales, } \\
\text { formalista, centrada } \\
\text { en el diseño. } \\
\text { Final cerrado, } \\
\text { demasiada de } \\
\text { estructuración dén de } \\
\text { problemas: única } \\
\text { posibilidad } \\
\text { acción de } \\
\text { Reduccionista }\end{array}$ \\
\hline
\end{tabular}


Tabla 5. Escuelas de la planificación (Continuación)

\begin{tabular}{|c|c|c|c|c|}
\hline \multicolumn{5}{|c|}{ Planificación situacional. Carlos Matus } \\
\hline Características & $\begin{array}{l}\text { Cómo se } \\
\text { entiende } \\
\text { planificar }\end{array}$ & Paradigmas & $\begin{array}{l}\text { El proceso de } \\
\text { planificar }\end{array}$ & Críticas \\
\hline $\begin{array}{l}\text { Sujetos dentro } \\
\text { del objeto que } \\
\text { contiene sujetos. } \\
\text { Explicación } \\
\text { situacional. } \\
\text { Incertidumbre } \\
\text { Final abierto, } \\
\text { cuasi } \\
\text { estructuración de } \\
\text { los problemas }\end{array}$ & $\begin{array}{l}\text { Todos } \\
\text { planificamos. } \\
\text { Proceso social a } \\
\text { construir a partir } \\
\text { del análisis } \\
\text { situacional } \\
\text { Más de una } \\
\text { posibilidad de } \\
\text { acción. }\end{array}$ & $\begin{array}{l}\text { Subjetividad del } \\
\text { conocimiento } \\
\text { Metodologías de } \\
\text { investigación } \\
\text { participativa. } \\
\text { - Conocer la } \\
\text { realidad } \\
\text { encontrándos } \\
\text { e en ella } \\
\text { Los sistemas } \\
\text { sociales en } \\
\text { su dinámica } \\
\text { crean sus } \\
\text { propias leyes }\end{array}$ & 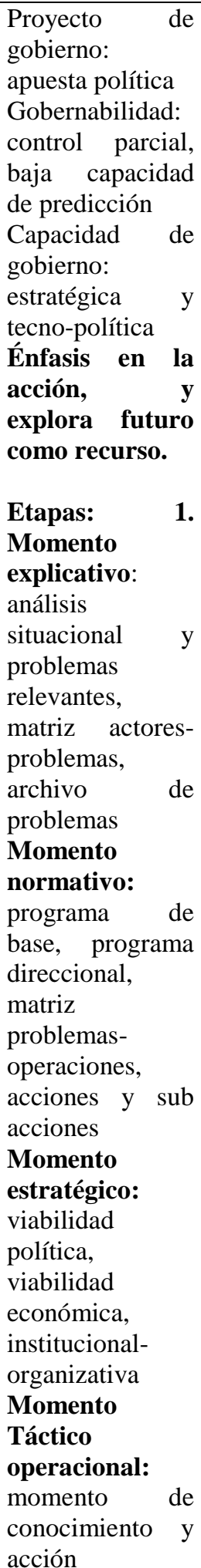 & $\begin{array}{l}\text { La participación se } \\
\text { plantea como } \\
\text { importante, a partir de la } \\
\text { diversidad de análisis, } \\
\text { pero no es condición } \\
\text { para el proceso. } \\
\text { El cómo lograr la } \\
\text { participación en el } \\
\text { proceso para no caer en } \\
\text { lo tradicional no se } \\
\text { evidencia claramente } \\
\text { Dificultades } \\
\text { aplicación práctica }\end{array}$ \\
\hline
\end{tabular}


Tabla 6. Escuelas de la planificación (Continuación)

\begin{tabular}{|c|c|c|c|c|}
\hline \multicolumn{5}{|c|}{ Planificación estratégica } \\
\hline Características & $\begin{array}{l}\text { Cómo se } \\
\text { entiende } \\
\text { planificar }\end{array}$ & Paradigmas & $\begin{array}{l}\text { El proceso de } \\
\text { planificar }\end{array}$ & Críticas \\
\hline $\begin{array}{l}\text { Origen en } \\
\text { administración } \\
\text { del desarrollo y } \\
\text { escuelas de } \\
\text { negocios. } \\
\text { Método DOFA. } \\
\text { Crear relación } \\
\text { entre } \\
\text { capacidades } \\
\text { internas } \\
\text { posibilidades } \\
\text { externas }\end{array}$ & $\begin{array}{l}\text { La } \\
\text { responsabilidad } \\
\text { por el control y } \\
\text { conocimiento } \\
\text { debe descansar } \\
\text { en el directivo de } \\
\text { máxima } \\
\text { jerarquía } \\
\text { La estrategia es } \\
\text { el patrón que } \\
\text { integra las } \\
\text { principales metas } \\
\text { y políticas de } \\
\text { una } \\
\text { organización, } \\
\text { establece una } \\
\text { secuencia } \\
\text { coherente de } \\
\text { acciones }\end{array}$ & $\begin{array}{l}\text { Único de la } \\
\text { visión } \\
\text { empresarial. } \\
\text { La estrategia es } \\
\text { guiada por } \\
\text { planificadores } \\
\text { expertos. }\end{array}$ & $\begin{array}{ll}\text { Misión } & \\
\text { Visión } & \\
\text { Instrucciones } & \text { de } \\
\text { planificación } & \text { en } \\
\text { niveles } & \\
\text { jerárquicos } & \\
\text { Carta } & \\
\text { negocios } & \\
\text { Identificación de } \\
\text { modos } \\
\text { competir } \\
\text { Formulación } \\
\text { estrategias } \\
\text { negocios, de } \\
\text { presupuestos } \\
\text { funcionales etc }\end{array}$ & $\begin{array}{l}\text { Lógica estrictamente } \\
\text { jerárquica en las } \\
\text { organizaciones } \\
\text { Proviene del mundo } \\
\text { privado. } \\
\text { Enfatiza demasiado en la } \\
\text { formación de una } \\
\text { estrategia } \\
\text { Excesiva formalidad, } \\
\text { separación tajante en } \\
\text { etapas, la planificación } \\
\text { como responsabilidad } \\
\text { principal de los } \\
\text { planificadores y no } \\
\text { involucramiento den el } \\
\text { diseño de r los } \\
\text { responsables de ejecutar }\end{array}$ \\
\hline \multicolumn{5}{|c|}{ Planificación prospectiva } \\
\hline Características & $\begin{array}{l}\text { Cómo se } \\
\text { entiende } \\
\text { planificar }\end{array}$ & Paradigmas & $\begin{array}{l}\text { El proceso de } \\
\text { planificar }\end{array}$ & cas \\
\hline $\begin{array}{l}\text { Los seres } \\
\text { humanos pueden } \\
\text { tener impacto en } \\
\text { el futuro. Hay } \\
\text { varios futuros }\end{array}$ & $\begin{array}{lr}\text { Conjunto } & \text { de } \\
\text { conceptos, } & \\
\text { teorías, } & \\
\text { metodologías } & \text { y } \\
\text { técnicas } & \text { para } \\
\text { analizar, prever, } \\
\text { explicar } & \text { y } \\
\text { construir } & \text { futuros } \\
\text { posibles } & \text { y } \\
\text { deseables } & \end{array}$ & $\begin{array}{l}\text { Integra } \\
\text { pensamiento } \\
\text { científico con el } \\
\text { pensamiento } \\
\text { estratégico. } \\
\text { Visualizar un } \\
\text { destino } \\
\text { construirlo } \\
\text { competitivamente }\end{array}$ & $\begin{array}{l}\text { En donde } \\
\text { estamos } \\
\text { Hacia dónde } \\
\text { vamos } \\
\text { Hacia dónde } \\
\text { queremos ir } \\
\text { Hacia donde } \\
\text { podemos ir } \\
\text { Que hacer ahora } \\
\text { Escenarios: tiene } \\
\text { sentido a través } \\
\text { de resultados y } \\
\text { consecuencias } \\
\text { para la acción }\end{array}$ & $\begin{array}{l}\text { Continua hablando de la } \\
\text { lógica empresarial } \\
\text { La fase de elección de } \\
\text { opciones estratégicas } \\
\text { corresponde a un } \\
\text { número limitado de } \\
\text { personas (miembros del } \\
\text { comité de la empresa) } \\
\text { El árbol } \\
\text { competencias, } \\
\text { Es una prospectiva del } \\
\text { entorno competitivo }\end{array}$ \\
\hline
\end{tabular}

Fuente: Umbarila (2014)

De manera que la pregunta por las lógicas y contenidos de los procesos de planificación se sitúan en la etapa de diseño del ciclo de políticas públicas. Conforme al modelo de planeación, implementación es una extensión del diseño. Lo cual significa dos cosas, primero la pertinencia de las políticas y la especificación de una variedad de condiciones que pueden ocurrir. (Majone y Wildavsky, 1998, 275).

El lograr un despliegue de acción que involucre la pertinencia y la especificidad de la acción en los territorios, implica el análisis conjunto de quienes están involucrados con la situación socialmente problemática susceptible de transformación. Otro de los 
grandes inconvenientes de la implementación se asocia justamente con la pertinencia y la especificidad de las acciones respecto al contexto, entendido como ámbito de intervención, por tanto, el camino de anticipar las dificultades que se descubren en la implementación plantea entonces, la incorporación temprana de -múltiples- sectores al proceso de formulación y planeación de políticas (Pressman y Wildavsky, 1998, $56)$.

Ante estas evidencias se hace perentorio inaugurar procesos de cooperación entre distintas prácticas de las ciencias sociales. Es necesario abrirlas al pluralismo metodológico porque "... la multiplicidad inherente y necesaria de perspectivas con respecto a un problema requiere un pluralismo de metodologías, incluso dentro de los componentes científicos" (Funtowitz y Ravetz, 1993, 82) y también "reducir el tiempo con que se introduce a las arenas decisorias la identificación de cualquier innovación" (Brunner, 1993). Se destaca en este punto, la necesidad de llevar a cabo metodologías de planificación participativa que permitan que los planes, programas y proyectos construidos sean fruto del consenso de múltiples actores sociales que convergen en la situación socialmente problemática que se busca solucionar. Respecto a estos puntos, se sitúan discusiones contemporáneas que en respuesta a los interrogantes sobre la participación y posibilidades de incidencia de los colectivos de población, se posicionan como alternativas para incentivar la transformación social en las lógicas de la administración y gestión pública, entre ellas encontramos la estrategia ética, conceptual y metodológica que se propone en el enfoque y las Metodologías de Planificación Participativa y Gestión Asociada PPGA, entendida como escenario de acción profesional y como enfoque que se instala en los procesos decisorios de política pública, al incentivar prácticas de cogestión que enriquecen la acción democrática, creando nuevos actores colectivos que replantean e interpelan el proceso tradicional de toma de decisiones.

La Gestión Asociada permite la construcción. Es un ámbito en el cual se desarrollan acciones conjuntas entre la comunidad y el estado, donde los canales de participación dan lugar a la elaboración de acuerdos, negociaciones o concertaciones a partir del reconocimiento de los conflictos, diseñando propuestas y acciones que integran visiones e intereses contrapuestos. Se trata de un espacio de naturaleza interdisciplinaria e intersectorial que utiliza una mecánica abierta y pluralista, de fácil acceso, operando por acuerdo y consenso. Tiene como objetivo la movilización y articulación de actores (...) estableciendo acuerdos y grados de responsabilidad y compromiso mutuos, formulación de metodologías y planes de trabajo, gestión de recursos humanos y financieros que viabilicen los emprendimientos $(\mathrm{m}, 13)$

Este enfoque metodológico que se posiciona como transformador de los discursos y prácticas de las lógicas habituales de planeación social, constituirá fundamento para generar la propuesta de evaluación de política pública municipal como producto de este trabajo de investigación doctoral. Partiendo por supuesto, de considerar que la evaluación no es una simple fase de un proceso desarticulado de pensar estrategias de abordaje e intervención de los problemas sociales, sino pensándola como oportunidad y 
fortaleza para incentivar lógicas otras, dentro de la gestión pública, lógicas que posibiliten el verdadero trabajo articulado y cogestivo de los actores sociales.

Por otra parte, cuando se habla de la etapa de diseño de políticas se abordan elementos vinculados con la identificación y construcción de problemas y de agendas políticas, por lo que resulta indispensable desarrollar un análisis situacional que involucre: naturaleza, dimensión, alcance, repercusiones, consecuencias, afectaciones de la situación negativa entre otros aspectos relevantes. Así, se sitúan diversas formas de ingreso de los problemas a la agenda pública que pueden analizarse con ocasión a: i) los escenarios, ii) los actores-demanda iii) los intereses o iv) modelos, como se observa en el siguiente gráfico.

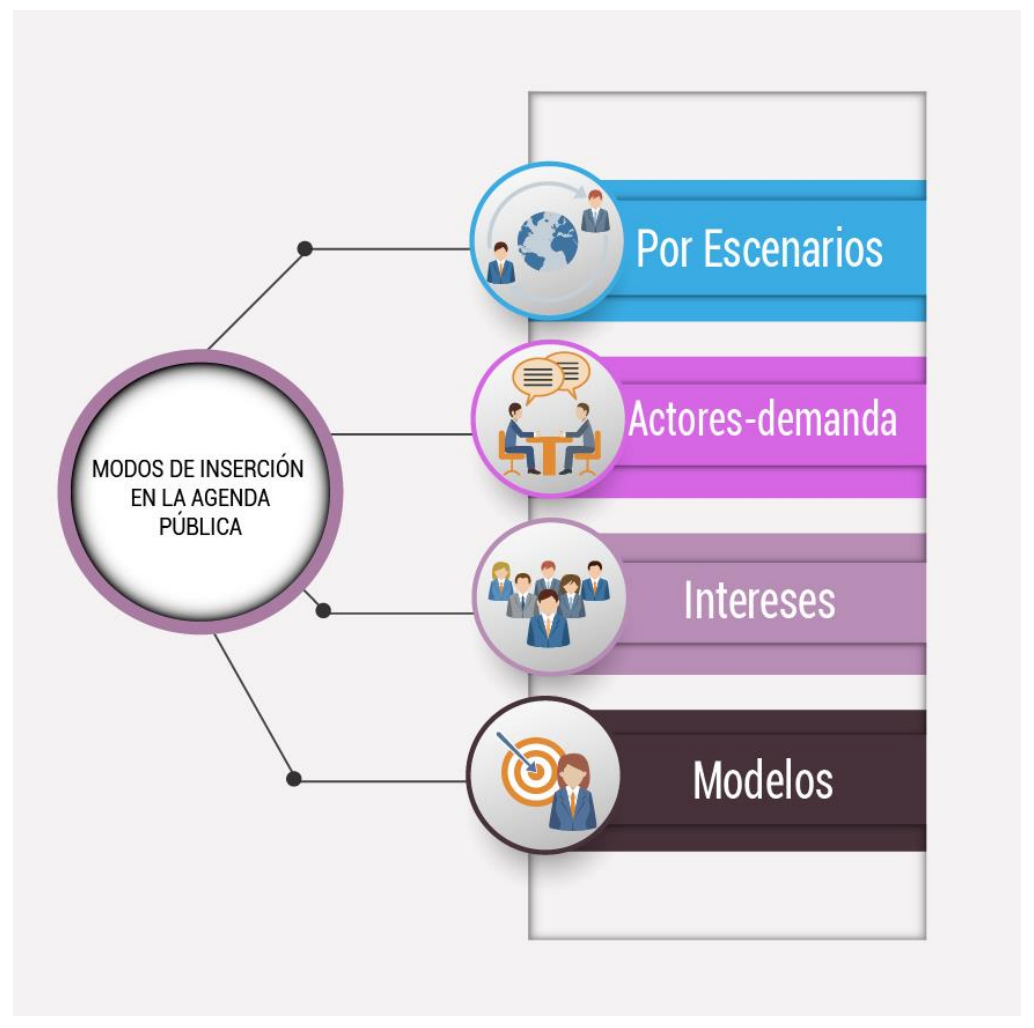

Fuente: Elaboración propia, 2014.

Figura 12. Identificación y construcción de problemas y agenda política

La construcción de agendas operativas en política pública aparece antecedida por la comprensión de lo que hemos denominado "la situación socialmente problemática" que da origen a las alternativas de solución materializadas en construcción de planes, programas y proyectos. Entender la situación problemática implica a su vez dar cuenta de la naturaleza, causas, dinámicas, consecuencias del problema; así como hacer un balance de los sujetos, actores, agencias y agentes involucrados y que resultan afectados. Ellos serán también los actores de las políticas públicas.

A su vez, existe un tránsito entre el problema social y la situación socialmente relevante que está mediado por la inserción del tema-problema en la agenda pública. Éste se 
inserta en la agenda al ser priorizado por el régimen político (es decir por el conjunto de instituciones estatales, sistema de partidos, sistemas de mediación sociedad-estado, sistema de toma de decisiones, administración pública y gestión estatal). El ingreso a la agenda gubernamental se puede realizar por: escenarios (externo o interno al estado); por actores y demandas (mediadores políticos: partidos políticos, grupos de presión, gremios. Mediadores sociales: representantes sociales y/o intelectuales. Mediadores administrativos) y por intereses (de reajuste o correctivos; de explotación; de reacción a circunstancias -eventos, accidentes-; por intereses públicos).

De igual forma, autores como Roth (2002) mencionan que la inscripción en la agenda pública también puede analizarse con ocasión a establecer modelos de inserción; entre los que se destacan: Modelo de movilización (procesos democráticos y de reivindicación), Modelo de oferta política (lanzamiento del problema como obra de organizaciones, medios de comunicación etc.), Modelo de mediatización (a través de los medios de comunicación) y Modelo de anticipación (como estrategia de prevención o mitigación).

\subsubsection{Implementación de políticas públicas}

El momento de implementación de la política pública constituye un factor determinante en el ciclo de vida de los planes, programas y proyectos. Es el espacio en el que se ponen en evidencia los problemas y/o dificultades de todo el proceso político de pugnas y controversias que entraña el pensar alternativas de solución a problemas socialmente relevantes. Para diversos autores que estudian, caracterizan o realizan aproximaciones teóricas-conceptuales sobre el tema, la implementación representa un mero encargo administrativo, caracterizado por problemas técnicos o de simple ejecución. Desde la perspectiva del analista esta etapa es fundamental porque es ahí que la política, que hasta entonces habían sido discursos y palabras, se transforma en hechos concretos (Roth, 2002: 107).

La implementación de la política es parafraseando a Clausewitz (1999), la continuación de la lucha política con otros medios y en escenarios diferentes. Menospreciar el proceso de implementación es olvidar que la política de implementación es la determinante definitiva del resultado de una decisión (Pressmann y Wildavsky, 1998: 327).

El momento de implementación evidencia la estructuración de ámbitos intervenidos entendidos como espacios sobre los que recae la acción estatal para contribuir a la resolución de la situación socialmente relevante, ello determina la identificación y caracterización de racionalidades, órdenes, prácticas, naturaleza de las interacciones configurando así espacialidades múltiples (urbanas, campesinas, vecinales y barriales) en las que se materializará el despliegue territorial (Ver figura 13) 


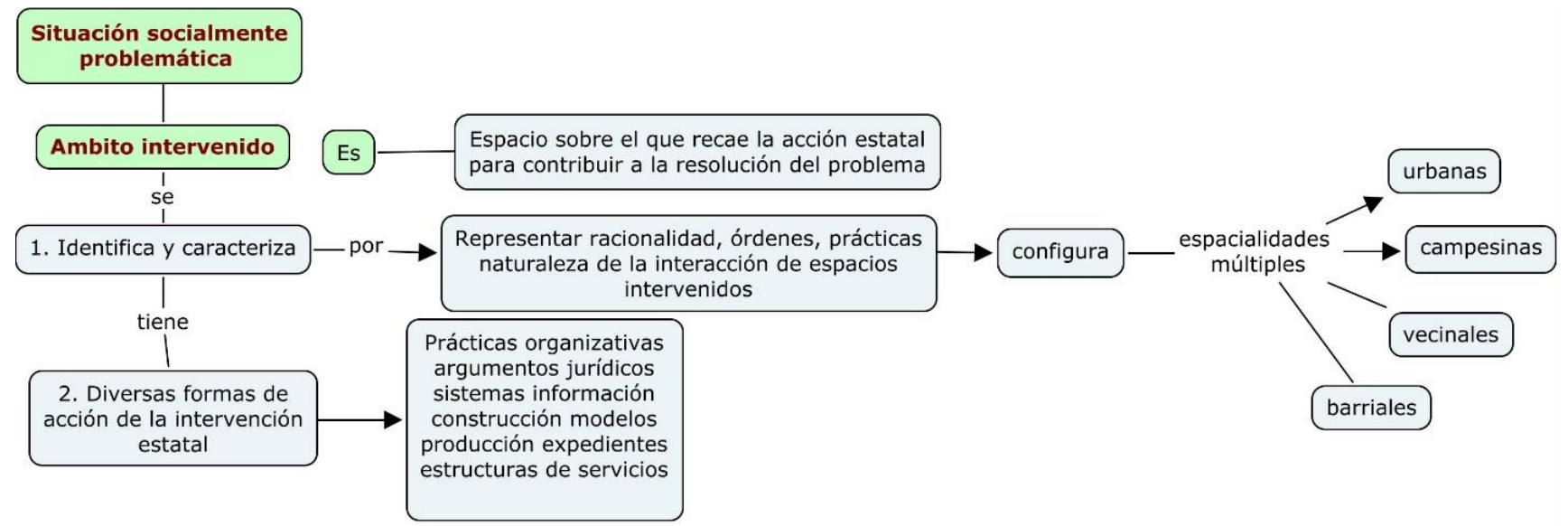

Fuente: Elaboración propia, 2016

Figura 13. Definición de ámbitos de intervención.

De igual manera, el momento de implementación al ser entendido como etapa de materialización de las acciones de política pública involucra formas de intervención estatal que logran su especificidad y varían en el tiempo según se trate de las dinámicas propias del ámbito intervenido, de las transformaciones mismas del estado, de los comportamientos del mercado y de procesos de naturaleza internacional $\mathrm{o}$ supranacional. La intervención de estado, propia de los procesos de política se viabiliza dada la multiplicidad de funciones que enmarcan $y$ orientan las tareas de organizaciones, funcionarios, gobernantes, legisladores y jueces, así como el alcance de sus responsabilidades. Así se generan al interior del aparato estatal campos funcionales que hacen factible su intervención y determinan su naturaleza, singularidad y alcance (Lozano, 2008; 32).

La política pública designa encargos institucionales específicos para orientar las acciones de ejecución de planes, programas y proyectos. En este sentido, el campo funcional se entiende como el conjunto de funciones que posibilitan y precisan la intervención de estado. La responsabilidad de la operación de la política se asigna a un ente institucional específico y especializado en los tema-problema de interés y que constituyen el ámbito intervenido.

La implementación se relaciona con la ejecución de los mandatos que se encuentran consignados en las directrices de política, en esta parte del proceso se busca lograr objetivos, tener resultados, generar los impactos deseados; es un momento en el que el propósito consignado, verbalizado en el mandato se encuentra con las dificultades de realización. Con la implementación la acción de las autoridades estatales se despliega en el territorio, se divide en segmentos de agenciamiento especializados que laboran de manera sucesiva y simultánea. Son múltiples actividades, desarrolladas por diferentes tipos de expertos y organizaciones, orientadas a diversos grupos poblacionales (estratos, localidades, barrios, grupos de riesgo, etc.) (Ibíd, 2008: 118) 
Este proceso de ejecución involucra acciones legislativas y judiciales, así como factores de cultura política, de organización y movilización de sectores sociales, políticos, económicos y culturales que entran en pugna o promueven proyectos de vida colectiva. La implementación está caracterizada por un conjunto de aspectos que dan cuenta de la intervención de estado y la acción gubernamental. Dentro de los factores de caracterización, se encuentran los de la figura 14.

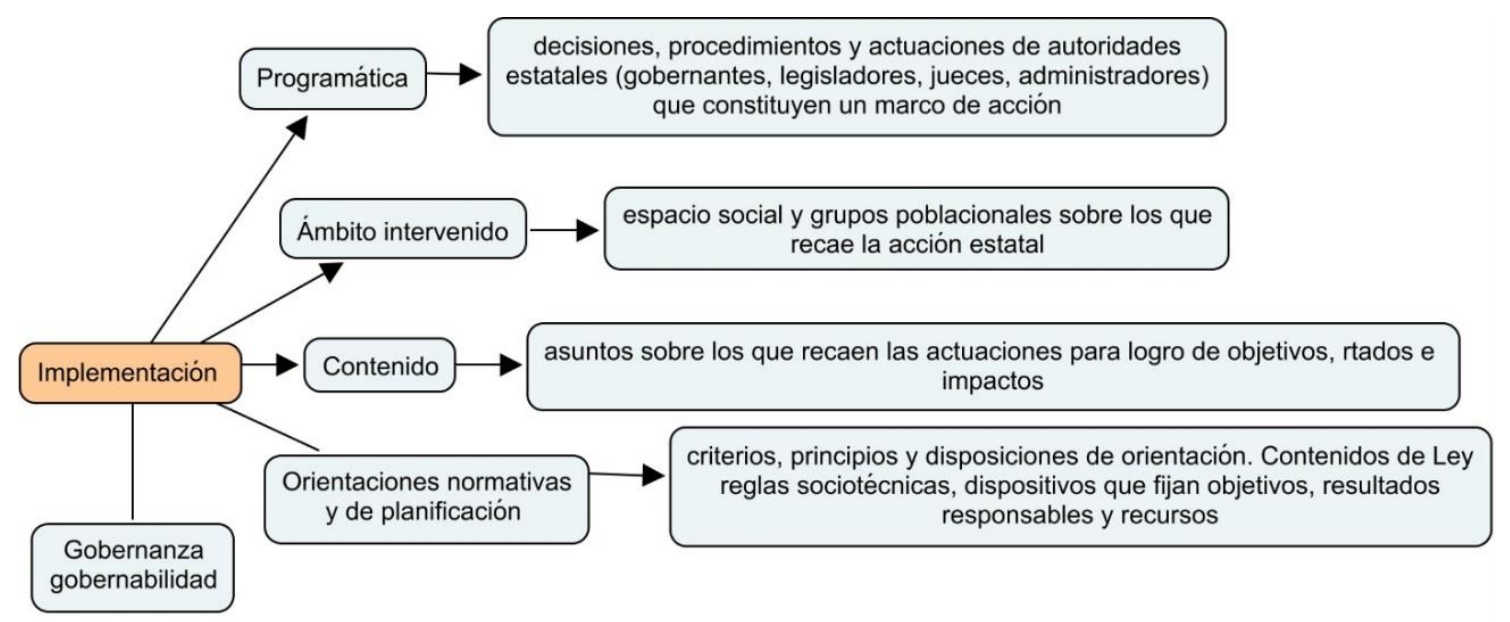

Fuente: Elaboración propia, 2014

Figura 14. Factores de identificación intervención estatal y acción gubernamental

Analizar el proceso de implementación de una política pública implica rastrear los elementos contenidos en la figura 14. Pero igualmente hacer el análisis de la trayectoria de los planes, programas y proyectos. Para lo cual, es necesario identificar los datos detallados sobre (objetivos, resultados programados, resultados obtenidos, fuentes de financiación, ámbitos geográficos cubiertos por la acción estatal, unidades ejecutoras, población objeto) dicha información permitirá hacer un balance de la trayectoria de política pública con miras a desentrañar las particularidades de la ejecución y por ende los elementos de caracterización de la red organizacional de apoyo del proceso de implementación.

De igual manera, es posible encontrar instrumentos de análisis que permitan sintetizar los principales aspectos de la lógica jurídica que respalda la intervención de estado, las redes de unidades organizacionales que realizan el despliegue territorial así como los campos temáticos que estructuran la acción estatal y/o gubernamental, elementos necesarios para comprender las pugnas, contradicciones, sentidos y contenidos de las políticas en el marco de posibilidades de resolución de situaciones socialmente problemáticas en un régimen político determinado. 
Tabla 7 Aspectos a identificar en el análisis de políticas públicas

\begin{tabular}{|l|l|l|l|l|l|}
\hline & OBJETIVOS & $\begin{array}{c}\text { RESULTADOS } \\
\text { PROGRAMADOS }\end{array}$ & $\begin{array}{c}\text { RESULTADOS } \\
\text { OBTENIDOS }\end{array}$ & $\begin{array}{c}\text { COMPOSICIÓN Y } \\
\text { FUENTES DE } \\
\text { FINANCIACIÓN }\end{array}$ & $\begin{array}{c}\text { AMBITO } \\
\text { GEOGRAFICO } \\
\text { CUBIERTO }\end{array}$ \\
\hline $\begin{array}{l}\text { Nombre del } \\
\text { Proyecto: }\end{array}$ & GENERAL: & $\bullet$ & & & \\
\hline $\begin{array}{l}\text { Unidad } \\
\text { ejecutora: } \\
\text { Entidad: }\end{array}$ & & & & & \\
\hline Período & & & & & \\
\hline $\begin{array}{l}\text { Monto del } \\
\text { proyecto: }\end{array}$ & & & & & \\
\hline $\begin{array}{l}\text { Pobjación } \\
\text { objeto: }\end{array}$ & & & & & \\
\hline
\end{tabular}

Fuente: Lozano, Alejandro. Universidad Nacional de Colombia, 2008

\subsection{A propósito de la incidencia en política pública: la evaluación como aprendizaje colectivo}

Lo fundamental de la evaluación ha sido la constatación de los objetivos y finalidades de una política pública con la realidad en la cual se desarrolla la misma. Posteriormente ha habido un intento de ampliar su comprensión y se le ha considerado como parte de todo el proceso de una política pública y en esa medida ella misma como un proceso (Vargas, 1999: 142). La acción de evaluación implica valorar unos criterios preestablecidos, se puede asimilar a la apreciación de resultados, efectos e impactos de la acción pública. Implica por ende, construir conceptos, métodos, descripciones, explicaciones y valoraciones de la acción gubernamental. Este momento valorativo, da cuenta de los éxitos, fracasos y posibilidades de mejoramiento de planes, programas y proyectos, contiene un ejercicio reflexivo de comprensión de los elementos sistemáticos de actividades específicas, que desarrolla el gobierno para cumplir metas y producir efectos esperados de acuerdo con políticas y programas.

Cuando se habla de evaluación es posible identificar diferentes momentos para su realización, igualmente se habla de niveles frente a los cuales ésta se ejecuta. Sobre los momentos se halla que puede ser ex ante (estimación crítica de la pertinencia, viabilidad y eficacia potencial de una actividad, realizada antes de tomar la decisión de emprenderla), evaluación sobre la marcha (seguimiento y monitoreo, continua y de proceso) y evaluación ex post o final (que se trata del análisis de los resultados, efectos, repercusiones, impactos de una política después de concluida la misma o una parte sustancial de su ejecución) 
Tabla 8. Momentos realización evaluación

\begin{tabular}{|c|c|c|c|}
\hline $\begin{array}{l}\text { CRITERIOS DE } \\
\text { ANÁLISIS }\end{array}$ & SEGUIMIENTO & EVALUACIÓN CONTINUA & $\begin{array}{l}\text { EVALUACIÓN } \\
\text { EXPOST }\end{array}$ \\
\hline Finalidad básica & $\begin{array}{l}\text { Observar el avance de la } \\
\text { ejecución de PP y sus diversos } \\
\text { componentes en relación con } \\
\text { metas, oportuna superación de } \\
\text { obstáculos y retrasos y } \\
\text { rectificaciones si fuere necesario }\end{array}$ & $\begin{array}{l}\text { Determinar si se mantiene la } \\
\text { pertinencia y los productos } \\
\text { presentes y probables; efectividad } \\
\text { e impacto de una actividad } \\
\text { durante la ejecución; } \\
\text { rectificaciones importantes si hay } \\
\text { necesidad }\end{array}$ & $\begin{array}{l}\text { Evaluar los productos } \\
\text { efectos e impactos } \\
\text { globales de obtener } \\
\text { enseñanzas para la } \\
\text { planeación futura }\end{array}$ \\
\hline $\begin{array}{c}\text { Fuentes de } \\
\text { información }\end{array}$ & $\begin{array}{l}\text { Informes administrativos, } \\
\text { periódicos, observaciones }\end{array}$ & $\begin{array}{l}\text { Estudios detallados, observación } \\
\text { de la participación, encuestas por } \\
\text { muestreo, reconocimiento rápido }\end{array}$ & $\begin{array}{l}\text { Encuestas } \\
\text { socioeconómicas y } \\
\text { políticas }\end{array}$ \\
\hline $\begin{array}{l}\text { Destinatario de } \\
\text { informes }\end{array}$ & $\begin{array}{l}\text { Dirección operativa (en distintos } \\
\text { niveles) beneficiarios, organismos } \\
\text { de financiación }\end{array}$ & $\begin{array}{l}\text { Administración de la PP, } \\
\text { encargados de formulación, } \\
\text { beneficiarios, organismos de } \\
\text { financiación }\end{array}$ & $\begin{array}{lr}\text { Administración de } & \text { PP, } \\
\text { encargados } & \text { de } \\
\text { formulación, } & \\
\text { beneficiarios, } & \\
\text { organismos } & \text { de } \\
\text { financiación } & \end{array}$ \\
\hline $\begin{array}{c}\text { Cuestiones } \\
\text { fundamentales }\end{array}$ & $\begin{array}{l}\text { Insumos y su utilización, } \\
\text { oportunidad de las operaciones y } \\
\text { obtención de los productos con } \\
\text { respecto a las metas establecidas, } \\
\text { relación entre insumos y } \\
\text { productos (orientación hacia las } \\
\text { necesidades de la gerencia de la } \\
\text { PP) }\end{array}$ & $\begin{array}{l}\text { Apreciar validez y pertinencia } \\
\text { constantes en el diseño de la PP y } \\
\text { valoración de los efectos y } \\
\text { análisis de la eficacia en función } \\
\text { de costos, orientación hacia la } \\
\text { consecución de metas }\end{array}$ & $\begin{array}{l}\text { Objetivos máximos y a } \\
\text { largo plazo, efectos e } \\
\text { impactos diferenciales } \\
\text { sobre beneficios del } \\
\text { proyecto. } \\
\text { Enseñanzas para el } \\
\text { futuro respecto de } \\
\text { factores críticos que } \\
\text { influyen en el éxito o } \\
\text { fracaso de la PP }\end{array}$ \\
\hline Frecuencia & $\begin{array}{l}\text { Durante todo el periodo de } \\
\text { ejecución }\end{array}$ & $\begin{array}{l}\text { Durante todo el periodo de } \\
\text { ejecución }\end{array}$ & $\begin{array}{l}\text { Encuesta de base antes } \\
\text { o durante el primer año } \\
\text { de ejecución de la PP, } \\
\text { repetición de encuestas } \\
\text { a mediados de su } \\
\text { terminación }\end{array}$ \\
\hline $\begin{array}{l}\text { Ubicación de la } \\
\text { unidad de } \\
\text { seguimiento y } \\
\text { evaluación }\end{array}$ & $\begin{array}{l}\text { Dentro de la unidad ejecutora del } \\
\text { proyecto }\end{array}$ & $\begin{array}{l}\text { Ministerio y/o organismo central } \\
\text { de planificación. Unidad debe ser } \\
\text { interdisciplinaria }\end{array}$ & $\begin{array}{lr}\text { Ministerio } & y / 0 \\
\text { organismo central de } \\
\text { planificación. Unidad } \\
\text { debe ser } \\
\text { interdisciplinaria. }\end{array}$ \\
\hline
\end{tabular}

Fuente: Elaboración propia con base en el grupo de trabajo sobre desarrollo rural del CAC de las Naciones Unidas. Panel sobre seguimiento y evaluación. "seguimiento y evaluación pautas básicas para el desarrollo rural” Roma, 1984 
En cuanto a niveles de la evaluación, a partir de Nioche (1982) se plantea que es posible encontrar los niveles: medios, realización de resultados, impacto, eficiencia, satisfacción. Ver figura 15.

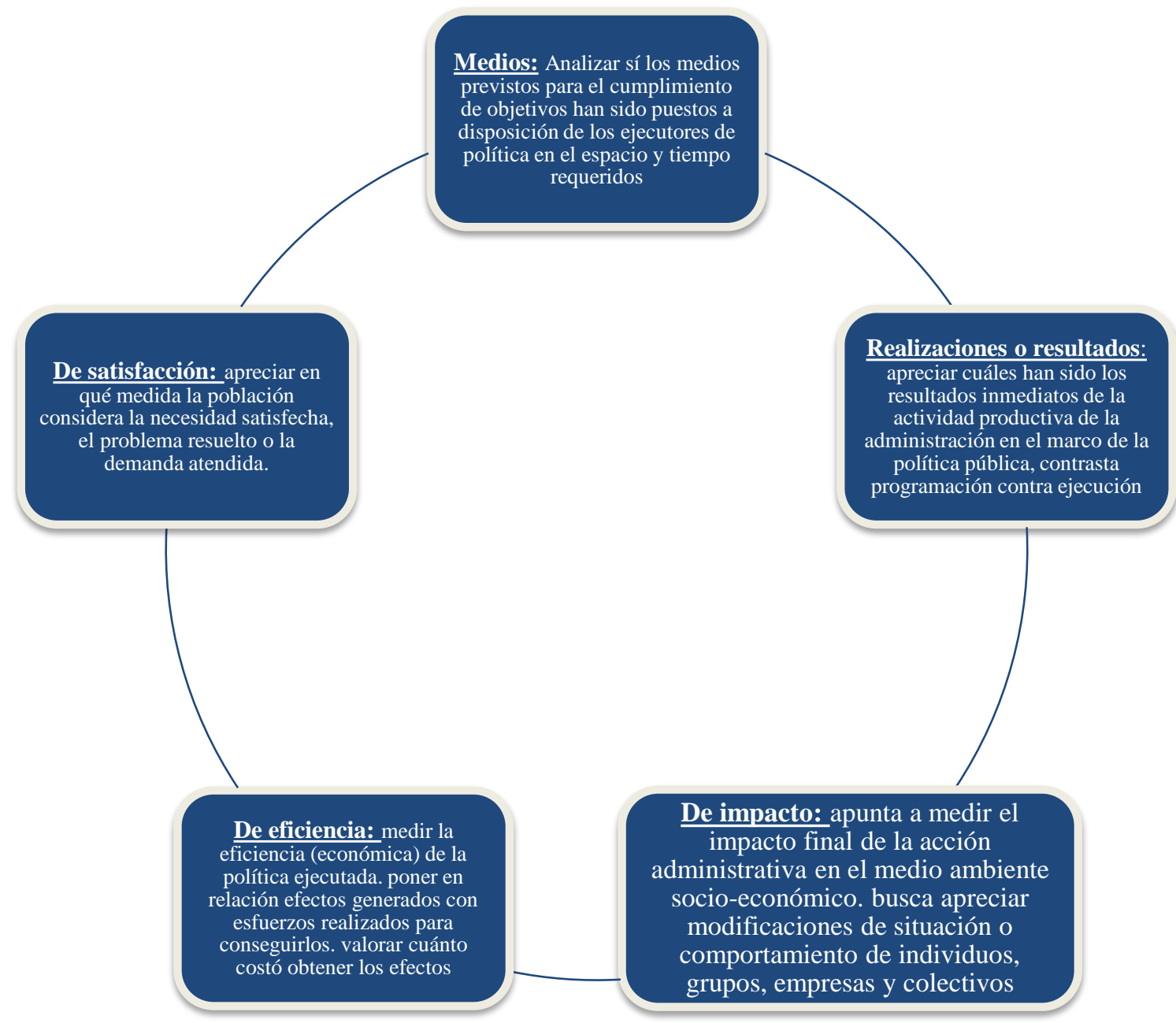

Fuente: Elaboración propia, 2014. Tomando como referencia el texto de Vargas (1999) Reflexiones acerca del análisis de las políticas públicas. En: Estado y las Políticas Públicas

Figura 15. Evaluación de políticas públicas por niveles.

La evaluación de política pública debe orientarse a generar procesos de aprendizaje para los actores involucrados en términos de realización de análisis sobre las omisiones, errores y dificultades encontradas en la ejecución de las políticas. Para propiciar escenarios con estas características deberá ser elaborada por los diversos actores sociales que se involucran en el proceso o ciclo de políticas públicas. Deberá tener en cuenta el análisis contextual o escenario en el que se desarrollan las acciones o intervenciones de estado sobre el ámbito intervenido.

Pensando la evaluación en términos de la política pública se considera importante tener en cuenta algunos enfoques de orientación de este proceso, que pueden desempeñar el papel de ser directrices o lineamientos de valoración que impulsen procesos sociales 
que promuevan la acción articulada multiactoral y sean más pertinentes a las realidades sociales complejas. Se destacan entre ellos los enfoques: territorial que parte de tomar en cuenta las singularidades y particularidades de los territorios, entendiendo a éstos como espacios de realización de los sujetos y de despliegue de las acciones cotidianas de individuos y colectivos de población. La política pública debería tener en cuenta dichas particularidades territoriales que igualmente deberán tenerse en cuenta en los procesos de evaluación. Igualmente está el enfoque participativo que parte de considerar la existencia de múltiples actores sociales que deben incluirse y tomarse en cuenta en las políticas públicas, la evaluación formativa que busca desarrollar aprendizajes deberá también fomentar espacios de construcción de ciudadanías y gobernanza.

En última instancia, se halla el enfoque de fortalecimiento de lo público desde lo público que busca principalmente devolver a la sociedad su papel protagónico en la esfera pública estatal, teniendo en cuenta que al hablar del escenario público como se dijo al iniciar este texto, se concibe como lo colectivo, los proyectos de sociedad compartidos, los intereses generales que permiten reconstruir el concepto de la comunidad y lo comunitario en la escena social.

Hablar de ese sentido comunitario que convoca a los otros como pares, como interlocutores válidos y agentes de cambio y desarrollo, pone en evidencia la importancia de la articulación como una de las posibilidades que debería permitir la participación en lo social. De esta manera, y tomando como referencia las hipótesis construidas hasta este momento, se hace especial énfasis en que la evaluación debería instituirse como proceso social que potencie el trabajo colectivo y cooperativo. La evaluación permitiría entonces en este sentido, contar con los esfuerzos realizados por entidades públicas, privadas y sociedad civil (hay historias previas que deben analizarse y tomarse como experiencias susceptibles de valoración) respecto a los planes, programas y proyectos de política pública y desde allí deconstruir la lógica en la que se incorporan los actores en la toma de decisiones, este análisis a profundidad permite partir de lo ya construido para valorarlo y proyectar un mejor futuro.

Justo este es el fin último del quehacer en lo público incidir en el futuro desde acciones que se configuran en el presente. Lo anterior es indudablemente, requisito fundamental para la planificación desde una lógica participativa, que se aúna a la capacidad de anticiparse al futuro, proyectarse a la realidad que puede venir luego del presente. Sobre este asunto, resulta ser valiosa la prospectiva no tanto como adivinación o predicción sino como herramienta que permite superar el temor o apatía ante la posibilidad del futuro, para determinar la acción en el presente.

La prospectiva nos ayuda a pensar que hay futuros alternativos. En el rango de posibilidades la existencia de voluntades dispares niega la perspectiva de un futuro fatal. La prospectiva (...) como un ordenamiento analítico de futuribles, permite colocar la deseabilidad como elección entre lo probable. El futuro deseable es aquel que entre los futuros probables elegiremos o preferiremos, es una opción (Poggiese, 2004: 18) 
Aunque pareciera que la prospectiva debe ser una capacidad para quienes se supone, tienen la responsabilidad de administrar el territorio, es importante comprender que las decisiones que pudieran derivarse de esta proyección en el presente, no competen sólo a ellos-ellas; ésta, resulta ser una tarea para todas las personas que de una u otra manera afectan y son afectadas en su relación territorial con las políticas públicas. Al respecto, se está planteando el enfoque del "buen gobierno" que centra su atención en los procesos más que en los resultados.

Todos concuerdan que el "buen gobierno" hace referencia a estilos de gobernar que otorgan una importancia primordial a aquellos mecanismos de gobierno que no se basan exclusivamente en los recursos tradicionales de la autoridad y de la sanción, sino que más bien crean estructuras que son resultados de la interacción de una multitud de actores sociales y políticos dotados de una cierta autoridad y que se influyen mutuamente. Es decir, que se trata de crear escenarios, estrategias y mecanismos de participación o de inclusión de organizaciones no estatales para aumentar las posibilidades de éxito de la gestión (Deubel, 2002: 111)

Sí se piensa en partir de valorar lo existente en el territorio (desde la evaluación o control a las políticas públicas), por una parte se da importancia a lo ya construido, no se parte de cero, se parte de un entramado de experiencias que los actores ya han construido como formas de relación y acción; es desde allí y desde su reflexión retro y prospectiva, desde dónde se encuentra sentido a la posibilidad, necesidad e importancia de generar cambios en varios frentes, por una parte en el cómo nos concebimos como actores del territorio - como agentes, como individuos activos, como individuos pasivosimplica desentrañar el ser del sujeto en su lugar darle un significado como legítimo otro. Por otra parte, implica el reflexionar sobre la relación que se ha configurado en el espacio territorial en el que se interactúa, considerar que en la mayoría de los casos ha sido una relación vertical, autoritaria y hegemónica que es necesario desmontar y transformar para poder construir juntos, así como para develar las tramas históricas que constituyen el territorio y que proyectan el presente y el futuro, ello implica el dar paso a las relaciones democráticas y democratizadoras de la construcción en lo público.

Para ello se hace necesario entonces que exista la posibilidad y apertura tanto individual como colectiva de asociarnos, en este sentido aludiendo a la concepción que tiene Morroni (Morroni \& Redín, 2002: 21) cuando se refiere a la "voluntad de asociarse":

Es fundamental para esta concepción [voluntad de asociarse], la construcción de un "nosotros". Esto significa que no estamos trabajando "para resolverle el problema a otros/as", o que se trata de un problema que a nosotros/as no nos afecta. Esta mirada integral y compleja de lo socio urbano, nos coloca en un lugar donde, aun sin ser afectados/as directos (necesarios o involucrados) por la problemática en cuestión, estamos interesados/as en su resolución (Ibíd, 2002: 14) 
Desde esta perspectiva, se parte de considerar que todos los individuos son seres complejos que se construyen, de-construyen y desarrollan en la medida en que se reconocen recíprocamente con el otro-la otra, los otros-las otras, puesto que es justamente este conocer el que evidencia motivaciones y garantías a sus necesidades, esta es la oportunidad que les permite crecer integralmente, no sólo en términos de su subsistencia, seguridad y trascendencia para su estima y autorrealización, sino además como sujeto social que contribuye al desarrollo igualmente integral, de su comunidad: "la proyección personal y social constructiva y desarrolladora es la expresión del ser y hacer de un individuo armónico consigo mismo y con la sociedad, con una conciencia ética ciudadana para la responsabilidad, la libertad y la dignidad humana." (Valbuena, 2010: 13)

En este escenario entonces se demanda una suerte de alejamiento de las ideas de lo económico, la productividad y la rentabilidad como referentes exclusivos del desarrollo del ser humano, pues su realización plena debe concebirse desde una concepción humanista en la que primen todas sus cualidades y limitaciones, y sus necesidades e intereses propios así como su identidad, cultura y contexto histórico y sociocultural: "Una política de desarrollo orientada hacia la satisfacción de las necesidades humanas (...) trasciende la racionalidad económica convencional porque compromete al ser humano en su totalidad." (Max-Neef, 1993:22)

Así se encuentra que, frente a los asuntos en mención, la Gestión Asociada se articula con la interpretación de las necesidades sociales como derechos. En este sentido, la participación como derecho encontraría su expresión y su ejercicio más acabado en los espacios más o menos ampliados de gestión asociada, donde los actores sociales ejercerían su derecho a influir y a conducir los cambios sociales (Cardarelli \& Rosenfeld, 2002: 6)

Esto implica la utilización de sus metodologías que, entre otras apuestas, logre a partir del compromiso colectivo, garantizar el fortalecimiento de todos los actores incluidos aquellos que lleguen al escenario en condiciones de debilidad política, temática, técnica, organizativa y/o metodológica.

La perspectiva de una influencia mutua en el sentido de que la recuperación y recomposición de un sector depende de la recuperación del otro (...) "El estado y la sociedad deberían entender que se necesitan para fortalecerse y que abriendo el juego hacia la co-gestión facilitan la transparencia, el control, la integración y un trayecto hacia una sociedad más democrática y equitativa. Lo que significa también que deberían "entenderse" de otro modo (...) con un método de acción que ponga en igualdad de situación a ambos. En lo que respecta a los sectores sociales, capacitándolos para negociar con el estado. En lo que respecta al estado, capacitando a sus funcionarios para entenderse con la sociedad (Poggiese, 2004:9) 
Ahora bien, es importante destacar que la GA no puede considerarse como una "receta mágica" con la que se "mejore" el escenario como tal. De considerarlo así, estaría cayéndose no sólo en una postura irrespetuosa con quienes están haciendo parte de las experiencias de control social y/o evaluación de políticas públicas, sino que además se estarían replicando modelos autoritarios, verticales y tecnócratas que subestiman y desconocen los saberes y experiencias de los individuos como tal. "Todos poseemos "saberes e ignorancias", que es necesario interrelacionar y complementar para la construcción de un conocimiento colectivo." (Morroni \& Redin, 2002: 25)

La GA requiere la acción mancomunada, simultánea y sistemática de todos y cada uno de los actores del escenario en el que se esté aplicando:

Los escenarios necesitan ser construidos e instalados como una práctica concreta. Por eso, el planificador participativo, a diferencia de otros planificadores, no hace un plan para otros, utilizando su formación y dominio técnico, sino que organiza y posibilita el escenario y la metodología por medio de los cuales otros, junto con él, harán el plan (Poggiese, 2004: 8)

En este sentido, se concibe que el momento valorativo de las políticas públicas -bien sea bajo la figura evaluación o la de control social-, construye sus prácticas sociales, codecidiendo con otros-otras, su realidad y existencia. Tal y como lo expresa Poggiese (2000), se espera que cada individuo en tanto molécula social que es, "actúe en cualquier sitio (especialmente en su lugar próximo, lo local, donde se le presentan los problemas), con un esmerado cuidado -una práctica ecologista- de todo el globo (Poggiese, 2000: 2)

De acuerdo a lo anterior, es posible afirmar que toda territorialidad en tanto constructo social, construye dinámicas propias de gobenanza para su desarrollo y sustentabilidad. Para Valbuena resulta interesante el análisis que al respecto hacen (Montañez y Delgado, 2000: 6):

1. Toda relación social tiene ocurrencia en el territorio y se expresa como territorialidad. El territorio es el escenario de las relaciones sociales y no solamente el marco espacial que delimita el dominio soberano de un Estado.

2. El territorio es un espacio de poder, de gestión y de dominio del Estado, de individuos, de grupos y de organizaciones y de empresas locales, nacionales y multinacionales (...)

3. La actividad espacial de los actores es diferencial y por lo tanto, su capacidad real y potencial de crear, recrear y apropiar territorio, es desigual.

En palabras de Poggiese (2000), se observa que:

...en todo "local" hay una forma estatal (y por ende gobierno formal), esto es, no hay un local debajo de un nivel mínimo de gobierno descentralizado y en todo "local" hay una forma social (y por ende una comunidad organizada) que se articulan y producen un "gobierno de lo local 
Ahora bien, a través de esta lógica de vida social, surge la idea de ciudadanía en tanto se fundamenta a partir de:

reglas, códigos de significación, recursos de autoridad y de fijación (Giddens, 1987:12), susceptibles de ampliar o limitar la extensión e intensidad en el ejercicio de derechos y deberes. Pero, especialmente, se constituye un "pacto territorial" (Santos, 1987, p. 133), es decir, se configura la "cara jurídica" o la forma legal por medio de la cual la sociedad civil puede intervenir en el proceso político-jurídico (...) "cada hombre vale por el lugar donde está: su valor como productor, consumidor, ciudadano, depende de su localización en el territorio (Silveira, 2011: 26)

Sin embargo, no siempre el individuo cuenta con las condiciones necesarias para asumir una efectiva ciudadanía. Tal es el caso de los colectivos sociales que concurren en el control social o evaluación, que por su condición de género, etnia, generación han sido histórica y culturalmente discriminados a nivel mundial. Sus cuerpos, subjetividades, identidades y conductas son generalmente mediatizadas por estereotipos que logran de uno u otro modo, supeditar su soberanía bajo el yugo del sistema hegemónico y economicista. De hecho, hasta hace muy poco, desde el punto de vista formal, son considerados ciudadanos de segunda clase.

$\mathrm{Y}$ es que para que el concepto de ciudadanía alcance en la práctica su sentido igualitario, es decir, que las personas participen como iguales --que no idénticas-- en la toma de decisiones de orden público sobre sus vidas y las de sus comunidades, se hace imperativo partir de tomar en consideración los enfoques de género, generación y etnia. En otras palabras, concebir de manera neutral la ciudadanía, sin especificar la experiencia de vida diferenciada y marcada por las prescripciones de estos escenarios.

En diversas ocasiones se evidencia una suerte de concepción de la participación como elemento de consumo, de acumulación en términos de la cantidad de espacios o escenarios de los cuales, supuestamente, se ha sido o es parte. Morroni \& Redín (2002) lo exponen escuetamente:

¿Qué significamos con participación? Aquí debemos atender la lógica desde la que pensamos y actuamos, ¿desde la lógica del mercado, como "consumidores" deseosos de conocer y ejercer nuestros derechos, utilizando los mecanismos existentes para reclamar por ellos?, o desde una lógica social, comunitaria, colectiva "personas en situación ciudadana" que participan en el modelo de toma de decisiones y construyen propuestas de resolución (Ibíd, 2).

Sin duda, la participación ciudadana debe superar esta lógica y trascenderla hacia una participación incidente y corresponsable en la construcción del territorio como tal, luego entonces, vale la pena rescatar la definición que sobre ella establece Velásquez (2003):

La participación significa el ejercicio, por parte de una diversa gama de sujetos, de una ciudadanía activa que intenta poner en el escenario público sus respectivas lecturas y 
apuestas para visibilizarlas y construir acuerdos colectivos en un contexto de pluralidad. La participación posibilita la expresión de lo diverso, el fortalecimiento de la esfera pública y la movilización de voluntades en torno a objetivos comunes (pág s.d).

Sobre el tema, resulta pertinente la cita que Vargas (1999) hace de Habermas, quien hace una propuesta mucho más amplia del concepto de participación, al señalar que ésta debe asumirse como un ideal o modelo alternativo democrático, que define "Pragmático", instando a un diálogo público entre políticos, expertos científicos y opinión pública o de la ciudadanía, para facilitar procesos mutuos de aprendizaje y empatía cambiando posibles posturas autoritarias o cientificistas por procesos decisionales dialógicos.

Tabla 9. Tipología de Jurgen Habermas.

\begin{tabular}{|c|c|c|c|}
\hline & Modelo decisionista & $\begin{array}{c}\text { Modelo } \\
\text { Tecnocrático }\end{array}$ & Modelo Pragmático \\
\hline $\begin{array}{l}\text { Relación funcional } \\
\text { entre experto y } \\
\text { político }\end{array}$ & Separación & Separación & $\begin{array}{l}\text { Intercambios mutuos } \\
\text { y dialécticos. El } \\
\text { público deviene como } \\
\text { tercer actor }\end{array}$ \\
\hline Relación Jerárquica & $\begin{array}{l}\text { Político } \\
\text { Experto }\end{array}$ & $\begin{array}{l}\text { Experto } \\
\text { Político }\end{array}$ & $\begin{array}{c}\text { Diálogo entre experto } \\
\text { y político, relación } \\
\text { horizontal }\end{array}$ \\
\hline $\begin{array}{l}\text { Naturaleza del } \\
\text { poder }\end{array}$ & Autocracia & $\begin{array}{l}\text { Las coacciones } \\
\text { objetivas dominan } \\
\text { todo } \\
\text { Tecnocracia }\end{array}$ & $\begin{array}{c}\text { Un control } \\
\text { democrático es } \\
\text { posible }\end{array}$ \\
\hline Papel del público & Aclamar a las élites & $\begin{array}{l}\text { Ningún papel. } \\
\text { Eventualmente elegir } \\
\text { a los expertos }\end{array}$ & $\begin{array}{c}\text { Debate público sobre } \\
\text { objetivos y medios }\end{array}$ \\
\hline $\begin{array}{l}\text { Relación objetivo } \\
\text { medio }\end{array}$ & $\begin{array}{c}\text { Determinación } \\
\text { intencional de los } \\
\text { objetivos y racional } \\
\text { de los medios }\end{array}$ & $\begin{array}{l}\text { Optimización de } \\
\text { objetivos }\end{array}$ & $\begin{array}{c}\text { Objetivos y medios } \\
\text { debatidos. Posibilidad } \\
\text { de aprendizaje }\end{array}$ \\
\hline
\end{tabular}

Fuente: Widmaier (1976: 120). Adaptación A.N Roth

Este modelo participativo, según Velásquez Vargas, implica desafíos tanto para la institucionalidad como para la ciudadanía por cuanto se requiere formación y disponibilidad de tiempo para garantizar una participación activa y sustentable, además de una capacidad instalada para construir en medio de la diferencia y llegar a consensos Vargas (1999: 103). 
De hecho, López (1998: 23) considera el consenso como un paradigma postmoderno de la participación, por cuanto permite evidenciar y poner en común, los sentires e intereses a través del diálogo en lugar de la imposición "convencer antes que vencer".

Así entonces, acuñando la definición de planeación, de gestión y de evaluación que comparten Velásquez y González (2003), éstas se comprenden como procesos sociopolíticos y escenarios de interlocución entre actores que:

Comprenden una serie de dinámicas sociales y políticas en torno a la identificación de problemas y potencialidades del presente y a la formulación de apuestas de futuro. Como escenario, (...) son una oportunidad de encuentro entre voces diferentes interesadas en construir consensos básicos sobre metas de bienestar y sobre los procedimientos, instrumentos y acciones necesarios para alcanzarlas (2003:18)

Ambos autores precisan además, que la planeación y por ende la evaluación son por esencia participativas y por consiguiente, deben ser abierta e incluyentes. Sin embargo, reconocen una serie de obstáculos o barreras para su realización, entre los que señala la desconfianza de la gente en sus representantes y la apatía ciudadana frente a los asuntos públicos -se halla en juego la confianza institucional-. Sobre este asunto, proponen que la administración distrital y las alcaldías locales consideren la participación ciudadana como la "columna vertebral" de su gestión. Dicen que esto debe reflejarse en el "fortalecimiento de los espacios de participación existentes, en la creación de otros espacios que sean necesarios y en la promoción de la organización y el liderazgo social." (Velásquez y González, 2003:6)

Ahora bien, la planeación o planificación según Matus (1988), reconociéndole como herramienta de gobierno desde diferentes actores sociales y dentro del marco de la Planeación Estratégica Situacional (PES), requiere de conciliar:

a) lo que se proyecta o que se crea, puede suceder en el futuro con lo que está ocurriendo en el presente. “...es hoy cuando puedo hacer algo para estar en condiciones de aprovechar las oportunidades de mañana y evitar los problemas futuros."

b) el pasado con el futuro para "aprender de mis errores"

c) el conocimiento con la acción, en la medida que es importante "...reflexionar antes de actuar"

d) la acción central con las acciones particulares en tanto “...cada actor produce (...) hechos en relación a sus visiones y propósitos particulares y nada garantiza la coherencia del resultado social global”

En efecto, la teoría de la PES (Laguens \& Rozenhauz, s.f.), desarrolla cuatro momentos que pueden ser simultáneos para un proceso de planificación: a) situacional o diagnóstico causal de los problemas que se pretenden intervenir; b) operativo o de la 
formulación de un plan que brinde posibles alternativas de solución; c) construcción de la viabilidad de dicho plan y d) táctico - operacional a través del que se busca implementar el plan bajo un constante ejercicio de seguimiento y evaluación.

Otro tema que en el marco del debate sobre la participación, es imposible no considerar, es el de la representación o representatividad por cuanto, un proceso de planificación o evaluación participativo, implica poner de manifiesto no sólo las necesidades e intereses particulares sino además, las propias del territorio, sector o comunidad de la cual se hace parte. “...el individuo deja de ser un ente aislado, y pasa a ser la corporización de una comunidad que lo impregna, social y culturalmente (...) una persona que tiene otras identidades más allá de la jurídica que le otorga el Estado.”(Mires, 1994: 16)

\subsection{Gestión Asociada y Redes Sociales}

Según Poggiese (2004), la Gestión Asociada (GA) es un modelo y herramienta de planificación-gestión, que se desarrolla de manera simultánea en un mismo proceso o escenario ciudadano de naturaleza interdisciplinaria e intersectorial, donde se llevan a cabo acciones conjuntas entre la comunidad y el Estado, a través de canales de participación que dan lugar a acuerdos y consensos para el tratamiento del desarrollo, en base a una visión y un método integrador.

Tiene como objetivo la movilización y articulación de actores con peso relativo en los proyectos y políticas, estableciendo acuerdos y grados de responsabilidad y compromiso mutuos, formulación de metodologías y planes de trabajo, gestión de recursos humanos y financieros que viabilicen los emprendimientos (Poggiese \& Francioni, 1993: 13)

Incluso para Morroni y Redín (2002), la GA logra retomar los planteamientos de la PES de Matus para profundizarla desde el enfoque de la participación: "Esta planificación PPGA amplifica la concepción de la PES (Planificación Estratégica Situacional) de Matus, al agregarle el componente participativo y dialógico.”. Esta concepción de gestión colectiva entre organizaciones diversas del Estado y sociedad, implica una lógica distinta de relación horizontal, de vínculo estrecho sostenido en el tiempo entre quienes comprometen su voluntad de asociarse, catalogado por el mismo autor como "affetio societatis" lo cual resulta absolutamente aplicable también en el momento de la evaluación o del control social de los planes, programas y proyectos.

Para estos mismos autores, la GA es como "un sistema de trabajo planificado que va construyendo una relación articulada de colectivos en torno a proyectos elaborados y gestionados co-gestivamente." (Morroni y Redín, 2002: 23), esta concepción resulta alternativa a las lógicas tradicionales de planificación que fundamentalmente se habían tranzado en la investigación-acción sin mayor proyección, especialmente, respecto a la co-gestión de la esfera pública: "Las primeras tres fases de la secuencia lógica [de la GA], permiten realizar una investigación participativa con finalidad diagnóstica; las 
últimas tres [de la GA], conforman un cuadro planificado de acciones estratégicas." (los corchetes son anexos) (Ibíd, 2002: 15).

Por consiguiente, la GA para Poggiese (2004), Morroni \& Redín (2002), resulta ser una oportunidad de potenciación a sociedades democráticas que buscan fortalecer sus procesos de planeación, toma de decisiones y participación social: "La Familia de Metodologías PPGA se sustenta en una concepción que hace eje en el aumento de la participación popular en la formulación de políticas públicas, materializada en una planificación y gestión conjuntas entre Estado y Sociedad."(Morroni \& Redín, 2002: 2).

Es importante reconocer que efectivamente en el desarrollo de la GA, se evidencia su aporte pedagógico a la construcción de Democracia puesto que permite a sus protagonistas “aprender a aprender" mientras son parte de la planeación y co-gestión de sus territorios.

Como experiencia democratizante el escenario es también un aprendizaje social para tratar las diferencias, aceptar y trabajar el conflicto, entrenar el pluralismo y estrenar formas transparentes de negociación técnico-disciplinarias y de asociación de intereses. Genera también la posibilidad de relacionar la práctica de la representación como intermediaria en cuanto a cargo electivos y la producción de consenso para la consolidación de fuerzas sociales, así los representantes que según las reglas de la democracia formal deben resolver según la ley de la mayoría pueden asentarse sobre bases consensuales más sólidas y anticipadas, y otros ciudadanos pueden también intervenir en la formulación de decisiones bajo las reglas del consenso (y del disenso) explicitado (Negrilla es anexa) (Poggiese \& Francioni, 1993: 19)

De hecho, otro elemento crucial de este modelo de planificación-gestión es la producción de conocimiento por cuanto todo el tiempo promueve, rescata, visibiliza y reconoce los saberes, reflexiones y aprendizajes que se van construyendo en el proceso:

se pretende construir una nueva forma de "saber-hacer", un nuevo conocimiento a partir de los saberes e ignorancias de todos los que participan, una nueva cultura de lo político, de lo público y de lo social, donde "se preparan las decisiones" que serán adoptadas por los funcionarios responsables, ampliando la base en la toma de decisiones, es decir colaborando en la profundización del sistema democrático (Cardarelli y Rosenfeld, 2002: 2).

Morroni y Redín (2002) lo confirman cuando señalan que la finalidad de la GA:

Es producir un conocimiento colectivo "anticipado" de la situación problemática, posibilitando a los grupos sociales pensar de una manera diferente el contexto en un marco de confianza y solidaridad. Define objetivos, gestiona recursos (humanos, financieros, etc.), pondera la viabilidad, prioriza al actor más débil para reducir desigualdades de poder tanto políticas, económicas como institucionales. Elabora los 
instrumentos, reglas, procedimientos y convenios necesarios para el desarrollo de proyectos co-gestivos. Se efectúan articulaciones y contactos con los organismos pertinentes, construyendo así el "tejido estructural de sostén" para la viabilidad de los proyectos (institucional, normativo, organizativo, funcional) (2002: 24)

Ahora bien, como lo manifiesta Poggiese, la GA puede operar bajo el entendido de que la articulación para la gestión, superará "la vieja instancia de la mera articulación de actores demandantes en función de resolver sus necesidades o de promover sus intereses." (2000:5). Lo que Cardarelli y Rosenfeld (2002), confirman al resaltar la apertura o disponibilidad por parte de cada actor comprometido con el proceso, para adecuarse a las condiciones que su rol o papel le requiera.

Para estas autoras, hacer GA supone:

Por parte del Estado, una fuerte vocación de distribución del poder y con ello arreglos organizativos que sienten las bases de la democratización de la política social. Por parte de la sociedad civil se pone en juego su capacidad para apropiarse de la cuota de poder que le corresponde manteniendo su identidad y su autonomía. "La gestión asociada" remite a problemas políticos, entre otras cosas porque exige la consolidación de una cultura política basada en la evaluación y la rendición de cuentas, sostenida en una visión que supere el cortoplacismo y promueva una visión de conjunto de los problemas y de las estrategias de resolución (Cardarelli \& Rosenfeld, 2002: 14)

Lo anterior, en congruencia a la necesidad que Poggiese (2000) evidencia cuando refiere que las ciudades requieren de una articulación multilateral que garantice pactos de resolución conjunta. En este sentido, es importante evidenciar los criterios que el mismo autor junto con Francioni y Poggiese (1993:17), sugieren, deben cumplirse en un escenario en el que se pretenda aplicar la GA:

a) descentralizados para garantizar la relación novedosa entre Estado y sociedad en torno a lo local/micro regional, respecto a la elaboración e implementación de un plan de desarrollo local/micro regional;

b) intersectoriales por los que circulen procesos decisorios del Estado y la sociedad, garantizando la influencia de lo local en lo nacional;

c) proclives a la generación y puesta en marcha de voluntades por parte del Estado y sociedad para asociarse y contribuir mancomunadamente a la creación y operación de organizaciones sociales en condiciones de coparticipar en la gestión política y la administración del desarrollo;

d) contribuyentes a la eficiencia social del Estado respecto a los proyectos de desarrollo local/micro regional y políticas diferenciadas de descentralización; y

e) constituyentes de experiencias que devuelvan la credibilidad y confiabilidad a la democracia como sistema de conjugación de intereses y debate sobre el destino de la sociedad. 
Según Poggiese y Redín (1997), la GA ha evolucionado durante las tres últimas décadas, contribuyendo a la planificación de proyectos y planes de desarrollo local y regional, formulación e implementación de políticas públicas y configuración de nuevos actores colectivos o redes mixtas socio-gubernamentales en la región: "la Gestión Asociada, es punto de partida y punto de llegada porque impulsa la secuencia de escenarios y es también su resultado, al reconfigurarse durante el proyecto alcanzando nuevos niveles de articulación y sistematicidad." (Poggiese \& Redín, 1997: 9)

En efecto, la GA tiene como uno de sus propósitos derivados del proceso de articulación sistemática, la configuración de nuevos escenarios como actores sociales y políticos con ingerencia en la gobernanza de su territorio. Nuevos escenarios que se reconocen como redes fundamentadas en el enfoque y metodologías de la GA, lo que sin duda aseguraría su sustentabilidad.

lo que distingue a las redes de gestión asociada (GA) es estar dotadas de una concepción y una práctica sistemática, utilizando en sus procesos de conformación metodologías pertinentes que combinan procesos de planificación participativa con mecanismos de gestión compartida entre los más diversos actores. Estas permiten a las redes moverse dentro de lineamientos estratégicos y de gestión diseñados en forma conjunta y sujetos a revisión periódica. Estas prácticas dan al conjunto de actores de la red ideas del qué hacer, lo sustantivo, las hipótesis, las estrategias y del cómo hacer, la metodología y los procedimientos reglados. Otra de sus notas distintivas es que estas redes se dan en torno a proyectos cogestivos. Otro aporte sustantivo de estas redes es que como construcciones adquieren, dentro de este proceso metodológico, cierta sustentabilidad sin verse desvirtuadas (ni estructuradas ni cristalizadas) en su funcionamiento (Poggiese, Redín \& Alí, 1999: 12).

Redes que pueden contribuir a la generación y/o fortalecimiento de movimientos sociales como por ejemplo, los movimientos de mujeres: "La red como concepto propositivo de los movimientos sociales aparece una alternativa de construcción de relaciones más horizontalizadas y por mismo, una nueva utopía democrática con la posibilidad de conectar lo local con el mundo más amplio” (Poggiese, 2000: 7).

En este punto es necesario traer a colación, la reflexión que se hace respecto al cómo un escenario puede en su dinámica o cotidianidad, y de acuerdo a los ideales políticos de quienes le conforman, configurarse en un movimiento social: “...un movimiento social no es, sino que llega a ser en el recorrido de su propia auto reproducción” (Poggiese, 2000: 7)

De acuerdo a todo lo expuesto respecto a la GA, y de acuerdo con los postulados de Francioni \& Poggiese (1993:11), Morroni \& Redín (2002:9), es indudable que para lograr su aplicación en un espacio en el que se pretenda un modelo decisorio cogestivo, se requiere que éste: 
a) Se reconozca como un escenario descentralizado en el que se haya configurado un nuevo pacto entre Estado y sociedad, de tal manera que sea un potencial actor colectivo emergente en la gestión del territorio donde concentre su acción.

b) Se asuma como un escenario multipropósito desde el que se contribuya con y durante su proceso, a transformaciones sociales en el territorio y las comunidades sobre las que actúa.

c) Se comprometa a lógicas de relacionamiento y toma de decisiones horizontales y desde distintas disciplinas, miradas o enfoques que permitan el abordaje integral de la complejidad que suele caracterizar a las problemáticas sociales, de tal modo que se configure como un escenario socio-gubernamental.

d) Se disponga a hacer de la participación, un ejercicio procesual en el que se garantice su incidencia en la planificación y gestión local, constituyéndose en un escenario incidente.

Tomando en consideración los aspectos desarrollados hasta este momento, como parte del ejercicio propositivo que subyace al desarrollo investigativo de este trabajo se considera pertinente que los ejercicios de evaluación de políticas públicas y de control social resignifiquen sus discursos y prácticas, se conviertan en oportunidades de democratización social del ciclo de las políticas públicas y en este sentido, se asegure la acción de propiciar espacios para la escucha, la argumentación y la construcción de acuerdos desde las distintas voces que le constituyan, de tal manera que se caracterice como un escenario de construcción de consensos en contextos multipropósito en los que se posibilite la permanente relación dialéctica entre planificación-gestión.

\subsection{Síntesis}

En este capítulo se realizan importantes reflexiones respecto a la planificación participativa y la gestión asociada como marco de acción de las políticas públicas, éste resulta ser un escenario interesante para la promoción de capacidades de gestión de planes, programas y proyectos que vinculen la acción colectiva como motor de la construcción de mejores condiciones de vida de las poblaciones y grupos sociales. Se realiza un balance conceptual sobre las diferentes nociones de las políticas públicas y así de cada uno de los momentos de los que se compone su ciclo, ello coadyuva a considerar como factor importante la escuela de pensamiento en la que se sitúe el discurso y la práctica de la planificación; el situarse en una u otra escuela, determinará el curso de la acción que se desarrolle en términos de planes, programas y proyectos, e incidirá en la concepción de sujetos que se tenga, en los actores que se consideren como válidos y activos participantes para intervenir en el proceso de construcción de políticas y en la concepción que se tenga sobre la incidencia ciudadana.

En el planteamiento sobre el que se sustenta la presente investigación, se apuesta por una noción de políticas públicas en la que de paso a la consideración de la interacción- 
participación de múltiples actores sociales que convergen en la acción pública; se apuesta por la ampliación de la noción de lo público y la democratización de la administración pública, éstos como contextos que no solo le competen al Estado, sino que son de actuación y reflexión de la sociedad como conjunto. En este sentido, el ciclo de la política pública debe concebirse justamente como un escenario cíclico, más no como algo lineal de dirección causa-efecto; por tanto, resulta importante construir un escenario multipropósito de planificación-gestión, en donde las lógicas de colectividad, articulación de actores-intereses-escenarios, constituyan la configuración por consenso de procesos de toma de decisión en donde los actores son concebidos como legítimos otros y construyen participativa y colectivamente las políticas públicas.

En este marco conceptual re-pensar lo público es un elemento ineludible para conceptualizar o reflexionar sobre la política pública. En primer lugar, se dilucida la autonomía de las esferas estatal y público social, entendiendo que lo público no solo obedece al Estado, sino que se enraíza en todas las discusiones que son de interés común, involucrando tanto al estado como a la sociedad. Así se vislumbra la reflexión sobre autonomía toda vez que las dos esferas (estado-sociedad) tienen sus propias lógicas de configuración, consolidación y fortalecimiento, pero deberían establecer sinergias frente a la toma de decisiones, la definición de agendas y la estructuración de políticas y acciones públicas.

Es importante considerar que en el ciclo de política pública intervienen múltiples factores incidentes en el proceso de diseño y formulación, pugnas de intereses y fuerzas; tensiones y conflictos que se activan, equilibran y reactivan en la dinámica de estructuración. En este sentido, el reconocimiento de estos factores de convergencia genera una posibilidad de ampliación del panorama de análisis de los momentos que subyacen a dicho ciclo de políticas.

El carácter participativo, multipropósito y multiactoral que debe constituirse en fundamento de las políticas públicas, estructura la necesidad de llevar a cabo metodologías de planificación participativa que permitan que los planes, programas y proyectos construidos sean fruto del consenso de múltiples actores sociales que convergen en la situación socialmente problemática que se busca solucionar. Desde esta perspectiva, la Gestión Asociada permite la construcción. Es un ámbito en el cual se desarrollan acciones conjuntas entre la comunidad y el estado, donde los canales de participación dan lugar a la elaboración de acuerdos, negociaciones o concertaciones a partir del reconocimiento de los conflictos, diseñando propuestas y acciones que integran visiones e intereses contrapuestos. Se trata de un espacio de naturaleza interdisciplinaria e intersectorial que utiliza una mecánica abierta y pluralista, de fácil acceso, operando por acuerdo y consenso.

A partir de la construcción colectiva de los procesos de toma de decisión en la gestión pública, se reconfiguran las lógicas de acción de las políticas, de manera que se considera que al afectar -positivamente- uno de los momentos del ciclo de construcción de planes, programas y proyectos, se estará afectando todo el proceso de la política. Sí 
se trabaja en el momento de la evaluación y allí se generan cambios a partir de lo que ya está construido y se logra hallar aspectos susceptibles de mejorarse, se logrará incidencia en los demás momentos a saber, diseño, planificación, implementación etc. Es por ello, que esta investigación doctoral se centra de manera específica en el momento de la evaluación, logrando estructurar rutas para construir lo colectivo, desde la gestión asociada del territorio con miras a potenciar las capacidades ciudadanas para participar en lo público; se piensa en partir de valorar lo existente en el territorio (desde la evaluación o control a las políticas públicas), por una parte se da importancia a lo ya construido, no se parte de cero, se parte de un entramado de experiencias que los actores ya han construido como formas de relación y acción; es desde allí y desde su reflexión retro y prospectiva, desde dónde se encuentra sentido a la posibilidad, necesidad e importancia de generar cambios en varios aspectos de la planificación social.

En este sentido, se concibe que el momento valorativo de las políticas públicas -bien sea bajo la figura evaluación o la de control social-, construye sus prácticas sociales, codecidiendo con otros-otras, su realidad y existencia. Tal y como lo expresa Poggiese (2000), se espera que cada individuo en tanto molécula social que es, "actúe en cualquier sitio (especialmente en su lugar próximo, lo local, donde se le presentan los problemas), con un esmerado cuidado -una práctica ecologista- de todo el globo (Poggiese, 2000: 2)

Así, la Gestión Asociada del Territorio aplicada a la evaluación, resulta ser un modelo y herramienta de planificación-gestión, que se desarrolla de manera simultánea en un mismo proceso o escenario ciudadano de naturaleza interdisciplinaria e intersectorial, donde se llevan a cabo acciones conjuntas entre la comunidad y el Estado, a través de canales de participación que dan lugar a acuerdos y consensos para el tratamiento del desarrollo, en base a una visión y un método integrador. Es por ende una metodología participativa que tiene como uno de sus propósitos derivados del proceso de articulación sistemática, la configuración de nuevos escenarios como actores sociales y políticos con ingerencia en la gobernanza de su territorio. 


\section{CAPÍTULO 3. EL CONTEXTO DE ESTUDIO. DOS REALIDADES LATINOAMERICANAS: COLOMBIA Y BOLIVIA}

Para iniciar es importante mencionar que el tema central de esta tesis doctoral versa sobre la evaluación de políticas públicas, desde esa perspectiva, se intenta hacer un abordaje sobre las dinámicas participativas que promueven la construcción y/o fortalecimiento de la agencia social en las comunidades que se vinculan con las dinámicas de control social o evaluación. Por lo tanto, se parte de concebir que la evaluación de políticas públicas es una práctica representativa de la gestión territorial para la paz; así es indispensable decantar los marcos conceptuales y de sentido que entraña dicha noción como parte de la contextualización de los conceptos base del estudio.

Hablar de la Gestión del territorio para la paz (como discurso y práctica, así como desde su sentido -lógica de concreción- y significado -elementos que componen su resolución en el territorio-) resulta un ejercicio que suscita la pregunta por el contexto, por las claridades sobre el devenir histórico-social, por las características, los actores y escenarios que interactúan en el ámbito territorial y que estructuran pautas, formas de acción y de interrelación que dan cuenta de las dinámicas en las que se desarrolla la vida social de los diferentes colectivos de población. Es por ello que, en primera instancia, se hace importante la alusión a aspectos fundantes de las realidades sociales en las que se enmarca este estudio, con miras a deconstruir los ámbitos sociales, políticos, culturales que representan caminos de lectura, comprensión e interpretación de los avatares de las realidades latinoamericanas en experiencias sociales y de participación en la administración pública u otros campos de acción y/o inserción. 
Así las cosas, este apartado del documento desarrollará los principales planteamientos de carácter contextual que permitirán situar el estudio en los lugares de interés a saber Colombia-Bogotá y Bolivia-Sacaba. En este punto resulta necesario mencionar que debido a que de manera previa año 2012 se desarrolló la tesis Máster que es conducente ahora a este trabajo de tesis doctoral, se retomarán de allí aspectos base para caracterizar la realidad colombiana en la que se evidencian fuertes consecuencias del conflicto armado interno en los ámbitos social y comunitario, fue éste el escenario en el que originariamente se proyectó y construyó el concepto -Gestión del territorio para la paz; de manera que retomando este acervo conceptual, documental y analítico-reflexivo se desarrollará la aproximación al contexto boliviano y específicamente al Municipio de Sacaba, como lugar en el que interesa evidenciar la aplicabilidad de la Gestepaz en términos del planteamiento de una propuesta de estructuración de un sistema de evaluación de políticas públicas que potencie el empoderamiento de la ciudadanía a través de un proceso social de soporte y un sistema técnico de indicadores o insumos metodológicos como aportes al impulso de procesos de democratización social e incidencia en políticas públicas.

Como se menciona anteriormente, es necesario partir de la caracterización de los contextos dada su importancia en términos de situar el tiempo-espacio y la coyuntura de ubicación de las nociones articuladas con la gestión del territorio, de allí la necesidad de partir de mencionar las características del (los) lugar(es) en donde estas tendrían aplicabilidad, para posteriormente decantar la parte conceptual subyacente a éste.

En los dos contextos se evidencian referencias a prácticas violentas, en el primero Colombia- asociadas a la violencia sociopolítica y a las lógicas del conflicto armado interno, en el segundo escenario -el boliviano- una pervivencia y reproducción en el tiempo de altos índices de inseguridad ciudadana y violencia estructural. A continuación se desarrollarán los principales planteamientos al respecto.

Las dinámicas de la violencia se inscriben en el espacio cotidiano de hombres, mujeres, adultos mayores, comunidades étnicas e indígenas y de niños, niñas y adolescentes, como situaciones que instauran el miedo y la amenaza, y que a su vez expresan la desestructuración social que reproducen las lógicas de los diversos tipos de violencia: política, social, cultural y/o estructural. En esta perspectiva, el análisis de las dimensiones que en el contexto colombiano subyacen a la confrontación armada y la comprensión de sus consecuencias sobre los diferentes grupos poblacionales y en el caso boliviano el desentrañar los patrones sociales, culturales e incluso económicos que inciden en la aparición y mantenimiento de prácticas violentas (inseguridad ciudadana, consumo de drogas, violencia de género, pobreza), representa una oportunidad que permite proyectar reflexiones ligadas con las estructuras legislativas, de caracterización, de definición, así como de atención y prevención de situaciones que hacen parte de estas realidades. Lo anterior además remite a interrogar las prácticas y discursos de las políticas públicas en tanto iniciativas, acciones y decisiones que buscan dar respuesta a 
situaciones socialmente problemáticas en un escenario determinado, se interpelan en tanto productoras de sentido y contenido de las administraciones públicas, que desde los contextos locales deberían constituirse en prácticas y experiencias de democratización social, incidencia ciudadana y por ende fomento de prácticas de paz.

En primera instancia -caso Colombia- se habla de un contexto marcado por el conflicto armado, ya que el devenir histórico colombiano ha estado atravesado por éste, materializado en hechos violentos que han transformado las dinámicas sociales, políticas y económicas de la sociedad nacional. En sus distintas modalidades, la violencia política se ha posicionado como correlato de la historia del país, menoscabando enormemente el lazo social. Hechos como las masacres, los asesinatos selectivos, las desapariciones y los desplazamientos forzados, dan cuenta de la violación sistemática de los Derechos Humanos, y de la pervivencia del conflicto por varias décadas.

¿Cómo caracterizar la gestión del territorio para la paz en un contexto marcado por la persistencia del conflicto armado interno, a partir de la identificación de aspectos neurálgicos para la construcción de paz desde los escenarios locales?

La discusión señala varias fuentes de análisis, de manera que iniciar un abordaje de las nociones y términos subyacentes a la investigación planteada, de cuyos resultados surge este documento implica la realización de un marco contextual que permita que los lectores se sitúen en la importancia de este estudio, las implicaciones de pensar un tema tan complejo en un escenario signado históricamente por la violencia sociopolítica, cuyos efectos recaen en diversidad de colectivos de población generando profundos impactos psicosociales; es una tarea que involucra desde este enfoque, el rescate y la visibilización de los aspectos que hacen que a pesar de lo adversas que puedan resultar las miradas a un país como Colombia, también puedan hacerse reflexiones que generen la alusión a buenas prácticas de paz como posibilidades de análisis a profundidad, que coadyuvan a establecer la importancia de una relación dialéctica, necesaria y urgente de trabajo, cooperación y esfuerzos conjuntos entre los países del norte y los del sur.

En segunda instancia se hará referencia a dinámicas del contexto Bolivia que configuran una realidad social en la que se evidencia la presencia de diversas situaciones socialmente problemáticas que evidencian aquello que conceptualmente se denomina como violencia estructural (caracterizada por situaciones que exacerban la desigualdad y disparidad social). Este análisis contextual permitirá enriquecer la referencia al concepto Gestión del Territorio para la paz en el marco del objetivo de potenciar la construcción de nuevos conocimientos e innovaciones metodológicas, así como instrumentos que contribuyan en el área de estudios, pensando específicamente en la estructuración de la propuesta de trabajo e intervención para el Municipio de Sacaba en el contexto boliviano. 


\subsection{Colombia: Contexto y dinámica del conflicto armado}

Como se observa en los planteamientos anteriores, hablar de un determinado aspecto en el contexto colombiano, nos remite a tocar el tema del conflicto armado que ha permeado las esferas sociales, políticas, culturales y económicas del contexto nacional y que desafortunadamente se ha convertido en un aspecto transversal a estos escenarios. Así las cosas, cabe mencionar que según el Derecho Internacional Humanitario (DIH) se habla de conflicto armado cuando en un país hay presencia de fuerzas no estatales estables, que ejercen algún tipo de control o presencia permanente en un territorio, que tienen mandos establecidos y que desarrollan acciones militares permanentes. Así, desde esta perspectiva y con el sustento conceptual del DIH se observa que en Colombia existe un conflicto armado caracterizado porque se desarrolla en el contexto de un Estado, se ejerce un tipo de control sobre el territorio, se desarrolla entre fuerzas estatales y disidentes y se identifican diversidad de fuerzas con un variable nivel de jerarquía. En el devenir histórico de esta confrontación se ha evidenciado que tal como menciona Clausewitz (1999) la guerra ha cambiado sus dinámicas, modalidades y naturaleza en cada caso concreto convirtiéndose en una extensión de la política por otros medios, de manera que los objetivos políticos de la confrontación armada, tienen como telón de fondo la búsqueda por el poder territorial, así como unos intereses políticos arraigados.

El conflicto armado en Colombia ${ }^{7}$ ha sido marginal al sistema político, dicho carácter de marginalidad resultó hace unos años decisivo para un determinado modo de actuación de los actores armados, los grupos insurgentes no tienen oportunidad de inserción en escenarios políticos y geográficos de forma directa; en el país no están las condiciones para que dichos grupos sean exitosos, ya que han sido y son ilegitimados por la sociedad en su conjunto, no cuentan con apoyo de base para generar un movimiento social fuerte que logre el derrocamiento de las autoridades existentes y mucho menos el control del aparato estatal; por otra parte, la degradación del conflicto (debida también a la inclusión del narcotráfico, el terrorismo mundial y las drogas, entre otros) y la barbarie de las acciones insurgentes hacen que la sociedad en su conjunto repudie a estos grupos, ya que se encuentra que "más específicamente, la dinámica de degradación propia de este conflicto resultaría de seis lógicas o "inercias" no políticas, que se superponen y alimentan entre sí. Llamaremos a tales inercias las lógicas de militarización, rentismo, territorialización, terror, criminalización y vinculación apolítica, respectivamente” (Programa de las Naciones Unidas para el Desarrollo -PNUD-, 2003).

Aunque se observa que en un inicio el conflicto fue más urbano que rural, en la actualidad se identifica lo contrario, la periferia campesina se convierte en un referente

\footnotetext{
${ }^{7}$ Para la construcción de la parte contextual de este documento en lo referente al conflicto armado colombiano se retoman planteamientos de: PNUD informe de desarrollo humano 2003; de Zuluaga Jaime En: Descentralización, conflicto, participación y territorio. Memorias de curso de contexto. Universidad Nacional de Colombia 2008; Gonzalo Sánchez en varios textos sobre historiografía de la guerra y la violencia.
} 
geográfico, cultural y político importante. Encontramos varias hipótesis en las que podría enmarcarse su origen: la que ha sido mayormente apoyada tiene que ver con que la guerra surge en una estructura bimodal de tenencia de la tierra, cuya extensión territorial es distribuida en latifundios y minifundios, dicha explicación es respaldada por varios autores (Romero, 2008; PNUD 2003; Zuluaga, 2008), que sitúan el nacimiento del conflicto en el momento en que se inicia la pugna por la tierra y el problema agrario.

El PNUD en 2003 en el Informe Nacional de Desarrollo Humano "conflicto: callejón con salida" precisamente en un esfuerzo por dar cuenta del devenir histórico de la confrontación armada, alude a realizar un breve balance historiográfico de la época de la colonia, de forma que se inicia por mencionar la división territorial en latifundios y minifundios. De dicha organización colonial data la vulnerabilidad de algunas zonas a las prácticas de justicia desde la perspectiva privada o la privatización de la justicia y el surgimiento de ejércitos irregulares. Sobre los ejércitos ilegales se encuentra que se estructuran de una forma inequívoca o representativa a través de las llamadas “autodefensas campesinas" y las guerrillas revolucionarias por mencionar dos ejemplos.

Una vez transcurridas las guerras civiles del siglo XIX, las dos fuerzas políticas más importantes del país se encuentran enfrentadas en el periodo denominado la Violencia (que comprende los años de 1946 a 1965, aproximadamente), cuyo resultado son más de un centenar de víctimas en un país que entonces tenía aproximadamente una población que ascendía a los trece millones, este periodo es objeto de múltiples disertaciones en el ámbito académico. Es importante mencionar que las reformas políticas y sociales del liberalismo en la década de los treinta caracterizadas por un auge del intervencionismo de Estado, la promoción del laicismo, un incremento y posicionamiento en la escena social de las fuerzas sindicales y una incipiente Ley de tierras entre otros, son aspectos que darían cuenta del impulso de un paradigma modernizador en el contexto nacional, en el cual una de sus metas fundamentales era la "integración" de los sectores de la clase media, obrero y campesino que en este momento de la historia eran colectivos de población excluida. Este elemento causó efecto contrario al generar gran resistencia en el panorama político de aquel entonces, generando un alto en el gobierno de Eduardo Santos en el que se ocasiona una división al interior del partido liberal en donde se observa una polarización entre el ala moderada y la populista radical representada por Jorge Eliecer Gaitán; líder popular que emergió en un contexto histórico de grandes transformaciones económicas y sociales del país ligadas al proceso de modernización capitalista, constituyéndose no sólo en uno de los principales protagonistas de la vida política, sino también en el gran transformador de las prácticas políticas en Colombia.

En 1948 se produjo el asesinato del líder popular Jorge Eliécer Gaitán, este suceso representó un hito historiográfico que da cuenta del desencadenamiento de la violencia campesina en Bogotá y otras ciudades, en dos registros: i) Llanos orientales donde la ideología de la guerrilla responde a la disciplina liberal y ii) en zonas la mayoría de minifundio andino, y con una estructura económica soportada en el café. En teoría la 
violencia acaecida por esta época, década de los cuarenta en adelante, debería haberse extinguido tras la puesta en marcha de dos elementos: el primero la amnistía del entonces presidente general Rojas Pinilla en el proceso de desmovilización de los grupos insurgentes del llano y el segundo el Frente Nacional como estrategia de paridad y alternación del poder entre los partidos políticos tradicionales (liberal y conservador) con lo cual se desmovilizarían las guerrillas liberales y las bandas conservadoras o “pájaros". Sin embargo, la puesta en marcha de la estrategia política del Frente Nacional termina convirtiéndose en factor auspiciador de las guerras de la década de los sesenta, ligadas con la exclusión de la participación política de fuerzas diferentes a las hegemónicas, en esta época las guerrillas dan origen a un conflicto armado interno, de carácter ideológico-político, propio de la guerra fría.

Cabe mencionar que el Frente Nacional en el S. XX se instaura como norma vigente en los años de 1958 a 1974, representando una división de la burocracia nacional y departamental, en un contexto en el que ningún otro partido (diferente a liberal o conservador) podía participar en el escenario político; de esta forma, el país se encuentra ante lo que se podría denominar una exclusión por vía constitucional, que actúa como factor determinante del surgimiento de las guerras en los años sesenta (Ver Tabla 1). En este contexto, las guerrillas se proclaman la vanguardia nacional, pero en ningún momento en su devenir histórico se les ha permitido proyectarse como opción política real.

Tabla 10. Surgimiento de las guerrillas en Colombia.

\begin{tabular}{|c|c|c|c|}
\hline Grupo & Objetivo y proyecto político que persigue & Contexto de surgimiento & \\
\hline $\begin{array}{l}\text { FARC } \\
(1964)\end{array}$ & Reformismo agrario & $\begin{array}{l}\text { Encuentro entre guerrilla campesina y partido } \\
\text { comunista, que no encuentran espacio en el } \\
\text { sistema político. }\end{array}$ & \multirow{3}{*}{ 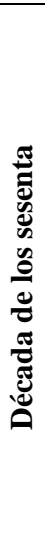 } \\
\hline $\begin{array}{l}\text { ELN } \\
(1965)\end{array}$ & $\begin{array}{l}\text { Revolución socialista, que solo se puede lograr a través } \\
\text { de las armas }\end{array}$ & $\begin{array}{l}\text { Nace como guerrilla revolucionaria (de } \\
\text { naturaleza liberal, se nutre de la teología de la } \\
\text { liberación y el sindicalismo) }\end{array}$ & \\
\hline $\begin{array}{l}\text { EPL } \\
(1967)\end{array}$ & Revolución de la nueva democracia. & $\begin{array}{l}\text { Nace cuando el partido comunista marxista- } \\
\text { leninista ordenó el traslado de } 4 \text { directivos al } \\
\text { campo. Logro penetrar el movimiento } \\
\text { campesino y tuvo presencia significativa en } \\
\text { regiones de Córdoba y Urabá. }\end{array}$ & \\
\hline $\begin{array}{l}\text { M-19 } \\
(1974)\end{array}$ & $\begin{array}{l}\text { Lucha por la construcción de un poder de obreros, } \\
\text { campesinos y trabajadores en general, el cual } \\
\text { destruyendo el actual estado oligárquico mediante una } \\
\text { guerra en donde participen todos los explotados, logre la } \\
\text { liberación de nuestra patria y la instauración del } \\
\text { socialismo }\end{array}$ & $\begin{array}{l}\text { Nace como movimiento armado para defender } \\
\text { las elecciones. Guerrilla urbana que reconoce } \\
\text { este contexto como importante. } \\
\text { Surge en el seno del movimiento político } \\
\text { Alianza Nacional Popular (ANAPO). } \\
\text { Se desmoviliza en } 1990 \text { en el gobierno de } \\
\text { Virgilio Barco Vargas. }\end{array}$ & 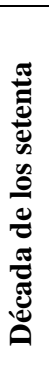 \\
\hline
\end{tabular}


Tabla 11. Surgimiento de las guerrillas en Colombia. (Continuación)

\begin{tabular}{|c|c|c|c|}
\hline Grupo & Objetivo y proyecto político que persigue & Contexto de surgimiento & \\
\hline $\begin{array}{l}\text { Movimiento } \\
\text { armado } \\
\text { Quintin } \\
\text { Lame } \\
\text { MAQL } \\
\text { (1984) }\end{array}$ & $\begin{array}{l}\text { Integrado principalmente por indígenas nasa, quienes } \\
\text { tomaron el nombre del representante y defensor de los } \\
\text { cabildos indígenas del Cauca que libró una lucha jurídica } \\
\text { en los primeros } 20 \text { años del siglo XX en defensa de los } \\
\text { resguardos indígenas no sólo del departamento del Cauca } \\
\text { sino también del Tolima }\end{array}$ & $\begin{array}{l}\text { Nace en un contexto de tendencias } \\
\text { opuestas entre guerrillas e indígenas; se } \\
\text { dan constantes presiones de grupos } \\
\text { armados a las comunidades indígenas y } \\
\text { exhortación constante para que hagan } \\
\text { parte de uno u otro bando. }\end{array}$ & 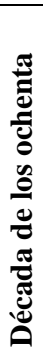 \\
\hline
\end{tabular}

Fuente: Elaboración propia, retomando como insumos los textos consultados para la contextualización de este estudio. Enero de 2012.

Desde la perspectiva analítica propuesta, la violencia bipartidista como factor en el que se enmarca el surgimiento del conflicto armado interno, procede del centro geográfico (urbano), expresándose con todas sus fuerzas en la periferia campesina como se ha mencionado líneas atrás. Conceptualmente vemos a la violencia como una disputa burocrática e ideológica por el control estatal entre los dos partidos hegemónicos, dicha violencia se nutrió de aspectos de exclusión social y política y fue alimentada por conflictos agrarios.

El avance en los campos industrial, tecnológico y científico son indispensables en este escenario, sin embargo también es importante destacar el avance político logrado, ya que en la década de los sesenta el socialismo marchaba un paso adelante del capitalismo, produciendo un fuerte efecto en diversas partes del mundo. De dichos efectos, cabe rescatar el gran significado que adquieren en la época tanto el pensamiento marxista como las teorías de la producción, sobre todo en el ámbito académico, avanzando enormemente en países como Francia, Alemania, Estados Unidos, entre otros. Esta influencia obviamente tiene repercusión en Latinoamérica; es en este momento en que se evidencia una polarización del socialismo de forma que un ala del mismo está liderada por la Unión Soviética y la otra se halla representada por China; tal división ocasiona una escisión en los partidos comunistas alrededor del mundo y también en Colombia. De ahí, que en el país este aspecto se viese reflejado en optar por las autodefensas campesinas o por el partido comunista fascista-leninista, cuyo planteamiento tiene su raíz en proponer una guerrilla ofensiva que conquistara al pueblo. En suma, en este escenario también debe hacerse una referencia a la Revolución Cubana que en las condiciones anteriormente descritas ve surgir a su antecesor el movimiento insurgente 26 de julio como escenario para su posterior desarrollo; este aspecto aunado a los sociales y políticos de fines de los cincuenta representa un hito importante en la historia de América Latina al ser la primera de las revoluciones de izquierda que suceden y permanecen con el pasar de los años, es entonces bajo la influencia del proceso revolucionario en Cuba que surgen guerrillas en muchos países de Latinoamérica. 
La guerra que atraviesa la sociedad colombiana hunde sus raíces en los convulsionados años sesenta, época de emergencia de fuerzas guerrilleras en muchos países de América Latina. El surgimiento de guerrillas revolucionarias, la mayoría de las cuales tuvo una existencia efímera, se produjo en un contexto internacional caracterizado por el auge de las luchas de liberación nacional en Asia y África, avances significativos del llamado campo socialista, auge de las ideas socialistas, en particular del marxismo académico, $e$ influencia incuestionable de la Revolución Cubana. (Zuluaga, 2008, p. 158)

Por otra parte, según Zuluaga (2008) también se reconocen factores de desarrollo interno que sirven de marco para el surgimiento y mantenimiento de las guerrillas y por ende del conflicto armado en el país, entre ellos distinguimos tres dimensiones a saber: a) escasez de reformas, b) modelo económico, social y político excluyente y c) el problema agrario. Teniendo en cuenta lo anterior, desarrollaremos cada uno de los factores internos así:

a) Colombia no es un país que pudiéramos llamar reformista, si revisamos la historia nacional, se encuentra que solo hasta el año 1991 tiene éxito un proyecto reformista de gran envergadura; los fracasos de tiempos anteriores a la década de los noventa, se deberían a la coalición permanente entre los partidos hegemónicos, pugna que se destaca por haber sido bastante conservadora en lo referente a las ideas sobre el Estado.

b) En el modelo económico, social y político se observa que el país se ha regido desde muy temprano por un modelo de desarrollo profundamente excluyente, aspecto que toma gran fuerza luego de la segunda guerra mundial, produciendo una sociedad con altísimos niveles de inequidad y pobreza, carente de integración de amplios sectores de población, aspecto que se dilucida en que casi el 60\% de los trabajadores del país se encuentran en el sector informal de la economía siendo excluidos de los beneficios que otorga la jurisprudencia laboral. El panorama político no escapa a las difíciles condiciones, el régimen político igualmente excluye a amplios colectivos sociales, situación que se refleja en el asesinato de líderes políticos importantes en el país Jorge Eliecer Gaitán, Luis Carlos Galán Sarmiento, Carlos Pizarro; así como el exterminio de fuerzas políticas preponderantes como la Unión Patriótica.

El genocidio practicado contra el movimiento político colombiano Unión Patriótica (UP) se inscribe en el proceso de exterminio de fuerzas políticas de oposición en el mundo. Se trata de un caso paradigmático de aniquilación de los miembros y líderes de un grupo en razón de sus convicciones ideológicas, así como de la persecución de sus simpatizantes y la destrucción de su entorno social. (Cepeda, 2006, p.1)

A diferencia de otros contextos Latinoamericanos, Colombia ha sido históricamente un país en el que el gobierno no se apoya en los sectores populares en lo concerniente a toma de decisiones o ejercicio de poder, contrariamente los espacios son bastante reducidos y los existentes son suprimidos una vez se identifica su incidencia en un determinado escenario ya sea social o político. 
c) La tercera circunstancia nombrada como factor interno determinante para el surgimiento del conflicto armado en el país, está ligado con el problema agrario que subyace a la historia nacional,

Colombia es un país cuya estructura económico-social es básicamente agraria. A partir de ello, el origen de los problemas sociales, económicos y políticos que se viven actualmente dentro del territorio colombiano, tienen su fundamentación en los problemas del campo que se remontan a las históricas y abrumadoras contradicciones que se presentan en este sector. (Ramírez, 2011, p.4)

De esta forma, uno de los orígenes del conflicto armado es la distribución desigual de la propiedad de la tierra, situación resultante del actuar de poderes dominantes que promocionan, promueven y legitiman políticas y programas que terminan apoyando los intereses de grandes propietarios de la tierra, en este escenario, se observa cómo el latifundio ha existido a través de los años y se continua perpetuando luego de muchas décadas de finalizada la colonia. Son varios los factores atribuidos al problema agrario y que permiten establecer su relación con el surgimiento del conflicto armado en Colombia, entre ellos cabe destacar el estímulo de la violencia en las ciudades por parte de líderes como Laureano Gómez y Mariano Ospina quienes sin recurrir a las armas, promovieron que los campesinos edificaran liderazgos de base pioneros en el país, consolidando redes de poder que terminan ejerciendo un control importante situándose al margen de los partidos políticos. Este ejercicio de violencia con fines políticos, desde la actuación de sectores populares con cierto nivel de envergadura, alimenta posteriormente el surgimiento de las guerrillas, de allí que no sea por el azar que grupos como el ELN y el EPL hayan surgido en zonas de antiguas guerrillas liberales.

Hasta este momento se ha hecho referencia al surgimiento del conflicto armado en Colombia, vinculándolo con el nacimiento, surgimiento y pervivencia de las guerrillas en el país. Sin embargo, es importante situar otros actores que también están involucrados en la confrontación armada, tales como los paramilitares cuyos antecedentes se remontan al siglo XIX y se asocian con "la ley del llano", los "chulavitas" y los "pájaros".

Ya a comienzos de la década de los ochenta emerge un paramilitarismo con algunas diferencias puesto que ya no es autodefensa pero tampoco es estatal, tiene su materialización en extensiones de ejércitos privados de las industrias ilegales como el narcotráfico y el comercio de esmeraldas. Desde sus orígenes locales varios de estos grupos confluyen en las llamadas "Autodefensas Unidas de Colombia AUC, si bien el discurso de estos grupos es de carácter nacional, las autodefensas aparecen como respuestas locales a las guerrillas.

Los grupos paramilitares en la década del noventa tienen un respaldo muy importante de sectores renombrados en la sociedad, las élites del país. Dicho aspecto se materializa en una suerte de legitimidad que ofrece una coyuntura política indispensable para un 
proceso de "desmovilización" (puesto en cuestión), que se convierte en un mecanismo de conservación de patrimonio y de situación jurídica de los integrantes de estos grupos; este proceso es materializado o llevado a la práctica a través de la Ley 975 de 2005 o Ley de Justicia y Paz, por la cual se dictan disposiciones para la reincorporación de miembros de grupos armados organizados al margen de la ley, que contribuyan de manera efectiva a la consecución de la paz nacional y se dictan otras disposiciones para acuerdos humanitarios.

Pero observemos qué pasó con la desmovilización paramilitar. Ellos se apuntaron a la negociación para conseguir reconocimiento político, y con ello garantías jurídicas de no extradición, y que el delito del narcotráfico quedara conexo a la sedición, para no ser condenados como narcotraficantes. (Zuluaga, 2008, p. 166).

En este contexto surge el interrogante de ¿Por qué si los paramilitares se "desmovilizaron", aún existen en el territorio nacional, zonas de presencia paramilitar? En conexidad con el cuestionado hecho de la desmovilización, surge un nuevo lenguaje para signar a determinados grupos que ejercen actos denominados como delincuenciales, grupos que ocupan casi que los mismos territorios que los ocupados por los paramilitares, dichos colectivos se denominan "Bandas criminales", que según el gobierno no son paramilitares sino bandas dedicadas a actividades delincuenciales.

Según la Misión de Apoyo a Procesos de Paz de la Organización de Estados Americanos (MAPP OEA), hay en este momento 22 grupos rearmados localizados en 14 departamentos; el Instituto de Estudios para el Desarrollo y la paz (Indepaz) ha localizado 84 grupos en 25 departamentos y en 224 municipios del país. Las fuentes son: policía, ejército, defensoría del pueblo, la OEA, organizaciones humanitarias como la Consultoría para los Derechos Humanos y el Desplazamiento (Codhes) y periódicos locales. Esto significa que hay un fenómeno paramilitar muy complejo. Además, cabría preguntarse si el paramilitarismo de ahora es como el de antes. Yo no lo creo; algunos son los mismos y otros son diferentes. Lo importante es que algunas estructuras se mantienen... (Zuluaga, 2008, p. 167)

Otro factor importante para el análisis de la dinámica del conflicto en Colombia está ligado con la inserción del narcotráfico como factor económico auspiciador de las acciones violentas, de manera que

La expansión del narcotráfico y el desarrollo del paramilitarismo indujeron un cambio significativo en la lógica del conflicto, representado en la lucha por el control del territorio. El narcotráfico produjo relevos en las élites regionales y penetró, a través de complicidades, diversos sectores sociales, públicos y privados en aras de garantizar las condiciones mínimas para el desarrollo de su actividad. Las ganancias generadas por esta última le han permitido financiar tanto a la guerrilla como a los paramilitares y convertirse en el "combustible" de la guerra. (Velásquez, 2010, p. 1) 
El narcotráfico se hace presente en la historia nacional aproximadamente en la década de los ochenta en donde la denominada "clase emergente" a través de actos ilegales que podríamos decir en un inicio están vinculados con la delincuencia (tales como robo de autos y contrabando) incursionan en el mundo de la droga logrando un rápido ascenso. A través de este medio se observa entonces la historia de los carteles de Medellín y de Cali. Los líderes de dichos grupos intentan tener un cierto nivel de incidencia en la política y con ello lograr también reconocimiento en la sociedad en general. Debido a su nulo éxito en los anteriores objetivos y a su deslegitimación social los grupos del narcotráfico empiezan a utilizar acciones violentas con el objetivo de instaurar el miedo y la amenaza en la población que no los apoya para el logro de sus metas, dando origen así a grupos como "los extraditables" y a los fenómenos de "narco-guerrilla" y "narco-terrorismo", estrategias que posteriormente vendrán a poner en marcha los paramilitares en la década de los noventa.

En este contexto, se dilucida que el narcotráfico tuvo efectos perversos en las guerrillas corrompiendo su ideario revolucionario logrando influenciar negativamente sobre todo a los paramilitares, que en sus inicios por ausencia y precariedad estatal eran autodefensas de grandes sectores de la sociedad.

\subsubsection{Efectos psicosociales del conflicto armado}

El devenir histórico colombiano ha estado atravesado por el conflicto armado como escenario de inscripción y socialización de las nuevas generaciones, con el paso de los días, los meses y los años la confrontación ha llegado hasta el punto de alcanzar un alto nivel de degradación debido a la crueldad y barbarie de las acciones violentas que tienen un gran nivel de incidencia en diferentes grupos poblacionales que quiéranlo o no se ven inmersos en este escenario.

En la Tabla 8 se puede observar el número de víctimas del conflicto armado interno, a partir de la variable "desagregación por hechos", dichas cifras son proporcionadas por la Red Nacional de Información de la Unidad de Atención y Reparación Integral a las víctimas a finales del año 2014. Allí se puede ver que a noviembre de 2014 se reportan 7.028.776 personas registradas como víctimas de hechos violentos tales como abandono o despojo forzado de tierras, amenaza, desplazamiento, homicidio, desaparición forzada, secuestro, tortura, vinculación de niños/adolescentes entre otros. El hecho violento que causa un mayor número de personas víctima es el desplazamiento forzado. 
Tabla 12. Víctimas del conflicto armado Colombia, desagregado por hechos

Total Nacional
Personas
7.028 .776
*Personas: Victima identificada de manera única ya sea por su número de identific ación, por su nombre completo o por una combinación de ellos.
"Eventos: Ocurrencia de un hecho victimizante a una persona, en un lugar (municipio) y en una fecha determinada.

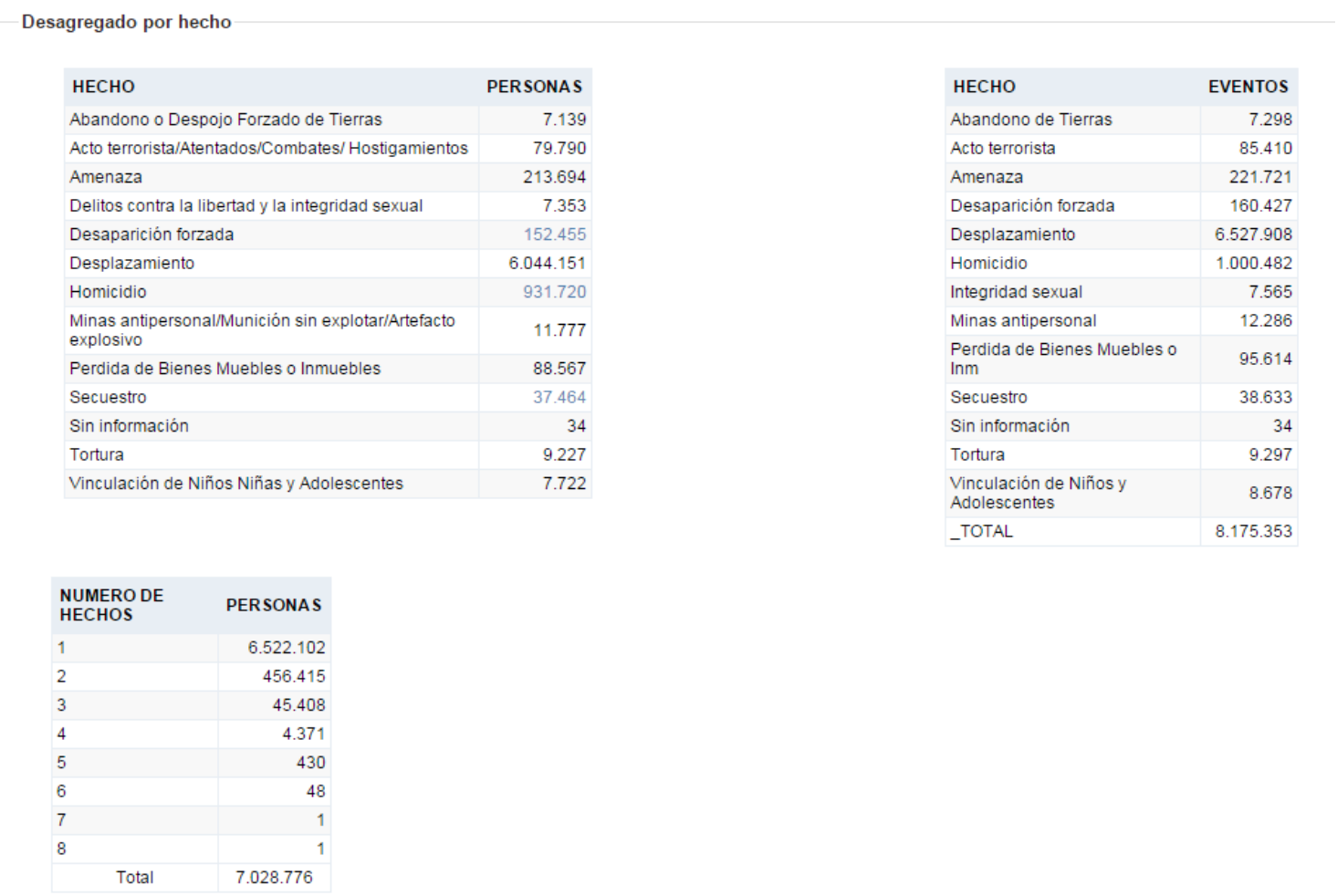

Fuente: RNI - Red Nacional de Información

Fecha de corte: 01 nov 2014

Nota: Por lo menos 89.750 personas que integran 17.950 familias fueron desplazadas en Colombia durante el primer semestre de 2011, reveló la Consultoría para los Derechos Humanos y el Desplazamiento (CODHES) en un informe en el que atribuye la salida forzada a "hechos de violencia e intimidación contra la población civil, sucedidos en medio del conflicto armado interno y atribuidos a grupos post desmovilizados, guerrillas y, en ocasiones, a acciones u omisiones de la Fuerza Pública. (Codhes, 2011)

Las cifras de alguna manera permiten evidenciar la degradación del conflicto armado, aspecto que se materializa en las violaciones masivas a los Derechos Humanos y el incremento de éstas con el pasar del tiempo. Esta degradación se constata a través de varios factores que son expuestos por el Programa de las Naciones Unidas para el Desarrollo (PNUD, 2003) en el Informe Nacional de Desarrollo Humano Colombia: la militarización, el rentismo, la territorialización, el terror, la criminalización y la vinculación apolítica. 


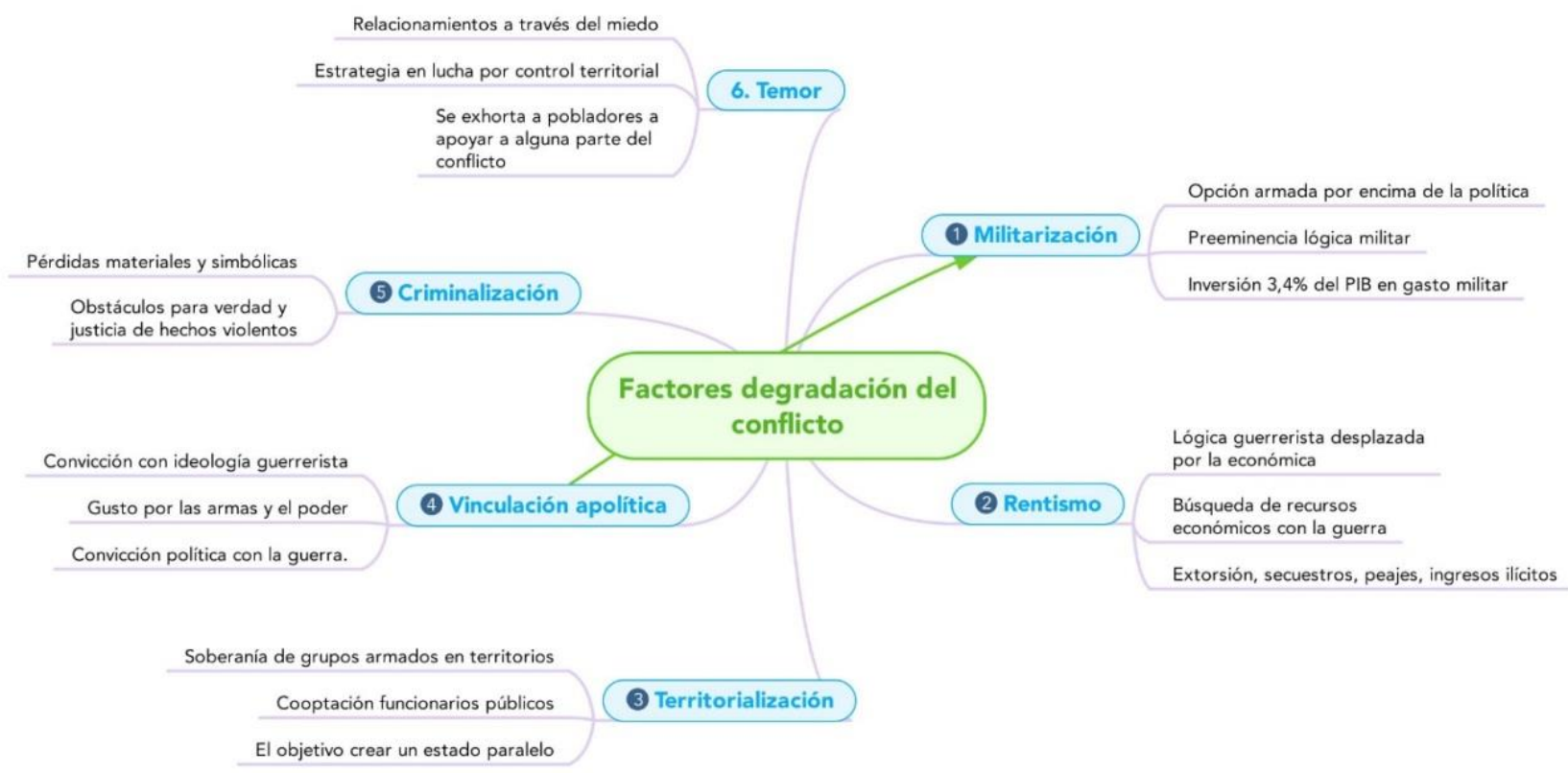

Fuente: Elaboración propia, 2015. A partir de planteamientos de PNUD, 2003.

Figura 16. Factores de degradación del conflicto

Con estas características y en este contexto de análisis es posible dilucidar qué tanto por la persistencia del conflicto (más de cincuenta años) así como por su difusión tanto por los medios de comunicación como por la opinión pública, como aspecto "inherente a la situación nacional", se vislumbra un espacio que ha naturalizado y cotidianizado acciones violentas debido a su perpetuación histórica en el contexto nacional. Son aproximadamente cinco décadas, en las que la vida cotidiana colombiana, ha visto cómo las acciones violentas menoscaban los aspectos subjetivos, comunitarios y sociales de este escenario; en el que el horror y la amenaza emergen como caminos a los que conlleva una adscripción histórica a la violencia política, en un país como Colombia.

En estos contextos de violencia, se ocasionan graves rupturas con el entorno, en la parte relacional, emocional, individual y social que también recogen aspectos que le son inherentes, como la conexión entre lo individual-lo social, y lo individual-comunitario, en este sentido, se identifica que la violencia genera graves afectaciones en los lazos significativos para las víctimas. De igual manera, la incursión violenta estructura nuevas y diferentes formas de ser y de estar en el mundo.

Desde esta perspectiva, los escenarios comunitarios se reconfiguran y adquieren unas características particulares, determinadas por la dinámica de la violencia; en este sentido, se hace indispensable pensar en una intervención desde la perspectiva psicosocial en la que se consideren los aspectos subjetivos, comunitarios y sociales fuertemente golpeados por la inmersión de acciones violentas en un contexto determinado 


\subsubsection{Condiciones de desigualdad e inequidad social}

Colombia es un país caracterizado por la existencia de grandes disparidades cuyos efectos recaen en diferentes grupos poblacionales, no se escapa a un contexto Latinoamericano en el que la desigualdad social se convierte en protagonista de la escena continental. Según el informe regional de desarrollo humano para América Latina y el Caribe del PNUD, la desigualdad ha perdurado a través de los años con amplios efectos sobre el Índice de Desarrollo Humano $\mathrm{IDH}^{8}$, por ello en tiempo reciente éste ha presentado tan solo una leve disminución "La tasa de crecimiento promedio anual del IDH disminuyó ligeramente durante los años más recientes, de 0,8\% en la década de los años noventa a 0,6\% en el período 2000-2007" (PNUD, 2010).

En dicho informe también se vislumbra cómo a pesar del reporte de una leve disminución de la pobreza en el continente, se siguen perpetuando las desigualdades en los niveles territorial y de aspectos vinculados con el IDH. Las condiciones de vulnerabilidad y desventaja en el nivel de ingreso y acceso a la educación y otros servicios sociales en que se encuentran algunos grupos en un mismo país, son muestra de la disparidad territorial. En esta perspectiva, la desigualdad social se constituye en un elemento de gran incidencia en el desarrollo humano, ya que obstaculiza el reconocimiento de los sujetos como activos y de igual manera no posibilita oportunidades de acceso igualitario a bienes y servicios; estos aspectos permiten dilucidar que los factores de incidencia en el mantenimiento y persistencia de la desigualdad, están ligados con los procesos políticos diferenciados, la debilidad institucional que reporta altos índices de corrupción y de cooptación del Estado por grupos minoritarios tales como los grupos armados o insurgentes, así como el bajo, nulo o deficiente acceso a políticas públicas sociales.

En esta perspectiva y teniendo en cuenta lo mencionado anteriormente, es posible dilucidar una relación existente entre la ciudadanía y la desigualdad social entre tanto la primera se ve limitada por la segunda. Retomando las elaboraciones de Adela Cortina (sf, p. 8) diremos que entendemos la ciudadanía como la posibilidad de inserción igualitaria en la sociedad en los ámbitos legal, político y social. Al analizar el concepto o mejor los conceptos construidos sobre ciudadanía, nos encontramos con las vicisitudes para su definición, dependiendo de la corriente de pensamiento desde la que se actúe es posible vislumbrar una determinada noción. Sin embargo, se observa cómo algunos planteamientos aparecen limitados tanto en los discursos como en las prácticas cotidianas, de manera que

\footnotetext{
${ }^{8}$ Cabe destacar que el Informe Mundial de Desarrollo Humano 2010 (PNUD) menciona que existe una clara relación entre desigualdad y desarrollo humano. De forma que las sociedades desiguales reportan un menor nivel de Desarrollo Humano y de manera más enfática, todos los países con un desarrollo humano elevado presentan poca inequidad. Aquí es importante recordar también que la desigualdad es medida por el coeficiente de Gini que mide la desigualdad en la distribución individual del ingreso en un país. El coeficiente asume valores entre 0 y 1 , de forma tal que cero corresponde con la perfecta igualdad (todas las personas con los mismos ingresos) y uno se corresponde con la desigualdad total (en donde una sola persona concentraría el ingreso). De esta forma a mayor desigualdad en los ingresos más alto será el valor del coeficiente de medición (PNUD, 2010).
} 
la concepción liberal de ciudadanía, entendida como igualdad ante la ley, como derechos, deberes y garantías de los individuos que componen la comunidad política, es insuficiente y no da cuenta de una cuestión fundamental para el desarrollo de las democracias actuales, y es que la pretendida igualdad ante la ley no neutraliza ni resuelve el acuciante problema de la desigualdad social que se deriva del constante incremento de la pobreza, la marginalidad y la exclusión en determinados sectores de la población que componen las sociedades contemporáneas. (Mancini, 2009, p. 1)

Por tanto, el ejercicio pleno de derechos en el marco de la ciudadanía implica la existencia de condiciones mínimas que permitan la participación de los individuos en las variadas esferas de la vida social. Así las cosas, vemos que la mencionada participación adquiere tres lógicas en las que siguiendo los planteamientos de Cortina destacamos:

a) La ciudadanía legal como el reconocimiento jurídico del ejercicio de los derechos ciudadanos de primera generación, es decir aquellos vinculados con las libertades civiles y políticas propendiendo por la participación ciudadana.

b) La ciudadanía política vinculada con la habilidad real para participar en las deliberaciones y toma de decisiones colectivas

c) La ciudadanía social materializada en la garantía de los derechos sociales, económicos y culturales (DESC), aspecto que supedita la realización tanto de la ciudadanía legal como de la política.

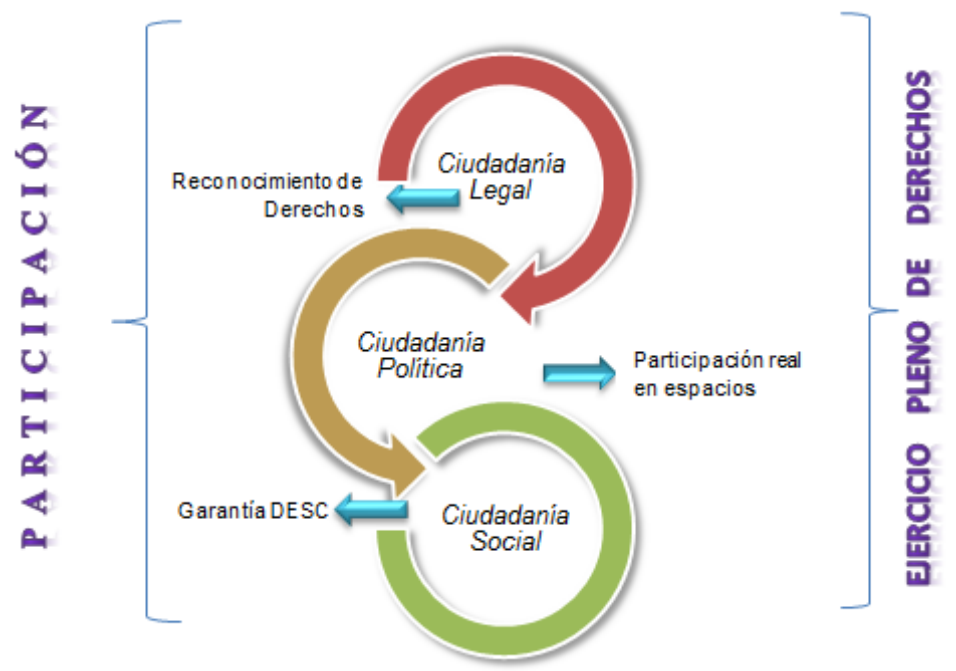

Fuente: Elaboración propia a partir de las dimensiones de la ciudadanía propuestas por Adela Cortina. Marzo de 2012.

Figura 17. Dimensiones de la ciudadanía

La ciudadanía es, principalmente, un estatus conformado por el acceso a los recursos básicos para el ejercicio de derechos y deberes. La no-discriminación en el acceso a esos recursos constituye la condición necesaria y suficiente de la ciudadanía. Caso contrario los titulares de derechos permanecen en una situación de precariedad expresada ésta como déficit de ciudadanía. (Moreno, 2003, p. 2). 
El logro del estatus de ciudadano en sentido amplio da cuenta de la participación en su sentido más originario, dicho estatus está vinculado entonces con la satisfacción de necesidades básicas; de igual manera, como afirma Cachón (2009) sobre las tres R diré que el reconocimiento como proceso dialéctico, dialógico y con significados profundos en el discurso y por ende en la subjetividad colectiva, la representación como mecanismo y ejercicio para la realización de derechos y ciudadanías (elemento constitutivo de las sociedades democráticas) y la redistribución como condición sine qua non para la modificación de las situaciones discriminatorias, a mi parecer se convertirían en elementos fundamentales en el escenario de la eliminación progresiva de las condiciones de desigualdad e inequidad sociales en los países empobrecidos, como Colombia.

De otro lado, es posible analizar el IDH y ligada a éste la desigualdad social, a partir del enfoque propuesto por Amartya Sen según el cual “...el desarrollo puede concebirse (...) como un proceso de expansión de las libertades reales de las que disfrutan los individuos" (Sen, 2000) entre tanto se observa que el desarrollo debe ser medido en términos del logro de libertades individuales, como opciones reales de vida u opciones disponibles para los individuos en tanto ser y hacer en el escenario social en el que habitan. En el contexto Latinoamericano existen en este sentido, elementos que se convierten en factores que reproducen las situaciones de desigualdad en desarrollo humano, a saber:

a) A nivel económico la alta correlación entre niveles de activos, ingresos y escolaridad de una generación y la anterior.

b) A nivel político/social los factores históricos de desigualdad de oportunidades y acceso al poder en un contexto de exclusión.

c) A nivel económico/político el acceso inequitativo a la representación institucional y las posibilidades de participación y visibilidad de opiniones en la escena sociopolítica.

En definitiva, se observa que la desigualdad tanto en el nivel territorial como en el marco del desarrollo humano se materializa en tres aspectos: bajo reconocimiento (de ciudadanía y ejercicio pleno de derechos), dificultades en la representación (política y de participación en toma de decisiones) y nulos mecanismos de redistribución (dada la inequidad social y las disparidades económicas en los niveles local, regional y nacional).

En Colombia "El aumento del IDH entre 2000 y 2010 es positivo y muestra, que en general, el país ha mejorado. Pero el resultado no es tan optimista si (a) se miran las diferencias regionales o (b) si el IDH se ajusta por dos variables con profunda incidencia en la sociedad colombiana: la inequidad resultante de la elevada concentración de la propiedad de la tierra y la violencia" (PNUD, 2011). Por ello el equipo de trabajo del PNUD Colombia para la realización del Informe Nacional de Desarrollo Humano 2011, propone la creación del IDH ajustado (IDH*) que incluye las 
variables inequidad y violencia para medir el logro de desarrollo humano (Ver Figura 4) en el contexto nacional en un periodo determinado

La comparación entre las series del IDH convencional y del IDH ajustado ilustra el deterioro causado por ambos fenómenos al desarrollo humano de todos los colombianos. Al revisar la evolución del IDH en sus tres componentes, se observa que el crecimiento ha sido mayor en educación (Ver Figura 5) que en esperanza de vida e ingreso. Esto se explica en parte por el hecho de que la cobertura educativa ha crecido en forma sostenida, especialmente en las ciudades. Sin embargo, los logros conseguidos en el promedio nacional no deben ocultar las profundas brechas que existen entre personas y entre regiones, sobre todo en el componente del ingreso. (PNUD, 2011, p. 26)

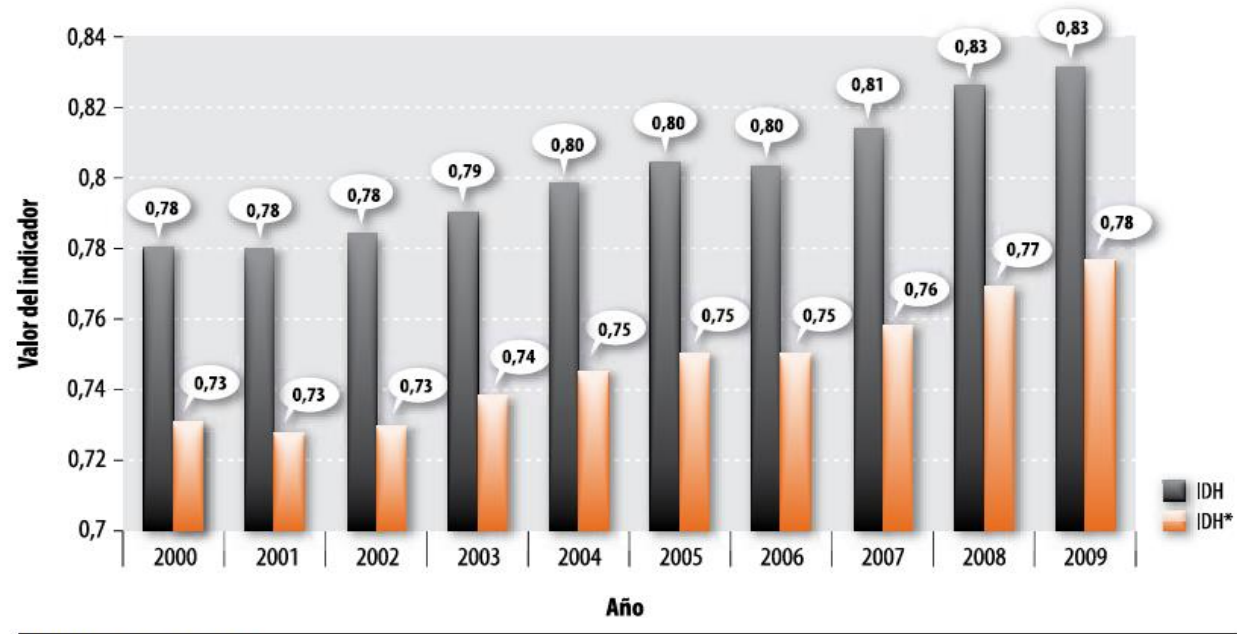

Fuente: cálculos INDH 2011.

Figura 18. Evolución del IDH tradicional y el IDH* ajustado. 2000-2009.

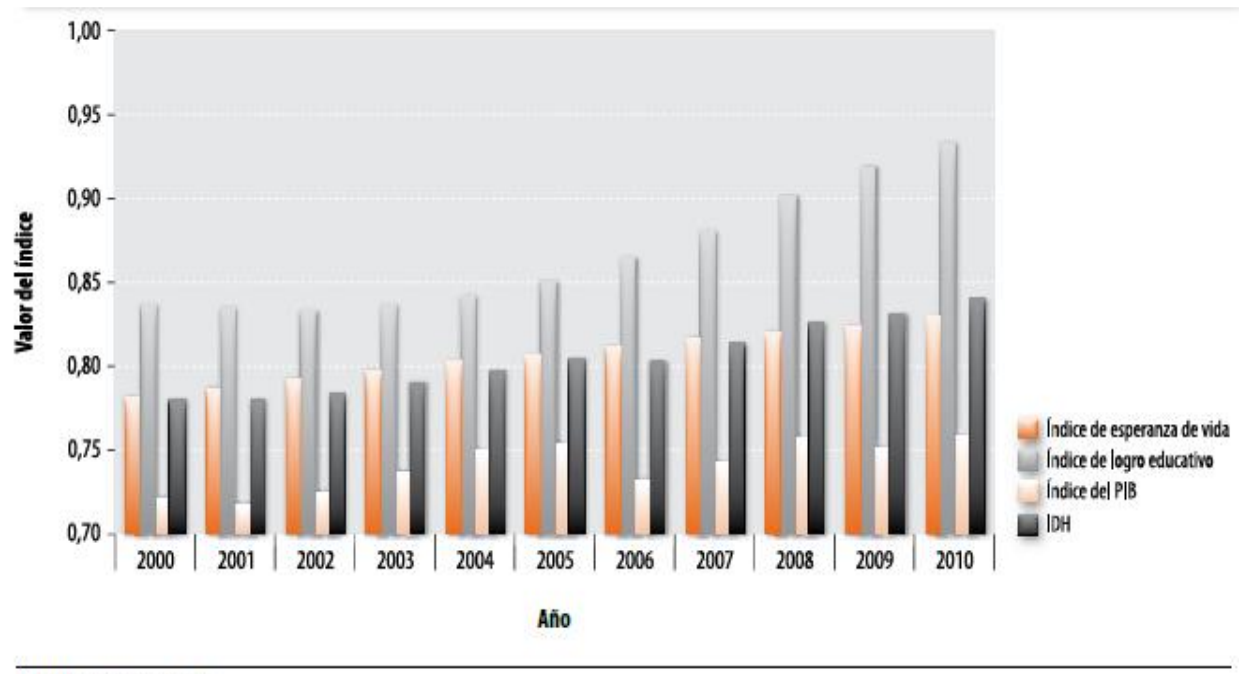

Fuente: cálculos sor 2011.

Figura 19. Evolución del IDH tradicional y el IDH* ajustado. 2000-2009. 


\subsubsection{El horizonte de la construcción de paz}

El 4 de septiembre de 2012 se informa a la opinión pública de manera formal sobre las negociaciones entre las Fuerzas Armadas Revolucionarias de Colombia FARC y el Gobierno Nacional. Estos diálogos se dan en Oslo y en la Habana, con miras a lograr la finalización del conflicto armado con el grupo guerrillero. Luego de varias reuniones en secreto, que buscaban salvaguardar la prudencia del proceso y aunar esfuerzos para que éste fuese exitoso, se establece una agenda de discusión para desarrollar el diálogo. En el Acuerdo General entre las partes se definieron como puntos de negociación, los siguientes:

- Política de desarrollo agrario integral

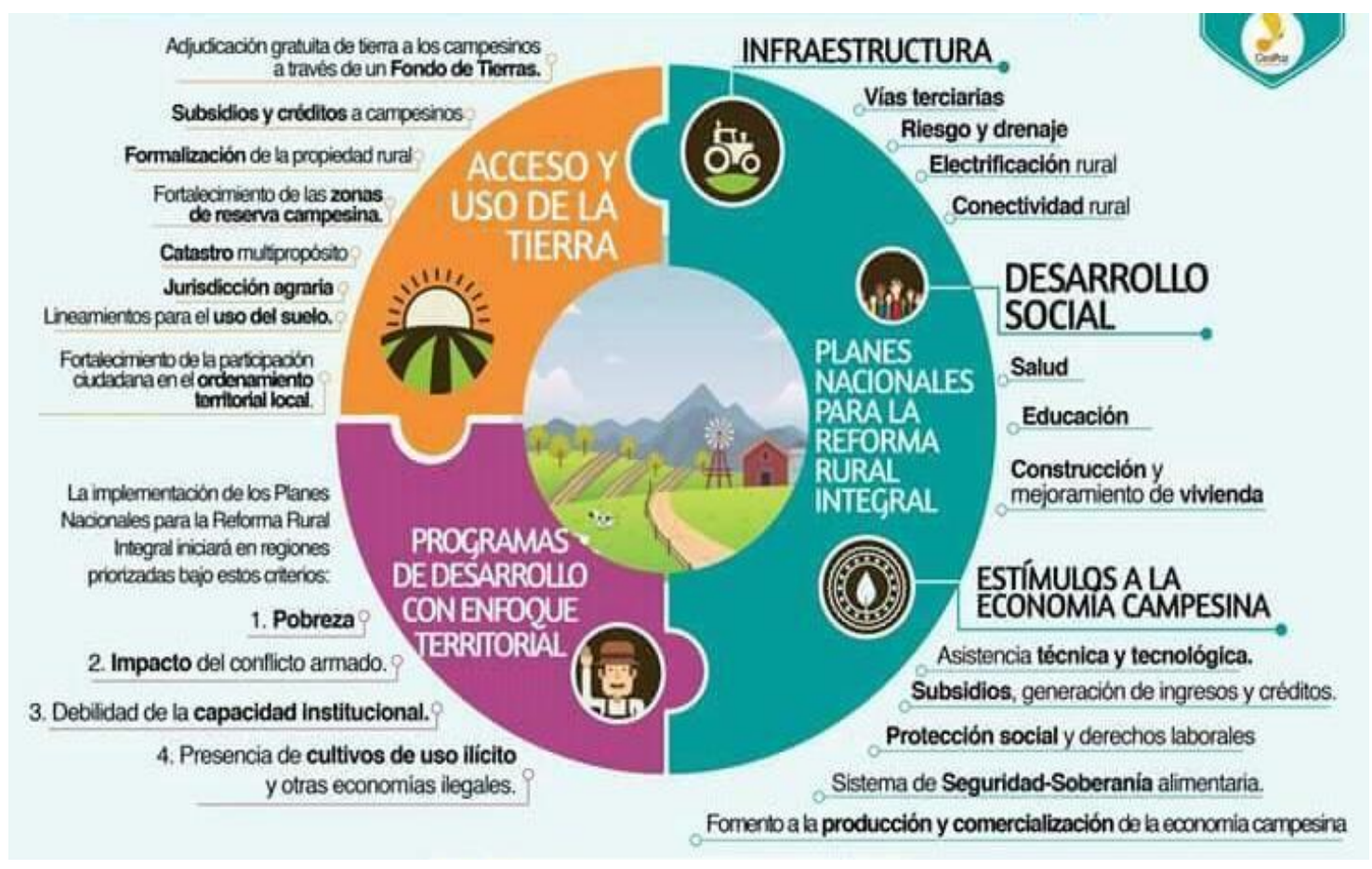

Fuente: Colectivo de Abogados Restrepo, 2016.

Figura 20. Acuerdos frente a la política de desarrollo agrario integral.

Uno de los puntos primordiales en cuanto a la negociación de paz entre las FARC y el Gobierno Nacional, resulta ser justamente el tema de tierras y vinculado al desarrollo agrario integral. Según varios expertos en el tema, se considera que este es un punto nodal en el origen de la violencia en el país, de manera que como se ha visto en el recorrido histórico realizado anteriormente en este capítulo, se observa que es necesario generar cambios y transformaciones importantes en este tema. En este sentido, en los acuerdos ampliamente discutidos en la Habana se encuentran tres pilares centrales en este punto, entre ellos el tema de acceso y uso de la tierra, directamente relacionado con la reforma agraria, la formalización de la propiedad rural, el catastro multipropósito, la jurisdicción agraria y los lineamientos de suelo. También se consideró necesario la existencia de planes nacionales que acompañasen a la reforma rural integral y que promuevan el desarrollo social de las comunidades. 
Como tercer punto nodal en este tema agrario, se encuentra la necesidad de establecer programas de desarrollo con enfoque territorial que permitan impactar las desigualdades sociales que causan la pobreza, reducir el impacto del conflicto armado, la debilidad en la capacidad institucional y contrarrestar la presencia de cultivos de uso ilícito y otras economías ilegales.

- Participación Política

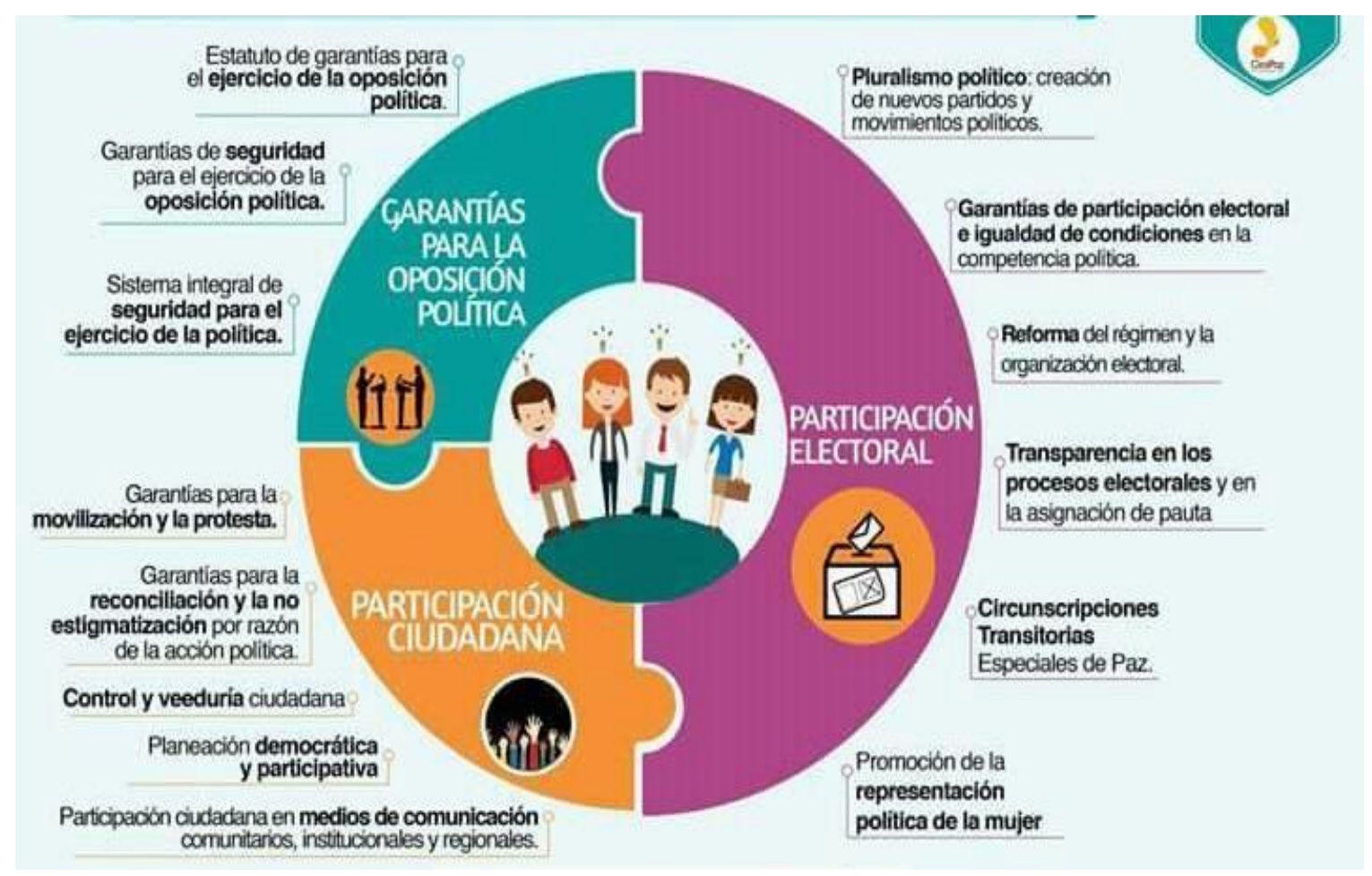

Fuente: Colectivo de Abogados Restrepo, 2016.

Figura 21. Acuerdos frente a la participación política.

De igual manera, el tema de la participación política se considera desde la llamada época del Frente Nacional un punto neurálgico en la realidad colombiana, por lo que resulta ser prioritario igualmente en estos acuerdos. Dentro de la participación se habla de propiciar escenarios que promuevan garantías en cuanto a la oposición política, esto a través del establecimiento de un estatuto de garantías, también de la generación de estrategias que velen por garantizar el derecho político a la deliberación y a la oposición en un escenario abierto y democrático y finalmente la generación de un sistema integral para la seguridad en cuanto al ejercicio político. También se halla el escenario de participación electoral que deberá velar por el pluralismo político, las garantías para la participación electoral con igualdad de oportunidades, la reforma al régimen y la organización electoral tradicional entre otros vinculados con la transparencia y el enfoque de género que fomente la participación y representación política de la mujer.

El tercer subtema vinculado con este punto central de acuerdo está vinculado directamente con lo referente a la participación ciudadana en cuanto a habilitación de escenarios libres de movilización y protesta, la garantía para la reconciliación y la no estigmatización por razón de acción política, incentivar mecanismos de control 
y veeduría ciudadana, de la mano de impulso de contextos para la planeación democrática y participativa (en los cuales contribuirían escenarios como los planteados en esta tesis), y la participación ciudadana en medios de comunicación.

- Fin del conflicto

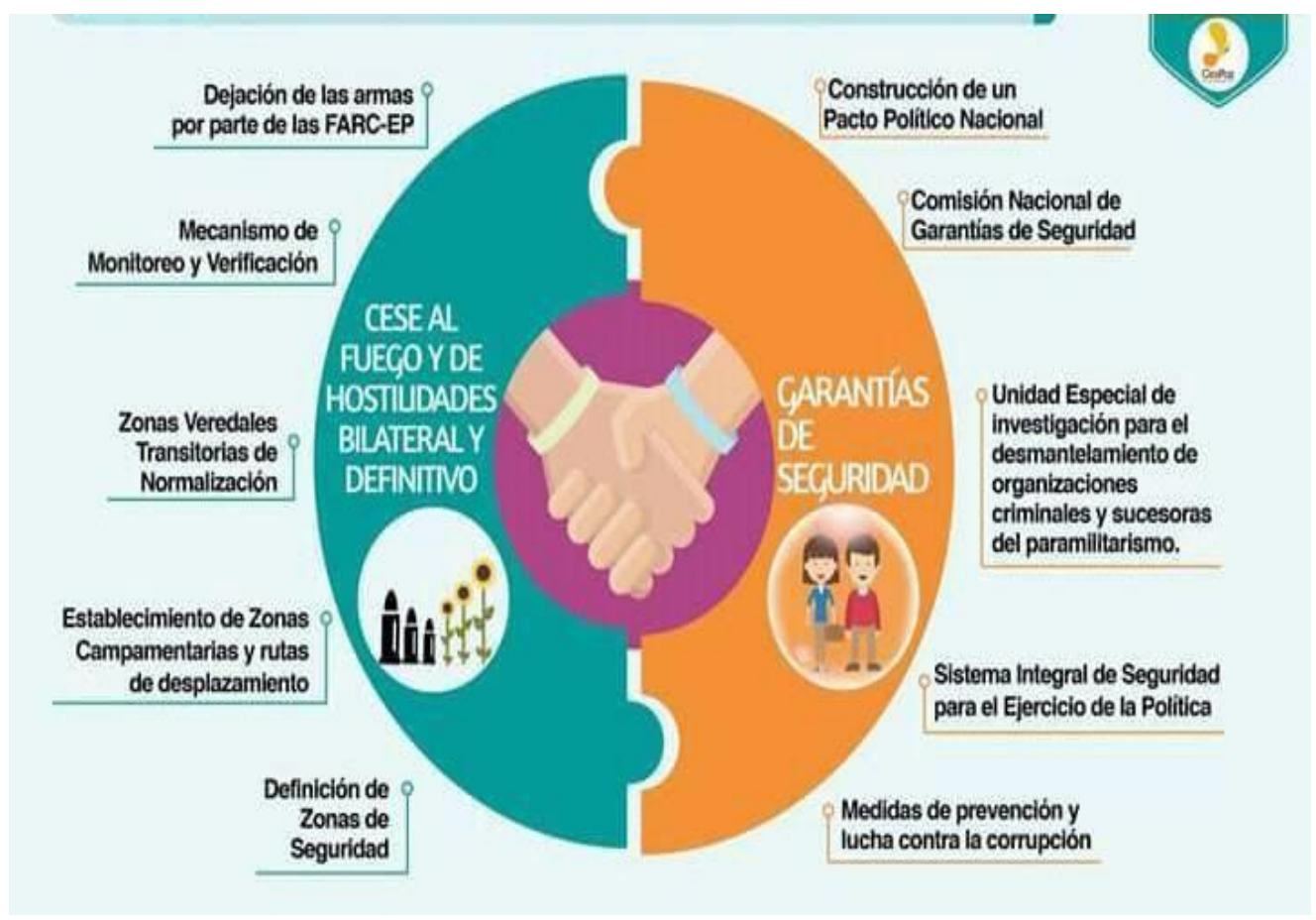

Fuente: Colectivo de Abogados Restrepo, 2016.

Figura 22. Acuerdo fin del conflicto.

En cuanto al tema de fin de conflicto se pactan dos estrategias por una parte el cese al fuego y de hostilidades bilaterial y definitivo que incluye la dejación de las armas, los mecanismos de monitoreo y evaluación, las zonas veredales transitorias de normalización, el establecimiento de zonas complementarias y zonas de desplazamiento y la definición de zonas de seguridad. Por otra parte, se decide el establecimiento de garantías de seguridad en cuanto a la construcción de un Pacto Político Nacional, la Comisión Nacional de Garantías de Seguridad, el Sistema Integral de Seguridad para el ejército de la policía y las medidas de lucha contra la corrupción.

\section{- Solución al problema de las drogas ilícitas}

En lo referente a la problemática de las drogas ilícitas se mencionan la sustitución de cultivos de uso ilícito que incluye el establecimiento de un Programa nacional de sustitución, los Planes Comunitarios y Municipales que también van por esta vía así como la apertura de un Programa nacional de sustitución de cultivos de uso ilícito en los Parques Nacionales Naturales. Por otra parte, el tema de solución al problema del narcotráfico vincula una estrategia de política criminal, así como de lucha contra la corrupción, el control sobre la producción, importación y comercialización de insumos para fabricación de drogas y la Conferencia Internacional y espacios de diálogo regional para la evaluación de la política antidrogas. También dentro de este 
punto de la agenda, se habla de la política de salud frente al consumo en cuanto a un Sistema de evaluación y seguimiento a la prevención del consumo, planes de acción participativos frente al consumo con enfoque territorial y poblacional y el Programa Nacional Integral frente al consumo de drogas ilícitas.

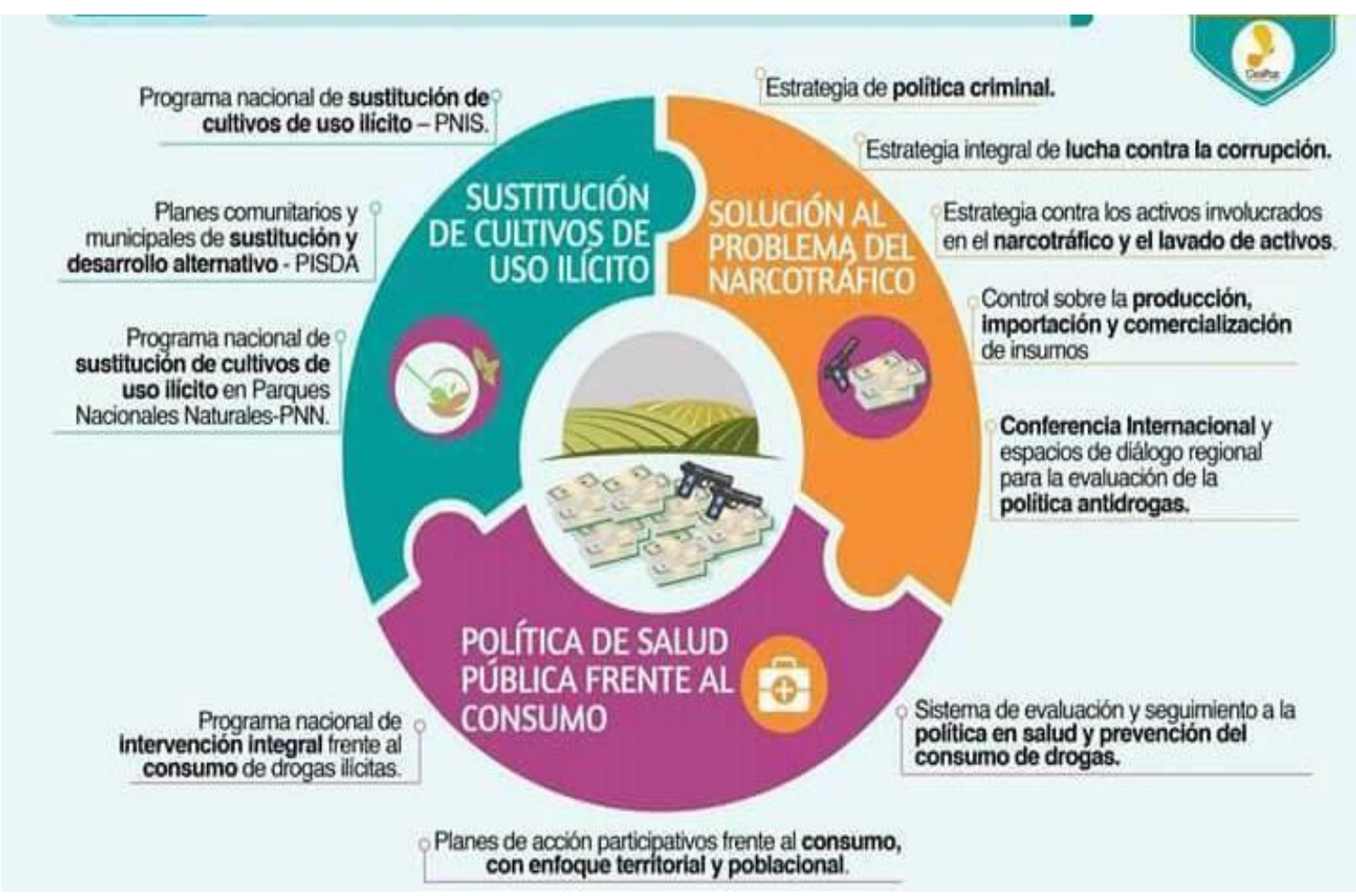

Fuente: Colectivo de Abogados Restrepo, 2016.

Figura 23. Acuerdos frente al problema de las drogas ilícitas.

- Víctimas del conflicto armado

Sobre el tema de víctimas del conflicto armado se discutieron ampliamente cinco puntos dentro de los acuerdos. El primero de ellos referido al tema de la Comisión para el esclarecimiento de la verdad, la convivencia y la no repetición ítem en el que se busca que se esclarezca la verdad identificando las responsabilidades de los participantes en las diferentes modalidades de violencia en el país, para de esta manera fomentar la convivencia en los territorios y la garantía de no repetición de hechos violentos. En segunda instancia, se incluye la Unidad especial para la búsqueda de personas desaparecidas que será una unidad de alto nivel y de carácter humanitario que estará a cargo de establecer los hechos que circundan la desaparición como resultado tanto de agentes estatales como de agentes del Estado durante el conflicto.

El tercer punto se refiere a la jurisdicción especial para la paz, que ejercerá funciones judiciales en lo concerniente a conductas graves, infracciones al Derecho Internacional Humanitario o violaciones de DDHH, que hayan ocurrido durante el conflicto armado. Esta jurisdicción deberá incluir salas de justicia, sala de amnistía e indulto y Tribunal para la paz. El cuarto punto habla concretamente sobre las medidas de reparación integral para la construcción de paz que incluye los derechos de indemnización, rehabilitación, satisfacción y no repetición. De igual manera, en este punto se habla de 
medidas para la reparación colectiva de territorios y poblaciones más afectadas por el conflicto.

Finalmente, el punto quinto habla de las garantías de no repetición, que serían el resultado de la implementación de los puntos anteriores, así como el cumplimiento de los puntos del Acuerdo Final, especialmente lo referido al punto de fin del conflicto.

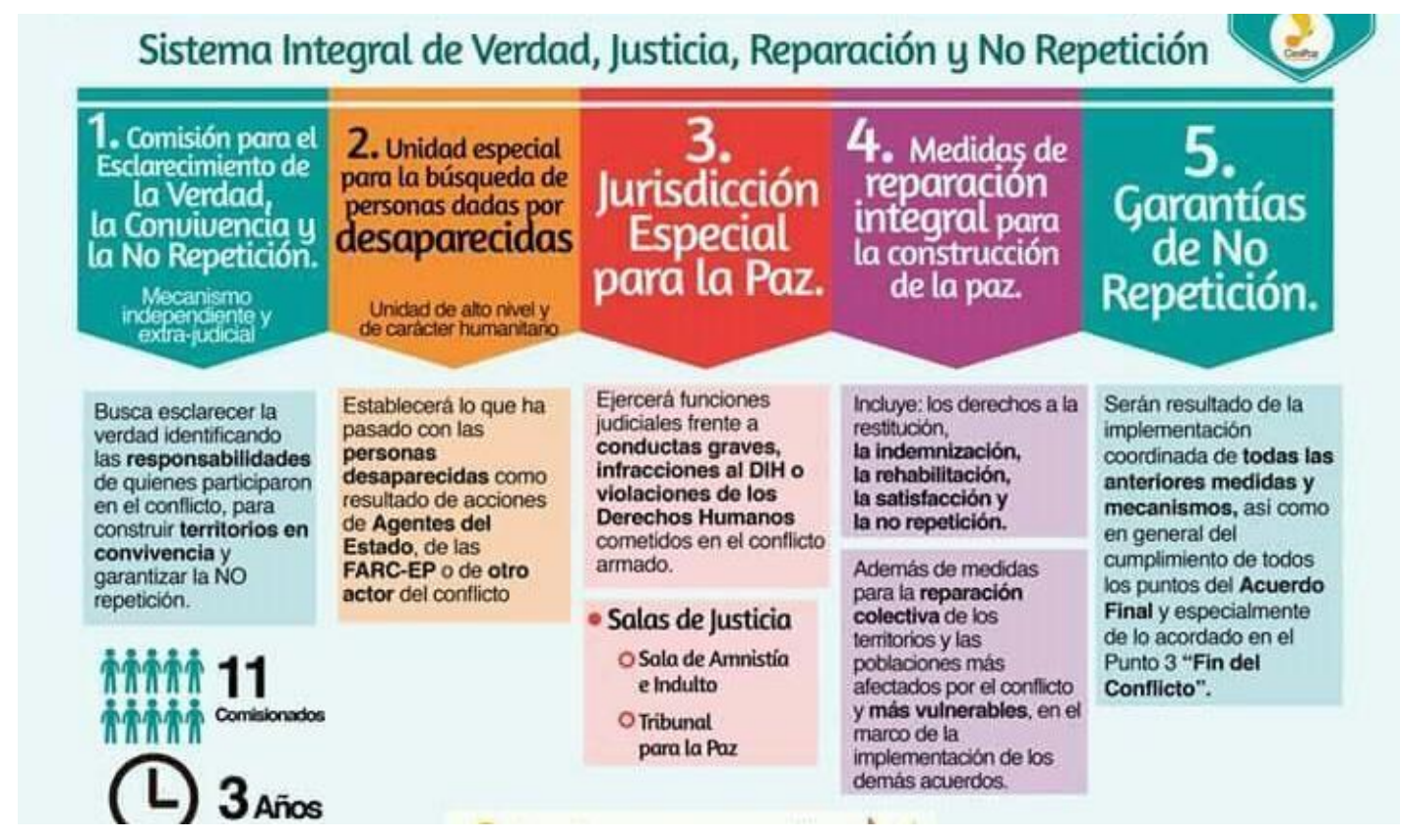

Fuente: Colectivo de Abogados Restrepo, 2016.

Figura 24. Acuerdos sobre el tema de víctimas.

\subsection{Bogotá: Escenario de múltiples complejidades}

La ciudad de Bogotá, está ubicada en el Centro del país, en la cordillera oriental, ramal de los Andes americanos y perteneciente al altiplano cundiboyacense, es conocida como la Sabana de Bogotá. En lo que respecta a su extensión, se encuentra que cuenta con 33 kilómetros de sur y norte y 16 kilómetros de oriente a occidente. Descansa sobre la extensión noroccidental de la cordillera de Los Andes en una sábana con gran variedad de climas, tipos de suelos, cuerpos de aguas y otras formaciones naturales. Aspectos ambientales que tienen repercusión en el ordenamiento del territorio en la capital, dadas las particularidades ecológicas vinculadas con las características físicas de ubicación de la ciudad.

Como Bogotá está ubicada entre montañas, estas sirven como barrera natural que restringe el flujo de humedad, influyendo en el régimen de lluvias. La temperatura varía de acuerdo con los meses del año, en diciembre, enero y marzo son altas, al contrario de abril y octubre en donde son más bajas. La orientación general de la ciudad, está determinada porque sus carreras son orientadas de sur a norte y sus calles de oriente a occidente. Su altura media está en los 2.600 metros (2625) sobre el nivel del mar. 
En términos de los intereses específicos de la temática que se abordará en este trabajo interesa destacar algunos aspectos relevantes de la organización territorial de la capital colombiana. Bogotá está administrativamente dividida por localidades a partir del Acuerdo 2 de 1992 proferido por el Concejo de Bogotá, ésta organización posibilita que los ciudadanos en cada territorio local cuenten con redes de servicios públicos tales como infraestructura vial, entretenimiento y abastecimiento de otros productos; de igual manera podría pensarse en que esta distribución sería un factor importante a la hora de pensar que la descentralización administrativa de la ciudad permitiría ampliar los espectros de participación de las y los ciudadanos en las instancias más cercanas a sus barrios y organizaciones sociales. Cada localidad cuenta con un alcalde propio y una Junta Administradora Local (JAL).

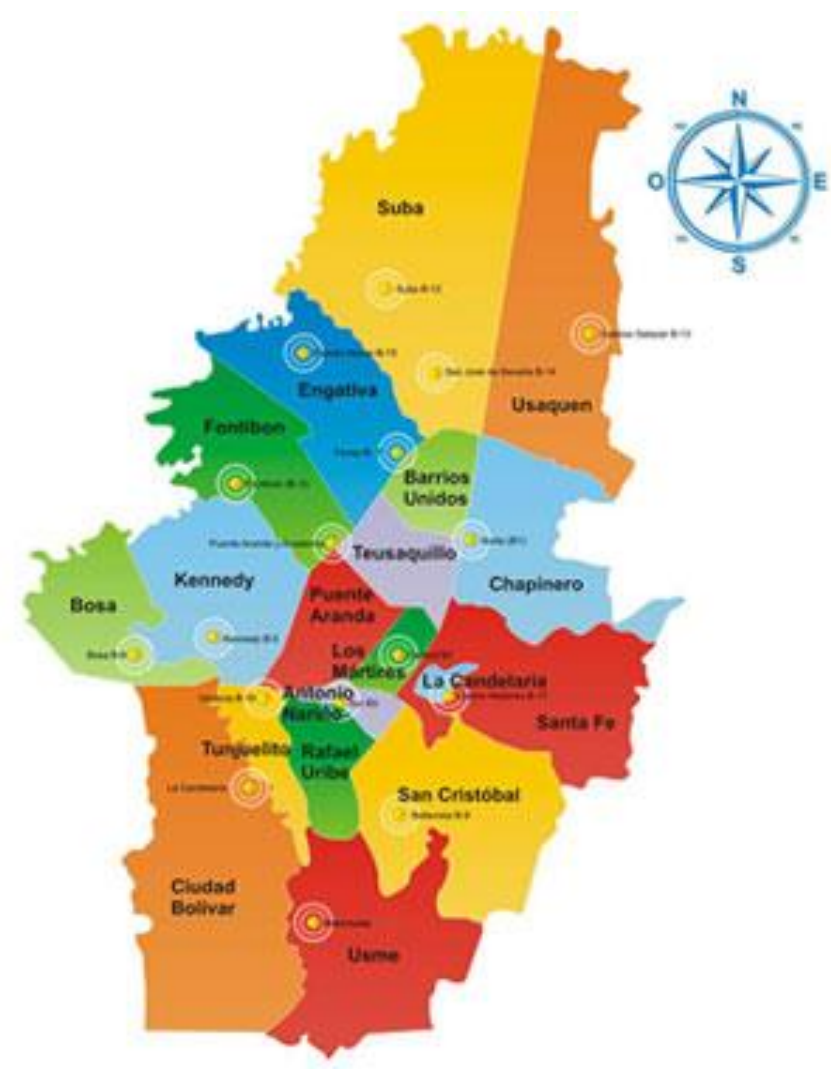

Fuente:http://bogota.gov.co/sites/default/files/pictures/mapa_estaciones_bomberos_bogota.jpg

Mapa 1. Bogotá

Por otra parte, la caracterización de los aspectos demográficos de Bogotá constituye un referente importante, ya que posibilita tener un contexto general que permita comprender la complejidad de la ciudad como una metrópoli que reúne diversos aspectos vinculados con las desigualdades y/o disparidades que se mantienen en las localidades de la ciudad o territorios capitalinos. Así las cosas, se hace indispensable partir de la comprensión del espacio bogotano como una mega ciudad dados los aspectos de densidad del territorio, número de habitantes, características socioeconómicas entre otras. De acuerdo a lo anterior, es importante partir de afirmar que esta caracterización no corresponde solo a la recopilación de datos e información 
analítica de carácter socio-demográfico, hace parte de una contextualización que permite situar un escenario con complejos determinantes socioeconómicos, físicos, demográficos, ambientales y poblacionales que hacen de la capital un escenario con alta diversidad en términos poblacionales y de temas-problema en su territorio.

La población bogotana en el Distrito Capital en el año 2011 según estadísticas del Departamento Administrativo Nacional de Estadística DANE y la Secretaría de Planeación Distrital era de 7.451.231 personas, de las cuales aproximadamente 16.573 habitaban áreas rurales. Los resultados de la Encuesta Multipropósito para Bogotá en 2014 revelan un crecimiento significativo, al reportar 7.794.463 habitantes. De igual manera, la comparación proporcional de los años en términos de sexo es interesante en tanto que en 2011 la población de hombres era de 3.592.556 mientras que en 2014 se reporta un incremento en más de 100.000 evidenciando que 3.764 .994 de la población está constituida por hombres. Por otro lado, en el caso de las mujeres la cantidad en 2011 era de 3.858.675 y en 2014 se incrementa a 4.027.358.

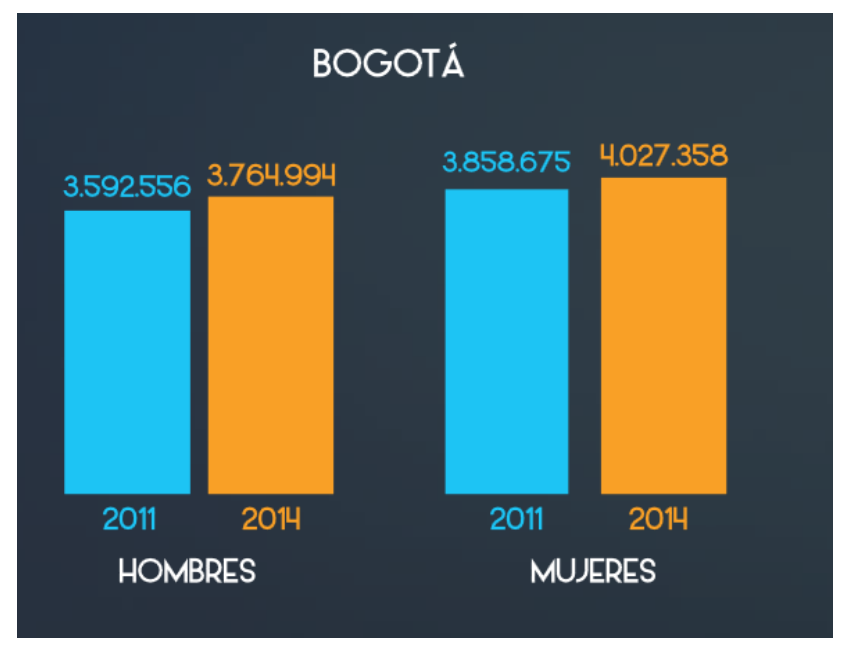

Fuente Encuesta Multipropósito para Bogotá, EMPB 2014.

Figura 25.. Bogotá D.C. Crecimiento poblacional-Bogotá 2011-2014.

En lo referente a distribución poblacional por edad se observa que del número de hombres en la ciudad (3.764.994) el total de varones cuyo ciclo de vida se encuentra entre 0-19 años es de 238.017; mientras que en la población femenina este mismo rango de edad es menor con 229.372 mujeres. A partir de los 20 años de edad se incrementa la población femenina en comparación con la masculina "al comparar la estructura por edad y sexo de la población bogotana entre los años 2011 y 2014, se evidencia una reducción en los niños y niñas en el grupo de edad de cero a cuatro años que se explica por un descenso en la tasa de fecundidad en la ciudad de Bogotá. Adicionalmente, al comparar los años 2011 y 2014, se observan diferencias en la población de los grupos de edad de 20 a 24 años y de 45 a 49 años entre estos dos años e incrementos en la población a partir de los 50 años en el periodo de análisis" (DANE-SDP, 2015: 18) 


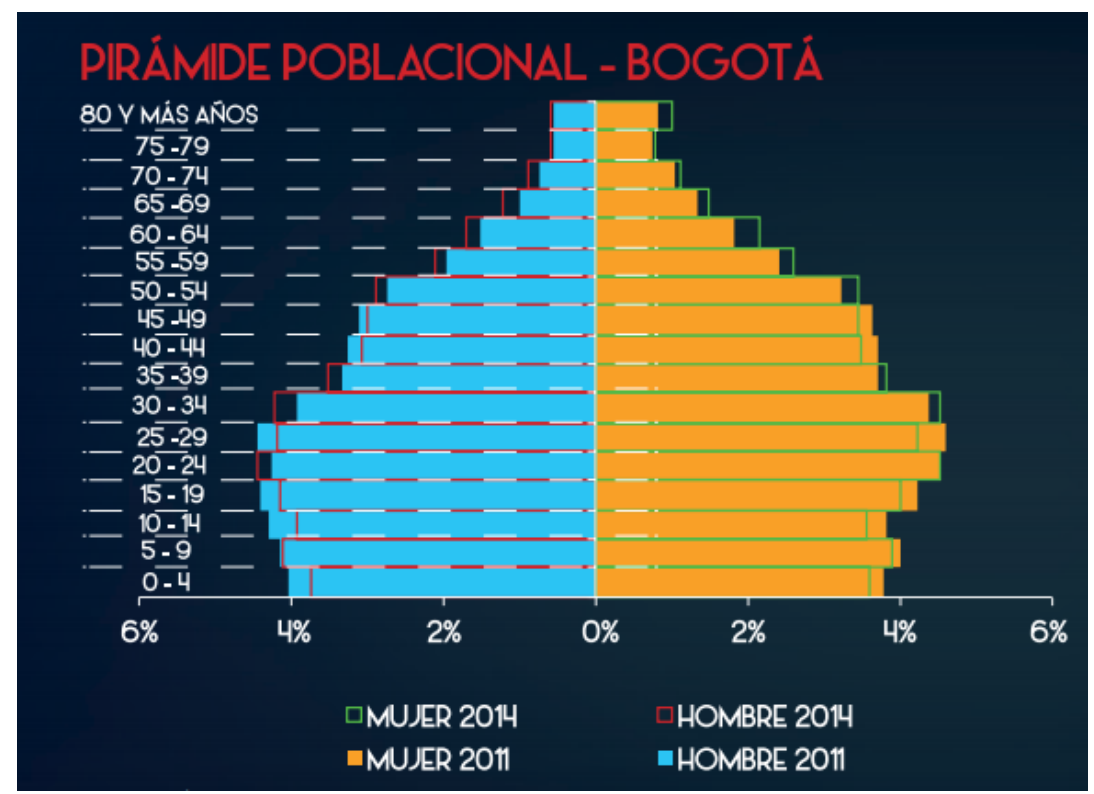

Fuente Encuesta Multipropósito para Bogotá, EMPB 2014.

Figura 26. Bogotá D.C. Pirámide poblacional-Bogotá 2011-2014

Estos datos en términos del proyecto a realizar, dan cuenta de un análisis poblacional que debe reflejarse en los planes, programas y proyectos subyacentes a las políticas públicas territoriales en los niveles distrital y local, tomando en cuenta esta información como referente de los enfoques y temas privilegiados en dicho escenario.

Las dos localidades que para 2014 reportan mayor crecimiento poblacional son Usme (3.39\%), seguida de Bosa (2.43\%), Suba (2.33\%) y Fontibon (2.33\%). Las localidades de San Cristobal, Tunjuelito y Rafael Uribe Uribe fueron las de menor crecimiento poblacional con $(0.18 \%) ;(0.21 \%)$ y $(0.24 \%)$ respectivamente. 


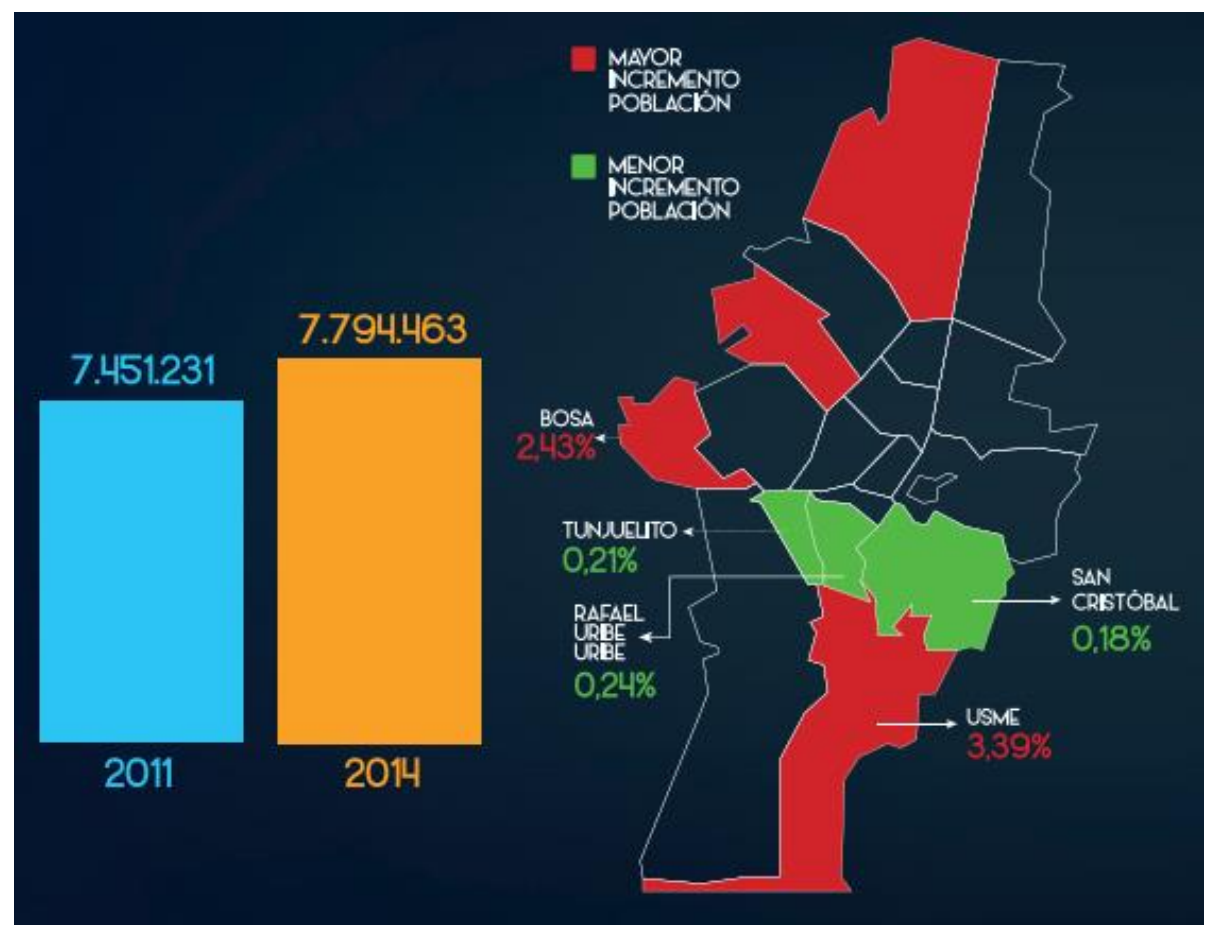

Fuente Encuesta Multipropósito para Bogotá, EMPB 2014.

Figura 27. Bogotá D.C. Crecimiento poblacional-Bogotá 2011-2014. EMPB 2014.

En lo concerniente a aspectos del orden socioeconómico, se hace necesario mencionar los porcentajes que evidencian la estratificación social de la ciudad, "para los estratos socioeconómicos en la ciudad, la distribución de la población muestra una concentración de personas en los estratos 2 y 3 (41,3\% y 36,0\% viven en estos estratos, respectivamente). El estrato que más creció en población entre 2011 y 2014 fue el estrato 1 y el que disminuyó su población fue el estrato 4" (EMB, 2014.P. 29)

Tabla 13. Aspectos socioeconómicos Bogotá, por estratos de población años 2011 y 2014.

\begin{tabular}{|l|r|r|r|r|}
\hline Estrato & \multicolumn{1}{|c|}{$\mathbf{2 0 1 1}$} & \multicolumn{1}{c|}{$\%$} & \multicolumn{1}{c|}{$\mathbf{2 0 1 4}$} & \multicolumn{1}{c|}{$\%$} \\
\hline Sin estrato & 107.409 & $1,4 \%$ & & \\
\hline Estrato 1 & 679.957 & $9,1 \%$ & 810.266 & $10,4 \%$ \\
\hline Estrato 2 & 3.008 .857 & $40,4 \%$ & 3.220 .105 & $41,3 \%$ \\
\hline Estrato 3 & 2.660 .570 & $35,7 \%$ & 2.807 .349 & $36,0 \%$ \\
\hline Estrato 4 & 667.169 & $9,0 \%$ & 604.219 & $7,8 \%$ \\
\hline Estrato 5 & 190.141 & $2,6 \%$ & 204.002 & $2,6 \%$ \\
\hline Estrato 6 & 137.128 & $1,8 \%$ & 148.522 & $1,9 \%$ \\
\hline Total & $\mathbf{7 . 4 5 1 . 2 3 1}$ & $\mathbf{1 0 0 , 0} \%$ & $\mathbf{7 . 7 9 4 . 4 6 3}$ & $\mathbf{1 0 0 , 0} \%$ \\
\hline
\end{tabular}

Fuente: DANE-SDP. Encuesta multipropósito para Bogotá, 2014.

La anterior tabla muestra la relación entre crecimiento poblacional y pertenencia a estrato socioeconómico, ahora bien, si se analiza el cruce de variables estrato social vs hogares y viviendas se encuentra que el mayor número de viviendas se encontraba en el estrato 2, tanto para 2011 como para 2014. Igualmente, en estos dos años, el estrato 2 concentró el mayor número de hogares y el mayor número de personas. Siguiendo al 
estrato 2, el estrato 3 reportó el 37\% de las viviendas, 36,9\% de los hogares y 36\% de las personas para 2014

Tabla 14. Aspectos socioeconómicos de Bogotá, por estrato social según viviendas, hogares y personas, trayectoria histórica 2011-2014.

\begin{tabular}{|c|c|c|c|c|c|c|c|c|c|c|c|c|}
\hline \multirow{3}{*}{ Localidad } & \multirow{2}{*}{\multicolumn{2}{|c|}{$\begin{array}{c}\text { Viviendas } \\
2011\end{array}$}} & \multirow{2}{*}{\multicolumn{2}{|c|}{$\begin{array}{c}\text { Viviendas } \\
2014\end{array}$}} & \multirow{2}{*}{\multicolumn{2}{|c|}{$\begin{array}{c}\text { Hogares } \\
2011\end{array}$}} & \multirow{2}{*}{\multicolumn{2}{|c|}{$\begin{array}{c}\text { Hogares } \\
2014\end{array}$}} & \multirow{2}{*}{\multicolumn{2}{|c|}{$\begin{array}{c}\text { Personas } \\
2011\end{array}$}} & \multirow{2}{*}{\multicolumn{2}{|c|}{$\begin{array}{c}\text { Personas } \\
2014\end{array}$}} \\
\hline & & & & & & & & & & & & \\
\hline & Total & $\%$ & Total & $\%$ & Total & $\%$ & Total & $\%$ & Total & $\%$ & Total & $\%$ \\
\hline Estrato 1 & 157.415 & 7,5 & 218.852 & 9,2 & 172.199 & 7,9 & 222.600 & 9,1 & 679.957 & 9,1 & 810.266 & 10,4 \\
\hline Estrato 2 & 786.494 & 37,5 & 908.110 & 38,1 & 830.377 & 38,0 & 939.833 & 38,5 & 3.008 .857 & 40,4 & 3.220 .104 & 41,3 \\
\hline Estrato 3 & 772.632 & 36,8 & 880.361 & 37,0 & 798.621 & 36,5 & 898.665 & 36,9 & 2.660 .570 & 35,7 & 2.807 .349 & 36,0 \\
\hline Estrato 4 & 229.638 & 10,9 & 227.319 & 9,5 & 232.492 & 10,6 & 230.190 & 9,4 & 667.169 & 9,0 & 604.219 & 7,8 \\
\hline Estrato 5 & 69.360 & 3,3 & 79.835 & 3,4 & 69.360 & 3,2 & 79.965 & 3,3 & 190.141 & 2,6 & 204.002 & 2,6 \\
\hline Estrato 6 & 53.521 & 2,6 & 66.651 & 2,8 & 53.594 & 2,5 & 66.743 & 2,7 & 137.128 & 1,8 & 148.522 & 1,9 \\
\hline $\begin{array}{l}\text { Sin } \\
\text { Información } \\
\text { de Estrato }\end{array}$ & 28.637 & 1,4 & & & 29.231 & 1,3 & & & 107.409 & 1,4 & & \\
\hline $\begin{array}{l}\text { Total } \\
\text { Bogotá }\end{array}$ & 2.097 .697 & 100 & 2.381 .129 & 100 & 2.185 .874 & 100 & 2.437 .996 & 100 & 7.451 .231 & 100 & 7.794 .463 & 100 \\
\hline
\end{tabular}

Fuente: DANE-SDP. Encuesta multipropósito para Bogotá, 2014.

Aunado al número de viviendas y hogares que forman parte de cada uno de los estratos socioeconómicos de la ciudad, la pobreza monetaria constituye una variable importante para la medición de indicadores relevantes en este aspecto. De esta forma según la EMB 2014 se halla que la pobreza monetaria está calculada tomando como referente las líneas de pobreza e indigencia comparadas con el ingreso per cápita de la unidad de gasto, el cual es construido siguiendo la metodología de la Misión para Empalme de las Series de Empleo, Pobreza y Desigualdad (MESEP).

El $15.8 \%$ representa el porcentaje de personas que estuvieron por debajo de la línea de pobreza monetaria en la Capital para 2014, lo cual equivale numéricamente a 1.228.033 personas.

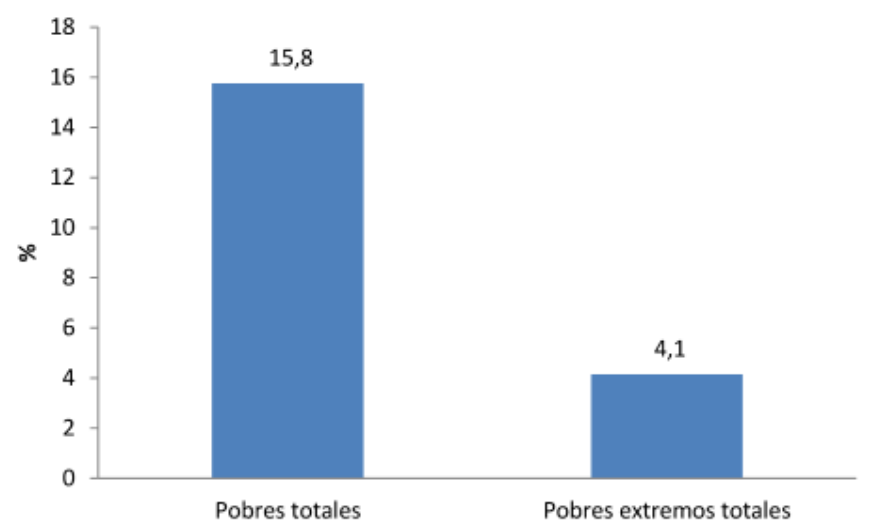

Fuente: DANE-SDP. Encuesta Multipropósito Bogotá, 2014.

Figura 28. Pobreza monetaria, 2014. 
La encuesta revela grandes diferencias en esta medición por localidades, Ciudad Bolívar y Usme evidencian el 29\% mientras que otra como Santafé, San Cristóbal y Bosa el $23 \%$ e incluso Chapinero, Engativá, y Suba tienen cantidades muy inferiores de pobres monetarios con apenas $9.1 \%, 9.0 \%$ y $8.1 \%$ respectivamente.

Tabla 15. Pobreza total y extrema total en Bogotá año 2014.

\begin{tabular}{|c|c|c|c|c|c|c|}
\hline \multirow{2}{*}{ Localidad } & \multicolumn{3}{|c|}{ Pobres Totales } & \multicolumn{3}{|c|}{ Pobres Extremos Totales } \\
\hline & Total & $\%$ & CVe & Total & $\%$ & CVe \\
\hline Usaquén & 46.095 & 9,4 & 13,3 & 18.371 & 3,7 & 15,0 \\
\hline Chapinero & 12.567 & 9,1 & 10,9 & 8.405 & 6,1 & 13,7 \\
\hline Santa Fe & 24.336 & 23,2 & 6,7 & 4.847 & 4,6 & 12,8 \\
\hline San Cristóbal & 95.249 & 23,1 & 7,1 & 19.246 & 4,7 & 21,0 \\
\hline Usme & 123.252 & 29,1 & 5,4 & 22.457 & 5,3 & 15,4 \\
\hline Tunjuelito & 30.548 & 15,0 & 9,1 & 4.764 & 2,3 & 23,6 \\
\hline Bosa & 147.299 & 23,5 & 7,2 & 32.638 & 5,2 & 14,8 \\
\hline Kennedy & 184.845 & 17,4 & 9,9 & 51.932 & 4,9 & 18,1 \\
\hline Fontibón & 33.592 & 9,1 & 13,8 & 12.628 & 3,4 & 21,5 \\
\hline Engativá & 78.641 & 9,0 & 12,1 & 28.378 & 3,2 & 17,4 \\
\hline Suba & 92.524 & 8,1 & 14,2 & 25.860 & 2,3 & 21,9 \\
\hline $\begin{array}{l}\text { Barrios } \\
\text { Unidos }\end{array}$ & 24.640 & 10,2 & 14,8 & 8.874 & 3,7 & 16,8 \\
\hline Teusaquillo & 6.517 & 4,3 & 14,9 & 5.259 & 3,5 & 14,8 \\
\hline Los Mártires & 15.585 & 15,6 & 8,6 & 4.606 & 4,6 & 16,9 \\
\hline $\begin{array}{l}\text { Antonio } \\
\text { Nariño }\end{array}$ & 10.443 & 9,5 & 14,0 & 2.633 & 2,4 & 22,5 \\
\hline $\begin{array}{l}\text { Puente } \\
\text { Aranda }\end{array}$ & 32.616 & 12,5 & 11,0 & 15.187 & 5,8 & 14,3 \\
\hline $\begin{array}{l}\text { La } \\
\text { Candelaria }\end{array}$ & 3.900 & 15,9 & 11,1 & 1.228 & 5,0 & 18,4 \\
\hline $\begin{array}{l}\text { Rafael Uribe } \\
\text { Uribe }\end{array}$ & 67.819 & 17,8 & 9,2 & 13.307 & 3,5 & 27,3 \\
\hline $\begin{array}{l}\text { Ciudad } \\
\text { Bolívar }\end{array}$ & 197.566 & 29,3 & 7,0 & 42.751 & 6,3 & 16,1 \\
\hline Total Bogotá & 1.228 .034 & 15,8 & 2,7 & 323.371 & 4,1 & 5,2 \\
\hline
\end{tabular}

Fuente: DANE-SDP. Encuesta multipropósito para Bogotá, 2014.

Desde esta perspectiva y según datos de la encuesta del DANE y la SDP para 2014, se observa que los colectivos de población que tienen un menor nivel de ingresos, y que por ende se encuentran con un nivel de pobreza mayor, estarían concentrados en los estratos 1y 2. Cruzando los dos análisis tanto el porcentaje de población por estrato social, como el porcentaje de población según estrato que está dentro de las personas pobres o en indigencia por ingreso, se halla una correspondencia entre los dos aspectos de caracterización socioeconómica; aspecto que se ve priorizado en las políticas públicas distritales y locales, en términos de criterios de focalización con miras a dirigir el gasto social a "aquellos sectores poblacionales que se hallan por debajo de cierto umbral de pobreza o en riesgo social" (Raczynski, s.f. P. 218). 


\subsubsection{Contexto capitalino: construcción de sentido en el marco del Plan de Desarrollo Distrital 2012-20169}

Todos los planes, programas y proyectos que se desarrollan en los escenarios locales y que constituyen iniciativas de política pública para la ciudad, se enmarcan en las estrategias, e iniciativas que subyacen al plan de desarrollo distrital. Es por esto, que como parte del contexto realizado, es necesario dar cuenta de los principales planteamientos derivados de éste con el objetivo último de construir sentido a las experiencias analizadas. Es importante aclarar que el desarrollo de las experiencias de fortalecimiento de las capacidades ciudadanas para la evaluación de políticas públicas en la ciudad de Bogotá, se desarrollaron en el marco de la implementación del Plan de Desarrollo de la alcaldía de Gustavo Petro, es decir durante los años 2013 y 2014 respectivamente. Es por ello que en este apartado del documento se alude a mencionar los principales aspectos de este marco de acción gubernamental en el Distrito Capital.

De esta forma, los principios que fundamentan la iniciativa gubernamental materializada en el Plan de Desarrollo Distrital son: el respeto por todas las formas de vida, la defensa de la dignidad del ser humano, lo público primero y el desarrollo humano como idea que nuclea toda la estrategia consignada en el plan, dando prioridad a los sectores poblacionales de la infancia y la adolescencia, de manera que el enfoque diferencial es un pilar fundamental en el gobierno "Bogotá humana". De acuerdo a lo anterior, se identifica que son tres los ejes fundamentales en los que se materializan los mencionados principios del plan de desarrollo (Ver figura 5).

El primero de estos ejes corresponde a una idea de ciudad fundamentada en la reducción de la segregación y la discriminación, posicionando un paradigma en el que el ser humano es el centro de las preocupaciones del desarrollo; frente a esto se evidencia que los principales objetivos giran en torno a: reducir la desigualdad y la discriminación en las esferas social, económica y cultural; reducir así mismo aquella discriminación vinculada con la pertenencia étnica, cultural de identidad de género y orientación sexual; incrementar la capacidad financiera en los sectores más pobres; garantizar la defensa, protección y restablecimiento de los derechos humanos de los distintos grupos vulnerables y por esta vía construir un territorio que garantice el acceso equitativo a la ciudad.

\footnotetext{
${ }^{9}$ Plan de Desarrollo Distrital.
} 


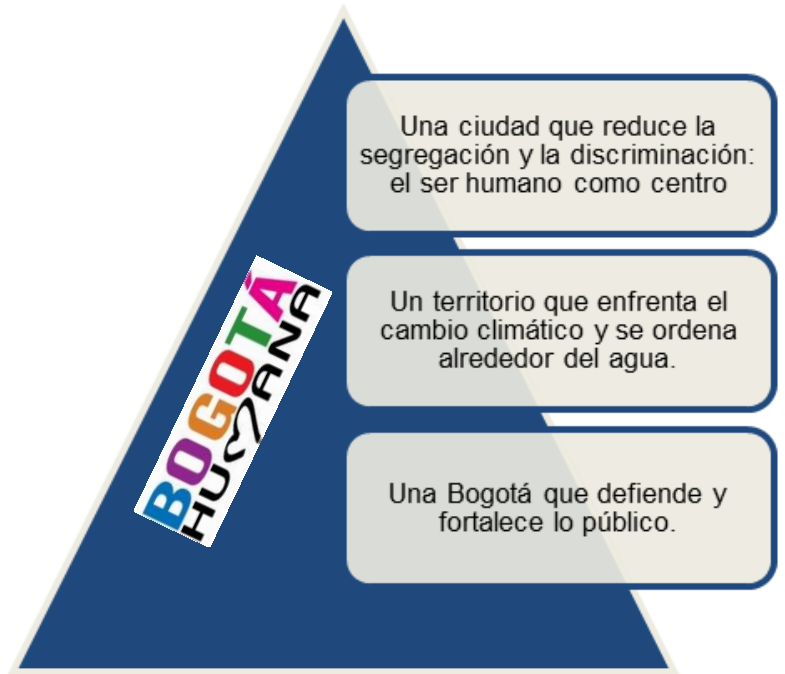

Fuente: Elaboración propia, tomando como referente el plan de desarrollo distrital 2012-2016.

Figura 29. Ejes estratégicos del plan de desarrollo distrital 2012-2016

El segundo eje abarca todas las estrategias que buscan posicionar la reflexión en torno a un territorio que enfrenta el cambio climático y se ordena alrededor del agua, estrategia que buscan superar un modelo de ciudad que se convierte en depredador del medio ambiente. En este sentido, se habla de políticas de ordenamiento territorial, de gestión ambiental, de prevención de desastres articuladas con el fin último de enfrentar el cambio climático. De esta manera, se pretende asegurar el equilibrio de los ecosistemas.

Frente a este punto se ubican como objetivos principales los de: visibilizar el medio natural y el entorno del agua, situando la naturaleza en el centro de las decisiones para la planeación del desarrollo de la ciudad. Aspecto que resulta innovador ya que es la primera vez que se realizan esfuerzos en torno al replanteamiento del modelo de ciudad, centrado en la naturaleza como ordenadora del territorio. Otro de los objetivos es impulsar cambios tecnológicos en los modos de transportes, reducir la vulnerabilidad de la ciudad respecto al cambio climático y los desastres naturales, promover cambios culturales, facilitando así las condiciones para la transformación de la ciudad; recuperar la estructura ecológica principal, movilidad humana (introducción de energía eléctrica en el transporte masivo, línea férrea), la gestión integral de los residuos sólidos, el programa basuras cero; todo ello enmarcado en la necesidad de fomentar una cultura ambiental integral.

El tercer eje estratégico habla de un modelo ciudad que defiende y fortalece lo público. En esta estrategia se enmarcan las iniciativas realizadas por la Veeduría Distrital ${ }^{10}$, entre ellas la alianza público-privada con la Universidad Nacional de Colombia, para llevar a

\footnotetext{
10 Creada por el Decreto Ley 1421 de 1993, su naturaleza jurídica la concibe como un organismo de control, independiente de la Administración o del Gobierno. Se diferencia sustancialmente de los órganos de control externo, en la medida en que su perspectiva de acción es fundamentalmente preventiva. Surgió como respuesta a la necesidad de la Administración de contar con un instrumento de control preventivo, encaminado a mejorar la capacidad de gestión de las diversas entidades distritales, así como a coadyuvar en la tarea de erradicar las prácticas deshonestas dentro de la Administración y, con ello, mejorar las condiciones de gobernabilidad de la Ciudad
} 
cabo el proyecto "Fortalecimiento de capacidades sociales para el control social a la gestión pública en el Distrito Capital”, que será objeto de reflexión más adelante.

Esta estrategia del plan de desarrollo, busca fomentar la participación y la deliberación informada y amplia de los ciudadanos y ciudadanas sobre la gestión de la ciudad, de manera que se fortalezca la democracia. En este marco analítico, la construcción de paz con seguridad ciudadana y convivencia, así como el impulso del uso transparente y responsable del patrimonio y los recursos de la ciudad, sin tolerar la corrupción, se convierten en temas fundamentales. De igual manera, se busca promover una tributación equitativa y progresiva que permita elevar los niveles de calidad de vida de los habitantes de la ciudad. Desde este eje estratégico, se construyen los objetivos de: fomentar la participación y la capacidad de decisión de la ciudadanía sobre asuntos de la ciudad; fortalecer la gobernabilidad democrática local; recuperar la confianza ciudadana en las instituciones del Distrito Capital; construir territorios de paz con seguridad ciudadana; todo ello como parte del objetivo de procurar las garantías de una estructura administrativa distrital, eficiente y comprometida con las necesidades de la ciudadanía.

En este contexto, para la ciudad de Bogotá, los planteamientos a favor de la participación, tienen como sub registro el propósito de recuperar lo público para la ciudadanía, promoviendo la construcción de una cultura política, cuyo fundamento está en la formación, información, capacitación y construcción de conocimiento de sus colectivos sociales, de tal forma que se potencialicen las capacidades de agencia social sobre lo público, a partir del conocimiento real de las dinámicas institucionales y de política que inciden en los procesos de democratización, inclusión, reconocimiento y redistribución, concomitantes a la existencia de intereses diversos en el territorio (B. Niño, 2012. P. 2)

En este escenario, se observa la importancia de iniciativas para la creación y/o fortalecimiento de capacidades sociales como marco para la construcción de procesos de control social a la gestión pública. Según Cunill (2007), entendiendo el control social desde un enfoque que encuentra en la democracia y la construcción de ciudadanía sus premisas insoslayables, cuyo anclaje se halla inmerso en las particularidades de la relación Estado-Sociedad; se hallan tres aspectos subyacentes a este contexto: inicialmente se asume que la elección puede constituirse en mecanismo de influencia ciudadana sobre la administración pública, pero en ningún caso es el único y jamás el fundamental. En segunda instancia, se considera que la ciudadanía se realiza cuando actúa básicamente como ciudadanía política, presionando por la realización y ampliación de sus derechos no sólo individuales, sino que colectivos. Y tercero, se releva la importancia crucial del Estado a los efectos de la construcción de la ciudadanía social.

Desde esta perspectiva, la participación ciudadana derivada de ejercicios de control social, puede tomar gran auge. En términos de posibilidades para la ampliación de la democracia a partir de su contribución a la gobernabilidad democrática, desde escenarios de promoción del empoderamiento de la ciudadanía en el ejercicio directo de responsabilidades políticas. 


\subsection{Bolivia: contexto y dinámica}

Para varios países Latinoamericanos la experiencia boliviana de constitución del Estado Plurinacional cuyo antecedente resulta ser la extinguida república, resulta una experiencia significativa en términos de la descolonización y avance hacia la construcción de modelos económicos socialistas. El modelo boliviano, es concebido desde otras latitudes como significativo en tanto logra a partir de luchas sociales, hacer el tránsito - por lo menos en el papel- de una república a un Estado Plurinacional en el que se abre paso a la descentralización, la interculturalidad, el sentido comunitario y en el que al mismo tiempo se amplía la democracia reconociendo en la Carta Magna la existencia de grupos sociales que socio históricamente habían sido excluidos, como lo fueron en este contexto los pueblos indígenas y originario campesinos.

La Constitución Política del Estado que fue promulgada en el año 2009, pone en evidencia la consigna de un país unitario y social de derecho, con características de un contexto Plurinacional Comunitario, libre, independiente, soberano, democrático, intercultural, descentralizado y con autonomías en sus territorios, autonomías que descansan en la pluralidad y pluralismo político, económico, jurídico, cultural y lingüístico, en el marco de la integración social del país. Son estos los preceptos que evidenciarían entonces el cambio social, que permitiría establecer fuertes rupturas con el tradicional modelo neoliberal de Estado. El avance en el reconocimiento de las poblaciones indígenas y originario campesinas, devela la existencia de la diversidad cultural que es característica de este país y que se ve representada en el más de $60 \%$ de la población nacional; se promueve el enfoque intercultural como aquel que permitiría la cohesión social, así como la convivencia armónica y equilibrada entre todos los pueblos y naciones en el país, a partir del fomento del respeto por las diferencias y la igualdad de condiciones.

El advenimiento del Estado Plurinacional encuentra sus raíces en aspectos de orden socio-histórico que paulatinamente aunaron esfuerzos en torno a este cometido. Por ello resulta importante hacer alusión a algunos de ellos como fundamento inexorable de este tránsito paradigmático. En este sentido, resulta necesario partir de mencionar la configuración histórica de las redes de asambleas indígenas cuyo entramado organizativo se teje en el territorio conocido como tierras bajas o la Amazonía boliviana, que comprende también los escenarios conocidos como llanos orientales y el Chaco boliviano. En este escenario, se alude a mencionar principalmente la articulación de las diversas comunidades de una misma cultura que en épocas anteriores se caracterizaban por ser nómadas y que en épocas recientes se asientan en territorios del país logrando articularse en las llamadas tierras bajas. De igual manera, es importante tomar en consideración que la mencionada articulación de comunidades que comparten rasgos culturales da cuenta del establecimiento de centrales regionales interétnicas.

Por otro lado, dicho proceso de unificación a través de centrales regionales da cuenta del proceso de estructuración de la asociación que ahora se conoce como Central 
Indígena de Pueblos del Oriente de Bolivia CIDOB, que se instituye como forma de organización en estos territorios en los que además se concentra la mayor cantidad de diversidad cultural presente en el país. Como fruto de estos procesos de organización social, que se desarrollan principalmente en pueblos y naciones indígenas en los territorios nacionales, se desarrollan diversas movilizaciones sociales que con mayor fuerza se dilucidan hacia la década de los noventa, en donde además se evidencia todo un movimiento social alrededor del territorio, así como de reivindicación por el reconocimiento de la diversidad e identidad cultural de los diferentes pueblos y naciones presentes en el país.

Diversidad cultural que se expresa en las diversas formas de relación y entramados sociales que evidencian los vínculos de las comunidades con sus territorios en una suerte de lo que podría llamarse territorialidad, como concepto que tiende un puente conceptual, epistemológico y político entre los rasgos derivados de la identidad cultural con las formas de producción y apropiación territorial, que son inherentes a estas comunidades principalmente indígenas y que expresan igualmente las diferentes cosmovisiones y formas de configuración social y política, que se develan en los territorios en los que están los asentamientos de estas comunidades.

Como producto de las citadas luchas sociales y reivindicaciones de las naciones y pueblos indígenas del país, se sitúan los orígenes de la demanda de Asamblea Constituyente, con ello se establece también la necesidad de transformación del estado boliviano en perspectiva de fomentar y reconocer efectivamente la presencia de diversidad de pueblos y culturas; logrando el tránsito hacia un estado pensado desde la igualdad como forma de contrarrestar las desigualdades históricas y relaciones de poder que en este devenir, habían invisibilizado a una gran cantidad de pobladores en el territorio nacional, es así que la lucha social, intenta separarse tajantemente de los idearios de la colonización.

El devenir histórico de la movilización resulta ser por tanto un aspecto fundamental en cuanto al reconocimiento de la diversidad cultural, así como la educación bilingüe es visibilizada en la década de los noventa; de igual manera, representa un hito histórico que logra evidenciar el reconocimiento de las tierras comunitarias de origen TCO, como un precepto que se enmarca dentro de la organización social anclada en el régimen de la propiedad privada. Así, se avanza en términos del reconocimiento de estas comunidades como sujetos políticos que históricamente habían sido excluidos de la vida social.

Este proceso de reivindicación de los derechos fundamentados en la identidad cultural, da cuenta de la ampliación de la escena socio política, así como del hasta entonces restringido margen de la sociedad civil. Igualmente, se evidencian numerosas experiencias de articulación, que develan la organización social de estos pueblos y culturas, a través de la figura de naciones o colectividades, que desarrollan un ejercicio político orientado principalmente a la configuración de estructuras propias de autogobierno que requieren el reconocimiento del ente estatal. 
Otro hito histórico importante para la constitución del Estado Plurinacional se encuentra en la conformación de la Central Sindical Única de Trabajadores Campesinos de Bolivia, como producto de las transformaciones acaecidas en la década del setenta, resultantes de los cambios en la estructura de organización del sindicalismo campesino producto del capitalismo. En este contexto, el katarismo concebido como movimiento político cultural de las llamadas tierras altas, resulta un actor que propone una mirada de dos vías, la primera de ellas enfocada a visibilizarse como clase explotada o campesinos que trabajaban el agro y por otra parte, como nación desde la perspectiva cultural en la que se insertan la lengua, la memoria, la identidad, así como las formas de organización del espacio social y el entramado relacional con la naturaleza, la transformación de ésta y las estructuras sociales y políticas reproductoras de determinadas formas de relación en el marco del siglo.

A finales de la década del 70 este llamado katarismo logra que sus partidos políticos asciendan a la esfera de poder ingresando al parlamento como grupos minoritarios. Con la bandera de dicho katarismo aymara se impulsa un escenario de fortalecimiento del campesino sindicalista en el país. Se generan fuertes sinergias entre lo aymara-quechua, que evidencia una fusión tal que dan la imagen de ser un mismo proyecto político, aunque años más tarde cada cultura de éstas reivindica su autonomía y su construcción propia. Los anteriores, representan los antecedentes de la construcción del Estado Plurinacional que evidencia la diversidad cultural de la nación boliviana, en la que todos sus pueblos indígenas y originario-campesinos, demandan su reconocimiento y su autonomía.

En este sentido, hablar de lo Plurinacional es hacer una referencia clara a la existencia de diversidad de naciones, cuyos procesos de organización y unificación son singulares tanto en territorios altos como en los bajos, ello da cuenta de la constitución de sujetos, de colectivos, de comunidades y sociedades que se orientan a partir de un conjunto de símbolos culturales y de formas de autogobierno que deben entrar a formar parte del estado. El reconocimiento de dichas diferencias y la reivindicación de las diversas naciones que debiesen formar parte del estado, son acumulados históricos que en la época de la llamada guerra del agua sirven de caldo de cultivo para avivar la idea de resistencia, que en esta situación en particular estaba presente dada la ampliación del control privado de empresas trasnacionales en cuanto a los recursos naturales y la búsqueda de su inserción en las dinámicas de la economía boliviana. Es así que la instancia de la Defensa de la Vida y el Agua resulta como escenario responsable que retoma estos aspectos y abandera la lucha contra la privatización, a partir del impulso de programas de nacionalización, la restitución del carácter de público a los servicios y el impulso de la Asamblea Constituyente.

Esta idea de la asamblea constituyente fue el mecanismo que lograría responder a la demanda por instaurar un estado plurinacional, cometido que posteriormente fue asumido por la instancia denominada para ese entonces como Pacto de Unidad 
La forma de unificación de las ocho grandes organizaciones agrarias, es decir, campesinas indígenas en el país, que se configura como una especie de intelectual orgánico colectivo, y que produce los dos documentos globales más importantes. Uno inicial, que está más marcado por los principios organizativos y una segunda propuesta que ya contiene un diseño bajo la forma de una constitución

Uno de los rasgos más importantes para la definición de lo que sería el estado plurinacional se asocia con las autonomías indígenas y por esta vía con los principios de autodeterminación y autogobierno que le son inherentes y que además se materializan en sistemas jurídicos, económicos, sociales y culturales particulares. En este sentido, los elementos que coadyuvan para la definición de la autonomía territorial indígena serían:

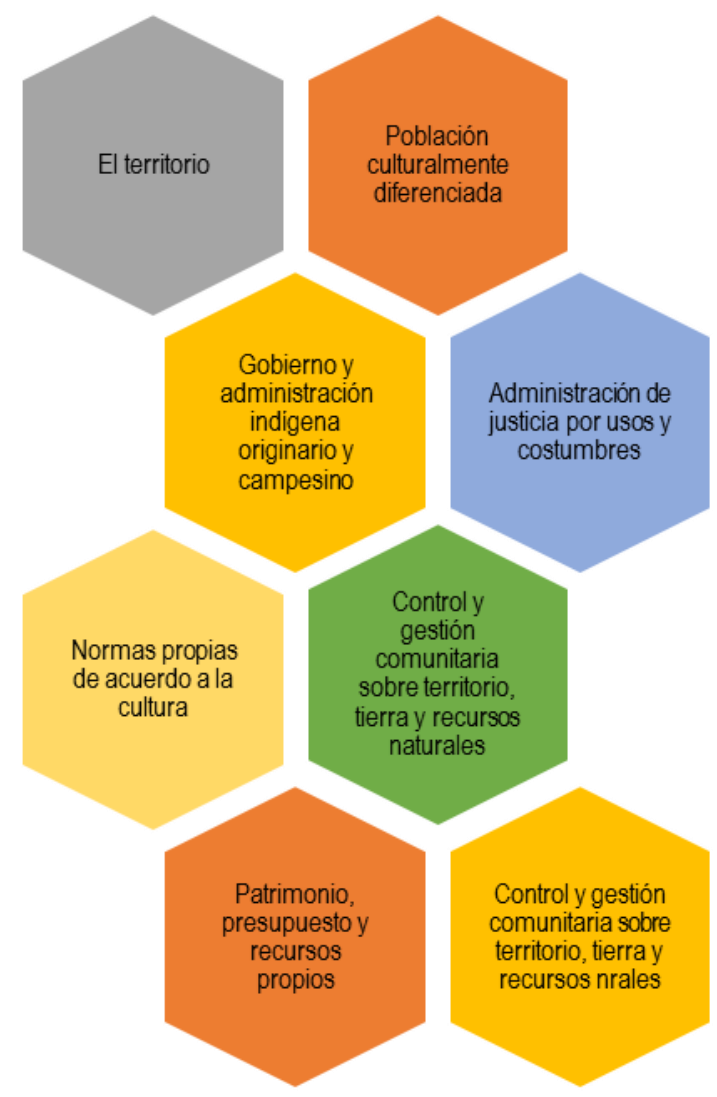

Fuente: Elaboración propia, 2016.

Figura 30. Elementos que coadyuvan para la definición de la autonomía territorial indígena

Como resultado del proceso de Asamblea Constituyente en el año 2010, se dicta la nueva Constitución Política del Estado que:

Establece que en el nuevo modelo de país los pueblos indígenas tendrán una profunda participación civil, política y económica. Para que nunca más seamos excluidos. Antes, las hermanas y hermanos quechuas, aymaras, guaraníes y otros hermanos de tierras bajas no podíamos entrar al Palacio, no podíamos entrar a la Plaza Murillo, no podíamos caminar 
en las aceras, en las ciudades importantes; ése es el pasado de los pueblos indígenas en Bolivia y en Latinoamérica. Ahora, los pueblos indígenas somos uno de los pilares fundamentales de un nuevo país (Morales Evo, 2010)

Recientemente a finales del año 2015, el PNUD realiza el lanzamiento del Informe Nacional de Desarrollo Humano para Bolivia, de allí se retomarán algunos elementos centrales para dar cuenta de la realidad cambiante de este contexto latinoamericano, cuyo rostro está signado fuertemente por las dinámicas de metropolización de las que es protagonista en los últimos años. Cada uno de los informes lanzados por PNUD, se ha enfocado en una o varias dimensiones específicas del país, buscando siempre avizorar análisis sobre el estado de situación del desarrollo humano desde diversos ámbitos en los que se realiza énfasis; en este sentido, para el año 2007 en la publicación el estado del Estado se hacen importantes aportes sobre la dinámica nacional boliviana a partir de desentrañar aspectos relativos a las relaciones Estado-Sociedad, desde esta perspectiva se evidencia a una ciudadanía que es individual, pero también colectiva y que está permanentemente movilizada en lo que concierne a la reivindicación de derechos, principalmente de aquellos vinculados con los servicios públicos, temática de especial relevancia en el escenario boliviano. Para el año 2010, el informe hace énfasis especial en lo que refiere a los cambios sociales, económicos y políticos acaecidos en el país y que repercuten directamente en el índice de desarrollo humano de la población, de igual manera, en aspectos vinculados con la movilidad social. En este sentido, se habla de la continuidad en el tiempo de desigualdades sociales en cuanto al acceso a bienes materiales, así como de carácter simbólico. Se menciona y se visibiliza la emergencia del estrato socioeconómico medio cuya característica principal está vinculada con su tendencia urbana.

Los anteriores fueron los principales aspectos que buscaron vislumbrar las características del país en los años 2007 y 2010, para el caso del último informe del PNUD a este respecto, en 2016 se habla sobre la configuración de una nueva agenda del desarrollo en el país en la que se habla de la potenciación de las condiciones de vida que se ubican particularmente en las zonas metropolitanas del territorio nacional. Se hace un énfasis en destacar los cambios ocurridos en las áreas urbanas, con el objetivo de hacer aportes en cuanto a la reflexión del desarrollo en el país; en el marco analítico que propone el informe se destacan áreas temáticas de particular relevancia en estos escenarios, entre ellas se destacan: la situación y calidad del empleo, la provisión de servicios básicos, las condiciones de entornos urbanos y las condiciones de seguridad ciudadana. Se evidencian los principales avances en materia de desarrollo humano, destacando el rol de la ciudad como contexto en que se sitúan las mejoras de bienestar.

El informe hace eco sobre las llamadas nuevas características del territorio boliviano, mencionando la emergencia de clases medias urbanas, como consecuencia de cambios de tipo estructural que se han dado en Bolivia en los últimos años. Este aspecto, configura un conjunto de dimensiones particulares que se insertan en el concepto de desarrollo humano, y que en definitiva responden a las condiciones en que se inscribe el espacio de lo urbano, desde esta perspectiva, se sitúa en el país una demanda por políticas públicas que reconozcan el nuevo panorama nacional de metropolización y 
urbanización creciente en los diversos municipios y regiones, en el marco de una planificación local que sitúe las particularidades territoriales en medio de los nuevos cambios y transformaciones del escenario nacional.

Se destaca como uno de los principales datos y de gran relevancia para la nueva configuración del territorio boliviano, la evolución de la población desde la década del 50 hasta 2012. A continuación, se evidencian estos datos, haciendo particular énfasis en el eje central del país, conformado por: La Paz, Cochabamba y Santa Cruz. En cuanto a características de estas ciudades principales, se observa que en el caso de La Paz se fue perdiendo población, mientras que Santa Cruz vio aumentada su población significativamente, llegando a triplicar en sesenta años sus habitantes, ello principalmente atribuido a los crecientes y vertiginosos procesos de migración. En el caso de Cochabamba se observa un aumento leve de su población. La mayor parte de los habitantes se concentra en el territorio conocido como eje central.

Para el año 2012 un $67.5 \%$ de la población afirma vivir en una zona urbana y el $68.7 \%$ se concentra en las regiones metropolitanas de La Paz, Cochabamba y Santa Cruz principalmente. Ello como menciona el informe "pone en evidencia un nuevo modelo de asentamientos humanos con predominancia urbana resultante de un proceso de redistribución de la población en el espacio" (PNUD, 2016; 22)

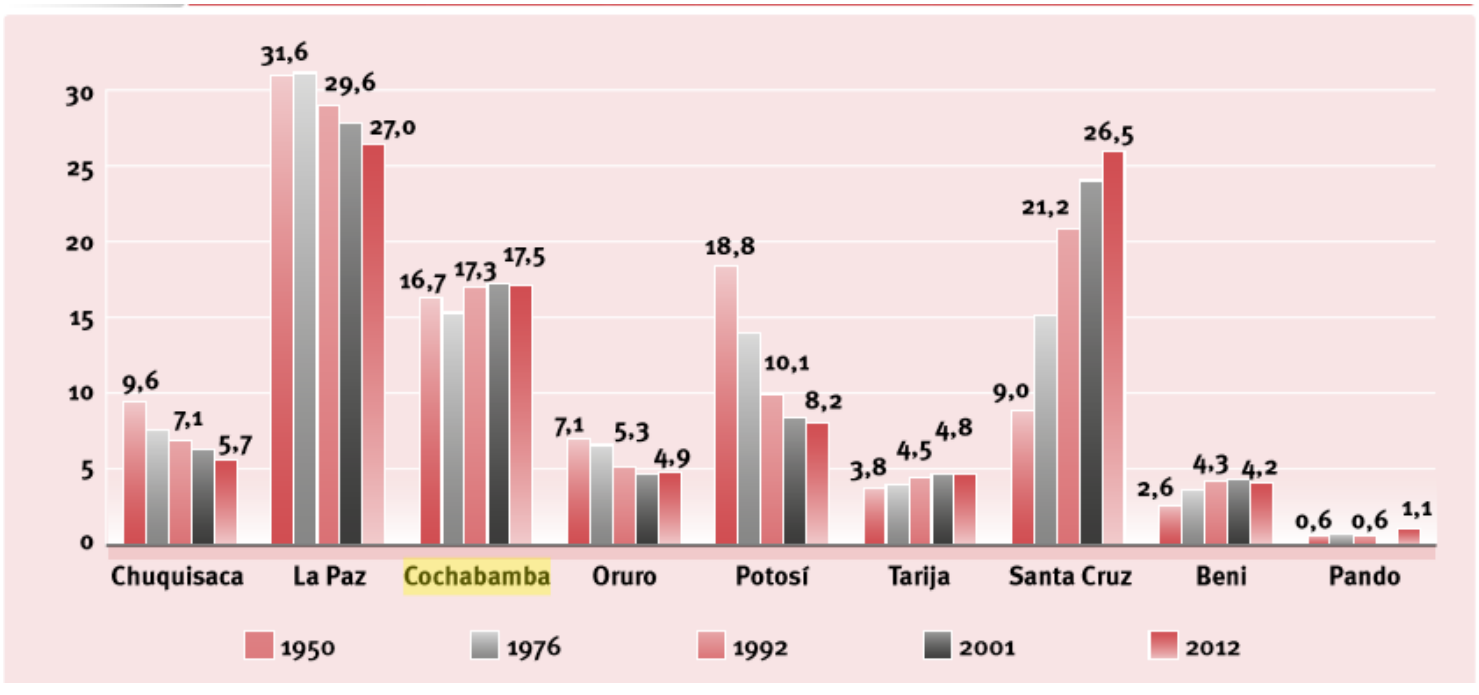

Fuente: Informe Nacional de Desarrollo Humano, PNUD, 2016.

Figura 31. Evolución de la población de Bolivia, según departamentos (en porcentaje)

En el informe del PNUD se destaca la sinergia que establecen los aspectos vinculados al desarrollo urbano como el crecimiento económico, y el cómo estos están directamente relacionados con el desarrollo humano, en el que según se afirma en este importante documento a mayor urbanización, mayor desarrollo humano, suponiendo que es en este contexto en el que primaría la disponibilidad a servicios básicos, aunque éstos no estén accesibles para toda la población. En el caso de la realidad boliviana en los últimos años se ha dilucidado que el proceso de urbanización de alguna manera ha estado relacionado 
con un aumento tendencial del desarrollo humano. Para la década del 90 se vislumbraba un IDH de 0.542 que hacía que el país apareciera como uno de los escenarios con desarrollo humano más bajo, para el año 2013 los datos evidenciaban 0.774 que ubicaban a Bolivia como un país con IDH medio-alto, indicando cómo supuestamente se había reducido la brecha entre lo económico y lo social. En lo que refiere a las áreas metropolitanas se destaca que el IDH ha evolucionado de manera similar al nacional. Haciendo una línea comparativa entre las ciudades, se desataca que Santa Cruz reporta un mejor desempeño, seguido de Cochabamba y luego por La Paz.

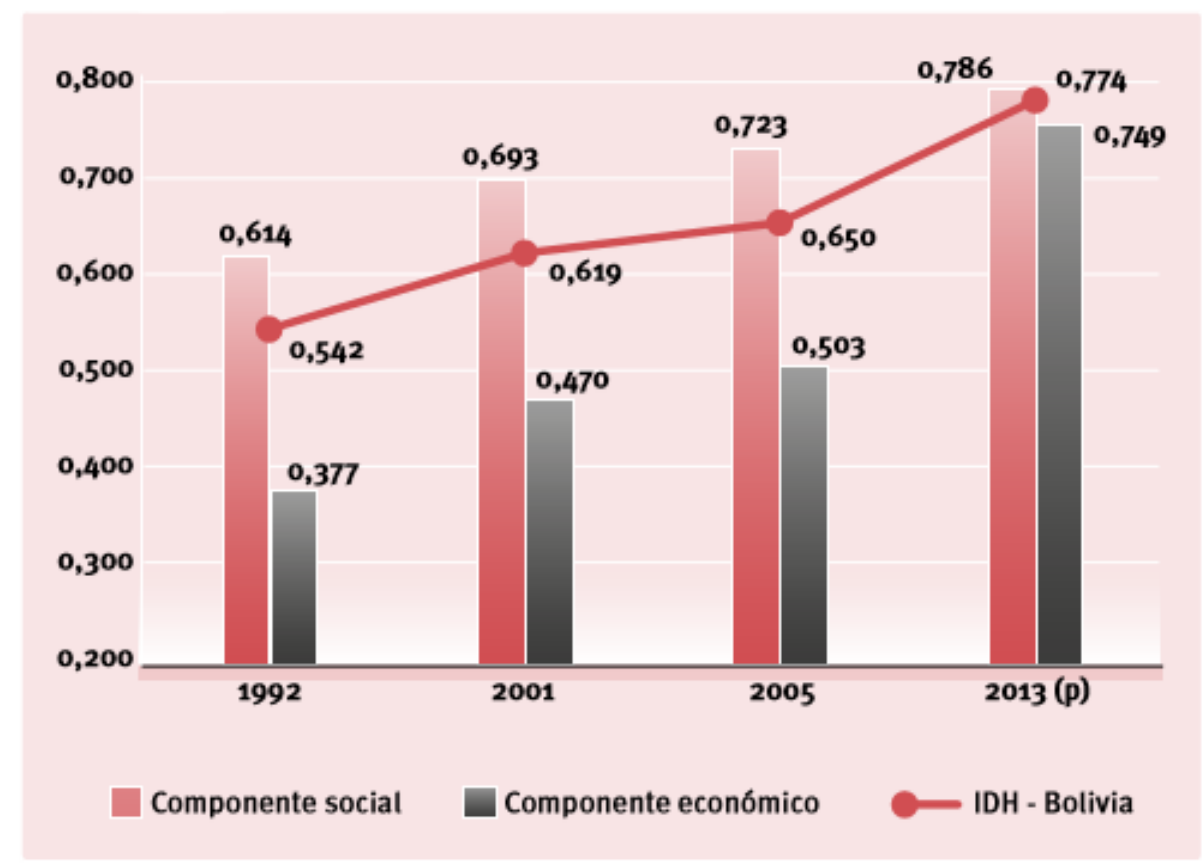

Fuente: Informe Nacional de Desarrollo Humano, PNUD, 2016.

Figura 32. Bolivia. Evolución del desarrollo humano en las últimas dos décadas, 1992-2013.

\subsubsection{Cochabamba y municipio de Sacaba: Tensiones entre lo rural y lo urbano}

La ciudad de Cochabamba fue fundada a fines del siglo XVI sobre la base de la antigua aldea precolombina de Kanata y adquirió relevancia con el desarrollo de las haciendas agrícolas orientadas a abastecer alimentos a la minería potosina (Ledo, 1986; Solares, 1990. Citados en PNUD, 2016; 49). Cuando se hablaba del auge minero en el país y en la parte occidente, esta ciudad era la piedra angular en la agricultura del país, sin embargo, más tarde y dadas las condiciones derivadas de épocas de depresión económica y de fragilidad del sector minero en los albores de la década de los 80 , se dio paso al auge de asentamientos humanos que fueron configurando un panorama de tipo urbano que propendería por el fortalecimiento de los llamados centros poblados.

La región cochabambina está conformada por siete ciudades principales, que corresponden a siete municipios, dentro de los que está el que resulta ser objeto de 
estudio. Los que se destacan como centros urbanos son: Cochabamba, Quillacollo, Sipe Sipe, Tiquipaya, Vinto, Colcapirhua y Sacaba. En el centro de esta región se encuentra la ciudad de Cochabamba, o también conocida como Cercado. En la parte periférica se encuentran dos de los centros poblados más importantes del Departamento, a saber Quillacollo y Sacaba.

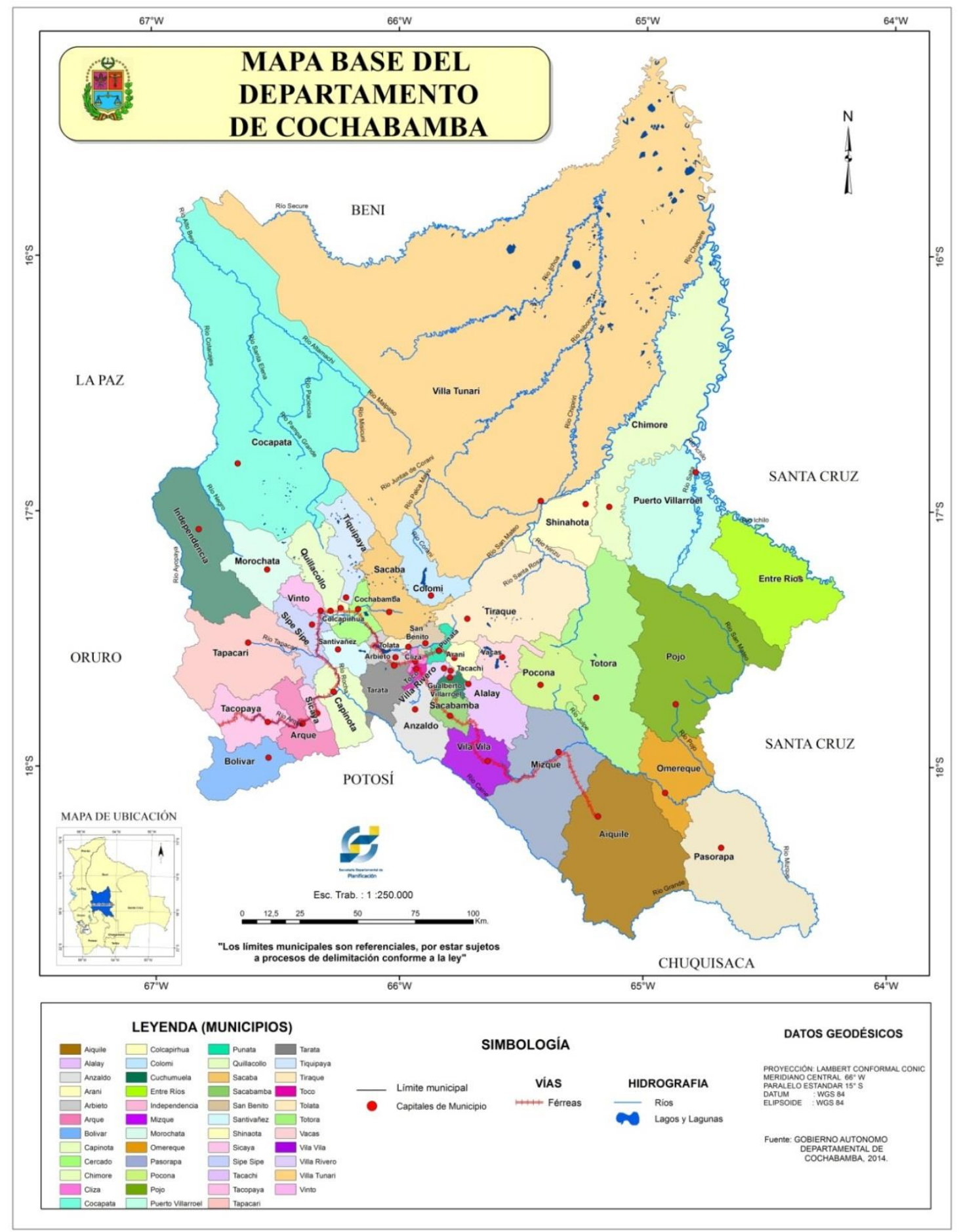

Fuente: Plan Territorial de Desarrollo Integral PTDI, GADC, 2016

Mapa 2 Mapa físico de Cochabamba 
Como se observa en el gráfico 33 la región metropolitana de Cochabamba ha tenido un histórico crecimiento poblacional desde la década del noventa. En 1992 el centro de Cochabamba contaba con 414.307 habitantes mientras que para el año 2012, se encuentra que la población asciende a 632.013 habitantes. En cuanto al resto de la región en el año 2012 se reportan 509.081 personas, como se ha afirmado un incremento significativo que da cuenta de cambios importantes en las diversas dimensiones de la vida social. Se alude a mencionar en el informe PNUD 2016, que para la década del 90 se evidencia una significativa expansión de la mancha urbana que ocupaba el territorio central del Departamento, e incluso contenía a los municipios de Quillacollo y algunas edificaciones de Sipe Sipe y Colcapirhua. En lo que respecta a la década del 2000, la mancha urbana densifica a Cochabamba hasta el punto de situarse como la segunda ciudad más densa del país,

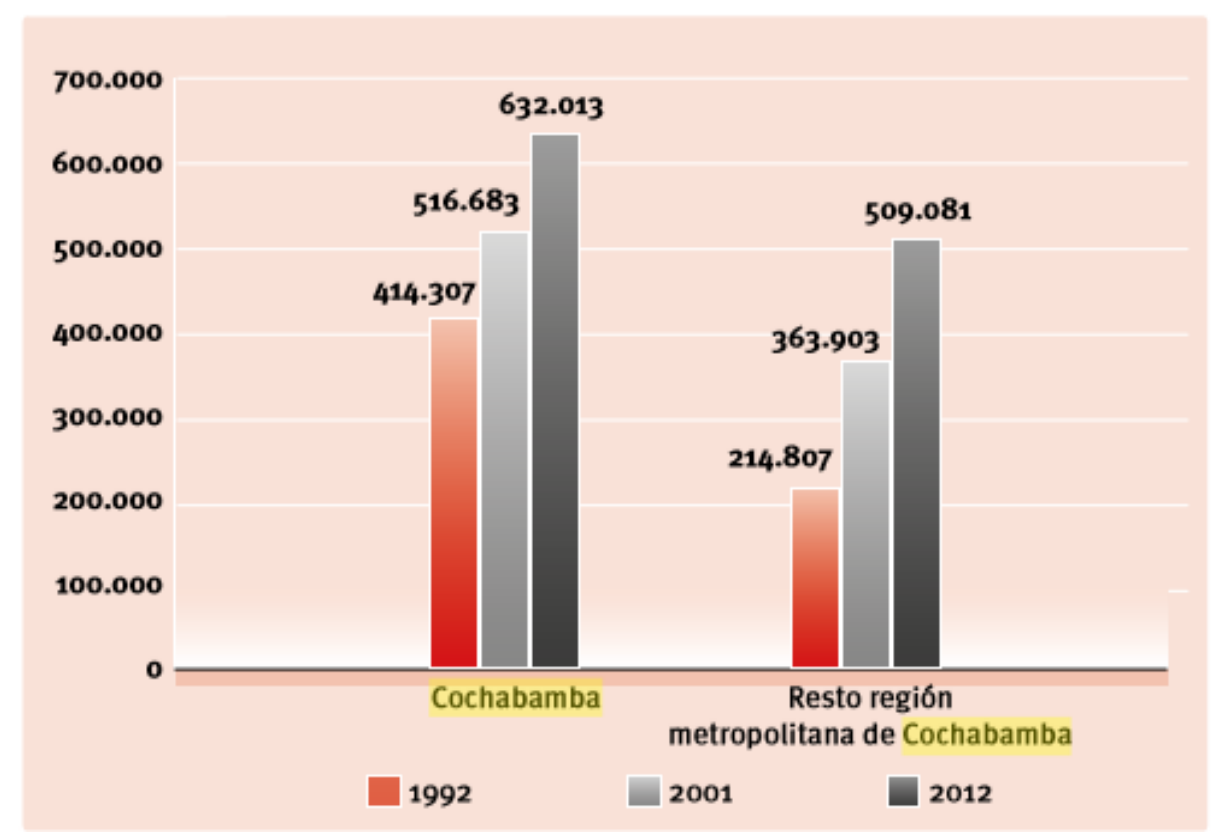

Fuente: Informe Nacional de Desarrollo Humano, PNUD, 2016.

Figura 33. Región Metropolitana de Cochabamba. Crecimiento de la población 1992-2012

Para 2010 la expansión urbana estalló, los asentamientos humanos sobrepasaron los límites de la región metropolitana y aparecieron edificaciones que se expandieron hacia los municipios vecinos del sur del territorio como Santibañez, Arbieto, Tolata y San Benito. Por otro lado, la ciudad de Cochabamba creció igualmente en dirección sudeste y se consolidó el resto de la corona periurbana (PNUD, 2016; 71)

El municipio de Sacaba toma, en sentido, principal importancia al constituirse en un reflejo casi perfecto de las características generales de la metrópoli en términos de cambio de uso de suelo, población, vivienda, servicios básicos e instancias de planificación espacial. Y, por tanto, un espacio clave de análisis de estrategias alternativas para configurar procesos que interpelen la lógica masiva de urbanización desordenada y descontrolada. Es posible que sí se proyectan e implementan procesos 
exitosos en este municipio, posteriormente puedan ser replicados en el resto de los municipios que conforman la metrópoli de Cochabamba, al considerar el contexto coyuntural rico y completo en el que se encuentra. Sacaba presenta, como el resto de municipios, una estructuración territorial distrital, compuesta por seis distritos urbanos y seis rurales.

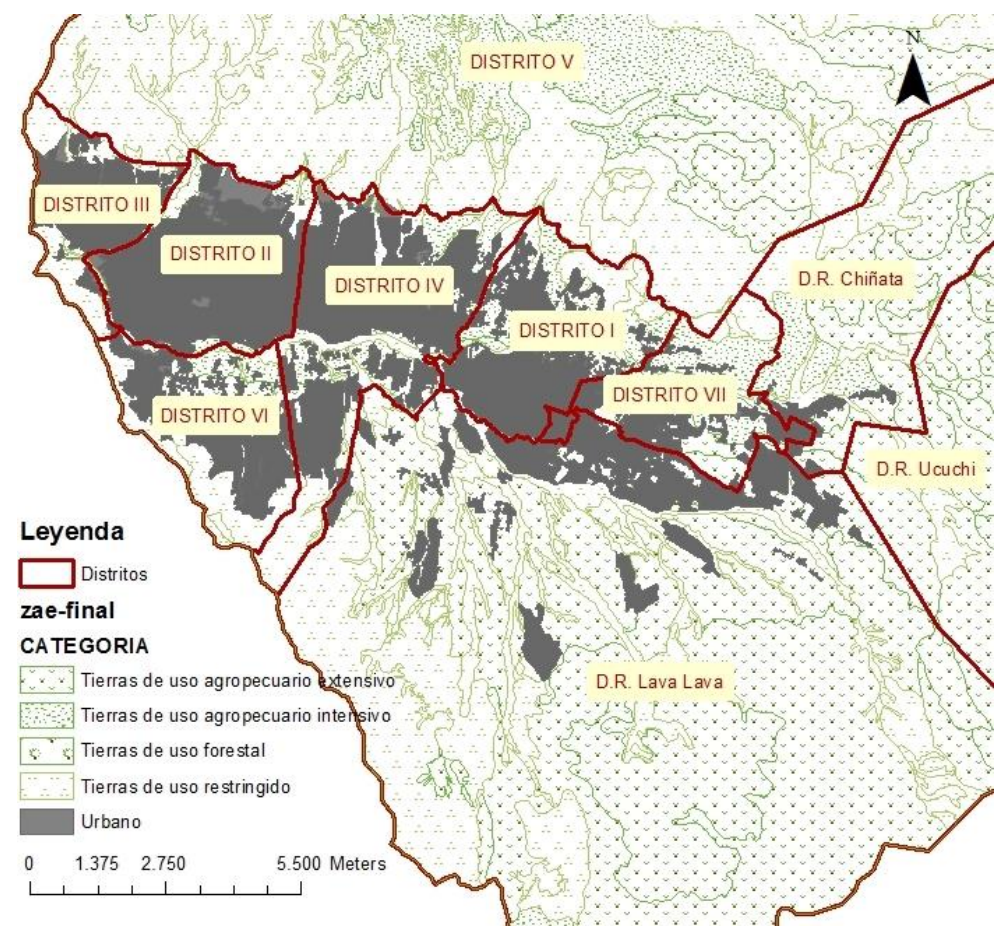

Fuente: PMOT Sacaba, 2014.

Mapa 3. Sacaba: Distribución de categorías de uso de suelo por distritos, 2014

Los distritos municipales ${ }^{11}$ son el espacio territorial constituido mediante ordenanza municipal conforme a un plan de ordenamiento y desconcentración administrativa de la municipalidad y del territorio del municipio. El proceso de creación de estas unidades territoriales homogéneas, llamada distritación municipal, tiene por finalidad la de desconcentrar la gestión administrativa, crear un espacio de agregación de demandas para formular planes distritales de desarrollo municipal, facilitar la participación de las organizaciones de base territoriales y utilizar adecuada y equitativamente los recursos financieros, técnicos y humanos del municipio. Por otra parte, también son pensados para facilitar el concurso y la gestión de otras instituciones públicas y privadas de desarrollo. Para la creación de un distrito municipal se tienen en cuenta criterios de población homogénea, con características socioculturales similares, la existencia de actividades productivas integradas, existencia de servicios públicos e infraestructura y condiciones físico-ambientales comunes a los asentamientos humanos. El alcalde designa un sub alcalde para cada distrito. En las áreas rurales extensas, con grupos étnicos determinados o pueblos originarios, el sub alcalde es nombrado de entre las

\footnotetext{
${ }^{11}$ Esta información se retoma de Aguilar, Ledo García, Ledo Espinoza, Marañon, Umbarila. 2015.
} 
autoridades tradicionales del área distritada. La Ley de Municipalidades establece los requisitos, criterios y procedimientos para la creación de distritos municipales y el nombramiento de sub alcaldes, ajustándose a normas técnico legales reguladoras de ese proceso.

La mayor proporción de la población del municipio de Sacaba, está concentrada en el sector urbano, por el "Eje de Conurbación" y la ciudad de Sacaba, constituidos por los distritos 1, 2, 3 y 4 principalmente. La población rural está distribuida en los distritos rurales Lava Lava, Chiñata, Ucuchi, Aguirre, Palca y el distrito 5, sin embargo la fuerza de la expansión urbana, comenzó a ocupar espacios considerados como terrenos agrícolas en el los distritos rurales; por tanto también existe población urbana en el área rural.

La población total del departamento de Cochabamba llegó para el 2012 a los 1.758.143 habitantes, según los datos oficiales del Censo de Población y Vivienda. Dos tercios de los mismos viven en el valle central, en el área metropolitana de Cochabamba. A lo largo de los años el municipio de Cochabamba (Cercado) ha concentrado el peso de población más alto debido a su antigüedad y posición geográfica dentro de la metrópoli. Justamente por este motivo, es un municipio con muchos contrastes y conflictos, lejano a la realidad de algunos de los municipios de menor peso poblacional.

Tabla 16. Área Metropolitana de Cochabamba: Distribución de la población según municipio, fecha de realización de censos de población e índice de masculinidad.

\begin{tabular}{|l|r|l|r|r|r|r|}
\hline \multirow{2}{*}{ Municipio } & \multicolumn{2}{|c|}{1992} & \multicolumn{2}{c|}{2001} & \multicolumn{2}{c|}{2012} \\
\cline { 2 - 7 } & Población & IM & Población & IM & Población & IM \\
\hline Cercado & 414.307 & 91,6 & 517.024 & 91,8 & 630.587 & 92,9 \\
\hline Quillacollo & 69.027 & 94,8 & 104.206 & 96,8 & 137.029 & 94,4 \\
\hline Sipe Sipe & 20.007 & 94,8 & 31.337 & 98,4 & 41.537 & 95,2 \\
\hline Tiquipaya & 13.371 & 98,1 & 37.791 & 94,6 & 53.668 & 93,7 \\
\hline Vinto & 20.573 & 97,2 & 31.489 & 96,1 & 51.869 & 94 \\
\hline Colcapirhua & 22.219 & 94,3 & 41.980 & 93,4 & 51.896 & 94,5 \\
\hline Sacaba & $\mathbf{6 9 . 6 1 0}$ & $\mathbf{9 3 , 8}$ & $\mathbf{1 1 7 . 1 0 0}$ & $\mathbf{9 4 , 3}$ & $\mathbf{1 6 9 . 4 9 4}$ & $\mathbf{9 4 , 9}$ \\
\hline Total & 214.807 & 94,9 & 880.927 & 93,3 & 1.136 .080 & 93,6 \\
\hline
\end{tabular}

Fuente: Ledo Espinoza, en base a datos oficiales de los Censos Nacionales de Población y Vivienda 1992-2001-2012, Instituto Nacional de estadística de Bolivia. 
Sacaba, sin embargo, con el segundo peso más importante (169.494 habitantes) representa más sólidamente la dualidad urbano - rural de los municipios. El desenvolvimiento histórico de Sacaba hasta la fecha demanda puntualizaciones relacionadas con el ámbito físico espacial, puesto que los acontecimientos a partir de la década del 50 se relacionan sobre todo con este tema, al evidenciarse una conformación urbana con ausencia de un soporte institucional en la parte técnica de control, a pesar de la existencia de instrumentos jurídicos de regulación urbana para este municipio o relacionados con él.

La magnitud de su población se ha incrementado considerablemente con los años, de los aproximadamente 69 mil habitantes en 1992, a los 169 mil al 2012. Este crecimiento se registró con un Índice de masculinidad relativamente constante, como casi en general el resto de la metrópoli de Cochabamba.

La tasa de crecimiento de la población metropolitana entre el 1992 - 2001 y el 20012012, es del 5,71 y 2,36\% respectivamente. Datos similares a los de Sacaba, mostrándose como un promedio entre los siete municipios; entre los cuales Cercado parece presentar un proceso más desacelerado de crecimiento, y Vinto un comportamiento completamente opuesto. Las tasas de crecimiento de Sacaba, entre los dos últimos periodos inter censales, no presentan la misma tendencia que el resto de los municipios. Esto podría reflejar que el área metropolitana de Cochabamba, como conjunto, ha ido atrayendo a pobladores de distintos lugares del departamento y del país de manera distinta por temporadas.

Se observa una tendencia de la población a abandonar las áreas rurales para incorporarse a la vida de las grandes ciudades. Este fenómeno se conoce con el nombre de éxodo rural. Las características de la vida moderna producen cada vez con mayor velocidad el crecimiento de las poblaciones urbanas. Su expansión llega a superar los límites de las mismas, anexando a los centros urbanos áreas que tenían características rurales y transformándolas. Las razones que provocan el éxodo de habitantes rurales hacia las ciudades son fundamentalmente económicas. Estas personas se trasladan a las grandes ciudades en busca de fuentes de trabajo y mejores condiciones de vida. Estas expectativas no pueden ser cumplidas siempre ya que las ciudades no cuentan con la posibilidad de brindar techo y trabajo a la gran cantidad de inmigrantes, dando lugar a la formación de barrios sumamente precarios en las periferias de las ciudades. 


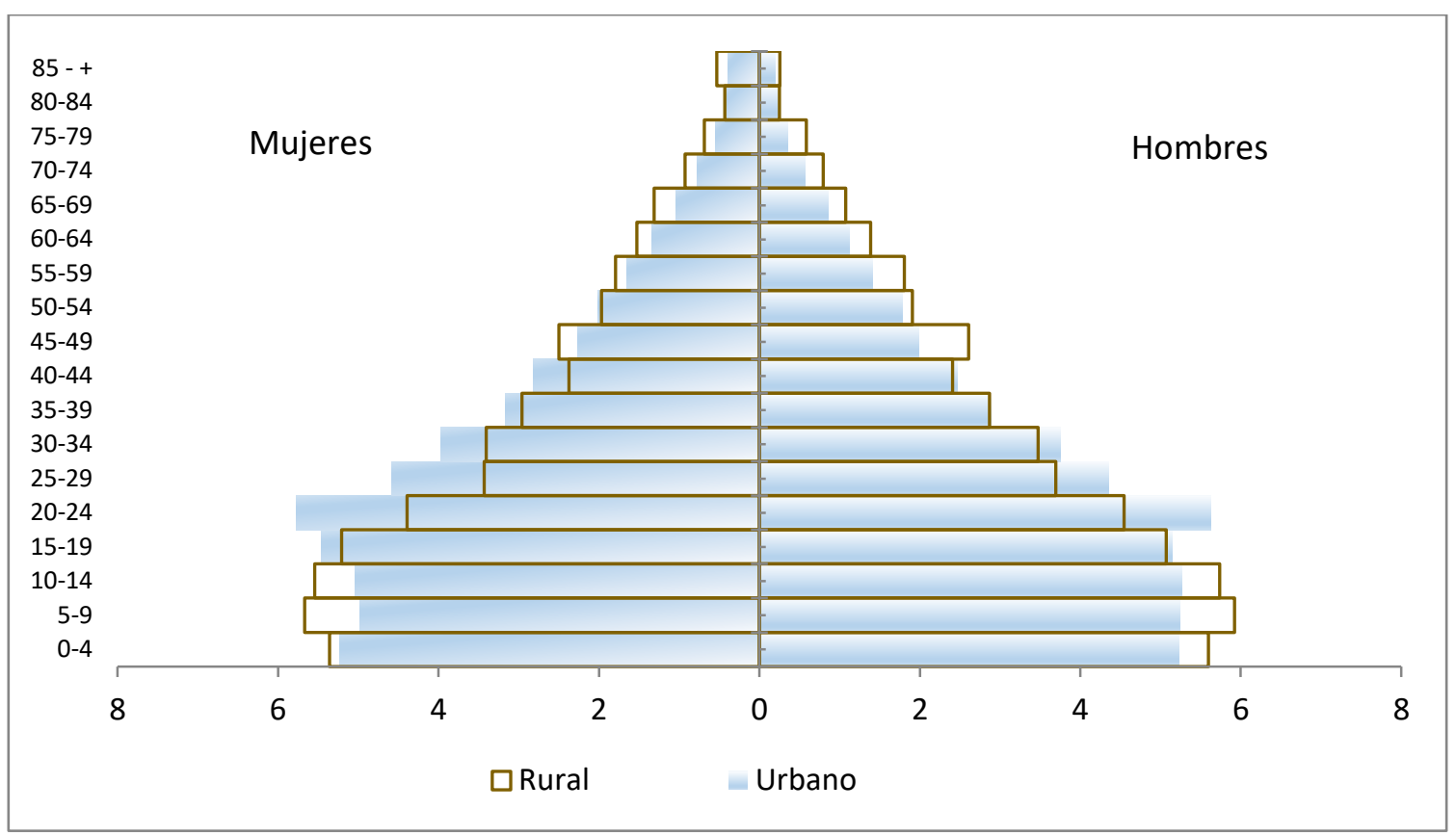

Fuente: Ledo Espinoza, en base a datos oficiales del Censo Nacional de Población y Vivienda 2012, Instituto nacional de estadística de Bolivia.

Figura 34. Sacaba: Estructura de la población por edad, sexo y grado de urbanización, 2012.

Este éxodo rural se ve impactado en la estructura de la población de las zonas rurales en contraste a la de las zonas urbanas. Como se observa en el anterior gráfico, tanto hombres como mujeres, en distintas etapas etarias tienen una mayor o menor presencia de acuerdo a la zona donde viven. En la zona rural existe mayor cantidad de niños de 0 a 14, y adultos mayores de más de los 45 años. Sin embargo en la zona urbana, el número de jóvenes/adultos entre 20 - 30 años es mucho más elevado. Se trata, posiblemente de jóvenes inmigrantes de zonas rurales, que buscan en el centro urbano mejores condiciones de educación y empleo.

De esta manera, los grandes flujos migratorios parecen haber tenido un efecto en la estructura demográfica del municipio. Afectando principalmente a la población económicamente activa, es decir de los 15 a 64 años. La emigración de jóvenes de entre 25 a 34 años de edad al exterior de país y la inmigración de jóvenes de 15 a 34 años procedentes de regiones más lejanas del departamento, o del país (zona altiplánica).

Los costos de la urbanización por los que las personas generalmente se preocupan incluyen un incremento en el desabastecimiento de servicios básicos, crimen, mayor contaminación, congestión vehicular, pérdida de lazos familiares, pérdida de las prácticas culturales tradicionales y los valores, entre otros.

El acceso a los servicios básicos que hacen posible tener vivienda digna para la población, es otro indicador de las condiciones favorables en el bienestar social y por tanto en el nivel relativo de desarrollo. La mejora de la cobertura de estos servicios 
sugiere un mejor nivel de desarrollo al reducir las enfermedades y aumentar la calidad de vida que finalmente significa acumulación de capital humano ${ }^{12}$.

La calidad de los servicios básicos es determinante para una sociedad urbana. La eficiencia para el acceso al agua potable, disponibilidad de servicio de drenaje, limpieza de la ciudad, servicio de electricidad y combustible para cocinar en la vivienda además de la dotación y mantenimiento de infraestructuras y el transporte público urbano son cometidos básicos e importantes dado que afectan a la totalidad de los ciudadanos.

Una restricción importante para la población de los municipios de la región metropolitana a la hora de mejorar y mantener su estándar de vida es la falta de acceso a servicios básicos, donde el acceso es definido como la facilidad o dificultad de alcanzar estos servicios.

El acceso a estos servicios básicos puede ser en gran medida mejorado por inversiones apropiadas en infraestructura (mejorando la proximidad y la calidad de los servicios, así como la infraestructura de transporte requerida).

Los principales servicios básicos de la región metropolitana de Cochabamba son expuestos en el siguiente gráfico, donde se puede advertir ciertas fortalezas y debilidades. En primer lugar, observamos que los servicios con mayores deficiencias son los de acceso al agua (65\%) y el sistema de alcantarillado (52\%). Sin embargo, los servicios de energía eléctrica y combustibles para cocinar se encuentran en una situación más favorable.

En Sacaba el escenario es muy similar, pero grado de cobertura en todos los servicios es un tanto menor que el de la metrópolis, a excepción del sistema de alcantarillado. El servicio básico que más desafíos presenta es el de acceso al agua por cañería de red, seguido del servicio de alcantarillado (que si bien presenta una mejor situación que el conjunto metropolitano, aun representa una importante dificultad para Sacaba), en tercer lugar se encuentra el acceso a combustible para cocinar y en último lugar el servicio de energía eléctrica.

\footnotetext{
${ }^{12}$ Ulises Castro Álvarez- estructuras regionales emergentes y desarrollo turístico sustentable: la región costa sur de Nayarit, México
} 


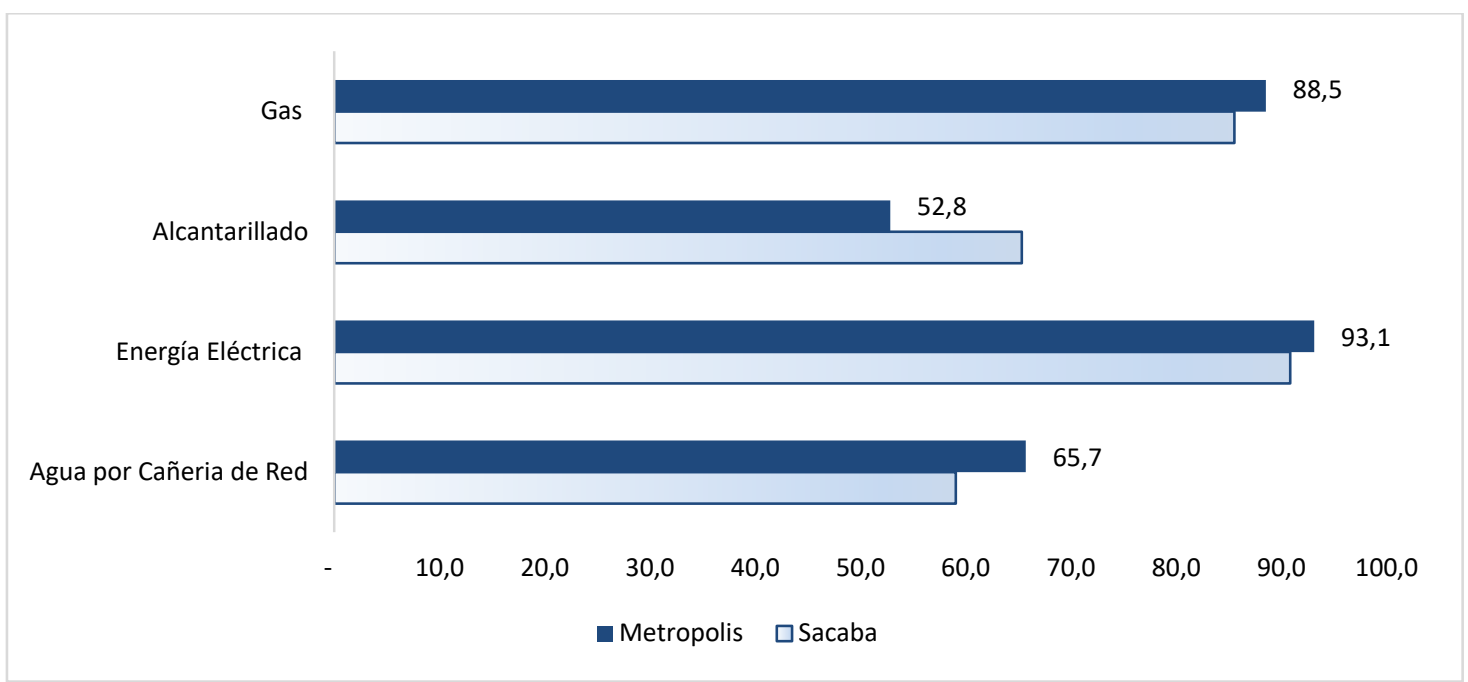

Fuente: Elaboración propia en base a datos oficiales del Censo Nacional de Población y Vivienda 2012, Instituto nacional de estadística de Bolivia.

Figura 35 Área Metropolitana de Cochabamba y Sacaba: Distribución porcentual de dotación de principales Servicios básicos, 2012.

Ante estas urgencias es importante dar un analizar el panorama específico de cada uno de estos servicios en el municipio de Sacaba. Este análisis contrastara una vez más la realidad urbana y rural del municipio con el fin de identificar las mayores amenazas para estas dos regiones.

El agua salubre y fácilmente accesible es importante para la salud pública, ya sea que se utilice para beber, para uso doméstico, para producir alimentos o para fines recreativos. La mejora del abastecimiento de agua, del saneamiento y de la gestión de los recursos hídricos puede impulsar el crecimiento económico de los países y contribuir en gran medida a la reducción de la pobreza. En 2010, la Asamblea General de las Naciones Unidas reconoció explícitamente el derecho humano al abastecimiento de agua y al saneamiento. Todas las personas tienen derecho a disponer de forma continuada de agua suficiente, salubre, físicamente accesible, asequible y de una calidad aceptable, para uso personal y doméstico ${ }^{13}$.

La fuente de abastecimiento de agua con la que cuenta la población del municipio de Sacaba se reparte entre cañería de red, y fuentes alternativas de abastecimiento con distinta relevancia. Entre estas la pileta pública tiene primordial importancia al igual que el carro repartidor o aguatero. Ambos no cuentan con procesos de tratamiento del agua, además su disponibilidad y precios son fluctuantes. El caso de los pozos es en su mayoría auto gestionados por las OTBs de periferia y/o rurales, bajo poco y ningún criterio técnico. 


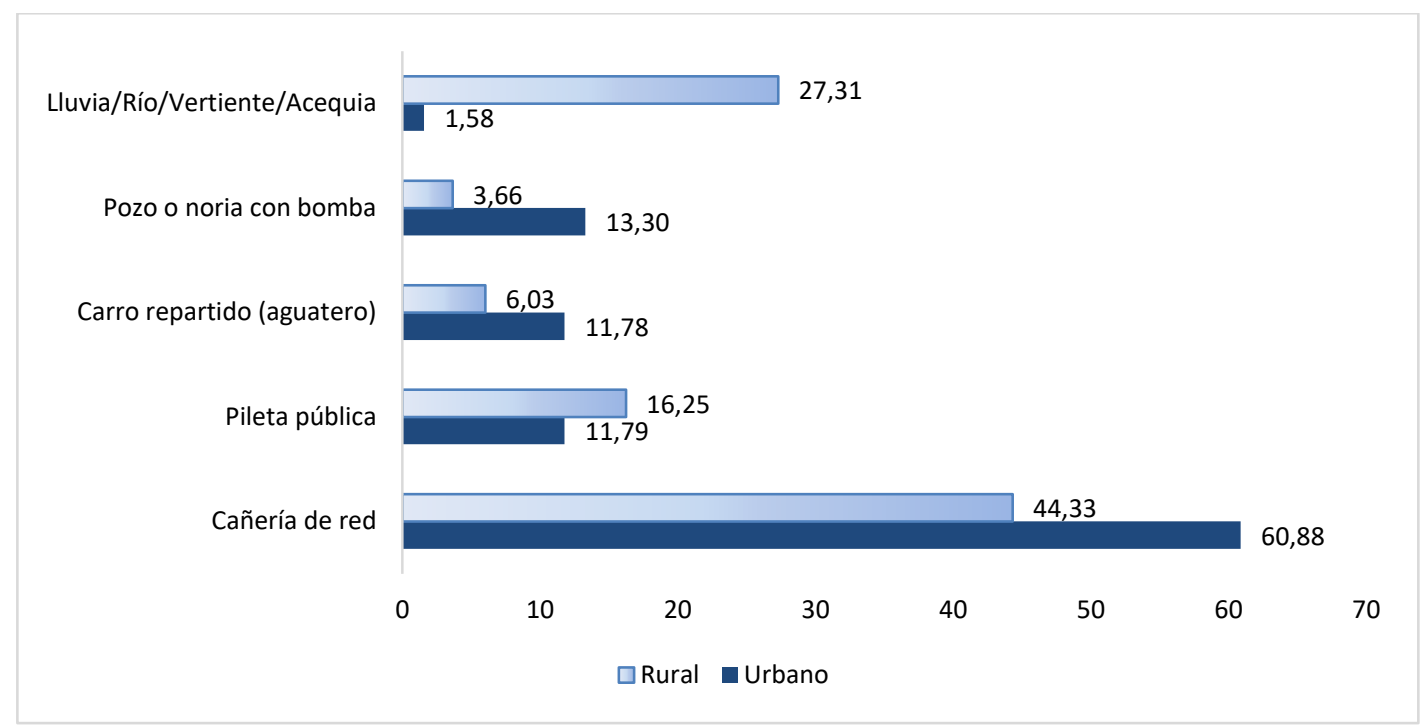

Fuente: Elaboración propia en base a datos oficiales del Censo Nacional de Población y Vivienda 2012, Instituto nacional de estadística de Bolivia.

Figura 36. Sacaba: Distribución porcentual de hogares por tipo de Sistema de abastecimiento alternativos de agua, 2012.

Sin embargo, esta fuente de abastecimiento de agua varía en la zona rural y la zona urbana. En la zona urbana un $60 \%$ de las viviendas cuenta con el servicio de cañería de red, $13 \%$ cuenta con agua proveniente de pozos, y $11 \%$ tanto pileta pública como carro aguatero. En la zona rural en cambio, solo el $44 \%$ de las viviendas se abastecen mediante cañería de red, un $27 \%$ de los hogares se abastecen a través de la lluvia, ríos, vertientes o acequias y el $16 \%$ utiliza la pileta pública.

La calidad del agua también varía según la zona y el tipo de fuente de abastecimiento de la misma, dado que las posibilidades y condiciones favorables para su contaminación incrementa en algunos casos. Por ejemplo, el agua de lluvia, ríos, vertientes y acequias tienen mayor probabilidad de estar contaminado. El agua contaminada puede transmitir enfermedades como la diarrea, el cólera, la disentería, la fiebre tifoidea y la poliomielitis. Usualmente no se realizan pruebas de calidad para la detección de toxinas en el agua, debido a que la fuente de abastecimiento con la que disponen los hogares es muchas veces la única posibilidad de acceso a este recurso escaso.

De los hogares que tienen abastecimiento de agua por cañería, solo un $54 \%$ se distribuye dentro la vivienda. Estos son hogares ubicados en la parte urbana del municipio (60\%), dado que las viviendas de la zona rural con cañería dentro la vivienda son apenas el $18 \%$. La zona rural tiene principalmente cañería dentro del terreno (43\%), o su abastecimiento no se realiza por cañería (34\%). Es posible que por falta de recursos económicos y/o apoyo técnico municipal, esta población rural (y urbana) no presenta ningún tipo de abastecimiento de agua por cañería. 


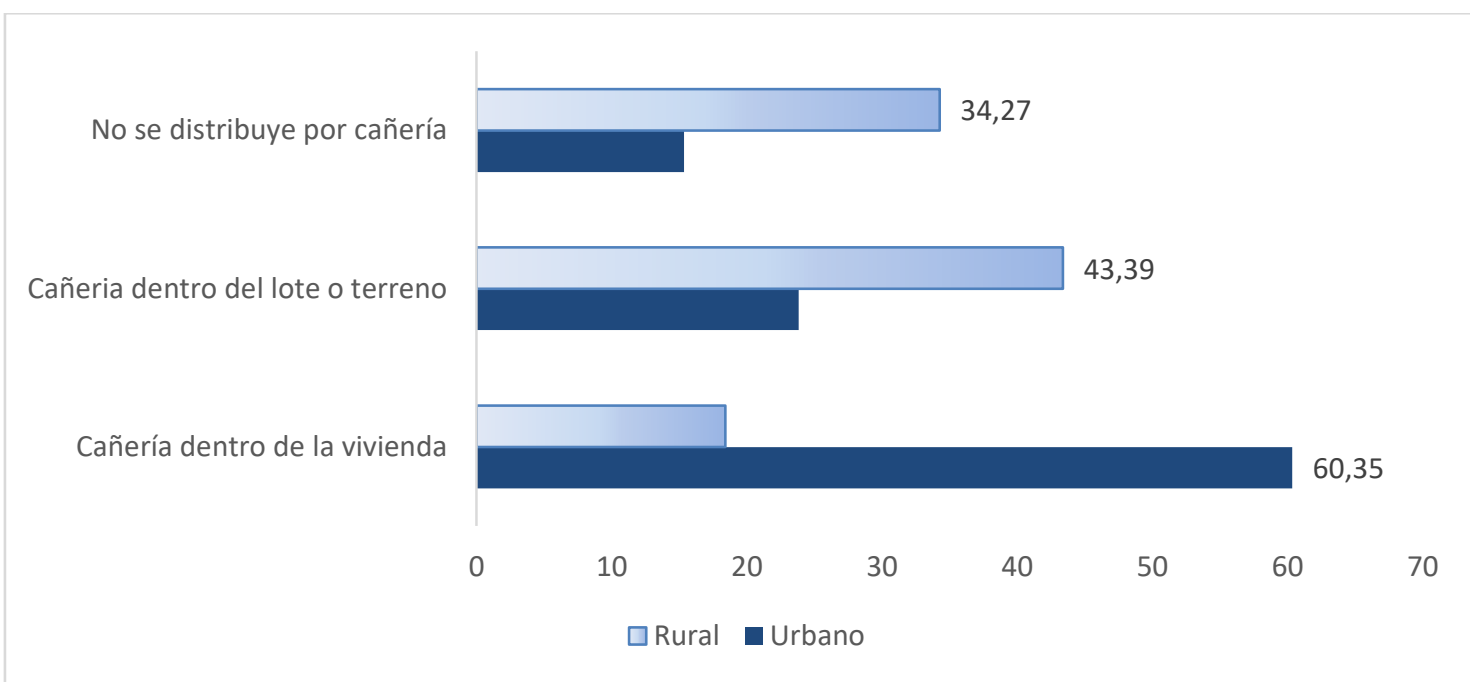

Fuente: Elaboración propia en base a datos oficiales del Censo Nacional de Población y Vivienda 2012, Instituto nacional de estadística de Bolivia.

Figura 37. Sacaba: Distribución porcentual de hogares por tipo de distribución del agua según grado de urbanización, 2012.

La complejidad y la heterogeneidad de los sistemas de abastecimiento de agua potable se pueden traducir en una serie de debilidades y amenazas que deben ser enfrentadas técnica y económicamente por el municipio. En efecto, las principales fuentes de abastecimiento de agua en Sacaba (tanto en la zona rural como urbana) pueden ser consideradas como fuentes de acceso inadecuadas ${ }^{14}$. El acceso a agua potable es un derecho humano fundamental como parte del derecho a la vida. Un abastecimiento de agua inadecuado condiciona la salud y el bienestar de las personas. Las demandas de los pueblos indígenas por el derecho al agua son recurrentes, ya que sus fuentes tradicionales de abastecimiento están desapareciendo por la alteración de sus ecosistemas, o son contaminadas por los desechos químicos e industriales. Los programas tendientes a garantizar este derecho, deberían considerar el profundo significado cultural y simbólico del agua, como elemento crucial de la cosmovisión y bienestar de los pueblos indígenas ${ }^{15}$.

Con la finalidad de desarrollar este estudio se retoma la idea de organización que se ha ideado en el CEPLAG, en términos de 4 distritos para concentrar el trabajo y a partir de allí proyectar acciones particulares para mitigar la expansión de la huella urbana. Estos 4 distritos tienen características territoriales particulares el Distrito 1 representa el casco viejo del municipio, fue uno de los primeros en sufrir el paso de la urbanización a gran escala perdiendo su origen rural; el Distrito 7 conocido por ser un espacio territorial de carácter periférico en donde se combinan la urbanidad desordenada y la ruralidad que lucha por mantenerse; el Distrito Lava Lava que es rural y se encuentra a expensas de

14 Los criterios para definir abastecimiento de agua "inadecuado" consideran el abastecimiento y el tipo de instalación. Metodología que sigue CELADE para el cálculo de las Necesidades Básicas Insatisfechas.

${ }^{15}$ Celade cepal org 
los asentamientos ilegales que se vuelven comunes con el pasar del tiempo y el Distrito Chiñata que a pesar del devenir de la urbanización ha logrado mantener su esencia rural.

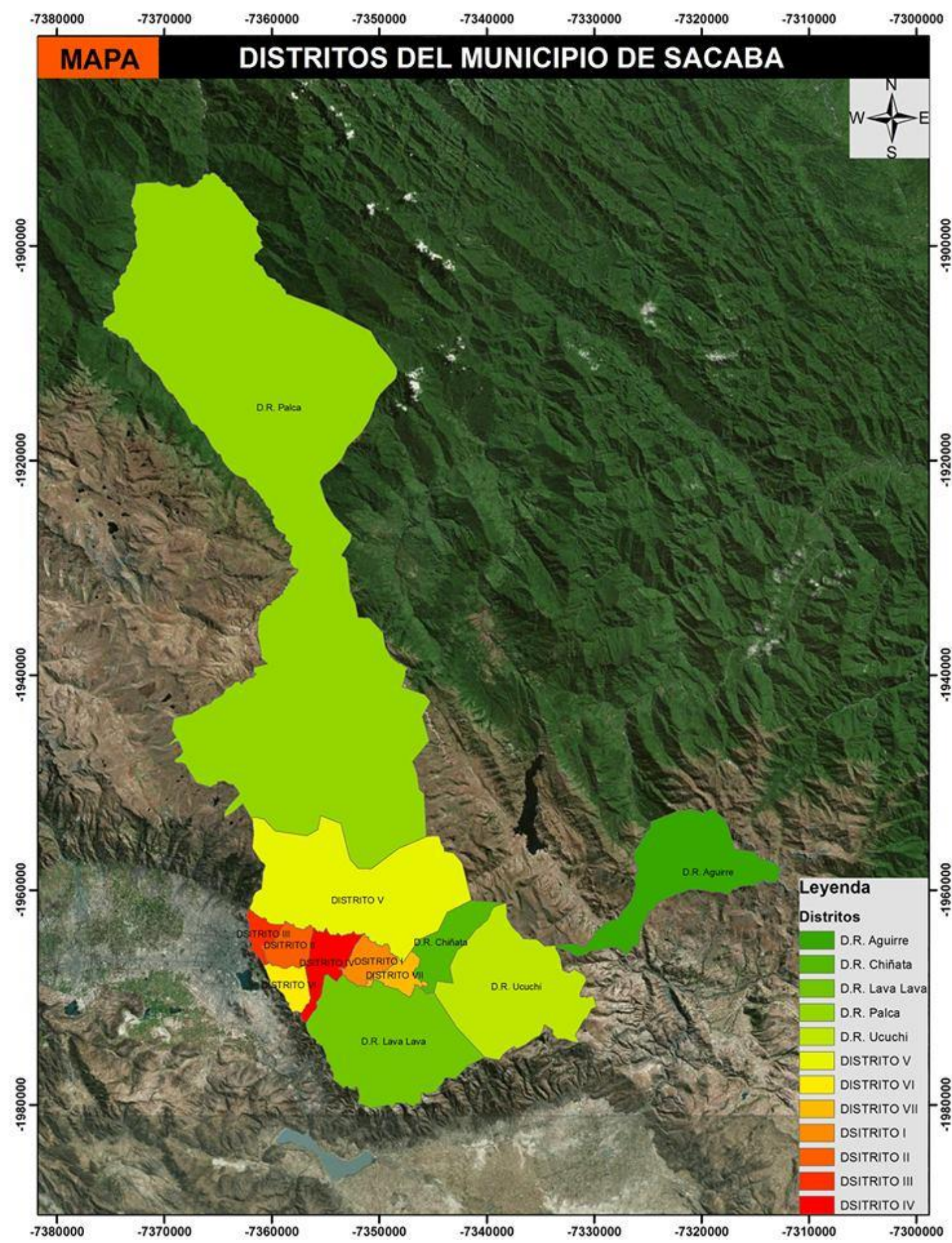

Fuente: Huaynoca Raúl, 2017

Mapa 4. Distritos del Municipio de sacaba. 


\subsubsection{Planes de desarrollo y PMOTS}

Como se ha evidenciado desde la perspectiva teórica que antecede a este apartado, la planificación está anclada en un paradigma de conocimiento determinado, que deriva un conjunto de discursos y prácticas para desarrollar el quehacer dentro del ciclo de la política pública. En este sentido, las lógicas a través de las que se adelantan los procesos de planificación en un Estado, dan cuenta de varios aspectos susceptibles de analizarse, uno de ellos es el vinculado con la relación Estado-Sociedad que se inscribe en el proceso de construcción e implementación de la toma de decisión, por otra parte, se encuentra el significado que se atribuye a la incidencia política (sí éste es real o es más bien utópico para los colectivos sociales). De igual manera, se habla de un entramado teórico y conceptual que da soporte a los discursos y prácticas y sobre el que se respalda el accionar de los diversos actores que se vinculan en el escenario de la planificación. El contexto boliviano, por supuesto no es ajeno a estos elementos, en este escenario, se encuentra que la práctica que por muchos años orientó el quehacer en materia de planificación social fue conocida como el Sistema Nacional de Planificación SISPLAN que hacía referencia al conjunto de procesos, normas y procedimientos a través de los que el Estado, en las diversas escalas territoriales (municipal, departamental y nacional), que racionaliza la toma de decisiones para la asignación de recursos públicos en función de lograr el Desarrollo -se decía sostenible- para el país.

Se evidencia haciendo un recorrido socio-histórico por este Sistema de Planificación, que su objetivo era racionalizar los recursos públicos en el contexto de la toma de decisiones, con miras a generar eficacia en términos de cumplimiento de objetivos que se definían en los planes y en los programas en un horizonte temporal de mediano y largo plazo. De manera que las fases que se contemplaron en este marco de acción fueron:

- Proceso tendiente a la elaboración de planes de desarrollo nacionales, departamentales y municipales que representan la visión de largo plazo de cada escala territorial y la programación de mediano plazo en términos de recursos

- La concertación que es el proceso participativo para elaboración del plan

- La ejecución que contempla el desarrollo de actividades para concreción del plan

- Seguimiento y adaptación continúa, es la dinámica de mejoramiento continuo del plan.

En el marco de funcionamiento del SISPLAN, los municipios bolivianos formulaban los Planes Municipales de Ordenamiento Territorial o PMOTs. El último PMOT del municipio de Sacaba fue en el año 2014, tenía como objetivo lograr en el Municipio suficiente cobertura de servicios sociales y básicos, a la par que generar procesos de desarrollo económico y social, mediante el uso sostenible de los recursos naturales. 
En esta perspectiva el municipio tenía como visión la de "ser un territorio integrado e interdependiente de la Zona Metropolitana de Cochabamba e internamente estar óptimamente vinculado, funcionalmente organizado y articulado en sus ámbitos urbano y rural, que aproveche y gestione equitativa y sustentablemente su patrimonio ambiental (material e inmaterial) como factor clave para el desarrollo social - comunitario, generando oportunidades para la población" (PMOT, 2014; 35)

En consonancia con el objetivo del PMOT, así como con la visión planteada se derivan unos ejes estratégicos, como se observa en la tabla

Tabla 17. Ejes, líneas de acción y componentes PMOT Sacaba, 2014

\begin{tabular}{|c|c|c|}
\hline EJES & LÍNEAS DE ACCIÓN & COMPONENTES \\
\hline \multirow[t]{4}{*}{$\begin{array}{l}\text { Eje 1. Consolidar a Sacaba } \\
\text { como } \quad \text { un } \\
\text { armónicamente organizado y } \\
\text { articulado en los ámbitos rural } \\
\text { y urbano }\end{array}$} & $\begin{array}{l}\text {-Organización sustentable del } \\
\text { espacio urbano y rural y } \\
\text { regulación de asentamientos } \\
\text { humanos }\end{array}$ & $\begin{array}{l}\text {-Determinación de unidades de } \\
\text { planificación } \\
\text {-Identificación de centros o núcleos } \\
\text { de desarrollo en cada unidad } \\
\text { territorial de planificación } \\
\text {-Determinación del uso de suelo } \\
\text { según zonificación agroecológica }\end{array}$ \\
\hline & $\begin{array}{l}\text {-Articulación eficiente e } \\
\text { integración física }\end{array}$ & $\begin{array}{l}\text {-Permanente atención } \\
\text { funcionalidad del eje vial este oeste } \\
\text {-Los caminos que conectan con la } \\
\text { carretera principal deben ser } \\
\text { mejorados, o en su caso } \\
\text { aperturados, pero siempre con } \\
\text { permanente mantenimiento } \\
\text {-El eje norte a su debe hacerse } \\
\text { funcional en correspondencia con } \\
\text { su creciente demanda durante todo } \\
\text { el año la vinculación en } \\
\text {-potenciar la } \\
\text { regiones estratégicas } \\
\text {-Desarrollar un programa de } \\
\text { reordenamiento y jerarquización } \\
\text { vial en el área urbana } \\
\text { (eventualmente se requerirá un } \\
\text { plan maestro de vialidad) }\end{array}$ \\
\hline & $\begin{array}{l}\text {-Acceso equitativo a } \\
\text { educación, salud y otros }\end{array}$ & $\begin{array}{l}\text { - Calidad de servicios de salud } \\
\text { óptima } \\
\text { - Promover el acceso equitativo } \\
\text { de la población a los servicios } \\
\text { sociales. }\end{array}$ \\
\hline & $\begin{array}{l}\text {-Organización y } \\
\text { funcionalización del sistema } \\
\text { económico: industria y } \\
\text { comercio }\end{array}$ & $\begin{array}{l}\text { - Promover un sistema municipal } \\
\text { de ferias que valoricen la } \\
\text { diversidad de la producción local } \\
\text { - Establecer un mercado a gran } \\
\text { escala, que además permita la } \\
\text { redistribución hacia mercados } \\
\text { barriales y eventualmente a otros } \\
\text { municipios y/o departamentos }\end{array}$ \\
\hline
\end{tabular}


Tabla 18. Ejes, líneas de acción y componentes PMOT Sacaba, 2014 (Continuación)

\begin{tabular}{|c|c|c|}
\hline EJES & LÍNEAS DE ACCIÓN & COMPONENTES \\
\hline \multirow[t]{3}{*}{$\begin{array}{l}\text { Eje 2. Realizar una gestión } \\
\text { sustentable del patrimonio } \\
\text { ambiental del municipio }\end{array}$} & Gestión del recurso tierra & $\begin{array}{l}\text {-Implementación de la propuesta de } \\
\text { Plan de Uso de Suelo PLUS, que se } \\
\text { constituye en recomendaciones } \\
\text { técnicas para el uso sostenible de la } \\
\text { tierra y de los recursos naturales } \\
\text {-Regulación de procesos extractivos } \\
\text { de agregados (arena, cascajo y } \\
\text { arcilla) principalmente para } \\
\text { resguardar los márgenes de ríos y } \\
\text { torrenteras y bancos naturales de } \\
\text { arcilla. }\end{array}$ \\
\hline & $\begin{array}{l}\text { Gestión comunitaria del } \\
\text { recurso forestal }\end{array}$ & $\begin{array}{l}\text { - Desarrollo de planes de manejo } \\
\text { forestal, respaldados por los } \\
\text { planes de gestión integral de } \\
\text { bosques, según los paradigmas } \\
\text { que plantea la Ley Marco de la } \\
\text { Madre Tierra acerca de la } \\
\text { responsabilidad y conservación } \\
\text { de recursos naturales } \\
\text { Promover programas de } \\
\text { forestación y reforestación } \\
\text { orientados al a producción } \\
\text { forestal y la restauración de los } \\
\text { ecosistemas y protección y } \\
\text { Planes de nativa } \\
\text { conservación de la flora nativa } \\
\text { orientados a mejorar las } \\
\text { poblaciones silvestres de } \\
\text { especies en peligro o en alguna } \\
\text { categoría de amenaza }\end{array}$ \\
\hline & $\begin{array}{l}\text { Gestión comunitaria de los } \\
\text { recursos hídricos }\end{array}$ & $\begin{array}{l}\text { - Priorizar el manejo y } \\
\text { conservación de las lagunas } \\
\text { como un sistema clave en la } \\
\text { dinámica natural de los } \\
\text { ecosistemas loticos alto andinos } \\
\text { Implementar un plan para el } \\
\text { manejo integral de las cuencas } \\
\text { que esté orientado a velar por la } \\
\text { calidad y cantidad de agua } \\
\text { disponible para la población } \\
\text { Desarrollar e implementar una } \\
\text { estrategia de restauración, } \\
\text { manejo y gestión ambiental del } \\
\text { río Rocha-Maylanco y sus } \\
\text { afluentes des lo sistemas de } \\
\text { Sobre la base de los existentes, elaborar un } \\
\text { riego exiego que } \\
\text { Plan Integral de Riego de } \\
\text { involucre al conjunto de las } \\
\text { tierras productivas } \\
\text { municipio. del } \\
\text { Promover usos complementarios } \\
\text { y ambientalmente adecuados del } \\
\text { sistema hídrico }\end{array}$ \\
\hline
\end{tabular}


Tabla 19. Ejes, líneas de acción y componentes PMOT Sacaba, 2014 (Continuación)

\begin{tabular}{|c|c|c|}
\hline EJES & LÍNEAS DE ACCIÓN & COMPONENTES \\
\hline \multirow[t]{3}{*}{$\begin{array}{l}\text { Eje 3. Realizar una gestión } \\
\text { sustentable y favorable para el } \\
\text { medioambiente de las Áreas } \\
\text { protegidas en el municipio }\end{array}$} & $\begin{array}{l}\text { Promover, difundir, valorizar } \\
\text { la importancia de las áreas } \\
\text { protegidas }\end{array}$ & 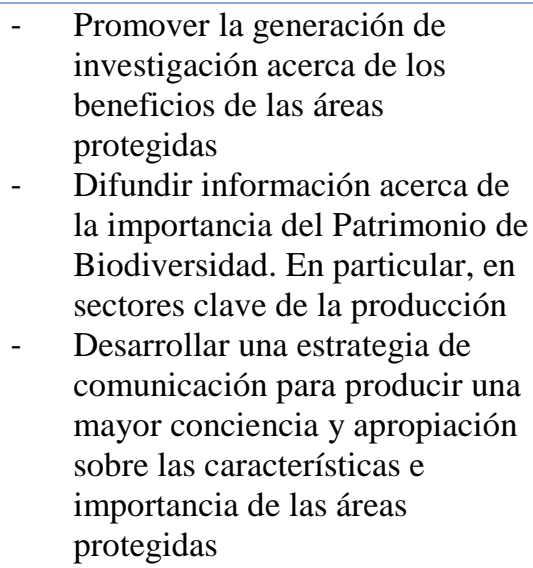 \\
\hline & $\begin{array}{l}\text { Participar, involucrarse en el } \\
\text { entramado institucional } \\
\text { responsable departamental y } \\
\text { nacional de gestión de las } \\
\text { áreas protegidas }\end{array}$ & $\begin{array}{l}\text { Fomentar una mayor } \\
\text { coordinación entre la } \\
\text { administración de las áreas } \\
\text { protegidas y el Gobierno } \\
\text { Municipal } \\
\text { Gestionar recursos económicos, } \\
\text { convenios de cooperación para } \\
\text { la conservación de la } \\
\text { biodiversidad } \\
\text { Mejorar la capacidad de gestión } \\
\text { y control de las áreas protegidas } \\
\text { en el municipio }\end{array}$ \\
\hline & $\begin{array}{l}\text { Generar acciones directas a } \\
\text { favor de la conservación }\end{array}$ & $\begin{array}{ll}\text { - } & \text { Inversión de recursos } \\
\text { económicos para la gestión de } \\
\text { las áreas protegidas } \\
\text { - Desarrollar planes de manejo de } \\
\text { áreas protegidas en el municipio } \\
\text { - } \quad \begin{array}{l}\text { Promover la declaración de área } \\
\text { protegida a la parte norte del } \\
\text { distrito de Palca }\end{array}\end{array}$ \\
\hline \multirow[t]{2}{*}{$\begin{array}{l}\text { Eje 4. Construir un desarrollo } \\
\text { económico social, comunitario } \\
\text { para vivir bien. }\end{array}$} & $\begin{array}{l}\text { Desarrollo social } \\
\text { comunitario del tejido } \\
\text { productivo a partir de las } \\
\text { vocaciones territoriales y } \\
\text { capacidades productivas }\end{array}$ & $\begin{array}{l}\text { - Articulación de economías } \\
\text { urbanas y rurales para romper la } \\
\text { atomización del tejido } \\
\text { productivo } \\
\text { Apoyo a la producción } \\
\text { agropecuaria priorizando } \\
\text { criterios de sostenibilidad } \\
\text { ambiental }\end{array}$ \\
\hline & $\begin{array}{l}\text { Articulación e integración de } \\
\text { las actividades económicas } \\
\text { vertical y horizontal }\end{array}$ & $\begin{array}{l}\text { - Fortalecer cadenas productivas } \\
\text { que involucren sectores } \\
\text { estratégicos de la economía } \\
\text { - Priorizar la inclusión de grupos } \\
\text { sociales vulnerables. }\end{array}$ \\
\hline
\end{tabular}

Fuente: elaboración propia a partir de PMOT, Sacaba, 2014 


\subsection{Síntesis}

Colombia es el único país de América que se encuentra en conflicto armado, situación que al parecer se ha instaurado en la historia nacional. El devenir histórico ha estado marcado por los efectos de modalidades de violencia que afectan gravemente los Derechos Humanos de sus víctimas tanto directas como indirectas, causando en este contexto afectaciones psicosociales de diversa índole, en las que se ve involucrado el aspecto individual-social y social-comunitario afectando a diferentes colectivos de población. De igual manera, se observa que escenarios sociales, políticos, económicos y hasta culturales desafortunadamente son testigos de cómo el conflicto armado y la violencia sociopolítica se convierten en ejes transversales de sus discursos y prácticas, así, al analizar un aspecto registrado en estas dimensiones siempre se ve referencia directa o indirecta a la relación o nivel de afectación del conflicto sobre éste.

La violencia de los años cincuenta, el surgimiento de los grupos armados en la década del sesenta y su proliferación, son factores que dan cuenta de medio siglo de confrontaciones, situación que aunada a la desigualdad e inequidad social en la distribución de riqueza, acceso a bienes y servicios, barreras a la participación y el ejercicio pleno en derechos supeditan la ciudadanía a lógicas vinculadas con aspectos netamente económicos y a la cantidad de poder adquisitivo de las personas para acceder a aquellos satisfactores de las necesidades básicas en espacios ligados con éstos. En este marco de análisis los derechos, el reconocimiento, la inclusión, la participación, las libertades y los deberes quedan entre interrogantes que indagan por las ciudadanías no realizadas; en este caso por la ciudadanía legal representada en los mecanismos de reconocimiento jurídico del ejercicio de derechos ciudadanos, la ciudadanía política como capacidad real de participar en las deliberaciones colectivas y la ciudadanía social representada en la garantía de los Derechos económicos, sociales y culturales (DESC). En suma, la desigualdad o inequidad social y el conflicto armado son factores que coadyuvan al no ejercicio de la ciudadanía política y legal en contextos de Estados frágiles, como el colombiano.

Los factores de degradación del conflicto armado, tales como rentismo, territorialización, terror, criminalización y vinculación apolítica dan cuenta tanto de la barbarie que caracteriza la violencia a través de la historia nacional, como de la deslegitimación social de los grupos insurgentes ante la población en general y en la mayoría de las ocasiones sobre los grupos de personas que se encuentran en espacios rurales, ya que en estas periferias es donde se desarrollan las acciones insurgentes con mayor frecuencia y fuerza. Igualmente al analizar el conflicto armado de larga duración en el país, es importante tener en cuenta los factores de incidencia e incluso de surgimiento de grupos armados ilegales en Colombia, es posible analizarlos por dos vías, la primera de ellas ligada con aquellas condiciones que en el ámbito interno favorecen la conformación de guerrillas y autodefensas, allí se encuentran: a) La escasez de reformas, ya que en el país sólo hasta 1991 se hace una gran reforma de la constitución política y por ende de varias dimensiones de manejo y administración del 
Estado, escudriñando la historia otro intento de reforma fue el de distribución de la propiedad de la tierra que tergiversó sus fines dando ejemplo de fracasos reformistas en el país, debidos principalmente a las coaliciones entre partidos tradicionales y que en este caso particular estaban vinculados con la perspectiva más conservadora. b) La vigencia de un modelo económico, social y político excluyente que adquiere mayor fuerza luego de la segunda guerra mundial, cuyo efecto es una sociedad con grandes disparidades sociales y una creciente inequidad y pobreza, como se mencionó en este capítulo aproximadamente el $60 \%$ de los trabajadores del país están en el sector informal de la economía sin posibilidad alguna de gozar de beneficios otorgados por la legislación laboral. c) El problema agrario, aspecto en el que se vislumbra una tradición histórica de concentración de la propiedad rural. En este punto también se menciona el "factor subjetivo fundamental" que según Zuluaga (2008) hace referencia a que determinado número de personas por concepciones políticas o ideológicas, deciden crear guerrillas ya que consideran que no pueden cambiar las estructuras del país por vías pacíficas, debido a ello toman el camino de las armas.

Por otro lado, existen unos factores externos que desde el plano internacional tienen incidencia en el surgimiento de grupos armados en Colombia, dichas condiciones están ligadas con hechos y circunstancias puntuales con alto nivel de incidencia no sólo para que en el país se conformaran estos grupos sino para que en Latinoamérica en diversas partes también se optara por la vía armada. Entre ellos encontramos: a) Las conmociones políticas, sociales y culturales que se enmarcan en la guerra fría, sumado a las confrontaciones entre el mundo occidental, democrático y cristiano y el oriental influido por el socialismo. b) Procesos de liberación de las colonias tradicionales de Asia y África, circulando con ello el imaginario de que las guerras de liberación son el camino para la construcción de naciones independientes. c) El triunfo del movimiento 26 de julio en Cuba y con ello el surgimiento de la Revolución Cubana.

Como se observa tanto en situaciones del contexto interno como externo tienen un grado de influencia alto para el surgimiento de grupos armados, estas circunstancias interactúan dialécticamente para definir un contexto determinado y determinante en el país, por lo tanto, la política pública social debe partir de considerar la importancia de fomentar espacios que propicien condiciones para el reconocimiento, la redistribución y la representación de los diferentes colectivos de población. Aspecto que debe materializarse en acciones estatales que aunadas a la participación social como mecanismo central promuevan condiciones para la equidad y la convivencia, así se encuentra que la gestión del territorio debe gestarse desde una perspectiva democrática y competente que suponga la promoción de procesos de inclusión, equidad social y transparencia en la gestión de políticas y en la toma de decisiones.

Otro de los contextos analizado en este estudio fue el boliviano, que resulta una experiencia significativa en términos de la descolonización y avance hacia la construcción de modelos económicos socialistas. El modelo boliviano, es concebido desde otras latitudes como significativo en tanto logra a partir de luchas sociales, hacer el tránsito - por lo menos en el papel- de una república a un Estado Plurinacional en el 
que se abre paso a la descentralización, la interculturalidad, el sentido comunitario y en el que al mismo tiempo se amplía la democracia reconociendo en la Carta Magna la existencia de grupos sociales que socio históricamente habían sido excluidos, como lo fueron en este contexto los pueblos indígenas y originario campesinos. El advenimiento del Estado Plurinacional encuentra sus raíces en aspectos de orden socio-histórico que paulatinamente aunaron esfuerzos en torno a este cometido. Por ello se hace alusión a varios aspectos que resultan ser el fundamento del este tránsito paradigmático del modelo de desarrollo, así como de gobierno en dicho escenario, destacando elementos clave para las experiencias Latinoamericanas.

Según el último informe de desarrollo humano del PNUD 2015, Bolivia evidencia múltiples cambios en su configuración territorial, que dan muestras de su constitución como una realidad cambiante, cuyo rostro está signado fuertemente por las dinámicas de metropolización de las que es protagonista en los últimos años. En 2016 se habla sobre la configuración de una nueva agenda del desarrollo en el país en la que se habla de la potenciación de las condiciones de vida que se ubican particularmente en las zonas metropolitanas del territorio nacional. Se hace un énfasis en destacar los cambios ocurridos en las áreas urbanas, con el objetivo de hacer aportes en cuanto a la reflexión del desarrollo en el país; en el marco analítico que propone el informe se destacan áreas temáticas de particular relevancia en estos escenarios, entre ellas se destacan: la situación y calidad del empleo, la provisión de servicios básicos, las condiciones de entornos urbanos y las condiciones de seguridad ciudadana.

En el informe del PNUD se destaca la sinergia que establecen los aspectos vinculados al desarrollo urbano como el crecimiento económico, y el cómo estos están directamente relacionados con el desarrollo humano, en el que según se afirma en este importante documento a mayor urbanización, mayor desarrollo humano, suponiendo que es en este contexto en el que primaría la disponibilidad a servicios básicos, aunque éstos no estén accesibles para toda la población.

A la par de lo anterior, la región metropolitana de Cochabamba ha tenido un histórico crecimiento poblacional desde la década del noventa. En 1992 el centro de Cochabamba contaba con 414.307 habitantes mientras que para el año 2012, se encuentra que la población asciende a 632.013 habitantes. Entre tanto, el municipio de Sacaba toma importancia al constituirse en un reflejo casi perfecto de las características generales de la metrópoli en términos de cambio de uso de suelo, población, vivienda, servicios básicos e instancias de planificación espacial. Y, por tanto, un espacio clave de análisis de estrategias alternativas para configurar procesos que interpelen la lógica masiva de urbanización desordenada y descontrolada. De esta manera, se considera que sí se proyectan e implementan procesos exitosos en este municipio, posteriormente puedan ser replicados en el resto de los municipios que conforman la metrópoli de Cochabamba, al considerar el contexto coyuntural rico y completo en el que se encuentra. 
En el contexto municipal de Sacaba se observa una tendencia de la población a abandonar las áreas rurales para incorporarse a la vida de las grandes ciudades. Este fenómeno se conoce con el nombre de éxodo rural. Las características de la vida moderna producen cada vez con mayor velocidad el crecimiento de las poblaciones urbanas. Su expansión llega a superar los límites de las mismas, anexando a los centros urbanos áreas que tenían características rurales y transformándolas; aunado a ello los costos de la urbanización por los que las personas generalmente se preocupan incluyen un incremento en el desabastecimiento de servicios básicos, crimen, mayor contaminación, congestión vehicular, pérdida de lazos familiares, pérdida de las prácticas culturales tradicionales y los valores, entre otros.

Una de las principales problemáticas que se encuentra tanto en el Departamento de Cochabamba como en el municipio de Sacaba y que últimamente hace parte del panorama analítico del contexto boliviano es el tema de carencia de agua tanto para consumo humano como para riego, con ello se ven amenazadas las lógicas de supervivencia de los habitantes, así como la seguridad alimentaria. Son pocos los niveles de precipitación al año, particularmente en los últimos años se han reducido las lluvias y con ello se han empeorado los escenarios de sequía y con ello se ha generado el debilitamiento de los terrenos y se han desincentivado las prácticas de agricultura, contribuyendo a la transformación del suelo rural en urbano.

La fuente de abastecimiento de agua con la que cuenta la población del municipio de Sacaba se reparte entre cañería de red, y fuentes alternativas de abastecimiento con distinta relevancia. Entre estas la pileta pública tiene primordial importancia al igual que el carro repartidor o aguatero. Ambos no cuentan con procesos de tratamiento del agua, además su disponibilidad y precios son fluctuantes. El caso de los pozos es en su mayoría auto gestionados por las OTBs de periferia y/o rurales, bajo poco y ningún criterio técnico.

En el marco de funcionamiento del SISPLAN, los municipios bolivianos formulaban los Planes Municipales de Ordenamiento Territorial o PMOTs. El último PMOT del municipio de Sacaba fue en el año 2014, tenía como objetivo lograr en el Municipio suficiente cobertura de servicios sociales y básicos, a la par que generar procesos de desarrollo económico y social, mediante el uso sostenible de los recursos naturales.

En esta perspectiva el municipio tenía como visión la de "ser un territorio integrado e interdependiente de la Zona Metropolitana de Cochabamba e internamente estar óptimamente vinculado, funcionalmente organizado y articulado en sus ámbitos urbano y rural, que aproveche y gestione equitativa y sustentablemente su patrimonio ambiental (material e inmaterial) como factor clave para el desarrollo social - comunitario, generando oportunidades para la población" (PMOT, 2014; 35)

En 2016 con el advenimiento de la Ley 777 de enero de 2016, se establece el Sistema de Planificación Integral del Estado (SPIE), que conducirá el proceso de planificación del desarrollo integral del Estado Plurinacional de Bolivia, en el marco del Vivir Bien. 
Dicho sistema es el conjunto organizado y articulado de normas, subsistemas, procesos, metodologías, mecanismos y procedimientos para la planificación integral de largo, mediano y corto plazo del Estado Plurinacional, que permitirá alcanzar los objetivos del Vivir Bien a través del desarrollo integral en armonía y equilibrio con la Madre Tierra, para la construcción de una sociedad justa, equitativa y solidaria, con la participación de todos los niveles gubernativos del Estado.

El nuevo Sistema de Planificación SPIE conmina a los gobiernos departamentales, municipales a elaborar los Planes Territoriales de Desarrollo Integral PTDIs, que deberán contener los elementos de desarrollo humano e integral, de economía plural, y de ordenamiento territorial, con un enfoque de gestión de sistemas de vida, gestión de riesgos y cambio climático, consolidando de forma gradual la articulación de la planificación del desarrollo integral con el ordenamiento territorial, en concordancia con el nivel central del Estado. Tanto el nuevo sistema como la elaboración de los nuevos planes, transforma el escenario de planificación de las entidades territoriales en Bolivia, lo cual se considera puede representar una oportunidad importante para insertar cambios en las lógicas tradicionales y positivistas de llevar a cabo la planificación, con miras a transitar hacia lógicas más democráticas y de construcción colectiva, que podrían verse enriquecidas y cualificadas con propuestas metodológicas como la estructurada en este estudio. 


\section{CAPÍTULO 4. ASPECTOS METODOLÓGICOS}

La puesta en marcha de un proceso de investigación social apunta a interrogar las nociones, sentidos, significados y caminos recorridos con anterioridad sobre un temaproblema determinado, representa un acercamiento a las construcciones conceptuales, metodológicas y hasta éticas alrededor de un tema específico. Son varios los caminos posibles para adentrarse en el mundo investigativo, las diversas perspectivas de indagación tanto cualitativas como cuantitativas de forma complementaria, ofrecen multiplicidad de alternativas en cuanto a métodos y técnicas, fomentando los procesos de triangulación (o utilización de varios métodos) con el fin último de enriquecer el estudio llevado a cabo, aprovechando al máximo la información que existe sobre el tema.

Por lo anterior, este capítulo versará sobre la exposición de los métodos y técnicas que, enmarcadas en los dos enfoques para la investigación, permitieron desarrollar el estudio presentado. Los métodos y técnicas empleados dan cuenta de la pluralidad de discursos y prácticas construidas sobre el tema de la Gestepaz, que como se ha mencionado constituye una práctica social que en el cotidiano evidencia el proceso mediante el cual los individuos decantan en la interacción social, lógicas que fortalecen las relaciones y los vínculos de convivencia, paz y sobre todo incidencia política en la cuestión pública.

El abordaje cuantitativo permitió contar con una base de "datos duros" que muestra la objetividad de las prácticas de participación ciudadana en el ámbito municipal tanto de 
Bogotá como de Sacaba, se toman estos datos como línea base de interpretación de estas realidades sociales que fueron complementados con la aplicación de técnicas de carácter cualitativo que buscaron dotar de sentido al "dato", abriendo caminos de comprensión de las dinámicas sociales, políticas, simbólicas, de lazo social e interacción que caracterizan la territorialidad de lo público y las políticas públicas.

A través de esta triangulación de información, se buscó rescatar la voz de actores sociales clave en los procesos sociales vinculados; se otorga la palabra a aquellas y aquellos que como agentes en el escenario, en su cotidianidad construyen y deconstruyen nociones y pautas metodológicas de trabajo territorial en el nivel local, a través de la interacción permanente y el establecimiento de lazos sociales de apoyo, colaboración y solidaridad en búsqueda de un desarrollo integral que trasciende las fronteras económicas y sociales posicionando a los individuos como sujetos activos.

\subsection{Disertación sobre paradigmas del conocimiento}

La investigación cuenta con unos fundamentos epistemológicos cuyo objetivo parte de la importancia de ver las realidades humanas como su objeto de trabajo, en este sentido, su quehacer gira en torno a objetos de conocimiento y transformación de la realidad humana, para lo cual establece enfoques y modalidades de acercamiento a los fenómenos. Dentro de estas modalidades encontramos dos que han sido ampliamente estudiadas y debatidas en la comunidad académica, a saber: la cuantitativa y la cualitativa. Si bien existen elaboraciones que dan cuenta de cómo la dinamicidad del contexto social, exige el posicionamiento de enfoques más sociales y con capacidad para profundizar lo simbólico del mundo social, es cierto que lo objetivo del dato duro y lo subjetivo de la interpretación y comprensión de la realidad son partes de un todo articulado que dota de sentido y significado a los discursos y prácticas sociales en cualquier contexto.

La distinción dicotómica entre ciencias naturales y ciencias sociales dejó de tener sentido y utilidad. Esta distinción descansa en una concepción de la materia y de la naturaleza, a la que contrapone con presupuesta evidencia, los conceptos de ser humano, cultura y sociedad (...) la superación de la dicotomía ciencias naturales/ciencias sociales, tiende así a revalorizar los estudios humanísticos. (Boaventura de Sousa, 2009: P. 48).

Interesa indagar lo particular desde una mirada interna en su escenario de inscripción, así, la articulación entre estos dos enfoques permitirá tener una información mucho más sólida sobre el tema en cuestión. De manera que desde allí se plantean las estrategias metodológicas que caracterizan y definen las formas, rutas y los medios de producción de conocimiento sobre uno o varios hechos sociales.

Sin embargo, como parte del ejercicio reflexivo que busca desentrañar los elementos de orden epistemológico e histórico que dan cuenta de la emergencia e importancia de lo subjetivo, a continuación se realiza un recorrido por los aspectos base de 
fundamentación de este tránsito epistémico que logra ampliar la mirada investigativa de las realidades.

A partir de lo que pareciese ser la declinación del método científico, determinada por la importancia de "una nueva manera de mirar las cosas, de una nueva racionalidad científica, y en síntesis, de una nueva ciencia" (Martínez, 2007, p. 36); hablamos de la emergencia de un nuevo paradigma, ya que las ideas y verdades únicas planteadas por el positivismo y el método científico; excluyen de la matriz epistémica, nociones como la de contexto, la verdad pluralista, la integración dialéctica de formas de leer la realidad social, las subjetividades entre otros aspectos.

Este nuevo entramado de pensamiento y de modos de percibir y valorar las realidades, da cuenta de la inscripción de otros aspectos, que en definitiva son parte constituyente del trasegar por la definición de un sujeto de investigación, que a su vez es problema y tema, que nos interroga por formas particulares de constitución del conocimiento en un espacio y tiempo específicos. Hasta este punto, es claro entonces que "no están en crisis los paradigmas de las ciencias, sino el paradigma de la ciencia en cuanto modo de conocer" (Martínez, 2007, p. 38).

Se mencionaba que la naturaleza de la realidad dentro del enfoque positivista era objetiva, estática y que no se otorgaba valor a la relación que se pudiera establecer entre aquello que se investiga y la persona que efectúa el estudio. Desde la década de los noventa cuando en la escena social se inscribe la subjetividad como factor determinante de varias lógicas de pensamiento y como un elemento importante de los procesos de investigación social, se encuentra que los contextos de investigación demandan de una lectura holística de las realidades sociales, acudiendo a observaciones que utilicen modelos intensivos, profundos y comprensivos de las dinámicas sociales, culturales, políticas y económicas enraizadas en el espacio de investigación. Por ello, la concepción del conocimiento de una manera constructivista y dialógica es indispensable, dentro de una lógica inductiva y particular, que rescate la heterogeneidad inherente a los contextos sociales, los actores involucrados y las relaciones que se establecen entre los núcleos temáticos del proceso de investigación.

Como parte de la definición y planteamiento de un tema-problema de investigación, nos situamos frente a formas específicas de lectura de las realidades sociales, en tanto perspectivas diferentes. Partimos pues, de la comprensión y valoración de estas miradas sobre la base de la indagación que supone el ejercicio del conocer y de responder los interrogantes que materializan nuestros objetivos dentro del proceso investigativo. Desde esta perspectiva, nos adentramos en un mundo con múltiples visiones y cosmovisiones que implica que como agentes del proceso, definamos maneras para aproximarnos al conocimiento.

Se pretende dar cuenta de las diferentes vertientes de construcción social que permiten estructura una verdad plural, concepto que valora y toma en consideración las diferentes 
posturas que existen con respecto a un hecho, o a una parte de la realidad social; aunque mejor como se ha venido denominando a lo largo de este texto las realidades sociales; partiendo de considerar que no existe "la realidad", sino que esas diferentes formas de comprensión, desde distintos modos de conocimiento, de entendimiento y de interpretación, hacen parte de rutas para conocer y comprender. Rutas que están ligadas con una historia de vida particular, con unos sentidos y significados transversalizados por valores, creencias y hasta costumbres en el entramado cultural y social que nos construye como personas.

En definitiva, la producción de conocimiento se concibe como:

Una creación compartida a partir de la interacción entre el investigador y el investigado, en la cual, los valores median o influyen la generación del conocimiento; lo que hace necesario "meterse en la realidad", objeto de análisis, para poder comprenderla tanto en su lógica interna como en su especificidad. La subjetividad y la intersubjetividad se conciben, entonces, como los medios e instrumentos por excelencia para conocer las realidades humanas y no como un obstáculo para el desarrollo del conocimiento como lo asumen (...) el positivismo y el pospositivismo. (Sandoval, 1996, P. 29)

En este sentido, dentro de este proceso de investigación se encontraron diferentes puntos de análisis del mismo hecho social, situación que en lo concreto permitió reconocer la interacción permanente entre las categorías de investigación planteadas y las emergentes.

Si bien es cierto que la perspectiva cualitativa es el enfoque que orientó esta investigación, es importante mencionar que sus planteamientos y criterios metodológicos no entran en contradicción total con postulados o aportaciones que brindan los datos cuantitativos, que para efectos de este proceso actuaron como elementos contextualizadores fundamentales para mostrar la importancia y relevancia del proceso investigativo.

La investigación cualitativa trata de identificar, básicamente la naturaleza profunda de las realidades, su estructura dinámica, aquella que da razón plena de su comportamiento y manifestaciones. De aquí que lo cualitativo (que es el todo integrado) no se opone de ninguna forma a lo cuantitativo (que es solamente un aspecto), sino que lo implica e integra, especialmente donde es importante. (Martínez, 2006, p. 66).

Los datos de orden cuantitativo en esta investigación presentan información estadística que es relevante para establecer la magnitud de los problemas sociales en Bogotá y en Sacaba; también se utilizan para dar cuenta del estado del conocimiento sobre el tema Gestepaz. Resulta ser una conexión interesante, que forma parte de un esfuerzo conjunto por construir conocimiento desde lo cualitativo con aportes significativos de la metodología cuantitativa.

Ahora bien, teniendo en cuenta la importancia de la participación de los actores sociales en la investigación considero fundamental brindar especial atención a quienes en su 
práctica cotidiana construyen discursos y prácticas para fortalecer lo público desde la ciudadanía, a través de estas iniciativas, se visibiliza el potencial comunitario para fomentar escenarios de progresiva incidencia en la gestión y administración pública por parte de los ciudadanos, se evidencia cómo las comunidades continúan resistiendo a la violencia y reivindicando sus derechos.

Teniendo en cuenta lo anterior, se mostrarán las categorías u ordenadores epistemológicos, así como el enfoque metodológico que orientó la puesta en marcha de esta investigación.

\subsection{Unidades de análisis y ordenadores epistemológicos}

A partir del análisis sobre el tema en cuestión, se lograron establecer ámbitos temáticos generales y específicos que demandaron ser estudiados en esta investigación. Entendiendo la importancia de la definición de categorías que coadyuvaran a desentrañar la información obtenida y hacer lecturas transversales y horizontales para ampliar la perspectiva de profundización sobre los ejes temáticos involucrados en el proceso, a continuación se presenta la Tabla 14 que contiene los ejes temáticos que fueron abordados a lo largo de este estudio, partiendo de considerar las categoría como “...ordenadores epistemológicos, campos de agrupación temática, supuestos implícitos en el problema y recursos analíticos. Como unidades significativas dan sentido a los datos y permiten compararlos y relacionarlos". (Galeano, 2004, p. 38)

\subsection{Consideraciones metodológicas y técnicas de recolección de información}

Hablar de los referentes epistemológicos que sustentan la definición de los conceptos relacionados, las fuentes, los criterios, los tipos de conocimiento posible y el grado con el que cada uno de estos asuntos resulta articulado, es preguntarnos también por la relación que existe entre el sujeto que conoce y el objeto conocido. De esta manera, entrar como investigadora a plantear conexiones teóricas entre la forma, las estrategias, enfoques y técnicas a utilizar en el camino investigativo, implicó indagar también por la deconstrucción del saber y de las teorías del conocimiento, que a partir de premisas determinadas y determinantes, dan cuenta de la aparición y desarrollo de los métodos cualitativos para la investigación social. Es desde allí desde donde se parte para llevar a cabo la investigación.

Como parte de la definición, planteamiento y puesta en marcha de un tema-problema de investigación, quien indaga se sitúa frente a formas específicas de lectura de las realidades sociales, en tanto perspectivas diferentes. Desde esta postura, el adentrarse en este mundo, con múltiples visiones y cosmovisiones, implica que como agente del proceso, defina maneras para aproximarse al conocimiento, teniendo en cuenta que:

Un conocimiento de algo, sin referencia y ubicación en un estatuto epistemológico que le dé sentido y proyección, queda huérfano y resulta ininteligible; es decir, que ni siquiera sería conocimiento. En efecto, conocer es siempre aprehender un dato en una cierta 
función, bajo una cierta relación, en tanto significa algo dentro de una determinada estructura. Pero, a su vez, el método para alcanzar ese conocimiento también estará siempre ligado a un paradigma específico, que le fija los rieles por los cuales ha de caminar, y atado a una función ideológica que le determina las metas y a la cual sirve (Galeano, 2004, p. 38)

Tabla 20. Categorías abordadas en la investigación.

\begin{tabular}{|c|c|c|c|}
\hline \multicolumn{4}{|c|}{ Operacionalización de variables. } \\
\hline Objetivo & Variable & Definición operacional & Ítems a trabajar \\
\hline \multirow{2}{*}{$\begin{array}{l}\text { General: } \\
\text { Evidenciar los } \\
\text { debates, realidades } \\
\text { y perspectivas de } \\
\text { procesos } \\
\text { evaluación de } \\
\text { política pública en } \\
\text { Bogotá (Colombia) } \\
\text { y Cochabamba } \\
\text { Sacaba (Bolivia), } \\
\text { con miras a la } \\
\text { estructuración de } \\
\text { un proyecto piloto } \\
\text { de control social } \\
\text { participativo para } \\
\text { el municipio de } \\
\text { Sacaba, } \\
\text { contribuya a la } \\
\text { construcción } \\
\text { fortalecimiento de } \\
\text { capacidades } \\
\text { ciudadanas para la } \\
\text { incidencia en la } \\
\text { política pública. }\end{array}$} & $\begin{array}{l}\text { Incidencia } \\
\text { ciudadana }\end{array}$ & $\begin{array}{l}\text { "Posibilidad de los ciudadanos de } \\
\text { participar en escenarios de discusión } \\
\text { sobre temas-problema de la gestión } \\
\text { pública, logrando que sus } \\
\text { perspectivas, opiniones, reflexiones, } \\
\text { propuestas se vean reflejadas en los } \\
\text { procesos de toma de decisión" }\end{array}$ & $\begin{array}{l}\text { Postura de ciudadanos reflejada } \\
\text { en toma de decisión } \\
\text { Tipologías de concepciones de } \\
\text { sujeto/ciudadano } \\
\text { Mecanismos de participación } \\
\text { ciudadana } \\
\text { En qué momento del ciclo se } \\
\text { incorpora el ciudadano }\end{array}$ \\
\hline & $\begin{array}{l}\text { Control social } \\
\text { participativo }\end{array}$ & $\begin{array}{l}\text { "Modalidad de participación } \\
\text { ciudadana. Buscará que los } \\
\text { derechos pasen de la potencia a } \\
\text { la acción, de la enunciación } \\
\text { constitucional y legal a la } \\
\text { política pública (...) el control } \\
\text { social es el catalizador de la } \\
\text { acción gubernativa que } \\
\text { garantiza la realización de una } \\
\text { sociedad equitativa, } \\
\text { democrática y participativa } \\
\text { (Beltrán, 2009. p. 23). }\end{array}$ & $\begin{array}{l}\text { Base social de soporte } \\
\text { Sistema indicadores de control } \\
\text { Metodología adecuada para } \\
\text { implementación }\end{array}$ \\
\hline \multirow{2}{*}{$\begin{array}{l}\text { Específico 1 } \\
\text { Analizar } \\
\text { críticamente } \\
\text { procesos } \\
\text { participativos } \\
\text { evaluación de } \\
\text { política pública en } \\
\text { Bogotá y } \\
\text { Cochabamba, en } \\
\text { partir de su aporte } \\
\text { al fortalecimiento } \\
\text { de capacidades de } \\
\text { agencia social sobre } \\
\text { lo público, en el } \\
\text { marco de la } \\
\text { ciudadanía y el } \\
\text { ejercicio pleno de } \\
\text { derechos. }\end{array}$} & $\begin{array}{c}\text { Procesos } \\
\text { participativos } \\
\text { evaluación PP }\end{array}$ & $\begin{array}{l}\text { Momentos de trabajo colectivo, } \\
\text { asociado y cooperativo entre actores } \\
\text { sociales para llevar a cabo la } \\
\text { valoración y análisis retrospectivo y } \\
\text { prospectivo de planes, programas y } \\
\text { proyectos de política pública. }\end{array}$ & $\begin{array}{l}\text { Dimensión social proceso } \\
\text { Dimensión política proceso }\end{array}$ \\
\hline & Agencia social & $\begin{array}{l}\text { Desde perspectivas sociológicas y } \\
\text { filosóficas, se ha dicho que la agencia } \\
\text { es la capacidad de un individuo de } \\
\text { actuar en el mundo. En este sentido, } \\
\text { se retoma para este estudio el } \\
\text { concepto de agencia social para hacer } \\
\text { referencia a la capacidad de un } \\
\text { individuo de tener incidencia en } \\
\text { procesos de toma de decisiones y en } \\
\text { procesos concernientes a las políticas } \\
\text { públicas. En este sentido, se reconoce } \\
\text { entonces la capacidad de los } \\
\text { individuos para actuar } \\
\text { independientemente y hacer sus } \\
\text { propias elecciones de modo libre. }\end{array}$ & $\begin{array}{l}\text { Información y conocimiento de } \\
\text { dinámicas gestión pública } \\
\text { Cualificación de las capacidades } \\
\text { ciudadanas }\end{array}$ \\
\hline
\end{tabular}


Tabla 21. Categorías abordadas en la investigación. (Continuación)

\begin{tabular}{|c|c|c|c|}
\hline \multicolumn{4}{|c|}{ Operacionalización de variables. } \\
\hline Objetivo & Variable & Definición operacional & Ítems a trabajar \\
\hline $\begin{array}{l}\text { Específico } 2 \\
\text { Realizar un estado } \\
\text { del conocimiento } \\
\text { sobre Gestión } \\
\text { Asociada del } \\
\text { Territorio para la } \\
\text { paz, con miras a la } \\
\text { construcción de una } \\
\text { base de datos como } \\
\text { introducción a la } \\
\text { investigación } \\
\text { cientimétrica }\end{array}$ & $\begin{array}{c}\text { Revisión } \\
\text { documental }\end{array}$ & $\begin{array}{l}\text { Inventariar y sistematizar la } \\
\text { producción en determinada área de } \\
\text { conocimiento. Pero también es una de } \\
\text { las modalidades cualitativas de } \\
\text { "investigación de la investigación" } \\
\text { que busca sistematizar los trabajos } \\
\text { realizados dentro de un área dada, se } \\
\text { realiza una revisión de fuentes y } \\
\text { documentos, para cumplir con un } \\
\text { nivel descriptivo (Gómez, 2015, p. } \\
\text { 32) }\end{array}$ & $\begin{array}{l}\text { Producción bibliográfica por país } \\
\text { Producción bibliográfica por } \\
\text { institución } \\
\text { Producción bibliográfica por } \\
\text { temas }\end{array}$ \\
\hline $\begin{array}{lr}\begin{array}{l}\text { Específico 3 } \\
\text { Caracterizar }\end{array} \\
\text { evaluación la } \\
\text { política de } \\
\text { como pública } \\
\text { representativa de la } \\
\text { gestión } & \text { del } \\
\text { territorio para } & \text { la } \\
\text { paz en } & \text { los } \\
\text { escenarios } & \text { de } \\
\text { investigación. }\end{array}$ & $\begin{array}{c}\text { Evaluación } \\
\text { políticas públicas }\end{array}$ & $\begin{array}{l}\text { "Análisis sistemático de la operación } \\
\text { o efectos de una política o programa } \\
\text { comparándolo con estándares o como } \\
\text { medio para mejorar la gestión } \\
\text { pública. Resulta ser un proceso } \\
\text { poderoso para la toma de decisiones, } \\
\text { el ajuste o mejoramiento de una } \\
\text { política y el proceso de planificación } \\
\text { futura, se convierte en mecanismo de } \\
\text { rendición de cuentas para la opinión } \\
\text { pública, promoviendo su incidencia } \\
\text { en lo público. }\end{array}$ & $\begin{array}{l}\text { Conocimiento procesos } \\
\text { evaluación } \\
\text { Quienes evalúan tradicionalmente } \\
\text { Cómo se evalúa la política } \\
\text { pública (percepción, indicadores } \\
\text { etc) } \\
\text { Alternativas ciudadanas para } \\
\text { evaluar }\end{array}$ \\
\hline $\begin{array}{l}\text { Específico } 4 \\
\text { Describir y analizar } \\
\text { los escenarios, } \\
\text { actores e intereses } \\
\text { vinculados a los } \\
\text { procesos de } \\
\text { evaluación } \\
\text { participativa de } \\
\text { política pública. }\end{array}$ & $\begin{array}{c}\text { Escenarios, } \\
\text { actores, intereses } \\
\text { de la evaluación } \\
\text { de PP }\end{array}$ & $\begin{array}{l}\text { Elementos que convergen a partir de } \\
\text { la evaluación de políticas públicas } \\
\text { entendida como proceso, conformado } \\
\text { por momentos en los que a partir del } \\
\text { trabajo gestionado y cooperativo de } \\
\text { quienes se involucran se construye un } \\
\text { escenario de gestión-valoración } \\
\text { permanente y sistemático. }\end{array}$ & $\begin{array}{l}\text { Tendencias temáticas intereses } \\
\text { Tipología de actores } \\
\text { Escenarios desarrollo evaluación } \\
\text { PP. }\end{array}$ \\
\hline $\begin{array}{lr}\text { Específico 5. } \\
\text { Estructurar una } \\
\text { propuesta } \\
\text { sistema de } \\
\text { indicadores técnicos } \\
\text { para evaluación } \\
\text { participativa de } \\
\text { política pública en } \\
\text { Sacaba con miras a } \\
\text { contribuir a la } \\
\text { construcción de una } \\
\text { base de datos que } \\
\text { sirva de plataforma } \\
\text { para la toma de } \\
\text { decisiones, que sea } \\
\text { enriquecida con la } \\
\text { experiencia rar de } \\
\text { control social } \\
\text { desarrollada ran } \\
\text { Bogotá en 2013. } \\
\end{array}$ & $\begin{array}{l}\text { Sistema de } \\
\text { indicadores } \\
\text { técnicos para } \\
\text { evaluación } \\
\text { participativa }\end{array}$ & $\begin{array}{l}\text { Sistema de variables e indicadores } \\
\text { que posibilitaría el análisis y la } \\
\text { construcción colectiva de insumos } \\
\text { sistemáticos para la evaluación de las } \\
\text { políticas públicas y con ella de la } \\
\text { gestión pública en cualquier escala } \\
\text { territorial. Se organizan por áreas } \\
\text { temáticas o cuadrantes de trabajo en } \\
\text { los que se ve reflejada la complejidad } \\
\text { de la realidad social territorial en las } \\
\text { escalas social, económica, política, } \\
\text { cultural, medio ambiental entre otras. }\end{array}$ & $\begin{array}{l}\text { Base de datos indicadores } \\
\text { Ruta de implementación y } \\
\text { construcción de plataforma para } \\
\text { toma decisiones. }\end{array}$ \\
\hline
\end{tabular}

El enfoque en el que se enmarca esta investigación, guía las elaboraciones, procesos, técnicas y abordajes del estudio, se dilucida una verdad plural, concepto que valora y toma en consideración las diferentes posturas que existen con respecto a un hecho, o a 
una parte de la realidad social; aunque mejor como lo hemos venido llamando a lo largo de este texto las realidades sociales.

En este sentido, retomamos los planteamientos según los cuales "La investigación social apunta a la comprensión de la realidad-para mí realidades-, como resultado de un proceso histórico de construcción a partir de la lógica de los diversos actores sociales, con una mirada "desde dentro", y rescatando la singularidad y las particularidades propias de los procesos sociales (...) el enfoque cualitativo se entiende como un complejo de argumentos, visiones y lógicas de pensar y hacer, algunas de ellas con relaciones de conflicto, y no como competencias entre tradiciones; y como un conjunto de estrategias y técnicas que tienen ventajas y desventajas para objetos particulares en circunstancias específicas". (Beltrán, 2005, p. 25.)

Como Galeano (2004), el trabajar en la investigación desde este enfoque, implica reconocer la particularidad de los actores sociales implicados en el proceso; por ende, también implica tomar en cuenta el entramado de estrategias y técnicas, que nos permiten una amplia gama de posibilidades en tanto acercamiento y recavación de información para la investigación a desarrollar. Algunos autores le llaman al proceso de utilización de diversas técnicas que responden a la particularidad de los actores: triangulación, otros como Beltrán (2005) le denominan pluralismo metodológico. En esencia, los dos persiguen lo mismo, aportar a la comprensión de lógicas y al significado de los procesos sociales para las personas, que finalmente son quienes producen y viven las realidades socioculturales.

\subsection{Abordaje metodológico de las fuentes: acercamiento conceptual a las técnicas utilizadas en el proceso investigativo}

Esta investigación se apoyó en la revisión de documentos en su mayoría digitales localizados a través de bases de datos como Dialnet, Redalyc ,Bivipas (base de datos de documentos electrónicos del Programa de Iniciativas Universitarias para la Paz y la Convivencia -PIUPC- de la Universidad Nacional de Colombia) y otras redes académicas que permanentemente elaboran artículos, dossiers y "papers" sobre políticas y administración pública tales como CLACSO, FLACSO, CLAD, entre otras.

Se realizó la búsqueda de documentos académicos cuyos descriptores fueron las categorías de investigación y los sub ejes temáticos de las mismas. Se analizaron algunas investigaciones de Másteres y Postgrados sobre los temas en cuestión. También se realizó consulta de documentos en la Universidad Nacional de Colombia y el centro de documentación del Programa PRIAC.

Para el análisis riguroso de la información obtenida con cada técnica o práctica de investigación se diseñaron y emplearon diversos instrumentos de análisis e interpretación, teniendo en cuenta que: 
Análisis e interpretación constituyen un proceso, al que puede denominarse dialéctico, de articulación del discurso producido con el marco teórico. Es un ir y venir entre la materialidad del discurso y las conjeturas que proceden del marco teórico de referencias. En cuanto proceso, es más de la práctica concreta que del orden abstracto... (Callejo, 2001, p. 147)

Los procesos de análisis e interpretación de la información obtenida implican el establecimiento y la puesta en marcha de secuencias metodológicas, en las cuales convergen diferentes fases mentales de revisión, abstracción, comprensión, aprehensión, reflexión y elaboración. Pero también se encuentra que el análisis es inacabable e infinito debido a la multiplicidad de niveles que es posible hallar, asî como a las innumerables perspectivas desde las que se puede abordar la información. Morse (1994, p. 25) menciona cuatro procesos cognitivos que acompañan a los métodos de investigación: comprensión, sintetización, teorización y recontextualización (Ver Figura 38), procesos que resultan interdependientes en el análisis. El investigador está inmerso en una variedad de discursos en los cuáles se mueve constantemente, encontrando en este camino el carácter cíclico de la investigación y de los procesos de análisis e interpretación; está vía está cargada de insumos y herramientas que buscan hallar el sentido o la multiplicidad de sentidos de las prácticas y discursos involucrados en el hecho social investigado.

Es necesario en este contexto, tener en cuenta que los procesos de investigación persiguen los datos y la información explícita pero que también se encuentran de frente con un tipo de información que no es del todo así, representada en lo tácito de la técnicas de investigación, aquello que en las entrevistas, los grupos focales, la observación participante y la revisión documental no salta a la vista fácilmente, pero que aun así está presente. "Perseguimos, no el significado manifiesto o la continuidad, sino lo que no dice (porque es inconveniente o no decible) y lo que contradice lo que dice" (Ibáñez, 1985, p. 128). 


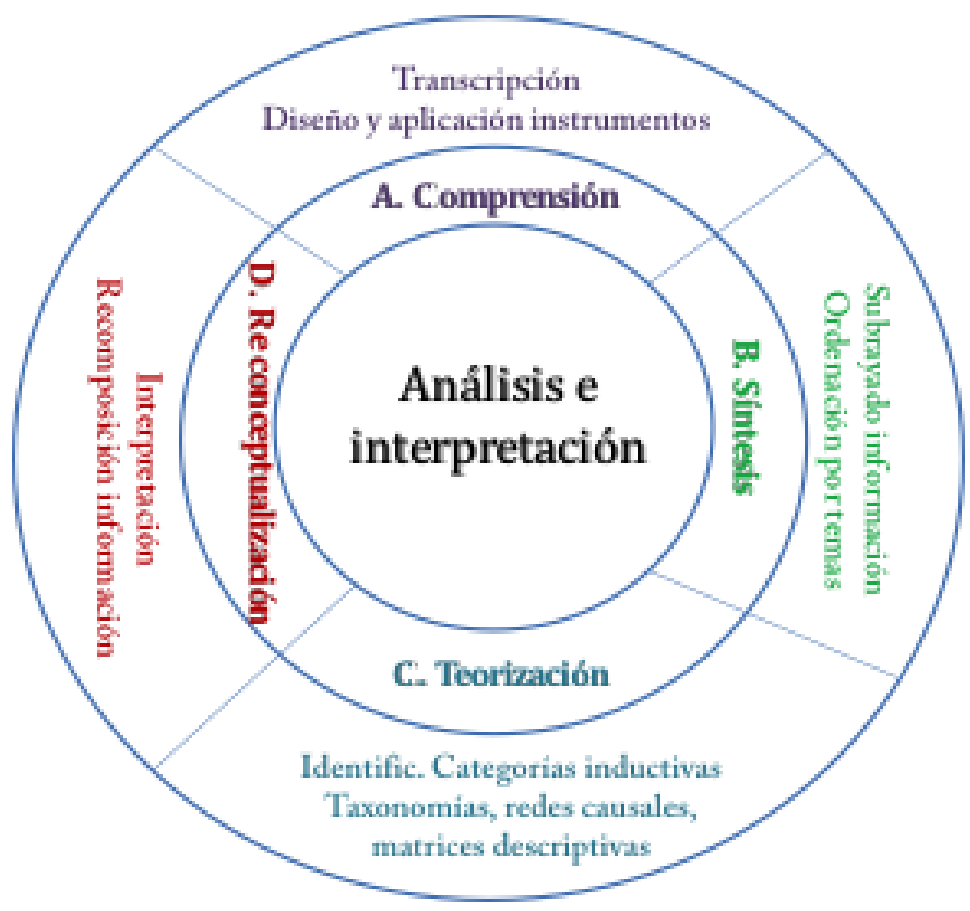

Fuente, Elaboración Propia, 2015.

Figura 38. Procesos cognitivos de los métodos cualitativos de investigación. Integra los aspectos propuestos por Morse $(1994 ; 25)$ con los propuestos por Bonilla (2000).

De manera que el proceso de análisis debe contemplarse de forma horizontal (lo que sigue a lo dicho por alguien más), pero también de forma vertical identificando aquello que se podría haber mencionado otorgando otro sentido a la información "Lo que está en el texto se confronta no sólo con lo que también está, sino también y sobre todo con lo que no está pero podría haber estado” (Ibáñez, 1985, p. 129). Dicho proceso horizontal-vertical puede realizarse de forma horizontal a partir de una lectura comparativa de los insumos que analizan determinada información (se incluyen varios insumos) y vertical como fruto del análisis de cada insumo en sí mismo, identificando su estructura discursiva, los componentes que lo integran, así como su sentido global y particular en relación con la temática tratada. Para dichas lecturas transversales las matrices de análisis, los mapas mentales, cuadros sinópticos, taxonomías de información, redes causales entre otros se convierten en herramientas importantes, ya que permiten visualizar de forma más clara la información susceptible de análisis. En este sentido, en esta investigación se construyen diversas matrices, cuadros, mapas, gráficos etc. cuyo objetivo es el anteriormente mencionado.

Los insumos de análisis de cada técnica o práctica investigativa en cada caso fueron construidos en razón de la información obtenida y de acuerdo a las demandas de cada técnica de investigación, siendo fiel siempre a mantener los datos como insumo de enriquecimiento fundamental para el proceso investigativo. Cada insumo en sí mismo es considerado indispensable por la información que contiene, bien sea la voz de las y los autores, o de quienes en su cotidianidad trabajan en iniciativas de reivindicación y lucha 
permanente por una transformación social que contrarreste la inequidad y desigualdad sociales, a saber las experiencias de organización social que se vinculan con el quehacer de lo público.

A partir de la definición epistemológica de esta investigación, las técnicas que permitieron la aproximación a la información necesaria para la puesta en marcha de la indagación fueron principalmente: la revisión documental, la elaboración de estados de la cuestión, los grupos focales, la observación participante y la entrevista semi estructurada como aportes cualitativos. Así mismo se construyen dos cuestionarios de encuesta que buscan medir indicadores vinculados con la participación ciudadana en el ámbito municipal de Sacaba y Bogotá.

\subsubsection{Revisión documental}

En relación con la técnica de revisión documental, para esta investigación, ésta se concibió como:

....una tarea siempre presente en la realización de estudios cualitativos. La expresión más característica de esta opción metodológica se encuentra en los trabajos basados en documentos recogidos en archivos (oficiales o privados); documentos de todo tipo, cuya elaboración y supervivencia (depósito) no ha estado presidida, necesariamente por objetivos de investigación social. (Valles, 2000, p. 109)

En este sentido, se revisaron documentos electrónicos teniendo en cuenta la creciente disponibilidad de información en Internet; se consultaron trabajos de grado del Máster en Estudios de Paz, Conflictos y Desarrollo de la Universitat Jaume I; así como libros que abordan temas vinculados directa o indirectamente con las categorías de investigación establecidas; se realizó un acercamiento en profundidad a textos colombianos que son fruto del trabajo de la Red de Iniciativas para la Gobernabilidad, la Democracia y el Desarrollo Territorial (RINDE) y publicaciones del Programa Interdisciplinario de Apoyo a la Comunidad (PRIAC) de la Universidad Nacional de Colombia. Se buscó igualmente contar con un panorama actual que evidenciara la discusión académica sobre políticas, gestión y administración pública por lo que se consultaron varios documentos de CLACSO, FLACSO y CLAD como aportes teóricos y reflexivos fundamentales para la decantación de los análisis vinculados con los objetivos general y específicos de la investigación.

El tema de la gestión del territorio para la paz tiene un desarrollo académico incipiente, la Red Rinde y el Programa PRIAC han venido aunando esfuerzos para visibilizar su importancia, sentido y significado en la escena social actual, se han propuesto contenidos académicos para la formación posgradual y diplomados sobre el tema en cuestión, con el fin último de ponerlo en la escena pública y construir conocimiento con los actores sociales involucrados en el mismo. De igual manera, otro de los temas que interesa destacar en este ejercicio reflexivo y que se caracteriza por posicionarse como 
discurso y práctica alternativa para transformar las lógicas tradicionales de la planificación social es la Gestión Asociada, este tema ha sido trabajado empírica y académicamente con mayor fuerza en Argentina y Brasil, algunas experiencias se han desarrollado en Bolivia y recientemente en Colombia.

Por ser éstos campos de reciente exploración, la consulta bibliográfica realizada para efectos de este trabajo, se realizó de forma general, no se estableció un periodo de tiempo determinado, sino que éste se dejó abierto, lo cual quiere decir que aparecieron textos de diferentes épocas y editados en distintos años, lo cual permite hacer un análisis sucinto de cómo han venido evolucionando con el tiempo estos temas de gran importancia para la gestión pública y territorial.

Con el objetivo que la lectura de los textos, fuera profunda y rigurosa se elaboró una ficha de resumen de textos (Ver Anexo 1), que se utilizó para la aproximación al estado de la cuestión sobre el tema, con el objetivo de recopilar la información requerida de forma rigurosa, teniendo en cuenta las categorías de investigación. La ficha diseñada facilitó la labor de "entrevista" a los documentos encontrados, en aras de indagar por las categorías, por los conceptos construidos y significados en la época de estudio, así como por las fuentes utilizadas para la construcción de conocimiento desde y para la Gestepaz, entre otros aspectos de enorme importancia para el proceso.

A todos estos textos en realidad se les puede entrevistar mediante preguntas implícitas y se les puede observar con la misma intensidad y emoción con la que se observa un rito nupcial, una pelea callejera, una manifestación popular. En este caso la lectura es una mezcla de entrevista/observación y puede desarrollarse como cualquiera de ellas. (Ruiz Olabuénaga e Ispizua, 1989, Citado en Valles, 2000, p. 120).

Desde esta perspectiva, es importante aclarar que la revisión documental tuvo dos vertientes, la primera de ellas referida a la consulta de aquella bibliografía construida sobre uno de los dos bloques gruesos de información, a saber: gestión del territorio o construcción de paz, con el fin de identificar elaboraciones propias en los ámbitos conceptual, metodológico y ético. Por otra parte, se consulta aquella bibliografía que permite: i) establecer un marco contextual general que visibilice la importancia de investigar estos temas en contextos sociales marcados aun por la permanencia de indicadores de desigualdad e inequidad social y ii) la de-construcción de categorías conceptuales y metodológicas asociadas con las políticas públicas, la gestión pública y la planificación como elementos que permiten establecer unos principios, valores, sentidos y significados específicos a partir de los que es posible evidenciar discursos y prácticas de fortalecimiento de capacidades para el control social y fortalecimiento de lo público, en contextos nacionales, regionales y locales; centrando especialmente la atención en este último.

Respecto a las oportunidades que ofrecieron tanto la revisión documental como la elaboración del estado de la cuestión, se dilucida la importancia del diálogo establecido 
con los autores y autoras de los documentos consultados. El acercamiento a tan valiosos acervos documentales permitió resignificar los conceptos y la evolución de los temas consultados, a la luz de identificar la importancia que adquieren estos en determinados momentos de la historia. El ejercicio de investigación a través del estado del conocimiento, también posibilitó el planteamiento de sub ejes de trabajo que permitieron la presentación y sistematización de los hallazgos analíticos de la investigación.

Como insumo fundamental para recabar información concreta sobre prácticas o experiencias de evaluación de política pública en los contextos de análisis, igualmente dentro del eje revisión documental se construyen fichas analíticas (i. Para recopilar información de caracterización de las experiencias de evaluación y ii. Para recoger los indicadores que algunas experiencias construyen como aportes para la medición de eficacia, eficiencia y efectividad de la gestión pública en los territorios).

\subsubsection{Entrevistas semi estructuradas}

Esta modalidad de entrevista hace referencia a los encuentros de carácter no excesivamente formal con las personas clave para la investigación. Comprende la elaboración de una guía de entrevista que no actúa como orientador inamovible sino como referente flexible de la conversación, buscando encauzar las disertaciones de la persona entrevistada hacia uno o varios ejes temáticos susceptibles de investigar y que están ligados con las categorías generales o específicas planteadas como hilos conductores del proceso.

\footnotetext{
(...) en la investigación naturalista, las entrevistas adoptan más la forma de un diálogo o una interacción (...) Permiten al investigador y al entrevistado moverse hacia atrás y hacia adelante en el tiempo (...) Las entrevistas pueden adoptar una variedad de formas, incluyendo una gama desde las que son muy enfocadas o predeterminadas a las que son abiertas (...) La más común es sin embargo, la entrevista semiestructurada, que es guiada por un conjunto de preguntas y cuestiones básicas a explorar, pero ni la redacción exacta, ni el orden de las preguntas está predeterminado (...) Este proceso abierto e informal de entrevista es similar y sin embargo diferente a una conversación informal. El investigador y el entrevistado dialogan de una forma que es una mezcla de conversación y preguntas insertadas". (Erlandson, Harris et. al, 1993, pp. 85-86. Citado en Valles, 2000, p. 38)
}

En la entrevista semiestructurada se destaca la postura otorgada al entrevistado, que se caracteriza por ser concebido como sujeto dentro de la investigación, es un agente con voz y voto ya que todos sus aportes son válidos para el estudio. La entrevista se convierte así en una relación de intercambio, donde la cooperación se sitúa como un enclave fundamental del proceso relacional entrevistador-entrevistado, que trabajan juntos para alcanzar el logro de la construcción de conocimiento y el entendimiento sobre un determinado hecho social. Se relacionan dialécticamente y se vislumbran como legítimos en participación e interacción. 
Entendiendo que el rol de los participantes es activo, se hace énfasis en destacar que en esta modalidad de entrevista, el entrevistador adopta una postura de escucha permanente, buscando encauzar la conversación haciendo las pausas y contextos necesarios para profundizar en análisis fundamentales, con el objetivo de captar el detalle y la relación que se establece entre los ámbitos en cuestión. Con esto se logra trascender de la conversación meramente cotidiana a una conversación profesional con técnicas y propósitos propios

... la entrevista de investigación difiere de las conversaciones cotidianas en dos rasgos principales a) la conciencia metodológica de los modos de interrogación e interacción b) la asimetría de poder (en contraste con los intercambios recíprocos de las conversaciones cotidianas (...) tiende a haber un interrogatorio unilateral del sujeto por parte del profesional. (Kvale, 1996, p. 20. Citado en Valles, 2000, p. 40)

Uno de los propósitos de esta técnica y que a su vez se convierte en una fuente de enriquecimiento investigativo, lo constituye la posibilidad de obtención de descripciones de los mundos vividos por los individuos entrevistados, se logran interpretaciones fieles al significado que tienen los aspectos ligados con las experiencias y sus relaciones temáticas, discursivas y prácticas con el objeto de investigación. Por otra parte, la flexibilidad inherente a esta técnica, fomenta aperturas al cambio de dirección de las preguntas o secuencias de entrevista, en consonancia con las articulaciones logradas y la situación actual del entrevistado.

\subsubsection{Grupos focales}

Son muchas y variadas las referencias que se encuentran sobre esta técnica de investigación, es posible hallar definiciones que la comparan con otras herramientas para recabar información mostrando sus similitudes, tal es el caso de la entrevista, donde se hace una alusión a la posibilidad que ofrece como instrumento y se le otorga el nombre de entrevista de grupo. Autores como Valles (2007) y Callejo (2001) hablan de la difícil tarea de definición de esta técnica de investigación por su naturaleza participativa y por los objetivos que persigue; mencionan que más que un instrumento los grupos focales pasan a ser una práctica. El hecho de decir grupo, implica un sentido amplio de membrecía y el reconocimiento de la misma por parte de quienes lo integran, pero sí se trata de reuniones esporádicas para tratar un tema puntual a través de la reflexión y discusión conjunta esta afirmación no alcanza a abarcar todas las dimensiones que expresan la amplitud del término mencionado que involucra la grupalidad. Para ilustrar dichos aspectos se retomarán algunas definiciones de diversos autores:

- en tanto forma de investigación cualitativa, los grupos focalizados son básicamente entrevistas de grupo, aunque no en el sentido de una alternancia entre las preguntas del entrevistador y las respuestas de los participantes de la investigación. En vez de ello hay una dependencia de la interacción entre el grupo, basada en los temas que proporciona el 
investigador, quien típicamente adopta el papel de moderador. Los datos fundamentales que producen los grupos focalizados son transcripciones de discusiones de grupo (Morgan, 1988, pp. 9-10)

- Puede ser definido como una conversación cuidadosamente planeada, diseñada para obtener información de un área definida de interés, en un ambiente permisivo, no directivo. Se lleva a cabo con aproximadamente siete a diez personas, guiadas por un moderador experto. La discusión es relajada, confortable y a menudo satisfactoria para los participantes ya que exponen sus ideas y comentarios en común. Los miembros del grupo se influyen mutuamente, puesto que responden a las ideas y comentarios que surgen en la discusión. (Krueger, 1991, p. 24)

- Por grupo focal, en sentido estricto, se entiende un grupo cuyo objetivo es llevar a cabo una confrontación de opiniones, de ideas o de sentimientos de los participantes, con vistas a llegar a unas conclusiones, a un acuerdo o a unas decisiones. (Mucchielli, 1969, p. 107).

Las anteriores definiciones tienen varios elementos común, entre ellos, se destaca la mención de la discusión, como un medio de conversación cuyo objetivo es analizar un determinado tema a través del diálogo entre varias personas, la existencia de alguien que modera pero que no sigue ningún camino directivo sino más bien orientador, la definición previa de unos temas eje que bien pueden ser preguntas, ideas o categorías, el encuentro entre personas que muy posiblemente no se conocen previamente. Por último, otro rasgo común en las definiciones está ligado con la importancia de establecer las características de los grupos focales (Ver Tabla 15).

Para efectos de este trabajo se entenderá el grupo focal como: una práctica investigativa que implica una interacción cara a cara entre, personas reunidas por un interés común a nivel temático. Dicho encuentro se da como parte de un objetivo compartido, de poner en circulación pública un conjunto de discursos ligados con el o los temas principales planteados. Se realiza en razón de una demanda de investigación en un espacio y tiempo determinados, organizados por quien o quienes lideran la investigación, pero teniendo en cuenta las disponibilidades y aspectos de accesibilidad para quienes asisten. Implica una labor de coconstrucción y de-construcción de saberes vinculados con discursos y prácticas subyacentes al o a los temas centrales planteados. 
Tabla 22. Caracterización de los grupos focales.

\begin{tabular}{|l|l|}
\hline \multicolumn{1}{|c|}{ Rasgos principales del grupo focal } & \multicolumn{1}{c|}{ Características subyacentes } \\
\hline Interrelación cara a cara & $\begin{array}{l}\text { El estar de varios individuos frente a frente. Se } \\
\text { destaca el interés por el tema a debatir. }\end{array}$ \\
\hline Situación pública & $\begin{array}{l}\text { Escenario para la circulación pública de } \\
\text { discursos. }\end{array}$ \\
\hline Encuentro & $\begin{array}{l}\text { Que se da entre personas que probablemente no } \\
\text { se conocen, se debe dar un proceso de } \\
\text { adaptación mutua. }\end{array}$ \\
\hline Demanda de investigación & $\begin{array}{l}\text { Existencia de un otro que hace investigación, los } \\
\text { participantes se preguntan el para qué y el por } \\
\text { qué de la investigación. Los participantes pueden } \\
\text { concebirse como objetos y tener resistencias } \\
\text { frente al proceso. }\end{array}$ \\
\hline Estímulos & $\begin{array}{l}\text { El grupo focal debe entenderse como una forma } \\
\text { de interrogación. Los estímulos pueden ser: } \\
\text { interés por el tema, gratificaciones por trabajo en } \\
\text { la reunión, entre otros. }\end{array}$ \\
\hline Moderador & $\begin{array}{l}\text { Establece la dinámica de la reunión. Subjetiviza } \\
\text { los estímulos, es representante de la demanda de } \\
\text { investigación. }\end{array}$ \\
\hline identidades & $\begin{array}{l}\text { Se realiza en espacios y tiempos particulares, no } \\
\text { son impuestos. Se buscan espacios y tiempos } \\
\text { neutrales. }\end{array}$ \\
\hline Fspacio y tiempo & $\begin{array}{l}\text { Puede ser un escenario de conflicto de intereses } \\
\text { e identidades, no siempre se llega al consenso. } \\
\text { Es un proceso de respuestas y confirmaciones. }\end{array}$ \\
\hline
\end{tabular}

Fuente: Elaboración propia con base en Valles (2007; pp, 65-76)

\subsubsection{Observación participante y diario de campo}

A diferencia de un ejercicio meramente pasivo en el que quien ejerce el rol de observador se mantiene al margen de las realidades susceptibles de ser estudiadas, la observación participante implica una inmersión del investigador en dichos contextos sociales, en tanto dentro de estos escenarios es desde donde se hace posible internalizar un rol activo haciendo que quien lo cumple tenga la posibilidad de indagar a profundidad por los discursos, prácticas y quehaceres en una realidad social.

El investigador en desarrollo de su papel activo interactúa de forma prolongada con las personas y/o comunidades sujeto de la investigación, haciendo parte de la cotidianidad para identificar las pautas culturales, relacionales, modalidades y estilos de vida, interacción con el territorio y aspectos vinculados con estos ámbitos para posteriormente incluirlos en las notas de campo como instrumento que apoya el proceso de observación. Así, tenemos que:

La observación participante implica un arte (... tener cualidades personales) y una técnica (saber hacerlo). Partimos de la necesidad de crear un clima entre el observador y el grupo que permita la comunicación espontánea y auténtica, la presencia y la 
participación en todas las facetas de la vida ordinaria y extraordinaria del grupo y desde este clima, recoger los datos. (Amezcua, 2009, p. 32)

La participación es entonces un ingrediente fundamental de este tipo de observación, la cual debe realizarse con un alto grado de rigurosidad buscando identificar los elementos que se quieren en relación con los objetivos y las categorías de investigación. También la integran aquellos aspectos más complejos como la comunicación no verbal, los sentimientos, las narrativas y la construcción particular del lenguaje en relación con la cultura. En definitiva, como exponen Hernández, Fernández y Baptista (1998) (Citados en Valles, 2000) la observación cualitativa conocida también como observación de campo tiene como propósitos los de: explorar ambientes, contextos y aspectos de la vida social, describir comunidades, escenarios, comprender procesos, interrelaciones entre personas y sus situaciones, identificar problemas y generar hipótesis para futuros estudios (p. 23)

Desde esta perspectiva, según Adler y Adler (1994) (Citados en Valles, 2000) se encuentra que la observación participante ocurre en el contexto cotidiano en el que participan los actores sociales (Ver Tabla 4), así que tiene la ventaja de incluir al observador en la complejidad fenomenológica del mundo, donde puede ser testigo de las conexiones, correlaciones y causas tal y como se desenvuelven. Los observadores no se encuentran atados a categorías determinadas, por el contrario son libres para buscar conceptos y categorías que tengan significado para los sujetos (p. 378). Es en este contexto en donde se encuentra que este tipo de observación en el marco de la investigación social cualitativa cuenta con un conjunto de características o rasgos particulares.

Tabla 23. Características del observador participante

\begin{tabular}{|l|l|}
\hline \multicolumn{1}{|c|}{ Observador participante. } \\
\hline 1. & $\begin{array}{l}\text { Propósito doble: implicarse en actividades concernientes a la situación social a estudio y } \\
\text { observar a fondo dicha situación. }\end{array}$ \\
\hline 2. & Atención incrementada, estado de mayor alerta \\
\hline 3. & $\begin{array}{l}\text { Observación de ángulo abierto, ampliada por el propósito añadido de estudiar los aspectos } \\
\text { culturales tácitos de una situación social. }\end{array}$ \\
\hline 4. & $\begin{array}{l}\text { Experiencia desde dentro y desde fuera de escena, desde la doble condición de miembro y } \\
\text { extraño }\end{array}$ \\
\hline 5. & $\begin{array}{l}\text { Introspección aplicada. Explotación de la introspección natural como instrumento de } \\
\text { investigación social y registro sistemático de actividades, observaciones, introspecciones }\end{array}$ \\
\hline
\end{tabular}
Fuente: Miguel Valles (2007; p.150). Basado en Spradley (1980; pp.54-58)

La labor de observación participante demanda del ejercicio riguroso y sistemático de registro de la información con el fin de aprovechar al máximo los datos que se han recogido en campo, ya que la voz de los sujetos del estudio tanto desde la perspectiva cualitativa como desde esta técnica de investigación, resulta indispensable para el proceso de análisis y ordenamiento epistemológico de los resultados. Las interacciones investigador-sujeto de la investigación también desencadenan nuevos aprendizajes, reflexiones y análisis particulares sobre las realidades que se están investigando y los 
procesos involucrados, en este sentido, las notas de campo juegan un rol importante, pues se convierten en la sistematización consciente y reflexiva de lo que se observa y de las interacciones resultantes de las relaciones que se establecen en los escenarios a investigar.

Por ello, como herramienta de la investigación las notas o diarios de campo son un instrumento de registro que permite la recolección sistemática de la información que se produce en la observación, cuya intencionalidad está ligada con el objetivo de captar los sentidos y significados de los escenarios y procesos de forma integral (Ver Figura 39). El pilar orientador para su realización son las categorías de investigación planteadas, como aspectos que posibilitan el hecho de identificar y desarrollar análisis retrospectivos sobre el sujeto y los fenómenos subyacentes al estudio.

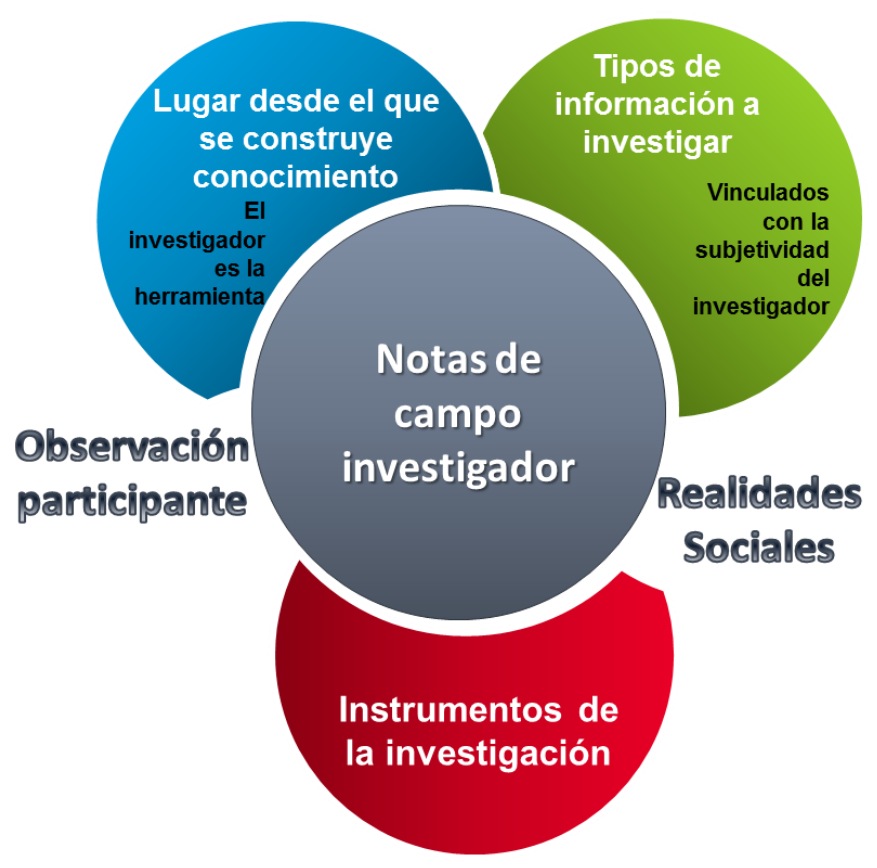

Elaboración propia, 2012.

Figura 39. Diario de campo: Aspectos vinculados.

La realización de diarios de campo ${ }^{16}$ implica varios aspectos que hacen de éste un ejercicio sistemático fundamental para registrar la observación participante en el marco de la investigación social cualitativa. Según Bertha Niño en su seminario sobre diarios de campo realizado en 2011 en primera instancia, se encuentra que el lugar desde donde se construye el conocimiento, es un lugar que interroga por la interioridad o subjetividad del investigador. El segundo hace referencia a los tipos de información a

\footnotetext{
${ }^{16}$ La información sobre diarios de campo y observación así como sus tipologías, son retomadas de documento de memorias realizado a partir de un taller sobre diarios de campo impartido por la docente Bertha J. Niño Martínez en la Universidad Nacional de Colombia en 2011 en el marco de las actividades del programa PRIAC. Se construye el documento como síntesis de sus planteamientos que son los que aparecen en este apartado de la tesis Máster.
} 
sistematizar, en donde se encuentran aspectos sociales, políticos y colectivos; finalmente se hace referencia a los instrumentos de la investigación, donde se habla del sujeto que investiga, como herramienta en sí mismo.

Es importante destacar que el conocimiento es construido a partir de observaciones sistemáticas y de contrastación entre diferentes fenómenos; en este sentido, encontramos tres registros de la observación: bajamente estructurada, estructurada y altamente estructurada (Ver Figura 40). La bajamente estructurada aparece ligada con información global sobre una situación o hecho social, incluye datos muy básicos del estudio a realizar; el campo de lo estructurado mantiene la tendencia hacia datos generales que permiten contextualizar situaciones o fenómenos sociales.

Cuando se construye información a través de la observación estructurada, se debe establecer el objeto/sujeto de la indagación, por ende, las categorías de investigación, que son los pilares sobre los cuales se desarrollan las descripciones, reflexiones y análisis consignados en el diario de campo.

El nivel altamente estructurado corresponde a observaciones profundas, que interrogan o llevan a la reflexión al sujeto investigador; en este registro se inscriben aspectos como la emocionalidad y subjetividad, aquello que llamamos la estructura interna (intereses, miedos y gustos). Este tipo de observación implica la vinculación del investigador como sujeto activo del conocimiento (el yo como instrumento), que es sensible frente a diferentes temas. Siempre se debe recordar que para el caso de las Trabajadoras y los Trabajadores Sociales debemos tener presente la tríada conocer-intervenir-transformar que es la razón de nuestro ser profesional.

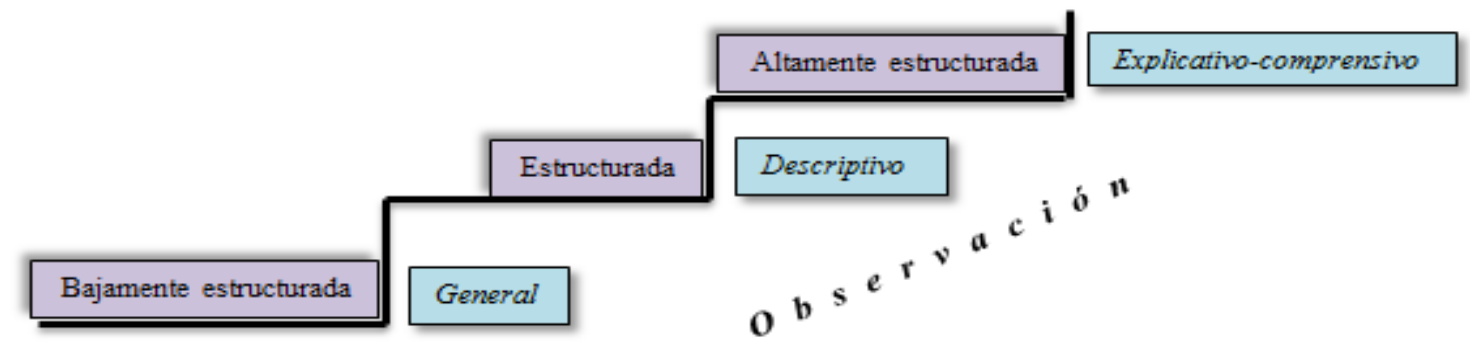

Fuente: Elaboración propia, 2012.

Figura 40. Niveles de observación

Las elaboraciones con un nivel bajo de estructuración están registradas en el diario técnico (Ver Tabla 17), cuya lógica de realización es descriptiva. En este diario no hay un objetivo claro de referencia, se encuentran escritos con percepciones generales que no están relacionadas ni explicadas claramente, la información es de carácter universal. También se puede ubicar un nivel de observación descriptiva e informativa en donde el interés es retratar los hechos o fenómenos, registrados y ordenados de forma 
sistemática; este ejercicio puede desembocar en la caracterización de los hechos, o la definición diagnóstica.

Tabla 24. Diario de campo técnico.

\begin{tabular}{|l|l|l|l|}
\hline ACTIVIDAD & METODOLOGIA & RECURSOS & RESPONSABLES \\
\hline & & & \\
\hline
\end{tabular}

Estructura de un diario técnico. Niño, 2011.

Las observaciones altamente estructuradas forman parte del diario intensivo cuya lógica es de verificación y de descubrimiento; en este sentido, el instrumento es el investigador. Esta elaboración de carácter etnográfico, implica dos tipos de información: aquella que proviene del sujeto investigado, conocida como némica y la constituida por la interpretación de los hechos hecha por el investigador llamada nética. La realización de este diario implica una mirada retrospectiva del investigador hacia sí mismo, se deben evitar juzgamientos sobre el fenómeno o sujeto de la indagación; los juicios de valor no están presentes, se propende por la posibilidad de esclarecimiento de sentimientos presentes en el estudio.

El diario intensivo tiene un carácter individual, implicando así un intento de calibración del sujeto investigador; se convierte en una posibilidad para referenciar procesos de confrontación, identidad, aprehensión, apegos entre otros, resultantes de sentimientos y valoraciones propias que salen a la luz en el momento de observar al otro y al sí mismo, en la construcción de interpretaciones de hechos sociales. Desde esta perspectiva, se intenta vincular procesos reflexivos y de conocimiento del sujeto que indaga.

La sistematización de información a partir de la comprensión y explicación siempre está presente en los diarios de campo, uno de los objetivos de este ejercicio de escritura y reflexión consiste en establecer las redes explicativas en las que se identifica el sentido y los valores presentes a través del descubrimiento y planteamiento de categorías.

En específico se encuentra que el diario intensivo, está orientado por lógicas de verificación y descubrimiento, en donde el investigador es el instrumento; desde esta perspectiva, es importante la reflexión sobre nuestro lugar y papel como profesionales, preguntándonos permanentemente ¿Cómo nos posicionamos en un momento determinado y ante una situación específica? Aparecen en este punto, diferentes hipótesis y preguntas ligadas con el hecho social investigado. Como profesionales en disciplinas de las Ciencias Humanas y Sociales, siempre somos observadores participantes.

En relación con los niveles de observación bajamente estructurada, estructurada y altamente estructurada encontramos también sus lógicas de caracterización que se 
refieren a criterios que permiten hablar de la función práctica de dicho tipo de observación, así encontramos:

- Bajamente estructurada: General: Corresponde a aquello que se ve, no tiene un nivel de análisis profundo.

- Estructurada: Descriptivo-informativo: Nivel de observación que se interesa por la reconstrucción de hechos y situaciones sociales.

- Altamente estructurada: Explicativo-comprensivo: Comprende las redes relacionales que determinan el problema a investigar, se interesa por el sentido y los valores presentes. En este nivel, se construye otro tipo de información que busca empoderar a los individuos y colectivos, de manera que se construyan subjetividades diferentes.

La posición de observadores (combinando los tres registros mencionados), nos permite entrenar la capacidad de sacar el o los sentimientos, analizarlos retrospectivamente, y dejarlos ir. En este sentido, el diario intensivo se trabaja a manera de bitácora, se realiza una reflexión del aquí y el ahora, pensando un poco en ¿Por qué estamos aquí y ahora? ¿Qué de la vida me trajo a donde estoy actualmente? Preguntas trabajadas a manera de reflexión biográfica (Ver Figura 41). La primera tarea del ejercicio de escritura en el diario de campo, corresponde precisamente al análisis retrospectivo sobre nosotras y nosotros mismos, a través de la autobiografía, debemos tener en cuenta la reflexión sobre ¿Por qué estamos estudiando y somos profesionales de las Ciencias Sociales y Humanas? ¿Qué nos permitió estar en el sitio en el que estamos ahora, bien sea estudiando o trabajando?

También se deben tener en cuenta los aspectos fundamentales en el ciclo vital de quien recoge los procesos de interpretación, este ejercicio se configura como pre-texto del investigador y de la investigación. Es algo que está definido antes de que el investigador se configure como tal, pre-existe al estudio. Como elementos de construcción identitaria, tendrán influencia en las formas, sentidos, significados, discursos y prácticas de quien investiga, de allí que sean importantes en dos sentidos: i) para ser analizados como texto anterior a la investigación y como insumo que tiene un nivel de incidencia en el devenir del estudio y ii) como aspectos subjetivos que de una u otra forma se visibilizan en el proceso de investigación y que deben trabajarse, como susceptibles de enriquecimiento a partir de un auto-análisis del investigador. 


\section{Diario Intensivo}
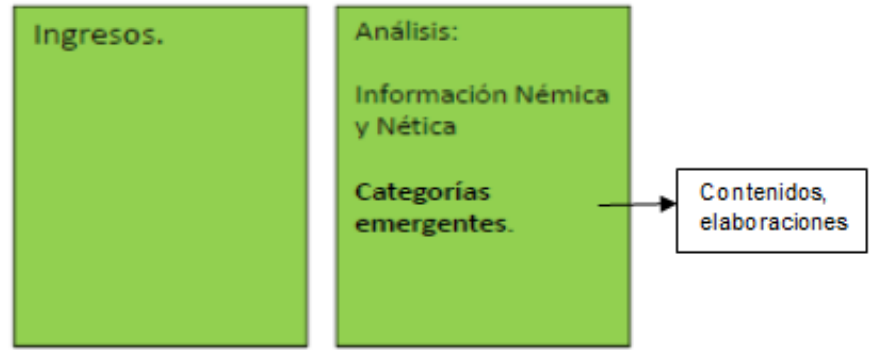

Información cualitativa (Arqueos y bitácoras)

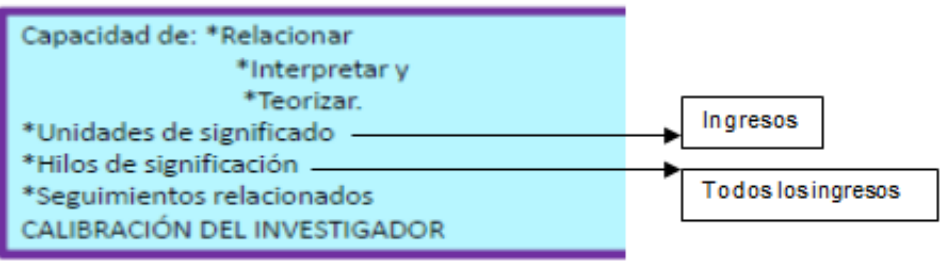

Registros y aspectos del diario intensivo. Niño, 2011

Figura 41. Lógicas de registro en el diario de campo intensivo.

El diario híbrido pretende recoger de manera sistemática dos tipos de información (instrumental y de contenido), permitiendo por un lado sistematizar el proceso investigativo en sus diferentes fases, actividades, recursos y cumplimiento de objetivos; construyendo una información confiable y pertinente del proceso adelantado (Ver Figura 42). Por otro, registrar la información de orden nético y némico obtenida a partir de las indagaciones de sentido sobre el sujeto de la investigación. Este segundo registro requiere de un trabajo reflexivo permanente y riguroso del investigador sobre el entorno y sobre sí mismo. Es fundamental reiterar, que el diario es una herramienta de sistematización de información que el investigador elabora como instrumento de la investigación

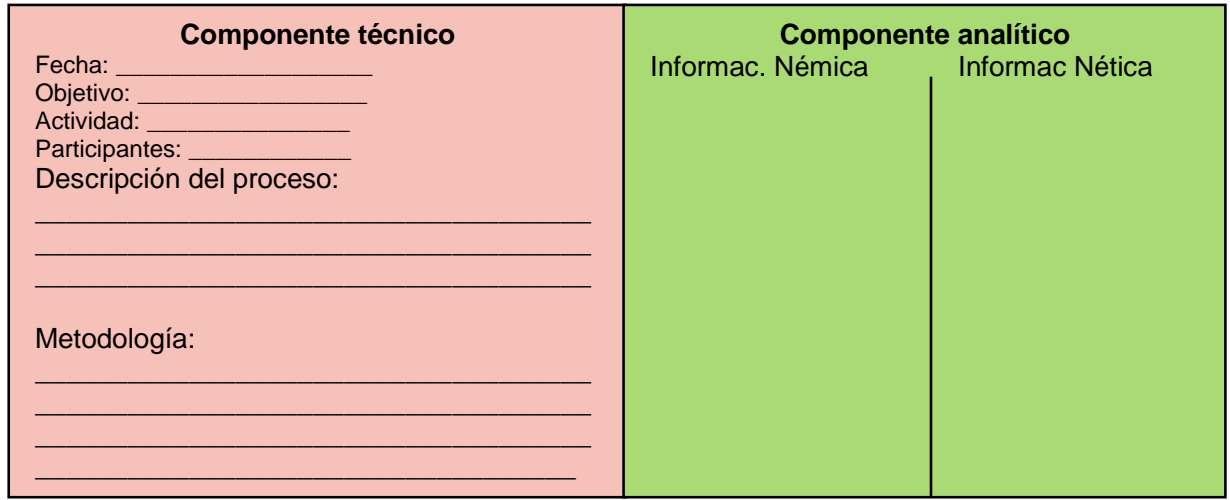

Fuente: Niño, 2011.

Figura 42. Estructura de un diario híbrido que combina dos lógicas, la de verificación y la de descubrimiento. 
En el marco de la investigación realizada la observación participante posibilitó el acercamiento a realidades sociales diversas que están enraizadas en un territorio específico como lo es Bogotá o Sacaba. A partir de la interacción en espacios comunitarios con actores sociales locales que día a día desempeñan multiplicidad de papeles (líderes, liderezas, amas de casa, trabajadoras y trabajadores entre otros), esta técnica de investigación permitió el reconocimiento de dinámicas que desde el nivel barrial generan procesos sociales tendientes a la reivindicación de derechos, las apuestas de transformación de realidades de desigualdad e inequidad social, y la búsqueda permanente de un desarrollo orientado desde los principios de la ética, la transparencia en el manejo de recursos económicos, físicos y humanos entre otros aspectos subyacentes a la lógica de gestión territorial.

Las categorías de investigación promovieron la observación participante y las discusiones, reflexiones y elaboraciones en y con las comunidades a partir de un papel de co-construcción y cooperación permanente entre el sujeto de la investigación y el investigador. Como parte del proceso de operacionalización de las técnicas empleadas para la realización del estudio, se plantea un marco guía para dicha observación como instrumento que permite encauzar las conversaciones que se establecen en cada una de las visitas a los barrios o a las experiencias de evaluación participativa.

\subsubsection{Encuesta}

Se considera fundamental que la investigación cuente con información cuantitativa que permita caracterizar las realidades sociales tanto de Bogotá como del municipio de Sacaba, este tipo de información se sitúa como línea de base para el diagnóstico sobre temas clave que constituyen referentes importantes para la indagación; es el caso de temas como la organización social, la participación ciudadana, la incidencia entre otros. Estos datos cuantitativos permiten la correlación de variables de interés para la investigación y la objetividad de la medición el vislumbrar la realidad actual de los escenarios en mención. En este sentido, el instrumento más utilizado para recolectar los datos es el cuestionario.

\footnotetext{
"Un cuestionario consiste en un conjunto de preguntas respecto a una o más variables a medir. El contenido de las preguntas de un cuestionario puede ser tan variado como los aspectos que se midan a través de éste. Y básicamente, podemos hablar de dos tipos de preguntas: "cerradas" y "abiertas". Las preguntas "cerradas" contienen categorías o alternativas de respuesta que han sido delimitadas. Es decir, se presentan a los sujetos las posibilidades de respuesta y ellos deben circunscribirse a éstas. Las preguntas "cerradas" pueden ser dicotómicas (dos alternativas de respuesta) o incluir varias alternativas de respuesta" (Sampieri, Collado y Baptista, 1991: p, 161)
}

El enfoque con el que se ha desarrollado el presente informe que describe la "metodología cuantitativa" de la presente investigación, se ha fundamentado en la construcción de variables e indicadores fundamentados en la información recolectada a 
través de la aplicación de las Boletas de Encuesta de 16 preguntas $\left(\operatorname{ECOS}^{17}\right.$ 1) y 27 preguntas $\left(\mathrm{EVAPACI}^{18}\right)$ respectivamente, dichas boletas fueron validadas mediante pruebas piloto

La ECOS 1 fue aplicada a líderes de 300 organizaciones sociales de Bogotá durante la primera sesión de capacitación sobre la herramienta ISO/IWA 4 para evaluación de la gestión pública local y distrital en abril de 2013. Y la EVAPACI se aplicó a una muestra seleccionada de manera aleatoria a habitantes, líderes y lideresas sociales de la municipalidad de Sacaba durante 2015.

Cabe destacar que en lo que respecta a la muestra de la encuesta ECOS 1, ésta desarrolla un muestreo de tipo probabilístico por conglomerados. De manera que dichos conglomerados o "clusters" fueron seleccionados de manera aleatoria y forman parte de las organizaciones sociales de la ciudad de Bogotá. Se seleccionan las organizaciones sociales pertenecientes a diversas localidades de la ciudad y se les invita a participar de un evento de capacitación en la herramienta de evaluación ISO/IWA 4, a dicho espacio asisten representantes sociales de varias organizaciones quienes son finalmente a quienes se les aplica la encuesta, para sumar un total de 300 personas que responden dicho instrumento. Aparecen así entonces como unidad de análisis las organizaciones sociales y dentro de éstas los líderes sociales.

Para el caso de la encuesta EVAPACI se realiza un muestreo no probabilístico por cuotas, en el que se definen varios criterios que dividen a la población de Cochabamba en varios grupos en razón de: su edad (mayores a 18 años); a su zona de residencia (Sacaba) y dentro de dicha zona los distritos de pertenencia (1 y 7 principalmente). Este instrumento se aplica a 150 personas en total. La unidad de análisis es entonces la persona.

\subsection{Síntesis}

Investigación cuantitativa y cualitativa suelen verse a simple vista como caminos contradictorios en el tránsito investigativo. Se presentan al investigador varios caminos y hace parte de su definición cuál de ellos recorrer, se ofrecen múltiples vías para acceder a la información en distintas dimensiones de la vida social, mostrando con ello también diferentes métodos y técnicas que se inscriben en el espectro de la recolección de información, su análisis y su sistematización.

La investigación basada en el planteamiento de hipótesis y su comprobación en el marco de una ley pre establecida es una vía agotada, en un momento de la historia surge la importancia por aquello que está fuera de la comprobación, a saber campos investigativos denominados "realidades sociales" sobre las que no es posible establecer ni están pre establecidas las leyes para su funcionamiento o análisis. Por el contrario encontramos aquí la subjetividad como un factor que se considera aporta en gran

\footnotetext{
${ }^{17}$ Encuesta capacidades organizaciones sociales

${ }^{18}$ Encuesta para la evaluación de la participación ciudadana.
} 
medida a los procesos investigativos, de igual manera aparece la importancia de otorgar la palabra a las otras y otros que interactúan en dicha realidad considerada plural, reconociendo la particularidad de los actores sociales implicados en el proceso, posibilitando con ello el uso de varias técnicas o entramados de estrategias de investigación, para fomentar los procesos de utilización de diversidad de ellas, de triangulación o de pluralismo metodológico como se realizó en esta investigación.

Es desde esta perspectiva, desde donde parte esta investigación, el enfoque cualitativo principalmente. A través de la utilización de varias técnicas, entre las que se destacan: la entrevista semi estructurada, los grupos de discusión, la observación participante, notas de campo y la revisión documental se realizó una aproximación a la realidad social de los colectivos de población en los dos estudios de caso que se desarrollan y que buscaron desentrañar los discursos y prácticas de la evaluación de políticas públicas y el control social local.

La triangulación generó la oportunidad para escuchar estas voces en un ejercicio de auto-retroalimentación, de forma que las experiencias tomaron un momento para releerse a la luz de identificar los pilares éticos, metodológicos y conceptuales que guían su quehacer cotidiano en el trabajo realizado en las diferentes localidades de la capital colombiana. La participación de dichos actores sociales fue un principio fundamental, se aunaron esfuerzos para la reflexión y el análisis del trabajo desarrollado en cada iniciativa, los espacios promovidos por los grupos de discusión fomentaron la construcción o consolidación de relaciones sociales de solidaridad entre diferentes organizaciones sociales. Ilustrando así la necesidad de establecer una relación entre el investigador y el "fenómeno" a investigar, en este caso las actividades desarrolladas en las organizaciones sociales y aquellas otras vinculadas con evaluación de políticas públicas y control social.

Las y los participantes en los procesos fueron considerados siempre como sujetos activos, con grandes potencialidades, conocimientos y capacidades para aportar elementos fundamentales en la investigación adelantada. Los encuentros periódicos tanto entre investigador-sujeto de la investigación y entre experiencias de organización social hicieron de la palabra una expresión de lo que Orlando Fals Borda llama los sujetos sentipensantes, que actúan con base en la razón involucrando también los aspectos subjetivos ligados con los sentimientos y el amor por lo que se hace.

Las técnicas y métodos de la investigación cualitativa promueven el análisis creativo, término que encierra la oportunidad de construcción de herramientas metodológicas de recolección y análisis, que como insumos propios nos permiten decantar la información obtenida con el objetivo de aprovechar al máximo sus aportes para la investigación. Al avanzar el proceso, van emergiendo nuevos puntos de reflexión y categorías, por ello el crear un instrumento que permita registrar todo lo recolectado y al mismo tiempo hacer lecturas transversales tanto verticales como horizontales, es entonces un camino para 
vislumbrar discusiones sintéticas, vacíos en el conocimiento y campos a explorar en el futuro.

En suma, los métodos cualitativos para la investigación social son un aporte fundamental en el análisis, reflexión y de-construcción de categorías vinculadas con un tema-problema específico, promoviendo la interacción permanente entre investigador sujeto de la investigación a través del establecimiento de una relación cooperativa y de co-construcción. Igualmente es importante tener en cuenta que la utilización de dichas técnicas no exime el empleo de herramientas que desde el enfoque cuantitativo permiten ampliar el panorama general de contexto de un hecho o situación social, por lo tanto no son contradictorios del todo estos caminos, sino por el contrario pueden llegar a ser complementarios en tanto se establezca un equilibrio entre sus aportaciones al proceso de investigación. 


\section{CAPÍTULO 5. DESARROLLO DE LA INVESTIGACIÓN}

El ámbito local se convierte en contexto en el que se evidencian múltiples iniciativas de organización y/o movilización social que dan cuenta del potencial de las comunidades para la construcción de estrategias que les permitan ampliar su participación en el escenario de lo público. Lo local constituye el ámbito más cercano a los individuos, y por ende se concibe como entramado de interacción social en el que se evidencian construcciones simbólicas y relacionales como aporte a los procesos de reivindicación de derechos.

Las prácticas democratizantes deberían tender a ampliarse a los procesos de formulación de las políticas públicas y a los proyectos de desarrollo, para multiplicar a nivel social las posibilidades del ejercicio de derechos políticos fundamentales de consulta, opinión e información sin desmedro de los mecanismos representativos. Aumentar la cantidad y la calidad de esas prácticas democratizantes sería un objetivo a perseguir a través de un aumento de la participación social, contribuyendo al sostenimiento del sistema democrático (Francioni y Poggiese 1993, p, 5).

Tanto la gestión del territorio como la incidencia ciudadana en lo público se consideran procesos esencialmente participativos en los que interactúan multiplicidad de actores sociales a partir justamente de una marcada conciencia y valoración de lo público como constructo social vinculado con el bienestar social, así como un nivel de participación social en la toma de decisiones y la vida colectiva. Desde esta propuesta de fortalecimiento de las capacidades de agencia ciudadana en los territorios y específicamente en las políticas públicas, a continuación se presentan los desarrollos de la investigación, aludiendo a mencionar los objetivos que como piedras angulares de la puesta en marcha del proceso, orientaron la búsqueda de información, el análisis y la 
construcción de la tesis doctoral. Posteriormente se realizará un recorrido descriptivo de los instrumentos de recolección de información y aquellos otros que posibilitaron el análisis de los insumos de investigación; a continuación, se pondrá en evidencia la muestra del estudio y los resultados del mismo para finalmente terminar el capítulo con análisis e inferencias respecto del tema en cuestión.

\subsection{Objetivos de la investigación}

\section{Objetivo general:}

Evidenciar los debates, realidades y perspectivas de procesos de evaluación de política pública en Bogotá (Colombia) y Cochabamba - Sacaba (Bolivia), con miras a la estructuración de un proyecto piloto de control social participativo para el municipio de Sacaba, que contribuya a la construcción y fortalecimiento de capacidades ciudadanas para la incidencia en la política pública.

\section{Objetivos específicos:}

1. Analizar críticamente los procesos participativos de evaluación de política pública en Bogotá y en Cochabamba, a partir de su aporte al fortalecimiento de capacidades de agencia social sobre lo público, en el marco de la ciudadanía y el ejercicio pleno de derechos.

2. Realizar un estado del conocimiento sobre Gestión Asociada del Territorio para la Paz -Gestepaz-, con miras al diseño de una base de datos como introducción a la investigación cientimétrica.

3. Caracterizar la evaluación de política pública/control social, como práctica representativa de la gestión asociada del territorio para la paz, en los escenarios de investigación.

4. Describir y analizar los escenarios, actores e intereses vinculados a los procesos de evaluación participativa de política pública.

5. Estructurar una propuesta de sistema de indicadores técnicos para evaluación participativa de política pública en Sacaba, con miras a contribuir a la construcción de una base de datos que sirva de plataforma para la toma de decisiones; que sea enriquecida con la experiencia de control social desarrollada en Bogotá en 2013.

Los anteriores objetivos orientaron esta investigación y dan cuenta de discursos y prácticas de construcción y fortalecimiento de capacidades ciudadanas para la evaluación de política pública en Cochabamba y Bogotá, teniendo en cuenta la caracterización de los contextos actuales de cada país, el devenir histórico del ciclo de política pública en cada escenario y las especificidades de las experiencias de evaluación y/o control social. Los mencionados objetivos se materializan en el planteamiento de categorías de investigación u ordenadores epistemológicos (mencionados en el capítulo anterior) que permitieron encauzar los esfuerzos de 
búsqueda y de análisis de la información obtenida a través de cada uno de los insumos de estudio empleados.

\subsection{Participantes, instrumentos, procedimientos y resultados}

Como parte de las concreciones que aporta la fundamentación epistemológica de una investigación, es importante destacar que dichas premisas orientadoras como piedra angular, permitieron la definición de estrategias con significado, atendiendo a las demandas del tema y de los objetivos de investigación.

Las orientaciones metodológicas que se presentan en cada una pretenden ser eso: orientaciones, guías que faciliten el ejercicio de la investigación y no pautas fijas o caminos rígidos. Las estrategias se aprenden como un oficio, como un artesano, en palabras de Wright Mills y por tanto no son susceptibles de estandarización ni de formalización absoluta (Galeano, 2004, p. 23).

En la investigación se construyeron instrumentos en dos registros: i) Aquellos que posibilitaron la búsqueda de información tanto primaria como secundaria y ii) Aquellos otros que viabilizaron el análisis de la información recopilada en los instrumentos. Se hará alusión a cada ámbito de diseño instrumental.

Los presentados a continuación constituyeron pilares orientadores cuyo fin último fue el de aprovechar al máximo la información recabada en el proceso, logrando un enriquecimiento de la misma a partir de la triangulación de métodos y técnicas.

\section{A) Revisión documental.}

\section{Muestra}

El ejercicio de lectura se convirtió en una entrevista a profundidad ${ }^{19}$, a una muestra de 135 publicaciones, que permitió recoger la información de forma fiel, no dejando por fuera ninguna referencia al tema de tal manera que se conservaron de forma fidedigna los datos.

Sin duda como insumo de la investigación para la realización de estados de la cuestión, el instrumento empleado permitió dar la palabra a los textos en su contexto, así como a las personas partícipes de estos procesos y concebidos como actores sociales situados. De esta manera, "El investigador de estados de la cuestión concede la palabra al texto en cuanto él tiene una verdad que decir, unos datos que ofrecer, unos factores que señalar, unos indicadores que describir, pero aún más, un sentido para transmitir y un significado para revelar" (Hoyos, 2000, p. 66).

\footnotetext{
${ }^{19}$ Implica un análisis exhaustivo de los aspectos vinculados con las categorías de investigación, análisis que será realizado en cada uno de los escenarios de recolección de información. En este caso, en lo concerniente a la lectura de textos interesa lograr un acercamiento cuidadoso y profundo a los planteamientos de cada autor para escudriñar las relaciones entre categorías y nuevas reflexiones teóricas sobre las mismas.
} 


\section{Instrumento}

Aparecen entonces en el diseño de la ficha de lectura a profundidad (Ver Anexo 1), aquellos aspectos consignados en los objetivos y preguntas de investigación, como caminos que permitieron establecer núcleos temáticos o categorías para posteriormente realizar el análisis general de la producción encontrada, y el estado actual del conocimiento alrededor del tema.

La ficha mencionada ha sido diseñada con el objetivo de aprovechar al máximo toda la información de cada insumo bibliográfico, en aras de dar respuesta a las preguntas de investigación mencionadas en el planteamiento del problema; dicho insumo está conformado por los siguientes ítems:

1.- Tipo de documento revisado: Ítem que alude a caracterizar si se revisa un libro completo, las memorias de un evento, un capítulo de libro, una revista o cartilla, una publicación electrónica, un trabajo de investigación en modalidad de tesis, un documento investigativo sin publicar. En este apartado también se consignan datos referentes a autor (es), año y país de publicación, edición del texto, editorial y organización (es) que apoya (n) la publicación. Esta parte del instrumento corresponde más a aspectos vinculados con la descripción del tipo de producción bibliográfica encontrada y analizada.

2.- Palabras clave del texto: Aquellas que aparecen nombradas de forma explícita o las que es posible identificar a partir de la lectura a profundidad del texto. Dan una idea general de los contenidos centrales que aparecen en el escrito.

3.- Resumen del contenido del documento: Ítem propuesto con el objetivo de generar una síntesis de cada uno de los documentos consultados; algunas veces este resumen aparece como una construcción propia a partir de la lectura, en el caso de los artículos es la síntesis que estos traen y en el caso de libros aparecen en la mayoría de fichas las ideas principales identificadas a lo largo de la lectura.

4.- Objetivos del autor o autora: Que pueden aparecer de forma explícita o pueden inferirse a partir de la lectura.

5.- Grupos poblacionales mencionados: Se busca identificar los grupos sociales mencionados en los textos, también aparecen actores sociales (institucionales, comunitarios, estatales, gubernamentales, municipales entre otros)

6.- Categorías de investigación: En este apartado se recopila la información sobre los ordenadores temáticos propuestos, tanto las categorías generales como las específicas, pueden provenir de apartados textuales del documento o de lecturas inferenciales de quien lee el texto.

7.- Observaciones y otras alusiones importantes: Se incluyen comentarios adicionales, referencias a otros textos mencionados por el autor o autora que se está consultando, sugerencias de búsqueda de información para ampliación de contenidos, especificación de conceptos del texto como componentes 
fundamentales para su comprensión; estas además de las que quien lee el texto de referencia considere pertinentes.

8.- Enfoques destacados: Se rescata la alusión a corrientes de pensamiento o perspectivas de trabajo territorial que son mencionadas en el texto y están articuladas con el tema de la gestión del territorio para la paz. Pueden ser poblacionales, territoriales, sectoriales, de intervención etc.

9.- Citas importantes: Aquellas que se consideran importantes para nutrir la elaboración del texto de investigación, teniendo en cuenta las categorías y objetivos de la investigación.

10.- Anexos: Aquellos que como resultado de la lectura pudieran construirse, incluye mapas conceptuales, mapas mentales, gráficos o figuras de análisis de contenidos mencionados en el texto de forma explícita o implícita. Pueden ser creados por los autores o de elaboración propia a partir de la lectura.

Para el análisis de la información recopilada se construye en primera instancia una base de datos bibliográfica (ver Anexo 2) con el fin de registrar los documentos encontrados sobre las categorías generales y particulares de la investigación (ver Cd Anexo). Dicha base de datos con posterioridad a la aproximación a los textos, es tematizada en razón de la lectura a profundidad de cada documento.

Dicho insumo también permite hacer un balance cuantitativo de los niveles de escritura sobre un tema determinado, resultando muy útil cuando se quieren hacer estados del conocimiento desde la perspectiva cuantitativa o combinando ambos paradigmas de investigación. Más adelante se analizan las fichas de lectura a profundidad haciendo una lectura comparativa de la información obtenida en cada una de ellas y de todas en su conjunto.

\section{$\underline{\text { Resultados }}$}

Los descriptores mencionados (Ver Tabla 18), así como las categorías centrales de la investigación ya expuestas, guiaron la búsqueda de textos. Es decir, los documentos que se mencionan y los resultados presentados se enmarcan en los criterios de: analizar las contribuciones de procesos locales de organización y educación popular a la gestión del territorio para la paz en Colombia. Tarea que también implicó la deconstrucción del concepto de gestión del territorio para la paz y la caracterización de los aspectos de trabajo territorial que desde lo local, promueven la Gestepaz en contextos signados por el conflicto armado y la desigualdad e inequidad sociales.

Tabla 25. Descriptores temáticos de búsqueda bibliográfica.

\begin{tabular}{|l|l|l|}
\hline Gestión del territorio & Construcción de paz & Organizaciones populares \\
\hline Gestión & Paz positiva & Organizaciones populares Bogotá \\
\hline Territorio & Transformación de conflictos & Organizaciones sociales \\
\hline Territorialidad & $\begin{array}{l}\text { Construcción de paz en } \\
\text { Colombia }\end{array}$ & Acción colectiva \\
\hline Gestión del territorio para la paz & $\begin{array}{l}\text { Educación popular y } \\
\text { organizaciones populares }\end{array}$ \\
\hline
\end{tabular}


El balance de la producción escrita hace referencia a aquel acervo documental que se consideró pertinente analizar, debido a sus sentidos, significados y los sistemas categoriales de los que estaba compuesto. Se localizaron textos provenientes de diferentes ámbitos del saber cómo la Economía, la Geografía, la Sociología, la Educación, la Psicología, el Trabajo Social entre otros, que posibilitaron una perspectiva interdisciplinaria sobre los entramados conceptuales, éticos y metodológicos en los que está enraizada la Gestepaz.

Frente a la caracterización de la producción bibliográfica analizada, cabe destacar que se encontraron documentos, tales como: i) Textos publicados por departamentos editoriales de organizaciones gubernamentales y organizaciones no gubernamentales (ONG) que trabajan temas ligados con la construcción de paz, la cooperación al desarrollo, y la gestión territorial, tales como los mencionados en la Tabla 19.

Tabla 26. Textos por departamentos editoriales de organizaciones y de ONG.

\begin{tabular}{|c|c|}
\hline Entidad & $\begin{array}{l}\text { País o continente de } \\
\text { actuación }\end{array}$ \\
\hline $\begin{array}{l}\text { Agencia Española de Cooperación Internacional para el Desarrollo } \\
\text { (AECID) }\end{array}$ & \multirow{5}{*}{ España } \\
\hline Cáritas Española & \\
\hline Bakeaz & \\
\hline Escola de Cultura de Pau & \\
\hline $\begin{array}{l}\text { El Instituto de Estudios sobre Desarrollo y Cooperación Internacional } \\
\text { (HEGOA) }\end{array}$ & \\
\hline Agencia Latinoamericana de Información & Latinoamérica \\
\hline Consejo de Educación de Adultos de América Latina CEAAL & Latinoamérica \\
\hline Comisión Económica para América Latina (CEPAL) & Latinoamérica \\
\hline Centro de Estudios Estado y Sociedad (CEDES) & Argentina \\
\hline ONG Colombia Diversa & \multirow{11}{*}{ Colombia } \\
\hline Departamento Nacional de Planeación de Colombia & \\
\hline ONG Dimensión Educativa & \\
\hline Federación Colombiana de Municipios & \\
\hline Fundación Foro Nacional por Colombia & \\
\hline PIUPC & \\
\hline Red RINDE & \\
\hline Consorcio Swisspeace & \\
\hline Fundación Corona & \\
\hline Fundación Ideas para la Paz & \\
\hline Instituto de Estudios de Desarrollo y de Paz & \\
\hline Escuela Nacional de Salud Pública (ENSAP) & Cuba \\
\hline PNUD & Mundial \\
\hline Organización de las Naciones Unidas para la Educación (UNESCO) & Mundial \\
\hline
\end{tabular}

ii) Documentos académicos editados por centros de investigación o universidades en diversos países, en este punto se localizaron estudios de entidades como las nombradas en la Tabla 20. 
Tabla 27. Documentos académicos editados por centros de investigación o universidades

\begin{tabular}{|c|c|}
\hline Institución académica & País \\
\hline Universidad de Oxford & Inglaterra. \\
\hline Pontificia Universidad Javeriana en Colombia & \multirow{10}{*}{ Colombia } \\
\hline Universidad Nacional de Colombia & \\
\hline Universidad Pedagógica Nacional & \\
\hline Universidad Externado de Colombia & \\
\hline Universidad Central de Colombia & \\
\hline Universidad de los Andes & \\
\hline Universidad de Antioquia & \\
\hline Universidad de Medellín & \\
\hline Universidad Autónoma de Bucaramanga & \\
\hline Instituto de Estudios para el Desarrollo y la Paz & \\
\hline Universidad Autónoma de Barcelona & \multirow{6}{*}{ España } \\
\hline Universidad Complutense de Madrid & \\
\hline Universidad de Granada & \\
\hline Universidad de Valencia & \\
\hline Universitat Jaume I & \\
\hline Instituto Universitario de Desarrollo Social y Paz & \\
\hline Universidad Bolivariana de Venezuela & Venezuela \\
\hline Universidad Central de Chile & Chile \\
\hline Universidad Nacional de la Plata & \multirow[t]{2}{*}{ Argentina } \\
\hline Instituto de Investigaciones Gino Germani & \\
\hline
\end{tabular}

Por otra parte, es importante tener en cuenta que la mayoría de los documentos revisados se editaron, re-editaron o escribieron en Colombia, algunos de los textos permiten establecer un contexto a nivel Latinoamericano. Se revisaron documentos en su mayoría de Colombia por ser el escenario en el que se desarrolló la investigación. Seguido de documentos editados en España en donde también existe producción destacada sobre el tema. En este contexto se observa que se consultó bibliografía en la que: el 19,26\% corresponde a textos editados en España, el 53,33\% textos colombianos; el 8,14\% bibliografía de otros países de América del Sur (Argentina, Brasil, Venezuela, Chile y Uruguay); el 6,66\% de producción la comparten países de América del Norte, Centroamérica y el Caribe; el 1,48\% corresponde a otros países de Europa (Inglaterra y Alemania) (Ver Figura 43). El porcentaje restante equivale a textos de los que no se encontró su país de origen y que evidentemente pueden incrementar la producción escrita de uno o varios de los países antes referenciados. 


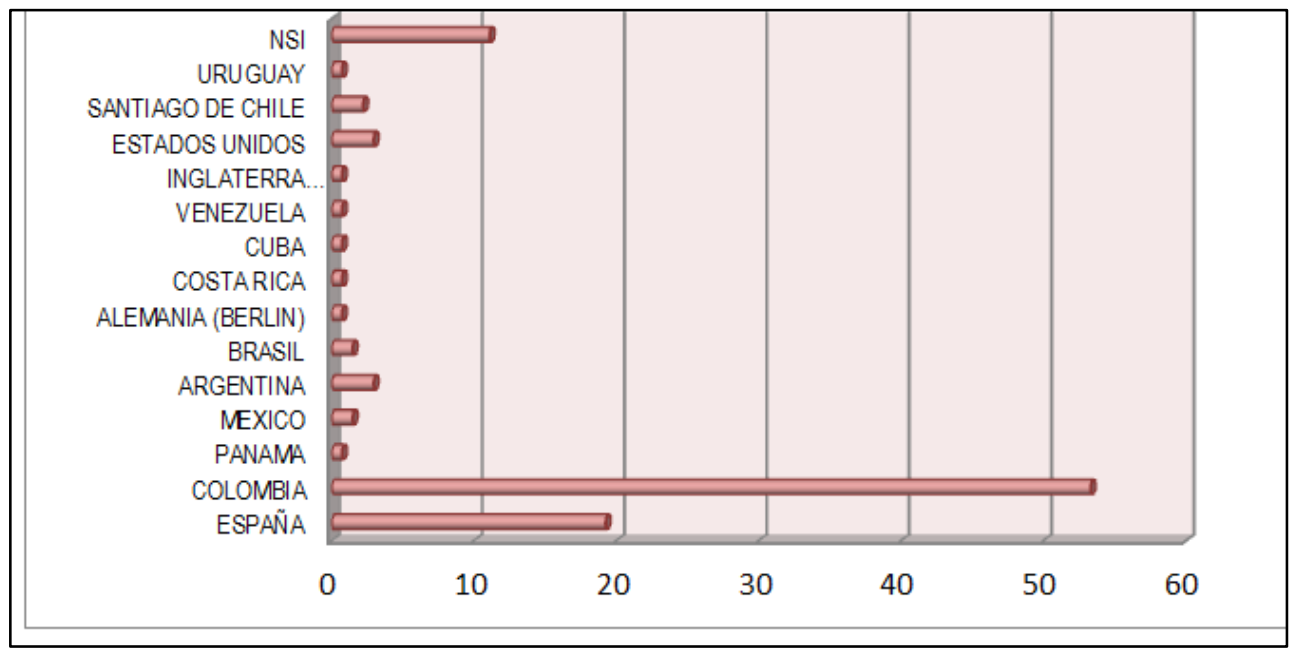

Fuente: Elaboración propia a partir de la base de datos construida para la realización del estado de la cuestión. Marzo de 2012. La sigla N.S.I: no se encuentra información, corresponde a aquellos textos de los que no se hallan datos del país de origen.

Figura 43. Producción bibliográfica: Análisis por países.

Para esta presentación de resultados de la revisión documental se construyó inicialmente una base de datos general de textos, insumo que posteriormente pasó a ser tematizado a la luz del cuadro de ordenadores epistemológicos presentado en el capítulo anterior. Una vez tematizada la base de datos, se realizaron sub-bases en las que se procesó la información por categorías de investigación. En la Figura 44, se observa un balance general de los temas y subtemas abordados en la producción bibliográfica analizada. Se presenta esta generalidad con el fin de que se puedan identificar las tendencias en la producción escrita, pero para efectos de esta tesis estos temas se reorganizan desde la perspectiva de análisis propuesta en el cuadro de categorías, que en sí mismo, representa una abstracción del abordaje conceptual que se realiza de la Gestepaz desde este trabajo investigativo. 


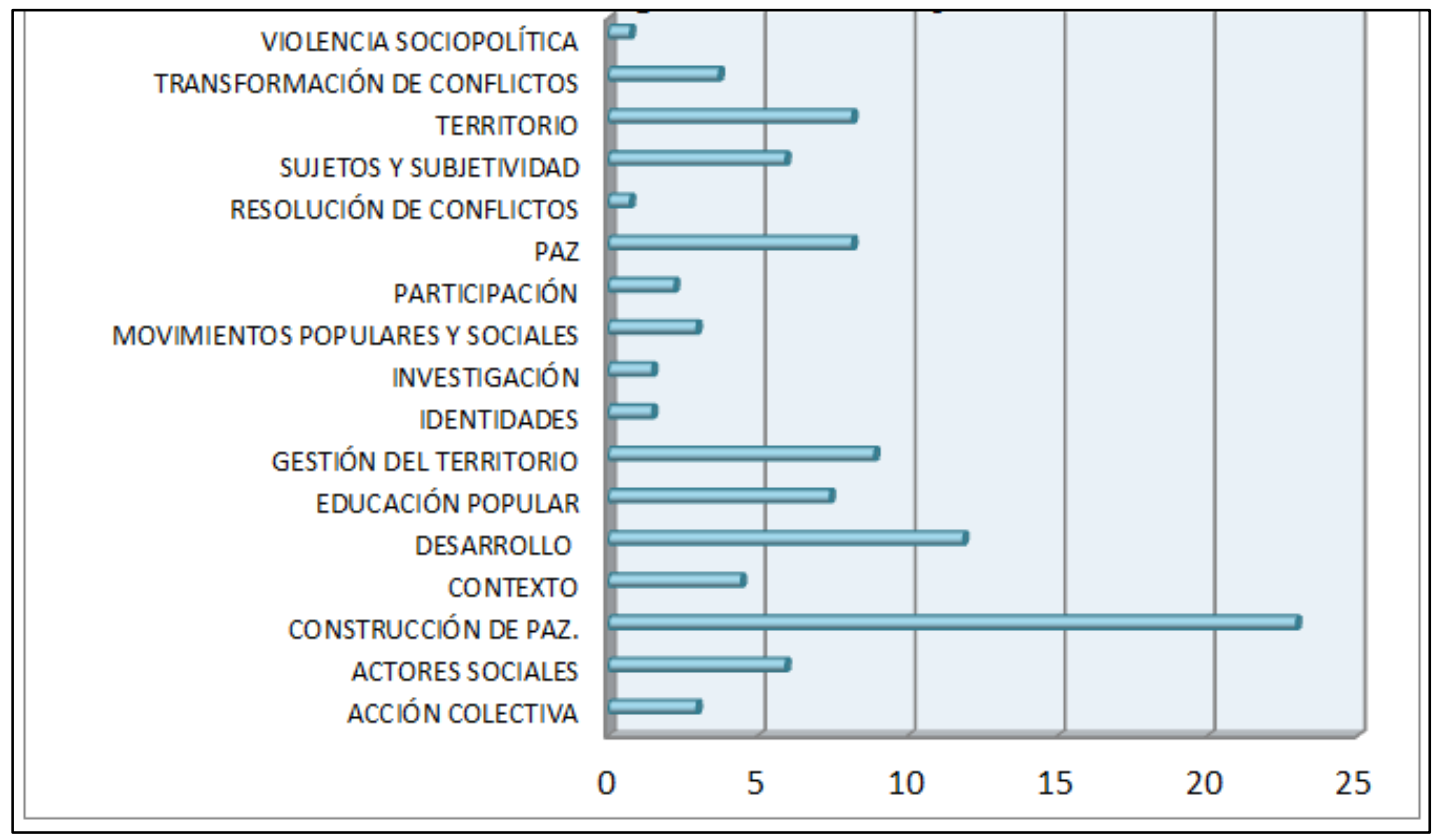

Fuente: Elaboración propia a partir de la base de datos construida para la realización del estado de la cuestión. Marzo de 2012

Figura 44. Producción bibliográfica: Temas y subtemas.

El mayor porcentaje de producción escrita consultada fue sobre el tema de construcción de paz (el 22,96\%), donde se destaca la relación con temas como el enfoque de acción sin daño (ASD) Anderson (2009), Bello (2009), Chaparro (2009), Florez (2009) y Medrano (2009) entre otros; la sensibilidad al conflicto Mera (2011), Federación Colombiana de Municipios (2009), Sanjurjo (2010), Vásquez (2010); la teoría de transformación de conflictos con autoras como Zapata (2009) y autores como Galtung quien desde 1982 viene escribiendo y aunando esfuerzos de reflexión y análisis frente a este tema articulándolo con elaboraciones vinculadas con la teoría de la paz. De hecho es considerado uno de los pioneros de dicha teoría.

Por otra parte, se evidencia que un gran número de textos colombianos sobre los temas mencionados, fueron escritos en 2009 lo cual puede estar ligado con la realización del evento "Retos y propuestas sobre acción sin daño y construcción de paz en Colombia", realizado por el PIUPC en la Universidad Nacional de Colombia, con apoyo de COSUDE-Embajada de Suiza GTZ, Ministerio Federal de Cooperación Económica y Desarrollo.

La acción colectiva y la referencia a actores sociales comparten el 8,88\% del total de la producción escrita analizada. Estas subcategorías de investigación son planteadas así: la acción colectiva aparece como tema vinculado con la Educación Popular y los actores sociales están ligados con la participación, el desarrollo, la descentralización que son vertientes de análisis que subyacen a la gestión del territorio como se verá más adelante. Temas como el contexto, el desarrollo, las identidades y la investigación ocupan la atención del 19,21\% de los textos consultados. Sobre el contexto nos situamos en las 
dimensiones social, económica, política y cultural en las que se desenvuelve el cotidiano de los escenarios locales, regionales, nacionales e internacionales. Por otra parte, el $21,46 \%$ de los textos se refieren a temas ligados con la educación popular, la gestión del territorio, los movimientos populares y sociales y la participación. La paz, la resolución y transformación de conflictos ocupan el $12,58 \%$, mientras que sujetos y subjetividad y territorio son objeto del $14,06 \%$ de las elaboraciones bibliográficas.

También es posible hacer un análisis por las categorías más específicas planteadas en el proceso de investigación, dicha referencia permite visibilizar un panorama más amplio de reflexión retrospectiva sobre los temas en cuestión. Vemos que en la construcción de paz, convergen multiplicidad de subtemas tales como la política pública, los procesos de paz, la participación, los estudios y teorías de la paz, la cultura de paz y la acción humanitaria internacional (Ver Figura 45). Campos de análisis que se enmarcan en escenarios locales, nacionales e internacionales, en sus dimensiones ética, metodológica y conceptual y a partir de enfoques como el de sensibilidad y transformación de conflictos y el de acción sin daño (ASD).

Respecto al enfoque ASD (que recientemente también es denominado de sensibilidad al conflicto), se observa que está en auge y es fuertemente trabajado desde la aparición del texto pionero de Anderson (2009), donde se destaca cómo la ayuda humanitaria puede apoyar la paz o la guerra; este texto y por ende el enfoque representan un insumo fundamental en escenarios de cooperación al desarrollo, actuación en contextos de conflicto armado y en general en diversidad de espacios en los que acciones de instituciones, personas, gobiernos o Estados en vez de generar procesos positivos favorecen la afectación negativa a partir de la puesta en marcha de determinadas actividades o acciones en las comunidades en las que desarrollan su quehacer.

A partir de estas reflexiones derivadas del trabajo de la mencionada autora y de las organizaciones internacionales y organizaciones no gubernamentales locales en zonas de conflicto (brindando apoyo humanitario y de desarrollo), se generan reflexiones conceptuales y más enfáticamente acercamientos desde la perspectiva ética, que deben ser inherentes a la acción en y con las comunidades locales, desde la identificación de capacidades en estos escenarios para la paz, al respecto también se identifican las elaboraciones de Chaparro (2009) donde se destacan los aspectos psicosociales y su relación con el enfoque de ASD en contextos de conflictos armados de larga duración, cuya afectación en los aspectos individual-subjetivo y colectivo-social aparecen como correlatos de un país con una grave vulneración a los Derechos Humanos, que pareciese posicionarse como inherente al devenir histórico nacional en países como Colombia. 


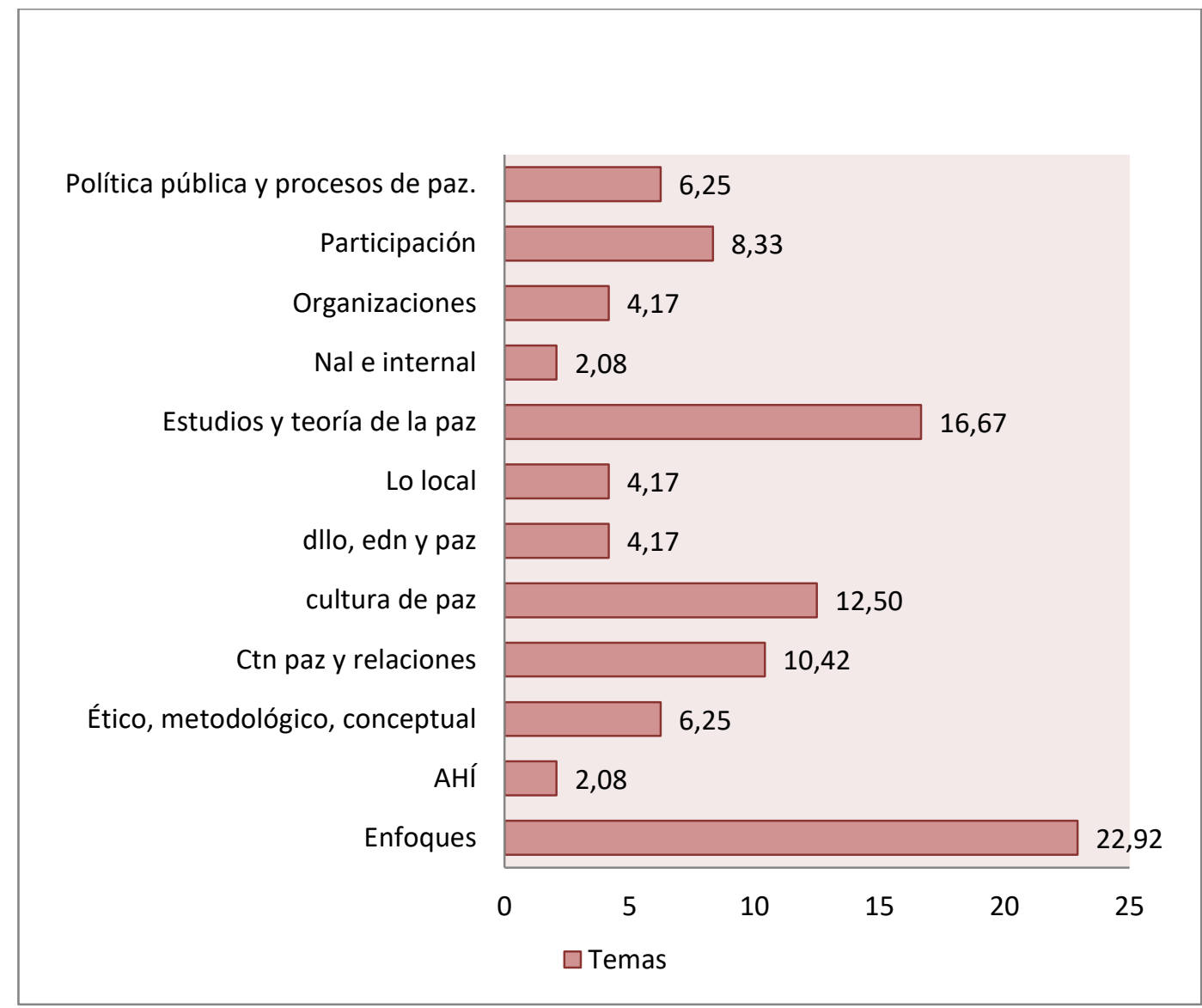

Fuente: Elaboración propia a partir de la base de datos construida para la realización del estado de la cuestión. Marzo de 2012. Análisis realizado sobre el tema de la EP dentro de los datos de producción escrita: temas y subtemas.

Figura 45. Textos sobre construcción de paz

Otras elaboraciones como las de Flores (2009) y Medrano (2009) promueven la reflexión sobre ejes transversales a la acción en escenarios de construcción de paz o ayuda humanitaria en conflictos armados, a saber el enfoque étnico y el enfoque diferencial, estos como escenarios que:

...Se centran en la necesidad de reconocer los efectos de la violencia y el desplazamiento diferenciados por género, edad y origen étnico. El empleo de estas tres categorías de diferenciación en el análisis de la vulneración de los derechos, de los procesos sociales generados a partir del desarraigo y de la política pública de atención a la población desplazada, se recogen bajo el término de Enfoque Diferencial (...) El enfoque diferencial de género, edad y etnia parte de los principios básicos del libre ejercicio de los derechos, de la equidad, y del reconocimiento de las diferencias entre los grupos poblacionales (Meertens, sf, p.1)

Así mismo, en el análisis de la producción escrita realizado, se dilucida que para la estructuración de explicaciones y abordajes conceptuales y metodológicos de la Gestepaz, se recogen aportes de variedad de disciplinas de las ciencias sociales y humanas así como desde la economía y la administración pública. 
Se evidencia en algunos textos una marcada postura económica que hace énfasis en el uso productivo del territorio y las relaciones económicas que se inscriben en él, véase Rendón (2009) allí se destaca que "La discusión sobre el territorio y su gestión tiene en la economía un nodo muy importante en el concepto de economías externas" (p. 8), nociones de macro y micro economía dan sustento a la gestión territorial y la hacen estar afincada en instancias meramente administrativas y de élites intelectuales en este campo. De igual manera, aparecen referencias en las que se menciona que al estar en un mundo globalizado el territorio debe leerse a la luz de analizar los elementos económicos que de allí subyacen, desde una perspectiva centrada en las transformaciones de las lógicas de producción y organización de los espacios empresariales y de gestión administrativa en los ámbitos financieros, otorgando así especial atención a las relaciones económicas que se despliegan en estos escenarios (Alburquerque, 1999; Álvarez y Acevedo, 2010; Berzosa, 2006; Bustelo, 2003), (ver Figura 46).

De igual manera, e insertos en un modelo de producción capitalista que da cuenta del surgimiento de disparidades que se observan en los niveles regionales, locales y nacionales, es importante hacer esta mirada de contexto, que trasciende el mero hecho de encasillar las reflexiones retrospectivas únicamente a este ámbito; con ello se posibilitan miradas alternativas que centran su análisis en aspectos culturales de construcción de tejido social e identidades socioculturales en un espacio que es significado y dotado de sentido, para pasar a ser: territorio, a este respecto autores como Giménez (1996, 1999), Hadad y Gómez (2007) y Velásquez (2010), hacen aportes indispensables que amplían el espectro de reflexión sobre las implicaciones materiales, simbólicas, físicas y sociales del territorio tanto para los diversos actores sociales que convergen en él como para los procesos de todo tipo que subyacen a las lógicas de interacción que se desarrollan. 


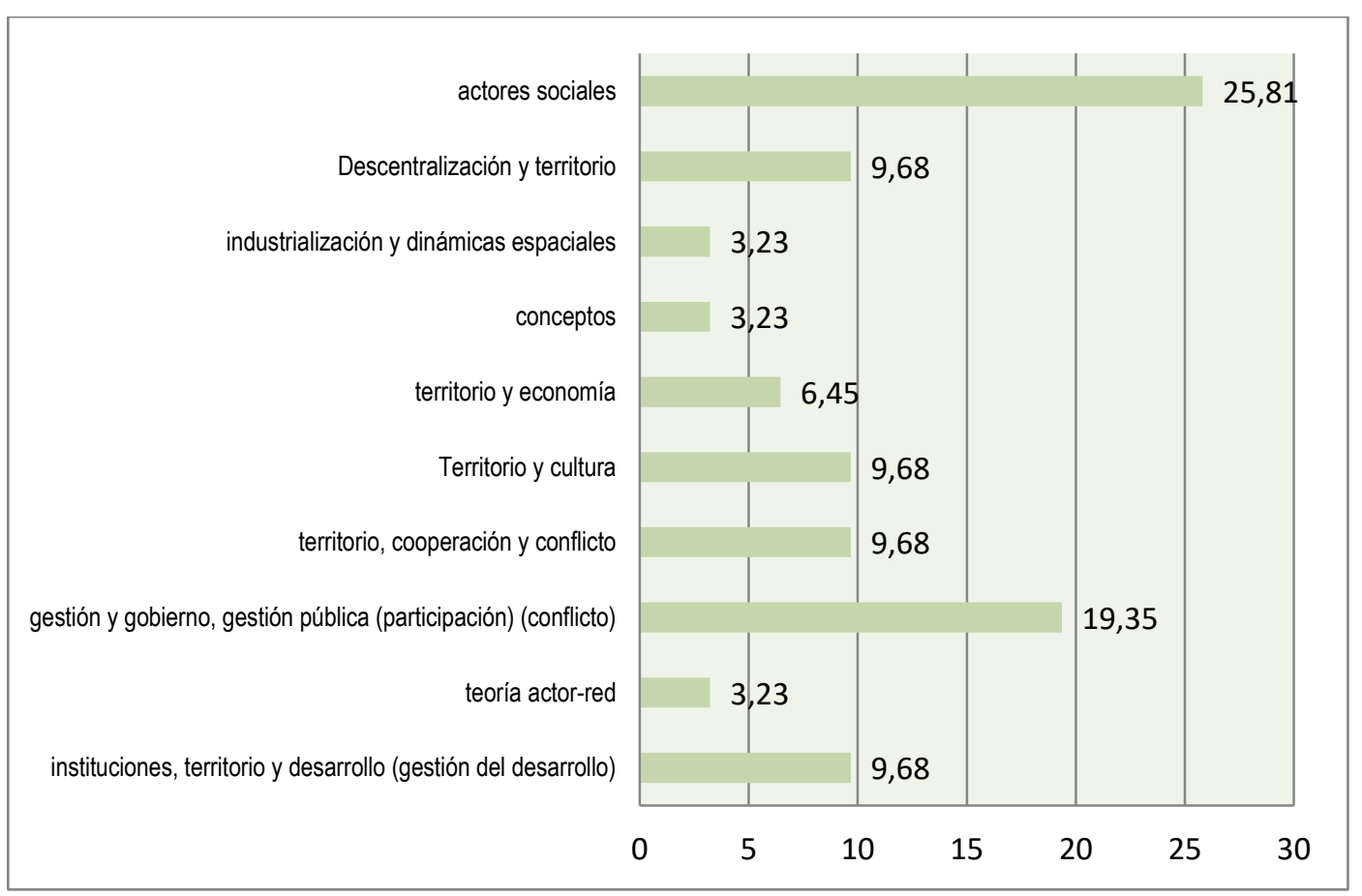

Fuente: Elaboración propia a partir de la base de datos construida para la realización del estado de la cuestión. Marzo de 2012. Análisis realizado sobre el tema de la EP dentro de los datos de producción escrita: temas y subtemas.

Figura 46. Textos sobre gestión del territorio.

En el análisis realizado, se evidencia que los picos más altos en términos de producción bibliográfica sobre el tema de territorio, se encuentran en los análisis vinculados con el desarrollo, la cooperación y el conflicto, la cultura y la economía. Esta última dilucida que un primer acercamiento a la de-construcción de la noción de territorio, parte de desentrañar las relaciones de producción, intercambio, distribución y consumo de bienes y servicios, a saber las dinámicas económicas enraizadas en él.

Por tanto, dentro de la categoría territorio encontramos producción bibliográfica que aborda temas como el control territorial de los actores armados sobre el territorio, la panorámica de la gestión y el gobierno en relación con dinámicas como la ordenación y el uso del suelo o del espacio físico de una determinada región; la relación entre las instituciones, el territorio y el desarrollo. Así mismo, se observa que textos como el correspondiente a la teoría actor-red posicionan el espacio físico y simbólico del territorio como entramado de sentido y significado que da cuenta de la construcción de pautas de interacción, circunscritas a ámbitos culturales y sociales que las determinan y en las que se fundamentan.

Cuando hablamos de territorio también se dilucida una importante relación con la noción de desarrollo que irá a ser conceptualizada en razón de la corriente de pensamiento, así como desde la perspectiva de análisis a partir de la que se sitúen las discusiones sobre este tema; nociones como las de desarrollo económico, desarrollo endógeno, desarrollo comunitario, desarrollo local, desarrollo sostenible, desarrollo humano se hacen presentes en estos debates que transitan el campo que va desde la 
epistemología hasta el pragmatismo, unas de ellas mostrando una fehaciente articulación entre las anteriores y otras evidenciando una contradicción que para algunos autores es inherente Escobar (1996) o están fundamentadas en heterodesignaciones impuestas de acuerdo a la división de los países en desarrollados y subdesarrollados; contextos a los que también desde los países desarrollados se les asigna una determinada taxonomía de caracterización, dando cuenta de términos como países del tercer mundo, tercermundistas, menos adelantados y recientemente en vías de desarrollo.

La Educación Popular EP constituye una corriente de pensamiento de gran importancia dentro de esta investigación, ya que en ella se enmarca el trabajo de las organizaciones sociales bogotanas que generan aportes indispensables a la construcción de paz desde el espacio local. Por ello interesó hacer un sucinto balance de su devenir histórico, conceptual, ético y metodológico, identificando algunos aspectos centrales que permiten hacer interesantes articulaciones temáticas (Ver Figura 47). Desde esta perspectiva, se encuentran relaciones temáticas de la EP con la acción colectiva, los movimientos sociales y populares, el desarrollo local y la identidad, en contextos influenciados por dinámicas globalizadoras y de globalización, que a través del impulso de paradigmas de modernización trajeron consigo relaciones sociales marcadas por la desigualdad e inequidad social.

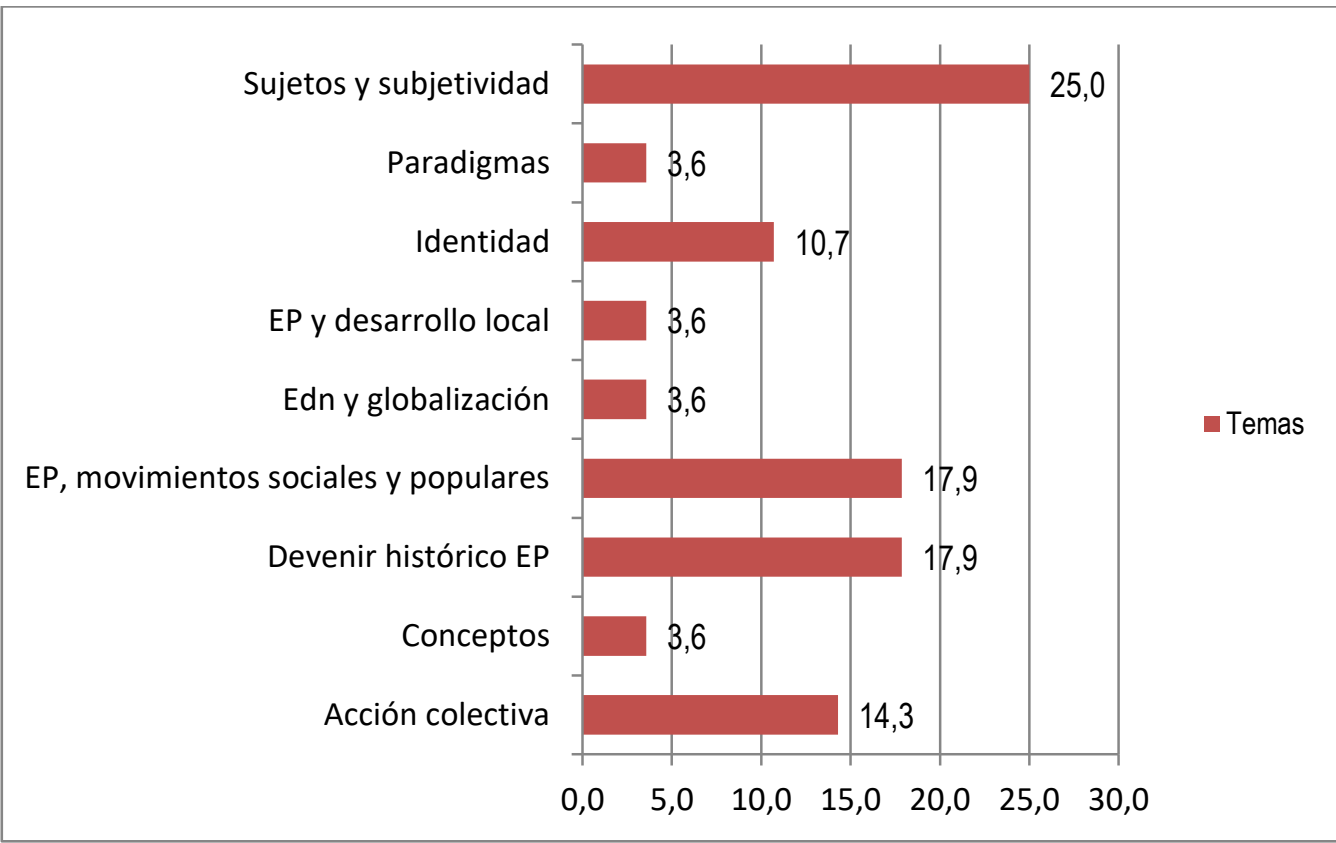

Fuente: Elaboración propia a partir de la base de datos construida para la realización del estado de la cuestión. Marzo de 2012. Análisis realizado sobre el tema de la EP dentro de los datos de producción escrita: temas y subtemas.

Figura 47.Textos sobre Educación Popular 


\section{B) Entrevistas semi estructuradas}

\section{Participantes}

En lo que respecta a las entrevistas semi estructuradas y considerando los dos escenarios de trabajo para la investigación doctoral participaron 15 personas en total. Se realizaron en Bogotá entrevistas a líderes sociales integrantes de los Observatorios Ciudadanos de Control Social que se constituyeron a través de la herramienta ISO/IWA 4. Mientras que en el contexto de Cochabamba y Sacaba se realizaron entrevistas a líderes del Observatorio Cochabamba Nos Une, la Unidad de Transparencia del Gobierno Autónomo Municipal de Sacaba y líderes sociales integrantes del Consejo de Coordinación de Participación y Control Social de Sacaba.

\section{Instrumentos}

Para la realización de dichas entrevistas se diseñaron los instrumentos guía teniendo en cuenta los perfiles de las personas a entrevistar, a saber:

Experiencias en Bogotá-Colombia.

- Entrevistas a ciudadanos participantes de la experiencia de evaluación PP Bogotá

- Entrevistas a pasantes que acompañaron los procesos de construcción OC Bogotá

- Entrevistas a líderes sociales integrantes de los Observatorios Ciudadanos

Experiencias en Cochabamba- Bolivia

- -Entrevistas a líderes sociales de OTB y líderes de organizaciones sociales de control social

- Entrevista con funcionarios vinculados con política pública y potenciación de la participación ciudadana.

- Entrevista a integrantes de Observatorio Ciudadano Cochabamba Nos Une

Por una parte, el primer instrumento guía de entrevista está conformado por los siguientes bloques: a) experiencia personal del entrevistado (respecto a la política pública y la planificación/evaluación); b) categorías vinculadas con la investigación (del cuadro de ordenadores epistemológicos, ya presentado) y c) evaluación, ciclo de políticas públicas e incidencia ciudadana, con el objetivo de indagar por experiencias en el contexto local. -Ver anexos 5 a 9-

En tanto se construyen varias guías de entrevista en razón de las que se plantearon en líneas anteriores, igualmente se construyen matrices analíticas de información para cada tipología de entrevista cruzando las variables actor social indagado vs categorías planteadas en la investigación. 


\section{Resultados}

En cuanto al procedimiento desarrollado para la realización de las entrevistas se destaca que en el escenario bogotano, se contó con la oportunidad de formar parte del equipo consultor que llevó a cabo la experiencia de conformación de los Observatorios Ciudadanos a través de la herramienta ISO/IWA 4, ello permitió un contacto permanente con las personas e instituciones que formaron parte de dicho proceso y en este marco de relación se llevaron a cabo las entrevistas mencionadas.

En el escenario boliviano se estableció contacto con la Unidad de Transparencia del Gobierno Autónomo Municipal de Sacaba en donde uno de sus técnicos proporcionó información en cuanto a otros contactos y con él se logró llevar a cabo la entrevista respectiva. Por otra parte, se establece contacto con el Consejo de Coordinación de la Participación y Control Social en el Municipio de Sacaba y allí se realizan entrevistas a varios de los líderes sociales que de los 7 distritos forman parte de esta instancia.

En lo que se relaciona con el análisis de la información resultante de esta técnica de investigación, resultó importante la construcción de Matrices de análisis de información, cuyo objetivo era el de organizar las transcripciones de las entrevistas en relación a la información que se necesitaba analizar para efectos del trabajo doctoral y en consonancia con las categorías de investigación que se plantearon, de acuerdo a ello a continuación se presentan dichas matrices. En primer lugar, se encuentra la matriz analítica referida a los relatos de los actores sociales de la experiencia de Bogotá, y en segundo lugar se da paso a la sistematización de información de los relatos de la experiencia Boliviana en Sacaba.

\section{MATRIZ ANALÍTICA INFORMACIÓN OBTENIDA A PARTIR DE LOS RELATOS DE LAS ENTREVISTAS REALIZADAS EN BOGOTÁ}

\begin{tabular}{|l|l|}
\hline $\begin{array}{l}\text { Localidad de } \\
\text { entrevistado }\end{array}$ & \multicolumn{1}{c}{ BARRIOS UNIDOS } \\
\hline $\begin{array}{l}\text { Papel de la } \\
\text { acompansidad en el }\end{array}$ & $\begin{array}{l}\text { Pues siempre ha sido un trabajo de acompañamiento, un trabajo en el cual, no } \\
\text { guían a la ciudadanía, precisamente sobre una herramienta, una herramienta con } \\
\text { la cual estamos haciendo el control de calidad a la administración local de Barrios } \\
\text { Unidos inicialmente. Hemos dejado la sugerencia de que podamos crecer como } \\
\text { observatorio uniendo a algunos representantes de cada uno para hacer un } \\
\text { observatorio a la Alcaldía Mayor, ya que la herramienta está, pero el } \\
\text { acompañamiento de, en este caso de las estudiantes de la Universidad Nacional }\end{array}$ \\
$\begin{array}{l}\text { Dina y de la Universidad Minuto de Dios fue excelente, fue un apoyo muy } \\
\text { interesante porque las dudas fueron resueltas, y ellas se esmeraban por ser } \\
\text { también como interlocutores con la Veeduría y con la misma Alcaldía y estar } \\
\text { mediando algunas cosas que de pronto surgían de algunos de nuestros líderes } \\
\text { porque se trataban de salir de la herramienta, yo a veces de pronto era uno de } \\
\text { ellos, en el que, pues queríamos, pues como hacerles una rendición de cuentas } \\
\text { porque uno se entera de muchas falencias a veces de la administración, pero había } \\
\text { que marcarla en la herramienta, entonces ellas fueron como siendo esa guía y esa, } \\
\text { cómo se le puede decir... conductoras, hacían que nos enfocáramos precisamente } \\
\text { en el desarrollo de hacer el control de calidad con la herramienta. }\end{array}$
\end{tabular}




\begin{tabular}{|c|c|}
\hline $\begin{array}{l}\text { Transformación } \\
\text { del interés en } \\
\text { asuntos públicos }\end{array}$ & $\begin{array}{l}\text { Sí, el Observatorio ha sido como te digo un refuerzo a esa participación } \\
\text { ciudadana, gracias a Dios en Barrios Unidos hemos venido trabajando en la } \\
\text { participación y lógicamente el espacio cívico es el conjunto de todos los espacios } \\
\text { de participación, o sea, nosotros somos el conjunto mayor sí, ahí están metidos } \\
\text { los copacos, los consejos, está metido asojuntas, juntas comunales, la misma } \\
\text { academia sí?, forma parte de nosotros, del espacio cívico de participación, la } \\
\text { Universidad Nacional forma parte del gran espacio cívico de participación de } \\
\text { Bogotá, por decir algo, entonces nosotros reunimos todo eso y hemos logrado } \\
\text { actividades importantes y reforzar la participación ciudadana y nos parece algo } \\
\text { bonito que la administración se costumbre a que tiene que tener calidad, y } \\
\text { entonces esta herramienta que manejamos la hizo } 18091 \text { llamada aquí ISO/IWA } \\
\text { 4, va calificando eso, entonces ellos saben que tiene que hacer un esfuerzo y cada } \\
\text { vez ir mejorando sus actividades. } \\
\text { Se fortaleció porque vimos la oportunidad de tener una herramienta, una } \\
\text { herramienta maravillosa en el cual se le hace un control de calidad, después } \\
\text { podíamos entrara a hacer calificadores de la administración, entonces eso sí muy } \\
\text { interesante para la ciudadanía, saber que los puede calificar y no es ese el fin no?, } \\
\text { realmente el fin que nosotros buscamos, yo como coordinador de coordinadores y } \\
\text { como líder de la Localidad de Barrios Unidos al ser el vocero del espacio cívico, } \\
\text { qué queremos, que realmente las necesidades básicas insatisfechas de nuestra } \\
\text { población más vulnerable ser atendida, ese es el gran quid del asunto, es de que } \\
\text { sólo tengamos una calificación y amarillo, verde rojo, no!, sino que lleguemos a } \\
\text { que a través de ese mecanismo, la administración se interese por esas personas } \\
\text { más vulnerables que tenemos, y como devolver esa labor social desde nosotros } \\
\text { como ciudadanos. }\end{array}$ \\
\hline $\begin{array}{l}\text { Cómo se } \\
\text { transforma la } \\
\text { concepción e } \\
\text { interés por lo } \\
\text { público. Antes y } \\
\text { después del OC }\end{array}$ & $\begin{array}{l}\text { Hemos sido como un ejemplo, nosotros logramos en una de las reuniones } \\
\text { precisamente en la rendición de cuentas del Alcalde nosotros rendimos cuentas } \\
\text { también, de lo del Observatorio, también nos hemos ido visibilizando y queremos } \\
\text { es, ojalá que continuemos con el apoyo de la academia a fortalecernos sugerimos, } \\
\text { de que no solamente sean guías sino partícipes, o sea, que los Observatorios } \\
\text { tengan más estudiantes universitarios que cumplan entre comillas su "labor } \\
\text { social", yo no sé si eso lo tengan en algunas de las, cómo te diría, materias como } \\
\text { tal, el tema de labor social que puedan estar con los Observatorios } \\
\text { fortaleciéndolos, no uno sino varios, ojalá bienvenidos todos los que lleguen a } \\
\text { fortalecer, es una sugerencia no?, que estén ahí con nosotros y ayudándonos y que } \\
\text { uno se meta en un cuadrante o dos en un cuadrante y tendríamos el apoyo de la } \\
\text { academia. }\end{array}$ \\
\hline $\begin{array}{l}\text { Importancia de } \\
\text { la participación } \\
\text { en espacios como } \\
\text { el observatorio } \\
\text { ciudadano }\end{array}$ & $\begin{array}{l}\text { Pues que en primera medida es una herramienta nueva, la cual no existía, } \\
\text { entonces le está cambiando el paradigma a la administración de que puede hacer } \\
\text { lo que se le da la gana, y me perdonas ser tan crudo no?, ellos ya se dan a } \\
\text { entender de que habiendo un control de calidad pues no van a hacer lo que se les } \\
\text { da la gana sino van a mejorar la inversión de los recursos, y todo en beneficio de } \\
\text { nuestra comunidad, esa es la importancia que vemos en esa herramienta. }\end{array}$ \\
\hline $\begin{array}{l}\text { Considera usted } \\
\text { que queda el } \\
\text { Observatorio } \\
\text { consolidado y en } \\
\text { capacidad de } \\
\text { agenciar sobre lo } \\
\text { público de mejor } \\
\text { manera }\end{array}$ & $\begin{array}{l}\text { Sí, hubo una guían en donde nos enseñaron a manejar los cuadrantes, en donde no } \\
\text { llegábamos tan en frío a las reuniones, aunque hubo ehhh momentos de verdad, } \\
\text { en donde ni ellas ni uno sabíamos cómo íbamos a sacar adelante el Observatorio, } \\
\text { pero nos preparábamos, tratábamos de que esos momentos no fueran tan difíciles, } \\
\text { o sea, íbamos preparados, y sí había una metodología en el cual ellas trataron de } \\
\text { enseñarnos a los ciudadanos a manejar la herramienta. }\end{array}$ \\
\hline
\end{tabular}




\begin{tabular}{|c|c|}
\hline $\begin{array}{l}\text { Localidad de } \\
\text { entrevistado }\end{array}$ & FONTIBÓN \\
\hline $\begin{array}{l}\text { Papel de la } \\
\text { universidad en el } \\
\text { acompañamiento }\end{array}$ & $\begin{array}{l}\text { La labor de la Universidad, fue básicamente hacer una convocatoria inicialmente } \\
\text { para crear un grupo semilla para escuchar por primera vez en febrero del año } \\
\text { pasado sobre la herramienta IWA } 4 \text { y luego, mantener la convocatoria abierta } \\
\text { hasta poder consolidar el Observatorio que se consolidó unos dos meses después; } \\
\text { la labor de ahí en adelante fue de acompañamiento ehhh, en todo sentido, } \\
\text { logística, llevaba actas, hacía todo lo que fuera necesario para que el Observatorio } \\
\text { fuera tomando su ruta poco a poco. }\end{array}$ \\
\hline $\begin{array}{l}\text { Transformación } \\
\text { del interés en } \\
\text { asuntos públicos }\end{array}$ & $\begin{array}{l}\text { Se ha transformado en el sentido en que se ha fortalecido, tengo ya una historia } \\
\text { larga en eso, he sido misionero de la Iglesia Católica, he estado en todos los } \\
\text { barrios del Noroccidente trabajando por la pobreza, en el sur en Patio Bonito con } \\
\text { madres ehhh cabeza de familia, tengo ya un recorrido en eso y el IWA, la } \\
\text { herramienta me ha permitido como centrar, ver que es bueno tener en el bolsillo } \\
\text { una herramienta bien diseñada, un herramienta suiza que aunque merece algunas } \\
\text { mejoras de diseño pero la herramienta sea la base del proceso. }\end{array}$ \\
\hline $\begin{array}{l}\text { Cómo se } \\
\text { transforma la } \\
\text { concepción e } \\
\text { interés por lo } \\
\text { público. Antes y } \\
\text { después del OC }\end{array}$ & $\begin{array}{l}\text { En las personas del Observatorio considero que sí, porque el control social suele } \\
\text { hacerse y la participación suele hacerse de manera desorganizada con un poco, } \\
\text { una mezcla entre cerebro estómago pero sin metodologías, y pienso que es } \\
\text { necesario definitivamente meternos un poquito con una metodología y el IWA } 4 \\
\text { sin ser una metodología perfecta, pero es una metodología que permite cierto } \\
\text { nivel de adaptabilidad, cierto nivel de crecimiento, y eso ha hecho que las } \\
\text { personas se transformen, al tratar de transformar la herramienta las personas se } \\
\text { han transformado y ya su labor de control social nunca vuelve a ser lo mismo una } \\
\text { vez que pasan por una metodología, la mayoría de esas personas no tienen ningún } \\
\text { tipo de preparación, algunos bachillerato otros ni siquiera eso y para ellos } \\
\text { enfrentarse a una metodología una organización mental y todo es algo complicado } \\
\text { y el IWA } 4 \text { creo que lo ha conseguido para algunos, yo diría que estamos } \\
\text { hablando de un } 40 \% \text { de las personas del Observatorio, otros simplemente han } \\
\text { ido, escuchan un poco, están durante alguna parte del proceso pero nunca lo } \\
\text { introyectan. }\end{array}$ \\
\hline $\begin{array}{l}\text { Importancia de } \\
\text { la participación } \\
\text { en espacios como } \\
\text { el observatorio } \\
\text { ciudadano }\end{array}$ & $\begin{array}{l}\text { Bueno ahí si voy a hacer copialina y voy a utilizar las palabras de la Veedora } \\
\text { Distrital, y es que el Observatorio por el hecho de corresponder a una } \\
\text { metodología que ahora es norma internacional, al anexo b de la norma ISO } \\
\text { 18091, ehhhh, facilita el camino para que se convierta en el sitio expedito para } \\
\text { hacer control social, ya no más pequeños núcleos desorganizados de ciudadanos } \\
\text { con esa mezcla que llamo yo de cerebro y estómago, sino unas personas que } \\
\text { corresponden a una metodología que tienen una ruta que seguir y una ruta que } \\
\text { ellos mismo pueden modificar y hacer crecer. }\end{array}$ \\
\hline $\begin{array}{l}\text { Considera usted } \\
\text { que queda el } \\
\text { Observatorio } \\
\text { consolidado y en } \\
\text { capacidad de } \\
\text { agenciar sobre lo } \\
\text { público de mejor } \\
\text { manera }\end{array}$ & $\begin{array}{l}\text { Nos costó trabajo después de la rendición de cuentas, incluso durante esa parte, } \\
\text { por eso nos costó trabajo volver a consolidarnos como equipo y después de } \\
\text { ciertos inconvenientes podría decir yo que hace unos dos miércoles volvimos a } \\
\text { sentir éramos un equipo de trabajo, sabemos lo que podemos hacer, ya lo hicimos, } \\
\text { nuestro informe de fue de altísima calidad, nuestro proceso fue muy bueno, pero } \\
\text { nos costó trabajo volver a consolidarnos como Observatorio, en este momento } \\
\text { estamos en proceso, algunas personas se retiraron, estamos en proceso de } \\
\text { incorporar a otras, de educarlas y todo, para darle fortaleza al Observatorio; } \\
\text { pienso que todavía no conocemos cómo va a funcionar el Observatorio en el } \\
\text { futuro porque quizá no sea con los mismos miembros que empezamos, vamos a } \\
\text { empezar a extrañar a algunas personas pero va a ser hasta necesario que se vayan, } \\
\text { porque son personas que no han permitido el crecimiento del Observatorio, que } \\
\text { ha tratado de frenarlo, que tienen intereses políticos, habían personas con } \\
\text { intereses políticos, por ejemplo veían eso como una plataforma política, otros con } \\
\text { intereses económicos o muy personales, estamos tratando de meter en este } \\
\text { momento sólo a personas que tengan un real liderazgo; la primera convocatoria } \\
\text { facilitó quizá que se filtraran algunas personas, por amistad, bueno, por algún tipo } \\
\text { de relación personal o algo, ahora estamos tratando de pulir la convocatoria para } \\
\text { que el Observatorio sea realmente un Observatorio de líderes sociales. }\end{array}$ \\
\hline
\end{tabular}




\begin{tabular}{|c|c|}
\hline $\begin{array}{l}\text { Localidad de } \\
\text { entrevistado }\end{array}$ & KENNEDY \\
\hline $\begin{array}{l}\text { Papel de la } \\
\text { universidad en el } \\
\text { acompañamiento }\end{array}$ & $\begin{array}{l}\text { Es importante que como ciudadanos, la universidad conozca la importancia } \\
\text { obviamente de hacer control social, el IWA es una herramienta de hacer control } \\
\text { social y nosotros como ciudadanos, los que pertenecemos a grupos o solitos, } \\
\text { siempre hemos visto a los estudiantes como sujetos importantes pero que estaban } \\
\text { allá en la universidad, y a nivel social, ese ejercicio cuando nos dijeron "vienen } \\
\text { los estudiantes a las Localidades" y uno "wow" ehhhh "qué lindo, vienen los } \\
\text { estudiantes es a formar a los ciudadanos", porque ellos tienen los procesos, ellos } \\
\text { saben de escribir textos, saben de lectura, saben de guías, mientras que el } \\
\text { ciudadano corriente puede tener la berraquera de denunciar, puede tener la } \\
\text { berraquera de hacer control, pero ese tipo de procesos ya a nivel educativo, no lo } \\
\text { tienen, entonces uno imaravilloso!. Iniciamos el proceso y afortunadamente para } \\
\text { nosotros, tuvimos, en sus inicios el acompañamiento únicamente de los } \\
\text { estudiantes, de la Veeduría no tuvimos ese acompañamiento iniciando; estuvo con } \\
\text { nosotros Estefanía Cerquera, ella no es de la Nacional, es de la Uniminuto, pero } \\
\text { igual una niña a pesar de su edad porque son niños para nosotros, ehh, pero con, } \\
\text { con una idea social, con esa idea de prestar ehh todo su saber, acompañar a un } \\
\text { grupo y decir "mire está ésta herramienta y es de ésta manera", acompañarnos, } \\
\text { guiarnos a hacer los documentos, para nosotros fue muy importante, y me parece } \\
\text { que no sólo la Facultad de... Trabajo Social sino, consideramos que éste espacio } \\
\text { es valioso para todos los estudiantes, unos dice "qué rico que los de Derechos } \\
\text { tengan esto y no salen de la Universidad como... como terminando su parte } \\
\text { netamente académica sino el sólo hecho de pisar el terreno real de lo social ya les } \\
\text { da un bagaje en su experiencia profesional. }\end{array}$ \\
\hline $\begin{array}{l}\text { Transformación } \\
\text { del interés en } \\
\text { asuntos públicos }\end{array}$ & $\begin{array}{l}\text { Sí, uno porque, puede estar el deseo de hacer control social, porque es un deber y } \\
\text { un derecho pero, se tenía como el deber y el derecho pero ya manejando ésta } \\
\text { herramienta nos dio los elementos para estudiar y profundizar y tener argumentos } \\
\text { concisos para exigir a los gobiernos, que ya no es que como grupo pedimos sino } \\
\text { que hay una norma y que es internacional y que está muy bien organizada y nos } \\
\text { debemos es estudiar, entonces eso nos da a los ciudadanos a nivel persona, de que } \\
\text { para hacer control social, hoy tengo que prepararme, no sólo organizarme como } \\
\text { grupo social sino que tengo que estudiar, tengo que educarme para ello para } \\
\text { poder exigir, porque puedo exigir es con la Ley, pero si yo no la conozco, si yo no } \\
\text { leo, no me preparo para ello, y con pataleta ya sabemos que no y menos por otros } \\
\text { medios, no vamos a exigir que haya transparencia y más en el manejo de dineros } \\
\text { públicos en lo que es la gobernanza. }\end{array}$ \\
\hline $\begin{array}{l}\text { Cómo se } \\
\text { transforma la } \\
\text { concepción e } \\
\text { interés por lo } \\
\text { público. Antes y } \\
\text { después del OC }\end{array}$ & $\begin{array}{l}\text { Ś, igual, ingresamos números de personas, ingresamos en Kennedy más de } 15 \\
\text { organizaciones y en el proceso la gente va desertando, va desertando, va } \\
\text { desertando porque la misma herramienta, el mismo proceso, no digamos que es } \\
\text { estricto sino organizado, como ciudadanos no estamos organizados, no estamos } \\
\text { por cultura no estamos listos a hacer un proceso, sino queremos como proponer } \\
\text { algo y que aleguemos y se dé ya, que nos pongan cuidado y se dio o no se dio, en } \\
\text { cambio esto nos decían hay un derrotero, hay un camino organizado, y es un } \\
\text { proceso que tiene etapas, es un proceso de aprendizaje, es un proceso de ensayo } \\
\text { pero que es a largo plazo, o sea, quienes inician como todo, es lo más fuerte, pero } \\
\text { esto es a futuro y las personas que nos quedamos y los que van llegando } \\
\text { fortalecen el grupo como organización, como Observatorio y vemos, vemos que } \\
\text { va creciendo. }\end{array}$ \\
\hline $\begin{array}{l}\text { Importancia de } \\
\text { la participación } \\
\text { en espacios como } \\
\text { el observatorio } \\
\text { ciudadano }\end{array}$ & $\begin{array}{l}\text { La oportunidad que tenemos como ciudadanos en un elemento organizado como } \\
\text { la herramienta IWA, aprender y obviamente exigir, exigir que ella se cumpla, y } \\
\text { ella hoy, ya en el proceso que estamos nos ha mostrado que nuestros gobiernos, } \\
\text { no podemos decir que la transparencia no esté porque no la hacen sino que se } \\
\text { trabaja en una forma muy desordenada, muy desarticulada, entonces cuando uno } \\
\text { va a hablar de... de competencia e incumbencia "es que esto no nos compete", } \\
\text { pero cuando ya estudiamos la norma, cuando vemos lo que está en el Plan de } \\
\text { Desarrollo en el Plan Local lo llamamos "miré acá que esto está planeado y } \\
\text { ustedes no, no nos están dando evidencia de eso" y ellos quedan "miércoles ésta } \\
\text { gente del Observatorio, mire éstos ciudadanos como se están organizando", y } \\
\text { resulta que la herramienta nos dio los elementos, entonces eso, no para nosotros }\end{array}$ \\
\hline
\end{tabular}




\begin{tabular}{|c|c|}
\hline & $\begin{array}{l}\text { como Observatorio sino... que tenemos nosotros como grupo el deber de ampliar } \\
\text { lo que se está haciendo, lo que viene más adelante, especialmente estudiantes y } \\
\text { juventudes porque en dos tres años es posible que nosotros no estemos y } \\
\text { queremos es que ésta herramienta la sigan los estudiantes, ehhh, por lo menos la } \\
\text { primer niña que ya no está con nosotros conoce muy bien hoy Kennedy y dijo } \\
\text { "ya no como estudiante, voy a ingresar al Observatorio", me parece genial, que } \\
\text { no le estamos diciendo, "ya no está usted siguiendo, o no está usted buscando un } \\
\text { Cupido en la Veeduría ni nada por el estilo", pero dice "no, es que sé para donde } \\
\text { me lleva la herramienta", entonces ya, logró el objetivo. }\end{array}$ \\
\hline $\begin{array}{l}\text { Considera usted } \\
\text { que queda el } \\
\text { Observatorio } \\
\text { consolidado y en } \\
\text { capacidad de } \\
\text { agenciar sobre lo } \\
\text { público de mejor } \\
\text { manera }\end{array}$ & $\begin{array}{l}\text { Precisamente porque conocimos a través del acompañamiento de la estudiante, } \\
\text { tuvimos más claridad sobre la herramienta si? y aprendimos que, que debíamos } \\
\text { profundizar, aprendimos a estudiar, a leer de donde viene la herramienta, para } \\
\text { dónde va, que no era solamente aquí con estos ítems, vamos a preguntar, sino } \\
\text { realmente fundamentarnos sobre cada uno de ellos, eso se lo da a uno el } \\
\text { estudiante, y eso es lo valioso que el estudiante le da a uno esa gana como que lo } \\
\text { ve que está estudiando y uno también. } \\
\text { Si es posible que la Universidad a nivel de sus facultades pudiera, que todas las } \\
\text { facultades tengan esa experiencia con, con los ciudadanos, si bien es cierto no } \\
\text { solamente en el Observatorio porque ésta es una organización, pero en todos los } \\
\text { entes, si vamos a ver en educación, en salud, que pudieran ellos participar y de } \\
\text { qué manera? es a través de la educación, porque ustedes tiene una formación que } \\
\text { hoy en día en cualquier lugar que lleguen, hay personas que necesitan por salud y } \\
\text { van a un grupo de la salud, pero si es el estudiante el que está ahí de guía, le } \\
\text { genera a uno confianza al dialogar al que nos enseñen, aunque no se para } \\
\text { directamente el que nos llega a exigir... pero es un derrotero; entonces me parece } \\
\text { no solamente la facultad de... los que conocí es de Ciencias de... Trabajo Social, } \\
\text { de Sociología, pero otros estudiantes no, pero me parece importante que no } \\
\text { solamente la Universidad porque estamos hablando como a nivel universitario, no } \\
\text { ésta como Universidad si? porque fue un sinnúmero de universidades, entonces } \\
\text { nos parece que si, hoy decimos van a hacer ese trabajo social, que realmente } \\
\text { fueran todos y tuvieran la oportunidad de ir realmente al campo, donde está la } \\
\text { necesidad y es desde allí es donde se aprende. }\end{array}$ \\
\hline $\begin{array}{l}\text { Localidad de } \\
\text { entrevistado }\end{array}$ & PUENTE ARANDA \\
\hline $\begin{array}{l}\text { Papel de la } \\
\text { universidad en el } \\
\text { acompañamiento }\end{array}$ & $\begin{array}{l}\text { Esencialmente era el de la convocatoria, ellos, pues los contactamos con } \\
\text { los profesionales de ahí de la Alcaldía para conseguir la base de datos y se } \\
\text { encargaron de hacer fue llamadas y convocar. }\end{array}$ \\
\hline $\begin{array}{l}\text { Transformación } \\
\text { del interés en } \\
\text { asuntos públicos }\end{array}$ & $\begin{array}{l}\text { Yo eso he sido un bichito de muchos años, no solamente ahorita en el } \\
\text { Observatorio, de mucho antes, porque pues me gusta la política, estoy } \\
\text { metido, he sido presidente de juntas, fui Edil, entonces esto y pues yo veo } \\
\text { esto como y más ahorita me metí al Consejo de Planeación Local y soy el } \\
\text { Secretario Ejecutivo y nos tocó dar el concepto sobre el Plan de } \\
\text { Desarrollo Local entonces conozco algo de planeación, sobre el Plan de } \\
\text { Desarrollo Distrital en el Consejo Territorial que dimos el concepto sobre } \\
\text { el Plan de Desarrollo Distrital, sobre el POT, entonces yo lo veo como una } \\
\text { herramienta valiosa para la rendición de cuentas de las Administraciones } \\
\text { Locales, lástima que en nuestra Localidad el Alcalde no lo ha entendido } \\
\text { así, con él ha sido muy complicado, en éste momento estamos, porque se } \\
\text { hizo la verificación, se hizo el dictamen y se está socializando con ellos } \\
\text { pero ha sido complicado, las niñas que tienen Alexandra y la otra que } \\
\text { tiene que consiguieron de Gestión... se me olvidó el nombre, pero ellas no } \\
\text { no no. Diana en determinado momento me dijo, me dijo hace como un } \\
\text { mes, "déjeme" porque es que yo siempre los he criticado, al Alcalde de } \\
\text { frente en la rendición de cuentas, entonces tienen como una siempre de } \\
\text { rechazo, como de animadversión contra mí, entonces Diana me llegó, me } \\
\text { mencionó y me dijo "Sigifredo, déjeme que yo me reúno unas dos o tres } \\
\text { veces con ellas y después más bien...", porque siempre ha habido como }\end{array}$ \\
\hline
\end{tabular}




\begin{tabular}{|c|c|}
\hline & $\begin{array}{l}\text { reticencia, como entonces, pero sí, la conozco, veo que es importante pero } \\
\text { lástima que no en todos los gobiernos locales ha sido aceptada de la } \\
\text { misma manera. Conozco por ejemplo Barrios Unidos, el Alcalde es un } \\
\text { berraco que dijo "no, es que aquí no están dando en bandeja de plata la } \\
\text { herramienta para la rendición de cuentas", y el hombre si se sentaba desde } \\
\text { las ocho hasta las dos de la tarde ahí y llamaba a los funcionarios y traían } \\
\text { la información traían los funcionarios, traían lo documentos, mejor dicho, } \\
\text { colaborador 1A. En cambio, éste Alcalde de Puente Aranda, no sé, ha sido } \\
\text { difícil, a pesar de que no hemos bajado la guardia pero difícil, difícil con } \\
\text { él. Poca voluntad política para ello. }\end{array}$ \\
\hline $\begin{array}{l}\text { Cómo se } \\
\text { transforma la } \\
\text { concepción e } \\
\text { interés por lo } \\
\text { público. Antes y } \\
\text { después del OC }\end{array}$ & $\begin{array}{l}\text { Sí, porque ahí estamos los cuatro coordinadores de los cuatro cuadrantes o } \\
\text { ejes temático, son compañeros que conocen, manejan, son interesados, } \\
\text { Flor Lucila, ella fue funcionaria, manejó los Consejos Locales de Puente } \\
\text { Aranda, Marco Tulio está metido en lo ambiental toda una vida, y Pablo } \\
\text { en la parte empresarial, entonces, sobre todo ellos cuatro, ellos tres y mi } \\
\text { persona pues sí. }\end{array}$ \\
\hline $\begin{array}{l}\text { Considera usted } \\
\text { que queda el } \\
\text { Observatorio } \\
\text { consolidado y en } \\
\text { capacidad de } \\
\text { agenciar sobre lo } \\
\text { público de mejor } \\
\text { manera }\end{array}$ & $\begin{array}{l}\text { Sí pero muy es decir, muy poca representación de parte de los que están } \\
\text { constituyendo el Observatorio como son en este momento, lo que le comentaba, } \\
\text { en estos momentos somos, que deberían ser } 15 \text { ciudadanos, no estamos sino } \\
\text { cuatro, entonces pues, de nosotros cuatro pues que tenemos el conocimiento, la } \\
\text { capacidad, pues sí, pues nos hemos podido dar cuenta que... así sea de manera } \\
\text { obligatoria a través de un derecho de petición porque nos toca todo con derecho } \\
\text { de petición para que nos den la información, para que nos respondan, para que } \\
\text { nos den el espacio, para nos invitaran a un Consejo Local de Gobierno, qué } \\
\text { tragedia!, y con copia, derecho de petición con copia a Personería Distrital, } \\
\text { entonces si no es así a la brava, obligados no lo hacen, la Administración no, en el } \\
\text { caso de Puente Aranda no lo hacen, no sé otras Localidades, no, yo sé que en } \\
\text { otras Localidades han hecho más voluntad política y ha habido mucha } \\
\text { colaboración en ese sentido y ha habido mucha más acogida y más respaldo, más } \\
\text { apoyo a los Observatorios, a pesar de eso nosotros en Puente Aranda no vamos a } \\
\text { dar el brazo a torcer, tenemos que seguir, sabemos de las bondades de la } \\
\text { herramienta y de los importante que es, vamos a ver. }\end{array}$ \\
\hline
\end{tabular}

De igual manera, se realizó una entrevista específica para aplicar a Observatorios Ciudadanos de Bogotá, en varias localidades. Ello para tener un panorama sobre la actualidad de estos espacios, y las dinámicas en las que se desenvuelven a 2016, ello con el fin de hacer un análisis sobre la sostenibilidad en el tiempo que ha tenido el proceso tomando en consideración que el ejercicio de incidencia ciudadana se constituyó en 2013 a partir del ejercicio coordinado con la Universidad Nacional de Colombia y la Veeduría Distrital, en el marco de la evaluación a la gestión pública de la ciudad a partir de la herramienta ISO/IWA 4. Dicha entrevista se diseñó y se montó en la plataforma de Google Forms con el objetivo de ser enviada a quiénes la contestarían. A continuación, se presenta una síntesis de las respuestas obtenidas:

1. ¿Qué es el control social? Y ¿Qué es la evaluación de políticas públicas?

Control social en una acción ciudadana orientada a observar de cerca el manejo de los recursos públicos y de todas las acciones encaminadas al bienestar de los ciudadanos y de su entorno natural y construido.

Evaluación consiste en valorar positiva o negativamente la gestión.

Control social es un derecho, una acción ciudadana, un logro de la movilización social

2. ¿Qué son y por qué es importante que existan los Observatorios Ciudadanos? 
Los OC son importantes porque utilizan como base una metodología muy organizada (Norma ISO 18091:2014) y se articulan con entidades de control social del gobierno (Veeduría Distrital) para alcanzar sus fines.

Son espacios para incidir en las políticas públicas, para discutir los ritmos de la gestión pública, para velar por los recursos de los ciudadanos, para controlar según las leyes lo que hace el gobierno, para establecer canales entre el gobierno y la sociedad

3. El trabajo que desarrolla el Observatorio ¿Es de control social o de evaluación de políticas públicas?

El trabajo del OC9 (Observatorio Ciudadano de Fontibón) tiene que ver con verificar que existan unos mínimos de gobernabilidad y propende por la creación de ambientes de confianza entre los ciudadanos y el gobierno. Su verificación tiene que ver con políticas públicas, planes, programas, proyectos y acciones que se den en en territorio.

Nuestro observatorio hace control social a la gestión pública

Este OC es de control social y a partir de eso se evalúa la gestión de la alcaldía de la localidad

4. ¿Cómo se desarrolla el trabajo en el Observatorio?

El observatorio se reúne una vez a la semana, los jueves a las 2 de la tarde y excepcionalmente fija otros espacios de encuentro para analizar el devenir de la localidad. En las reuniones se hace análisis de acciones de gobierno, acciones de la comunidad, se revisa y ajusta la herramienta ISO 18091 a nivel de subindicadores, se adelantan capacitaciones, etc.

Nos reunimos cada mes, y a partir de allí planeamos las actividades y los procesos de rendición de cuentas

Nos reunimos cada 15 días, hay que tener una periodicidad, y en estas reuniones construimos colectivamente una agenda de trabajo que nos permita orientar el trabajo que hacemos. Aunque no tenemos presupuesto tratamos que el OC se sostenga en el tiempo.

5. ¿Cómo y cuáles son las metodologías para evaluar las políticas públicas en la localidad? (por ejemplo, existen indicadores, cómo participa la ciudadanía, cada cuánto se hace)

La norma ISO 18091 cuenta con una base inamovible de 39 indicadores, de los cuales emergen subindicadores (cuyo número varía). El OC y el gobierno se sientan en una "Mesa de pactos", en la que hacen acuerdos sobre los documentos requeridos como evidencia de las acciones del gobierno, sobre la metodología, etc. El gobierno envía los documentos al OC El gobierno y el OC se reúnen en una "Mesa de Verificación" en la que se hace entrega y explicación de los documentos. En esa mesa el OC califica al gobierno. El OC elabora un informe y lo presenta en la rendición pública de cuentas a la comunidad.

6. ¿Cuáles los aprendizajes de la experiencia con la Universidad Nacional y la Veeduría Distrital en 2013?

La Universidad Nacional de Colombia estuvo en una primera fase como facilitadora del proceso, ofreciendo capacitaciones, consolidación de información y coordinación de otras universidades.

A cómo construir un espacio de participación ciudadana, la importancia de éste en las realidades de cada localidad y pensar un observatorio a nivel distrital.

7. Actualmente ¿En qué proceso se encuentra el Observatorio? 
Actualmente estamos a la espera de la nueva versión de la herramienta ISO 18091:2014 para acordar con el gobierno fechas de mesas de pactos y verificación.

Continúanos reuniéndonos, esperamos que alguna entidad apoye nuestro trabajo para no perder la experiencia que hemos adquirido

Reuniéndonos como siempre buscando financiación.

8. ¿Cuáles son los principales logros que ha tenido el Observatorio?

Hemos sido reconocidos en algunos momentos del proceso por: -Ser el mejor Observatorios de la ciudad. -El mejor informe final de gestión -El observatorio más propositivo -El observatorio más creativo -Creación de medios de comunicación alternativa (https://www.facebook.com/ObservatorioCiudadanoFontibon/)

9. ¿Qué impacto tiene el Observatorio en cuanto a los procesos de rendición de cuentas en la localidad?

Se nos asigna un tiempo igual al que se da al gobierno y en este tiempo hemos conseguido al paso del tiempo que la ciudadanía se interese por el control social argumental y tome decisiones de participar de cerca.

10. ¿El Observatorio tiene incidencia en los procesos que desarrolla la administración local? ¿Por qué? ¿Cómo se logró

Los miembros del OC están de cerca en todos los procesos: --Participan activamente en la formulación del Plan de desarrollo de la localidad. -Hacen parte de otros espacios de participación como la Mesa ambiental, la mesa de asuntos educativos (padres y madres de familia, Veedurías especializadas, etc.) La base del éxito está en tener una forma adecuada de acercamiento con la institucionalidad en la que se dejan de lado los juicios irresponsables y las agresiones y se construyen argumentos basados en evidencias.

11. ¿Cuáles han sido las principales dificultades del Observatorio y cuáles son en la actualidad sus necesidades?

Sostenibilidad económica: el OC requiere cada vez más tiempo para desarrollar sus actividades, pero los miembros (que son padres y madres) no cuentan con recursos económicos para sostenerse. Se han hecho propuestas al gobierno para que se generen los caminos para alcanzar esta sostenibilidad, pero no se ha tenido respuesta. -La sostenibilidad política es muy incierta y depende de la voluntad de cada administración. -La sostenibilidad técnica depende de la Veeduría Distrital y el OC cuenta con muy pocas personas capacitadas para esa labor. Si estas personas se van del OC, el proceso puede llegar a su fin.

12. ¿Qué consejos daría el OC9 a ciudadanos que quisieran conformar un Observatorio Ciudadano en otras ciudades, en otros países?

Les aconsejaríamos que es el camino correcto a la vez que una obligación de los ciudadanos. Los invitaríamos a que busquen en su país las diferentes formas de participación (Observatorios, veedurías ciudadanas, grupos de interés, ...) y se unan a ellas. 


\section{MATRIZ DE SISTEMATIZACIÓN DE INFORMACIÓN ENTREVISTAS REALIZADAS EN SACABA-COCHABAMBA}

\begin{tabular}{|c|c|}
\hline ACTOR SOCIAL & Delegados Consejo de Coordinación de la Participación y Control Social \\
\hline CONCEPTOS & 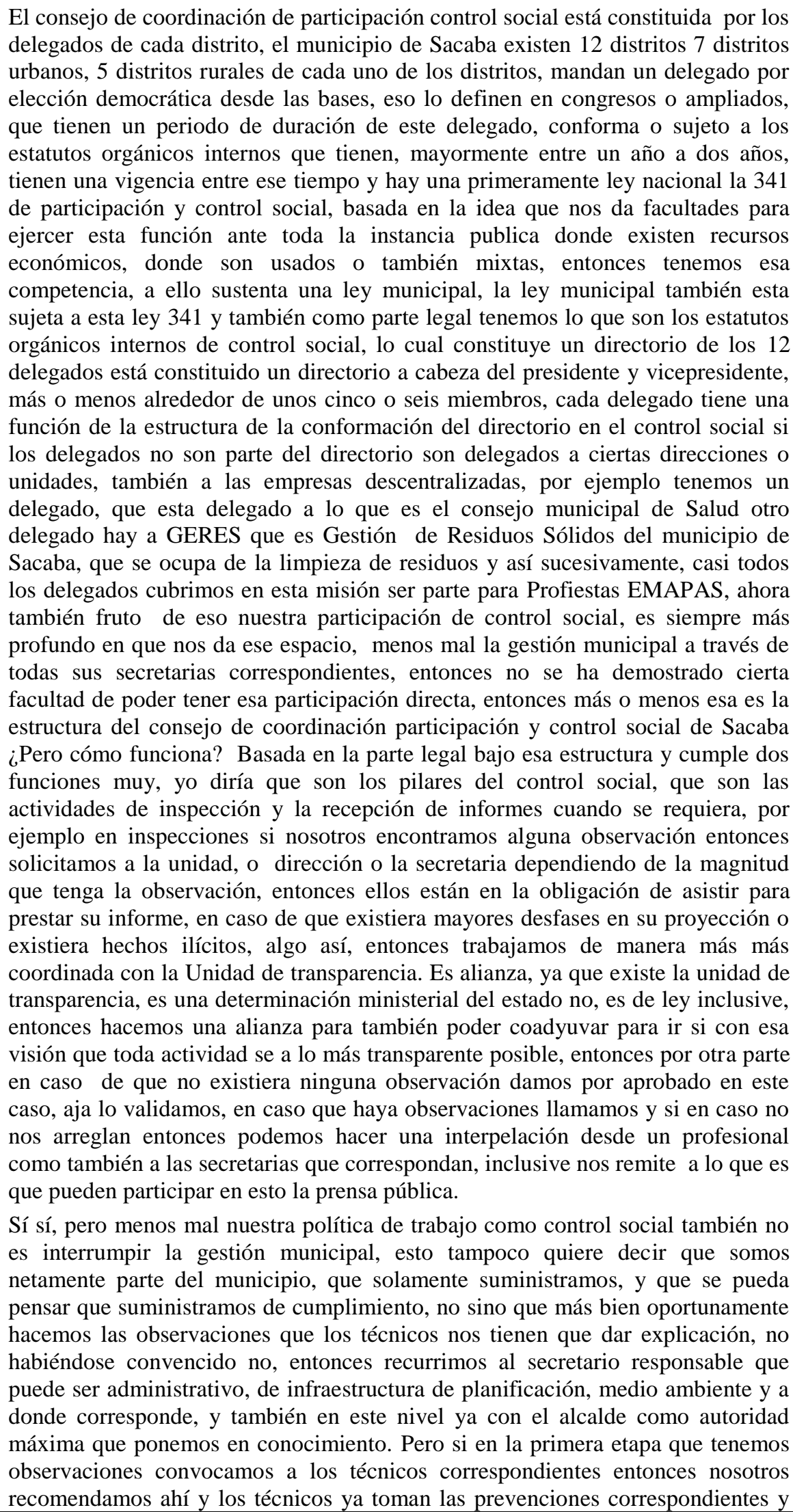 \\
\hline
\end{tabular}




\begin{tabular}{|c|c|}
\hline & $\begin{array}{l}\text { bueno, pues certifican. Si algún proyecto presenta mal, si va a una demolición } \\
\text { tienen que demoler y si es cuestión estética también tienen que hacer algunas } \\
\text { correcciones y tienen presupuestaria nosotros como manda la ley también } \\
\text { hacemos que da la validación correspondiente tanto los informes y control social } \\
\text { es uno de los pilares también para transparentar que las autoridades avaladas por } \\
\text { ley, servidores públicos deben cumplir con las rendiciones públicas y cuentas que } \\
\text { mínimamente son dos veces al año. Y también entonces somos los que } \\
\text { convocamos en este caso, ahora el municipio también incorpora dentro de lo que } \\
\text { es control social a la organización de la central regional del morro, que esto } \\
\text { aglutina más que todo a los compañeros que se dedican a la parte del agro, lo que } \\
\text { son los distritos rurales, ósea los distritos rurales tendrían dos tipos de } \\
\text { representatividad: uno por vía del morro y otro por vía control social o consejo } \\
\text { entonces se les respeta y da lugar como corresponde, a veces con esta instancia } \\
\text { que es la organización de campesinos el Morro que es de la provincia, enlazamos } \\
\text { esas coordinaciones por el ejemplo este tema del agro que estamos tratando, } \\
\text { entonces también nosotros somos los que coordinamos con la parte social } \\
\text { prácticamente tal vez nuestro municipio ha quedado un poco más atrás, no sé en } \\
\text { qué términos se le puede utilizar, lo que es el comité cívico porque los distritos } \\
\text { son las organizaciones máximas representativas en cada distrito porque ahí están } \\
\text { los comerciantes en cada distrito, si hay un comerciante no importa de cual } \\
\text { distrito, es parte del distrito si hay un transporte es parte del distrito, nos } \\
\text { respetamos lo que es la conformación de sindicatos, asociaciones pero si es de esa } \\
\text { manera que está constituida y cumple esa función de control social. }\end{array}$ \\
\hline $\begin{array}{l}\text { METODOLOGÍAS } \\
\text { PARA EVALUAR } \\
\text { O HACER } \\
\text { CONTROL } \\
\text { SOCIAL }\end{array}$ & 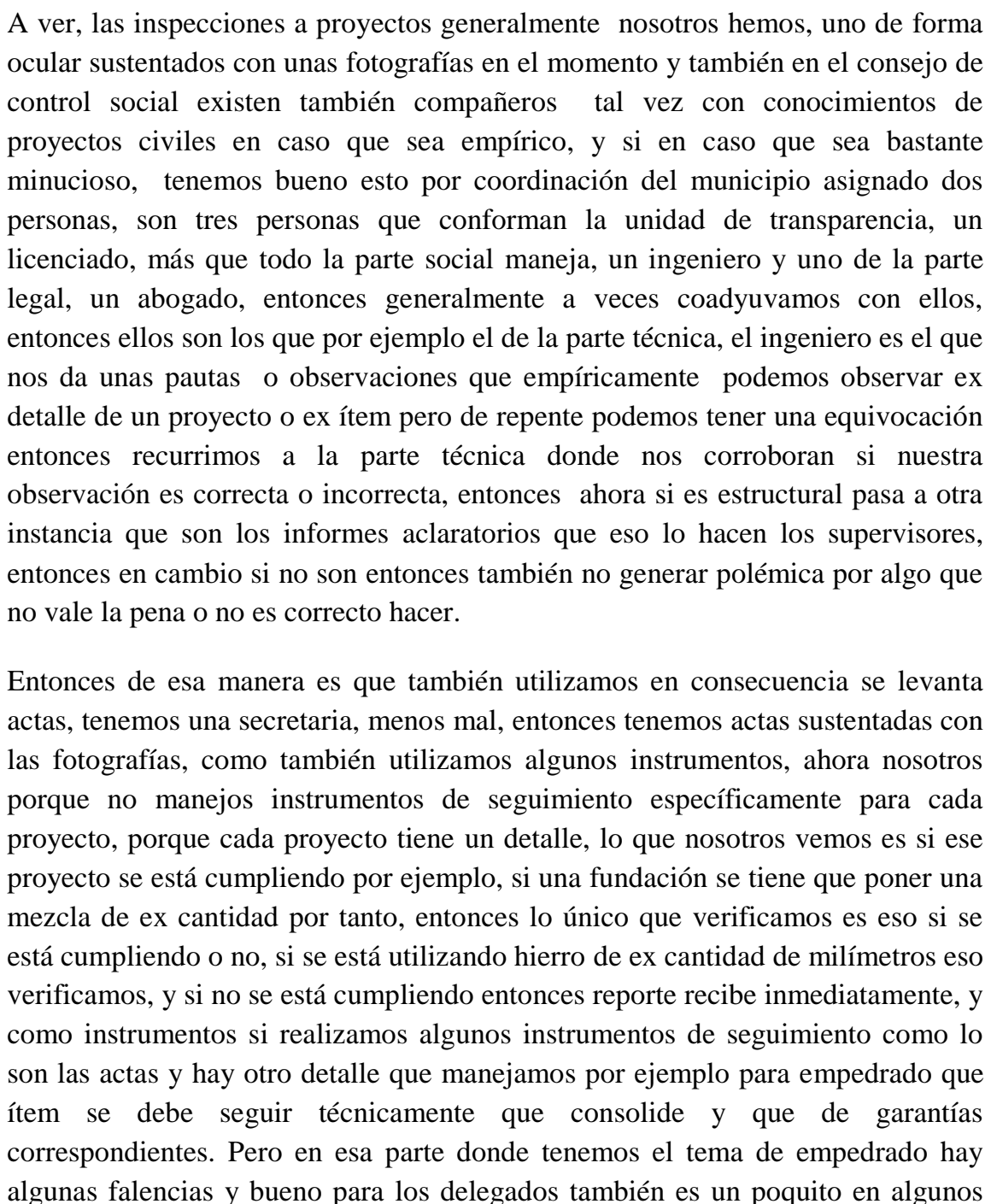 \\
\hline
\end{tabular}




\begin{tabular}{|c|c|}
\hline & $\begin{array}{l}\text { casos no para todos, el llenado del formulario, por qué? Bueno pues a veces sí es } \\
\text { muy técnico que a veces nosotros nos fijamos pues cómo debe cumplir conforme } \\
\text { al pliego especificaciones si está cumpliendo o no, y la parte técnica tiene pues } \\
\text { cientos de detalles más técnicos no, entonces un poquito a veces que nos queda } \\
\text { cierta morosidad pero eso no es obligatorio, no está dentro de lineamientos nada, } \\
\text { si más bien vamos incorporando por recomendaciones de transparencia también, } \\
\text { aquí hay apoyo jurídico legal y también técnico, ahora como funcionamos si en } \\
\text { caso a veces lamentablemente la unidad de transparencia económicamente es } \\
\text { dependiente del municipio, no son pagados por el ministerio si quiera, entonces a } \\
\text { veces cuando hay una dureza de parte de la unidad de transparencia, no han hecho } \\
\text { lo que hemos visto pero son sujeto a ciertas observaciones, entonces a veces } \\
\text { nosotros coordinamos no solo a los que observan sino a nosotros. }\end{array}$ \\
\hline NECESIDADES & 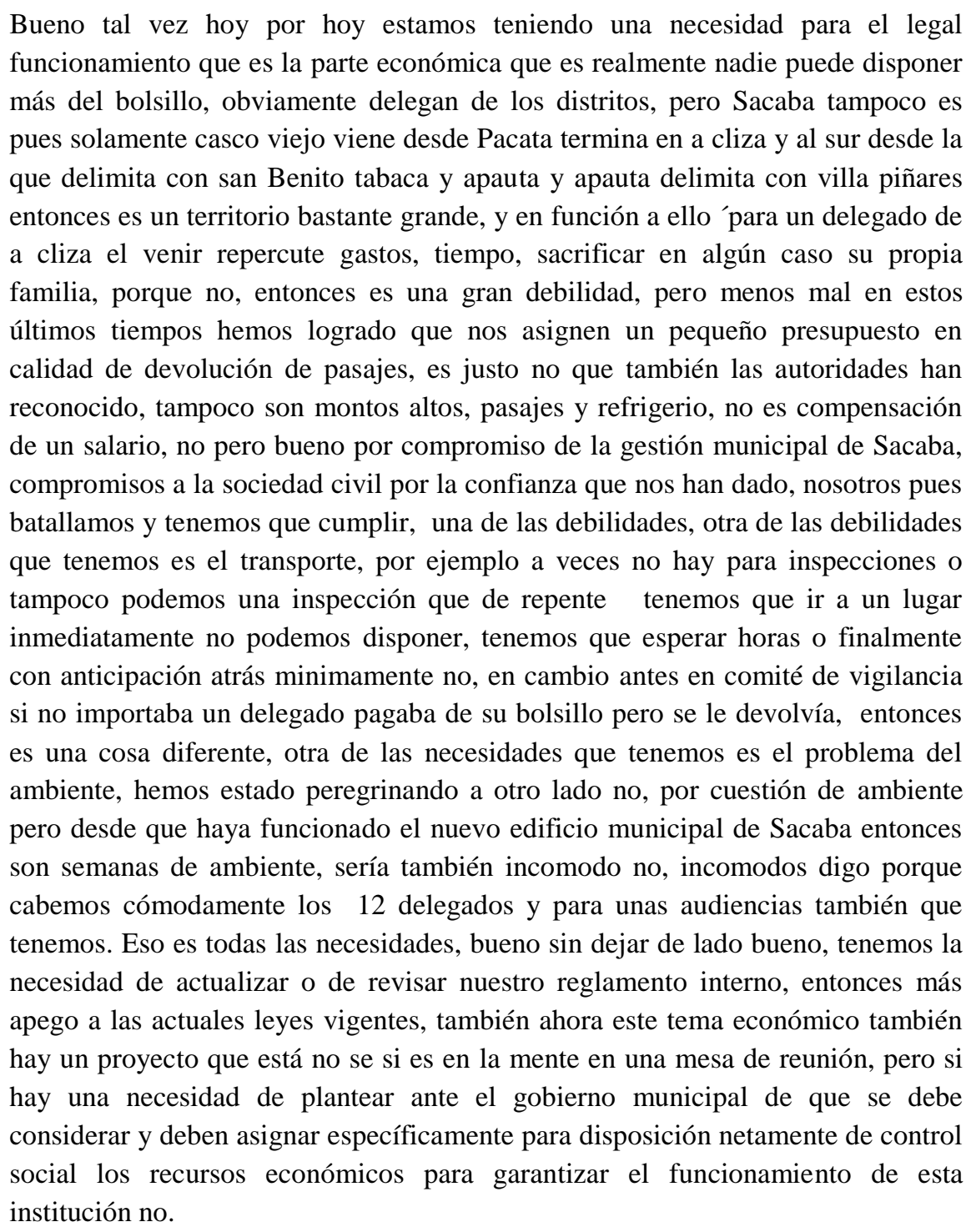 \\
\hline OTROS & $\begin{array}{l}\text { REGLAMENTO: A la fecha basado en la ley } 341 \text { segundo, en lo que es la ley } \\
\text { municipal, esa fue una de las bases y también tomando una referencia la realidad } \\
\text { orgánica social que tiene de cada distrito, entonces de ahí surge la elaboración del } \\
\text { reglamento y también la participación. Obviamente a sido tal vez porque ha sido } \\
\text { un año y medio ha tenido una historia critica esta institución, ha tenido una } \\
\text { decadencia fuerte, porque antes cuando existía lo que es la llamada ley 1551de } \\
\text { participación popular de municipalidad y se conocía estas leyes al comité de }\end{array}$ \\
\hline
\end{tabular}




\begin{tabular}{|c|c|}
\hline & 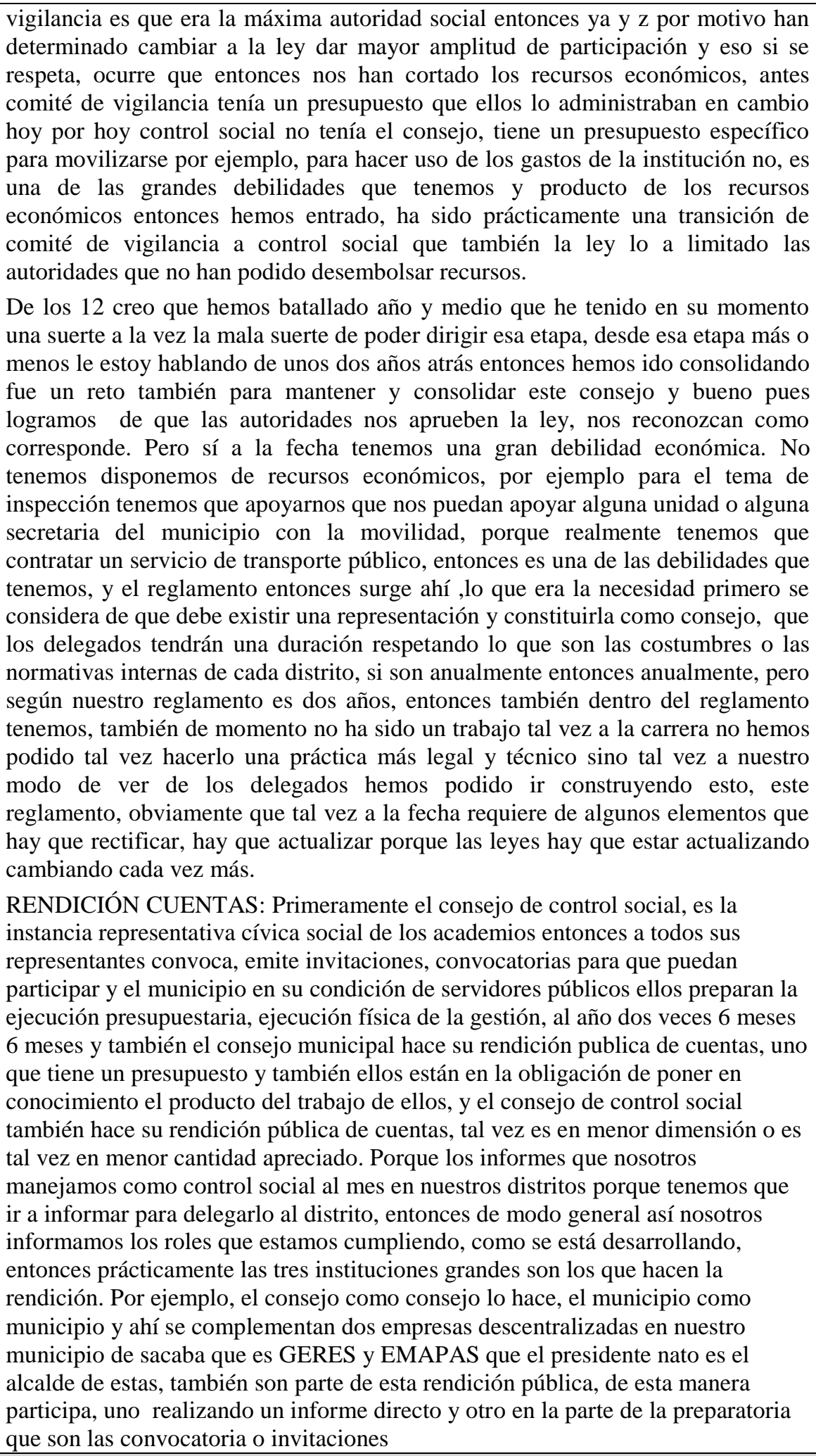 \\
\hline ACTOR SOCIAL & Funcionario Unidad de Transparencia GAMS \\
\hline CONCEPTOS & $\begin{array}{l}\text { El control social es una instancia del justamente poder controlar todo lo que } \\
\text { significa la transparencia en la gestión pública, entonces control social va hacer } \\
\text { eso además hay una ley que rige su accionar como lo es la ley } 341 \text {, y ahí } \\
\text { identifica cuales son las atribuciones, identifica qué tipo de control social si existe } \\
\text { no, sin embargo en el municipio de Sacaba tenemos un control social conformado } \\
\text { por delegados de cada distrito, son } 12 \text { distritos son } 7 \text { distritos urbanos y } 5 \text { rurales } \\
\text { y conforma lo que significa el consejo de participación y control social del }\end{array}$ \\
\hline
\end{tabular}




\begin{tabular}{|c|c|}
\hline & $\begin{array}{l}\text { municipio de Sacaba, entonces esta es la instancia legalmente constituida, sin } \\
\text { embargo la ley } 341 \text { nos marca de que todas las personas, todos los academios, } \\
\text { todos los bolivianos y bolivianas pueden ejercer el control social, justamente para } \\
\text { ver como se está invirtiendo los recursos económicos en el caso de sacaba, en el } \\
\text { caso de Bolivia como se invierte y si son transparentes los procedimientos o no } \\
\text { son transparentes, } \\
\text { También, el control social tiene atribuciones para poder evaluar, para poder } \\
\text { diseñar las políticas públicas, no solamente es atribución del consejo municipal } \\
\text { poder diseñar políticas municipales del como el ejecutivo, sin embargo, el control } \\
\text { social como parte de la sociedad puede elaborar y evaluar las políticas } \\
\text { municipales, entonces como sugerencia. }\end{array}$ \\
\hline $\begin{array}{l}\text { METODOLOGÍAS } \\
\text { PARA EVALUAR } \\
\text { O HACER } \\
\text { CONTROL } \\
\text { SOCIAL }\end{array}$ & 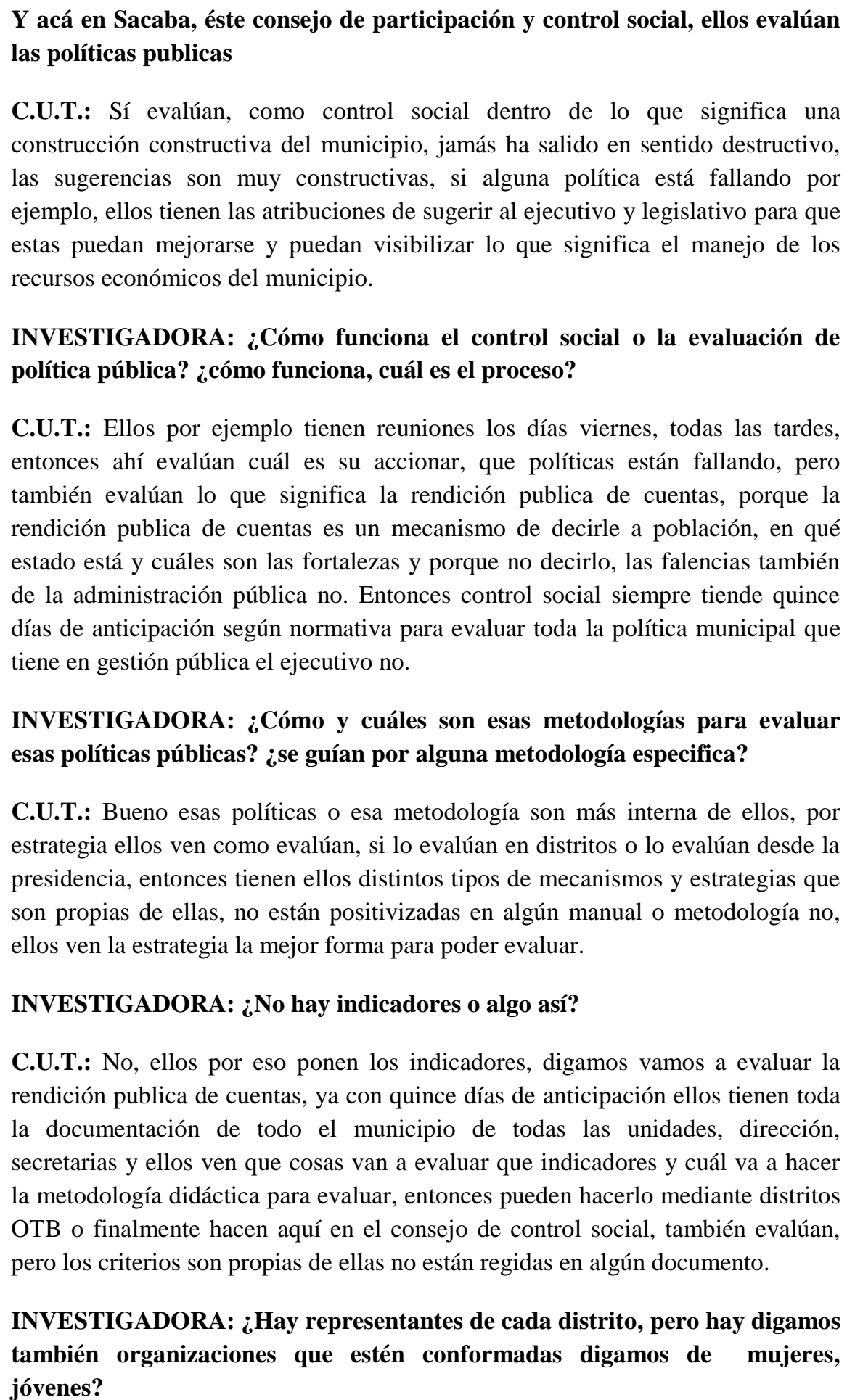 \\
\hline
\end{tabular}


C.U.T.: Sí, finalmente la misma normativa, la ley 341 de control social, regula actores de control social, aquellos que son orgánicos por ejemplo que tienen personería jurídica, entonces puede ejercer también y pueden conformar y solicitar al consejo de control social su participación con algún delegado por ejemplo el sector de profesionales, arquitectos o ingenieros pueden solicitar, comerciantes tienen su personería ellos vienen y mandan un delegado y conforman el consejo, entonces distintos sectores de la sociedad con personerías jurídicas son orgánicos pueden conformar, pero también reconocen la misma normativa de control social circunstancial, vale decir que hay un grupo de personas que se organizan para hacer seguimiento y transparentar, un determinado proyecto, por decir está salud, la construcción de hospital Salomón Klein de Salud, entonces todos los médicos conforman un control social circunstancial que solamente surte al efecto para ese objetivo, pero también, podrían conformar lo que significa nuestro consejo de participación y control social de Sacaba. Y finalmente están el control social indígena, entonces son los pueblos indígenas originarios los cuales pueden tener su representante también dentro del control social, y como es hay comerciantes el delegado ya tiene en el consejo su participación, y todos los sectores tendrían que conformar lo que significa el control social, ahí está por ejemplo el tema de la Policía, el tema del aparato judicial, entonces tendrían que ya empezar a mandar los delegados para que conformen, entonces no es solamente el municipio el consejo sino abarca mucho más allá, pero evidentemente la debilidad está en el tema de la remuneración, el control social y no solamente en Sacaba sino a nivel nacional, cuando no hay remuneración lamentablemente las personas no le toman el interés de ese $100 \%$ para poder ejercer ese derecho del control social, entonces es una debilidad no, y motivar a la población que pueda ejercer esto es una tarea titánica, es difícil motivarlos.

Para la evaluación de política pública, ¿cómo debería ser esa evolución, digamos que indicadores se deberían tener en cuenta, que sectores se deberían tener en cuenta, para hacer esa dinámica de evolución de las políticas públicas?

C.U.T.: Tendría que ser una conformación de todos, y todos tendríamos que poner esos indicadores para poder evaluar, pero los indicadores también tendría que estar bajo los principios éticos bajo los principios legales bajo los principios sociales y porque no decirlo bajo los principios políticos todos tendríamos que conformar criterios indicadores para evaluar las políticas públicas que tiene el municipio, es una tarea finalmente de todos, de los servidores públicos, del ejecutivo, del legislativo o de las empresas descentralizadas pero sobretodo del ciudadano, en ese sentido creo que esas evaluaciones van a ser muchos más objetivas, muchas más valiosas porque cuanto mayor participación es mayor el análisis pero no solamente que se queden en evaluaciones ahí para escritorio sino que esas evaluaciones tienen que ayudarnos a mejorar y Sacaba es un municipio que está mejorando a pasos cuantitativos y cualitativos pasos gigantescos que se están dando, Cochabamba es el segundo municipio más grande, no solamente en población y en territorio sino también en recursos económicos, y además es un municipio que tiene un alcalde que realmente le está poniendo mucho dinamismo no solamente teoría sino es práctica, apropia lo que significa tener una gestión transparente y tener los mecanismos y los procedimientos para poder ejercer eso también, entonces están dadas las cosas estamos creciendo como una ciudad muy pujante y muy fuerte y las evaluaciones al municipio nos hacen muy bien, es una 


\begin{tabular}{|c|c|}
\hline & $\begin{array}{l}\text { tarea de todos. } \\
\text { INVESTIGADORA: Si se quisiera construir una propuesta para fortalecer } \\
\text { esa evaluación de política etc. ¿qué recomendaciones tendríamos que tener } \\
\text { en cuenta para hacer la propuesta? } \\
\text { C.U.T.: A partir de la evaluación se sacan recomendaciones, no podemos decirles } \\
\text { saben que recomiéndenos esto o aquello puesto que es una tarea a priori, sería } \\
\text { irresponsable decirles eso porque ya estaríamos encaminando qué es lo quiero que } \\
\text { nos digan, y ahí perdemos la objetividad, entonces haremos los pasos, } \\
\text { evaluaremos sacaremos la radiografía de cómo estamos y a partir de eso } \\
\text { recomendaremos. }\end{array}$ \\
\hline NECESIDADES & $\begin{array}{l}\text { es decir que en el consejo están: ¿los representantes del distrito, algunos } \\
\text { representantes de algunas organizaciones sociales y la unidad de } \\
\text { transparencia? } \\
\text { C.U.T.: Sí, la Unidad de Transparencia como obligación para poderles brindar } \\
\text { algunos mecanismos al control social para que ellos puedan ejercer con mayor } \\
\text { objetividad su trabajo, no está en el reglamento que transparencia tendría que } \\
\text { estar conformada dentro del control social, pero la obligación y una de las tareas } \\
\text { que hace la unidad de transparencia justamente es fortalecer el control social, bajo } \\
\text { el eje que nos dice, fortalecimiento de la participación ciudadana que está } \\
\text { estipulado en la política nacional y la política municipal de transparencia y lucha } \\
\text { contra la corrupción, entonces la tarea de transparencia es fortalecerlas, } \\
\text { evidentemente que control social es una entidad autónoma e independiente, las } \\
\text { cuales rigen sobre un reglamento y la normativa que es la ley } 341 \text { todo su } \\
\text { accionar pero independientemente de eso nos solicitan el apoyo como unidad de } \\
\text { transparencia, en las inspecciones conjuntas por ejemplo que siempre nos } \\
\text { solicitan, el poderles brindar instrumentos como planillas para que ellos puedan } \\
\text { hacer distintos tipos de control social ya sea en obras ya sea en manejo de los } \\
\text { bienes del municipio, ya sea también la visibilidad de los recursos humanos que } \\
\text { existen, etc. Entonces nosotros les brindamos todos esos instrumentos para que } \\
\text { ellos puedan ejercer de forma mucho más objetiva y mucho más precisa por no } \\
\text { decir técnica y legal, el control social. } \\
\text { INVESTIGADORA: ¿Y esos instrumentos son de acceso público? } \\
\text { C.U.T.: Son de acceso público, por ejemplo en una planilla de como inspeccionar } \\
\text { o que cosas inspeccionar en un empedrado, y el empedrado está colgado en el } \\
\text { DVC está dentro del SICOE que es información pública, que de ahí sacamos } \\
\text { indicadores y les decimos que cosas tenemos que observar, en inspección de un } \\
\text { empedrado por ejemplo, y se saca una planilla y la planilla es más fácil de llenar } \\
\text { para el control social del delegado, puesto que algunos de control social no tienen } \\
\text { profesión no tienen estas cosas, entonces con las planillas les es más fácil llenar y } \\
\text { hacer observaciones mucho más técnicas y mucho más precisas. }\end{array}$ \\
\hline OTROS & $\begin{array}{l}\text { ¿Entonces toda la información de rendición de cuentas la prepara la Alcaldía } \\
\text { y las entidades del municipio? } \\
\text { C.U.T.: Exactamente, la prepara la alcaldía, la prepara el ejecutivo pero también } \\
\text { prepara el legislativo porque ambos hacen la rendición publica de cuentas, } \\
\text { también las empresas descentralizadas, nuestro alcalde vía instructiva faltando } \\
\text { dos meses, él solicita informes a todas sus unidades, a todas sus direcciones, sus } \\
\text { jefaturas, vía secretaria que es la parte operativa, los secretarios se encargan de }\end{array}$ \\
\hline
\end{tabular}


acoplar la información y estos se los resume como síntesis para que el alcalde pueda hacer su rendición publica de cuentas. Existe una mitología para rendición publica de cuentas pero es una guía, entonces nosotros tenemos que cumplir conforme a normativa también algunas cosas, en el 2014 por ejemplo se hizo una rendición publica de cuentas, con una metodología de feria, todas las unidades, las direcciones del municipio de Sacaba el consejo, las empresas descentralizadas como es EMAPAS, GERES prepararon paneles de información directo a los ciudadanos sacabeños, entonces hubo inicial un informe del Alcalde, después invito a que pasen por todos los paneles a feria para que el ciudadano vaya a hacer preguntas más concretas más a detalle y los servidores han estados dispuestos en esta tarea.

INVESTIGADORA: ¿Y cómo participa la población dentro de la rendición, solo digamos en que momento participa?

C.U.T.: En todo momento, inclusive por periódico siempre publicamos y llamamos con 15 días de anticipación va a ver la rendición publica de cuentas y en control social está toda la información, los delegados vía distrito y la información siempre bajan, entonces ahí ya están participando todos los academios cuando se hace el evento mismo desde el inicio hasta el final pueden participar con preguntas, con interrogaciones, con sugerencias, con felicitaciones también, a lo que significa la administración de los recursos económicos del municipio de Sacaba, lo que significa que son espacios activos donde tiene control social y el ciudadano, son activos en ningún momento se restringe el acceso a la información, no se les restringe ni el acceso a opinar se les puede restringir.

INVESTIGADORA: ¿Qué acciones desarrolla la unidad de transparencia en el municipio y como desde allí se promueve la participación social?

C.U.T.: LA unidad de transparencia de sacaba, es importante hablar de transparencia, entender la acciones que se entiende por trasparencia, y, la transparencia es ese manejo visible y claro de los recursos económicos en la gestión municipal pero conforme a la normativa y la normativa son esos procedimientos que existen, existen cuatro ejes de trabajo que tiene la unidad de transparencia y que están estipulados en la política municipal de transparencia, pero también tiene cuatro componentes con mayor fuerza donde visibiliza su trabajo, el primer componente por ejemplo es el tema de fortalecimiento del acceso a la información y el derecho a la información es un derecho constitucional el articulo 21 y sin embargo hay que sacar carta bien que este derecho también se ejerce, si bien hay derechos también hay obligaciones, hay información también reservada que atribuye al mismo estado por su seguridad y a los municipios por ejemplo, información de las llaves de las cajas fuertes de la unidad de recaudación, por ejemplo es información seleccionada y no se puede mucho abarcar en ese sentido. El otro componente que tiene es el tema de control social justamente, les decía que es una tarea titánica para poder trabajar con la población en este tema de control social, motivarlos a ellos de que ellos tienen el derecho a ejercen control social en esta administración pública, llámese en obras llámese en tema de visibilidad de los recursos humanos, o en el tema del manejo de los bienes y servicios que tiene el municipio. El otro eje con el que trabajamos con mayor fuerza es el tema de las rendiciones públicas de cuentas, desde que nosotros asumimos la unidad de transparencia hemos estado tratando de acopiar toda la información de lo que significa las rendiciones públicas que hizo el municipio desde su conformación de la Unidad, entonces es una información que 
cualquier ciudadano sacabeño pueda venir y nosotros tenemos la obligación de brindarle esa información, puede revisarla, puede sacarle copias para el fin que ellos puedan desear. El otro componente que trabajamos con mayor fuerza como unidad de transparencia es el tema de la ética pública, la ética pública entendida en esas buenas relaciones o las prácticas de los valores, relaciones interpersonales que se tiene entre los academios con mayor énfasis entre servidor público y ese contribuyente, ese ciudadano, pero también del ciudadano hacia el servidor público y a todos los servidores públicos siempre tiene que existir esa práctica de valores y principios que tiene que tener una persona como digna de existir pero enmarcados en lo que significa doctrinal y filosóficamente en la ética que es pública. Esos serían los 4 componentes que trabaja con mayor fuerza la unidad de transparencia: acceso a la información, la ética pública, y todo esto lo hacemos también desde el componente preventivo, hay que prevenir bastante para que podamos concientizar a los servidores públicos de que la lucha de tener cero corrupción con una política nacional y una política municipal tiene que ser real, porque también les hablamos de valores y principios, porque los valores y principios finalmente se forman en la sociedad, institucionalmente en la familia como núcleo principal de la sociedad. Entonces si tuviéramos valores éticos y morales que tuviera la persona como tal, creo que no hablaríamos de transparencia, no hablaríamos de corrupción, no hablaríamos de unidad de transparencia no hablaríamos de ese pensamiento todavía que existe en el ciudadano que yo entro al servicio público y es mi oportunidad para aprovechar todo lo que venga. No hablaríamos de eso si tuviéramos valores y principios bien enraizados, pero que hacen como ser humano, entonces siempre la unidad de transparencia esta con el tema preventivo.

INVESTIGADORA: ¿Para hacer ese fortalecimiento de la participación y para que la gente entiende que el control social es su derecho, como lo hacen a través de qué?

C.U.T.: En este momento por ejemplo, estamos en plena estrategia de hacer talleres a más de sus 800 servidores públicos que existen en el municipio, de decirles que es transparencia, que es la política municipal y la política nacional, que es, que causas y qué consecuencias tiene si hay infracciones que es la 004 la ley Marcelo Quiroga Santacruz, brindando talleres de intercambio de ideas para poder prevenir justamente a los servidores públicos pero no solamente se quedarían los talleres de socialización de ideas en los servidores públicos, tenemos ya programado también bajar a todos los distritos a todas las OTB porque los ciudadanos también tienen que entender qué es transparencia, que es la ética pública, que es el derecho al acceso a la información y que cosas también ellos como control social no tendrían que hacer o tendrían que hacerlas, entonces decirles también los derechos conforme a la lay 341 que atribuciones tiene como control social, para poder fortalecer esa participación lo hacemos vía talleres, que son esos intercambios de ideas, porque nadie enseña a nadie finalmente porque son esos intercambios de ideas y experiencias y de criterios que tienen que existir, por eso los hemos nominado talleres, porque los talleres son esos espacios, no son seminarios, no son charlas no es más vertical la cosa, es más social, más dinámico pero también incitamos a la participación de los ciudadanos a que pueda ejercer esos derechos, vía prensa, tenemos un boletín que mensualmente se publica digital inicialmente y también se publica todo lo que trabaja no solamente la unidad de transparencia sino todas otras las direcciones y todas unidades del municipio de Sacaba. 


\section{C) Observación participante}

\section{$\underline{\text { Participantes }}$}

Los participantes de las 2 reuniones de coordinación tanto del proceso de constitución de Observatorios Ciudadanos en Bogotá, como en las reuniones de trabajo en la Gobernación de Cochabamba en cuanto a reflexión sobre la aplicación del nuevo Sistema de Planificación Integral del Estado SPIE.

\section{Instrumento}

El instrumento para el registro de las percepciones, análisis y reflexiones conceptuales, metodológicas y éticas vinculadas con la incidencia ciudadana en política pública fue el diario de campo híbrido en sus dos acepciones el componente técnico y de descripción de datos básicos de referencia de la actividad realizada, así como el componente más analítico y de registro de la información némica y nética.

Los diarios de campo en sí mismos se convirtieron en insumos que permitieron analizar la información, teniendo como marco las categorías de investigación planteadas, en una suerte de diálogo permanente entre el cuadro de ordenadores epistemológicos y los apuntes, reflexiones y análisis contenidos en las notas de campo.

\section{$\underline{\text { Resultados }}$}

En cuanto a esta técnica es importante mencionar que se desarrolla a partir de la participación de la autora en varios espacios de discusión y reflexión de la Gobernación de Cochabamba, sobre todo en la coyuntura de cambio de sistema de Planificación y en el momento en que se inicia la aplicación del nuevo Sistema de Planificación Integral del Estado SPIE, en donde se logra recabar información para la comprensión de dicho sistema y las posibilidades que éste ofrece para potenciar la participación e incidencia ciudadana a nivel de los municipios. Ello con miras a generar reflexiones para materializarlas en la propuesta que se presentará en capítulos subsiguientes. 
Tabla 28. Sistematización reuniones

\begin{tabular}{|c|c|c|c|c|c|}
\hline NORMATIVA & ACTORES & $\begin{array}{c}\text { FUENTES } \\
\text { PRIMARIAS }\end{array}$ & $\begin{array}{c}\text { FUENTES } \\
\text { SECUNDARIAS }\end{array}$ & VARIABLES & INDICADORES \\
\hline $\begin{array}{l}\text { Constitución } \\
\text { Política del Estado } \\
\\
\text { Ley 031 Marco de } \\
\text { Autonomías y } \\
\text { Descentralización } \\
\\
\text { LEY } 341 \text { (Esc: } \\
\text { Nal) } \\
\text { Reglamento del } \\
\text { Consejo de } \\
\text { Coordinación de la } \\
\text { Participación y } \\
\text { Control Social } \\
\text { (Esc: Municipal) }\end{array}$ & $\begin{array}{l}\text { Alcaldía } \\
\text { Municipal } \\
\\
\text { Unidad de } \\
\text { Planificación } \\
\\
\text { Organizaciones } \\
\text { sociales } \\
\text { (OTBS, } \\
\text { Asociación } \\
\text { ctaria, sub } \\
\text { centrales de } \\
\text { cantones, } \\
\text { organizac e } \\
\text { instituciones } \\
\text { sociedad civil) } \\
\text { CCPCS }\end{array}$ & 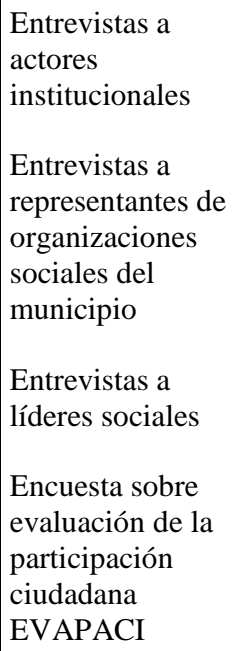 & $\begin{array}{l}\text { Estudios sobre } \\
\text { temática } \\
\text { participación } \\
\text { poblacional en } \\
\text { Sacaba. } \\
\text { Censos o encuestas } \\
\text { sobre tema } \\
\text { participación social } \\
\text { en el municipio }\end{array}$ & $\begin{array}{l}\text { AGENCIA } \\
\text { SOCIAL }\end{array}$ & $\begin{array}{l}\text { 1. \% de población } \\
\text { que pertenece a } \\
\text { alguna } \\
\text { organización } \\
\text { social } \\
2 . \% \text { de población } \\
\text { que participa en } \\
\text { procesos de } \\
\text { planificación } \\
\text { municipal } \\
\text { 3. Frecuencia de } \\
\text { participación de } \\
\text { población de } \\
\text { acuerdo a grupos } \\
\text { de edad }\end{array}$ \\
\hline $\begin{array}{l}\text { LEY } 341 \text { (Esc: } \\
\text { Nal) } \\
\\
\text { Reglamento del } \\
\text { Consejo de } \\
\text { Coordinación de la } \\
\text { Participación y } \\
\text { Control Social } \\
\text { (Esc: Municipal) }\end{array}$ & $\begin{array}{l}\text { Alcaldía } \\
\text { Municipal } \\
\text { Unidad de } \\
\text { Planificación } \\
\text { Organizaciones } \\
\text { sociales } \\
\text { (OTBS, } \\
\text { Asociación } \\
\text { ctaria, sub } \\
\text { centrales de } \\
\text { cantones, } \\
\text { organizac e } \\
\text { instituciones } \\
\text { sociedad civil) } \\
\text { CCPCS }\end{array}$ & $\begin{array}{l}\begin{array}{l}\text { Entrevistas a } \\
\text { actores } \\
\text { institucionales }\end{array} \\
\text { Entrevistas a } \\
\text { representantes de } \\
\text { organizaciones } \\
\text { sociales del } \\
\text { municipio } \\
\text { Entrevistas a } \\
\text { líderes sociales }\end{array}$ & $\begin{array}{l}\text { Estudios sobre } \\
\text { temática incidencia } \\
\text { ciudadana en Sacaba. } \\
\text { Censos o encuestas } \\
\text { sobre tema } \\
\text { participación social e } \\
\text { incidencia en el } \\
\text { municipio }\end{array}$ & $\begin{array}{l}\text { INCIDENCI } \\
\text { A } \\
\text { CIUDADAN } \\
\text { A }\end{array}$ & $\begin{array}{l}\text { 1.\% de } \\
\text { participación de la } \\
\text { población en toma } \\
\text { de decisiones del } \\
\text { municipio } \\
\text { 2.\% de población } \\
\text { que participa en } \\
\text { construcción PTDI } \\
\text { 3. Cualidades de la } \\
\text { cohesión social } \\
\text { municipal } \\
\text { 4. Percepción de la } \\
\text { influencia en la } \\
\text { toma de decisiones } \\
\text { municipal } \\
\text { 5. Caracterización } \\
\text { de actores que } \\
\text { participan en } \\
\text { proceso PTDI }\end{array}$ \\
\hline
\end{tabular}


Tabla 29. Sistematización reuniones. (Continuación)

\begin{tabular}{|c|c|c|c|c|c|}
\hline NORMATIVA & ACTORES & $\begin{array}{c}\text { FUENTES } \\
\text { PRIMARIAS }\end{array}$ & $\begin{array}{c}\text { FUENTES } \\
\text { SECUNDARIAS }\end{array}$ & VARIABLES & INDICADORES \\
\hline $\begin{array}{l}\text { Constitución } \\
\text { Política del } \\
\text { Estado } \\
\text { Ley 031 Marco } \\
\text { de Autonomías y } \\
\text { Descentralizació } \\
\text { n }\end{array}$ & $\begin{array}{l}\text { Alcaldía } \\
\text { Municipal } \\
\text { Unidad de } \\
\text { Planificación } \\
\text { Unidad De } \\
\text { Transparenci } \\
\text { a } \\
\text { Organizacion } \\
\text { es sociales } \\
\text { (OTBS, } \\
\text { Asociación } \\
\text { ctaria, sub } \\
\text { centrales de } \\
\text { cantones, } \\
\text { organizac e } \\
\text { instituciones } \\
\text { sociedad } \\
\text { civil) } \\
\text { CCPCS }\end{array}$ & $\begin{array}{l}\begin{array}{l}\text { Entrevistas a } \\
\text { actores } \\
\text { institucionales }\end{array} \\
\text { Entrevistas a } \\
\text { representantes } \\
\text { de } \\
\text { organizaciones } \\
\text { sociales del } \\
\text { municipio } \\
\text { Entrevistas a } \\
\text { líderes sociales }\end{array}$ & $\begin{array}{l}\text { Estudios sobre } \\
\text { temática control } \\
\text { social y } \\
\text { transparencia en } \\
\text { Cochabamba y } \\
\text { Sacaba. } \\
\text { Censos o encuestas } \\
\text { sobre tema control } \\
\text { social en el } \\
\text { municipio }\end{array}$ & $\begin{array}{l}\text { CONTROL } \\
\text { SOCIAL }\end{array}$ & $\begin{array}{l}1 . \quad \% \text { de } \\
\text { población que se } \\
\text { involucra en } \\
\text { control social } \\
2 . \quad \% \text { de } \\
\text { población que } \\
\text { participa en } \\
\text { rendición de } \\
\text { cuentas } \\
3 . \quad \text { Caract } \\
\text { erización de } \\
\text { actores que } \\
\text { participan en } \\
\text { procesos de CS }\end{array}$ \\
\hline
\end{tabular}

Tabla 30. Reunión 2.

\begin{tabular}{|c|c|c|c|c|}
\hline \multirow[t]{3}{*}{ VARIABLE } & \multirow[t]{3}{*}{ INDICADOR } & \multirow{3}{*}{$\begin{array}{c}\text { FUENTES } \\
\text { SECUNDARIAS } \\
\text { (Preguntas que } \\
\text { orientan la } \\
\text { revisión fuentes } \\
\text { secundarias) }\end{array}$} & \multicolumn{2}{|c|}{ FUENTES PRIMARIAS } \\
\hline & & & \multicolumn{2}{|c|}{ Instrumentos recolección información. } \\
\hline & & & Actor: Institucional & $\begin{array}{c}\text { Actor: } \\
\text { Comunidad }\end{array}$ \\
\hline AGENCIA SOCIAL & 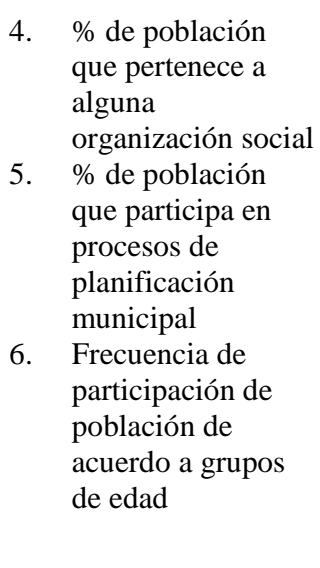 & $\begin{array}{l}\text { ¿Qué porcentaje de } \\
\text { población pertenece } \\
\text { a alguna } \\
\text { organización } \\
\text { social? } \\
\text { ¿Qué tipo de } \\
\text { organizaciones } \\
\text { sociales existen en } \\
\text { el municipio? } \\
\text { ¿Cómo se } \\
\text { organizan los }\end{array}$ & $\begin{array}{l}\text { ¿Qué es participación } \\
\text { ciudadana? } \\
\text { ¿Cómo promueven las } \\
\text { instituciones públicas la } \\
\text { participación } \\
\text { ciudadana? } \\
\text { Estrategias/procesos/act } \\
\text { ores }\end{array}$ & $\begin{array}{l}\text { ¿Qué } \\
\text { participación } \\
\text { ciudadana? } \\
\text { ¿En qué procesos } \\
\text { de la gestión } \\
\text { municipal se } \\
\text { participa } \\
\text { principamente? }\end{array}$ \\
\hline
\end{tabular}


Tabla 31. Reunión 2 (Continuación)

\begin{tabular}{|c|c|c|c|c|}
\hline \multirow[t]{3}{*}{ VARIABLE } & \multirow[t]{3}{*}{ INDICADOR } & \multirow{3}{*}{$\begin{array}{c}\text { FUENTES } \\
\text { SECUNDARIAS } \\
\text { (Preguntas que } \\
\text { orientan la } \\
\text { revisión fuentes } \\
\text { secundarias) }\end{array}$} & \multicolumn{2}{|c|}{ FUENTES PRIMARIAS } \\
\hline & & & \multicolumn{2}{|c|}{ Instrumentos recolección información. } \\
\hline & & & Actor: Institucional & $\begin{array}{c}\text { Actor: } \\
\text { Comunidad }\end{array}$ \\
\hline AGENCIA SOCIAL & & $\begin{array}{l}\text { habitantes del } \\
\text { municipio? } \\
\text { ¿Qué características } \\
\text { tienen los actores } \\
\text { que participan en } \\
\text { procesos r de } \\
\text { planificación } \\
\text { municipal? } \\
\text { ¿Con } \\
\text { frecuencia } \\
\text { participan } \\
\text { diferentes grupos de } \\
\text { edad en las etapas } \\
\text { de la planificación } \\
\text { municipal? }\end{array}$ & $\begin{array}{l}\text { ¿Qué tipo de apoyo se } \\
\text { da a las organizaciones } \\
\text { sociales en el } \\
\text { municipio? } \\
\\
\text { ¿Cómo incentivar la } \\
\text { participación ciudadana } \\
\text { en relación a enfoques } \\
\text { generacionales y de } \\
\text { género? }\end{array}$ & $\begin{array}{l}\text { razones por las } \\
\text { que participa? }\end{array}$ \\
\hline $\begin{array}{l}\text { INCIDENCIA } \\
\text { CIUDADANA }\end{array}$ & 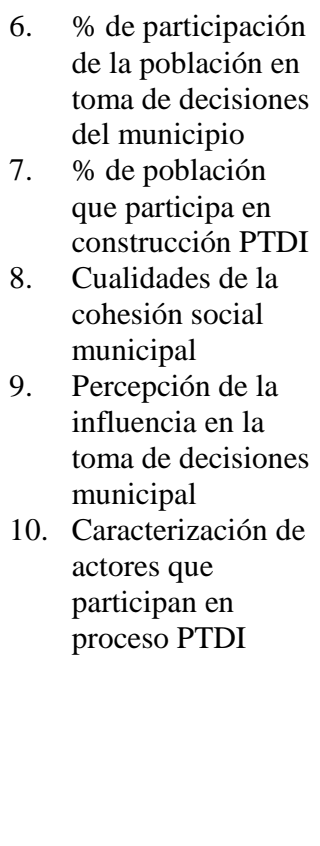 & $\begin{array}{l}\text { ¿Cómo incentivar la } \\
\text { participación de la } \\
\text { población en la } \\
\text { toma de decisiones } \\
\text { del municipio? } \\
\\
\\
\text { ¿cómo se desarrolló } \\
\text { el proceso de } \\
\text { participación r e } \\
\text { incidencia } \\
\text { ciudadana para la } \\
\text { construcción del } \\
\text { actual PTDI? }\end{array}$ & $\begin{array}{l}\text { ¿Cuáles fueron los } \\
\text { principales cambios en } \\
\text { la participación con la } \\
\text { elaboración de PTDIs? } \\
\\
\text { ¿Considera que gran } \\
\text { porcentaje de la } \\
\text { población participó en } \\
\text { la elaboración del } \\
\text { PTDI? Argumente su } \\
\text { respuesta. } \\
4 \\
\text { ¿La opinión y puntos de } \\
\text { vista de la población se } \\
\text { reflejan en la gestión } \\
\text { municipal? ¿Por qué? }\end{array}$ & $\begin{array}{l}\text { ¿Participa en el } \\
\text { proceso } \\
\text { construcción de } \\
\text { POAs o PTDI? } \\
\text { ¿Por qué? } \\
\\
\text { ¿Considera que su } \\
\text { opinión es valiosa } \\
\text { para la toma de } \\
\text { decisiones en el } \\
\text { municipio? ¿Por } \\
\text { qué? } \\
\text { ¿Cómo clasifica la } \\
\text { unidad social del } \\
\text { municipio? }\end{array}$ \\
\hline
\end{tabular}


Tabla 32. Reunión 2 (Continuación)

\begin{tabular}{|c|c|c|c|c|}
\hline \multirow[t]{3}{*}{ VARIABLE } & \multirow[t]{3}{*}{ INDICADOR } & \multirow{3}{*}{$\begin{array}{c}\text { FUENTES } \\
\text { SECUNDARIAS } \\
\text { (Preguntas que } \\
\text { orientan la } \\
\text { revisión fuentes } \\
\text { secundarias) }\end{array}$} & \multicolumn{2}{|c|}{ FUENTES PRIMARIAS } \\
\hline & & & \multicolumn{2}{|c|}{ Instrumentos recolección información. } \\
\hline & & & Actor: Institucional & $\begin{array}{c}\text { Actor: } \\
\text { Comunidad }\end{array}$ \\
\hline CONTROL SOCIAL & $\begin{array}{l}\text { 4. } \begin{array}{l}\% \text { de población } \\
\text { que se involucra } \\
\text { en control social } \\
\text { 5. } \\
\text { que población } \\
\text { que participa en } \\
\text { rendición de } \\
\text { cuentas }\end{array} \\
\text { 6. } \begin{array}{l}\text { Caracterización } \\
\text { de actores que } \\
\text { participan en } \\
\text { procesos de CS }\end{array}\end{array}$ & $\begin{array}{l}\text { ¿Cómo funciona el } \\
\text { control social en el } \\
\text { municipio? } \\
\text { ¿Cuáles son las } \\
\text { metodologías r y } \\
\text { herramientas para el } \\
\text { control social } \\
\text { municipal? r } \\
\text { ¿Cuál es el trabajo } \\
\text { que realizar la } \\
\text { Unidad rad de } \\
\text { Transparencia en el } \\
\text { municipio? Cómo } \\
\text { coordinan esfuerzos } \\
\text { con el CCPSCS? } \\
\text { ¿Cómo contribuye } \\
\text { el control social en } \\
\text { el municipio? }\end{array}$ & $\begin{array}{l}\text { ¿Qué es el control social } \\
\text { municipal? } \\
\text { ¿Quiénes participan en } \\
\text { el control social del } \\
\text { municipio? } \\
\text { ¿Por qué es importante } \\
\text { el CS en el municipio? } \\
\text { ¿Cuáles son los } \\
\text { aprendizajes del control } \\
\text { social en el municipio? }\end{array}$ & \begin{tabular}{|l|} 
Qué es el control \\
social municipal? \\
¿Quiénes \\
participan en el \\
control social del \\
municipio? \\
¿Por qué es \\
importante el CS \\
en el municipio? \\
¿Cuáles son los \\
aprendizajes del \\
control social en \\
el municipio?
\end{tabular} \\
\hline
\end{tabular}

\section{D) Grupos focales}

\section{Participantes}

En el escenario bogotano se desarrolló un grupo focal con líderes sociales pertenecientes a la experiencia de conformación de Observatorios ciudadanos de control social en la ciudad, dicho grupo focal coadyuvó a la recolección de información importante para la reflexión sobre la experiencia en mención.

En lo que respecta a Sacaba se tuvo la oportunidad de formar parte del proyecto de Hábitat y Medio Ambiente \& Asentamientos Humanos, desarrollado por el Centro de Planificación y Gestión CEPLAG de la Universidad Mayor de San Simón de Cochabamba en este proyecto se estaba desarrollando una tesis sobre el tema de Planificación Participativa ${ }^{20}$ y allí se acompañó a la tesista a realizar grupos focales con líderes sociales, habitantes del municipio y autoridades del Gobierno Autónomo Municipal de Sacaba, en los que se recabó información valiosa para el presente trabajo de investigación.

${ }^{20}$ La tesis está siendo desarrollada por Paola Ledo sobre planificación Participativa desde un enfoque sistémico. Gracias a la participación como consultora en este proyecto ASDI-CEPLAG, se obtiene información pertinente para ser analizada en el marco de este estudio doctoral, de allí se retoman los informes que se produjeron en el marco de la consultoría. 


\section{Instrumento}

El instrumento utilizado para la sistematización del grupo focal de Bogotá fue un diario de campo en donde se registró la información némica y la nética con miras a cualificar la reflexión que de allí se suscitó. Mientras que en el caso de Sacaba retomando el aporte de los diarios de campo como herramienta de sistematización se realizaron informes por cada grupo desarrollado.

\section{$\underline{\text { Resultados }}$}

Se desarrolló la técnica de grupo focal partiendo de las consideraciones conceptuales citadas en el capítulo anterior. Cabe destacar, que esta técnica se llevó a cabo para el análisis del caso Bogotá con el objetivo de evaluar los impactos del proyecto "Fortalecimiento de capacidades ciudadanas para el control social" en las localidades en las que se desarrolló a través de la constitución de Observatorios Ciudadanos de Política Pública.

En el marco del proceso evaluativo el grupo focal fue concebido como un espacio de diálogo y construcción colectiva de los actores participantes sobre la ruta de construcción hacia lo público.

El desarrollo del grupo focal comprende dos grandes fases para su implementación. La primera fase de diseño y preparación que involucra:

- La definición de objetivos del espacio tomando en cuenta categorías de investigación

- Establecer la ruta de planificación: diseñar la estrategia metodológica con antelación, identificar-seleccionar-comprometer a los participantes, localizar el lugar adecuado.

- Seleccionar invitados: informantes clave. El número adecuado de asistentes es $10-12$

- Diseño de guión: definir las preguntas con ocasión a las dimensiones del estudio

Desarrollar la guía del proceso en el taller: abarcar las etapas posibles, de manera que se ayude al coordinador a moderar el tiempo.

Selección de roles de participantes.

- Rol de coordinador: quien da la bienvenida a los asistentes, introduce la técnica de discusión, presenta los objetivos del encuentro y es encargado de mantener el hilo conductor de los debates que se suscitan, recordando permanentemente las preguntas orientadoras y encauzando los aportes.

- Rol de registro de información: esta persona es quien se encarga de recoger la memoria del encuentro, a manera de relatoría. Registra todos los aspectos que se conversan y analizan en el encuentro. 
- Rol de registro de información: bitácora némico y nético. Es quien se encarga de recoger la memoria, pero esta vez registrándola haciendo distinción entre la información de tipo némico (aquella que proviene del sujeto investigado) y nético (la constituida por la interpretación de los hechos hecha por el investigador). En esta recolección se destaca la información obtenida a partir de las indagaciones de sentido sobre el sujeto de la investigación. Este registro requiere de un trabajo reflexivo permanente y riguroso del investigador sobre el entorno y sobre sí mismo

- Rol del sujeto reflexivo o también llamado "más uno": este papel es desempeñado por un sujeto con capacidad de análisis a profundidad, desarrolla una función enfocada en la capacidad reflexiva de analizar las interacciones de los sujetos en el encuentro, tiene que recuperar la observación de los investigadores sobre "el objeto" pero también tiene que velar por la evidencia sobre la observación de la observación de los sujetos sobre "el objeto"; tener la capacidad de salir de sí mismo y de la escena que acontece para evidenciar los intercambios relacionales, las dinámicas de la discusión, a saber situarse en el segundo orden del grupo focal.

La segunda fase la comprende el desarrollo del grupo focal como tal, el número de preguntas a realizar a los participantes debe ser reducido, no se pretende realizar un abordaje exhaustivo, por el contrario, se pretende centrar la discusión sobre unos temaproblemas específicos, de forma que la redacción y/o formulación de estas preguntas debe ser muy clara para la comprensión de los asistentes. En este punto la labor del coordinador resulta fundamental, ya que es él quien está atento siempre a que no se disperse la atención o se pierda el foco de interés de la discusión. Para facilitar esta labor resulta importante escribir las preguntas en el pizarrón para que estén visibles para los participantes, igualmente leerlas cada determinado tiempo para encauzar los debates. El coordinador del grupo estuvo atento siempre a la dinámica de la discusión, de manera que en el momento en que se percibía en el ambiente el cambio de energía de los participantes, había muchos silencios o repetición de temas, se consulta a los sujetos para lanzar una nueva pregunta para la discusión, de igual forma, permanentemente se está retroalimentando a los participantes destacando los consensos o disensos grupales con el fin de intentar aproximar cierres a las discusiones.

La realización de un grupo focal demanda la planeación de un espacio físico adecuado, de preferencia cerrado en el que se puedan acondicionar las mesas para tener una organización del equipo de trabajo que posibilite la relación cara a cara.

El tiempo total de desarrollo del grupo focal no superó las dos horas de trabajo intensivo con un receso en el medio de $15 \mathrm{~min}$, mayor tiempo no es recomendable dado el cansancio del grupo y el nivel de agotamiento de los temas de discusión. 


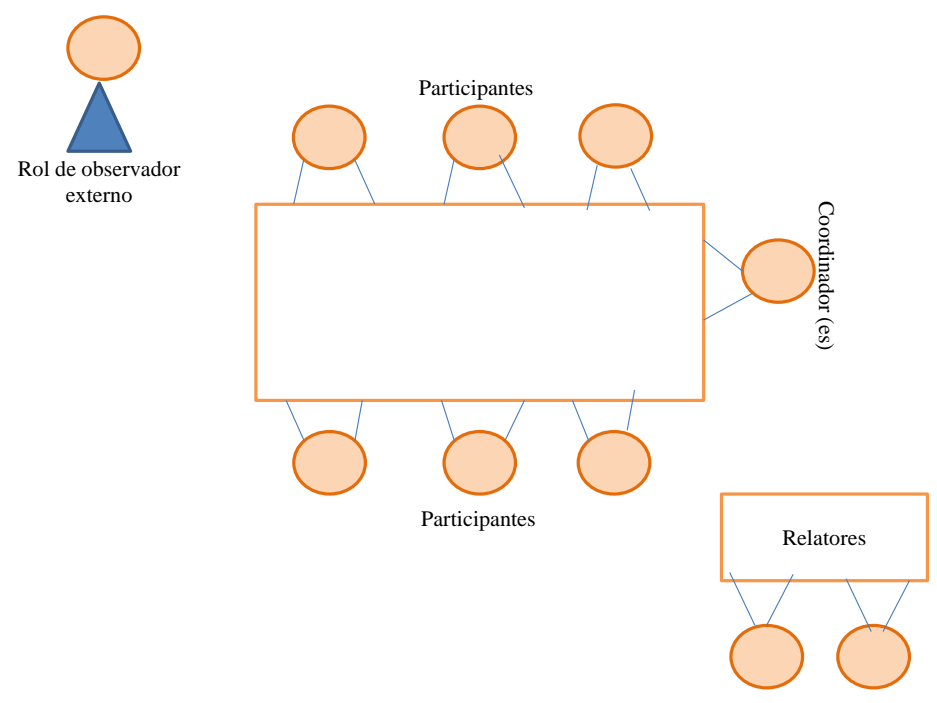

Fuente: Elaboración Propia, 2015

Figura 48. EStructructura física del grupo focal

Las preguntas orientadoras del grupo focal en el caso de Bogotá, fueron:

- Podrían por favor presentarse y contarnos cada uno y cada una ¿Cuál es su mayor orgullo?

- ¿Cuáles fueron los logros en el fortalecimiento de capacidades ciudadanas en el tema organizativo y colectivo?

- ¿Cuáles fueron los logros en el fortalecimiento de capacidades ciudadanas en lo participativo y lo público?

- ¿Cuáles serían las recomendaciones a las intervenciones de las y los estudiantes?

En el caso de Sacaba la dinámica de trabajo se detalla a continuación, tomando en consideración que para cada Organización Territorial de Base- OTB- se tiene un proceso particular.

Tabla 33. Grupos focales Sacaba

\begin{tabular}{|l|l|}
\hline \multicolumn{1}{|c|}{ GRUPO } & \multicolumn{1}{c|}{ DINÁMICA } \\
\hline $\begin{array}{l}\text { LÓPEZ RANCHO GRUPO FOCAL I } \\
\text { (Noviembre 2015) }\end{array}$ & $\begin{array}{l}\text { El día 20 de noviembre se lleva a cabo la actividad con la } \\
\text { participación de habitantes del sector en desarrollo de sus } \\
\text { reuniones mensuales de OTB. En este contexto, se busca } \\
\text { realizar un análisis situacional que permita caracterizar desde } \\
\text { las percepciones de este grupo poblacional, por una parte las } \\
\text { situaciones identificadas como problemáticas por parte de los } \\
\text { comunarios y por la otra, las soluciones que ellos y ellas } \\
\text { piensan como posibles frente a cada tema-problema. Para } \\
\text { ello se emplea una metodología que se enmarca en el } \\
\text { enfoque de sistemas blandos, en donde interesa desde una } \\
\text { acción comunal, aproximar estrategias y/o alternativas para } \\
\text { el mejoramiento de las situaciones problemáticas. }\end{array}$ \\
\hline
\end{tabular}


Tabla 34. Grupos focales Sacaba. (Continuación)

\begin{tabular}{|c|c|}
\hline GRUPO & DINÁMICA \\
\hline $\begin{array}{l}\text { MOLINO BLANCO GRUPO FOCAL I } \\
\text { (Marzo 2016) }\end{array}$ & $\begin{array}{l}\text { Se desarrollaron visitas a la OTB en mención con el objetivo } \\
\text { de llevar a cabo el taller número I de identificación de } \\
\text { necesidades de la población en el marco del Programa } \\
\text { Hábitat, el objetivo era el de aprovechar las reuniones de esta } \\
\text { comunidad para realizar la actividad y obtener como } \\
\text { producto una cartografía de problemáticas sociales que la } \\
\text { misma comunidad lograra identificar a partir de la discusión } \\
\text { colectiva. Dado que las dinámicas de trabajo de estos } \\
\text { dirigentes y población de la comunidad son bastante arduas, } \\
\text { no se logró desarrollar el trabajo en torno a mesas de trabajo } \\
\text { por lo que se desarrolló un plenario amplio para la } \\
\text { conversación. } \\
\text { En este contexto, se busca realizar un análisis situacional que } \\
\text { permita caracterizar desde las percepciones de este grupo } \\
\text { poblacional, por una parte las situaciones identificadas como } \\
\text { problemáticas por parte de los comunarios y por la otra, las } \\
\text { soluciones que ellos y ellas piensan como posibles frente a } \\
\text { cada tema-problema. }\end{array}$ \\
\hline $\begin{array}{l}\text { CURUBAMBA ALTA. } \\
\text { FOCAL I (abril 2016) }\end{array}$ & $\begin{array}{l}\text { Desde la coordinación del Programa Hábitat se da la } \\
\text { bienvenida a los técnicos del GAMS asistentes a esta jornada } \\
\text { se les explica que la idea del trabajo en este día era la de } \\
\text { debatir conjuntamente (gobierno-comunidad-universidad) } \\
\text { sobre la situación actual de la OTB Curubamba para ello se } \\
\text { habían citado a líderes de esta comunidad, quienes por } \\
\text { alguna razón no pudieron estar presentes. Se explica que el } \\
\text { fin último del Programa es el de contribuir al fortalecimiento } \\
\text { de la planificación participativa en el municipio, ello a través } \\
\text { del desarrollo de una serie de talleres cuyo objetivo es el de } \\
\text { finalizar con la construcción de un plan. }\end{array}$ \\
\hline $\begin{array}{l}\text { LÓPEZ RANCHO GRUPO FOCAL II } \\
\text { (Abril 2016) }\end{array}$ & $\begin{array}{l}\text { El día } 1 \text { de abril de } 2016 \text {, se visita nuevamente la OTB } \\
\text { López Rancho en Sacaba con el fin de llevar a cabo el taller } \\
\text { número II en el que se identificarían acciones concretas para } \\
\text { dar respuesta a los problemas identificados en la etapa I del } \\
\text { proceso. El objetivo era el de validar los objetivos que fueron } \\
\text { construidos por la comunidad en el momento anterior, de } \\
\text { manera que se pudiera entablar conversación sobre los } \\
\text { actores, intereses y escenarios (tareas y actividades) que se } \\
\text { tendrían que desarrollar para llevar a cabo aquello que se } \\
\text { planteó anteriormente como prioritario o futuro ideal. }\end{array}$ \\
\hline
\end{tabular}


Tabla 35. Grupos focales Sacaba. (Continuación)

\begin{tabular}{|l|l|}
\hline \multicolumn{1}{|c|}{ GRUPO } & \multicolumn{1}{c|}{ DINÁMICA } \\
\hline $\begin{array}{l}\text { CURUBAMBA ALTA. GRUPO FOCAL II (Junio } \\
\text { 2016) }\end{array}$ & $\begin{array}{l}\text { En esta ocasión se intenta desarrollar todo el ciclo } \\
\text { de trabajo con los asistentes, que va desde la } \\
\text { identificación de situaciones problemáticas hasta la } \\
\text { priorización de una situación susceptible de } \\
\text { convertirse en proyecto y la asignación de } \\
\text { responsabilidades para el planteamiento de la } \\
\text { propuesta. }\end{array}$ \\
\hline $\begin{array}{l}\text { GRUPO FOCAL CON FUNCIONARIOS DE LA } \\
\text { ADMINISTRACIÓN PÚBLICA MUNICIPAL } \\
\text { Octubre de 2016) }\end{array}$ & $\begin{array}{l}\text { Dicho taller buscaba generar reflexión sobre las } \\
\text { dinámicas de planificación en el territorio } \\
\text { municipal de Sacaba, a partir de una agenda de } \\
\text { trabajo constituida por preguntas de reflexión y } \\
\text { participación, para recabar las percepciones de los } \\
\text { actores participantes y como parte del objetivo de } \\
\text { proyectar escenarios futuros en los que se pueda } \\
\text { trabajar colectivamente para aunar esfuerzos, en } \\
\text { torno al mejoramiento de las lógicas de la } \\
\text { planificación municipal. }\end{array}$ \\
\hline
\end{tabular}

\section{SISTEMATIZACIÓN RESULTADOS DE GRUPOS FOCALES POR OTB DEL MUNICIPIO DE SACABA.}

Tabla 36. Resultados grupos focales

\begin{tabular}{|c|c|}
\hline OTB & RESULTADOS \\
\hline \multirow{4}{*}{$\begin{array}{l}\text { LÓPEZ } \\
\text { RANCHO } \\
\text { NOV } 15\end{array}$} & NÉTIC \\
\hline & En el primer momento se realiza la presentación general y entrega de materiales \\
\hline & $\begin{array}{l}\text { por grupos de trabajo, posterior a ello como coordinadores de la actividad en los } \\
\text { subgrupos conformados se inicia la discusión planteando la pregunta: ¿Cuáles son } \\
\text { los problemas más importantes de tu comunidad/OTB/distrito/municipio? Dicha } \\
\text { pregunta busca suscitar la reflexión grupal para posteriormente conformar una } \\
\text { lista de situaciones problemáticas, que sea consensuada por los integrantes del } \\
\text { grupo. El ambiente de discusión en el grupo amarillo al principio fue algo } \\
\text { silencioso, al parecer el número de personas por grupo fue muy amplio y ello } \\
\text { hasta cierto punto resultó complejo en términos de alternativas para propiciar la } \\
\text { discusión y para garantizar que la gran mayoría expresara sus opiniones o } \\
\text { percepciones sobre el cuestionamiento planteado. Para próximos talleres sería } \\
\text { importante re-pensar la cantidad de personas por grupo. }\end{array}$ \\
\hline & $\begin{array}{l}\text { Se formula la pregunta al grupo y se inicia la discusión, al respecto resulta } \\
\text { importante anotar que la mayor parte de respuestas se situaron en el espacio OTB, } \\
\text { el interrogante formulado hacía referencia a diferentes escalas y entornos } \\
\text { territoriales (comunidad/OTB/distrito/municipio) pero cuando las personas } \\
\text { configuraban respuestas, la mayor parte de éstas eran contextualizadas } \\
\text { directamente con su espacio más inmediato la OTB. Al respecto cabe destacar que } \\
\text { ésta -la OTB- constituye el lugar "es el local de la actividad - acción - } \\
\text { inmediata del sujeto, (...) es el local de identidades significativas. De esa manera, } \\
\text { este lugar tiene relación con el espacio de la vivencia y de la convivencia, y posee } \\
\text { como punto de referencia lo cotidiano que es imprescindible para la comprensión } \\
\text { de la sociedad" (Scheineider y Tartaruga 2006:11). }\end{array}$ \\
\hline
\end{tabular}




\begin{tabular}{|c|c|}
\hline OTB & RESULTADOS \\
\hline & 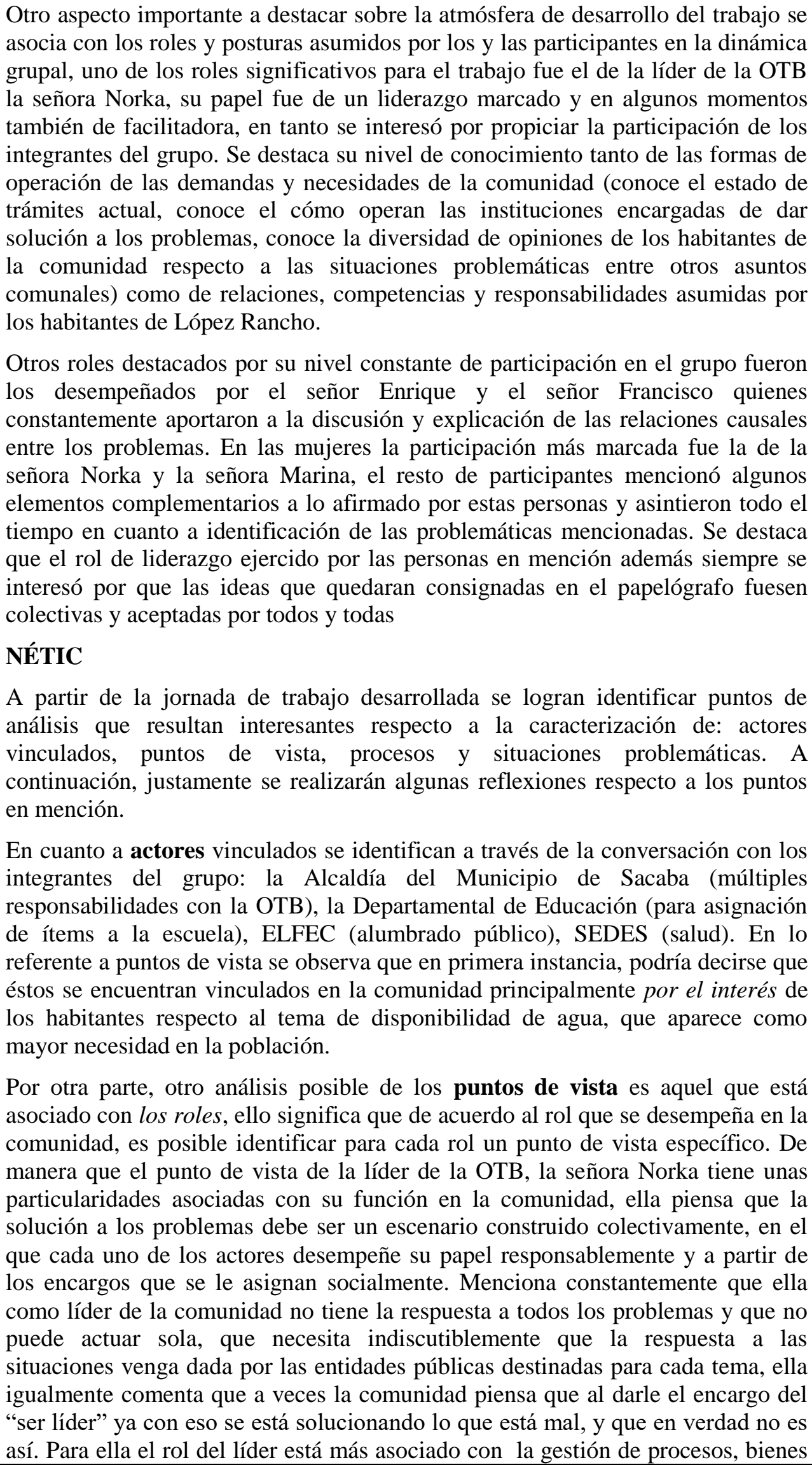 \\
\hline
\end{tabular}




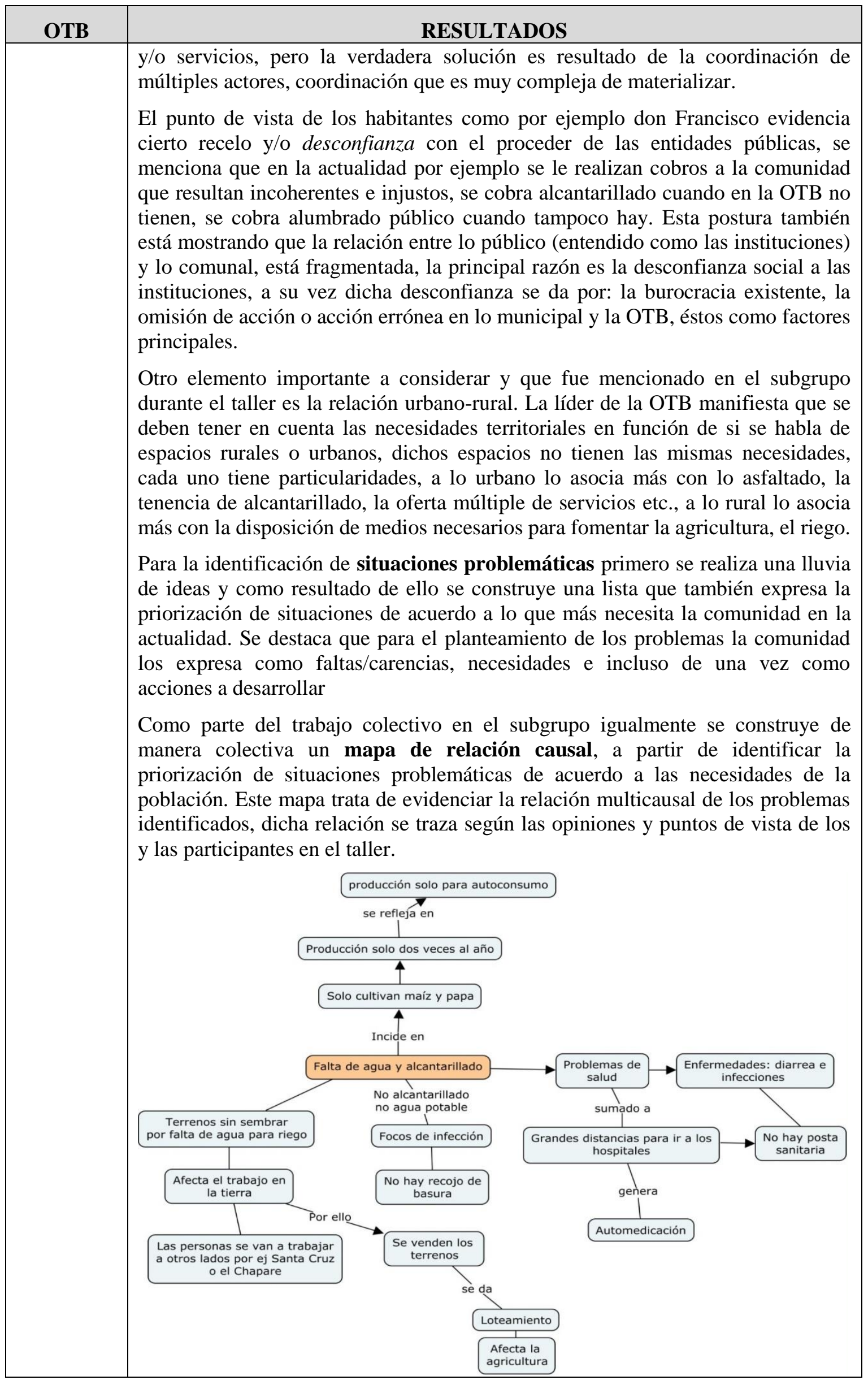




\begin{tabular}{|c|c|}
\hline OTB & RESULTADOS \\
\hline $\begin{array}{l}\text { MOLINO } \\
\text { BLANCO }\end{array}$ & 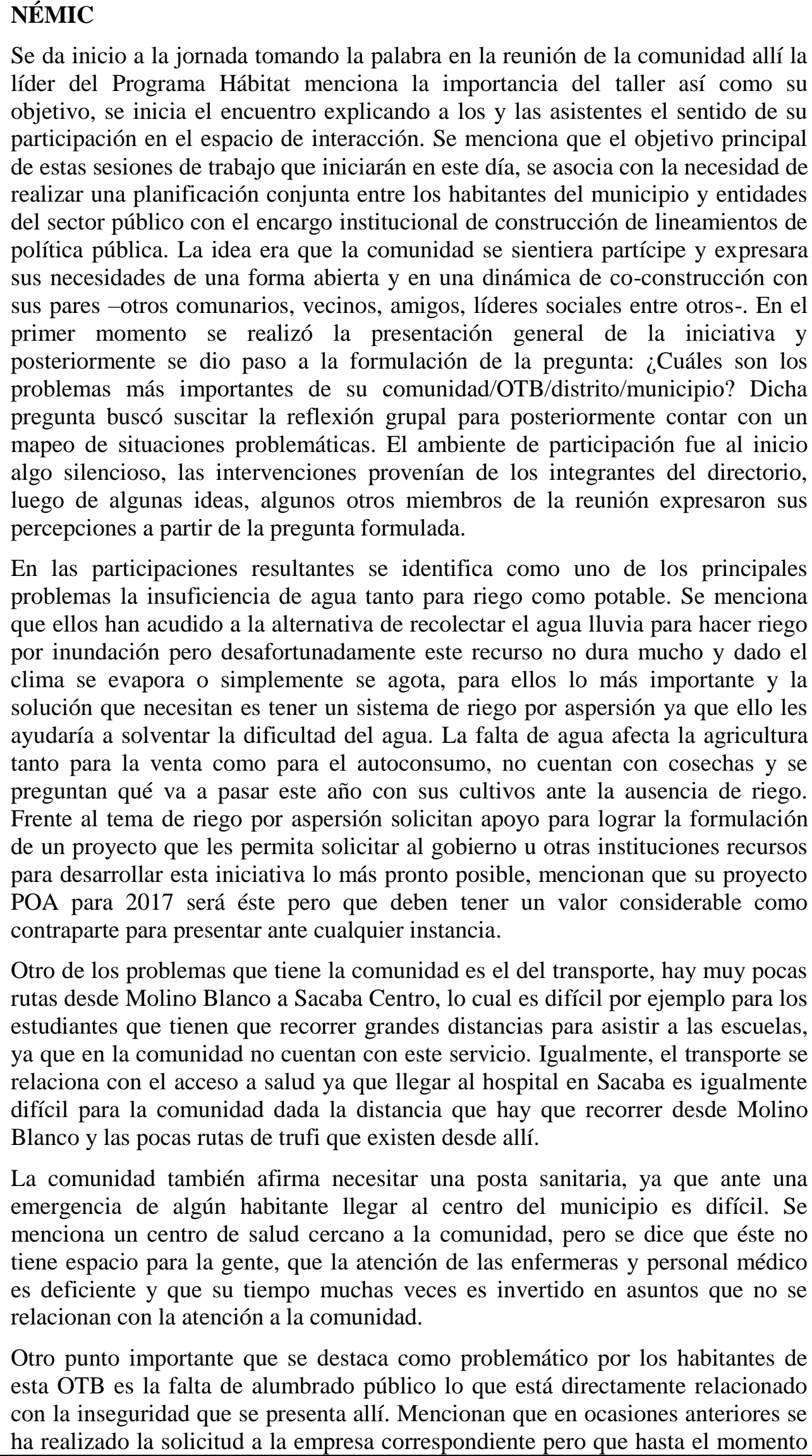 \\
\hline
\end{tabular}




\begin{tabular}{|c|c|}
\hline OTB & RESULTADOS \\
\hline & todavía no se ha dado solución a la problemática. \\
\hline & $\begin{array}{l}\text { Otro aspecto importante a destacar sobre la atmósfera de desarrollo del trabajo se } \\
\text { asocia con los roles y posturas asumidos por los y las participantes en la dinámica } \\
\text { grupal, la mayoría de participaciones fue asumida por integrantes del Directorio } \\
\text { de la OTB, quienes se mostraron más deseosos de participar respondiendo a las } \\
\text { preguntas formuladas. Se evidencia un liderazgo muy fuerte por parte del } \\
\text { Directorio, fueron contadas las participaciones de otros habitantes del sector, } \\
\text { participación que se considera muy baja dado el número de personas que se } \\
\text { encontraban en la reunión. }\end{array}$ \\
\hline & NÉTIC \\
\hline & $\begin{array}{l}\text { A partir de la jornada de trabajo desarrollada se logran identificar puntos de } \\
\text { análisis que resultan interesantes respecto a la caracterización de: actores } \\
\text { vinculados, puntos de vista, procesos y situaciones problemáticas. A } \\
\text { continuación, justamente se realizarán algunas reflexiones respecto a los puntos } \\
\text { en mención. }\end{array}$ \\
\hline & $\begin{array}{l}\text { En cuanto a actores vinculados se identifican a través de la conversación con los } \\
\text { integrantes del grupo: la Alcaldía del Municipio de Sacaba (múltiples } \\
\text { responsabilidades con la OTB), la Departamental de Educación (en lo referente a } \\
\text { la oferta educativa), ELFEC (alumbrado público), SEDES (salud). En lo referente } \\
\text { a puntos de vista se observa que en primera instancia, podría decirse que éstos se } \\
\text { encuentran vinculados en la comunidad principalmente por el interés de los } \\
\text { habitantes respecto al tema de disponibilidad de agua, que aparece como mayor } \\
\text { necesidad en la población. }\end{array}$ \\
\hline & $\begin{array}{l}\text { Por otra parte, otro análisis posible de los puntos de vista es aquel que está } \\
\text { asociado con los roles, ello significa que de acuerdo al rol que se desempeña en la } \\
\text { comunidad, es posible identificar para cada rol un punto de vista específico. De } \\
\text { manera que el punto de vista de la líder de la OTB, la señora Amanda, está } \\
\text { vinculado con el ejercicio de su rol como dirigente e integrante activa del } \\
\text { Directorio de la OTB. Tiene una postura bastante pragmática frente a las } \\
\text { situaciones de la comunidad, ello se evidencia en la demanda inmediata a la } \\
\text { universidad de un apoyo para la formulación de un perfil de proyecto frente a la } \\
\text { necesidad e interés del riego por aspersión. }\end{array}$ \\
\hline & $\begin{array}{l}\text { Como parte del trabajo de identificación de situaciones problemáticas se } \\
\text { construye a partir de los relatos de los comunarios un mapa de relación causal, a } \\
\text { partir de identificar la priorización de situaciones problemáticas de acuerdo a las } \\
\text { necesidades de la población. Este mapa trata de evidenciar la relación multicausal } \\
\text { de los problemas identificados, dicha relación se traza según las opiniones y } \\
\text { puntos de vista de los y las participantes en el taller. }\end{array}$ \\
\hline
\end{tabular}




\begin{tabular}{|c|c|}
\hline OTB & RESULTADOS \\
\hline & Inseguridad - se exponen a \\
\hline $\begin{array}{l}\text { CURUBA } \\
\text { MBA } \\
\text { ALTA I }\end{array}$ & 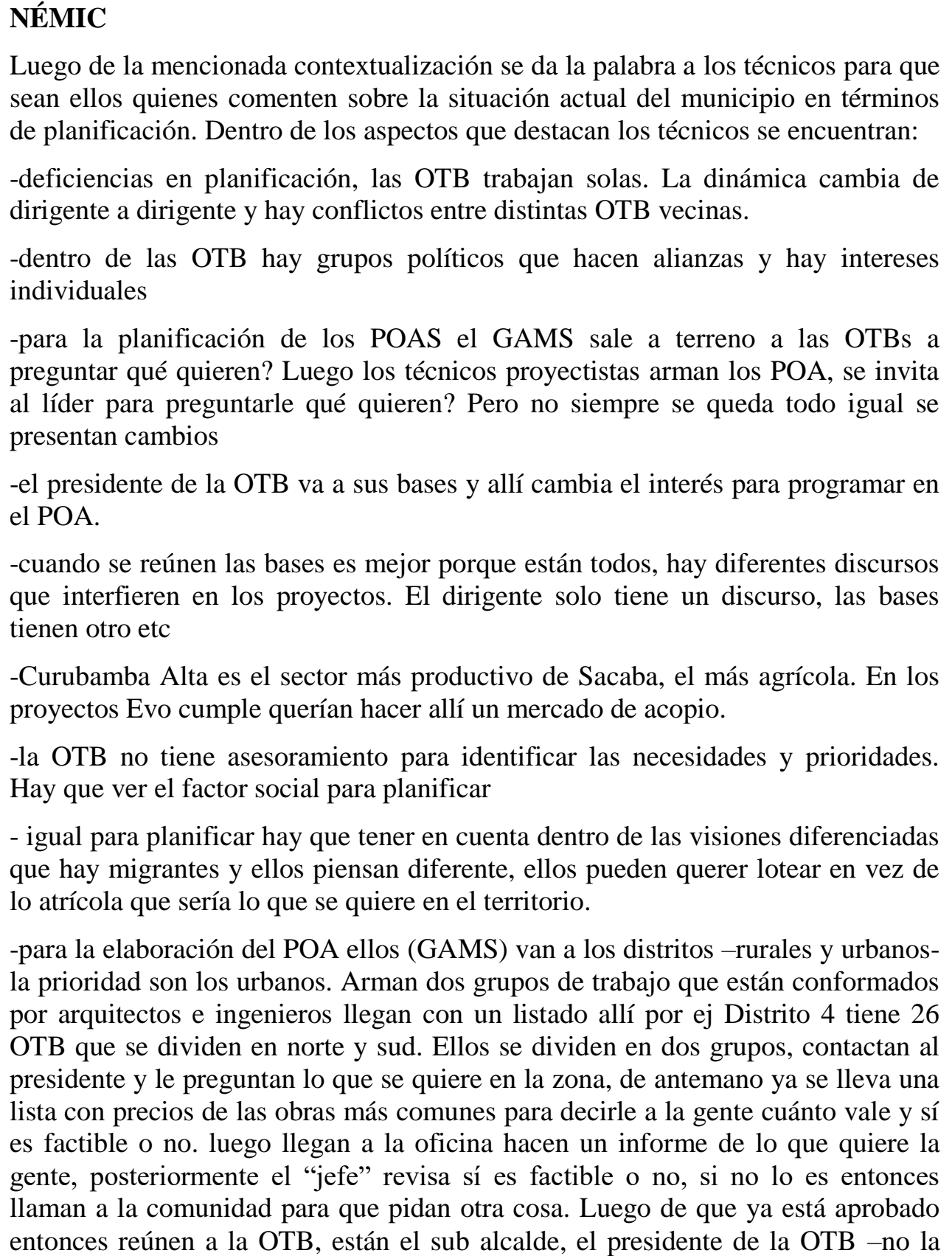 \\
\hline
\end{tabular}




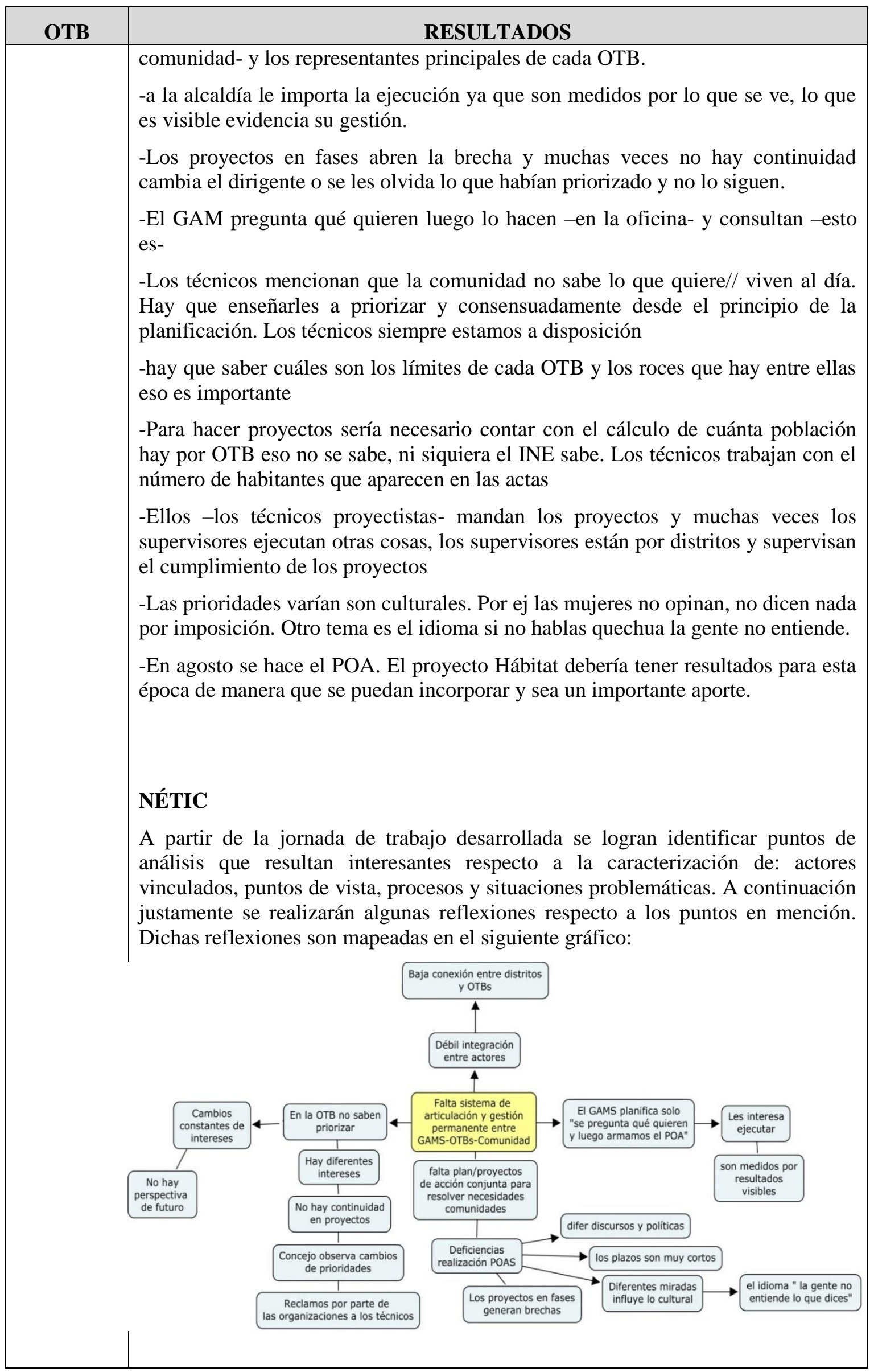




\begin{tabular}{|c|c|}
\hline OTB & RESULTADOS \\
\hline $\begin{array}{l}\text { LÓPEZ } \\
\text { RANCHO } \\
\text { II } \quad \text { (Abril } \\
16)\end{array}$ & 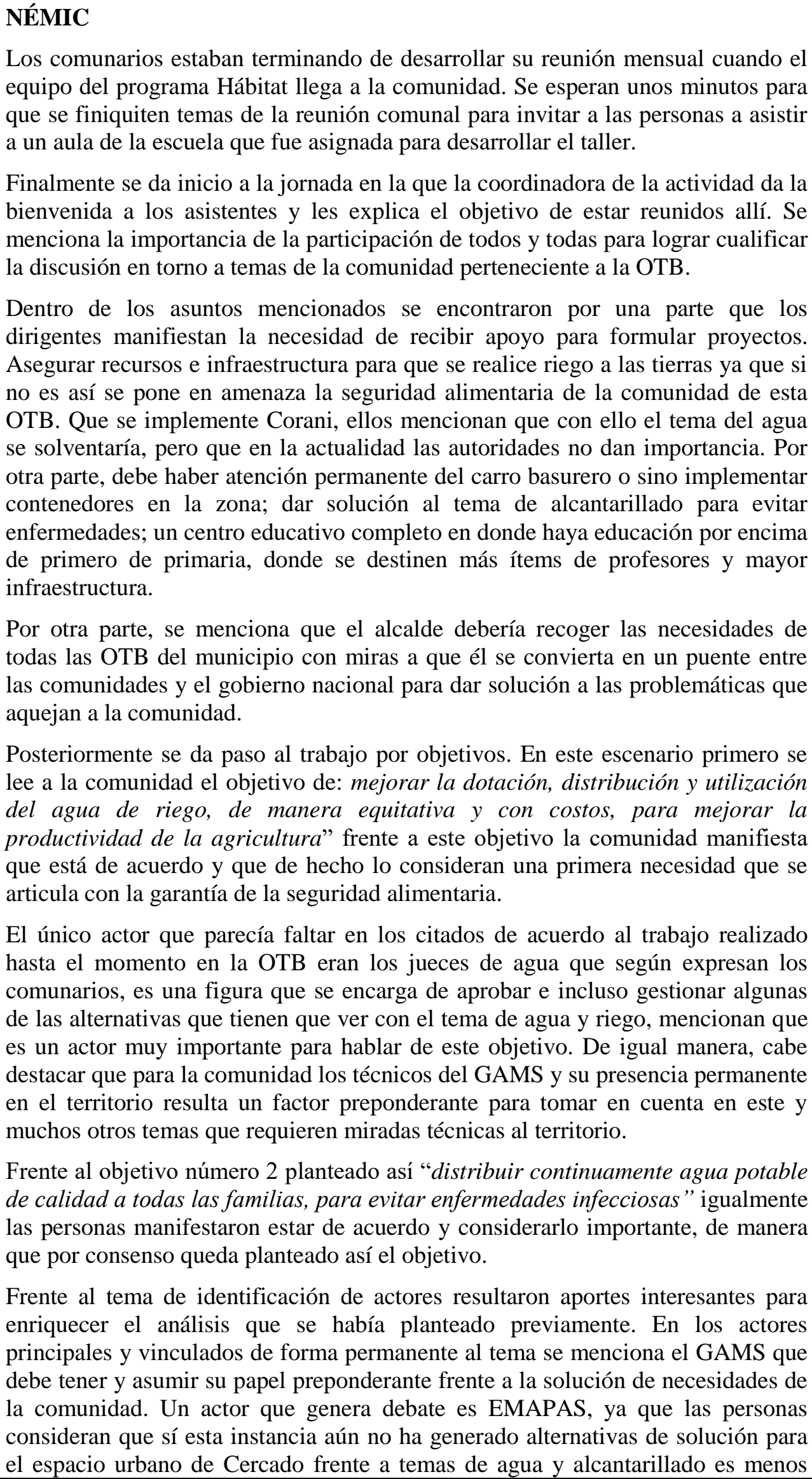 \\
\hline
\end{tabular}




\begin{tabular}{|c|c|}
\hline OTB & RESULTADOS \\
\hline & 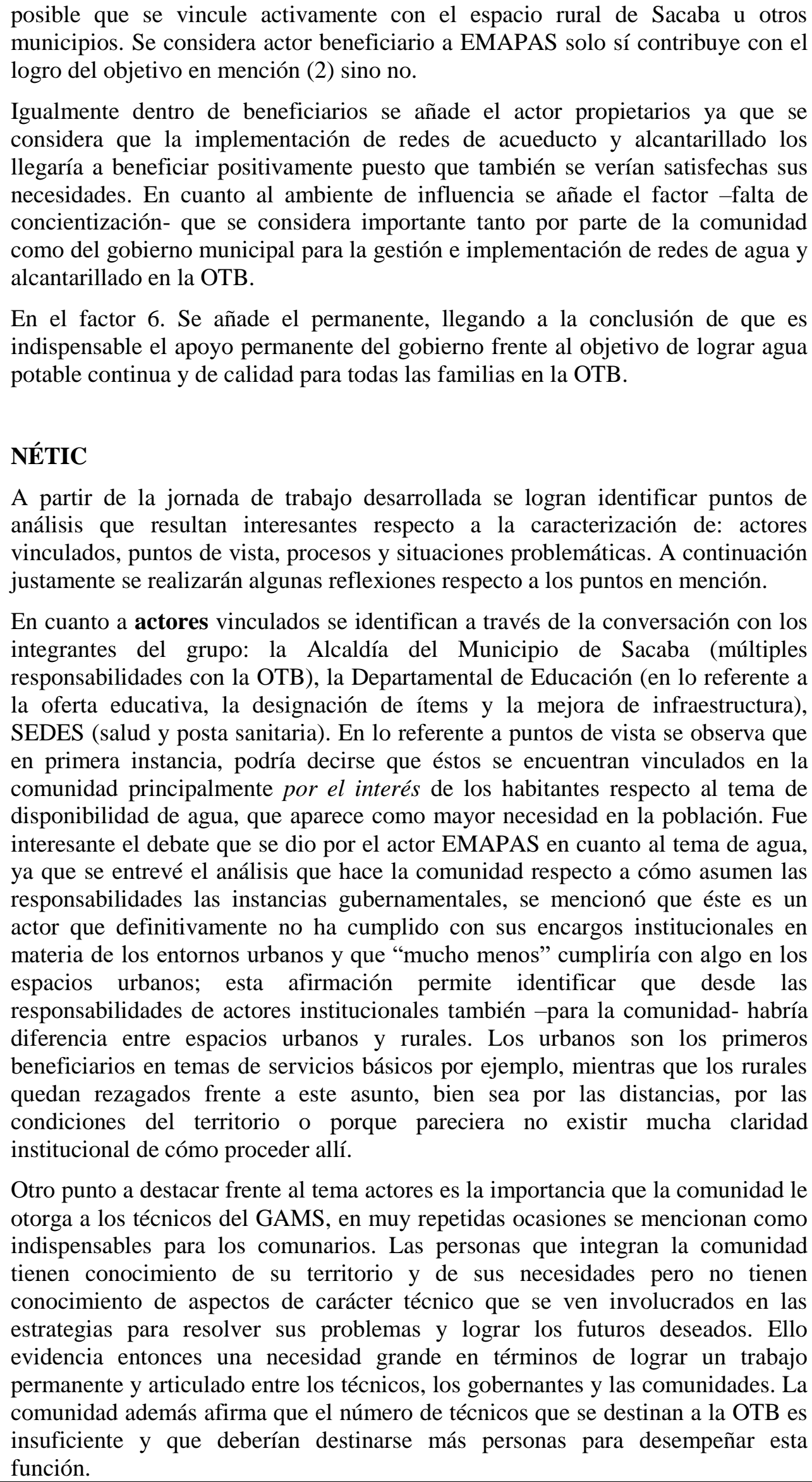 \\
\hline
\end{tabular}




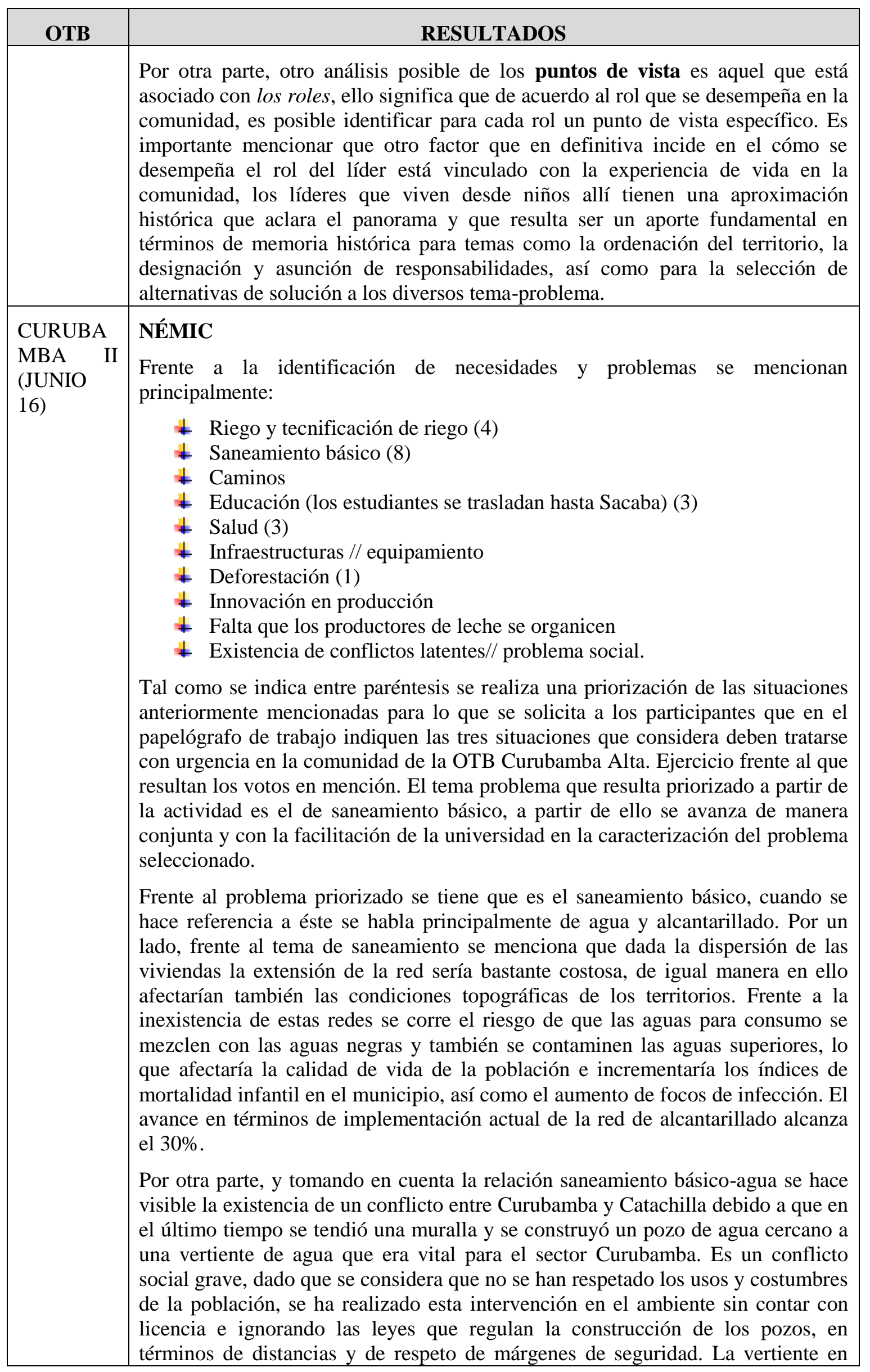




\begin{tabular}{|c|c|}
\hline OTB & RESULTADOS \\
\hline & 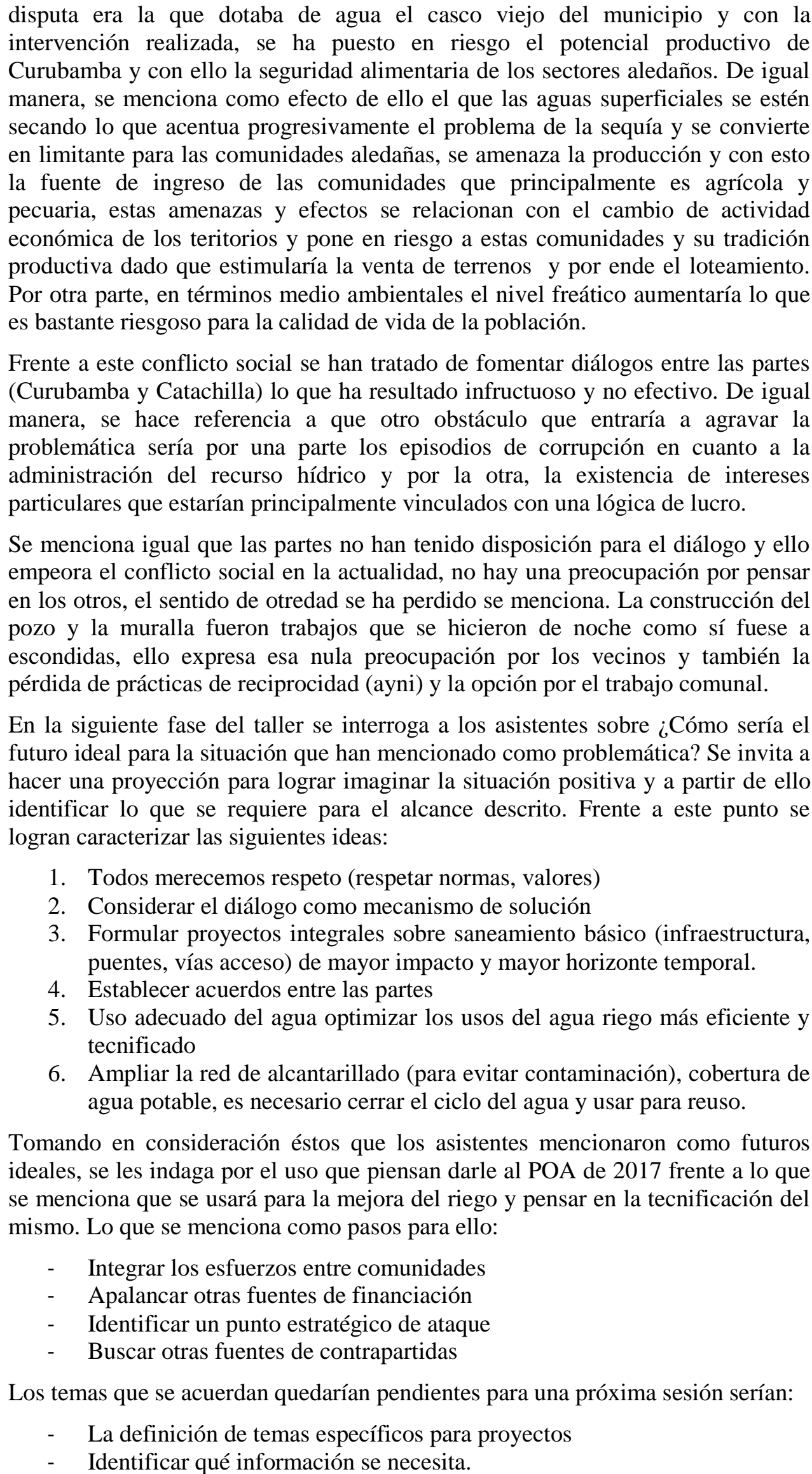 \\
\hline
\end{tabular}




\begin{tabular}{|c|c|}
\hline OTB & RESULTADOS \\
\hline & $\begin{array}{l}\text { Como tareas y/o responsabilidades de los asistentes para el próximo encuentro: } \\
\quad \text { Don Teodorico: pensará más clara y específicamente ideas de proyectos } \\
\text { para la comunidad } \\
\quad \text { El equipo sistematizará la información del taller } \\
\quad \text { Luis del GAMS revisará avances de la elaboración del POA y nos } \\
\text { comentará en la otra sesión } \\
\text { NÉTIC } \\
\text { A partir de la jornada de trabajo desarrollada se logran identificar puntos de } \\
\text { análisis que resultan interesantes respecto a la caracterización de: actores } \\
\text { vinculados, puntos de vista, procesos y situaciones problemáticas. La asistencia } \\
\text { de actores de la comunidad parece resultar algo problemática siempre ha sido } \\
\text { difícil que asistan más personas o miembros de los directorios de las OTB, ello } \\
\text { debería revisarse. En esta ocasión asistieron más personas del GAMS y solo un } \\
\text { líder de la comunidad, ello resulta limitante para incentivar la participación puesto } \\
\text { que tal vez existan temores para la expresión de ideas o procesos de } \\
\text { caracterización y conversación sobre situaciones problemáticas tan delicadas } \\
\text { como el conflicto por la construcción del pozo. } \\
\text { La estrategia de realizar el taller de manera conjunta entre GAMS y comunidad } \\
\text { pienso que es la mejor frente a la planificación, puesto que es en estos escenarios } \\
\text { en donde podría existir construcción colectiva y también incidencia política de la } \\
\text { ciudadanía. Sin embargo, la invitación a la comunidad tendría que fortalecerse } \\
\text { para que se construya un real escenario asociado de participación y se constituyan } \\
\text { insumos para la elaboración de planes, programas y proyectos de manera co- } \\
\text { construida, tomando en cuenta que } \\
\text { La gestión asociada se entronca con la interpretación de las necesidades } \\
\text { sociales como derechos. En este sentido, la participación como derecho } \\
\text { encontraría su expresión y su ejercicio más acabado en los espacios más o } \\
\text { menos ampliados de gestión asociada, donde los actores sociales ejercerían su } \\
\text { derecho a influir y a conducir los cambios sociales (Cardarelli \& Rosenfeld, } \\
\text { 2002, pág. 6) }\end{array}$ \\
\hline $\begin{array}{l}\text { FUNCION } \\
\text { ARIOS } \\
\text { ADMINIS } \\
\text { TRACIÓN } \\
\text { PÚBLICA } \\
\text { MUNICIP } \\
\text { AL }\end{array}$ & $\begin{array}{l}\text { NÉMIC } \\
\text { El taller inicia con la presentación de los objetivos del trabajo a desarrollar, se } \\
\text { menciona la importancia de la reflexión colectiva para considerar los diferentes } \\
\text { puntos de vista de los asistentes sobre los discursos y prácticas de la planificación } \\
\text { territorial en el municipio de Sacaba. Se menciona en este sentido, a los } \\
\text { participantes los pilares que contribuirán a construir un escenario participativo y } \\
\text { de reflexión conjunta, estos son: todos merecemos respeto, todos tenemos las } \\
\text { mismas oportunidades de hablar, todas las respuestas y opiniones son correctas, a } \\
\text { lo que se añade otro objetivo más que es el del criterio de confidencialidad de lo } \\
\text { que se converse en el escenario a crear conjuntamente. } \\
\text { Posterior a ello se desarrolla la dinámica de presentación entre los asistentes, que } \\
\text { permite distensionar el ambiente y crear empatía para el trabajo. Luego de esto, se } \\
\text { invita a los asistentes a reflexionar sobre ¿Cuáles son los problemas y necesidades } \\
\text { en el ejercicio de la planificación en el municipio? Y ¿Qué debilidades tenemos } \\
\text { como institución de planificación? A partir de ello se realiza una lluvia de ideas } \\
\text { cuyo objetivo metafóricamente hablando es el de tener "la fotografía" del estado } \\
\text { actual de la planificación en el nivel municipal y con ello lograr una imagen } \\
\text { compleja sobre las problemáticas y debilidades que se identifican en estos } \\
\text { ejercicios desde la administración municipal. Gracias a ello se logra configurar un }\end{array}$ \\
\hline
\end{tabular}




\begin{tabular}{|c|c|}
\hline OTB & RESULTADOS \\
\hline & 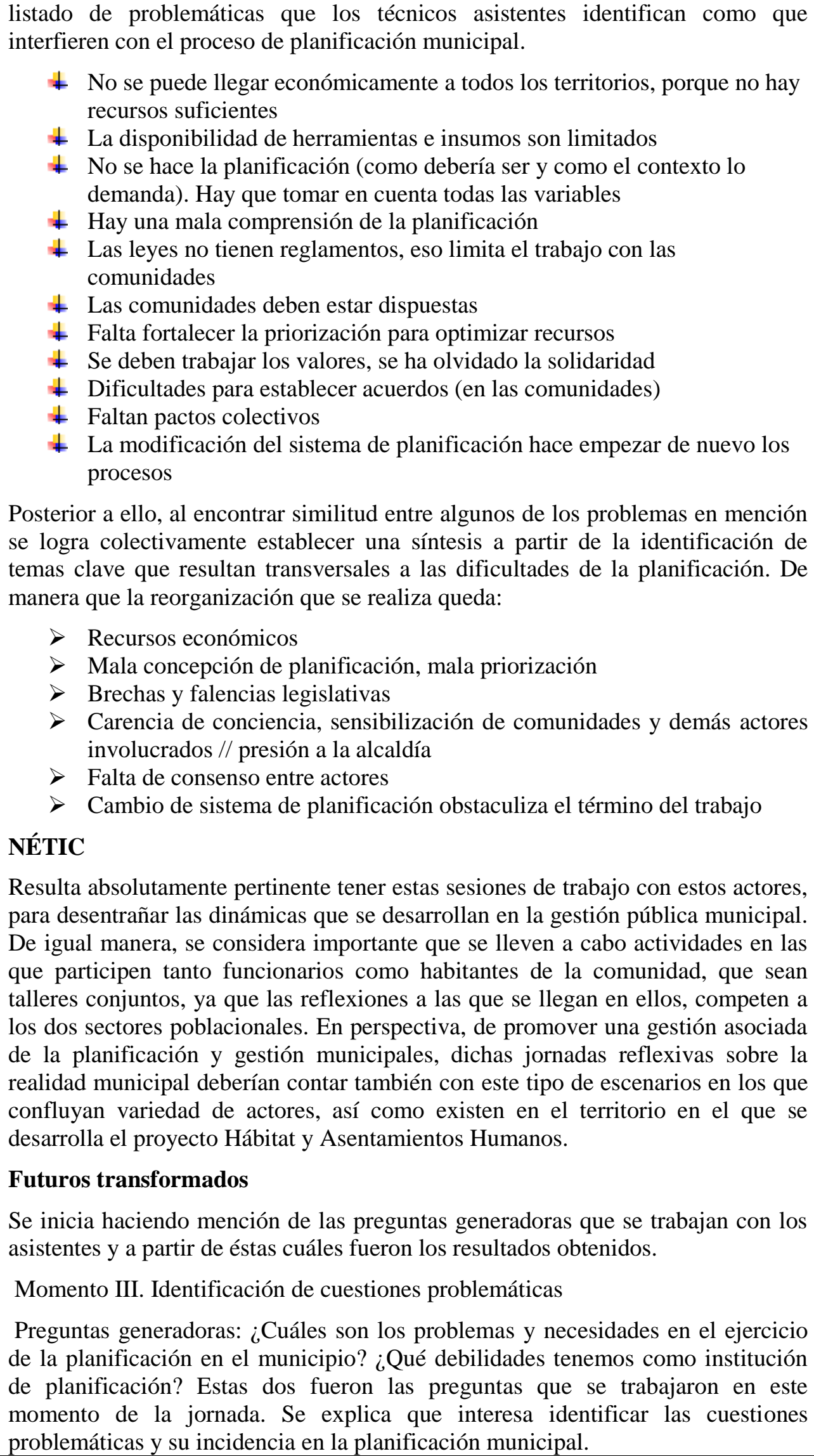 \\
\hline
\end{tabular}




\begin{tabular}{|c|c|}
\hline OTB & RESULTADOS \\
\hline & 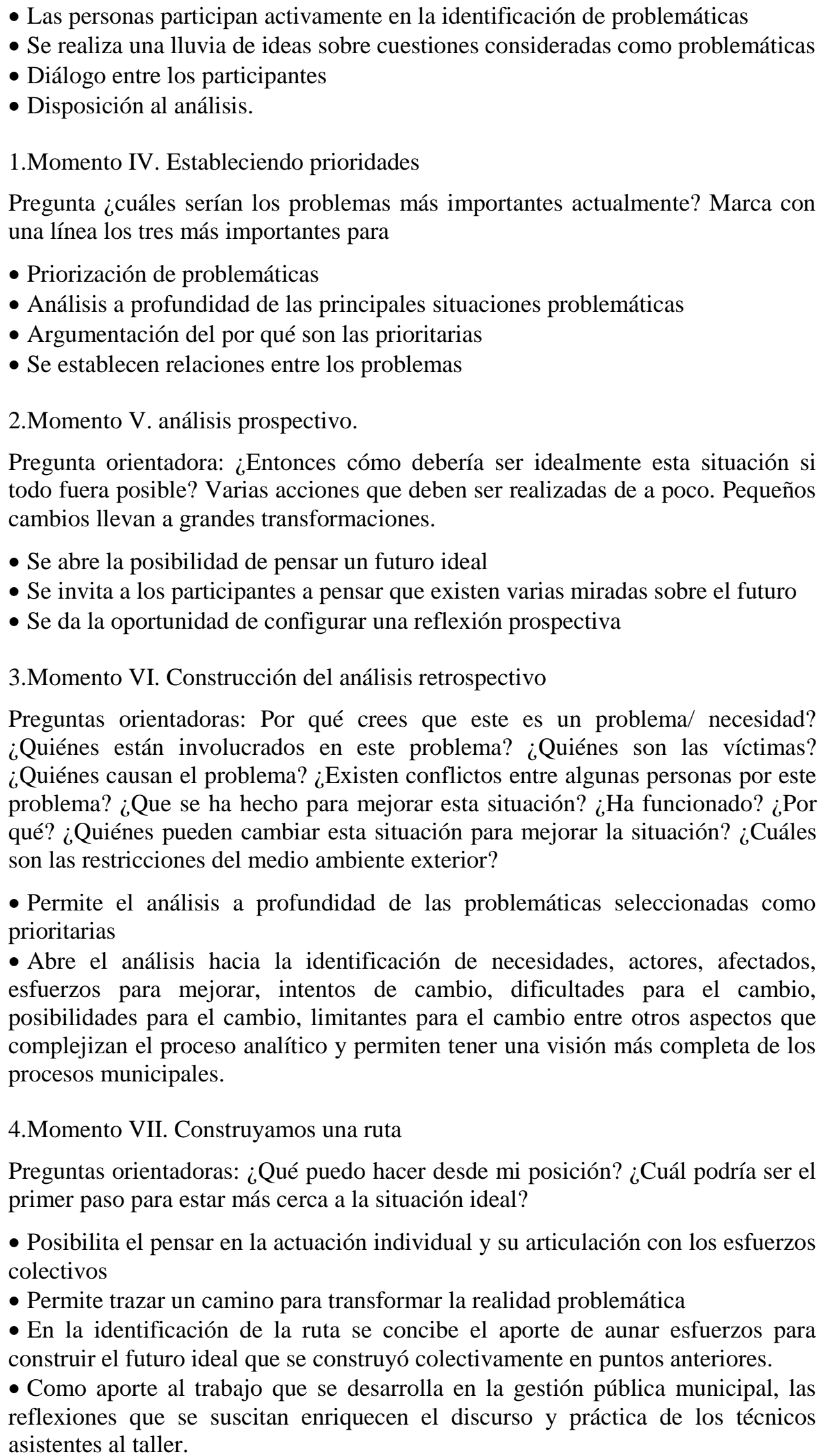 \\
\hline
\end{tabular}




\begin{tabular}{|c|c|}
\hline \multicolumn{2}{|c|}{ Sistematización grupo focal Bogotá. } \\
\hline NÉMIC & NÉTIC \\
\hline $\begin{array}{l}\text { "Participación de la alcaldía definitiva para el } \\
\text { proceso" "necesitan solución a problemas que } \\
\text { afectan a la población vulnerable" "mejorar la } \\
\text { inversión económica en cada localidad" "la } \\
\text { comunidad es un agente de cambio en el proceso } \\
\text { de OC" "se deben fortalecer las capacitaciones" } \\
\text { "como comunidad debemos ser apoyo de la } \\
\text { administración local" "conciliar dificultades" " }\end{array}$ & $\begin{array}{l}\text { Importancia del consenso en los procesos } \\
\text { sociales comunitarios. } \\
\text { La herramienta permite fortalecer la } \\
\text { evaluación del gobierno local, permite } \\
\text { articular la racionalidad técnica y la } \\
\text { racionalidad política en los procesos de } \\
\text { control social. }\end{array}$ \\
\hline $\begin{array}{l}\text { LOGROS } \\
\text { "aprender la metodología" "dialogamos con la } \\
\text { administración" "evaluamos a la administración }\end{array}$ & $\begin{array}{l}\text { Es fundamental que el proceso logra } \\
\text { compartir y transmitir ese sentido de } \\
\text { pertenencia territorial y de pensamiento y } \\
\text { construcción colectiva. }\end{array}$ \\
\hline $\begin{array}{l}\text { local" "nos fortalecemos aprendiendo la } \\
\text { herramienta" "somos interlocutores visibles en } \\
\text { temas" "construcción de consensos" "hemos } \\
\text { logrado el diálogo con la alcaldía" "la }\end{array}$ & $\begin{array}{l}\text { Cualifica la relación administración pública } \\
\text { y ciudad. Permite resignificar las nociones } \\
\text { de ciudad y ciudadanía. }\end{array}$ \\
\hline $\begin{array}{l}\text { herramienta tenía términos no tan aterrizados" } \\
\text { "salirnos de la intuición a la acción" "nos } \\
\text { organizamos a partir de una herramienta } \\
\text { internacional" "la ISO nos ofrece un ambiente }\end{array}$ & $\begin{array}{l}\text { Es necesaria y fundamental la voluntad } \\
\text { política de los actores, debe pensarse en que } \\
\text { es una pre-condición del proceso. }\end{array}$ \\
\hline $\begin{array}{l}\text { para la evaluación" "es importante localizar la } \\
\text { ISO" "fue difícil en algunas localidades, se hizo } \\
\text { con derechos de petición" "la herramienta al } \\
\text { inicio era complicada" "se dijo sí ajustémosla, } \\
\text { ahora se ha fortalecido el IWA" "algunos } \\
\text { pensaban que no era propicio para lo local" } \\
\text { "otros no se ajustaron" "la } 18091 \text { permite un } \\
\text { ambiente ordenado y riguroso" "recuperar la }\end{array}$ & $\begin{array}{l}\text { La racionalidad técnica está representada por } \\
\text { la herramienta ISO IWA como compendio } \\
\text { de insumos que permiten cualificar la } \\
\text { evaluación de PP, ello complementa las } \\
\text { discusiones políticas que venían } \\
\text { desarrollando los actores que se vinculan al } \\
\text { proceso y es un escenario de encuentro }\end{array}$ \\
\hline $\begin{array}{l}\text { costumbre de hacer control social" "antes solo } \\
\text { era el grito y la pelea } \\
\text { Ahora no" "la voluntad política es clave" "cada } \\
\text { plan de desarrollo es difernte" "debe haber una } \\
\text { doble flexibilidad } 1 \text {. de cada localidad y } 2 \text {. de }\end{array}$ & $\begin{array}{l}\text { La intersectorialidad en PP es clave, pero } \\
\text { igual aparece en los escenarios de } \\
\text { planificación. Es importante que los } \\
\text { procesos tengan continuidad administrativa } \\
\text { y que las acciones sean coordinadas }\end{array}$ \\
\hline $\begin{array}{l}\text { cada plan de desarrollo" "a la administración le } \\
\text { cuesta mucho lo colectivo" } \\
\text { "los OC deben fortalecerse" "es un reto para } \\
\text { nosotros en el ejercicio social" }\end{array}$ & $\begin{array}{l}\text { El proceso de evaluación participativa de PP } \\
\text { debe tener en cuenta un enfoque territorial } \\
\text { que parta de la singularidad y particularidad } \\
\text { de cada contexto local, pero ello debe } \\
\text { articularse con la racionalidad técnica que se } \\
\text { está implementando }\end{array}$ \\
\hline $\begin{array}{l}\text { "Excelente acompañamiento, tienen seguridad, } \\
\text { saben" } \\
\text { "la convocatoria" "el compromiso y respaldo } \\
\text { con los OC, Ccada uno comparte más cosas" } \\
\text { "en formación y acompañamiento a OC" }\end{array}$ & $\begin{array}{l}\text { En definitiva, pensar en el método y la } \\
\text { metodología de control social es } \\
\text { fundamental para gestar procesos de } \\
\text { articulación. }\end{array}$ \\
\hline $\begin{array}{l}\text { "facilidad de potenciar lo organizativo" } \\
\text { "vienen los estudiantes a acompañarnos, todos } \\
\text { deberían venir" } \\
\text { "sentimos respaldo nos convertimos en aliados" } \\
\text { "deberían ser estudiantes que vivan en la } \\
\text { localidad" }\end{array}$ & $\begin{array}{l}\text { Se destaca como factor importante del } \\
\text { proceso el que haya sido liderado por } \\
\text { mujeres de manera fuerte en localidades } \\
\text { como Kennedy, se reconoce allí una } \\
\text { tradición histórica de liderazgo femenino en } \\
\text { los procesos sociales comunitarios. }\end{array}$ \\
\hline
\end{tabular}


"el nivel de respuesta es idóneo"
"sino tiene la respuesta el estudiante admite que
no y la busca"

\section{PARTICIPACIÓN- LO PÚBLICO}

" al inicio fue más fuerte la participación" "venían muchos"

"la participación debe ser de calidad y de número"

"el espacio cívico fue clave" "últimamente somos los mismos"

"a los primeros que capacitamos fue a nosotros y luego a los funcionarios"

"logramos que participara la administración"

"algunas administraciones nos reconocieron"

"las personas proclives a la participación se fortalecieron"

"creíamos que éramos fuertes pero no era así"

"estamos en un proceso de formación" "es el OC

el que se acerca a la admón., la gente lo sabe y por eso nos buscan"

"el OC no es solo la herramienta, nos empoderamos como localidad"

"cuando se cumple una evidencia, algo está pasando"

"cómo hacemos que las ías estén acá, primero deben conocer el IWA"

"hay diferentes niveles de acercamiento, los que siempre están, otros los permanentes, y otros los que asesoran, eso fortalece los OC"

"los gobiernos se han fortalecido"

"nosotros tenemos más capacidad técnica"

"la administración ve al IWA como una posibilidad de fortalecer la gestión pública"

"el IWA es una oportunidad para trabajar colectivamente"

"nos dieron un costurero, ahora tenemos que llegar a un nivel de PP"

"como conectamos las herramientas para incidir a nivel de PP"

"elevar el nivel del discurso, a eso nos ayuda el OC"

"no pensar solo la localidad, sino otros espacios"

"si quiere dirigir acá debe decidir según lo que hemos construido"

"la administración desarrolla los planes de forma desarticulada"

"antes se trabajaba sin metas claras"

"ya sabemos a qué vamos en cada espacio de mesas"

"nosotros somos autónomos"

"participamos y estamos incidiendo"
La importancia de recuperar lo público para la sociedad. Y generar una articulación basada en pactos entre las esferas público social y público estatal.

Aumentar la escala territorial de aplicación de la herramienta para tener una mirada de ciudad es un elemento importante, además para identificar con mayor precisión las competencias e incumbencias de los agentes y agencias vinculados al proceso.,

La participación como concepto y categoría de articulación implica incidencia en la cosa pública, de manera que si no se toma en cuenta la voz de los actores en el momento de toma de decisiones es probable que la implementación de las políticas siga presentando problemas, los actores sociales deben vincularse tempranamente en el ciclo de PP, desde el momento mismo de la planificación.

La concepción de ciudad y de ciudadanía se transforma, ya no hay una visión restringida del ser ciudadano y de quiénes son ciudadanos. Implica un escenario que trasciende la posibilidad de ejercer el derecho al voto, implica opinar, dialogar, construir colectivamente. No solo actúa como ciudadano la comunidad, la administración también tiene un rol como ciudadano y desde allí se debe potenciar la vinculación a procesos sociales a partir del compromiso y de re-pensar lo colectivo como parte del fortalecimiento de la relación estado-gobierno-sociedad.

Se encuentra lo que Oszlak llama una desarticulación entre administración y política, pareciese que lo técnico y operativo era competencia única y exclusivamente de la gestión pública local -los funcionarios y agencias- y la política (las discusiones sobre lo social, sobre la participación -como fin y como medio- eran propios de la sociedad, de las organizaciones etc), con la herramienta esto se transforma ya que la comunidad también requiere de esa racionalidad técnica para pensarse los procesos en este caso de evaluación de política pública. Administración y política aparecieron articuladas en la práctica y en el proceso social de los OC. 


DEBILIDADES PROCESO
"la planeación es corta, el proceso necesita
presupuesto"
"la veeduría se queda corta"
"al principio la herramienta era muy confusa"
"falta incentivar a la ciudadanía para que la
participación sea masiva"
"cuando se dijo que no se podía cambiar,
desertamos"
"participamos
"el proceso de control social requiere un cambio
cultural"
"habría que compartirlo y estudiarlo"
"cuando uno hace control social lo ven como el
enemigo"
"creaba miedos en la gente"
"faltó socialización de la herramienta a la
comunidad"
"dejaron a los estudiantes solos y encargados de
la convocatoria"
"para criticar somos excelentes pero para hacer
no tanto"
"necesitamos pasión para hacer control social"

"debemos visibilizarnos en los medios de comunicación, a través del arte"

"necesitamos elevar la conciencia, ese es otro nivel debemos evolucionar y subir"

"necesitamos grandes transformaciones"

\section{RECOMENDACIONES}

"que no solo este Ciencias Humanas, que otros entren en la participación ciudadana"

"de otras áreas y que tengan sentido de pertenencia con la localidad"

"que cada ejercicio de práctica de los estudiantes sea completo"

"que la comunidad pudiese vincular estudiantes permanentemente"

"que la academia se articule permanentemente a la comunidad"

"que la academia se interese por alimentar el trabajo de los OC, por ejemplo a través de asesorías desde varias disciplinas"

"nos gustaría tener estudiantes de más disciplinas que acompañen los OC"

"un estudiante por cada cuadrante"
La articulación involucra una pregunta por el reconocimiento entre los actores como legítimos otros, no solo es importante que las organizaciones sociales y los ciudadanos sean visibles en esa administración pública, al reconocerlos como legítimos se les da la potestad de opinar, deliberar y participar de la decisión, se abre un camino allí para la incidencia política de estos actores sociales y su inserción en lo público-estatal.

Definir ¿Qué es el OC? Es una pregunta que tiene múltiples posibilidades de respuesta, habría que analizar que para la comunidad representa la posibilidad de construir un proyecto común, colectivo, lo público. Pero para la administración talvez una posibilidad para legitimar su acción o solo un proceso de formación más.

La profesión debe re-pensarse a la luz de la relación universidad-sociedad, desde allí es necesario configurar un colectivo social a partir de los escenarios de educación superior.

Frente a la formación de los estudiantes, el conocimiento debe ser situado, ello parte de una reflexión desde el lugar, el territorio que este sujeto ocupa en lo social, allí está el primer escenario reflexivo y de reflexividad para quien se está formando

La colectividad como impulsor de procesos participativos

La construcción de escenarios colectivos de evaluación de política pública implica un cambio cultural en el que se reflexione abiertamente sobre la dicotomía administración pública-política;

Dentro de los OC hay un reconocimiento de las singularidades de los sujetos hablan de entender las perspectivas de análisis de los jóvenes, adultos mayores, mujeres porque no todas son iguales o representan lo mismo Debe existir articulación entre evaluacióngestión-planificación de PP. La comunidad reconoce que es posible transformar la sociedad desde las PP.

El no reemplazo de actores sigue siendo un criterio de reflexión para las prácticas y discursos de TS 
Es importante mencionar que el análisis de la información recolectada está sustentado en la revisión teórico-conceptual que durante la experiencia orientó la intervención en territorio. De dicho análisis resulta la identificación de un conjunto de categorías deductivas que fueron susceptibles de construcción teórica, estas fueron:

- Lo público

- Lo colectivo

- La participación

- La organización

- Lo territorial

- Aprendizajes

- Diálogo de saberes

- Empoderamiento

Teniendo claros los elementos epistemológicos y teórico-conceptuales de soporte a las categorías deductivas, se procede con este conocimiento base a analizar las transcripciones del grupo focal, de manera que se asigna un color a cada categoría y en los documentos de transcripción se subrayó el contenido del relato que se asociaba con dicho código deductivo. De esta manera se ordenó la información cualitativa en los nueve subconjuntos de datos a partir de las categorías deductivas; las respuestas relativas a cada tema se agruparon identificando las fuentes de información y se ordenaron en la matriz con los campos:

\begin{tabular}{|l|c|c|c|}
\hline $\begin{array}{l}\text { CATEGORIAS } \\
\text { DEDUCTIVAS }\end{array}$ & $\begin{array}{c}\text { PROPOSICIONES } \\
\text { POR TEMAS }\end{array}$ & $\begin{array}{c}\text { CATEGORÍAS } \\
\text { INDUCTIVAS }\end{array}$ & $\begin{array}{c}\text { FUENTE DE } \\
\text { INFORMACIÓN }\end{array}$ \\
\hline
\end{tabular}

Posteriormente el análisis de los datos ordenados en esta matriz, permitió identificar patrones implícitos en los relatos, patrones que sugieren la construcción de nuevas categorías descriptivas para analizar la información de manera precisa y orientada por las narrativas de los sujetos de la investigación, en suma se procede de manera inductiva (ver análisis a profundidad en el capítulo de evaluación), se menciona entonces la categoría inductiva que subyace al relato susceptible de análisis.

Tras elaborar las matrices descriptivas se hace necesario utilizar recursos gráficos para dar cuenta de la información obtenida, las relaciones, las clasificaciones, las racionalidades subyacentes. En este sentido, se elaboran taxonomías y redes causales para mostrar gráficamente la información que se obtuvo a partir tanto de las entrevistas como de los grupos focales. 
E) Encuesta

Estructura de las Boletas de Encuesta

ECOS 01 (Ver anexo 2)

La boleta está constituida por 27 preguntas, distribuidas en las siguientes secciones:

1. Características Socio-Demográficas (1 a 10): Contempla, nombre de la organización representada, rol, dirección, teléfono, sexo, edad, educación)

2. La organización (p. 11 a 17)

3. Capacidades colectivas en la evaluación de políticas públicas (p. 18 a 27)

Fue elaborada por el equipo técnico del PRIAC vinculado al proyecto "fortalecimiento de capacidades ciudadanas para el control social". Consta de 2 Páginas tamaño carta dispuestas de forma vertical.

EVAPACI (Ver anexo 3)

La boleta está constituida por 27 preguntas, distribuidas en las siguientes secciones:

1.- Características Socio-Demográficas (1 a 10): Contempla sexo, edad, ocupación u oficio, educación, lugar de nacimiento, lugar de residencia, carácter de la vivienda)

2.- Bloque I: Agencia Social (p. 11 a 17). Contempla preguntas en relación con la pertenencia a organizaciones sociales, conocimiento de planes de desarrollo y PMOT, la participación municipal en diagnóstico, planeación y evaluación de políticas públicas,

3.- Bloque II: Incidencia ciudadana (p. 18 a 20): percepción sobre el nivel de influencia en el municipio, influencia en elaboración de planes de desarrollo y sobre unidad social.

4.- Bloque III. Procesos participativos en políticas públicas (p. 21 a 27). Preguntas sobre características de la participación en evaluación, obstáculos para vincularse a la administración pública, motivos para incentivar la participación.

Fue elaborada y diagramada por la doctoranda con revisión y supervisión por parte de la directora del CEPLAG. Consta de 5 Páginas tamaño carta dispuestas de forma horizontal.

\section{Validación de la Boleta de Encuesta}

La Validación de las Boletas de Encuesta se realizó mediante prueba piloto, así:

1.- Con el equipo PRIAC para el ECOS 01

2.- Con el equipo de investigadores del CEPLAG para la EVAPACI 
Cada uno de los equipos de los centros de investigación respectivos, tuvieron la posibilidad de diligenciar los instrumentos lo que permitió su ajuste de acuerdo a lenguaje de los contextos, claridad en las instrucciones para diligenciamiento del cuestionario, opciones etc.

\section{Matrices para la digitalización de los datos de la Encuesta}

Por las características de la información recolectada, fundamentada en la estrategia teórico/conceptual y metodológica planeada, se ha distribuido la información en dos archivos digitales (uno por cada encuesta) que fueron diseñados en función a la unidad principal de estudio que fue la persona. Cada boleta tiene un número de identificación asignado y el identificador espacial de cada ítem.

En las bases de datos se digitalizaron todas las respuestas registradas en las boletas de encuestas. Las variables se codificaron en función al número pregunta al que corresponden dentro la boleta. Los valores y etiquetas de cada valor de Variable se detallan en el anexo "Valores de Variable".

\section{F) Estrategia de análisis cualitativo de información}

El análisis de la información cualitativa recabada durante el proceso de investigación contó con dos insumos fundamental es tanto para la organización de los datos, como para su respectiva interpretación. El primer insumo a saber, se apoyó en los aportes de la observación participante y desde allí en el registro de la información némica y nética, considerando que la primera de ellas equivale a aquella información que proviene única y exclusivamente del sujeto investigado y la segunda conformada por la interpretación y reflexión de los resultados desarrollada por el sujeto investigador.

Un segundo insumo que resultó importante para la organización y sistematización de la información recolectada proviene de los aportes de las autoras Bonilla y Rodríguez (1997) en su texto "Más allá del dilema de los métodos", texto en el que se destina buena parte de la obra a la explicación sobre métodos para realizar categorización inductiva y codificación de la información cualitativa. De allí se retoma de manera específica

La construcción de sentido a partir de los datos cualitativos implica un ejercicio de inmersión progresiva en la información escrita, el cual comienza con un fraccionamiento del universo de análisis en subconjuntos de datos ordenados por temas, para luego recompenerlo inductivamente en categorías culturales que reflejen una visión totalizante de la situación estudiada. El proceso comprende entonces dos niveles el primero corresponde a la fase de codificación o categorización de los resultados y da lugar a un análisis descriptivo. El segundo nivel corresponde a la etapa de identificación de patrones 
culturales, los cuales orientan el ejercicio de interpretación de los datos cualitativos.

(Bonilla y Rodríguez, 1997, p, 134)

En lo que respecta al análisis de este estudio, se realiza una categorización inicialmente deductiva puesto que con anterioridad a los resultados y a partir de los objetivos ya se habían construido previamente categorías de análisis de la información. Sin embargo, cabe destacar que una vez recabada la información, ordenada y sistematizada se hallaron otras categorías susceptibles de analizarse de manera que fueron emergentes totalmente de los datos con base en el examen de los patrones y las recurrencias presentes en ellos; ello es resultado entonces de una categorización inductiva que evidencia el marco de referencia cultural de los grupos estudiados y constituyen también en alguna medida bases importantes en lo que se llamaría un tipo de investigación etnográfica.

Retomando dicho insumo analítico se realiza una relectura de las transcripciones de entrevistas y grupos focales y se va realizando un ejercicio de subrayado, asignando colores a los relatos según la categoría a la que pertenece dicha parte del relato. Por ejemplo el color rojo representaba la categoría -lo público- y con este color se subrayó la parte de los relatos que se asociaba más con dicha categoría y así sucesivamente. Posterior a ello, se construyó una matriz con las entradas: categorías deductivas (incluye las construidas de manera previa a los resultados de investigación y como resultado de los objetivos de investigación); proposiciones agrupadas por temas (se transcriben allí los relatos que corresponden a cada categoría deductiva) y finalmente categorías inductivas (corresponde a aquellas que emergen una vez que se organiza la información y se hace una relectura de la misma).

\begin{tabular}{|l|c|c|}
\hline $\begin{array}{l}\text { CATEGORÍAS } \\
\text { DEDUCTIVAS }\end{array}$ & $\begin{array}{c}\text { Proposiciones agrupadas } \\
\text { por temas }\end{array}$ & $\begin{array}{c}\text { CATEGORÍAS } \\
\text { INDUCTIVAS }\end{array}$ \\
\hline
\end{tabular}

Sin embargo, como se deduce de lo expuesto, la asignación de códigos no es un procedimiento mecánico o rutinario como puede ser el asignar números a un conjunto de variables. El ejercicio de nominar conjuntos de datos cualitativos demanda de un proceso de análisis que demanda: identificar los elementos esencialmente comunes a ellos (no siempre explícitos); crear subconjuntos de datos de tal modo que los elementos de uno no pertenezcan al otro y construir un concepto que designe lo más fielmente posible su pertenencia a esa categoría. (Bonilla y Rodríguez, 1997,p, 136)

Para describir los resultados de manera ordenada igualmente las autoras señalan varias herramientas que se han retomado en esta investigación una de ellas es la elaboración de "taxonomías" definidas como "clasificaciones detalladas de la información contenida en las subcategorías. Sirve para visualizar los datos y para comenzar a detectar relaciones entre ellos" (Bonilla y Rodríguez, 1997; 142). La otra son las matrices descriptivas

Que son tablas en las cuales se cruzan dos categorías que pueden estar relacionadas. Constituyen un recurso útil para describir sintéticamente volúmenes grandes de 
información, para descubrir patrones culturales que no son evidentes cuando se analizan por separado las categorías. (Op Cit, 1997; 142)

\subsection{Síntesis}

Al hablar de organización resulta imperativo hacer un recorrido y análisis retrospectivo sobre las acepciones que se otorgan a este término, connotaciones enmarcadas en elaboraciones conceptuales que subyacen a un periodo y tiempo determinados. Encontramos en este sentido, organización popular, organización comunitaria y organización social respectivamente, cada una de estas nociones cuenta con unas características determinadas que le son atribuidas en razón de su objetivo, aspecto en el que se evidencia que en todas aparece la referencia a la reivindicación de derechos, el papel activo de los individuos y comunidades, las luchas cotidianas de resistencia entre otros.

La capital colombiana y el municipio Cochabambino como contextos en los que se desarrolló la investigación para esta tesis doctoral en su devenir histórico pueden situar diversidad de formas organizativas y asociativas, como alternativas de acción colectiva que ponen en evidencia el esfuerzo de los colectivos poblacionales por enfrentarse a condiciones de precariedad social. Dichas iniciativas surgen de la mano de otros procesos sociales que las vehiculan a saber, el arte, la autogestión económica, la protección del medio ambiente, la reivindicación de la soberanía alimentaria, la comunicación entre otros no menos relevantes. Experiencias cuyo rasgo de identidad común está vinculado con el principio de autonomía frente al Estado, a partir de un distanciamiento crítico de las prácticas clientelistas.

Desde esta perspectiva, situamos a la organización comunitaria como fase dentro de la organización social

En este contexto la organización comunitaria se aparece como una fase de la organización social que constituye un esfuerzo consciente de las comunidades pequeñas para controlar sus problemas y lograr mejores condiciones específicas. También como la forma de relación entre grupos e individuos que les permite actuar conjuntamente a los fines de crear y sostener identidades (Contreras, 2004, p. 19).

Por su parte autoras como Carolina Ware y Amanda Gómez consideradas pioneras en el tema de la organización comunitaria, hacen referencia a la capacidad de los actores sociales de interactuar siendo responsables de su propio progreso. Escenario en el que se propende por el cambio de actitudes de las gentes. La concepción de las comunidades como actores sociales, da cuenta del reconocimiento de los recursos individuales y colectivos que posibilitan y encauzan las relaciones solidarias y cooperativas encauzándolas a hacer frente y permitir la superación de las problemáticas sociales que afectan a diversidad de colectivos poblacionales. 
En esta perspectiva, el barrio y la OTB como entramados simbólicos en los que se tejen sentidos y significados, aparecen como referentes territoriales de la construcción de la identidad colectiva, de manera que las relaciones sociales que se establecen en ellos dan cuenta de la generación y fortalecimiento de tejido social y asociativo. La reivindicación fundamental de las organizaciones sociales en estos contextos, estaría ligada con varios elementos que en la escena social aparecen vinculados con el devenir histórico de las organizaciones, entre ellos se destacan: la institucionalización, la incidencia de los momentos de crisis, los encuentros y reuniones para toma de decisiones, y la consolidación interna de las organizaciones en el nivel local.

En este contexto, se evidencia que el trabajo desarrollado por las organizaciones en el contexto bogotano y cochabambino como escenarios de inscripción de esta investigación se fundamentan en prácticas de control social, que aparecen como conjuntos de prácticas sociales y elaboraciones discursivas cuya intencionalidad está fundamentada en dos aspectos principales la concepción de las clases populares como sujetos protagonistas de su propia historia y en segunda instancia la reflexión y la acción centradas en la transformación social de contextos de inequidad, injusticia, exclusión y desigualdad social. En el terreno de la evaluación a lo público, la subjetividad cobra un valor importante, puesto que desde la década del noventa se otorga un papel fundamental en términos de acción social individual y colectiva que valora el mundo interior de los sujetos, a partir de su experiencia vivencial como aspecto que dilucida la trascendencia de la conciencia y el mundo de la razón, en escenarios en los que los universos simbólicos que convergen, interactúan para estructurar procesos sociales de transformación y cambio social.

Es posible comprender al control social y a la evaluación de las políticas públicas, como alternativas democratizadoras que vehiculan discursos y prácticas que contribuyen progresivamente a la transformación de condiciones de inequidad y desigualdad social, se sitúan como alternativas importantes que aúnan esfuerzos para la construcción de paz, resignificando la vida social en su conjunto y potenciando recursos comunitarios y barriales en aras de consolidar lazos sociales sostenibles y procurar la construcción de una conciencia crítica en torno a situaciones como la violencia y el conflicto armado; desde este escenario, se incide además en la satisfacción de necesidades de las comunidades, la reivindicación de derechos y el ejercicio pleno de la ciudadanía.

Desde allí las organizaciones sociales aportan a los principios de construcción de paz mencionados por Lederach en las dimensiones personal, relacional, estructural y cultural respectivamente; contribuyendo con ello a hacer frente a las condiciones derivadas de la violencia directa, la violencia cultural y la violencia estructural. Desarrollando a la par respuestas e iniciativas que estando enraizadas en el mundo real, son capaces de elevarse y construir lo que no existía. Se generan respuestas constructivas que buscan hacer ruptura con los patrones y ciclos destructivos. 


\section{CAPÍTULO 6. EVALUACIÓN DE POLÍTICAS PÚBLICAS: POTENCIACIÓN DE ESCENARIOS DE GESTIÓN ASOCIADA DEL TERRITORIO EN BOGOTÁ Y EN SACABA}

Pensar las políticas públicas se convierte en un ejercicio necesario y fundamental para proyectar un escenario de reflexión sobre las lógicas de la administración pública en un contexto determinado; interrogar la forma tradicional de construcción de planes, programas y proyectos implica una pregunta por las lógicas de relación estado-sociedad y nuevos actores sociales; evaluar la gestión pública remite inexorablemente a la estructuración y construcción colectiva de un escenario que en la vida cotidiana y en la efervescencia de lo público y lo social no existe, a saber un escenario de encuentro entre gobierno, sociedad, organizaciones comunitarias y demás actores vinculados, llamados, convocados y necesarios para re-pensar la cosa pública.

En esta perspectiva, la evaluación también ha estado sometida a los vaivenes de la modernidad y se ha perdido en la liquidez de lo inmediato y lo urgente, deviniendo en este proceso como un momento dentro del llamado "ciclo", que transita a posicionarse como correlato de un ejercicio meramente técnico. Las dinámicas de rendición de cuentas, lógicas de transparencia, procesos de control social, registros de seguimiento, los encuentros pre, ex ante y post son meros cumplimientos a directrices de entidades o instituciones que construyen metas a alcanzar; en este panorama la evaluación está en peligro inminente de extinguirse como un ejercicio de aprendizaje constructivo y creativo para los actores.

Como se mencionó en los capítulos iniciales de este trabajo doctoral, se concibe a las políticas públicas como entramado cíclico, no se habla de una sucesión lineal de momentos, se habla de un escenario en donde los diversos procesos que lo conforman interactúan entre sí en una suerte de retroalimentación permanente, que enriquece también de forma continua el quehacer de los actores sociales que allí se involucran. 
La evaluación representa un área interdisciplinar en la que diversos campos de estudio han generado aportes importantes, para pensarla a partir de su potencialidad para crear espacios de cooperación, co gestión y co construcción. Es producto de la investigación aplicada, e intenta valorar las especificidades del impacto de planes, programas y proyectos en los entornos para los que éstos se construyen. A su vez, expresa una relación estrecha entre problemas públicos, búsqueda de soluciones, análisis de aparatos institucionales e ideologías de cambio. Se identifican tres tendencias conceptuales sobre la evaluación a saber: instrumental, la inherente al proceso de construcción social y aquella que expresa análisis sistemáticos de la operación.

La concepción instrumental enfatiza en la definición de la evaluación, como proceso sistemático que combina acciones de recolección, procesamiento y determinación de la información y las intervenciones en aras de cualificar los procesos de toma de decisiones en la administración pública. En otro sentido, también se hallan referencias a un tipo conceptual de evaluación que estaría mucho más vinculado con los procesos de construcción social entre tanto, menciona la importancia de conocer la realidad, construir colectivamente la percepción de los problemas, así como las propuestas de transformación y mejoramiento de la sociedad, ello a partir de escenarios permanentes y amplios de deliberación.

En última instancia Weiss (1975) menciona una concepción estrechamente relacionada con el análisis sistemático de la operación o efectos de una política o programa, comparándolo con estándares como medio para mejorar. Es importante mencionar que dichas tipologías conceptuales desde la perspectiva que se plantea el presente trabajo investigativo, en algún sentido podrían verse combinadas para generar un sistema de evaluación que posibilitase el trabajo colectivo y cogestivo entre los actores sociales. La práctica evaluativa incluye como se ha mencionado procesos sistemáticos de recolección de información sobre varios aspectos, actividades, características, efectos, los procesos de conceptualización, de diseño, de implementación y utilidad de los programas de intervención social; para realizarla se requieren criterios razonables, pero dichos criterios no pueden cimentarse de forma única y exclusiva en paradigmas cientifistas dejando de lado la voz de quienes también son sujetos de las políticas, a saber los ciudadanos.

\subsection{Evaluación y monitoreo: una aproximación a los antecedentes}

Entrar a desentrañar los enfoques sobre los que se tejerán las discusiones y propuestas para cualificación de la evaluación en los dos casos de este estudio doctoral, requiere el conocimiento de las dinámicas desde las que se derivan las experiencias de monitoreo y evaluación (M\&E) en los dos países de referencia, a saber Bolivia y Colombia. De manera que en este sub apartado del documento, se hará alusión a dichos aspectos, articulándolos también con las discusiones y aspectos propios de la teoría M\&E. 
En los albores de la década del 90, en múltiples contextos Latinoamericanos se instauran el monitoreo y evaluación como procesos vinculados con el desempeño organizacional, principalmente en el sector público, es así que se da apertura a la creación de Sistemas a nivel Nacional de M\&E, muchos de ellos evidenciaron gran inversión en tecnologías y software de alta gama, con el fin de consolidar estos procesos como necesarios y articulados estrechamente con lógicas de eficiencia, eficacia y buenos resultados de la gestión pública, impacto de la gestión y calidad de los servicios prestados.

El paradigma que sustenta el quehacer de la gestión pública aunado a los ejercicios de monitoreo y evaluación como formas de seguimiento es el de la llamada Nueva Gestión pública, enfoque que busca transformar la mentalidad tradicional en que se fundamentaba el quehacer de la cosa pública, persiguiendo rutas sustentadas en mecanismos de seguimiento y evaluación aunados a estrategias de modernización del Estado. Se promueven lógicas orientadas a resultados y creación de valor público, que es contraria a los modelos tradicionales que históricamente han hecho énfasis en los procedimientos y procesos de gestión, es decir en miradas un poco más tecnicistas.

En esta perspectiva, la pregunta "para qué evaluar" halla su respuesta en la necesidad de "generar información que permita retroalimentar la toma de decisiones hacia el mejoramiento constante de la gestión pública" (Escobar, 1996: 15). Pero también esta respuesta, está ligada a los nuevos cambios que se han ido gestando en aras de modernizar el Estado y de acercar su gestión a los ciudadanos. En esa medida, "la introducción de métodos cuantitativos de medición de resultados de las acciones del Estado responde a un proceso político de ampliación de la democracia (...). Un proceso de democratización que lleva implícita la exigencia de hacer más pública la información referente a las ejecutorias del gobierno" (Gandour, 1996; P. 27).

Como se ha mencionado en líneas anteriores los sistemas M\&E sirven de plataforma para la toma de decisiones; en este sentido; cumplen con dos condiciones importantes a tomar en consideración, la primera de ellas se vincula con la generación de credibilidad de la información que se genera a partir de la línea de base de carácter cuantitativo, en segunda instancia se asegura una total vinculación de dicha información con el proceso de toma de decisiones que se pretende informar, son estos los aspectos que aseguran la sostenibilidad de estos sistemas dado que de lo contrario serían irrelevantes.

Retomando los planteamientos de Zaltsman (2006) se mencionarán a continuación, los aspectos a ser considerados cuando se busca que exista un alto nivel de conexión entre las actividades de monitoreo y evaluación con los procesos de toma de decisión que se buscan cualificar. En primer lugar debe existir alta articulación entre las preguntas de la evaluación o monitoreo con las necesidades de información que tengan los destinarios (de manera que por ello sería indispensable que todos los que se van a informar por este proceso se vinculen a él); el segundo aspecto preponderante resulta ser la existencia de condiciones para que los destinatarios de la información logren contar con ella, una vez 
se surta el proceso o cuando lo requieran (la existencia de acceso libre a la información debería convertirse en una condición sine qua non, contrarrestando y anulando progresivamente los fines asociados al lucro por el intercambio de datos); justamente el tercer requerimiento planteado por Zaltsman hace alusión a la accesibilidad del conocimiento producido, los resultados deben ser totalmente accesibles a los diversos actores (ello involucra no sólo la disposición física de los recursos, sino también la posibilidad de aprehensión de sus contenidos, de forma que deben estar en formatos fáciles de entender por cualquier actor y ser fáciles de consultar).

En última instancia como cuarto elemento o requerimiento de estos procesos, se encuentra el que los destinatarios de la información cuenten con los incentivos necesarios para consultarla y hacer uso de ella. En esta medida, se hace necesario que se promueva y fortalezca la concientización sobre la importancia de acceder a los resultados de ejercicios de monitoreo y evaluación, ello podría verse potenciado gracias a las instancias de control social participativo que existan en las diversas escalas territoriales y que coadyuven en la socialización y divulgación de los resultados de las experiencias de evaluación.

Los mencionados sistemas M\&E tienen distintos tipos de objetivos así como de destinatarios, ello determina una categorización de los mismos:

El primero de ellos es apoyar la identificación de prioridades y la planificación estratégica del gobierno a nivel global. El segundo es servir de base a la formulación de políticas sectoriales, y al diseño y mejoramiento de programas. El tercero consiste en informar el proceso de asignación presupuestaria. El cuarto, en inducir el mejoramiento continuo de la gestión organizacional; y el quinto en posibilitar la responsabilización con base en los resultados y el desempeño. A su vez, cada uno se encuentra orientado a atender un tipo de destinatarios cuyas necesidades también son diferenciadas (Zaltsman 2006; P. 122)

En la búsqueda y revisión bibliográfica realizada se aprecia que tanto en los tipos de objetivos como en los principales destinatarios de la información producida por los sistemas $\mathrm{M} \& \mathrm{E}$, se han priorizado aspectos vinculados con el desarrollo organizacional, la eficacia, los resultados de gestión, la planificación con un enfoque organizacional y estratégico y la asignación presupuestaria. En el cuadro a continuación una síntesis sobre el tema. 
Tabla 37. Principales destinatarios de los resultados del monitoreo y la evaluación, asociados con cada tipo de objetivo.

\begin{tabular}{|l|l|}
\hline \multicolumn{1}{|c|}{ Tipo de objetivo } & \multicolumn{1}{|c|}{ Principales destinatarios de la información } \\
\hline Planificación estratégica a nivel global & $\begin{array}{l}\text { Ministerio de planificación } \\
\text { Otros ministerios centrales de gobierno } \\
\text { Gabinete nacional }\end{array}$ \\
\hline $\begin{array}{l}\text { Formulación y mejoramiento de políticas } \\
\text { sectoriales y programas }\end{array}$ & $\begin{array}{l}\text { Ministerios sectoriales } \\
\text { Otras instituciones responsables por el diseño y la } \\
\text { implementación de programas }\end{array}$ \\
\hline Asignación presupuestaria & $\begin{array}{l}\text { Oficina nacional de presupuesto } \\
\text { Parlamento } \\
\text { Divisiones de presupuesto de los ministerios sectoriales } \\
\text { y las agencias públicas }\end{array}$ \\
\hline $\begin{array}{l}\text { Mejoramiento de la gestión organizacional } \\
\text { el desempeño }\end{array}$ & $\begin{array}{l}\text { Autoridades y distintos niveles gerenciales de la } \\
\text { organización }\end{array}$ \\
\hline $\begin{array}{l}\text { Ciudadanía } \\
\text { Organizaciones de la sociedad civil } \\
\text { Organismos de auditoría y control } \\
\text { Parlamento } \\
\text { Presidente de la república } \\
\text { Ministros } \\
\text { Funcionarios de distintos niveles jerárquicos }\end{array}$ \\
\hline
\end{tabular}

Fuente: Zaltsman Ariel, 2006; P. 125.

Es difícil evidenciar un objetivo de los sistemas y prácticas de M\&E asociados con la construcción de experiencias conjuntas entre la sociedad y los gobiernos; unos vinculados con la necesidad de construir puentes que resignifiquen los paradigmas tradicionales de evaluar, de manera que estos sean procesos sociales y embriones de transformación social, en donde de manera conjunta, y cogestionada los actores logren incidir en el cambio de la forma tradicional de construcción de políticas públicas. La evaluación debe ser un proceso de construcción de conocimiento que genere cambios en la política, que se sincronice armónicamente con los procesos de toma de decisión, de tal manera que para ello es indispensable decantar el concepto de evaluación asociada a los objetivos meramente organizacionales y de presupuesto, para trascender dichos elementos en búsqueda de construir escenarios de democratización social.

En los dos contextos retomados como estudios de caso (Colombia-Bogotá y BoliviaSacaba), se evidencia que los sistemas de $M \& E^{21}$ han tenido una trayectoria histórica determinada por los sistemas de planificación en las diversas escalas territoriales. La

\footnotetext{
${ }^{21}$ Para la construcción de las reflexiones que se presentan a continuación se han consultado los estudios sobre M\&E realizados en América Latina por el CLAD con apoyo del BID, tanto en Colombia como en Bolivia, ello en el marco de acciones tendientes al fortalecimiento de dichos sistemas.
} 
función de monitoreo y evaluación, ha estado articulada con los grandes sistemas y paradigmas de la planificación nacional y su subyacente aplicación en la escala local. En el caso colombiano, se asocia el origen e impulso de dichos sistemas a partir de la década de los noventa, en la que se introduce como mandato constitucional la importancia de estructurar un sistema de evaluación para medir los resultados de la política pública. En el año 1994 se instaura el Sistema Nacional de Evaluación de Resultados de la Gestión Pública SINERGIA, con los fines últimos de asegurar una mejor gestión pública y dotar a las respectivas entidades de información para desarrollar sus procesos de rendición pública de cuentas,

Se inició bajo el concepto de auto-evaluación para el monitoreo del desempeño sectorial; hoy, tras varios ajustes, es una herramienta para el monitoreo de las metas presidenciales a nivel de programas y políticas. Comenzó como un sistema netamente administrativo, pero terminó siendo un sistema de gestión en el cual está basada la toma de decisiones a nivel más alto de gobierno. (Frank, 2007; P. 10)

En el 2002, se replantean los objetivos de dicho sistema de manera que introducen dos nuevos elementos como son la injerencia en la planificación y la incidencia en la asignación del gasto público, de acuerdo a ello sus campos de acción están asociados con seguimiento a resultados, evaluaciones focalizadas y rendición de cuentas.

SINERGIA es coordinada por la Dirección de Evaluación de Políticas Públicas (DEPP) ubicada al interior del Departamento Nacional de Planeación (DNP); un departamento administrativo de la rama Ejecutiva que depende directamente de la Presidencia. Dentro de su arquitectura básica participan los ministerios y agencias sectoriales del Ejecutivo a ser evaluados, la DEPP, el DNP con sus direcciones técnicas y la misma Presidencia que en los últimos años ha adquirido una gran importancia en el proceso de $\mathrm{M} \& \mathrm{E}$

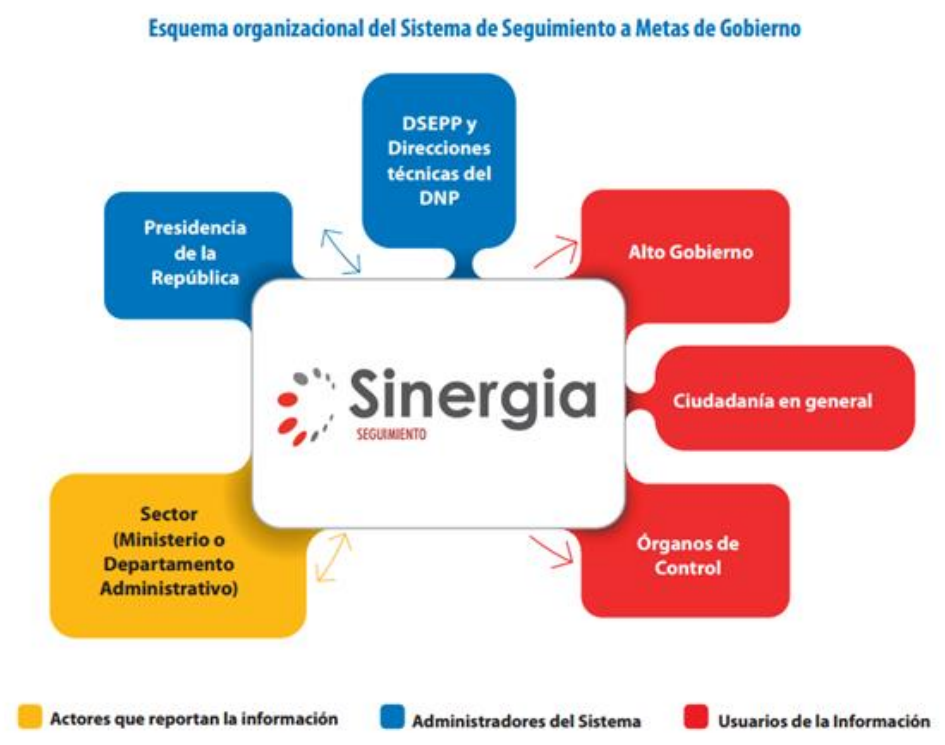

Fuente: Sistema Sinergia, DNP, Colombia. 2016.

Figura 49. Esquema organizacional del sistema de seguimiento a metas de Gobierno 
Como sistema de monitoreo y evaluación de aplicación en el contexto colombiano, SINERGIA ha tenido varios conflictos y problemas que más bien se presentan como retos a futuro en cuanto al mejoramiento de dicho sistema. Entre ellos se cuentan la baja visibilización de dicha herramienta conceptual-metodológica para diversos actores en la sociedad entre ellos la ciudadanía; la baja circulación que tiene la información que se produce, también entre diversos actores diferentes a las instituciones públicas; la relevancia del conocimiento producido para la ciudadanía, las organizaciones sociales y demás actores de contextos territoriales; estos entre los que más se destacan.

Básicamente, los objetivos que se trazaron con la creación de SINERGIA fueron el de evaluar y monitorear para "generar información que permita retroalimentar la toma de decisiones hacia el mejoramiento constante de la gestión pública” (Escovar, 1996: 15). Pero también evaluar y monitorear para "dar cuentas de las acciones del gobierno en términos del cumplimiento de objetivos prioritarios para la sociedad" (Gandour, 1996: 28).

Este proceso de evolución ha ido de la mano del desarrollo de un marco legal detallado que da sustento y apoyo a SINERGIA. De los artículos 343 y 344 de la Constitución Política Colombiana, que ponen de manifiesto el principio de evaluación continua de los planes de desarrollo, se derivan las siguientes disposiciones (Zaltsman, 2006):

- Ley 42 de 1993, que hace referencia al control fiscal y le da poderes a la Contraloría General de la República para ejercer estas funciones.

- Ley 87 de 1993, que regula la función de control interno dentro de las organizaciones públicas. · Resolución 063 de 1994 del Departamento Nacional de Planeación, que pone en operación el Sistema Nacional de Evaluación de Gestión y Resultados.

- Ley 152 de 1994, que establece los procedimientos de preparación, aprobación, ejecución, monitoreo y evaluación del Plan Nacional de Desarrollo.

- Ley 190 de 1995, que constituye la Ley Anticorrupción.

- Ley 819 de 2003, que estipula que el presupuesto nacional incluya detalles sobre los objetivos, resultados esperados e indicadores de gestión para todas las actividades del gobierno.

- Decreto 195 de 2004, que reorganiza la estructura organizacional de la Dirección de Evaluación de Políticas Públicas, estableciendo sus funciones además de su rol de coordinadora de SINERGIA.

Dada la multiplicidad de leyes y decretos emitidos en relación con el tema de monitoreo y evaluación, el último esfuerzo de la administración ha sido la redacción del documento CONPES (3294), de 2004, donde se clarifican y unifican conceptos y metodologías. Este documento CONPES constituye la carta de navegación que rige actualmente al sistema y que define sus alcances y límites en el desarrollo de sus funciones. 
En lo que respecta al contexto boliviano los sistemas de monitoreo y evaluación están en relación directa con la creación del Sistema Nacional de Monitoreo y Evaluación como parte de un proceso más amplio de fortalecimiento del Sistema Nacional de Planificación (SISPLAN). Estos dos sistemas forman parte de una serie de transformaciones institucionales iniciadas en enero de 2006, fecha en que tomó posesión el nuevo gobierno del presidente Evo Morales. La estructuración de un Sistema de Monitoreo y Evaluación (M\&E) se vincula con los esfuerzos destinados a mejorar las instituciones, especialmente a través del establecimiento de nuevos arreglos organizacionales, de herramientas y prácticas de gestión, así como del fortalecimiento de las capacidades del Gobierno boliviano para promover el logro de sus políticas.

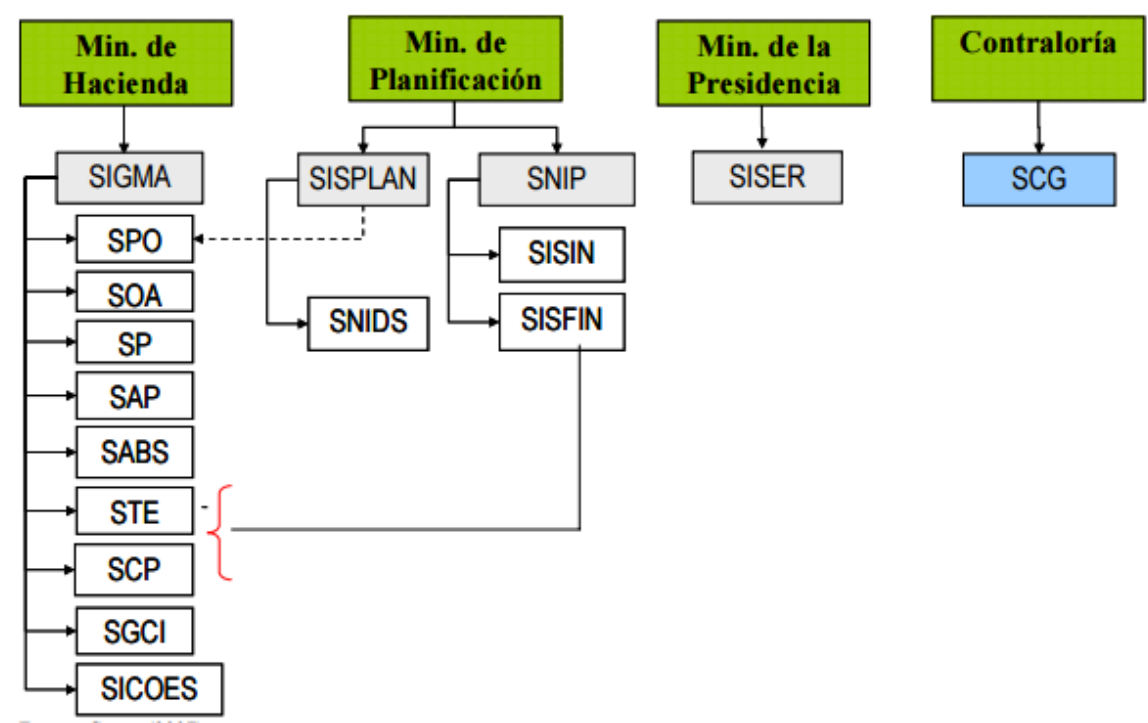

Fuente: Castro 2007.

Figura 50. Sistemas y Subsistemas de información para planificación y M\&E ${ }^{\mathbf{2 2}}$

En este caso también se han creado normas que respaldan el funcionamiento de los sistemas M\&E en el contexto boliviano, las cuales se ven reflejadas en la subsiguiente tabla:

\footnotetext{
22 Siglas

SIGMA: Integrado de Gestión y Modernización Administrativa; SPO: Programación de Operaciones; SOA: Organización Administrativa; SP: Presupuesto; SAP: Administración de Personal; SABS: Administración de bienes y servicios; STE: Tesorería del Estado; SCP: Crédito Público; SGCI: Gral de Contabilidad Gubernamental Integrada; SICOES: Información de Contrataciones Estatales; SISPLAN: Nacional de Planificación; SNIDS: Información para el Desarrollo Sostenible; SNIP: Nacional de Inversión Pública; SISIN: Información sobre inversiones; SISFIN: Información sobre Financiamiento Externo; SISER: Seguimiento y Evaluación de la Gestión por Resultados; SCG: Control Gubernamental.
} 
Tabla 38. Normativa $M \& E$ Bolivia.

\begin{tabular}{|c|c|c|}
\hline Número / Fecha & Ley & Temas \\
\hline Ley N. 1178 de 1990 & $\begin{array}{l}\text { Administración Financiera y } \\
\text { Control Gubernamental Ley } \\
\text { SAFCO }\end{array}$ & $\begin{array}{l}\text { Regula los sistemas de } \\
\text { administración y control de los } \\
\text { recursos del Estado y su relación } \\
\text { con los sistemas de planificación e } \\
\text { inversión pública } \\
\text { Incorpora a la administración } \\
\text { pública elementos de gestión por } \\
\text { resultados } \\
\text { Impulsa el desarrollo y la } \\
\text { organización de sistemas de gestión } \\
\text { e información M\&E. }\end{array}$ \\
\hline Ley N 2446 de 2003 & $\begin{array}{l}\text { Organización del Poder } \\
\text { Ejecutivo LOPE }\end{array}$ & $\begin{array}{l}\text { Organiza el poder ejecutivo, define } \\
\text { número de atribuciones de } \\
\text { ministerios y da lineamientos para } \\
\text { la formulación, ejecución y } \\
\text { evaluación de políticas }\end{array}$ \\
\hline Ley N. 1551 de 1994 & Participación Popular & $\begin{array}{l}\text { Fortalece instrumentos de } \\
\text { participación y control ciudadano. } \\
\text { Transfiere competencias a entidades } \\
\text { territoriales (salud, educación) } \\
\text { Da competencias fiscales a } \\
\text { municipios } \\
\text { Transfiere 20\% de impuestos } \\
\text { nacionales a municipios }\end{array}$ \\
\hline Ley 1654 de 1995 & $\begin{array}{l}\text { Descentralización } \\
\text { Administrativa }\end{array}$ & $\begin{array}{l}\text { Organiza administración del Poder } \\
\text { Ejecutivo a nivel departamental } \\
\text { Establece el régimen de recursos } \\
\text { económicos y financieros } \\
\text { departamentales } \\
\text { Fortalece la eficiencia y eficacia de } \\
\text { la administración pública en } \\
\text { prestación de servicios }\end{array}$ \\
\hline Decreto Supremo 24447 de 1996 & $\begin{array}{l}\text { Reglamenta Leyes } 1551 \text { de } \\
\text { Participación Popular y } 1654 \\
\text { de Descentralización } \\
\text { Administrativa }\end{array}$ & $\begin{array}{l}\text { Complementa la Ley de } \\
\text { participación Popular en Control } \\
\text { social, planificación, desarrollo } \\
\text { humano, salud y educación } \\
\text { Complementa la Ley de } \\
\begin{array}{l}\text { Descentralización Administrativa en } \\
\text { atribuciones de Prefectura y } \\
\text { Consejo Departamental }\end{array}\end{array}$ \\
\hline
\end{tabular}


Tabla 39. Normativa M\&E Bolivia.(Continuación)

\begin{tabular}{|c|c|c|}
\hline Número / Fecha & Ley & Temas \\
\hline $\begin{array}{l}\text { Resolución Suprema } 16.779 \text { de } \\
1996\end{array}$ & $\begin{array}{l}\text { Normas básicas del Sistema } \\
\text { Nacional de Planificación } \\
\text { SISPLAN }\end{array}$ & $\begin{array}{l}\text { Define bases conceptuales, reglas y } \\
\text { procedimientos de la Planificación } \\
\text { del Desarrollo Nacional } \\
\text { Supedita la programación del } \\
\text { presupuesto a las prioridades del } \\
\text { Plan de Desarrollo } \\
\text { Da lineamientos generales para el } \\
\text { M\&E del Plan de Desarrollo }\end{array}$ \\
\hline $\begin{array}{l}\text { Resolución Suprema } 16.961 \text { de } \\
1997\end{array}$ & $\begin{array}{l}\text { Planificación Participativa } \\
\text { Municipal }\end{array}$ & $\begin{array}{l}\text { Establece reglas y marco } \\
\text { institucional para el proceso de } \\
\text { planificación municipal } \\
\text { Considera lo establecido en } \\
\text { SAFCO, SISPLAN, Plan de } \\
\begin{array}{l}\text { Desarrollo Departamental, Plan de } \\
\text { Desarrollo Municipal, Alcalde, } \\
\text { Consejo, Sub-alcalde }\end{array}\end{array}$ \\
\hline $\begin{array}{l}\text { Decreto Supremo } 26.564 \text { de } \\
2002\end{array}$ & $\begin{array}{l}\text { Reglamento de mecanismos } \\
\text { de participación y control } \\
\text { social }\end{array}$ & $\begin{array}{l}\text { Reglamenta procedimientos, } \\
\text { mecanismos e instancias nacionales, } \\
\text { departamentales, y municipales de } \\
\text { control social y vigilancia para la } \\
\text { evaluación de resultados e impacto } \\
\text { de la gestión pública, los procesos } \\
\text { participativos y el acceso a la } \\
\text { información. }\end{array}$ \\
\hline $\begin{array}{llll}\text { Decreto Supremo } 27.329 & \text { de } \\
1999 & & & \end{array}$ & $\begin{array}{l}\text { Transparencia y Acceso a la } \\
\text { informaicón }\end{array}$ & $\begin{array}{l}\text { Procura la transparencia y acceso a } \\
\text { la información gubernamental } \\
\text { Promueve transparencia } \\
\text { gubernamental }\end{array}$ \\
\hline $\begin{array}{llll}\text { Decreto Supremo } 25.410 & \text { de } \\
1999 & & & \end{array}$ & $\begin{array}{l}\text { Creación del Sistema de } \\
\text { Seguimiento y Evaluación a } \\
\text { la Gestión Pública SISER }\end{array}$ & $\begin{array}{l}\text { Promueve la reforma y } \\
\text { modernización de las entidades de } \\
\text { la administración pública y pone en } \\
\text { marcha la creación del SISER }\end{array}$ \\
\hline Decreto Supremo 25875 de 2001 & Creación del SIGMA & $\begin{array}{l}\text { Establece normas generales, } \\
\text { definiciones conceptuales, niveles } \\
\text { institucionales, funciones y aspectos } \\
\text { operativos del proceso de inversión } \\
\text { pública a ser aplicadas por todas las } \\
\text { entidades y niveles de gobierno }\end{array}$ \\
\hline $\begin{array}{l}\text { Decreto Supremo } 216.768 \text { de } \\
1996\end{array}$ & $\begin{array}{lrr}\text { Marco legal } & \text { del } \\
\text { funcionamiento } & \text { del } & \text { Sistema } \\
\text { Nacional de } & \text { Inversión } \\
\text { Pública SNIP } & \end{array}$ & $\begin{array}{l}\text { Establece las normas generales, } \\
\text { definiciones conceptuales, niveles } \\
\text { institucionales, funciones y aspectos } \\
\text { operativos vinculados al proceso de } \\
\text { inversión pública }\end{array}$ \\
\hline
\end{tabular}


Tabla 40. Normativa M\&E Bolivia.(Continuación)

\begin{tabular}{|c|l|l|}
\hline Número / Fecha & \multicolumn{1}{|c|}{ Ley } & \multicolumn{1}{|c|}{ Temas } \\
\hline Decreto Ley 4100 de 1976 & $\begin{array}{l}\text { Sistema Nacional de } \\
\text { Información en Salud }\end{array}$ & $\begin{array}{l}\text { Establece la recolección y } \\
\text { administración de la información } \\
\text { para la planeación y el análisis de la } \\
\text { evolución sectorial }\end{array}$ \\
\hline Ley 1565 de 1994 & $\begin{array}{l}\text { Incluye el sistema de } \\
\text { Información Educativa }\end{array}$ & $\begin{array}{l}\text { Reglamenta la estructura de roles y } \\
\text { responsabilidades que promueve la } \\
\text { planificación, el desarrollo } \\
\text { institucional y la evaluación de las } \\
\text { políticas educativas en los niveles } \\
\text { central, departamental y distrital }\end{array}$ \\
\hline Ley 2028 de 1999 & Ley de municipalidades & $\begin{array}{l}\text { Regula el régimen municipal } \\
\text { establecido en la Constitución } \\
\text { Política del Estado }\end{array}$ \\
\hline
\end{tabular}

Fuente: Del Villar, 2007; P. 16.

Recientemente en el año 2016, el contexto boliviano modifica su estructura de planificación sustituyendo el SISPLAN por el Sistema de Planificación Integral del Estado SPIE, que

Es el conjunto organizado y articulado de normas, subsistemas, procesos, metodologías, mecanismos y procedimientos para la planificación integral de largo, mediano y corto plazo del Estado Plurinacional, que permita alcanzar los objetivos del Vivir Bien a través del desarrollo integral en armonía y equilibrio con la Madre Tierra, para la construcción de una sociedad justa, equitativa y solidaria, con la participación de todos los niveles gubernativos del Estado... (Art II. Ley 777 de 2016)

Uno de los objetivos de dicho sistema en el marco de la lógica de planificación que se pretende promover encauzada a lograr el vivir bien, justamente está referido a la evaluación, en él se menciona que se debe a través del SPIE realizar el seguimiento y evaluación integral de la planificación, basado en metas, resultados y acciones, contribuyendo con información oportuna para la toma de decisiones de gestión pública. Cabe destacar que el nuevo Sistema de Planificación se organiza en tres subsistemas como se evidencia en la figura que sigue 


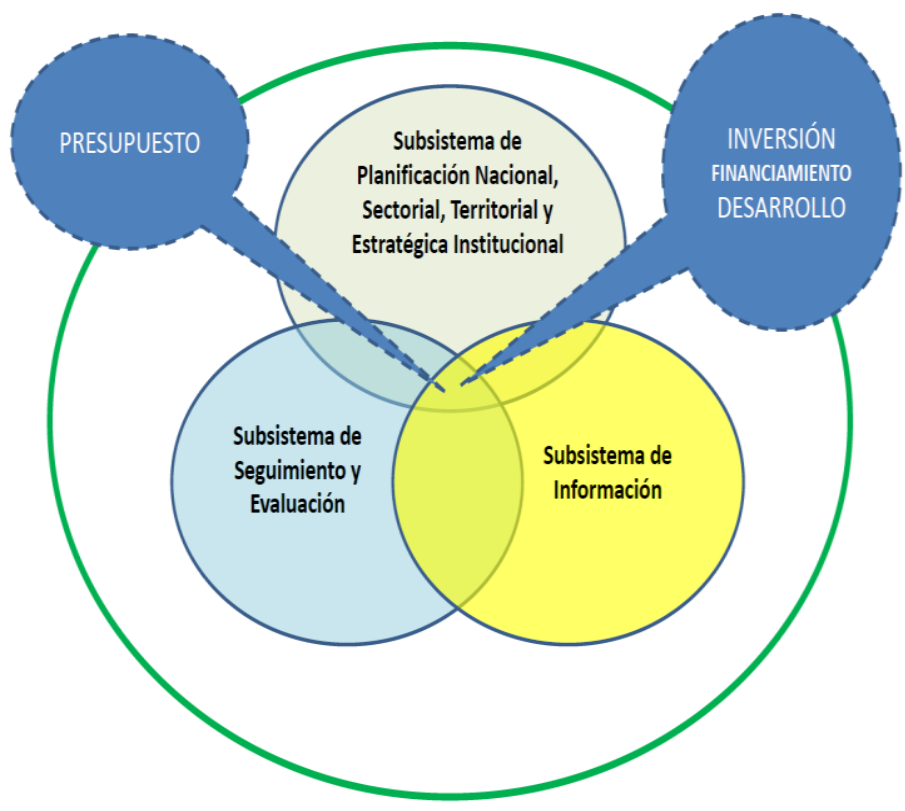

Fuente: Secretaría de Planeamiento y coordinación de estrategias, Gobernación de Cochabamba, 2016

Figura 51. Subsistemas del Sistema de Planificación Integral del Estado SPIE Bolivia

El capítulo III de la Ley 777 de 2016 menciona todo lo concerniente al Subsistema de Seguimiento y Evaluación Integral de Planes SEIP, allí se define como el conjunto de lineamientos, metodologías, procedimientos e instrumentos técnicos orientados a sistematizar, analizar y evaluar el cumplimiento de las metas, resultados y acciones de los planes de largo, mediano y corto plazo.

El Ministerio de Planificación del Desarrollo como órgano rector del Sistema de Planificación coordinará y administrará el Subsistema de Seguimiento y Evaluación Integral de Planes SEIP, que será aplicado por todas las entidades públicas. La evaluación integral de los planes de largo, mediano y corto plazo, se realizará en el marco de una valoración cuantitativa y/o cualitativa de medio término, respecto al alcance de las metas, resultados y acciones.

El artículo 6 de la Ley que regula la creación y puesta en marcha del Sistema de Planificación Integral del Estado, menciona los fundamentos del SPIE, como premisas que orientarán el desarrollo de procesos en el marco de la aplicación de la nueva Ley, entre dichos preceptos se menciona justamente la planificación con transparencia que consiste en la generación, procesamiento y difusión de información sobre la formulación, ejecución, seguimiento y evaluación de los procesos de planificación y su implementación en todos los niveles del Estado, con información oportuna sobre la administración de los recursos públicos, promoviendo el control social, permitiendo el acceso a la información y practicando la integridad y ética pública. Dicha alusión se sitúa como preponderante en términos de visibilizar el papel que se otorga a la evaluación y seguimiento en los sistemas de planificación y a partir del cambio legislativo. 
Por otra parte, el sistema de seguimiento y monitoreo en el marco del SPIE se apoya en un plataforma de datos, que funge como informadora para todas las entidades territoriales en cuanto a la situación de sus territorios, dicha plataforma de información se denomina INFO-SPIE, se encuentra a cargo del Ministerio de Planificación y representa un conjunto de datos oficiales, que permite informar, tomar decisiones y aportar al seguimiento y evaluación de los planes, sectoriales, territoriales, así como el PDES, de manera que con ello se busca aportar al manejo transparente y público de la información. En dicha base de datos se hallará información proporcionada por todas las entidades públicas del Estado y combinará diversas formas de análisis a saber estadístico, geográfico, cartográfico etc.

Realizando un análisis con mayor grado de profundidad se encuentra que la plataforma de datos del INFO-SPIE presenta inconvenientes de fondo, vinculados con la forma en que se construye la línea de base para los diagnósticos territoriales. La construcción de indicadores no es congruente con bases cuantitativas de "datos duros" que permitan construir una imagen real del estado situacional real actual de cada territorio, se utiliza una escala de 1 a 5 en la que se desconoce la metodología de construcción del indicador y de la valoración, por algunos es considerada demasiado subjetiva en cuanto a valoración de situación actual a nivel territorial.

\subsection{La evaluación desde la perspectiva de la Gestión Asociada del Territorio}

En el contexto de esta investigación y en el que se dará cuenta de las experiencias o estudios de caso para avizorar análisis sobre el momento de la evaluación dentro del ciclo de las políticas públicas, se busca propiciar una perspectiva a partir de la que se logre resignificar el sentido (la intención) y el significado (impacto proyectado) de la práctica evaluativa, considerándola como un momento crucial para las intervenciones sociales. De esta manera, se establece una relación entre el enfoque de la Gestión Asociada y la evaluación, en tanto que sí se menciona que evaluar es un momento contenido dentro de un ciclo de políticas y además que sí se logra afectar positivamente- dicho momento, se estaría afectando todo el ciclo en su conjunto; se está a su vez mencionando que la cogestión es una alternativa para transformar a la política pública en sí misma. Cuando se menciona el sentido transformador, se parte de considerar que en la actualidad las políticas públicas son pensadas desde la forma lineal, tradicional y positivista, lo que incide negativamente en los efectos de dichos planes, programas y proyectos en las realidades sociales que buscan afectar. En la implementación, se evidencian incoherencias con las singularidades territoriales, y contradicciones que son el resultado de un trabajo desarticulado entre los actores, así como frente a las particularidades contextuales en las que se enmarcan.

Se entenderá entonces la evaluación como el proceso político, deliberativo y multidimensional, en el que se busca dilucidar mediante la deliberación la brecha existente entre el discurso normativo y empírico, echando mano a 
enfoques metodológicos múltiples, intentando poner en evidencia diversas posturas sobre el conocimiento y la realidad, en oposición al excluyente discurso racional sobre la toma de decisiones. La evaluación en este contexto, sirve para generar consensos y acuerdos sociales, comprendiendo y mejorando la acción social y la interacción entre la sociedad y las instituciones (Solarte, sf: 12)

Así las cosas, se halla que la evaluación se convertiría en una herramienta cualificada y con mucho poder de potenciación para la toma de decisiones tanto para el mejoramiento de los escenarios actuales del curso de acción de las políticas públicas, como para la planificación territorial, la rendición de cuentas y para la opinión pública, incentivando el ejercicio de derechos e incidencia en las decisiones del Estado.

Se considera así el análisis y la evaluación de políticas como una contribución a la deliberación pública mediante la crítica, la defensa y la educación ya que un buen análisis debe proveer, además de datos, normas para la argumentación y una estructura intelectual para el discurso público (Majone y Wildavsky, 1998: P. 41)

Se pretende evidenciar a la evaluación entonces, como momento crucial que a su vez se muestra como potencial para incentivar un cambio de paradigma en la lectura y construcción de políticas públicas, así como en las dinámicas de la toma de decisión. Desde esta perspectiva, evaluar o valorar un plan, programa o proyecto es además escudriñar los argumentos y/o discursos que subyacen a la práctica, implica vislumbrar pruebas y evidencias que respaldan la tesis de un curso de acción desarrollado. Dicha tarea valorativa entraña además, el develar los valores, normas, percepciones, ideologías y consideraciones de carácter técnico, político, institucional o administrativo inherentes al diseño de un curso de acción; es en este sentido, que la estructura mental que se propone para adelantar la evaluación, debe contemplar tanto rutas cuantitativas como cualitativas que posibiliten el cualificar y dotar de sentido el quehacer público. Estos aspectos permiten dar cuenta de las incertidumbres y complejidades que integran el devenir de la toma de decisión y que también son parte fundamental del ciclo de políticas públicas.

De acuerdo a lo anterior, se destaca entonces que el evaluar resulta ser un proceso articulado inexorablemente con la investigación social "la incidencia en política pasa por una apropiación social amplia de ideas, valores o relaciones supuestas de causaefecto" (Roth, 2013: P. 29); de igual manera, evaluar trasciende el ejercicio de análisis de política justamente por su objetivo declarado de generar cambios en la política y de incidir en la decisión política. Para esta práctica resulta completamente necesario y pertinente el establecimiento de preguntas de investigación, recolección sistemática de información entre otros, vitales como parte de la visibilización de los avatares de planes, programas y proyectos. 


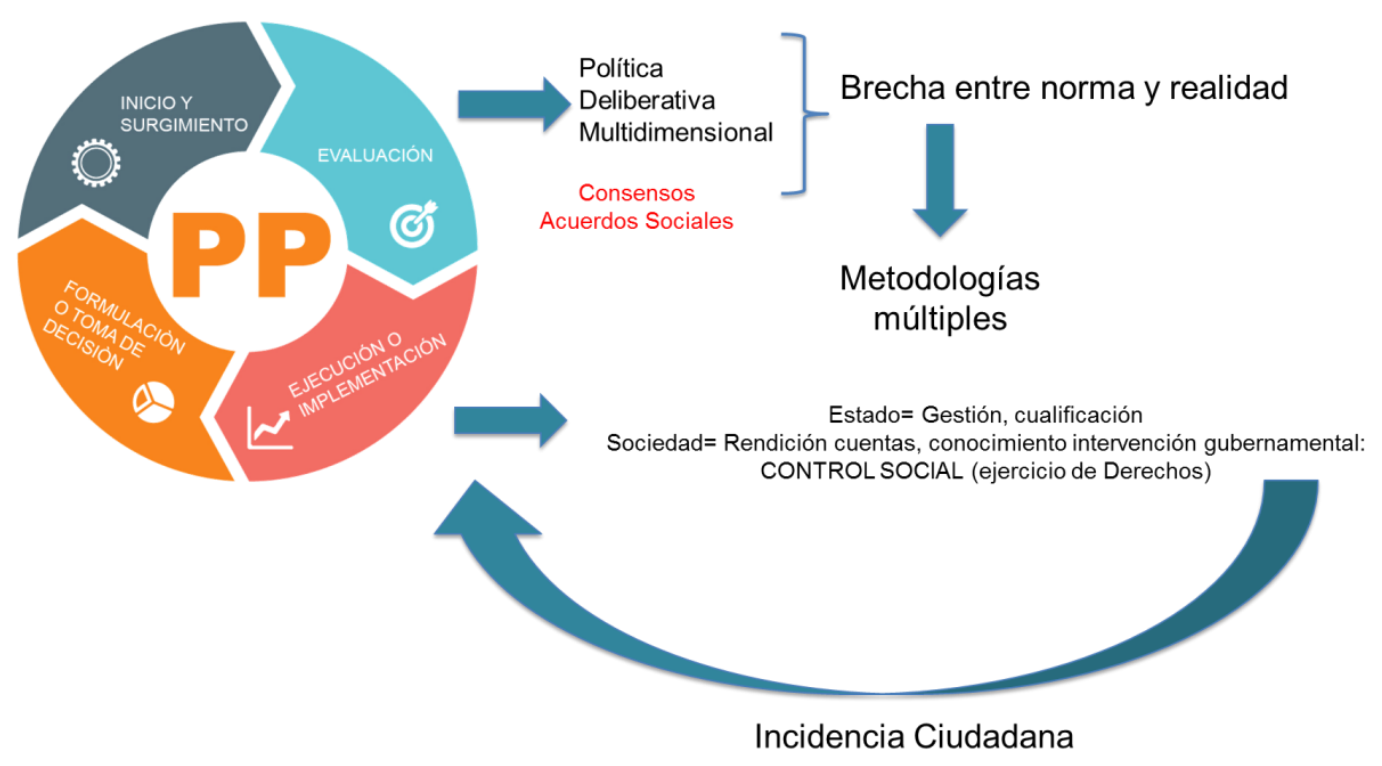

Fuente: Elaboración propia, 2016.

Figura 52. Esquema desarrollo y propuesta de evaluación Políticas Públicas

Resulta importante señalar que históricamente la evaluación como proceso de análisis, se ligó (hasta la década de los ochenta), con dinámicas mucho más cuantitativas que buscaban dar cuenta a partir de fundamentos numéricos, del grado de logro de las políticas en contraste con los objetivos que se trazaban; a partir de los años noventa y dada la influencia que subyace al llamado giro argumentativo se da paso a enfoques cualitativos que generan importantes aportes para el desarrollo de procesos de evaluación, ya que contribuyen a identificar y caracterizar los discursos de los sujetos que se involucran con los planes, programas y proyectos a valorar; de manera que gracias a técnicas como las historias de vida, las entrevistas y los métodos narrativos, se logra cualificar la evaluación, dando paso a la participación de los diversos actores que resultan vinculados o involucrados en estos procesos.

Dada la trayectoria histórica de los procesos de evaluación, se hace posible decantar el tránsito epistemológico de sus discursos y prácticas, así se identifican cuatro generaciones de la evaluación. La primera y la segunda marcadamente centradas en la medición y descripción, mientras que la tercera se caracteriza por hacer énfasis en la emisión de juicios de valor y la cuarta que ha sido propuesta por Guba y Lincoln (1989) se fundamenta en un paradigma alternativo, en tanto posee un carácter pluralista, dicho carácter pone en evidencia el hecho que el proceso no debe ser algo rígido y estandarizado, sino que por el contrario debe caracterizarse por la interacción y negociación permanentes entre los diversos actores sociales, que participarían de este momento de las políticas públicas.

De modo que los contornos o el perímetro de la evaluación no son fijados de manera autoritaria y a priori, sino que su definición es parte del proceso mismo de 
evaluación. el término constructivista se usa para señalar la metodología empleada para llevar a cabo la evaluación. Tiene sus fundamentos en una metodología interpretativa y hermenéutica, en ruptura con el paradigma científico positivista dominante (Roth, 2013: P. 32)

Desde esta perspectiva, se busca develar la diversidad de concepciones e interpretaciones de los actores sociales involucrados, las variadas miradas sobre la realidad social y las múltiples construcciones que de ella y en ella se realizan, a partir de las interacciones y los entramados de sentido que subyacen a estos contextos. En este sentido, quien evalúa ya no funge como agente que direcciona el proceso, sino que asume una postura de facilitación de procesos de negociación y establecimiento de acuerdos, su quehacer estará entonces enfocado hacia la construcción de consensos a partir de una información cualificada. Así, se estarían construyendo meta-discursos sobre la realidad social, narraciones ancladas en la construcción colectiva y compartida. "Eso implica que la evaluación es una actividad práctica, reflexiva, deliberativa y situada. Debe permitir elevar el nivel de los debates políticos ofreciendo datos, evidencias y argumentos a los diversos actores para permitir la deliberación pública" (Ibíd, 2013: P. 33)

La tercera generación de evaluación de políticas públicas está entonces fundamentada en una epistemología constructivista, se da paso a un reconocimiento amplio de la importancia y papel de la argumentación en cada momento de este proceso, restaurando con ello la preponderancia y centralidad de la deliberación pública para la toma de decisiones públicas; con lo que también se construyen modalidades de deliberación entre actores involucrados reconociendo que cada actor tiene sus propios argumentos y que dichos argumentos se ponen a circular en una suerte de construcción innovadora, creativa, de negociación cultural y finalmente de consenso y generación de acuerdos. Parafraseando las palabras del profesor Roth (2013) al respecto, se diría que tanto el reconocimiento como el asumir el pluralismo de argumentos y la pluriversidad de perspectivas de la realidad social, en definitiva es un llamado a la construcción de una nueva institucionalidad para ejercer la deliberación pública de la ciudadanía.

En este escenario, también se hace necesario reconocer que en la actualidad las instituciones no cuentan con capacidad de promoción de la deliberación, "ciertos" actores terminan asumiendo un papel preponderante hegemónico en la definición de problemas y soluciones, lo que favorece la cooptación de las políticas públicas por intereses particulares, dando paso al fomento de contextos de cabildeo y relaciones clientelares lo que restringe y anula los roles de control social, transparencia y ética pública, favoreciendo y haciendo extensivas en la sociedad las lógicas de abstencionismo, clientelismo y corrupción.

De allí que se haga importante fomentar lógicas de re significación que a su vez promuevan ejercicios y prácticas cooperativos y colectivos, en donde se evidencien la cogestión, corresponsabilidad y trabajo conjunto como insumos de verdaderos contextos 
deliberativos y críticos. Es en este sentido, que se construye el presente trabajo, para aportar a la aplicación del enfoque metodológico de la Gestión Asociada del Territorio a la evaluación, con el fin de cualificar sus prácticas.

\subsection{Aspectos de consideración experiencia control social en Bogotá: ISO/ IWA4}

Tomando en cuenta que este estudio retoma información y sistematiza los procesos de fortalecimiento de las capacidades ciudadanas para el control social, en lo referente a dos casos: Bogotá y Sacaba, en este apartado del documento se dará paso a caracterizar algunos aspectos importantes y relativos a la construcción de los Observatorios Ciudadanos de probidad, transparencia y lucha contra la corrupción tomando como orientación metodológica el estándar internacional ISO/IWA 4 en la experiencia Bogotá, a continuación se realizará una alusión sucinta a dicha herramienta de evaluación de políticas públicas en el marco de la promoción de gobiernos confiables. Esto con el objetivo de contextualizar el desarrollo del proceso adelantado mediante el Convenio entre la Veeduría Distrital y la Universidad Nacional de Colombia en el año 2013.

La ISO/IWA 4- $0^{23}$ resulta ser un instrumento que diagnostica, de manera colectiva, las necesidades mínimas indispensables reales que requiere la ciudadanía. Una vez el Gobierno actúe sobre estos temas de forma directa y efectiva, se reconstruye la confianza; se generan nuevos incentivos para la participación; se amplía la participación a nuevos actores; así se hacen visibles los avances y retos de la gestión pública, con lo que se empieza a garantizar la igualdad de derechos en todos los territorios de la ciudad (Ramírez, 2013. P. 19)

La verificación que se pretende desde la herramienta se realiza teniendo como referencia 39 indicadores de mínimos deseables distribuidos en cuatro (4) ejes construidos con base en Convenciones internacionales como la Agenda 21 de Naciones Unidas y los Objetivos de Desarrollo del Milenio. Los ejes son: i) Desarrollo institucional para un buen gobierno; ii) Desarrollo económico sustentable; iii) Desarrollo social incluyente y iv) Desarrollo ambiental sustentable. El primer ejercicio de verificación se realizó con una herramienta de 60 subindicadores que debe ser enriquecida con nuevos subindicadores que permitan profundizar cada vez más en la comprensión de las dinámicas territoriales y los desafíos institucionales.

Las características y grados de verificación se construyen autónomamente en cada localidad, a partir de los Sub-indicadores que son el elemento metodológico mediante el cual los ciudadanos pueden reconocerse no sólo con su realidad, sino con su gobierno, impulsando un enfoque de crecimiento conjunto, a partir de la implementación del instrumento de verificación con apariencia de "semáforo", donde los colores tienen el siguiente significado:

\footnotetext{
${ }^{23}$ Desde 2014 reconocida como NORMA ISO 18091 para la calidad en los gobiernos locales.
} 


\begin{tabular}{|l|l|}
\hline Verde & Prácticas del gobierno aceptables \\
\hline Amarillo & Prácticas del gobierno por debajo de lo aceptable \\
\hline Rojo & Prácticas del gobierno no aceptables \\
\hline
\end{tabular}

El ISO/IWA 4, Los Cuadrantes y los Indicadores se distribuyen de la siguiente manera:

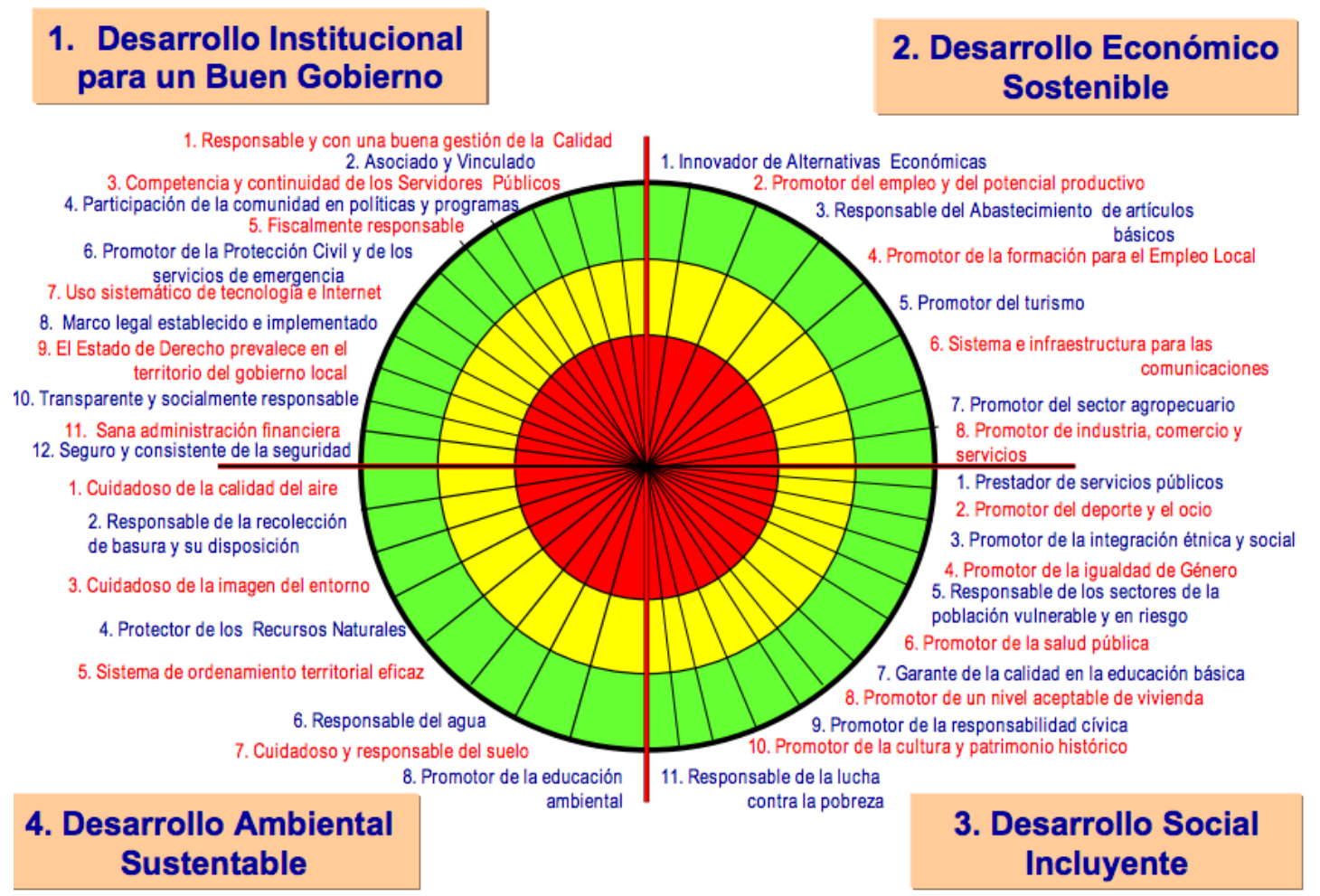

Fuente: Fundación internacional para los gobiernos confiables FIDEGOC. ISO/IWA4 nuevo paradigma para construir políticas públicas desde lo local.

Figura 53. Cuadrantes IWA 4

Por otra parte, la herramienta está constituida con base a la definición de 15 enfoques que orientan el trabajo de implementación del ISO/IWA 4 en los territorios, en este caso las localidades. Dichos enfoques se construyen con ocasión a la promoción de principios de inclusión e igualdad de derechos, que aporten progresivamente a la incidencia de los ciudadanos en la gestión pública a partir de su participación activa en la evaluación, seguimiento y control a las políticas públicas.

Los 15 enfoques de ISO-IWA 4.0 son (ver Tabla 41): 
1. Enfoque de abajo hacia arriba: donde los gobiernos locales como conocedores de las realidades territoriales, y por ser los más cercanos a la comunidad deben participar o ser los generadores de la política pública

2. Enfoque de mínimos integrales: permite empezar con una base de mínimos para luego avanzar hacia las mejoras de las prácticas, pues para evaluar estándares más altos, es necesario tener asegurados los mínimos aceptables.

3. Enfoque de integralidad: se presenta una visión holística de los temas de gobierno, pues no se puede ver un gobierno como sectores donde su acción está desconectada de los otros.

4. Enfoque donde los resultados importan

5. Enfoque sistémico: Cada uno de los cuadrantes se relaciona con los otros

6. Enfoque detonador: Los resultados obtenidos al final del ejercicio en rojo logran atraer la atención y visibilizar dónde están los problemas

7. Enfoque de redes de Política Pública: se crean redes de política pública entre las diferentes dependencias de los Gobiernos

8. Enfoque de transversalidad horizontal: todas las áreas de un Gobierno deben tener relación y constante y efectiva comunicación.

9. Enfoque de transversalidad vertical: todos los niveles distintos de gobierno deben mantener una comunicación constante y efectiva

10. Enfoque de comunicación: se crea un lenguaje y códigos comunes para todos los actores.

11. Enfoque de liderazgo: debe existir el compromiso de la más alta autoridad, que tenga a su vez la capacidad de dirigir y orientar a los otros niveles.

12. Enfoque político de los asuntos técnicos: una apropiada y eficiente comunicación entre los políticos y los técnicos

13. Enfoque de aprendizaje: IWA es un aprendizaje continuo

14. Enfoque donde los procesos siguen a los resultados: los resultados favorables crean los procesos.

15. Enfoque de verificación ciudadana: Los observatorios ciudadanos verifican y evalúan gobiernos

Fuente: Fundación internacional para los gobiernos confiables FIDEGOC. ISO/IWA4 nuevo paradigma para construir políticas públicas desde lo local.

En este sentido, la herramienta ISO/IWA 4 constituye un pre-texto para el impulso de procesos tendientes a fomentar la construcción de una base social sólida, cualificada e incluyente frente a los temas de evaluación, seguimiento y control a la gestión pública en los territorios (localidades) de la ciudad. Un insumo metodológico que trasciende totalmente la instrumentalidad técnica para posicionarse como posibilidad de re significación de la relación ciudadanía-administración pública local a partir de la 
promoción de la agencia ciudadana como factor preponderante de los procesos de democratización social.

\subsection{Experiencia de fortalecimiento de capacidades sociales para control social: Bogotá}

Es en este contexto, en el que el proyecto 001 "fortalecimiento de las capacidades sociales para el control social en la gestión pública del distrito capital”, resultado del convenio entre la Veduría Distrital y la Universidad Nacional de Colombia24 cobra enorme relevancia, de cara a cualificar los procesos de evaluación de políticas públicas a partir de la información, formación y capacitación tanto de la administración pública local y quienes forman parte de ella, como de las organizaciones de la sociedad civil que ejercen su acción en las diferentes localidades de la ciudad de Bogotá. Así las cosas el ISO/IWA 4 como estándar internacional de diagnóstico y evaluación participativa en materia de gobiernos locales, llega a la ciudad como una ruta metodológica que trasciende la racionalidad meramente técnica para involucrar reflexiones de carácter político sobre la ciudad y la ciudadanía, se convierte en pre-texto de procesos de fortalecimiento de la base social existente en cada territorio local, con objetivo de profundizar las lógicas de democratización de la gestión pública. Si bien la lógica de implementación del ISO/IWA 4, demanda todo un despliegue de carácter territorial, pedagógico y operativo, también como experiencia significativa de evaluación de la política pública y como escenario de acción territorial, requirió de un proceso de sistematización que se desarrolló como parte de ejercicios de consultoría de la autora en el mencionado proyecto y que ahora se sintetizan en este documento como reflexión que genera aportes teóricos que permiten pensar la evaluación de políticas públicas, como un espacio de Gestión Asociada del Territorio en el marco del fortalecimiento de la agencia social de la ciudadanía sobre lo público, y en el contexto de fortalecimiento de los discursos y prácticas de democratización social de la administración y gestión pública.

Entendido como una modalidad de participación ciudadana, "el control social permite que las personas de manera individual y colectiva, a partir de las organizaciones de la sociedad civil, influyan en los asuntos del Estado, con el fin último de incluir intereses y de aumentar la responsabilidad y la integridad en el manejo de la gestión pública. Sus contenidos hacen referencia básicamente a actividades ciudadanas de vigilancia, seguimiento, evaluación crítica y sanción”. (Veeduría Distrital, 2005. P 33). Se observa entonces que el control social encuentra como correlato la relación Estado-Sociedad en el marco de despliegue de la ciudadanía activa que vigila, controla, desarrolla y construye alternativas para proponer y participar en la cosa pública. Tomando en cuenta lo anterior y teniendo como marco contextual escenario bogotano se encuentra que las posibilidades que estructura el control social en tanto pieza clave para echar a andar la

\footnotetext{
${ }^{24}$ De manera específica a través del Departamento de Trabajo Social y de su Programa Interdisciplinario de Apoyo a la Comunidad PRIAC.
} 
maquinaria estatal en pro de la consecución del bienestar general, aparece restringida y limitada por las posibilidades de incidencia en los escenarios de la política pública. En este escenario, se evidencia que no basta con la reglamentación jurídica u ordenamientos constitucionales que prescriben los derechos, es el control y las capacidades de agencia social de los ciudadanos quienes construyen la base de la exigibilidad, de forma que las acciones de control social permiten que los derechos pasen de la potencia a la acción y del marco normativo a la incidencia en política pública.

Aunado a lo anterior, la participación ciudadana se convierte en premisa insoslayable de la prevención y control de la corrupción, por lo tanto, la potenciación de la participación como fin y como medio sería la arista fundamental de procesos de fortalecimiento de capacidades ciudadanas para el control social. Fortalecer el control social, remite necesariamente a la pregunta por la participación y sus niveles de realización. En este sentido, el interrogante sobre la participación en Bogotá, permite evidenciar que se cuenta con dos mediciones muy significativas, i) tercera medición de Capital Social y ii) la encuesta de percepción ciudadana del 2012 de Bogotá Cómo Vamos, las cuales demuestran que persisten los bajos niveles de participación (Fundación Restrepo Barco, 2012), con una caída muy significativa en la pertenencia a organizaciones voluntarias seculares de 33\% frente al 2005 (Veeduría Distrital, 2013) y que el 95\% de las personas expresaron no pertenecer a ningún grupo u organización comunitaria donde la razón principal es la falta de tiempo e información, o porque no saben cómo participar (Fundación Corona, Cámara de Comercio, el Tiempo, 2012).

Existen bajos niveles de participación en la ciudad de Bogotá, y de igual manera también frente al grupo reducido de quienes participan se hallan manifestaciones vinculadas con que la participación no logra el nivel de incidencia esperado por los ciudadanos frente a temas como la reducción de la corrupción o de lógicas clientelistas. La encuesta de Bogotá Cómo Vamos para el 2010, muestra que el 42\% de los ciudadanos, han asistido a un evento de Rendición Pública de Cuentas y que de este el $48,6 \%$ señalan que la información obtenida no les ha servido para conocer las decisiones de su Gobierno. En este mismo sentido, la Corporación Transparencia por Colombia, menciona que el " $77 \%$ los ciudadanos afirman que la participación no ha logrado reducir el clientelismo y la politiquería, y sólo el $29 \%$ cree que la participación ciudadana ha permitido influir en las decisiones de las autoridades locales. Sólo el 2\% tiene confianza en las veedurías ciudadanas para luchas contra la corrupción. Los medios de comunicación y las $\mathrm{ONG}^{\prime}$ s son identificadas como las instancias en las que mayor se tiene confianza en la lucha contra este flagelo" (Transparencia por Colombia, 2012)

Por otra parte, se evidencia que la Corporación Transparencia por Colombia en sus Agendas Ciudadanas por la Transparencia indica que hay una distancia entre las organizaciones sociales y las distintas instancias de participación, tanto a nivel distrital como local y que cada vez que hay un nuevo gobierno se promocionan y se implementan nuevas formas de participación que compiten. Así las cosas el panorama 
de análisis arroja problemas de realización e incidencia efectiva de la participación desde cuatro puntos de referencia I) Si bien existen mecanismos de participación avalados por prescripciones constitucionales y jurídicas, estos no se reflejan en la realidad concreta del devenir de la gestión pública II) Los niveles de participación ciudadana son reducidos con ocasión a variables como el tiempo y el no acceso a la información, III) Existe un bajo o inexistente nivel de incidencia de los ciudadanos que participan en asuntos de la gestión pública y V) Multiplicidad de iniciativas que convocan a la ciudadanía y compiten entre sí.

De igual manera, es importante señalar de cara a los obstáculos que encuentra la participación para materializarse, que la situación de desigualdad económica y de oportunidades inciden definitivamente en las diferentes formas de participación tanto política como ciudadana; en este sentido es necesario partir de entender que el trabajo de fortalecimiento de la participación social y comunitaria en el marco del control, seguimiento y evaluación de la Gestión pública de la ciudad, se adelanta en el seno de un conjunto de contradicciones de orden económico, social y político, más allá de las propias de la ciudad vinculadas con las asimetrías sociales, la caracterización de la misma como mega ciudad y sus modelos de crecimiento, densificación, distribución de recursos y población en el territorio.

La asimétrica distribución territorial de recursos, equipamientos, oportunidades y condiciones de acceso a la ciudad y sus servicios, vincularon este trabajo al análisis sobre las consecuencias visibles de un incremento progresivo de las brechas de desigualdad, pauperización y exclusión de amplios sectores de población en la ciudad, estableciendo de esta manera el enfoque de trabajo, que se convierten en pre-textos para el despliegue e impulso de escenarios de participación que permitan que los individuos y colectivos se inserten en lo público como agentes activos en lo concerniente a la instauración así como análisis retrospectivo sobre planes, programas y proyectos en los que finalmente se observa el estado en acción, en tanto busca el cumplimiento con su deber primigenio de garantizar condiciones y oportunidades para que la población tenga un alto nivel de calidad de vida y en este escenario se propicie el goce pleno de derechos.

Tomando como referente la información anterior en términos demográficos y socioeconómicos se evidencian dos puntos centrales que constituyen referentes de análisis fundamentales para la implementación del ISO/IWA 4, a saber 1) Que Bogotá es una mega ciudad con una densidad poblacional en aumento y 2). Que las condiciones de desigualdad social y precarización continúan presentándose. Aspectos que constituyen un marco analítico importante para fundamentar tanto las estrategias de trabajo a desarrollar en el proyecto, como las posibilidades que la herramienta en sí misma brinda a una ciudad que demanda el fortalecimiento de las capacidades ciudadanas para el control social a la gestión pública, con miras a incidir de forma definitiva en indicadores de calidad de vida, que muestran la perpetuación de las asimetrías territoriales en el nivel distrital y local, desde allí se visibiliza la importancia 
de tener como referente de trabajo la recuperación de lo público para la ciudadanía a partir de potenciar la participación ciudadana.

En suma, el proyecto demandó que las estrategias y acciones a desarrollar, partieran de un enfoque orientado hacia y desde el territorio, como escenario privilegiado donde se plasman las contradicciones propias del modelo de crecimiento económico y las singularidades que adquieren éstas en lo local; un enfoque que privilegió el carácter participativo, de fortalecimiento de lo público y de construcción de capacidades de agencia ciudadana sobre la vida colectiva en la ciudad. De manera que se entendieron dichos aspectos de la siguiente forma:

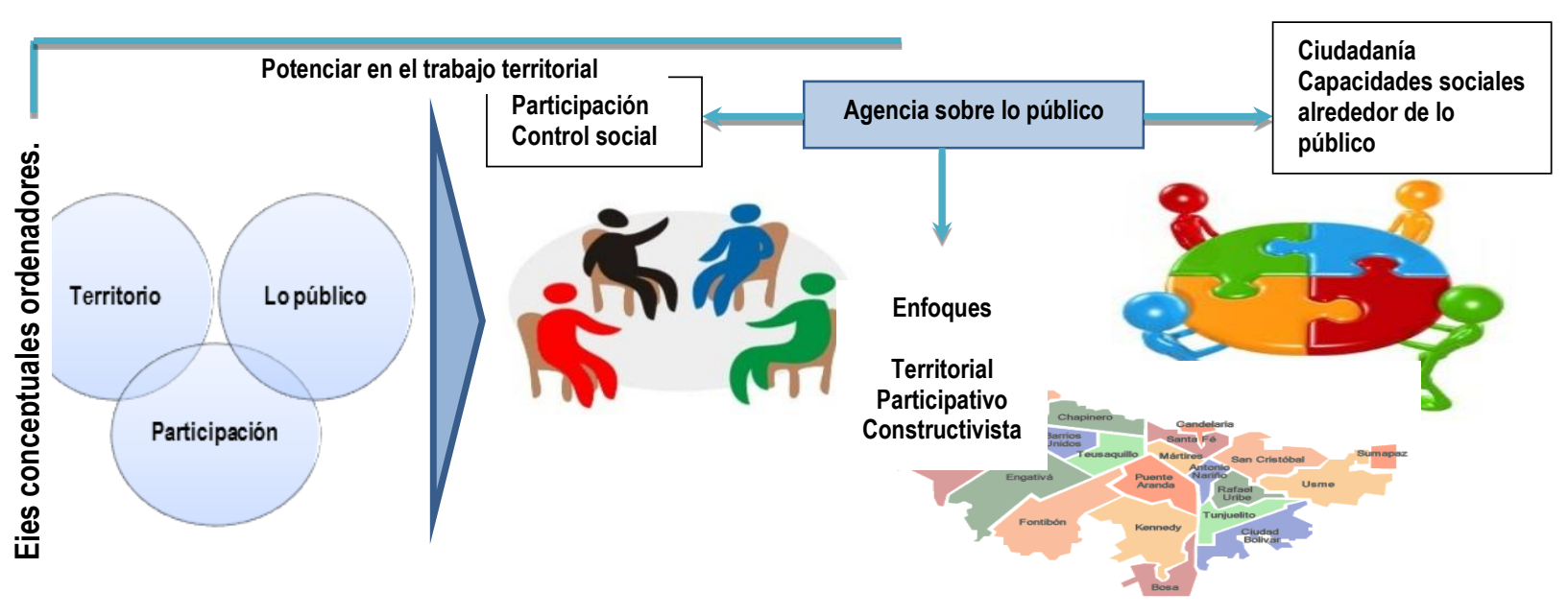

Fuente: Umbarila Patricia. 2013. Diagramación del proceso.

Figura 54. Fortalecimiento de veeduría ciudadana y construcción de confianza social en las instituciones

Como herramienta al servicio de la rendición de cuentas, la ISO/IWA 4 apareció como una metodología que contribuiría a mejorar progresivamente la calidad de las decisiones estatales así como los resultados de la gestión, en este sentido, se habla de su aporte a la gobernabilidad democrática de manera que su objetivo superior estaría encaminado a empoderar a la ciudadanía para ejercer sus responsabilidades políticas, fortaleciendo por esta vía la relación de los individuos con lo público "en otras palabras, la ciudadanía (que) supone la capacidad individual y colectiva de luchar por nuevos reconocimientos y de proponer iniciativas que -expresadas frente a lo público- conduzcan a mejorar la calidad de vida de las personas" (Pizano, 2003. P. 62)

Desde esta perspectiva, las posibilidades que construyen los escenarios de evaluación de políticas públicas y fortalecimiento de capacidades sociales para el control social, destacan principalmente en términos de profundización de la democracia, la oportunidad de construcción de capacidades en los ciudadanos y ciudadanas, tomando en cuenta que el control social se convierte en una estrategia 
de incidencia política, referida a su vez a la exigibilidad de los derechos sociales de la ciudadanía. (Nuria Cunill: 2008; P.34)

En suma, la construcción de un modelo participativo e incluyente debe estar orientado a promover un papel activo de la ciudadanía y de las entidades territoriales encargadas de la gestión de lo público y aquellas encomendadas a las tareas de transmisión, construcción y transformación del conocimiento, por el papel central que este cumple en los procesos de tejido y transformación de la sociedad. Dadas las particularidades de una sociedad caracterizada por profundas asimetrías sociales que estructuran realidades fragmentadas, con amplios grupos de población excluidos de los escenarios de política pública y por ende restringidos en sus posibilidades de realización de derechos, con expresión territorial en contextos caracterizados por problemas estructurales de corrupción, desempleo y bajos procesos de inclusión y fortalecimiento de expresión de ciudadanías; resulta fundamental la acción de los actores sociales en términos de reivindicación de derechos con un sentido de recuperación de los valores democráticos y de participación, desde la inserción en los espacios de toma de decisiones, es allí en donde se inicia la construcción de proyectos de país y de ciudad alternativos, que surjan desde las demandas, sentires y pensares de los ciudadanos y las ciudadanas.

Así las cosas, el proceso de implementación del ISO/IWA 4, llegó a Bogotá como una oportunidad para reflexionar sobre las finalidades y sentidos que subyacen a los procesos participativos de evaluación, seguimiento, control y veeduría a la gestión pública y a las políticas públicas de la ciudad. Posibilidad de fortalecimiento de lo público desde lo público, a saber desde la ciudadanía misma; a partir de la construcción de escenarios multipropósito de definición de un lenguaje común en términos de lectura de las dinámicas que agencian las instituciones en el ámbito local, en los registros social, ambiental, de desarrollo institucional y económico.

Constituyó una apuesta por la promoción y cualificación de la participación con el propósito de vincular a diversos grupos de la ciudadanía e incidencia en la consolidación de capital social al interior de las instituciones de la administración pública cualificando los ejercicios de gestión que desde allí se realizan. El trabajo desarrollado en el marco del proyecto "Fortalecimiento de capacidades sociales para el control social a la Gestión Pública Distrital y Local-Universidades por Bogotá” se ancló en la función de control social preventivo que ejerce una entidad distrital como lo es la Veeduría, "ejercer el control preventivo como conciencia crítica frente a la administración, para fortalecer en tiempo real la capacidad de gestión de las entidades" (Medina, 2007. P. 5) es uno de los objetivos generales que se conciben para dicha instancia gubernamental. En este sentido, enmarcado en este y los demás objetivos concebidos para ello, se buscó aunar esfuerzos para la construcción de capital social que involucrara la creación e instalación de capacidades ciudadanas en esta materia considerando que "la construcción de ciudadanía tiene que ver básicamente con una incorporación de sujetos a una comunidad pública y con la ampliación de las titularidades de los miembros de esta..." (Sánchez, 2003. P. 34) pero también que este aspecto tiene como correlato la participación en la vida pública, con el fin de encaminar 
la incidencia en procesos de toma de decisiones y con repercusión en los niveles de calidad de vida de la población.

\subsection{Bogotá y los instrumentos de control social}

"La promoción de la participación de los ciudadanos en el ejercicio del control social a la gestión pública y en la defensa de los intereses públicos, es un reto para la democracia colombiana en virtud del mandato constitucional y de los compromisos sociales y políticos, que es necesario asumir, para la promoción y la protección de los derechos ciudadanos, relacionados con las proyecciones y resultados de la acción de la administración pública” (Veeduría Distrital, 2011).

Teniendo en cuenta la importancia de generación de alternativas que promuevan la defensa de los intereses públicos, a partir de vincular a los y las ciudadanas en lógicas de control social, la Veeduría Distrital como entidad encargada de acciones preventivas frente al tema del control social, ha desarrollado en su trabajo varias acciones en torno a fomentar procesos de formación en el tema. La entidad sobre todo se ha enfocado en impulsar procesos de información, formación y capacitación "se ha desarrollado una valiosa experiencia formativa y educativa, en donde el desarrollo de procesos en los cuales la ciudadanía acceda al conocimiento, es factor que da sentido real a la participación y a la construcción ciudadana” (Ibíd. 2011)

Desde esta perspectiva se identifican como experiencias significativas la Escuela de Control Social y las Redes Ciudadanas de Control Social a la Gestión Pública. La primera de estas iniciativas constituyó en el año 2005 una estrategia de formación permanente e incluyente en la que actores sociales tradicionales y no tradicionales en el ejercicio del control social en Bogotá, se vinculan para el aprendizaje y generación de procesos de participación en la vigilancia y seguimiento a la gestión pública. A través de esta escuela la Veeduría logra un proceso de capacitación permanente en el Distrito, que para el año 2009 había formado alrededor de 12.000 personas. En este sentido, se logró consolidar como escenario de capacitación, el cual formó parte de un proceso de carácter estratégico y misional que persiguió el objetivo de generar habilidades y competencias para la ciudadanía. Dicha Escuela de Control Social

se concibió como "un proceso en el que participaron diferentes actores sociales e institucionales, que en diálogo avanzan en la reflexión y abordaje de dilemas teóricos y prácticos sobre la gestión pública y sus componentes. Así mismo mediante esta experiencia los ciudadanos y funcionarios se cualificaron, a través del conocimiento de las problemáticas de la ciudad y del desarrollo e implementación de herramientas sociales para el monitoreo y seguimiento a las políticas, programas, proyectos y/o contratos públicos" (Bello, 2009. P. 29).

La mencionada Escuela se posicionó como estrategia que promovió la capacitación en el tema del control social, logrando un amplio impacto en términos de egresados y/o personas capacitadas y concientizadas en los aspectos vinculados con el mismo. 
Por otra parte, las Redes Ciudadanas de Control Social a la Gestión Pública, constituyeron alternativas que pretendían orientar a aquellos ciudadanos interesados en la conformación de espacios de acción colectiva, asumiendo un rol de promotores de conocimiento relacionados con los mecanismos de defensa y protección de los intereses públicos. Las mencionadas Redes iniciaron en el año 2008 en el marco del proyecto 562 "Consolidación de la casa ciudadana del control social y fortalecimiento del ejercicio cualificado del control social"; "se conciben como un espacio de encuentro $e$ interlocución de la ciudadanía, donde a través del diálogo y el trabajo en equipo, en el marco de un proceso continuo y dinámico de construcción colectiva y autónoma, se entrelazan saberes e intereses, orientados al beneficio general" (Veeduría Distrital, 2011)

En el desarrollo de estas iniciativas se logra una identificación de colectivos de población, líderes comunitarios, experiencias organizativas que desde su rol ciudadano se convierten en participantes activos de dinámicas de control social y Veeduría ciudadana. También se hace visible la importancia de contar con insumos de carácter metodológico y técnico que posibiliten que la ciudadanía ejerza su rol ciudadano de control, a partir de una participación cualificada en el tema, de un proceso que potencie la construcción y fortalecimiento de capacidades ciudadanas para el control social, se estructura la necesidad de hacer un tránsito de las capacitaciones sobre control social al uso de una herramienta internacional de evaluación de política con experiencia operativa en el territorio. Así, la Veeduría elige ser parte del proceso internacional del IWA, luego de realizar un estudio de las posibilidades existentes; desde un análisis comparativo de los instrumentos y herramientas implementadas en otros países para promover procesos novedosos de control y seguimiento a la gestión de las políticas públicas desde una perspectiva ciudadana. Es así como se decide revisar la herramienta ISO-IWA 4, que es la aplicación de la norma ISO 9001:2008 a los gobiernos, este que se concibe como el primer esfuerzo de la Organización Internacional para la Estandarización (ISO) en materia de Gobiernos Locales.

"Es una herramienta que busca promover la participación y el control social de manera incluyente, esto es que todos los ciudadanos pueden acceder al proceso, crear un lenguaje común entre gobierno y ciudadanía, permitiendo un diálogo claro y transparente para comunicar y entender las acciones que adelanta el gobierno en los mínimos establecidos en las convenciones internacionales, los Objetivos de Desarrollo del Milenio-ODM; las Agenda 21 de Naciones Unidas y demás instrumentos que buscan garantizar el desarrollo y reducir los niveles de pobreza de los ciudadanos" (Ramírez, 2013, P. 19)

El ISO/IWA 4 resulta ser una herramienta de carácter metodológico y pedagógico que diagnostica, de manera colectiva, los requerimientos mínimos indispensables que demanda la ciudadanía en materia de bienestar social y desarrollo local. Una vez el Gobierno actúe sobre estos temas de forma directa y efectiva, se reconstruye la confianza; se generan nuevos incentivos para la participación; se amplía la participación a nuevos actores; se hacen visibles los avances y retos de la gestión pública. La 
herramienta se convierte en un pre-texto para la cualificación de la participación ciudadana y para la construcción de procesos sociales que permiten fortalecer la capacidad de agencia ciudadana sobre lo público, a partir de desarrollar su trabajo sobre los enfoques territorial, participativo y de fortalecimiento de lo público desde lo público. Es una herramienta que posibilita la construcción de escenarios de diálogo ciudadanía-gobierno, de manera que dicho espacio dialogal se realiza en igualdad de condiciones en términos de lenguaje, acceso a información y capacidad de incidencia. La herramienta pretende hacer visibles las competencias e incumbencias de la gestión del gobierno distrital y local, es decir evidencia y verifica la gestión en el territorio más cercano al ciudadano: la localidad.

El ISO/IWA 4 se implementa bajo el supuesto de la participación incluyente, en la medida que logra concentrar intereses diversos bajo un mismo esfuerzo, evitando la atomización de la participación. Por ser un ejercicio de control social integral que garantiza el acceso de la información a todos y todas, permite que todos los esfuerzos de las organizaciones se concentren y se construya una sola instancia que agrupe grupos con diversos intereses y necesidades, que finalmente se apoyan entre ellos. En este sentido, en la implementación de la metodología ISO/IWA 4, las organizaciones territoriales se reflejan en toda la herramienta, "posibilitando la participación desde los intereses (poblacional, sectorial, territorial), alrededor de una visión compartida de ciudad; teniendo como referente las acciones del gobierno distrital y del gobierno local'. (Ramírez, 2013. P 21)

\subsection{Bogotá y la Descentralización}

Desde los albores de la década del noventa, nos situamos en un país de apertura social y económica en donde la participación y la descentralización corren paralelas a un proceso de globalización, que transforma las dinámicas de comprensión y construcción de políticas y escenarios sociales, económicos y culturales. En palabras de García Canclini (1995: 13). es importante considerar que "la globalización no es un simple proceso de homogeneización, sino de reordenamiento de las diferencias y desigualdades sin suprimirlas" Elemento que implica entender que los contextos aparecen marcados por la reorganización de capital en el nivel global, lo cual genera nuevas dinámicas de producción del sistema, en este sentido, se habla entonces de nuevos mecanismos de concentración de la riqueza que se convierten en corolario histórico de las lógicas de mercado.

La reforma del Estado, las lógicas de desregularización que transformaron los Estados de Bienestar y las condiciones de derecho de ciudadanos y ciudadanas acontecidas desde la década del 90, la privatización de escenarios de interés colectivo y la inclusión de la renta privada en la prestación y uso de los mismos, construyen un panorama general donde derechos son trasformados en servicios, universalización de la prestación en focalización y garantías laborales colectivas en logros individuales en medio de un 
proceso general de pauperización de las poblaciones y concentración de renta y capitales en el exterior.

La paulatina ampliación de escenarios, normas y propósitos de la participación acontece en el marco de una filigrana de privatizaciones de escenarios de interés común (privatización de lo público). Esto obedece además, a que las lógicas de participación resultan restringidas y sectorizadas en relación con los planes presupuestales focalización de los sectores de política pública- entreabriéndose preguntas en torno a ¿Cómo la participación se vuelve una estrategia de cooptación hacia lo privado?; ¿Qué es lo privado y lo público del Estado?, y ¿Qué es lo privado y lo público de la sociedad?.

Se señalan entonces marcos generales de acción para desentrañar las lógicas bajo las cuales se establece la relación Estado-Sociedad en la actualidad, teniendo como puente de análisis lo público como posibilidad de deconstrucción de las lógicas que orientan las dinámicas institucionales y sociales que permiten adoptar decisiones de política pública en estos contextos. En primer lugar, se dilucida la autonomía de las esferas estatal y público social, entendiendo que lo público no sólo obedece al Estado, sino que se enraíza en todas las discusiones que son de interés común, involucrando tanto al Estado como a la sociedad. Así se vislumbra la reflexión sobre autonomía toda vez que las dos esferas (estado-sociedad) pueden incurrir en procesos de privatización; desde esta perspectiva, se hacen necesarios procesos de control mutuo que permitan un seguimiento a las acciones de uno y otro lado, así como la evasión a procesos de privatización.

Allí se presentan como inherentes, algunos criterios que devienen de la discusión, como la igualdad política, aludiendo al espacio donde no se reproducen lógicas de desigualdad (económicas, sociales, etc.); pluralismo político, donde se reconoce el disenso, las contradicciones, y las posiciones diversas. Esto no quiere decir que en el momento de reconocer las diferencias del otro, se aísle y de cierta manera se excluya de los procesos de participación, sino que por el contrario se invita a la deliberación por medio de argumentos que posicionen un punto de vista, se trata pues del reconocimiento de las diversas tomas de postura frente a uno o varios temas en la cosa pública. Estas tres iniciativas -igualdad política, pluralismo político y deliberación-, corresponden a lo público y configuran claves para los procesos de participación.

En el caso particular de la ciudad de Bogotá, el proceso de descentralización es un proceso que se desata años atrás, en 1993 con la promulgación del Estatuto Orgánico a través del Decreto 1421/93 con el que se da paso a un proceso importante, en términos de reconocimiento de las localidades como entidades territoriales cuyo gobierno estaría conformado por Alcaldes locales y Juntas Administradoras Locales, organismos que estarían orientados a promocionar las dinámicas de planeación local, así como el cumplimiento de normas y la participación ciudadana. Este modelo ha recibido muchas críticas en torno a preguntas sobre ¿Cuál sería el propósito fundamental del proceso de descentralización en una mega ciudad como Bogotá? Sobre todo porque dicho esquema 
pareciese no corresponder con las expectativas para las que fue pensado, en palabras del ex alcalde Mockus (1999) se halla que hasta el momento “(...) ha predominado la descentralización de procesos administrativos, de planeación y de control social (pero que) hacia adelante es necesario avanzar en los aspectos de la descentralización que conduzcan al logro del propósito básico de un - gobierno: mejorar el servicio a la comunidad y optimizar los procesos de formación ciudadana y de aprendizaje colectivo en materia de convivencia y productividad"(El Espectador, 1999)

Las dinámicas de descentralización en la ciudad propenderían por entregar un conocimiento completo de cada ente territorial (localidad), permitiendo identificar las singularidades territoriales, sociales, culturales, políticas y hasta económicas de cada sector. Dada la complejidad de la capital en razón a su tamaño pero también dado su permanente cambio, se considera necesaria la actuación de la administración a partir de este esquema organizativo que posibilita una lectura global de la dinámica bogotana como territorio en permanente construcción social; debe existir una suerte de complementariedad entre la autoridad central y los agentes descentralizados. Por otra parte, respecto a la descentralización es importante mencionar que si bien existen aspectos vinculados con las dimensiones gobierno, administrativa y de servicio a la comunidad (Fundación Corona, 2012), estas van a estar intrínsecamente asociadas con objetivos tales como la participación, formación ciudadanas y el aprendizaje colectivo como potenciadores de la democratización social y la construcción de ciudadanía activa.

Los principales problemas asociados con la descentralización son expresados por la Fundación Corona así”:

1. Indefinición e inconsistencia entre las funciones a cargo de las localidades y las atribuciones y recursos realmente asignados a ellas. Algunas funciones asignadas por el Estatuto Orgánico a los Alcaldes locales, sugieren un muy amplio campo de acción e importantes facultades normativas, lo cual abre la puerta para que se generen grandes expectativas sobre lo que las localidades pueden y deben hacer. Esto permite la coexistencia de diversas interpretaciones respecto de la verdadera "misión" de las localidades y dificulta la formulación de un marco concreto dentro del cual se pueda evaluar la marcha del proceso. En la práctica, sin embargo, el campo de acción es muy reducido y los recursos muy escasos, por lo cual el esquema tiende a generar frustración, tanto en los Alcaldes locales como en las comunidades;

2. Como consecuencia de lo anterior, se tiende a replicar el esquema "municipalista" en las localidades, sin considerar seriamente las diferencias existentes entre el ámbito global de la ciudad y los específicos de las localidades, generando inflexibilidades y costos de diverso orden que hacen imposible en la práctica la funcionalidad del modelo; 
3. De otra parte, la asimilación, así sea parcial, del concepto "participación ciudadana" con el de "representación política", introduce en las localidades una racionalidad electoral, no necesariamente coincidente con los criterios de servicio a la comunidad que deben orientar la participación ciudadana en este nivel.

Estos planteamientos se convierten por tanto en referentes fundamentales también de cara a las posibilidades de trabajo que deben abrirse en aras de procurar la realización de derechos y el ejercicio pleno de ciudadanías, en el Estado social. En el marco de procesos de descentralización, cuyos correlatos más representativos parecen ser las dimensiones fiscal y administrativa, se halla una participación concebida como sentido y fin último que definitivamente debe contribuir a la potenciación de capacidades institucionales que permitan mejorar las actividades desarrolladas en el terreno de la gestión pública, así mismo vale la pena mencionar que en este ámbito también se expresa la multiplicidad y diversidad de intereses de las diferentes fuerzas que convergen, subyacentes a las dinámicas de transformación social, modernización, urbanización y progresiva ampliación y apertura de mercados. De igual manera, aparecen las entidades territoriales municipales y locales y con ellas la importancia del reconocimiento de sus particularidades y singularidades como condición sine qua non que sumadas a la introducción de un componente político al tema de la participación, parten de considerar que ésta debe ir paralela a lógicas asociadas con la vinculación de mecanismos de inclusión social así como de control y vigilancia a las políticas públicas por parte de la ciudadanía, se sitúa entonces la discusión en otro terreno que se articula con la alusión a las especificidades de la acción colectiva en el marco de un Estado social de derecho.

\subsection{Bogotá y la sociedad civil (organizaciones sociales)}

Dentro de los pilares orientadores de la acción en el marco interpretativo y de desarrollo práctico de las estrategias contenidas en el proyecto, se halla también un eje anclado en la construcción y/o fortalecimiento de capacidades en las organizaciones sociales como objetivo superior, de manera que los ejercicios de control social, en este caso a través de la herramienta ISO/IWA 4, permiten que las intervenciones sociales de los ciudadanos y ciudadanas se posicionen como desempeños sociales sustantivos en los escenarios públicos.

La construcción y por ende el fortalecimiento de las capacidades ciudadanas, en este sentido involucra la pregunta por los funcionamientos valiosos de los sujetos como espacio que vincula tanto las garantías de existencia de bienes materiales que expresan valor, como lo referente a capital cultural, identidad y libertades de elección de individuos entre diversidad de formas y posibilidades de vida. En suma "un conjunto de disposiciones que posibilitan el que los sujetos desarrollen sus capacidades para realizar determinadas funciones que ellos mismos consideran tienen valor" (Sen, 2004: 12), un valor que se asigna tanto a funcionamientos que emergen desde "el lugar", de lo 
cotidiano simbólico, hasta las perspectivas de vinculación en la vida comunitaria y en los asuntos de interés común.

Remitiéndonos a observar las continuas e históricas limitaciones que tanto el Estado como el mercado han enfrentado en términos de asegurar las disponibilidades y garantías para la realización de derechos, se dilucida que la sociedad deviene como actor cuyo papel está estrechamente vinculado con tareas tendientes a construir regulaciones que posibiliten la profundización y ampliación de escenarios de inclusión social que se convierten en premisas insoslayables de la democracia. De esta forma Estado, sociedad y mercado tienen un grado de corresponsabilidad de compartir frente al tema-problema de la construcción de apuestas participativas vinculantes e incidentes en procesos de toma de decisión, en el marco del objetivo de contribuir al mejoramiento de condiciones de calidad de vida de los colectivos de población, su punto de convergencia toma cuerpo justamente en este fin.

En esta perspectiva, la sociedad asume el encargo de ejercer una función público-social, en términos de promoción y estructuración de escenarios que posibiliten la incidencia, el seguimiento, la vinculación, regulación y control social a las políticas públicas tomando en cuenta que se convierten en alternativas de respuesta a situaciones socialmente problemáticas con diversos márgenes de afectación en los grupos poblacionales y en su calidad de vida "el reconocimiento de una esfera pública no estatal, concomitante con las restricciones estatales de los últimos tiempos, señala un importante escenario para los procesos de democratización consustancial con movimientos sociales y formas variadas de participación social (Cunill, 1997: 20)"

La referencia a la corresponsabilidad frente al fortalecimiento de instancias de vinculación de ciudadanos a partir de la participación en los asuntos públicos y por esta vía en la gestión pública, remite al cumplimiento de un rol fundamental en la cualificación del quehacer político e institucional logrando así instalar capacidades (técnicas, operativas y sociales-ciudadanas) como funcionamientos valiosos para la regulación, seguimiento y evaluación de las políticas públicas.

Capacidades sociales cuyo eje articulador es la participación política y social que deviene como ámbito fundante y promotor de la inclusión social, en contextos de recuperación del interés general y lo común, potenciales de lo público. El fortalecimiento de lo público desde lo público, constituye entonces una apuesta por el capital social cualificado como saldo de experiencias organizativas y participativas que inciden en el aumento del nivel de confianza social entre las instituciones y las organizaciones sociales, lo cual repercute en el reconocimiento y visibilización de la importancia de los esfuerzos conjuntos y el trabajo articulado en materia de política pública, que derivaría en dos dimensiones constitutivas:

- Un saldo pedagógico de acumulación de capital social, a partir de los procesos de capacitación y fortalecimiento de capacidades ciudadanas para el control social a la gestión pública, desde la recuperación y re significación de lo público no estatal. 
- La participación social cualificada de los actores sociales, que incide en las capacidades de incidencia en los asuntos públicos y las políticas públicas, en el ámbito público social del Estado. En dicho sentido, tanto la acción colectiva, entendida como actuación conjunta, para obtener los bienes públicos que constituyen las disponibilidades necesarias para el (los) funcionamiento(s); como la confianza social entendida ésta como posibilidad de ampliación de las oportunidades de las políticas públicas, se convierten en ejes transversales de la discusión aquí planteada. De forma tal que se requiere aludir a su mención en el marco de la construcción de capacidades.

\subsection{Línea Base informativa de partida}

El contar con datos de caracterización de la población que pertenece a las organizaciones sociales vinculadas a la experiencia de fortalecimiento de capacidades ciudadanas para el control social constituye una tarea indispensable por cuanto interesa identificar las especificidades poblacionales de quienes participan; en este sentido se hace necesario avizorar algunos datos al respecto. Fueron un total de 300 organizaciones convocadas y capacitadas en la línea de partida. Su composición por edad, sexo y grupo etario es la siguiente:

\section{Consolidado Distrital por rango de edad}

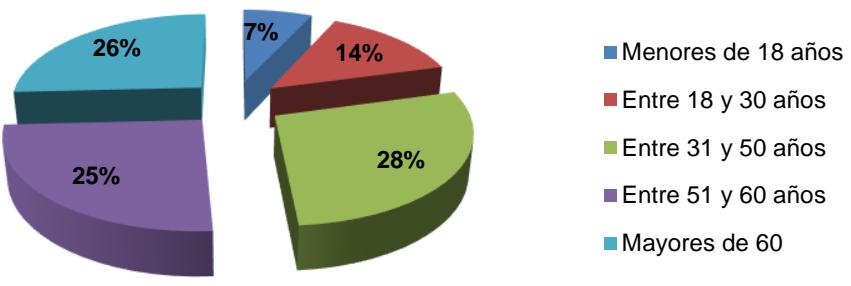

Fuente: Programa PRIAC, línea base de partida. 2013

Figura 55. Consolidado distrital por rango de edad.

Menores de 18 años (7\%), de 18 a 30 años (14\%); 31 a $50(28 \%) 51$ a 60 (25\%) y mayores de 60 (26\%) respondiendo a las características de descripción de los observatorios donde la población de adultos y adultos mayores tiene más presencia en términos de vinculación al proyecto, respecto a los adultos dicho nivel de participación estaría vinculado con tradiciones históricas de participación de sus familiares, abuelos y padres en experiencias organizativas hace algunas décadas. En el caso de los adultos mayores quizás por las dinámicas de "tiempo libre" que les acompaña.

El dato de población menor de 18 años es importante dado el análisis sobre los nuevos escenarios que cooptan los jóvenes en sus localidades y las oportunidades que esto les 
abre a la vida cívica, colectiva y comunitaria con miras a la construcción de lazo y vínculo con la sociedad.

\subsubsection{Composición por Géneros}

En directa relación con el incremento paulatino en el escenario público de las mujeres, el importante dato de un $62 \%$ de mujeres activas en el marco de los Observatorios como representantes de sus organizaciones, señala una interesante presencia y agencia de las mujeres en el ámbito de la vida colectiva y en escenarios donde históricamente habían sido excluidas.

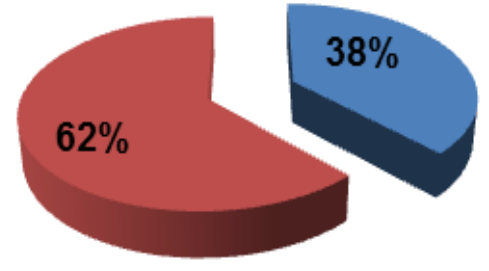

-HOMBRES MMUJERES

Fuente: Programa PRIAC, línea base de partida. 2013

Figura 56. Participación de mujeres y hombres. Total miembros organizaciones.

Desde el año 2005, cuando se sitúa la primera experiencia de la Escuela de Control Social de la Veeduría Distrital, se hace referencia al fenómeno de duplicación cifras por localidad, leyéndose:: "se observa el nivel de participación que está adquiriendo la mujer en el ámbito distrital; en la localidad de Bosa se determina que es casi el doble de participación en relación con la masculina, lo que permite inferir que el tipo de relaciones, condiciones de contexto, aspectos socioculturales y económicos influyen de manera importante en los niveles de participación de los individuos" (Medina, 2007. P. $36) "$

El análisis territorial comparativo muestra como Antonio Nariño (70\%), Barrios Unidos (67\%), Fontibón (63\%) son localidades con presencia fuerte de mujeres, no siendo estas localidades donde se concentren índices de exclusión social tan altos como los existentes en otras localidades entre ellas Bosa. El dato comparativo con el 2005 permite referenciar la ampliación de la presencia de la mujer en otros contextos no solamente ligados al de la supervivencia sino también al desarrollo de las capacidades de agencia sobre lo público que afectan la vida colectiva de la ciudad y sus habitantes.

La mayoría de las mujeres encuestadas consideran sus organizaciones como escenarios donde hay igualdades logradas en términos de reconocimiento, voz y voto, capacidad directiva, organizativa y de coordinación, entre otras. Sin embargo, el $78.3 \%$ de las mismas consideran que sus niveles de incidencia son aun restrictivos a escenarios 
específicos, muy micro dentro de la vida colectiva de la ciudad y por lo tanto de menos incidencia en el escenario de lo público y político ampliado.

Esto nos lleva a pensar con optimismo, pero no aun con triunfalismos frente a lo señalado en el 2005 como "preponderancia de la mujer en escenarios de igualdad política" toda vez que el incremento de la presencia de mujeres en los escenarios de seguimiento y evaluación de la Política Publica aún mantiene distancia frente a estas afirmaciones (2007, pg3), entendiendo que no sólo la opinión, la presencia y la deliberación garantizan una transformación de escenarios aún restringidos de participación que conducen a realizaciones restringidas de derechos.

Han de mirarse, monitorearse e investigarse las dinámicas de estos procesos y la incidencia de la presencia de las mujeres en la transformación orgánica de los mismos, referenciado las dinámicas de inclusión, reconocimiento y realización de derechos derivadas de estas acciones y a partir de los enfoques diferenciales que incluyen las identidades y los géneros.

Las localidades donde se identificó la más baja participación de mujeres fueron Usaquén y Candelaria. Dos localidades con difíciles procesos de organización de los observatorios. El caso de Candelaria es representativo de localidades con volúmenes importantes de población intermitente, en tanto este fenómeno incide en el arraigo territorial que construye pertenencia y permanencia para el trabajo colectivo. Usaquén al parecer por una baja gestión tanto del NUAGT durante el primer semestre del 2013, como la ausencia de soporte en este mismo periodo de la Veeduría Distrital, que con trabajo anterior en la localidad no logra dar soporte al proceso de la Universidad, la cual logra adelantar un trabajo con 4.? Organizaciones durante todo el proceso de sensibilización y capacitación.

Antonio Nariño Barrios Unidos, Chapinero y Fontibón son las localidades con mayor presencia de mujeres, reportando adicionalmente unos procesos de organización y trabajo sobre el IWA más cualificado: Organización rápida de los cuadrantes, apropiación, análisis y ajuste de la herramienta (ISO/IWA4), desarrollo de mesas de pactos, desarrollo mesas de verificación y preparación para los diálogos públicos Lo cual conduce a relacionar estas dos variables analíticas como vinculantes de un mejor proceso de análisis, adecuación e implementación del ISO/IWA4.

Como una Base social de soporte, las 300 organizaciones se identificaron como vinculadas a diferentes sectores de la política pública a nivel local: Salud, educación, medio ambiente, movilidad urbana, infancia, desarrollo, discapacidad fueron los principales escenarios de respuesta, concentrándose en Integración (15\%) y Salud (15\%) el mayor porcentaje. 


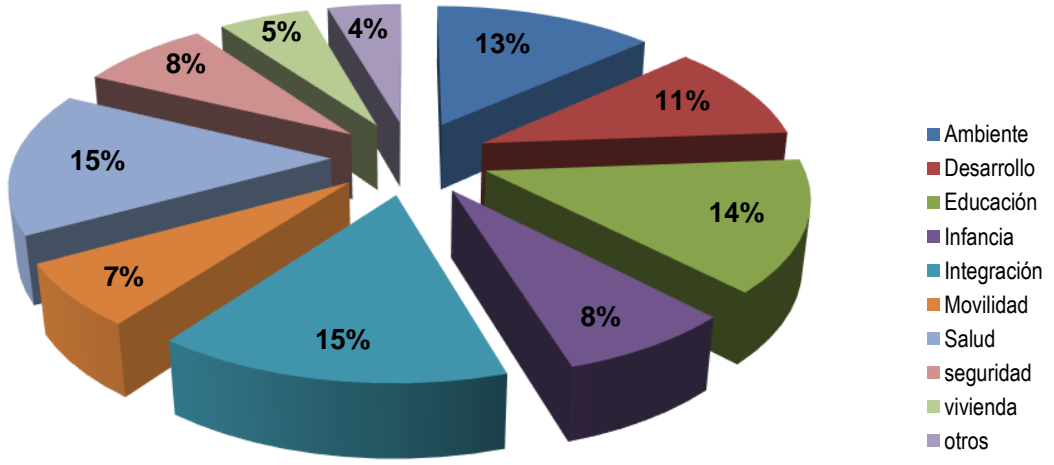

Fuente: Programa PRIAC, línea base de partida. 2013

Figura 57. Sectores de trabajo organizaciones sociales. Consolidado Distrital

Le siguen en su orden educación (14\%.) medio ambiente (13\%) y desarrollo económico (11\%), estos dos últimos considerados como importantes y novedosos en términos de las áreas tradicionales de trabajo de las organizaciones comunitarias de base. Medio ambiente por su importancia en los temas de sostenibilidad y sustentabilidad de recursos y condiciones de calidad de vida para las poblaciones presentes y futuras, y desarrollo económico por la posibilidad de injerencia de la ciudadanía en temas de anterior y exclusivo resorte estatal. No menos importantes a pesar de concentrar un menor porcentaje de trabajo de las organizaciones se hallan los sectores de vivienda (5\%), seguridad (8\%) y movilidad (7\%), como escenarios fundamentales e importantes de injerencia de la acción ciudadana a nivel local.

\subsubsection{Experiencia previa de las organizaciones sociales en proyectos de Control Social}

La pregunta por la participación en proyectos de control social reporta una interesante experiencia de las organizaciones en procesos de seguimiento a políticas, programas y proyectos, pero no así el conocimiento de herramientas específicas de evaluación, monitoreo y control en el tiempo parecidas o relacionadas con la herramienta ISO/IWA4. 


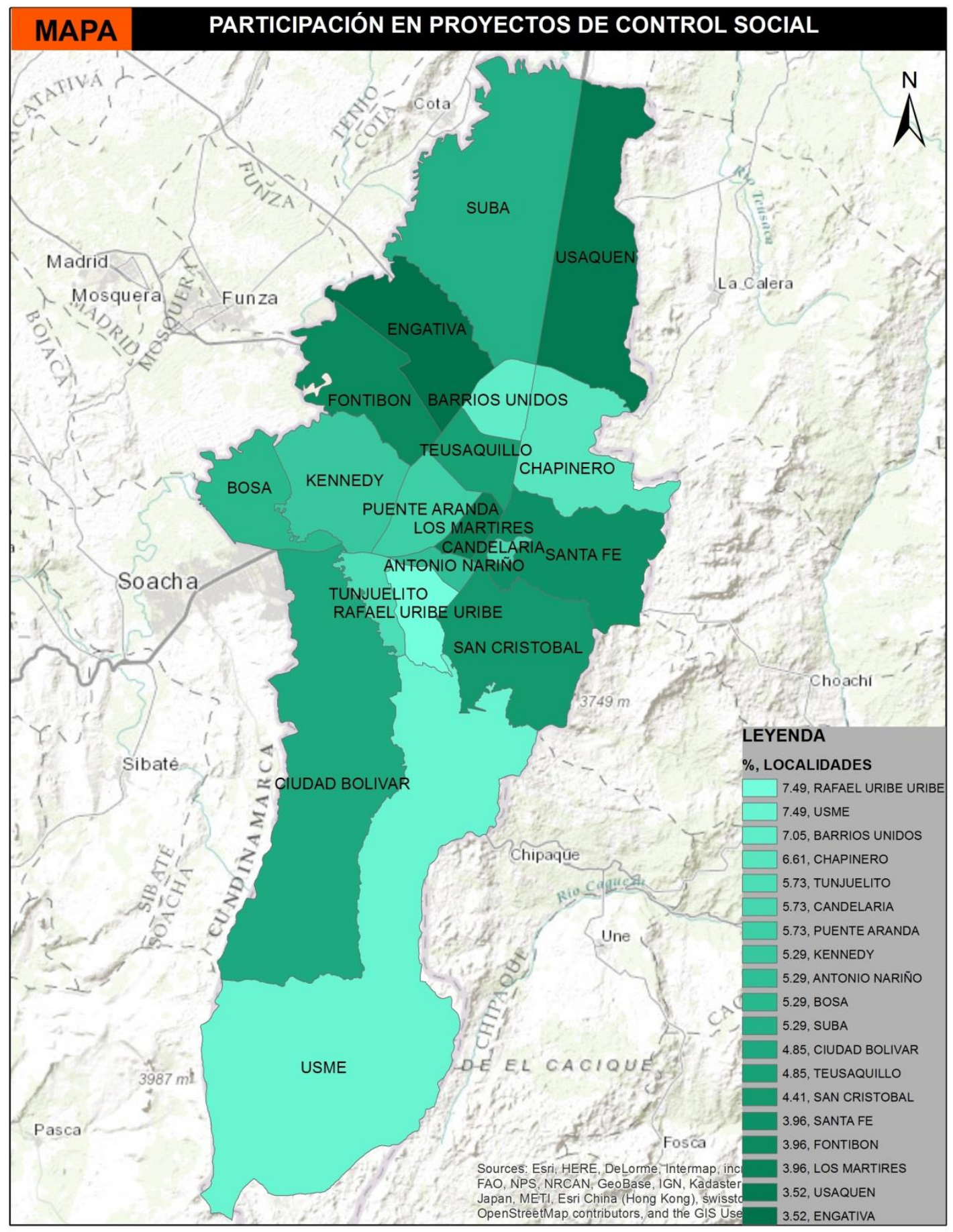

Fuente: Huaynoca Raúl. A partir de datos Programa PRIAC, línea base de partida. 2013

Mapa 5. Participación en proyectos de control social

En cuanto a la experiencia participativa en proceso de control social, entendida como experiencias diversas de seguimiento a los procesos de las Políticas públicas, se encuentra que son Las localidades de Rafael Uribe (7.49\%) y Usme (7.49 \%) en donde aparecen organizaciones con una mayor experiencia en el tema. Barrios Unidos Chapinero Suba, Bosa, Kennedy y Antonio Nariño, también referencian aprendizajes y 
experiencias importantes. Estas se constituyen en legados y acumulados de experiencia y conocimiento ciudadano contributivo a la cualificación de capacidades colectivas en el tema y referentes de partida para los procesos educativos $\mathrm{y}$ formativos que permitieron que algunas de estas localidades adelantaran de una manera muy organizada, reflexiva e interesante en términos de logros el proceso general del ISO/IWA4.

Con un interesante comienzo en este proceso, Usme sin embargo se retirara por la presión directa ejercida sobre este colectivo de personas no interesadas en fortalecer procesos organizativos comunitarios en la localidad y amenazas directas contra el resto de personas del observatorio.

Sumapaz, con una disciplina social de sus habitantes históricamente reconocida, no reporta información importante pues su presencia fue muy restringida dadas las dificultades geográficas que dificultaron el traslado y la llegada de las organizaciones convocadas. Este proceso tendrá otro desarrollo y acompañamiento agenciado desde la Universidad, por las características geográficas y políticas de la localidad.

La pregunta por experiencias puntuales de formación metodológica y participación en procesos de evaluación de políticas públicas, (Con metodologías incluidas) los niveles de participación cambian. Solo el 10\% referencia alguna participación en el tema. Siendo la localidad de Barrios Unidos donde se reporta mayor experiencias en el tema.

EL gráfico que ilustra el tema a continuación está organizado sobre ese $10 \%$ del conjunto de organizaciones que reportaron formación concreta y praxis en el tema. No hay que olvidar Barrios Unidos fue la primera localidad en lograr desarrollar todo el proceso del ISO/WA4 con un espíritu crítico y propositivo muy importante.

\subsubsection{Entidades de apoyo a los procesos de participación de las organizaciones}

Carácter de las entidades que apoyan el trabajo de organizaciones. Consolidado distrital

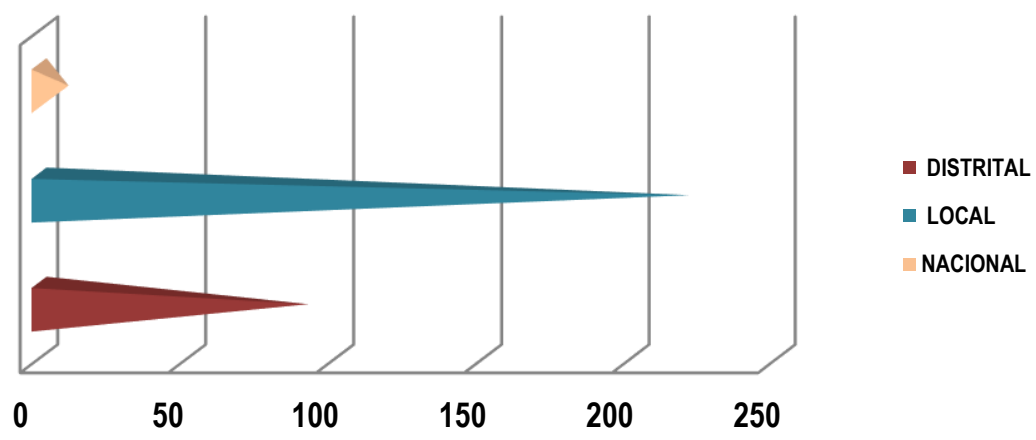

Fuente: Programa PRIAC, línea base de partida. 2013

Figura 58. Entidades que apoyan el trabajo de las organizaciones. Consolidado Distrital 
Frente a los procesos organizativos y los apoyos de soporte al trabajo colectivo la línea base precisa un importante apoyo proveniente de entidades y programas de carácter público de tipo local (68\%). Alcaldías locales, secretarias de gobierno local, consejos locales son entre otros los escenarios institucionales de carácter público que han venido abriendo sus puertas a la presencia de los ciudadanos y ciudadanas, a la vez que son referenciado como importantes escenarios de soporte para los mismos. Recursos, espacios locativos, encargos, cooperaciones, son entre otros aspectos, considerados como de vital importancia para la existencia y consolidación misma de la organización en sus tareas misionales. Entidades de soporte de carácter Distrital y público son referenciadas en un (28\%) señalando una importante relación de la administración central con las organizaciones de base en las localidades.

\subsubsection{Escenarios de desempeño de las Organizaciones}

Los escenarios de trabajo y desempeño refieren los espacios territoriales donde concentran sus actividades las organizaciones. Distrital, local, barrial, son descriptores territoriales de referencia del trabajo de las mismas. A esta información se pudo asociar la entregada por los y las entrevistados, quienes articularon inmediatamente el carácter de este trabajo con el referente vinculo Institucional (Derivado del trato con y para las instituciones) o el social, relacionado con un trabajo autónomo hecho para y con la sociedad, sin soporte institucional.

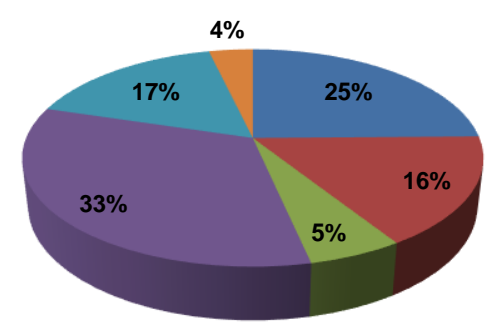

BARRIAL

- DISTRITAL

- INSTITUCIONAL

- LOCAL

- SOCIAL

- OTROS

Fuente: Programa PRIAC, línea base de partida. 2013

Figura 59. Escenarios de trabajo privilegiados por las organizaciones. Consolidado Distrital.

Tomando en cuenta los descriptores en mención se evidencia que los espacios territoriales que concentran la acción de las organizaciones sociales se distribuyen así: los escenarios locales con un (33\%) y barriales con un $(25 \%)$, son los escenarios de referencia fundamental para el trabajo de las Organizaciones convocadas, identificados como entornos más cercanos a los sujetos, que concentran el accionar de las mismas. Un referente de "lugar" referido a "lo nuestro" "lo propio"; la referencia constante a la acción entre organizaciones sociales y el nivel local, se explicaría a partir del concepto y contenido simbólico del lugar, definido de dos formas, por un lado, es el escenario de la actividad - acción - inmediata del sujeto, -; y, por otro, es el referente de identidades 
significativas. De esa manera, el lugar evidenciaría la relación con el espacio de la vivencia y de convivencia, vislumbrando como punto de referencia lo cotidiano aspecto preponderante para la comprensión de la dinámica de la sociedad. Al ser el escenario local el contexto en el que se despliega la acción de las organizaciones sociales, al representar el lugar de acción inmediata de los sujetos; dicho espacio es a su vez el de articulación inmediata de acciones entre las instituciones que allí se encuentran y los contextos de trabajo de las organizaciones.

\subsubsection{Carácter de las entidades que apoyan el trabajo}

Con respecto a la información de soporte institucional, son las Alcaldías locales, los consejos locales, las "secretarias", entre otros los referentes de "entidad" señalados como principales soportes a nivel local, de apoyo al trabajo. Entidades de carácter público, de gobierno y administración son las que privilegian el panorama frente a las de carácter privado.

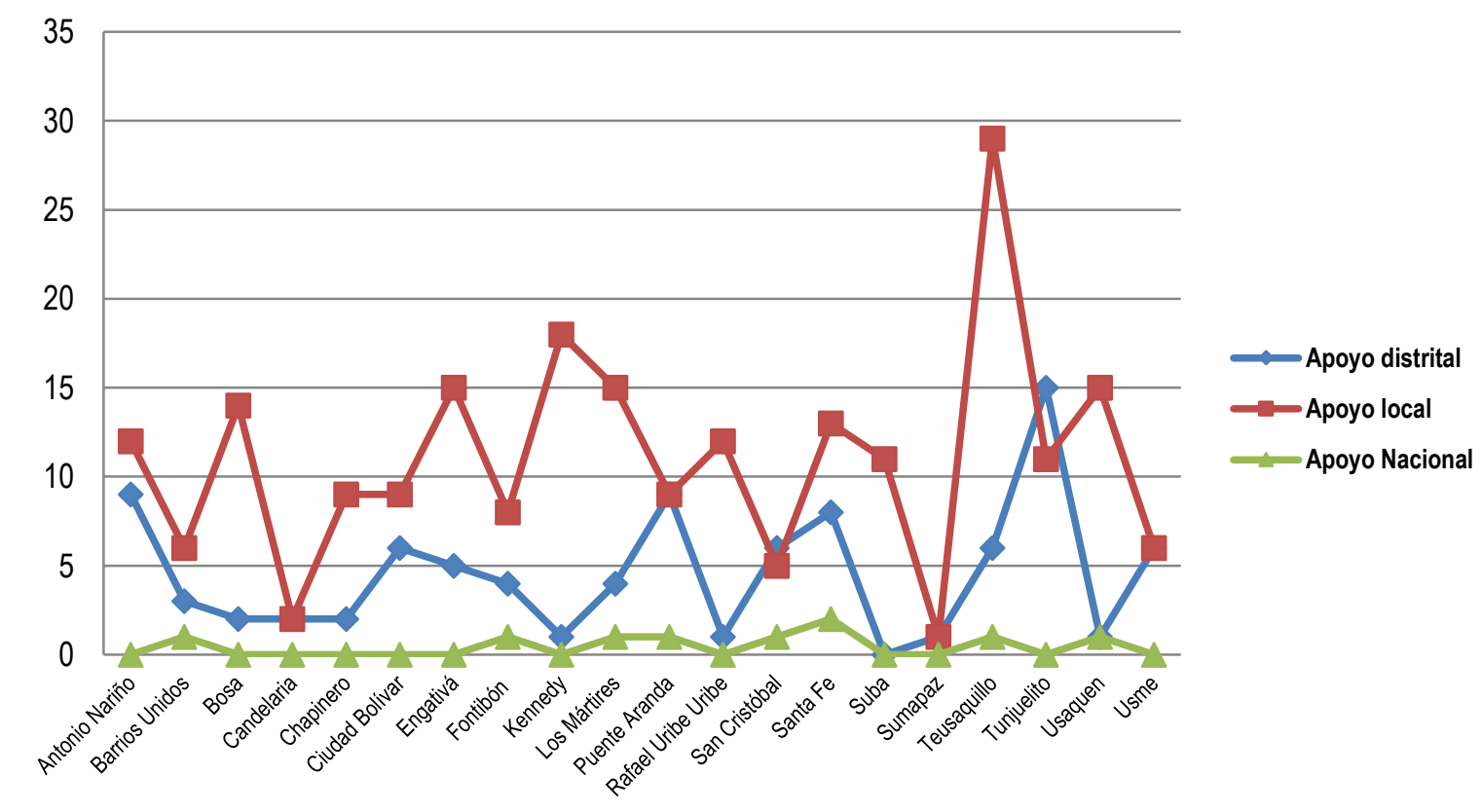

Fuente: Programa PRIAC, línea base de partida. 2013

Figura 60. Carácter de las entidades que apoyan el trabajo de las organizaciones sociales. Niveles local, distrital y nacional

Teusaquillo es la localidad en donde el $80 \%$ de los y las líderes entrevistados afirman que reciben apoyo económico, técnico, y operativo de entidades locales tales como la Alcaldía Local y los Consejos Locales. Kennedy también desarrolla articulaciones importantes con entidades del orden local de carácter público. Tunjuelito (26\%) es la localidad que expresa recibir mayor apoyo del ente distrital. Un trabajo conjunto entre entidades $y$ organizaciones sociales que ha permitido un proceso paulatino de 
consolidación de las organizaciones en tanto las mismas referencian este vínculo como importante para su desarrollo y su consolidación como colectivo.

94\% de los actores afirma que son las instituciones locales y de carácter público las que juegan un rol importante de soporte a sus actividades en los escenarios de la política pública. Las localidades en las que se evidencia un bajo apoyo de entidades de carácter público y/o privado son: Usme (12\%) y Antonio Nariño (15\%)

\subsubsection{Alianzas entre organizaciones}

Identificados como Capital Social los mecanismos de la organización social tales como las redes, normas, y la confianza social que facilita la coordinación y cooperación para beneficios mutuos" (Putnam 95), la pregunta por la capacidad asociativa y de alianza entre organizaciones, busco indagar por los desarrollos en confianza social, conciencia cívica y colectiva como referentes de su capacidad de incidencia y agencia sobre la cosa pública. Esto incluye la confianza, las normas y las redes que establecen relaciones de reciprocidad activadas por una confianza social que emerge de dos fuentes, las normas de reciprocidad y las "redes de compromiso ciudadano"

La respuesta a esta pregunta es muy interesante en tanto el $56 \%$ de los entrevistados contesta afirmativamente su pertenencia a redes de trabajo y alianzas con otras organizaciones. Se señala adicionalmente una alta disposición al trabajo colectivo, dada la confianza entre las organizaciones y el desarrollo de una conciencia cívica de los logros ciudadanos ganados con esto.

Con un trabajo asociativo y en realidad un trabajo de Red, el 56\% de las organizaciones responde afirmativamente al desarrollo de experiencias de trabajo colectivo y cooperativo con otras organizaciones del orden local o distrital. Estos gérmenes de acciones colectivas organizados, son la clave de los esfuerzos futuros del convenio en función de seguir fortaleciendo el trabajo asociativo y la confianza social entre organizaciones, planteándose retos más allá del capital social, para incursionar en el fortalecimiento del ámbito público y colectivo para la ciudad.

En el comparativo por localidades, Antonio Nariño con un 69\% aparece como la localidad que ha establecido en mayor medida alianzas con otras organizaciones para el desarrollo de su trabajo. De igual manera la localidad de Bosa también aparece como representativa en este aspecto, a pesar de que hubo baja participación de organizaciones sociales de esta localidad en el proceso de evaluación de políticas públicas a través del ISO/IWA 4, se evidencia que la mayor parte de las personas asistentes de esta localidad afirman que este escenario territorial cuenta con una trayectoria importante en cuanto a establecimiento de alianzas; ello incrementa entonces el porcentaje en mención en comparación con otras localidades.

En segunda instancia encontramos que localidades como Tunjuelito y Barrios Unidos con el $66 \%$ y $63 \%$ respectivamente, son localidades en las que también se identifica una 
marcada tendencia al establecimiento de redes y alianzas con otros escenarios organizativos.

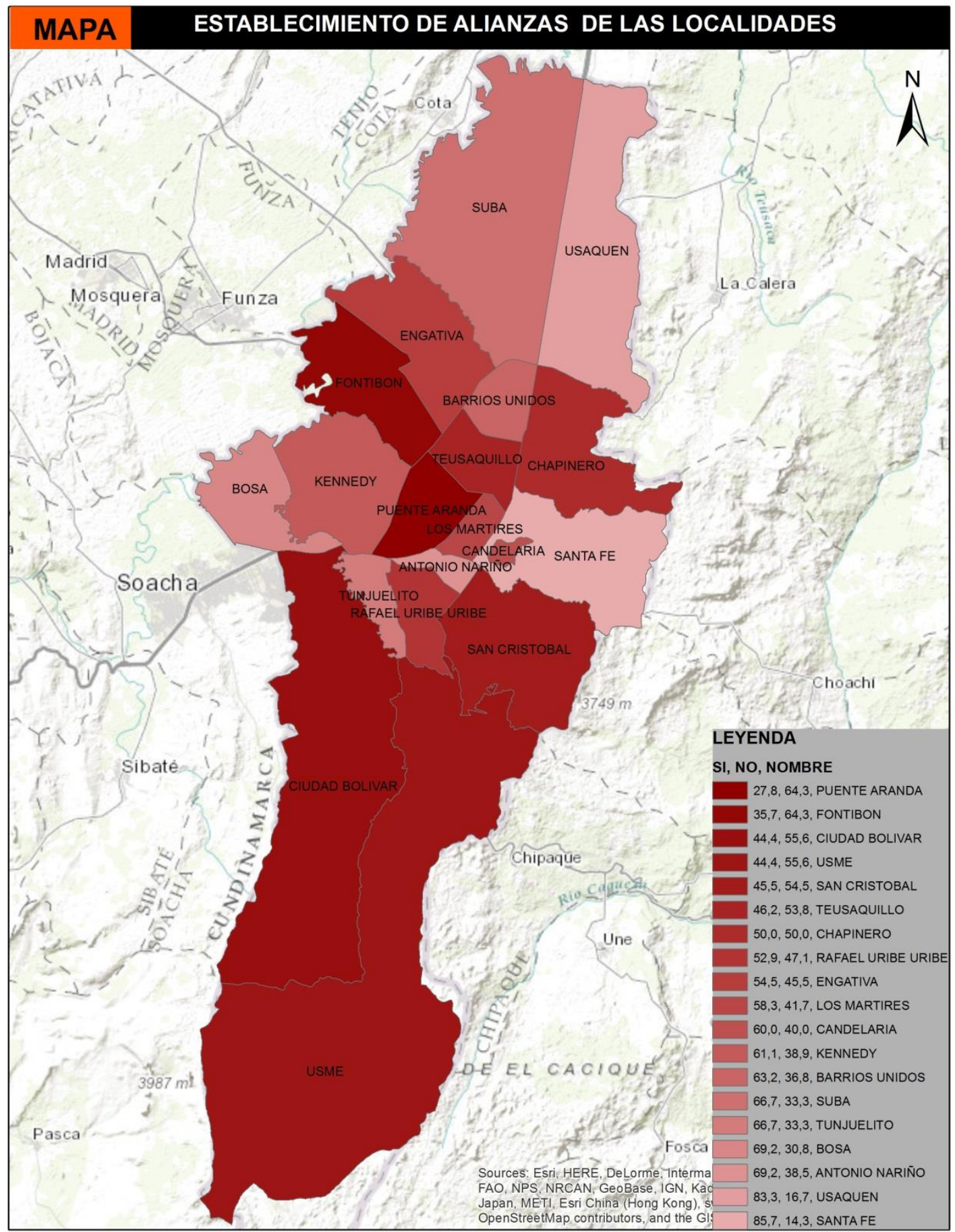

FUENTE: Huaynoca Raúl, a partir de Programa PRIAC, línea base de partida. 2013

Mapa 6. Establecimiento de alianzas de las localidades

Con menor porcentaje de establecimiento de alianzas y/o redes de trabajo, pero no sin la experiencia en ello, aparecen localidades como las de Puente Aranda, Fontibón, San Cristóbal y Usme. Espacios territoriales que se caracterizarían por el trabajo 
organizativo y comunitario completamente autónomo por parte de las organizaciones sociales presentes allí y por ende también por el bajo nivel de establecimiento de alianzas o redes estratégicas y la posible especialización de cada organización en cuanto a trabajo en sectores de política determinados.

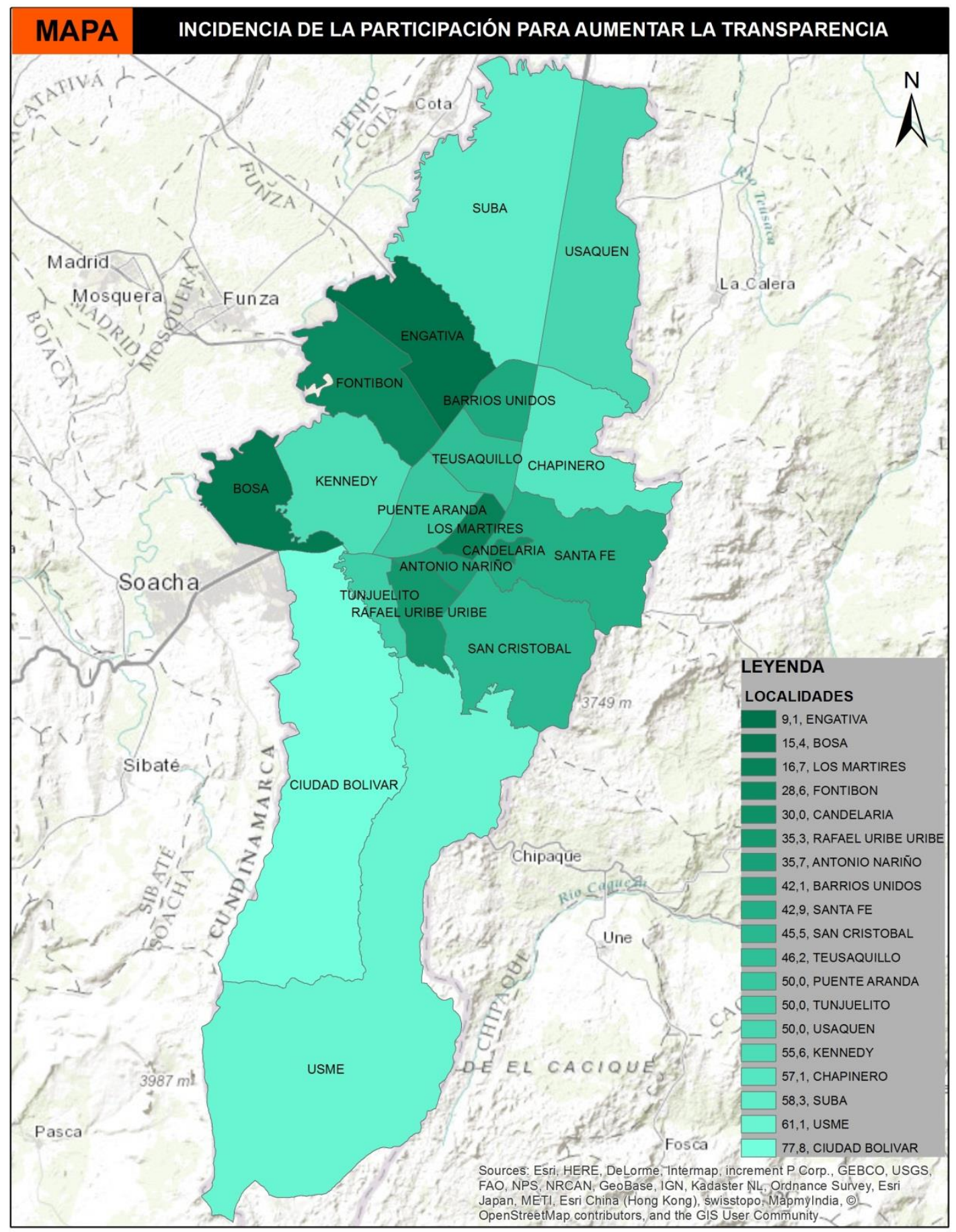

FUENTE: Huaynoca Raúl, a partir de Programa PRIAC, línea base de partida. 2013

Mapa 7. Incidencia de la participación para aumentar la transferencia 
En cuanto a temas vinculados con la percepción ciudadana de sí tiene influencia para aumentar la transparencia de su localidad se observa que en territorios como Engativa, Fontibón y Bosa las personas mencionan que no consideran que su participación logre incidir en el aumento de las lógicas de transparencia en la gestión pública local. De forma similar, se registran valores significativos en Los Mártires, Candelaria, y Rafael Uribe Uribe. En las demás localidades sorprendentemente se evidencia que la población considera que su participación sí podría llegar a influir en el fortalecimiento de lógicas vinculadas con el manejo transparente en la gestión pública de sus respectivas alcaldías locales y por ende en la gestión pública de estos territorios, como se observa en el mapa anterior.

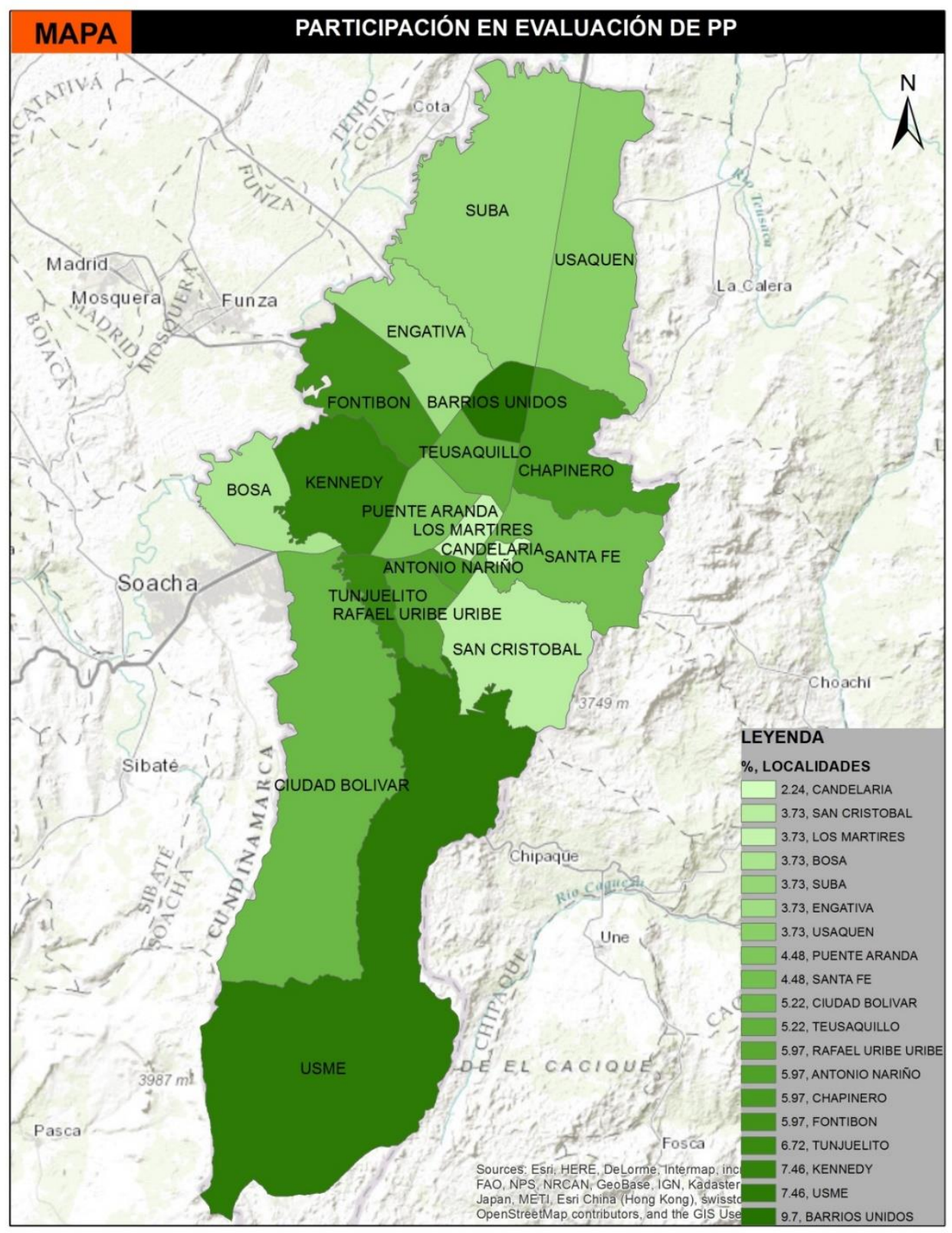

FUENTE: Huaynoca Raúl, a partir de Programa PRIAC, línea base de partida. 2013

Mapa 8. Participación en evaluación de PP 
Frente a la pregunta por la participación en procesos de evaluación de políticas públicas, que se realizó en el marco de la aplicación de la encuesta ECOS 01, se observa que las localidades en las que se registra una mayor vinculación de la población a este tipo de procesos son: Barrios Unidos, Usme, Kennedy, Tunjuelito y Fontibón. Este aspecto llama la atención tomando en cuenta que también son varias de dichas localidades en las que se logra consolidar como experiencia exitosa los Observatorios Ciudadanos, realmente resultan ser territorios en donde existe una amplia experiencia organizativa y de trabajo colectivo. Paradójicamente se evidencia que en las localidades en donde más se participa en la dinámica de evaluación a la gestión pública, no son siempre las mismas que consideran que su participación tenga incidencia en el tema de evaluación. Como se muestra en el mapa que sigue los territorios que consideran que su vinculación a dichos procesos realmente es escuchado y tiene impacto en las dinámicas valorativas son: Rafael Uribe Uribe, Chapinero, Barrios Unidos, Ciudad Bolívar y Suba. De dichos territorios sólo Barrios Unidos reportó un alto índice de participación en evaluación, el resto a pesar de identificar una baja vinculación, consideran que sí logran algún tipo de incidencia en los procesos locales.

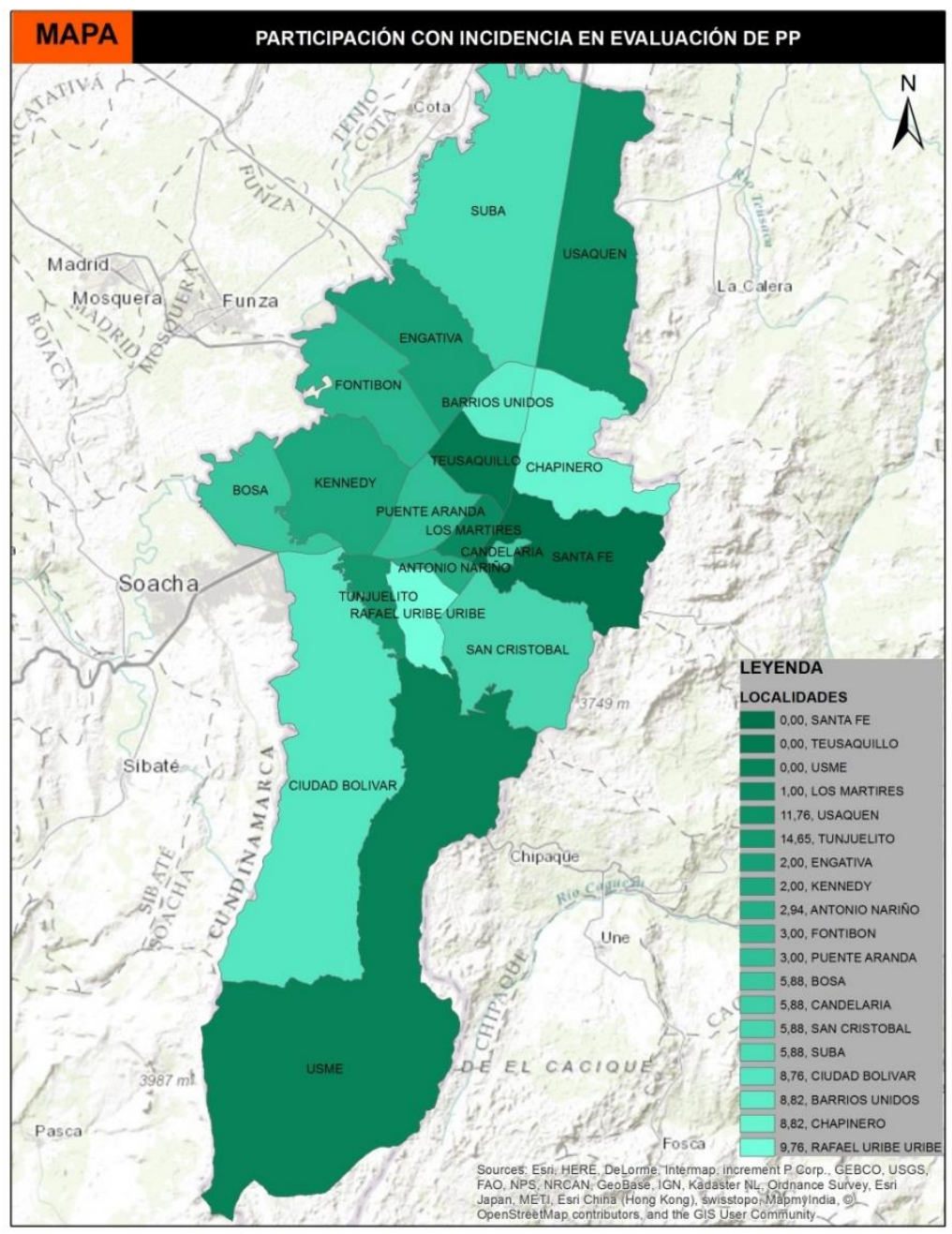

FUENTE: Huaynoca Raúl, a partir de Programa PRIAC, línea base de partida. 2013

Mapa 9. Participación con incidencia en evaluación de PP 


\subsection{Evaluación del proceso ${ }^{25}$}

Las preguntas vinculadas con los temas de evaluación e identificación de aprendizajes del proceso llevado a cabo a través de la construcción y fortalecimiento de capacidades ciudadanas para el control social en Bogotá, indiscutiblemente están ligadas con las discusiones sobre construcción de ciudad y ciudadanía, cuyo norte se halla anclado en la potenciación de la base social en los territorios. Proceso que a su vez implica la disposición de escenarios de ampliación y desarrollo de las capacidades ciudadanas para el control, un contexto que permitiese vincular a la pluralidad de actores del territorio, con miras a establecer lógicas de interacción y lenguajes comunes en torno a la lectura y evaluación de la gestión pública en lo local. Dichos escenarios para efectos de esta experiencia fueron viabilizados a través de los Observatorios Ciudadanos de Probidad, Transparencia y Anticorrupción (OC).

En este sentido, de manera particular este apartado del documento, busca dar a conocer la evaluación y aprendizajes que subyacen al proceso territorial que se desplegó en el Distrito Capital cuyo pre-texto metodológico fue la ISO/IWA 4, pero que de fondo resguardo la intención política de fortalecer lo público para la ciudadanía en el marco de apuestas a favor de la participación.

Así, como parte de las dinámicas de evaluación y devolución de resultados a la comunidad, se construyó una ruta metodológica que guio el componente evaluativo de la experiencia, la cual será sintetizada a continuación:

\subsubsection{Componente Evaluativo Cualitativo de la Metodología IWA/ISO-4 y su implementación}

Con el propósito de identificar y valorar los significados que los participantes de los Observatorios Ciudadanos y delegados de las Alcaldías Locales, otorgaron a la experiencia de la metodología IWA/ISO-4 en el territorio, se procedió a la realización de entrevistas semiestructuradas orientadas al desarrollo de los siguientes aspectos: i) percepciones generales de la Metodología IWA/ISO-4, ii) debilidades que ellos y ellas encuentran en esta herramienta, iii) fortalezas que resaltan. El siguiente diagrama da cuenta de esta dinámica.

\footnotetext{
${ }^{25}$ Dichos insumos referentes a los apartados anteriores, así como a la parte de evaluación del proceso y subsiguientes de la experiencia en Bogotá, se retoman de: Niño Bertha J. La experiencia de fortalecimiento del control social en la gestión pública del Distrito Capital, Taller y Libros Editorial, 2014. Bogotá. Publicación en la que participó activamente la autora de la presente tesis doctoral, ya que fue la investigadora principal de dicho proyecto.
} 


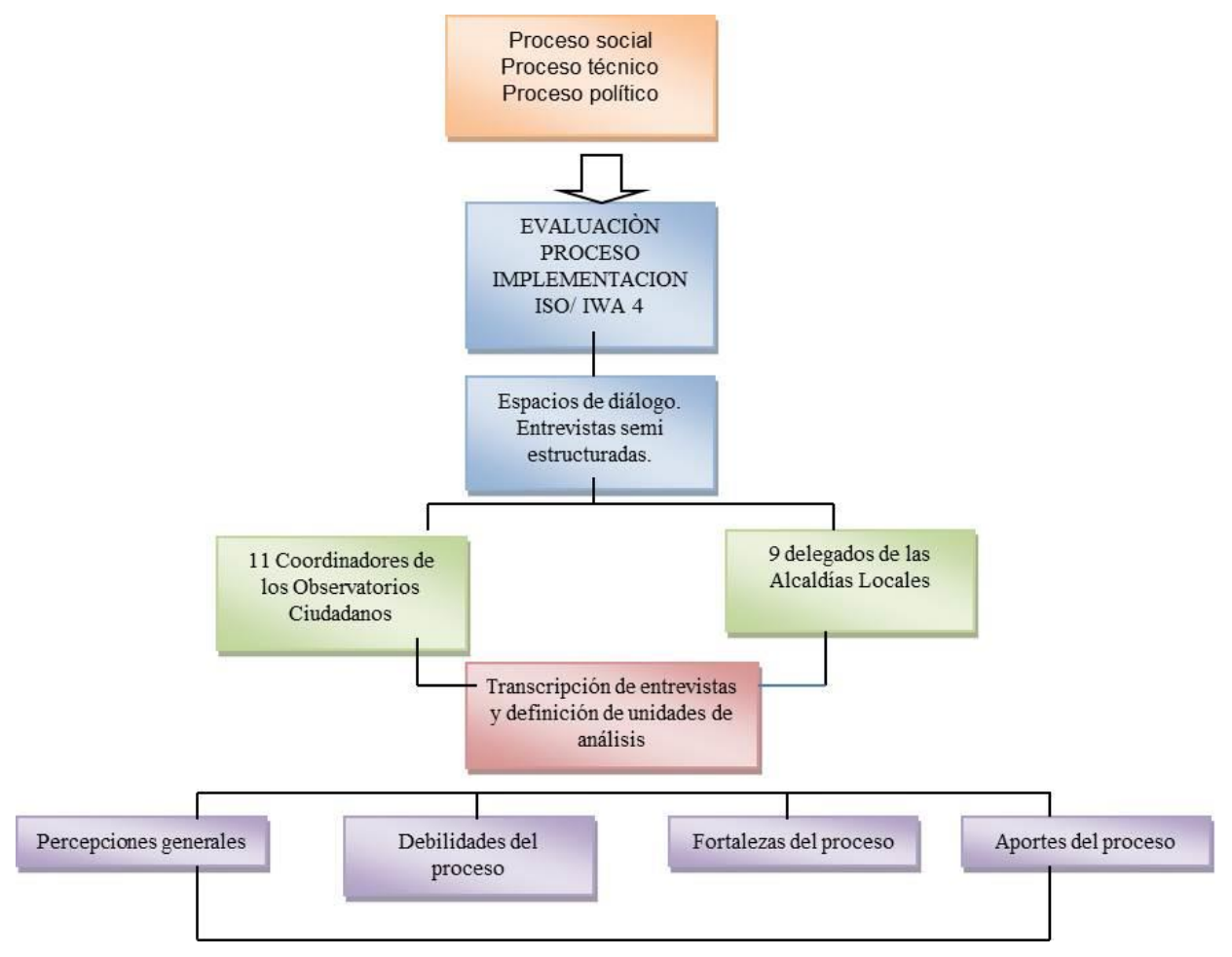

Fuente: Umbarila Patricia, Hernández Adriana. PROGRAMA PRIAC, 2014

Figura 61. Evaluación del proceso.

\subsubsection{Percepciones generales de la Metodología IWA/ISO-4}

Los/as entrevistados/as reconocieron la pertinencia de la Metodología IWA/ISO-4 en la evaluación de la gestión pública local; dicha pertinencia se da fundamentalmente en dos sentidos:

Como herramienta que técnicamente cuantifica y monitorea la ejecución del gasto y la implementación de las políticas públicas en el territorio, dado que su estructura por cuadrantes con sus respectivos indicadores y subindicadores permite seguir y evaluar las decisiones de lo público en el territorio y como herramienta que políticamente: a) promueve la construcción de acuerdos, b) favorece el desarrollo de nuevas actitudes y prácticas frente a la concepción del control social y c) proyecta nuevos retos locales con compromisos ciudadanos e institucionales.

En general para los y las entrevistadas, la participación de actores sociales representativos ha significado, la ampliación de capacidades de agencia sobre lo público, procesos de aprendizaje colectivo desde los Observatorios Ciudadanos para el control social, así como la resignificación de su ciudadanía activa. Pese a estas importantes bondades de la herramienta, para los coordinadores de los Observatorios Ciudadanos y delegados de Alcaldías Locales, la metodología IWA/ISO-4 debe adecuarse en su totalidad al contexto colombiano, dado que requiere para su efectivo desarrollo, de un reconocimiento de la estructura política y administrativa de las localidades, de la ciudad y de Colombia, porque la herramienta no tiene cómo modificar 
algunos ítems según la realidad de las localidades y utiliza terminología desconocida para el contexto colombiano.

\subsubsection{Percepción de Debilidades que los Actores Sociales y Delegados Institucionales identificaron en la implementación de la Metodología IWA/ISO-4}

En este registro, se identifican dificultades relacionadas con la falta de articulación existente entre las herramientas de planeación a nivel local como son el Plan de Desarrollo Distrital, los Planes de Desarrollo Local y la territorialización de las políticas públicas poblacionales y sectoriales distritales en las localidades.

Estas dificultades obedecen al desconocimiento, fraccionamiento y desarticulación entre las instituciones del nivel central y local, otra de las dificultades es la exclusión de políticas, programas y proyectos del nivel nacional, con incidencia local y que no pueden ser seguidas y evaluadas por la IWA/ISO-4, tal es el caso, entre otras, de instituciones como el Instituto Colombiano de Bienestar Familiar -ICBF, Servicio Nacional de Aprendizaje - SENA, que implementan políticas públicas nacionales determinantes en la protección de la niñez, o en el acceso a la educación de poblaciones vulnerables en las localidades.

Desde las debilidades de la ciudadanía y su participación en la implementación de la metodología, los entrevistados/as señalaron la falta de compromiso ciudadano para participar, en el sentido de que prevalece más una idea de participar como práctica utilitarista del "que me van a dar", que como un interés y preocupación por los asuntos locales, sus recursos y decisiones.

Otro factor que debilita la participación ciudadana en este proceso han sido los viejos problemas no resueltos y las rencillas entre algunos integrantes de los observatorios ciudadanos, lo que afecta la comunicación asertiva y sana al interior de los observatorios, elemento a tener en cuenta en los procesos de formación ciudadana a futuro. Los y las integrantes del Observatorio Ciudadano plantean el imperativo de la formación ciudadana, a fin de ampliar capacidades para el ejercicio de una ciudadanía activa, interesada por lo público con la creación de espacios para la deliberación y el diálogo.

Los entrevistados señalan que otra de las dificultades evidente en los diferentes momentos de la implementación de la Metodología IWA/ISO-4, tiene que ver con la débil capacidad técnica de algunos integrantes de los equipos institucionales no sólo para orientar y facilitar el desarrollo de las mesas de pactos y de verificación, sino para propiciar el sano debate, la deliberación pública desde el reconocimiento y el respeto. 


\subsubsection{Percepción de Fortalezas que los Actores Sociales y Delegados Institucionales identificaron en la implementación de la Metodología IWA/ISO-4}

Con el desarrollo de la Metodología IWA/ISO-4 se han logrado reconocer los diferentes objetivos misionales de las instituciones públicas presentes en las localidades que operan política pública en el territorio. Este reconocimiento evidencia y delimita los alcances y responsabilidades institucionales en desarrollo de programas y proyectos, muchas veces desconocidos por la misma institucionalidad y ciudadanía, ejerciendo control social sobre la veracidad de la información suministrada. La Metodología IWA/ISO-4 está dando pasos certeros hacia la articulación entre las instituciones, ejercicio necesario en las localidades dado que con frecuencia se tiene una mirada más intrainstitucional que interinstitucional.

Una de las sinergias que destacan los ciudadanos y ciudadanas es el trabajo conjunto entre la Veeduría y las Universidades en el acompañamiento y apoyo permanente a la ciudadanía para la implementación de la estrategia IWA/ISO-4. Se reconoce positivamente y se legitima el papel que juega la academia como impulsora de procesos sociales de fortalecimiento de la base social existente en las localidades de la ciudad. El que la institución establezca convenios y relaciones con las universidades muestra el interés por la articulación entre diferentes actores con miras a re-significar la relación Estado-Sociedad, desde el reconocimiento de la potencialidad del trabajo articulado.

La implementación de la Metodología IWA/ISO-4 ha permitido a algunos ciudadanos apropiación de lo público con miras a transformar el país desde las realidades de las propias localidades. En este sentido, se reconoce por parte de las autoridades locales y de la ciudadanía la cualificación de la participación en el control social de la gestión pública en las localidades.

\subsubsection{Aportes del proceso}

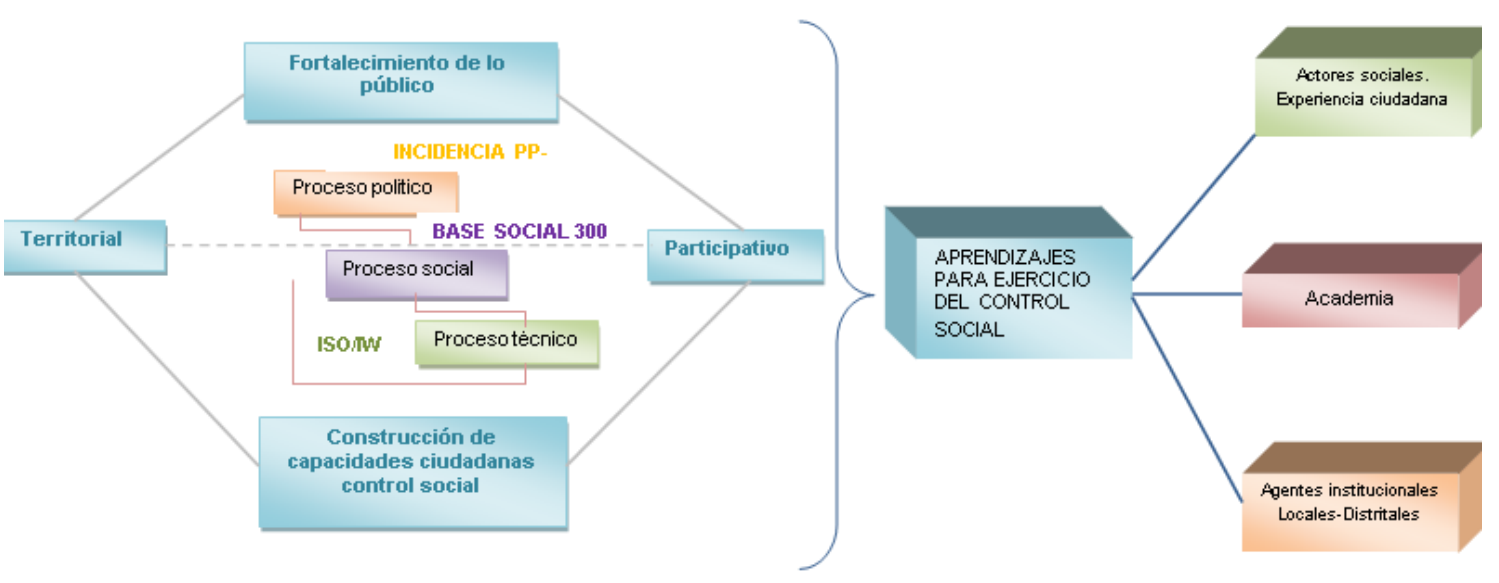

Fuente: Patricia Umbarila, Programa PRIAC. 2014

Figura 62. Aportes del proceso 
Así las cosas, es importante hacer énfasis especial en la trayectoria y día a día de las organizaciones sociales, ya que este espacio permitió extrapolar al mismo experiencias y actividades de estos colectivos orientadas a la materialización de una sociedad más igualitaria e inclusiva, con el propósito de generar experiencias de de-construcción paulatina del entramado de relaciones verticales y excluyentes, buscando fortalecer un tejido social emergente de capacidades y habilidades como ciudadanos para participar activamente en la gestión de lo público. Ello sin embargo no opera en el marco de prácticas institucionales activistas concentradas en el desarrollo de las etapas y aspectos del ISO/ IWA4, que no logran reconocer la importancia de incidir sobre las lógicas de reconocimiento de las singularidades, los saberes, los intereses locales, como instancias a inscribir en el trabajo colectivo de construcción de capacidades de agencia sobre lo público, no sobre la ISO/IWA 4 como estándar-.

Desde esta perspectiva, el proceso de implementación de la ISO/ IWA 4, llegó a Bogotá como una oportunidad para reflexionar sobre las finalidades y sentidos que subyacen a los procesos participativos de evaluación, seguimiento, control y veeduría a la gestión pública y a las políticas públicas de la ciudad. Posibilidad de fortalecimiento de lo público desde lo público, a saber desde la ciudadanía misma; a partir de la construcción de escenarios multipropósito de definición de un lenguaje común en términos de lectura de las dinámicas que agencian las instituciones en el ámbito local, en los registros social, ambiental, de desarrollo institucional y económico.

Constituyó una apuesta por la promoción y cualificación de la participación con el propósito de vincular a diversos grupos de la ciudadanía e incidir en la consolidación de capital social al interior de las instituciones de la administración pública cualificando los ejercicios de gestión que desde allí se realizan. En el marco de esta experiencia, y términos de la contribución de la misma a la realización de derechos de las poblaciones el ejercicio de implementación de la ISO/IWA4 y los procesos de conformación de los OC, se constituyeron en escenarios que aportan a los procesos de realización del derecho a la información, donde y cuando se logró el respaldo de las instituciones locales.

\subsection{Aspectos a considerar control social en Cochabamba}

Con el fin de establecer algunas pautas para comparar los dos casos de estudio de esta investigación, se aludirá a mencionar los mismos puntos de análisis que se tomaron en consideración en el caso Bogotá. De manera que se logre trazar una trayectoria analítica que logre evidenciar las perspectivas, debates y realidades del control social y la evaluación de políticas en los ámbitos locales en estudio.

En el caso Bogotá se vio que el ISO IWA 4 constituye una herramienta valiosa para desarrollar procesos de fortalecimiento de las capacidades ciudadanas para el control social, que además potencia la creación de estrategias de trabajo colectivo y cogestionado entre el gobierno local y la ciudadanía, y que además dichos aspectos se materializan a través de la construcción de un escenario participativo denominado 
Observatorio Ciudadano. Dicha experiencia representa entonces una práctica significativa en materia de potenciación de la evaluación de políticas públicas en la gestión local, así como del control social ejercido por los ciudadanos en búsqueda de caminos que posibiliten robustecer la incidencia en la cosa pública y en procesos de toma de decisiones.

En el caso de Cochabamba en la actualidad no existe un espacio con características similares a las encontradas en Bogotá. Hay iniciativas tanto de evaluación, como de control social, que no se encuentran en un escenario común; se caracterizan por ser independientes y en cierta medida se podría mencionar, que de alguna manera perpetúan la histórica separación entre administración local y ciudadanía, e incluso dentro de la sociedad civil, se evidencia que se profundiza la diferenciación entre actores que no se encuentran y que no trabajan juntos, pero que argumentan desarrollar acciones con el objetivo de apoyarse.

Para ilustrar mejor estos casos se analizará el contexto departamental, para posteriormente ver su repercusión e incidencia en el escenario local de Sacaba. Una iniciativa de evaluación de políticas públicas que toma como insumo la percepción ciudadana sobre las acciones desarrolladas por la gestión pública tanto departamental como municipal, se lleva a cabo por el Observatorio Ciudadano Cochabamba Nos Une -CNU-, que se describe como iniciativa de la sociedad civil que busca dar voz a los ciudadanos y a las instituciones ante instituciones públicas, para poner en evidencia las problemáticas sociales que afectan tanto al departamento como a los municipios y a partir de allí, activar la conciencia colectiva de la población, incidir en las políticas públicas y ser parte activa de la trasformación de condiciones de desigualdad e inequidad social que van en detrimento de la calidad de vida y bienestar de la población cochabambina.

La acción desarrollada por CNU se fundamenta en la aplicación de encuestas de percepción ciudadana, que muestra la opinión de los habitantes del departamento frente a diferentes temas que afectan su bienestar y la satisfacción con la oferta de bienes y servicios en Cochabamba. Se indaga por temas como salud, educación, movilidad, seguridad, buen gobierno, participación ciudadana entre otros. Ello resulta ser la base para la generación de una plataforma para el ejercicio ciudadano de opinión y seguimiento periódico a los cambios en la calidad de vida de la ciudad, defendiendo el interés público y promoviendo una cultura ciudadana, a partir de información de calidad e imparcial sobre los distintos ámbitos que hacen a la Calidad de Vida en la ciudad.

Dentro de sus búsquedas concretas se encuentran el propiciar la efectividad y eficiencia en la gestión pública, a partir de la entrega y el análisis sistemático de información sobre los indicadores de calidad de vida de la ciudad y de los planes y políticas en curso. El evaluar los cambios, contribuir al debate y ser referente permanente en las discusiones sobre la calidad de vida y la construcción de una ciudad justa y sostenible. La elaboración de estudios sobre temas que inciden en la calidad de vida de los ciudadanos cochabambinos. La promoción de una ciudadanía más informada, responsable y 
participativa, de alianzas para contribuir a desarrollar políticas que mejoren la calidad de vida.

Como antecedentes de la iniciativa se encuentra que dado que cerca de 48 ciudades latinoamericanas tales como La Paz, Santa Cruz, Bogotá, Asunción, Lima, entre otras, han desarrollado sistemas de monitoreo ciudadano creando Observatorios Ciudadanos para efectuar una veeduría de la calidad de vida y de la gestión pública, con el objeto de promover ciudades justas y sustentables. Considerando que estos Observatorios, conformados por instituciones comprometidas con el desarrollo local, se han encargado de establecer indicadores de calidad de vida, desde una postura objetiva, tratando temas tales como gestión pública, seguridad ciudadana, desarrollo económico, participación ciudadana, gobernabilidad, medio ambiente, movilidad, etc.; asimismo de producir y difundir informes técnicos y resultados de encuestas de percepción ciudadana sobre la calidad de vida en sus ciudades.

Lo anterior sumado a que como consecuencia se tiene una red de ciudades latinoamericanas que impulsan esta iniciativa tratando de propagar el ejemplo, para lograr que haya una ciudadanía participativa e informada sobre los asuntos públicos y de calidad de vida.

De allí, el interés y la necesidad de crear un espacio de reflexión para la ciudad de Cochabamba, hace que el Centro Cuatro Intermedio, la Cámara Departamental de Industria de Cochabamba, el periódico Los Tiempos y la Fundación Suiza de Cooperación para el Desarrollo Técnico Swisscontact, en alianza interinstitucional, hayan constituido el Observatorio Ciudadano COCHABAMBA NOS UNE, con el propósito de realizar seguimiento periódico a todos los aspectos que hacen la calidad de vida de los Cochabambinos a través del desarrollo de sistemas de monitoreo ciudadano, para promover una ciudad justa y sustentable. En la actualidad instituciones académicas, ONGs, e instituciones privadas conforman el Observatorio, la última encuesta realizada fue en el año 2014.

En este caso la ciudadanía aparece inscrita en este escenario en calidad de encuestados y/o receptores de la información que se produce, como resultado de los ejercicios de valoración de la percepción ciudadana. No cumple un papel activo en el control de lo que se evalúa y de manera directa no incide en los procesos de toma de decisiones. Ello podría verse como una debilidad de este espacio; en este sentido un punto de fortalecimiento de la iniciativa debería ser justamente el de la vinculación más activa de la ciudadanía, por ejemplo a través de organizaciones sociales. Habría que valorar las estrategias del Observatorio en términos de potenciación de escenarios de diálogo de saberes entre la administración local y los ciudadanos, el cómo se generan dichos escenarios, una alternativa que puede responder este interrogante podría ser la que CNU emplea en tanto organización de debates públicos, socialización de resultados de las encuestas con actores sociales, entre otros. Pero éstas al parecer jugarían más un papel de socialización, divulgación de conocimientos que de interacción social entre los 
actores en mención y de acción conjunta para la estructuración de soluciones a las problemáticas que se identifican.

\subsection{Cochabamba-Sacaba y la descentralización}

Hablar del contexto de la descentralización en Cochabamba y en las escalas municipales remite a hacer alusión al desarrollo de este proceso en el panorama nacional, para identificar sus avatares y la implicación de dichos aspectos en cuanto a la configuración de la participación y el control social.

En el país boliviano la descentralización, así como en la mayoría de países de la región toma impulso en la década de los noventa, que para el caso de este escenario se enmarca en el ejercicio presidencial de Gonzalo Sánchez de Lozada, a quien popularmente en dicho país se conoció como "Goni”, protagonista del modelo neoliberal, privatizador y modernizador que sería correlato de las lógicas que se amarraron a la descentralización. La fórmula vicepresidencial de Sánchez fue entonces Hugo Cárdenas quien en su historia política contaba el haber sido líder indígena participante del partido político Tupac Katari de Liberación Nacional; esta fórmula tuvo gran potencia en el espacio nacional al juntar dos caras de la moneda, que históricamente se habrían contrapuesto a saber, la ola empresarial y la representación indígena aymara. Ellos serían entonces los líderes del Plan para todos a partir del que posteriormente se formularía el Plan de Desarrollo El cambio para todos.

La alianza entre los mencionados y antes antagónicos escenarios, dio lugar a la visibilización hasta cierto punto de las clases anteriormente invisibilizadas, se mostró como oportunidad para la concepción de los pueblos indígenas y originarios como actores sociales activos. Lo que al parecer se concretaría realmente unas décadas después cuando Evo Morales, asumiera la presidencia del Estado Plurinacional. Sin embargo, se mostraban como puntos presentes en la agenda pública del gobierno tanto el reconocimiento de la participación como la transferencia de recursos hacia abajo y fuera del Estado.

Fue de esta manera que progresivamente se fue configurando el proyecto político de turno que se caracterizaría por el impulso de una tríada muy propia de la década (90) en América Latina, tomarían cuerpo así la descentralización, la privatización y la modernización del Estado. Un paquete que al parecer no contenía preceptos dispersos, sino que daría cuenta de un ensamble estructural claro que seguramente empataba con los intereses y estrategias del modelo económico.

En lo relativo a la descentralización, es importante mencionar que ésta tuvo un carácter inicialmente municipal, ya que dicha entidad territorial cobro protagonismo de los ajustes tendientes al fortalecimiento de las infraestructuras política, administrativa y fiscal, por un lado, tanto en términos de participación ciudadana como de potenciación de la administración pública. Desde la perspectiva de Restrepo (2014) se menciona que fueron varios los aspectos desarrollados, dentro de ellos se destacan la creación de 311 
municipios, en un país en el que con anterioridad existían 24 municipios con capacidad fiscal y administrativa. Un segundo punto, estaría dado por el reconocimiento de los sectores rurales en cuanto a la jurisdicción municipal, ya que antes éstos carecían de expresión político administrativa propia. Dichas medidas resultaban correspondientes con la actualidad de un Estado caracterizado por ser precario en cuanto a presencia territorial.

Como tercer aspecto de especial relevancia se encontraba la extensión del periodo de alcaldes de 2 a 5 años. De igual manera, se decidió el incremento de transferencias fiscales de la nación a los municipios, aspecto que con anterioridad era determinado por el esfuerzo tributario relativo a los municipios y que en adelante, sería calculado a partir de considerar la proporción de la población que habitaba cada territorio.

Por último, se menciona (Restrepo, P. 120) que el nivel local gubernamental potencia como lugar privilegiado para impulsar la participación ciudadana en la administración pública, a las Organizaciones Territoriales de Base OTB que se conformaron por asociaciones ciudadanas de vivienda y en lo rural por pueblos indígenas, comunidades campesinas y sindicatos agrarios. Fueron estos entramados organizativos los que se buscó autorizar para controlar el gasto público local, así como para actuar activamente en la formulación y ejecución de proyectos y programas descentralizados, así como ser partícipes en cuanto a la formulación de Planes de Desarrollo Municipal así como Planes Distritales de Desarrollo Indígena en escenarios en los que la mayoría de la población formara parte de estos pueblos. De la misma manera, estas organizaciones territoriales se facultan para conformar representaciones en los llamados Comités de Vigilancia, en términos de control social y administración de gasto público. Dicho comité:

Se conforman por representantes de las OTBs que tienen un importante papel de ser un mecanismo de control social, una suerte de apelación a la soberanía popular en circunstancias límite, y una instancia que canaliza la participación social directa (...) abre campo importante para la democratización de la democracia (Ardaya, 1998; P. 15)

Este organismo es creado con varios objetivos que se respaldaron en la Ley de Participación Popular de 1994, como se ha dicho en el marco de la expansión territorial de las lógicas derivadas del modelo de descentralización. A partir de estos cambios legislativos se buscó ampliar el espectro de la participación de la población en lo concerniente a los asuntos de la administración pública en este caso haciendo énfasis en el municipio como territorio de lo local, más próximo a los colectivos de población. Como es bien sabido, además del reconocimiento de las Organizaciones Territoriales de Base (que fue de gran magnitud, ya que se visibilizó la existencia de más de catorce mil de dichas organizaciones), se hacía necesario instaurar un escenario en el que sus demandas, necesidades, representatividad y voz se materializara por ello surgen los llamados en ese entonces Comités de Vigilancia que se vienen mencionando a lo largo de esta narración. 
Dicha organización y su reconocimiento causó inconformidades en algunos sectores, tal es el caso de algunos grupos de las élites que lo vieron como afrenta directa a sus acciones, así como intentos de división de los movimientos sociales ya existentes e incluso como acción represiva del gobierno. Representó un intento de construcción de un puente entre gobierno y sociedad civil que requirió un arduo trabajo, y representó acciones de obligatoriedad para el trabajo conjunto entre los actores públicos institucionales y gubernamentales- y civiles - organizaciones y movimientos sociales-. Para algunos intelectuales estos comités surtieron un papel más fiscalizador que de control social, dadas las dificultades que se presentaban para transparentar los asuntos públicos. Una de las que se identifican como mayores dificultades justamente para lograr que los Comités fuesen entes encargados y potenciadores del control social es la carencia de información de los actores públicos, no se contaba con información ni con ejercicios de generación de la misma, para que se respaldase la labor de control social, ello en alguna medida frustra este objetivo inicial de estas instancias organizativas territoriales.

La idea del control social pasa a un plano bajo de importancia y se da más preponderancia entonces a la representación socio-territorial ya que, a partir de ésta, se lograría un camino expedito para vincularse a la Bolivia de aquella época. Se pensó entonces, que este escenario sería un mecanismo para vigilar la democracia y los medios de vinculación de los ciudadanos en sus gobiernos, más que como una herramienta para velar por la eficacia de la gestión municipal. Hasta cierto punto, pareciese que la democracia representativa fue el objetivo principal de impulso de la legislación que respalda los temas de participación popular, y se identifica cierta dicotomía con la democracia participativa y lo que ésta implica.

Sin embargo, contrario a lo que se pensó con el planteamiento de la Ley de Participación Popular en el contexto boliviano, no se logra ampliar -al menos no como se pensaba- el espectro de participación y vinculación activa de los ciudadanos a la gestión gubernamental, ello principalmente porque el problema identificado no radicada en los ciudadanos sino en los partidos políticos que social e históricamente habían sido clasistas y tradicionalistas, promoviendo a través de su acción el racismo, el continuismo, el autoritarismo y lo urbano en detrimento de lo diverso, lo plurinacional, lo discontinuo, lo popular y lo rural. En este contexto, se encuentra que los Comités en su conformación eran poco representativos y resultaron ser más requisito $y$ obligatoriedad para las organizaciones sociales que invitaciones a ampliar la democratización social.

A pesar de lo anterior, y con el pasar del tiempo ya fuese instados u obligados normativamente los territorios instituyeron los Comités de Vigilancia en la mayoría de OTBs, recibiendo su personería jurídica y otros en el trámite de dicho requisito. Sin embargo, se destaca la continuidad en la presencia de problemas para su constitución como instancia de participación social activa, al parecer las élites gobernantes los veían más como enemigos políticos y sociales que como actor legítimamente válido en la escena pública y política. Se subordinan a la voluntad de los gobernantes municipales de 
turno para su funcionamiento, y ello ocasiona entonces que se desvirtúen y sean "organismos controlados" por la administración pública, para evitar luchas contra hegemónicas contra los poderes establecidos, aspecto que restringe el sentido y el impacto de la participación política popular, se habla en elaboraciones como las de (Ardaya, 1998) que se constituyen más como espacios de poder cooptados por las élites.

Los mencionados aspectos (Ibíd., 1998) encaminan a pensar que la participación popular, para que tenga contenido democratizador, debe transformarse en participación política. Y que los años de existencia de los Comités de Vigilancia tiraron por tierra el mito de la posibilidad de control social a los órganos públicos sin recursos económicos y sin formación técnica por parte de actores sociales.

La Ley de Participación Popular en su Art. 10 inciso B mencionaba que en cierto sentido el Comité era un instrumento de gerencia social de control del uso de los recursos de participación popular por parte del Gobierno Municipal, porque se le otorgaba la atribución de controlar que no se destinaran en gastos corrientes del Gobierno Municipal más del 15\% de los recursos de la participación popular. Además, se le facultó para pronunciarse sobre el presupuesto de los recursos de participación popular y rendición de cuentas de gastos e inversiones efectuada por el Gobierno Municipal.

A lo que se menciona que allí es donde se encuentra "el hoyo negro" del Comité. Porque se requería no sólo de especialización, sino especialidad y capacidad técnica. Esta atribución de gerencia ninguno de los Comités pudo realizarla (...) esta tarea sólo podría lograrla con la contratación de asesores expertos en los temas mencionados. Pero para el colmo, la escasa información que recibían del Alcalde era confusa y no asequible para su entendimiento (...) los vigilantes saben que tienen como obligación controlar el buen uso de lso recursos de participación popular, pero no tienen ni los instrumentos metodológicos ni instrumentales para hacerlo. Por ello tan sólo se dedican a hacer trámites de las OTBs (Ardaya, 1998; P. 48)

En los albores del 2012, se agudizan las críticas a los Comités de Vigilancia, mencionando entre otros aspectos que resultan ser insuficientes a los propósitos de la Nueva Constitución, de esta manera se da paso a cambios en la legislación vigente, institucionalización de la Ley 341 Participación y Control Social, que buscaría promover la creación de Consejos de Coordinación de la participación y control social como una instancia nueva. Pero antes de pasar a dicho tema, y retomando asuntos concernientes a las fallas del modelo orgánico de control social boliviano a partir del modelo de los Comités se mencionarán, las razones citadas por Nuria Cunill (sf)

- La circunscripción de roles, tanto como su confusión, como debilidad del control social.

- El control social fundamentado en la creación de órganos específicos puede lesionar el tejido social y suscitar problemas de representación. 
- Sobrecarga de atribuciones como de su contenido mismo

- Un diseño inadecuado de los recursos para forzar la observancia de la Administración, puede operar en contra de la eficacia del control social.

- La dependencia absoluta del control social respecto del control estatal lo torna vulnerable

Los anteriores se citan como aspectos que influyen en cuanto a caracterizar como intentos fallidos algunas experiencias de control social. La baja claridad en el rol de los actores, como elemento incidente, Cunill menciona el hecho de institucionalizar órganos específicos como producto de experiencias que menoscaban el tejido social, la no claridad en cuanto a funciones a desarrollar, los usos de recursos ineficientes para el apoyo al monitoreo de la gestión pública local y uno interesante más interesante en el análisis como lo es el hecho de que el Estado sea el auspiciador de dichas iniciativas, lo que podría llegar a politizar el proceso desarrollado.

\subsection{Experiencia de control social en Sacaba}

Luego de un intento no tan exitoso por institucionalizar las prácticas de control social a través de los Comités de Vigilancia en febrero del año 2013 se aprueba la Ley de Participación y Control Social que entraría a reemplazar la Ley de Participación Popular, con el argumento de estar más en línea con la Constitución Política del Estado y buscando resignificar estos espacios. Dicha ley "Tiene por objeto establecer el marco general de la Participación y Control Social definiendo los fines, principios, atribuciones, derechos, obligaciones y formas de su ejercicio en aplicación de los Artículos 241 y 242 de la Constitución Política del Estado" (Art. 1. Ley 341).

El Artículo 3 establece que como fines se cuentan los de consolidar la participación y control social como elementos transversales y continuos de la gestión pública y en los procesos de planificación, seguimiento a la ejecución y evaluación de las políticas públicas y las acciones del Estado Plurinacional, en todos sus ámbitos y niveles territoriales. Como se observa, se considera que tanto participación como control social son ejes intrínsecamente relacionados con el ciclo de planificación y construcción de políticas públicas y que por tanto deben verse materializados en todos los momentos del mismo. Con la negrita se destaca la mención de las experiencias de evaluación de políticas públicas y acciones estatales.

Para efectos de enmarcar el presente estudio en los lineamientos conceptuales que emanan de la legislación vigente, se citarán las definiciones de los dos términos de los que es objeto la Ley en mención, a saber:

Participación: Es un derecho, condición y fundamento de la democracia, que se ejerce de forma individual o colectiva, directamente o por medio de sus representantes; en la conformación de los órganos del Estado, en el diseño, 
formulación y elaboración de políticas públicas, en la construcción colectiva de leyes y con independencia en la toma de decisiones.

Control social: es un derecho constitucional de carácter participativo y exigible, mediante el cual todo actor social supervisará y evaluará la ejecución de la Gestión Estatal, el manejo apropiado de los recursos económicos, materiales, humanos, naturales y la calidad de los servicios públicos y servicios básicos para la autorregulación del orden social.

Hay varios aspectos sobre los que vale la pena reflexionar, el primero de ellos es que se menciona que la participación constituye un derecho y fundamento de la democracia y que debe estar presente y propiciar la construcción colectiva de leyes e incidir en la toma de decisiones. Este aspecto estaría incitando a que los actores deberían en la práctica y realidad concreta trabajar de manera conjunta y articulada para la producción de procesos de toma de decisión, ello resulta ser un fundamento jurídico de respaldo a una iniciativa de gestión asociada del territorio encaminada a la evaluación de la gestión pública.

Por otra parte, respecto al tema de control social se reconoce a éste como derecho consagrado en la Carta Magna y se le reconoce su deber de evaluar la gestión estatal, lo que debería efectuarse en todos los niveles territoriales del país, con objeto de lograr impactos significativos y positivos en la calidad de vida de la población.

En cuanto a lo referente a ejercicio de derechos de los ciudadanos en cuanto a instancias de participación y control social se mencionan varios puntos, pero interesa destacar particularmente:

- Los actores tienen derecho de participar en la formulación de políticas, planes, programas y proyectos y en la toma de decisiones en los procesos de planificación, seguimiento a la ejecución y evaluación de la gestión pública en todos los niveles del Estado

- Realizar control social y acceder a información documentada sobre la calidad de los servicios básicos que prestan las empresas públicas, privadas, incluyendo las cooperativas u otro tipo de entidades

- Acceder a información documentada y estadística, de todas las entidades públicas y de las privadas que administran recursos fiscales y/o recursos naturales

- Participar en los procesos de rendición pública de cuentas de las entidades del Estado Plurinacional.

Se destacan de manera específica los anteriores puntos, ya que evidencian por una parte que se reconoce la acción de los actores de la participación y control social como de incidencia en los procesos de toma de decisiones, así como en todos los momentos del 
ciclo de la política pública lo cual se convierte entonces en otro argumento a favor de lo que se propone en este estudio y es la estructuración de un sistema de Gestión Asociada del Territorio que dote de capacidades a los actores así como incentive su trabajo articulado y de cogestión, en aras de llevar a cabo de manera conjunta procesos de evaluación a la gestión pública local.

Por otra parte, también en la mencionada Ley aparece referencia concreta a procesos de evaluación. En el Artículo 31 se menciona que las entidades territoriales autónomas, así como las instituciones públicas, deben realizar procesos de rendición de cuentas y evaluación de resultados de gestión, ante la sociedad en general y ante los actores que ejercen Control Social en particular.

El anterior artículo, da cuenta de cómo la evaluación de la gestión pública, gracias a la jurisprudencia vigente, tiene carácter de obligatoriedad y en este contexto se habla de la existencia de una relación particular con los actores que ejercen el control social. Sí se toma en cuenta la alusión que se realizó en líneas anteriores, se encontrará que la evaluación como proceso de construcción social, igualmente cuenta con un carácter vinculante pero también de incidencia de los ciudadanos en la cosa pública.

Al hablar de la incidencia de los ciudadanos en la cosa pública se hace referencia a que los colectivos de población deben ser agentes incidentes de segunda generación, de manera que impacten en el nivel político-institucional "superior", un nivel ligado a las reglas, los actores y los procesos que determinan en el largo plazo - estructuralmente- el contenido específico de las políticas (Acuña, sf; P. 215). Esta magnitud de impacto es al que se hace referencia al mencionar la importancia de que la población tenga vinculación con la toma de decisiones en el ámbito municipal.

Continuando con la línea argumental de este apartado, es necesario mencionar que, a nivel del municipio de Sacaba, también existe un reglamento interno del Consejo de Coordinación de Participación y Control Social que se encuentra compatibilizado con la Ley 341 de 2013, anteriormente descrita. Dicha instancia es la encargada de materializar varios de los preceptos que se dictan en la normativa nacional sobre el tema y así mismo encargado de promover y fortalecer la participación ciudadana en temas de transparencia municipal. Al existir un grado de compatibilización del reglamento con la Ley se retoman gran parte de sus artículos, llama la atención la clasificación de actores que se realiza en ambas normativas. 


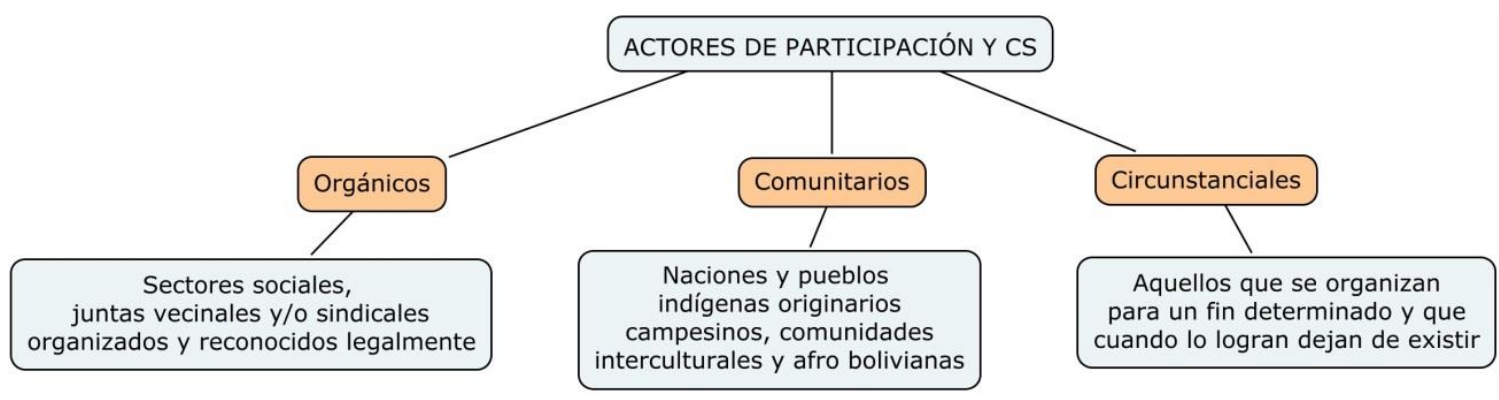

Fuente: Elaboración propia, a partir de las normativas vigentes.

Figura 63. Actores de la participación y el control social

El Consejo de Coordinación de la Participación y el Control Social es una institución de la sociedad civil que actúa dentro del marco legal específico previsto para su naturaleza y organización. Su estructura y funcionamiento es independiente de los órganos públicos debiendo estos abstenerse de intervenir en su gestión (Art. 3. Reglamento interno). Este Consejo está conformado por un presidente, un vicepresidente, el secretario general de hacienda, un vocal y un delegado por cada distrito que conforma el municipio (9 delegados a 2016).

Desde la perspectiva de uno de los integrantes del Consejo, se describe su labor como:

Basada en la parte legal bajo esa estructura y cumple dos funciones muy, yo diría que son los pilares del control social, que son las actividades de inspección y la recepción de informes cuando se requiera, por ejemplo en inspecciones si nosotros encontramos alguna observación entonces solicitamos a la unidad, o dirección o la secretaria dependiendo de la magnitud que tenga la observación, entonces ellos están en la obligación de asistir para prestar su informe, en caso de que existiera mayores desfases en su proyección o existiera hechos ilícitos, algo así, entonces trabajamos de manera más más coordinada con la Unidad de transparencia. Es alianza, ya que existe la unidad de transparencia, es una determinación ministerial del estado no, es de ley inclusive, entonces hacemos una alianza para también poder coadyuvar para ir si con esa visión que toda actividad se a lo más transparente posible, entonces por otra parte en caso de que no existiera ninguna observación damos por aprobado en este caso, aja lo validamos, en caso que haya observaciones llamamos y si en caso no nos arreglan entonces podemos hacer una interpelación desde un profesional como también a las secretarias que correspondan, inclusive nos remite a lo que es que pueden participar en esto la prensa pública. (Integrante Consejo, entrevista 2016)

El Consejo normativamente se instaura como una instancia encargada de ejercer representación de la población de los 12 distritos del municipio de Sacaba, se convierte entonces en un puente entre los habitantes de estos territorios y el Gobierno Autónomo Municipal -GAMS-. El marco de acción del Consejo resulta ser amplio según se determina tanto en la Ley 341 como en el reglamento interno, sin embargo el despliegue de su acción resulta ser algo reducido. En las entrevistas se evidencia que sobre todo el Consejo participa en lo que tiene que ver con supervisión de construcciones -que serían 
la mayor cantidad de proyectos que se ejecutan en el municipio-, sin embargo, para dichas inspecciones no cuentan con insumos técnicos claros, las herramientas de las que disponen para realizar la valoración y dar el visto bueno o no, son proporcionadas por la Unidad de Transparencia del GAMS, en este punto diría Cunill (sf) existe una intervención del estado en el quehacer del control social lo que sería perjudicial para el fortalecimiento de la instancia.

Se participa en procesos de rendición de cuentas pero desafortunadamente tampoco el Consejo cuenta con instrumentos metodológicos que le permitan ejercer su función de una manera más cualificada y clara. Al parecer no existen indicadores claros que ellos tengan y que les permitan dar cuenta de una valoración como se ha mencionado, cualificada a la gestión pública municipal. Ello se considera como una falencia a considerar, puesto que se requiere dotar a los delegados de capacidades tanto técnicas como metodológicas para ejercer su función de manera mucho más precisa y con un mayor grado de cualificación. Por otra parte, sí bien se menciona que existe una al parecer estrecha relación entre el Consejo y la Unidad de Transparencia que depende del GAMS, se evidencia que es un lazo meramente técnico y operativo, la Unidad participa en algunas reuniones del Consejo pero por ejemplo no se ha tenido conocimiento de que se realicen conjuntamente acciones de mejoramiento de la gestión pública o formulación de estrategias de cualificación de las mismas, no hay acción conjunta más allá de rendir un informe técnico que avale las obras realizadas en las diferentes OTBs.

Se considera importante el nexo entre estos escenarios, sin embargo podría potenciarse como un sistema de articulación permanente entre el gobierno local municipal y la ciudadanía. De manera que se desarrollen acciones conjuntas que permitan planificar y gestionar conjuntamente, en este caso, evaluaciones cualificadas a la gestión pública municipal, lo que vendría bien para los dos actores, puesto que se encuentra como función en su marco de acción y es un mandato que está dictado por las leyes vigentes respecto al tema. Otro punto a favor, es que justamente la jurisprudencia vigente también menciona que los actores tienen el derecho de participar en los procesos de toma de decisión, al decir el derecho, se está reconociendo el carácter de obligatoriedad que se da a las entidades públicas de procurar dicha participación. Esto también favorecería la construcción de un sistema de articulación y de gestión asociada del territorio para ejercicio de la evaluación de políticas públicas y del control social en Sacaba.

\subsection{Sacaba y la Sociedad Civil (organización social)}

Parte de las formas del ejercicio de la ciudadanía tiene que ver con la participación en organizaciones sociales. Estas son plataformas de agrupación democrática donde pueden concertarse y exponerse las demandas y necesidades de un grupo en particular e ir demandando a instancias públicas de toma de decisiones actuar de acuerdo a estas peticiones. También estas organizaciones parten de la idea de defender los derechos de 
sus asociados frente a cualquier otro grupo de interés que puede afectar directa o indirectamente con los fines que persiguen las mismas. Existen innumerables formas de organizaciones sociales, desde los sindicatos de trabajadores hasta los clubes deportivos, pasando por las organizaciones religiosas a las OTBs (Organizaciones Territoriales de Base) hasta las asociaciones de regantes, por mencionar algunas.

En este entendido trataremos de presentar las diferentes formas de participación en organizaciones sociales señaladas por la población estudiada. Para esto cabe aclarar que solo se han tomado en cuenta a las personas mayores de 18 años, ya que es desde esa edad que uno puede ejercer su derecho ciudadano para elegir y ser elegido como representante en los organismos de representación pública con pleno derecho. Por otro lado se ha sistematizado la información en seis categorías para hacer más sencilla su lectura. Las categorías elegidas son: OTB, sindicato obrero (que incluye a todos aquellos afiliados a un gremio de trabajadores), organización agrícola (tanto para aquellos pertenecientes a un sindicato agrario como para aquellos que forman parte de las distintas asociaciones de regantes o productores), organización profesional (para aquellos inscritos en una organización de profesionales o que pertenezcan al magisterio), otros (como las organizaciones religiosas, clubes deportivos, etc.) y por último los que no pertenecen a ninguna organización social.

En las cinco zonas de estudio, la mayor parte de la población señaló no pertenecer a ningún tipo de organización social. Como principales entes de organización surgen las OTB's, las cuáles se constituyen en actores claves para el desarrollo de las zonas estudiadas. El hecho de no tener otras organizaciones que puedan agrupar a las personas puede dificultar a la solución de distintas problemáticas que están presentes en la población.

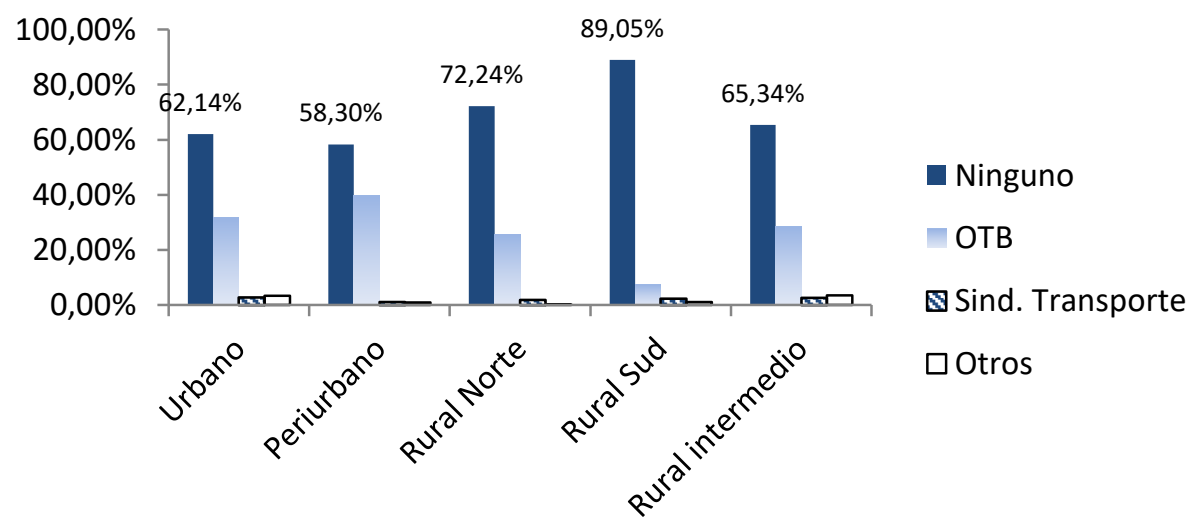

Fuente: Elaboración propia en base a CENSO de "Programa de Hábitat y Asentamientos Humanos" CEPLAG - ASDI, municipio Sacaba.

Figura 64. Tipos de organización a la que pertenecen, según zonas ${ }^{\mathbf{2 6}}$.

\footnotetext{
${ }^{26}$ Con fines analíticos y basados en las características del suelo en estos cuatro distritos, se han identificado cinco zonas principales: lo Urbano consolidado, lo Periurbano, lo Rural Intermedio, lo Rural Sud y lo Rural Norte. Cada
} 
Como se describió en el respectivo capítulo metodológico de este documento, se aplicó para el contexto de Sacaba una encuesta para valorar indicadores de participación ciudadana EVAPACI, de dicho instrumento es posible evidenciar interesantes análisis que serán presentados a continuación.

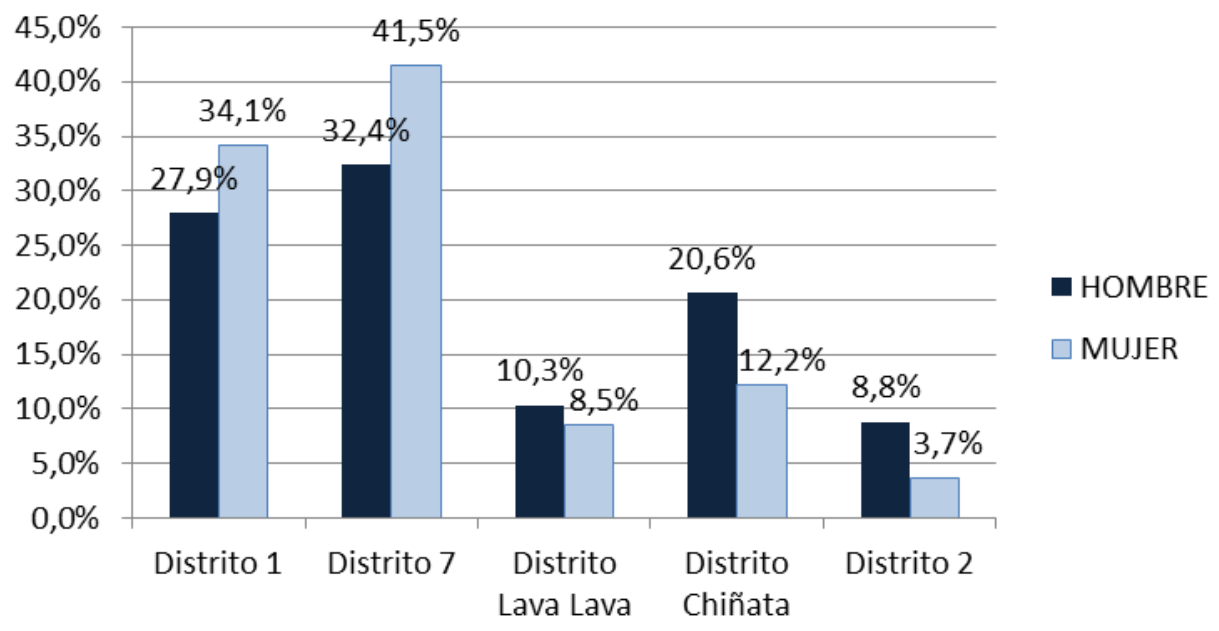

Fuente: Elaboración propia a partir de base de datos EVAPACI, 2016

Figura 65. Población encuestada EVAPACI

En la aplicación de la EVAPACI participaron hombres y mujeres mayores de 18 años. Se aprecia en la figura anterior que un gran porcentaje de participantes pertenecen a los distritos 1 y 7 respectivamente. Ello podría estar relacionado con el hecho que el instrumento de encuesta fue aplicado en el centro del municipio. La mayor participación de dichos territorios se realizó por mujeres, mientras que de los distritos más rurales participaron más hombres.

una de estas zonas presenta sus particularidades específicas de acuerdo al grado de urbanización que atraviesan, por lo cual se vio necesario hacer una caracterización de estas diferencias con el fin de identificar debilidades y recomendaciones de acción para evitar que la expansión urbana transforme estas zonas por completo. Los datos sobre formas de organización social en Sacaba se retoman de: Ledo García; Marañon; Ledo Espinoza; Umbarila; 2015. Planificación y territorio: Realidades, retos y riesgos de los procesos de expansión urbana. CEPLAG-UMSS. 


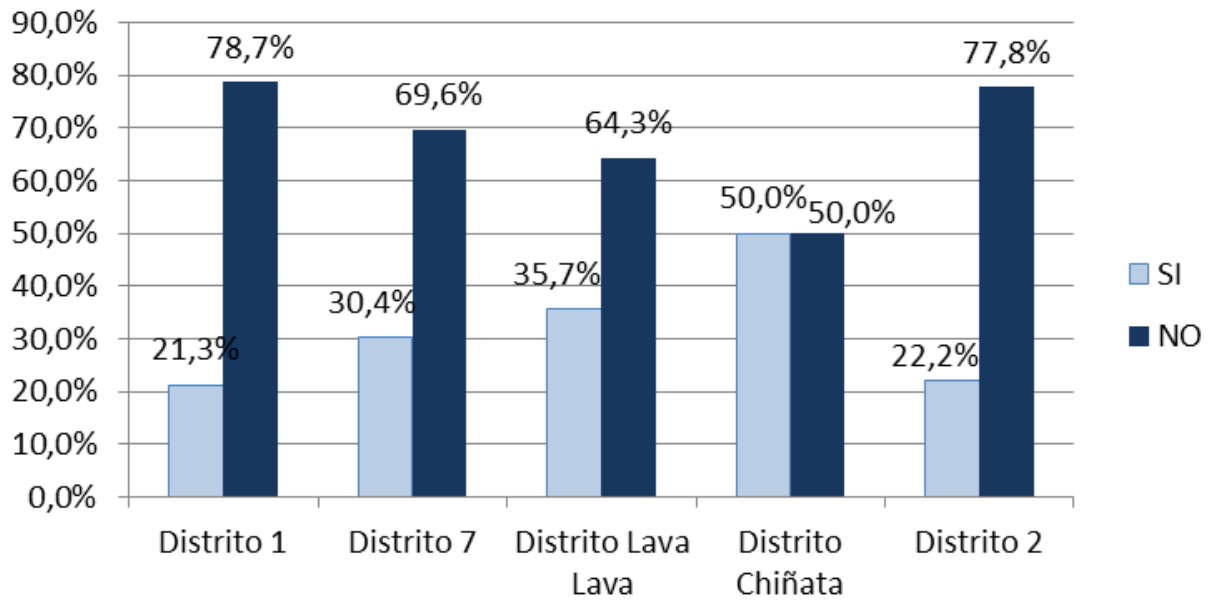

Fuente: Elaboración propia a partir de base de datos EVAPACI, 2016

Figura 66. Pertenencia a organizaciones sociales

En lo que respecta a la pertenencia de este grupo de población a organizaciones sociales, se confirma en cierta medida los hallazgos del censo del CEPLAG-UMSS en donde se afirmaba que había un gran porcentaje de la población que no participa de ningún tipo de organización social y dentro de los que más participan aparece el Distrito de Chiñata en donde el $50 \%$ de los encuestados afirma estar vinculado con alguna iniciativa de este tipo. Se observa de acuerdo a este dato, que hay una tendencia progresiva a la disminución de pertenencia y vinculación con escenarios de participación social, lo que podría atribuirse a las demandas crecientes en términos de tiempos y ritmos de vida que impone la lógica del modelo económico de acumulación, que van en detrimento de la creación y sostenimiento en el tiempo de vínculos y lazos sociales.

Tabla 42. Participación en proceso de diagnóstico y planeación

\begin{tabular}{|l|c|c|c|c|}
\hline & $\begin{array}{c}\text { Totalmente } \\
\text { en } \\
\text { desacuerdo }\end{array}$ & $\begin{array}{c}\text { Algo en } \\
\text { desacuerdo }\end{array}$ & $\begin{array}{c}\text { Algo } \\
\text { de } \\
\text { acuerdo }\end{array}$ & $\begin{array}{c}\text { Totalmente } \\
\text { de acuerdo }\end{array}$ \\
\hline $\begin{array}{l}\text { Durante el proceso de elaboración del } \\
\text { diagnóstico y planeación municipal se } \\
\text { respetó el punto de vista de vecinos y } \\
\text { vecinas }\end{array}$ & $13.3 \%$ & $27.3 \%$ & $41.3 \%$ & $15.3 \%$ \\
\hline $\begin{array}{l}\text { Los vecinos y las vecinas participan } \\
\text { activamente en actividades de grupos u } \\
\text { organizaciones del municipio }\end{array}$ & $16.7 \%$ & $27.3 \%$ & $34.7 \%$ & $20 \%$ \\
\hline $\begin{array}{l}\text { El proceso de diagnóstico generó mayor } \\
\text { contacto y conocimiento entre quienes } \\
\text { habitan el municipio }\end{array}$ & $16.7 \%$ & $22.7 \%$ & $38 \%$ & $18 \%$ \\
\hline
\end{tabular}

Fuente: Elaboración propia a partir de base de datos EVAPACI, 2016

Otro de los aspectos por los que se indagó en la EVAPACI fue sobre la participación de los habitantes del municipio en cuanto a determinadas fases del ciclo de construcción de políticas públicas. Un primer elemento de valoración está asociado con la etapa de 
diagnóstico y planeación, al respecto en primera instancia se pregunta sobre la percepción de las personas por sí se respeta el punto de vista de los vecinos y vecinas en la etapa de diagnóstico y planeación municipal, la mayoría afirma estar algo de acuerdo $(41.3 \%)$, lo que remitiría a pensar que algunas cosas derivadas del punto de vista de los pobladores se respetan, pero no todas, hay todavía un vacío en términos de incidencia ciudadana en cuanto a esta etapa del quehacer territorial.

En cuanto a la participación activa de los habitantes en actividades de grupos u organizaciones del municipio se hace referencia de igual manera a que se está algo de acuerdo con esta afirmación. Y finalmente en lo que tiene que ver en grados de cohesión comunitaria, se construye la afirmación de sí se genera mayor contacto y conocimiento entre quienes habitan el municipio a partir de participar en la etapa de diagnóstico y planeación municipales, en este punto el 38\% de encuestados afirma que en alguna medida sí se genera cohesión a partir de la participación en esta etapa del ciclo de políticas.

$\mathrm{Al}$ analizar la frecuencia de participación en etapa de diagnóstico y en relación a grupos de edad se encuentra que los encuestados afirman que los jóvenes casi nunca $(56,7 \%)$ se involucran en esta etapa. Ello remite a pensar que no hay un relevo generacional en términos de asumir roles en escenarios de participación social, no pareciese existir motivación por parte de este grupo etáreo para involucrarse en etapas de diagnóstico y planeación de políticas públicas.

Tabla 43. Participación en proceso de evaluación

\begin{tabular}{|l|c|c|c|c|}
\hline & $\begin{array}{c}\text { Totalmente } \\
\text { en } \\
\text { desacuerdo }\end{array}$ & $\begin{array}{c}\text { Algo en } \\
\text { desacuerdo }\end{array}$ & $\begin{array}{c}\text { Algo de } \\
\text { acuerdo }\end{array}$ & $\begin{array}{c}\text { Totalmente } \\
\text { de acuerdo }\end{array}$ \\
\hline $\begin{array}{c}\text { En la evaluación de PMOT, planes, } \\
\text { políticas o gestión de la alcaldía } \\
\text { municipal se toma en cuenta el } \\
\text { punto de vista de vecinos y vecinas }\end{array}$ & $13,3 \%$ & $36 \%$ & $38.7 \%$ & $6 \%$ \\
\hline $\begin{array}{c}\text { Hay organizaciones de la sociedad } \\
\text { que hagan control social o evalúen } \\
\text { políticas públicas en el municipio }\end{array}$ & $8 \%$ & $44 \%$ & $33.3 \%$ & $8.7 \%$ \\
\hline $\begin{array}{l}\text { Los vecinos y las vecinas participan } \\
\text { activamente la evaluación de la } \\
\text { gestión pública del municipio }\end{array}$ & $10.7 \%$ & $46 \%$ & $34 \%$ & $3.3 \%$ \\
\hline
\end{tabular}

Fuente: Elaboración propia a partir de base de datos EVAPACI, 2016

En lo concerniente al momento de evaluación de planes, programas y proyectos se encuentra que el $38.7 \%$ de la población encuestada afirma estar algo de acuerdo en que sí se toma en cuenta el punto de vista de vecinos y vecinas en el momento de valorar la política pública municipal. Por otra parte, el $44 \%$ dice que está algo desacuerdo con la afirmación de que hay organizaciones de la sociedad que hagan control social o evalúen, al parecer muchas personas de sacaba no conocen la existencia del Consejo de Coordinación de la Participación y el Control Social, ello se considera negativo por cuanto se evidencia que no hay un reconocimiento de este tipo de instancias para ejercicio de derechos, pero tampoco entonces hay apoyo a dicho escenario y todo se 
debe al desconocimiento del mismo por parte de la población. Finalmente, el $46 \%$ aparece en desacuerdo con la afirmación que dice que los habitantes participan activamente de la evaluación a la gestión, el desconocimiento de espacios como el consejo se aúna a la no participación de procesos de transparencia y control social ciudadano.

Lo anterior resulta algo contradictorio en el imaginario colectivo del municipio, ya que el $54 \%$ de las personas encuestadas responden que consideran tener mucha influencia en hacer que el municipio sea un mejor lugar para vivir, pero al parecer no ponen en acción esa capacidad que reconocen, ya que como se ha visto en los resultados la participación es muy reducida, no se conocen las instancias participativas municipales y se considera que no se toman en cuenta muchos de los puntos de vista de las personas. Se podría afirmar que hay una capacidad de agencia social reconocida pero que no es puesta en acción para lograr efectivamente que el municipio sea un mejor lugar para vivir.

Otro de los factores que puede verse como influyente en el hecho de la escasa participación de los habitantes de la comunidad en el escenario público, podría asociarse con la existencia de conflictos sociales en torno a varios temas. En los grupos focales se identifican varias problemáticas relacionadas con el tema agua por ejemplo y en una pregunta de la EVAPACI se evidencia que frente al interrogante de cómo se clasifica la unidad social de su municipio el $32.7 \%$ de las personas afirma que existen disputas y conflictos en la realidad de Sacaba. Ello debe analizarse a profundidad puesto que es un escenario susceptible de trabajarse sí se quiere incentivar la participación ciudadana en los asuntos públicos. Así, uno de los factores incidentes en términos de la participación social es en definitiva el surgimiento y mantenimiento en el tiempo de situaciones conflictivas en diversos sectores del municipio. A ello se suma las lógicas extensivas de urbanización a las que se enfrentan los territorios en la actualidad.

Estos distritos han sufrido durante distintos periodos las consecuencias de la expansión urbana. El Distrito 1, donde se encuentra el casco viejo del municipio, solía tener la mayor cantidad de terrenos agrícolas, pero el proceso desordenado de crecimiento urbano, ocasionó el deterioro de las tierras cultivables, constituyendo un efecto encadenado; para urbanizar talan árboles e invaden terrenos productivos, lo que produce erosión, luego los terrenos van perdiendo la capa cultivable, determinando la pérdida de productividad, que ocasiona un paulatino empobrecimiento de la economía familiar. El distrito 7, es un distrito periférico que se debate entre lo urbano y lo rural, y atraviesa el mismo proceso que atravesó el distrito 1 hace unos años. El Distrito Lava Lava, es un distrito rural ubicado en la zona sud del municipio y que cada vez se ve más amenazado por los asentamientos ilegales en zonas productivas. $\mathrm{Y}$ el distrito de Chiñata es un distrito rural ubicado en la zona norte del municipio que ha manejado eficientemente el riesgo de urbanización y mantiene su característica rural campesina (Umbarila; Aguilar; Ledo y Marañón, 2015; P. 169)

Dichas dinámicas de urbanización desordenada tienen como correlato el mercado de tierras y las lógicas vinculadas con el loteamiento, la deficiente planificación territorial 
y el avasallamiento a las tierras rurales; situaciones éstas que agudizan en gran medida la conflictividad municipal y como se ha visto van en detrimento del fortalecimiento de la participación social.

Por otra parte, se observa que hay una reducida participación de la población en procesos de evaluación a políticas públicas, el ejercicio del derecho al control social es bajamente desarrollado en estas zonas, se evidencia que sólo el 11.3\% de las personas que participaron en la EVAPACI han estado vinculados con este tipo de experiencias. Lo que genera una reflexión adicional y es que realmente hay muchos inconvenientes para el desarrollo de procesos de evaluación y control social a la gestión pública municipal en Sacaba. Sí se toman en cuenta los resultados presentados hasta el momento, se dilucida que hay problemáticas que impactan negativamente la participación, hay bajo conocimiento de instancias y escenarios construidos para evaluar la gestión local.

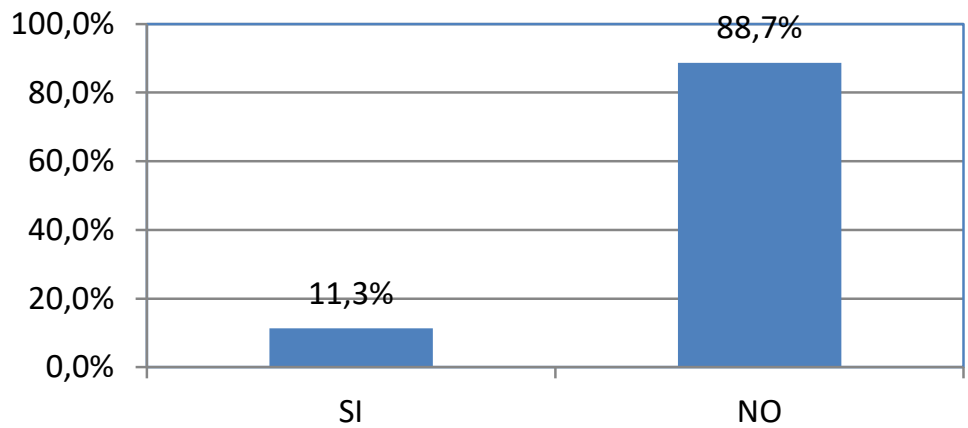

Fuente: Elaboración propia a partir de base de datos EVAPACI, 2016

Figura 67. Participación de encuestados en procesos de evaluación a políticas públicas.

De igual manera, otro de los indicadores que se analizó a partir de los resultados obtenidos con la encuesta es cuáles son las razones por las que la población no participa en ejercicios de control social o evaluación a políticas públicas, en este punto se halla que el $33.3 \%$ argumenta que se debe a la presencia de corrupción en la administración, este imaginario colectivo hace que los pobladores no se interesen por generar escenarios de evaluación, ni vincularse a los ya existentes, a pesar que como se vio anteriormente también existe la creencia de que tienen influencia para cambiar la realidad social Sacabeña. La segunda razón que se alude para la no participación es el que los funcionarios y la comunidad no trabajan conjuntamente (30\%); esto permite vislumbrar que la población considera como importante la existencia de alianzas entre gobierno y sociedad y de alguna forma este resultado está evidenciando que es necesario estructurar un sistema de articulación y planificación-gestión permanente entre la comunidad y la administración de manera que desde allí se impulsen escenarios de trabajo cogestionado y colectivo. 


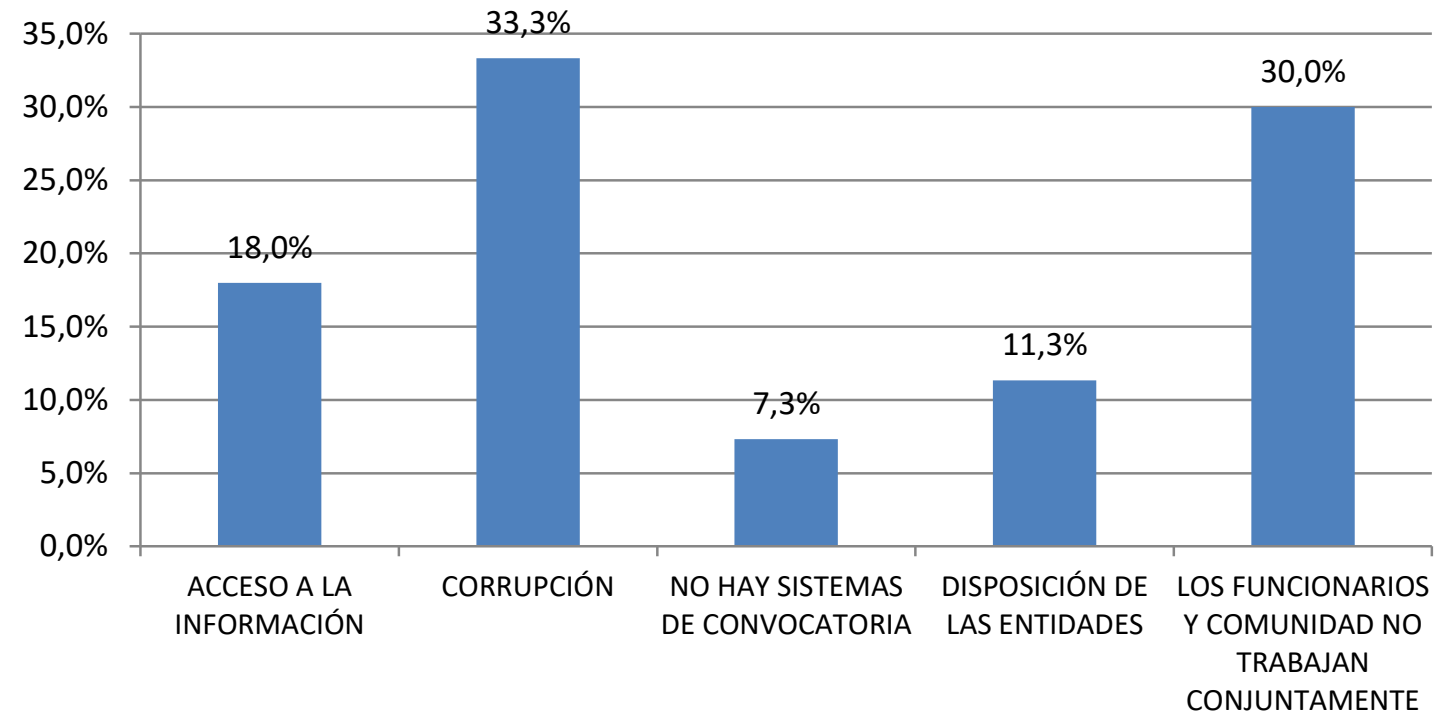

Fuente: Elaboración propia a partir de base de datos EVAPACI, 2016

Figura 68. Principales obstáculos para participar en procesos de evlauación de políticas públicas.

Los anteriores resultados nuevamente contrastan con la creencia en su totalidad de los habitantes del municipio encuestados, sobre que la evaluación de políticas contribuiría a hacer más transparente la gestión de las políticas públicas municipales. Estos resultados en suma, son bastante importantes puesto que evidencian contradicciones interesantes en cuanto al ejercicio de la participación ciudadana en el ámbito municipal, se considera importante evaluar, se piensa que ello contribuye a la transparencia en la gestión pero al mismo tiempo se dice que no hay una vinculación a procesos o experiencias de este tipo principalmente por el imaginario de que en las administraciones públicas hay lógicas de corrupción. Entonces en este sentido, se evidencian frentes de acción a partir de los cuales sería necesario que la propuesta de acción para cualificar las capacidades en evaluación de política establezca sus cimientos. 


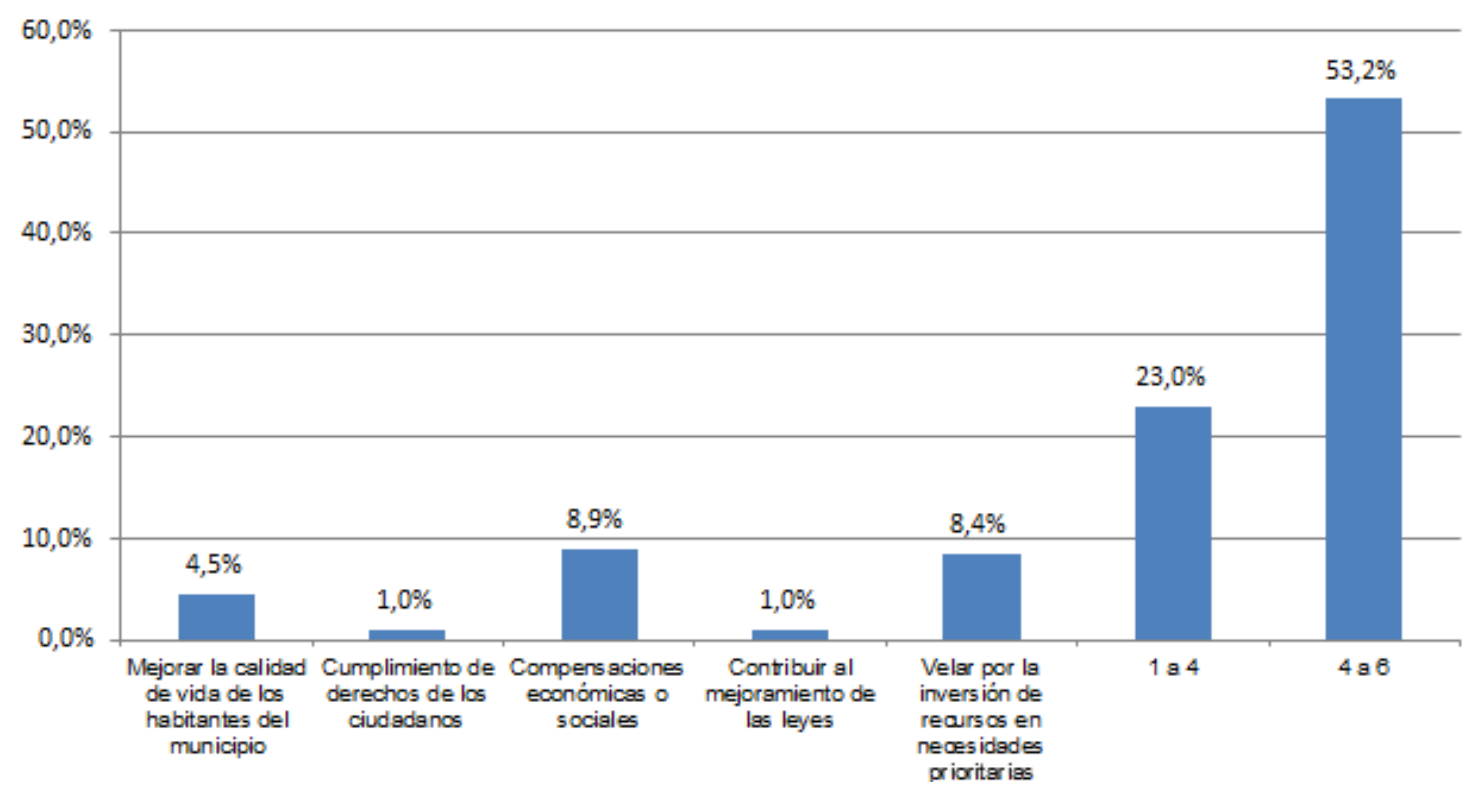

Fuente: Elaboración propia a partir de base de datos EVAPACI, 2016

Figura 69 principales razones que lo motivarían a participar en procesos de evlauación de políticas públicas.

Otra de las indagaciones que se hace en la EVAPACI es ¿Cuáles serían las razones que lo motivarían a participar en procesos de evaluación de políticas públicas? Ésta fue una pregunta en la que se permitió que los encuestados podían elegir varias de las opciones presentadas. En este aspecto se encuentra que de aquellas encuestas en las que se eligió una sola razón que motivaría a participar, el mayor porcentaje se reporta en compensaciones económicas o sociales $8.9 \%$, ello es un resultado que no sorprende en tanto que quienes se vinculan a experiencias o procesos de control social o evaluación lo hacen de forma ad honorem, es decir no reciben ningún tipo de retribución y para la población (por ejemplo los delegados del Consejo de Control Social) ello resulta complejo ya que dedican bastante tiempo a asuntos ligados con este espacio y no reciben compensaciones por ello, además de la de tener la posibilidad de incidir en el cambio social del municipio. Se argumenta que es necesario contar con recursos económicos para viáticos de quienes integran estas instancias o también para tener la posibilidad de contar con capacitaciones o apoyos técnicos de profesionales para cualificar su ejercicio de control social, ya que son muchos los sectores y temas a partir de los que se organizan las políticas públicas y ellos no conocen las especificidades técnicas de todos.

\subsection{Síntesis}

Pensar las políticas públicas resulta ser efectivamente un ejercicio fundamental para proyectar un escenario de reflexión sobre las lógicas de la administración pública en un contexto determinado; el establecimiento de interrogantes dirigidos a cuestionar la forma tradicional de construcción de planes, programas y proyectos implica una 
pregunta por las lógicas de relación estado-sociedad y nuevos actores sociales. En este marco analítico el evaluar la gestión pública remite inexorablemente a la estructuración y construcción colectiva de un escenario que en la vida cotidiana y en la efervescencia de lo público y lo social no existe, a saber un escenario de encuentro entre gobierno, sociedad, organizaciones comunitarias y demás actores vinculados, llamados, convocados y necesarios para re-pensar la cosa pública.

Se menciona que dichos escenarios no existen en la actualidad dado que las lógicas de lo tradicional han cooptado la posibilidad de la innovación en las prácticas de la gestión pública, y ello a su vez ha impactado negativamente en lo concerniente a la promoción de la participación ciudadana, como un medio eficaz para la toma de decisiones en las esferas de lo público. De igual manera, el pensar lo público como una tarea casi que exclusiva del Estado ha logrado minar las posibilidades de la co-construcción y establecimiento de alianzas que vinculen a los colectivos de población de manera efectiva en los mencionados escenarios. De allí que resulte preponderante que se aúnen esfuerzos en torno a la recuperación de lo público desde y para la ciudadanía, logrando así potenciar la democratización social, en perspectiva de ampliar el escenario social vinculado a la administración local.

En la época contemporánea, el paradigma que sustenta el quehacer de la gestión pública aunado a los ejercicios de monitoreo y evaluación como formas de seguimiento es el de la llamada Nueva Gestión pública, enfoque que busca transformar la mentalidad tradicional en que se fundamentaba el quehacer de la cosa pública, persiguiendo rutas sustentadas en mecanismos de seguimiento y evaluación aunados a estrategias de modernización del Estado. Se promueven lógicas orientadas a resultados y creación de valor público, que es contraria a los modelos tradicionales que históricamente han hecho énfasis en los procedimientos y procesos de gestión, es decir en miradas un poco más tecnicistas. Se propone un cambio paradigmático que se enfoque hacia un camino en el que se de paso a la construcción colectiva y articulación multiactoral y multipropósito en las prácticas y discursos de la planificación-gestión.

Es difícil evidenciar un objetivo de los sistemas y prácticas de M\&E asociados con la construcción de experiencias conjuntas entre la sociedad y los gobiernos; unos vinculados con la necesidad de construir puentes que resignifiquen los paradigmas tradicionales de evaluar, de manera que estos sean procesos sociales y embriones de transformación social, en donde de manera conjunta, y cogestionada los actores logren incidir en el cambio de la forma tradicional de construcción de políticas públicas. La evaluación debe ser un proceso de construcción de conocimiento que genere cambios en la política, que se sincronice armónicamente con los procesos de toma de decisión, de tal manera que para ello es indispensable decantar el concepto de evaluación asociada a los objetivos meramente organizacionales y de presupuesto, para trascender dichos elementos en búsqueda de construir escenarios de democratización social. 
En esta perspectiva, en este capítulo se ha logrado evidenciar cómo la evaluación ha estado sometida a los vaivenes de la modernidad y se ha perdido en la liquidez de lo inmediato y lo urgente, deviniendo en este proceso como un momento dentro del llamado "ciclo", que transita a posicionarse como correlato de un ejercicio meramente técnico. Las dinámicas de rendición de cuentas, lógicas de transparencia, procesos de control social, registros de seguimiento, los encuentros pre, ex ante y post son meros cumplimientos a directrices de entidades o instituciones que construyen metas a alcanzar; en este panorama la evaluación está en peligro inminente de extinguirse como un ejercicio de aprendizaje constructivo y creativo para los actores.

En el contexto de esta investigación y en el que se desarrolló el estudio sobre las experiencias Colombia y Bolivia en temas de evaluación y control social, se analizó el momento de la evaluación dentro del ciclo de las políticas públicas, se buscó construir conocimiento sobre una perspectiva a partir de la que se logre resignificar el sentido (la intención) y el significado (impacto proyectado) de la práctica evaluativa, considerándola como un momento crucial para las intervenciones sociales. De esta manera, se estableció una relación entre el enfoque de la Gestión Asociada y la evaluación, en tanto que se parte de la comprensión de la evaluación como un momento contenido dentro de un ciclo de políticas, momento que sí es impactado por cambios positivos en cuanto a la lógica de proceder y el marco conceptual que respalda la acción, se estaría afectando todo el ciclo en su conjunto; en este sentido, se propuso a la cogestión como una alternativa para transformar a la política pública en sí misma.

Se evidenció que la evaluación es entonces, un momento crucial que a su vez se muestra como potencial para incentivar un cambio de paradigma en la lectura y construcción de políticas públicas, así como en las dinámicas de la toma de decisión. Desde esta perspectiva, evaluar o valorar un plan, programa o proyecto es además escudriñar los argumentos y/o discursos que subyacen a la práctica, implica vislumbrar pruebas y evidencias que respaldan la tesis de un curso de acción desarrollado. Dicha tarea valorativa entraña además, el develar los valores, normas, percepciones, ideologías y consideraciones de carácter técnico, político, institucional o administrativo inherentes al diseño de un curso de acción; es en este sentido, que la estructura mental que se propone para adelantar la evaluación, debe contemplar tanto rutas cuantitativas como cualitativas que posibiliten el cualificar y dotar de sentido el quehacer público. Estos aspectos permiten dar cuenta de las incertidumbres y complejidades que integran el devenir de la toma de decisión y que también son parte fundamental del ciclo de políticas públicas.

Desde esta perspectiva, se mostró cómo la evaluación debe develar la diversidad de concepciones e interpretaciones de los actores sociales involucrados, las variadas miradas sobre la realidad social y las múltiples construcciones que de ella y en ella se realizan, a partir de las interacciones y los entramados de sentido que subyacen a estos contextos. En este sentido, quien evalúa ya no funge como agente que direcciona el proceso, sino que asume una postura de facilitación de procesos de negociación y establecimiento de acuerdos, su quehacer estará entonces enfocado hacia la 
construcción de consensos a partir de una información cualificada. Así, se estarían construyendo meta-discursos sobre la realidad social, narraciones ancladas en la construcción colectiva y compartida. "Eso implica que la evaluación es una actividad práctica, reflexiva, deliberativa y situada. Debe permitir elevar el nivel de los debates políticos ofreciendo datos, evidencias y argumentos a los diversos actores para permitir la deliberación pública" (Roth, 2013: P. 33)

A partir de las anteriores reflexiones, se desarrolló un significativo análisis de la experiencia de control social y evaluación a las políticas públicas que se llevó a cabo en Bogotá a partir de una normativa internacional, así mismo se realizó una aproximación reflexiva sobre los discursos y prácticas de control social en el municipio de Sacaba en Cochabamba. Evidenciando con estos estudios de caso, las realidades, debates y perspectivas de la evaluación de políticas públicas y la contraloría social ciudadana, logrando evidenciar que es importante que se cuente con un sistema de articulación permanente y de trabajo articulado entre sociedad-estado y los diversos actores sociales presentes en el territorio, ello con miras a constituir propuestas de valoración que tomen en consideración las múltiples perspectivas analíticas que se ubican en estos contextos, ya que es a partir de ellas que es posible resignificar el papel ciudadano en la administración pública y por esta vía la democratización social. 



\section{CAPÍTULO 7. PROPUESTA DE FORTALECIMIENTO DE LA INCIDENCIA CIUDADANA A TRAVÉS DEL CONTROL SOCIAL}

En este capítulo se presenta una propuesta de fortalecimiento de la incidencia ciudadana a través del control social a la gestión pública en ámbitos locales, en este caso la escala municipal de Sacaba. Dicha propuesta surge a partir del trabajo desarrollado durante estos años en el tema de evaluación de políticas públicas y control social, la presente estrategia de acción se enriquece a partir de la experiencia de fortalecimiento del control social a la gestión pública de Bogotá adelantada 2013-2014, en donde la autora participó como investigadora principal y consultora.

Por otra parte, los procesos de formación que se desarrollaron durante los años de duración de doctorado permiten estructurar la propuesta metodológica que se presenta, dicha formación en áreas como Metodologías de Planificación Participativa y Gestión Asociada y Ciudad, Ambiente y Gestión Socio Urbana, programas de posgrado adelantados en FLACSO-Argentina y que permiten nutrir y cualificar los desarrollos que se expondrán en el presente capítulo. De igual manera, vale la pena mencionar que reflexiones preliminares de la autora al respecto se han presentado en eventos internacionales y se han socializado -en parte- en artículos publicados en revistas indexadas $^{27}$

La propuesta está conformada por dos ejes, el primero de ellos la construcción de un sistema de gestión y trabajo permanente de Gestión Asociada del Territorio para la

\footnotetext{
${ }^{27}$ Los cuatro años de formación doctoral y desarrollo de la presente tesis se relacionan con publicaciones como: Niño M. Bertha "La experiencia de fortalecimiento del control social a la gestión pública del Distrito Capital" en donde la autora desarrolla algunos capítulos, participa en la construcción de la línea base y la estructuración del proceso social. Se exponen resultados preliminares en el III Congreso Internacional de Estudios para el Desarrollo organizado por la Universidad de Zaragoza, y en el artículo "Metodologías de Planificación Participativa y Gestión Asociada como campos de acción del Trabajo Social" publicado en la Revista de Trabajo Social N.17 de la Universidad Nacional de Colombia, principalmente. Estos también suman como resultados del estudio doctoral, cuya reflexión final y completa esta en esta tesis.
} 
cualificación de la evaluación y control social a políticas públicas locales y el segundo eje de trabajo es una propuesta tentativa de indicadores de valoración de la gestión pública municipal, para lo que se han retomado como antecedentes los resultados de ejercicios de análisis de iniciativas de evaluación tales como: la iniciativa ciudades emergentes del BID; la iniciativa de la Red de Ciudades Como Vamos y la herramienta IWA 4 O ISO 18091.

\subsection{Justificación y enfoque de la propuesta}

La iniciativa que se presenta en este apartado se construye a partir del estudio teórico presentado en esta investigación, toma como referente de desarrollo la experiencia significativa del contexto bogotano en términos de aprendizajes y algunos aportes metodológicos. Se fundamenta además en la indagación que se realiza sobre indicadores para valoración de la gestión pública municipal. Esta estrategia busca dar respuesta a los vacíos que se identificaron para el ejercicio del derecho de control social por parte de organizaciones sociales y ciudadanos de Sacaba, así como para la evaluación de políticas públicas municipales por parte del Gobierno Autónomo Municipal.

El escenario propuesto busca que los actores aúnen esfuerzos en torno a valorar la actualidad de la gestión pública en la escala municipal y a partir de allí, se logre consolidar un sistema de evaluación, planificación y gestión permanente de los asuntos públicos municipales en Sacaba. Sistema que evidentemente se plantea como objetivo el de lograr incidencia en la toma de decisiones y políticas públicas. De esta manera, se hace necesario que las instancias y experiencias existentes en la actualidad, se fortalezcan para potenciar las capacidades ciudadanas e institucionales, así como los escenarios de cambio social y la agencia social de los ciudadanos.

Desde esta perspectiva, el sistema de gestión y trabajo permanente de Gestión Asociada del Territorio GAT para la cualificación de la evaluación y control social a políticas públicas locales en este contexto, sería el que garantizaría la sostenibilidad de los procesos de evaluación de la Política Pública, dicho sistema resulta factible puesto que se respalda en normativas vigentes según las cuales los actores sociales, especialmente gobierno y sociedad deben ser co-partícipes en procesos de evaluación de la política pública como puede ser la rendición de cuentas.

La propuesta que se plantea se enmarca en el enfoque de las Metodologías de Planificación Participativa y Gestión Asociada PPGA, cuyo fundamento teórico de soporte fue abordado en el capítulo II del presente documento. El proceso planteado constituye una dinámica social compleja, que requiere de unas condiciones y prerequisitos para su configuración; dentro de los requisitos están:

- Existencia de voluntad política de los actores que participaran de la estrategia o posibilidad de construirla.

- Disponibilidad de metodologías específicas 
- Disposición de participar.

Debe existir la disposición de los actores por la construcción colectiva, por el trabajo articulado y conjunto, de lo contrario no habría espacio para la generación de esfuerzos colectivos y la co-construcción. Se evidencia que éste es un escenario de trabajo que se relaciona mucho con el construccionismo social, se habla de lo común, el trabajo articulado, los esfuerzos comunales y comunes, para ello es condición sine qua non la voluntad política de los actores que se integran al sistema GAT. Es importante mencionar que este contexto, representa una forma diferente a la tradicional para trabajar la planificación y cualquier momento del ciclo de política pública, rehúye los cánones tradicionalistas para funcionar, trascendiendo a un espacio en el que se desea funcionar de una manera diferente, por lo cual la parte metodológica resulta indispensable, está claro que se quiere cambiar el paradigma de trabajo en el hacer y quehacer de las políticas, pero surge un interrogante por el ¿Cómo hacerlo? Dicho cuestionamiento entraña aspectos referentes a lo metodológico, para solventar esta inquietud la PPGA aporta un conjunto de metodologías susceptibles de combinarse para producir el efecto transformador y deseado.

\footnotetext{
En este sentido, es necesario no perder de vista que la concepción de la planificación participativa y gestión asociada va más allá de lo metodológico. Si bien plantea métodos y técnicas para la toma de decisiones participativa, es básicamente una concepción de cómo formular las políticas, cómo formular los planes o programas, y cómo establecer las relaciones entre actores de diversos campos y de diversas escalas (Poggiese, 2011; P. 16)
}

Las condiciones a partir de la que se fundamenta la PPGA s e vinculan con: el desarrollo local: la relación entre estado y sociedad con la posibilidad de hacer un nuevo pacto; predisposición a asociarse; la eficiencia y eficacia en la acción del estado que descentraliza; y el compromiso y ampliación del proceso democrático.

Se ha planteado la PPGA para la construcción de decisiones de forma participativa, por lo general se habla de este enfoque aplicado al momento de planificación y diseño de las políticas públicas. En esta propuesta se parte de considerar que ya que la PPGA se proyecta como un enfoque y como marco teórico que fundamenta el quehacer en la toma de decisión, también resulta factible aplicarlo al momento de evaluación y monitoreo / control social de los planes, programas y proyectos, esto pensando en que a partir de la evaluación se diseñen otras políticas de mejoramiento y/o ajuste que re encaucen la acción desarrollada. De igual manera, se considera que en la evaluación también se planifica y se gestiona, la valoración incluye un entramado de estrategias que posibilitan la acción conjunta para examinar los resultados e impactos del curso de acción sobre las problemáticas sociales.

Por otra parte, desde el planteamiento de un sistema de GAT se asegura la generación de tres componentes metodológicos importantes para cualificar procesos sociales de articulación de actores. Entre ellos se destacan la creación de escenarios participativos; 
el acuerdo y consenso sobre reglas y procedimientos y la sistematización como un mecanismo de producción de conocimiento permanente.

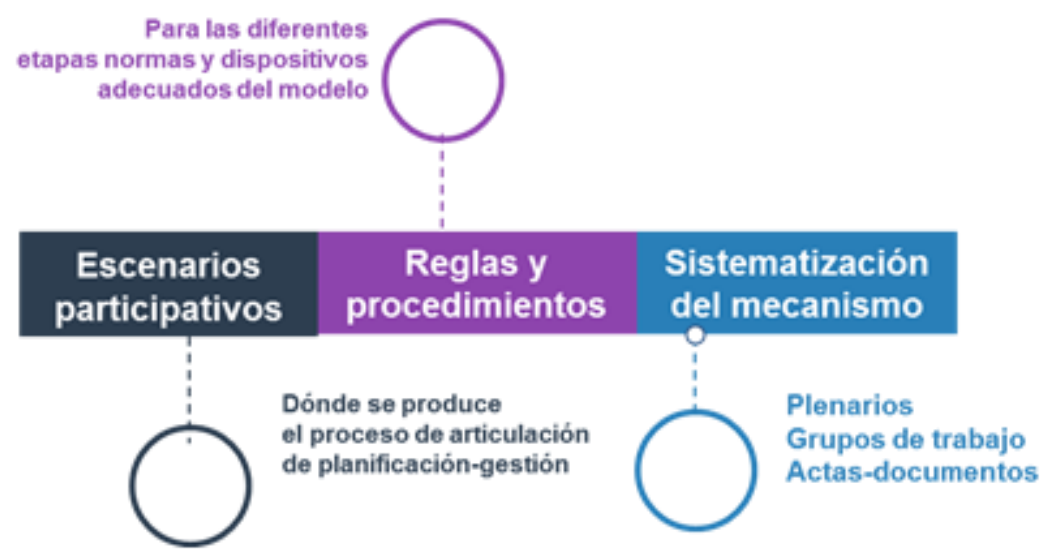

Fuente: Adaptación de Poggiese, 2011.

Figura 70. Componentes metodológicos sistema GAT aplicado a evaluación y control social de las políticas públicas

\subsection{Objetivos de la propuesta}

General

Estructurar una propuesta de de control social participativo para el municipio de Sacaba, que contribuya a la construcción y fortalecimiento de capacidades ciudadanas para la incidencia en la política pública

\section{Específicos}

- Construir una propuesta de evaluación de política pública que retome las singularidades territoriales del municipio de Sacaba en Bolivia y que sea enriquecida con la experiencia de control social desarrollada en Bogotá en 2013

- Estructurar una propuesta de sistema de indicadores técnicos para evaluación participativa de política pública en Sacaba con miras a contribuir a la construcción de una base de datos que sirva de plataforma para la toma de decisiones.

\subsection{Descripción de la propuesta}

Considerando que son varios los problemas que en la actualidad se presentan en el contexto municipal de Sacaba en términos de fortalecimiento de capacidades de agencia social para la evaluación de política pública y control social, se considera necesario que la presente propuesta de respuesta a dichos vacíos. De manera que por una parte se busca trabajar lo concerniente a la falta de trabajo conjunto entre los actores, aspecto asociado con la carencia de un sistema de articulación y gestión permanente entre quienes deberían involucrarse con estos temas. Por otra parte, se evidencia una baja cualificación de los actores para el desarrollo de los procesos valorativos de la gestión 
pública, por tanto es necesario dotar a los agentes de insumos, que permitan hacer frente a dichas dificultades y logren cualificar los procesos que se llevan a cabo, además de propiciar espacios para potenciar la participación ciudadana, desmontando los imaginarios sociales vinculados con el descrédito hacia las instancias de evaluación, a la administración pública, así como a la posibilidad de incidencia en lo público.

La propuesta diseñada en este contexto se inscribe en dos escenarios, en primera instancia se plantea un sistema de Gestión Asociada del Territorio aplicado a evaluación y control social de las políticas públicas y en segundo lugar se diseña una batería de indicadores organizados por ejes de la política pública, que fungirán como insumos técnicos de orientación sobre el qué evaluar en el GAMS. Cabe destacar que dichos indicadores se construyen a partir del estudio de las experiencias de valoración de la iniciativa Ciudades Emergentes del BID; los ejercicios de la Red de Ciudades Cómo Vamos y la experiencia de la norma ISO 18091 o IWA-4 en Bogotá.

Cabe aclarar que no se busca importar modelos de evaluación sin tomar en consideración las particularidades contextuales de un municipio como Sacaba. Lejos de ser modelos copiados de otras realidades, lo que se quiere lograr es un ejercicio de construcción a partir del diálogo de saberes entre las diversas experiencias significativas en materia de valoración de la gestión pública municipal. Justamente ésta aparece como una propuesta que tendrá que estudiarse en los primeros acercamientos y reuniones de trabajo que desarrolle el sistema GAT -que también se propone-, ser discutida y acordada/consensuada entre los actores que se vinculen, con el objetivo que sea lo más fiel a la realidad actual de Sacaba y sea susceptible de desarrollarse en este espacio territorial.

En este sentido, cabe destacar que un referente indispensable para la construcción de dicha propuesta de batería de indicadores sería el Plan de Desarrollo Municipal, pues allí se consignan las lógicas organizativas del territorio, así como las líneas gruesas de los planes, programas y proyectos a desarrollar. Anteriormente -previo a 2016- estaba en vigencia el Plan Municipal de Ordenamiento Territorial PMOT, posteriormente con la promulgación de la Ley 777 de 2016 se instó a las entidades territoriales a construir

Los Planes Territoriales de Desarrollo Integral para Vivir Bien (PTDI) que constituyen la planificación territorial de desarrollo integral de mediano plazo de los gobiernos autónomos departamentales, gobiernos autónomos regionales y gobiernos autónomos municipales. II. Los Planes Territoriales de Desarrollo Integral comprenden: Planes de gobiernos autónomos departamentales que se elaborarán en concordancia con el PDES y en articulación con los PSDI. Planes de gobiernos autónomos regionales y de gobiernos autónomos municipales que se elaborarán en concordancia con el PDES y el PTDI del gobierno autónomo departamental que corresponda, en articulación con los PSDI. III. Los Planes Territoriales de Desarrollo Integral podrán contar con la siguiente estructura y contenido mínimo: Enfoque Político. Comprende la definición del horizonte político de la entidad territorial autónoma articulado a la propuesta política del PDES. Diagnóstico. Es un resumen comparativo de los avances logrados en la 
entidad territorial autónoma en los últimos años, estado de situación, problemas y desafíos futuros, conteniendo elementos de desarrollo humano e integral, de economía plural, de ordenamiento territorial y uso del suelo. Políticas y Lineamientos Estratégicos. Establece las directrices y lineamientos generales para el alcance del enfoque político previsto en el PDES. Planificación. Es la propuesta de implementación de acciones en el marco de las metas y resultados definidos en el PDES desde la perspectiva de la entidad territorial autónoma, que comprende los elementos de desarrollo humano e integral, de economía plural y de ordenamiento territorial. (Ley 777 de 2016)

Dicho PTDI debe estar en línea con el Plan Departamental de Cochabamba para vivir bien y con el Plan Desarrollo Económico y Social del Estado Plurinacional en términos de ejes de implementación, así como de planes, programas y proyectos y su articulación con las mencionadas escalas territoriales. La propuesta de fortalecimiento de capacidades ciudadanas para el control social debería estar alineada entonces con el recién -a 2017- formulado PTDI, la cuestión es que en la actualidad dicho documento todavía no está disponible para su circulación pública, puesto que a fines de 2016 se estaba culminando el proceso de su construcción a partir de los lineamientos de la Ley 777 dictados en enero de 2016. En este sentido, se plantearán indicadores que sean compatibles con la escala municipal en concordancia con los siete ejes del Plan Departamental de Cochabamba para Vivir Bien 2013-2017, considerando que se articularía entonces con lo planteado en el reciente PTDI.

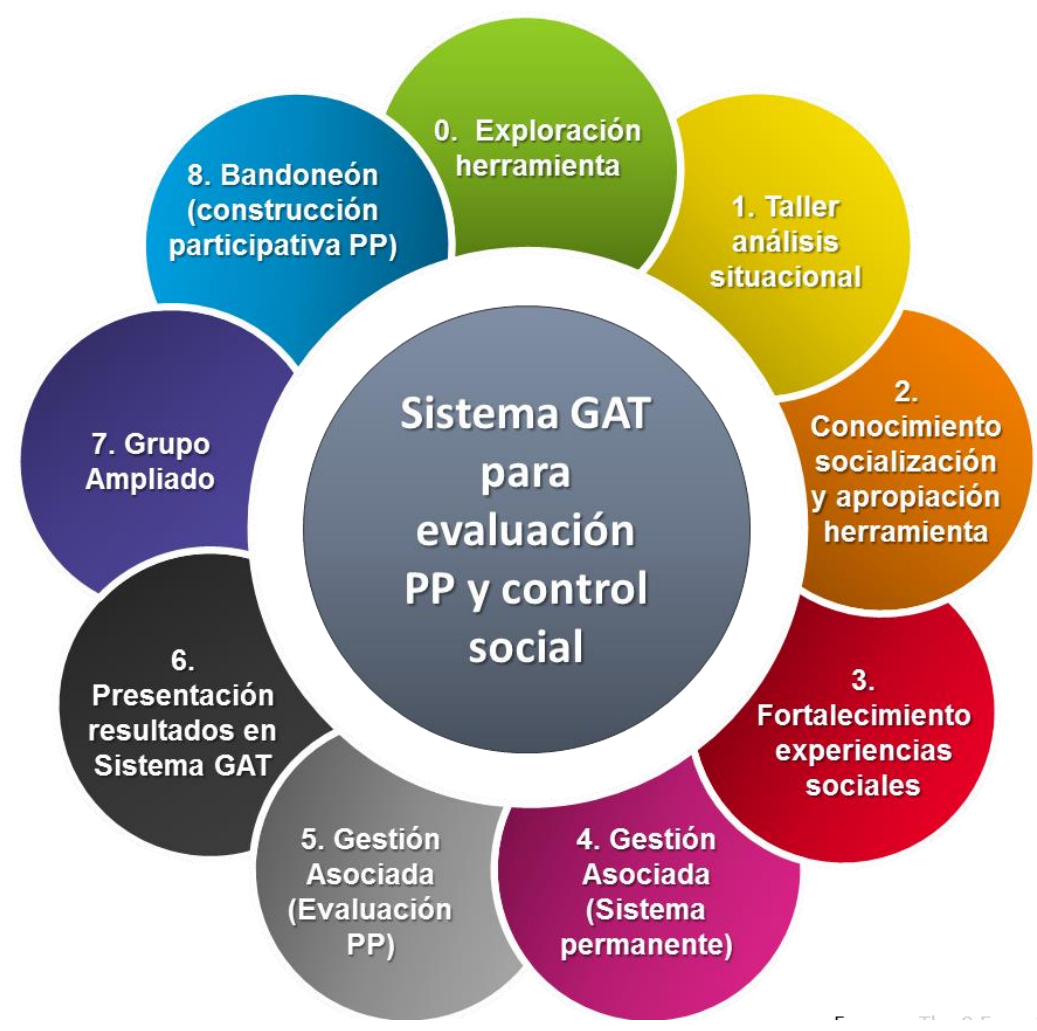

Fuente: Elaboración propia, 2016.

Figura 71. Momentos del proceso de construcción sistema GAT aplicado a evaluación y control social de las políticas públicas 
El Sistema de Gestión Asociada para el Territorio aplicado a evaluación y control social de las políticas públicas, responde a una de las necesidades identificadas como más importantes del contexto de Sacaba en la actualidad y es justamente la carencia de un sistema de articulación permanente entre gobierno-sociedad y otros actores sociales para planificar-gestionar las políticas públicas municipales. En esta oportunidad dicho sistema permanente se plantea para el momento de la evaluación de la gestión pública local, momento a partir del cual se considera posible la incidencia en todo el ciclo de la política. Es importante mencionar que sí se inicia y re-inicia el ciclo a partir de la valoración, no se estaría partiendo de cero, sino desde la comprensión objetiva de la actualidad territorial, se reconocerían los esfuerzos de múltiples actores puestos en configurar el panorama actual de la gestión del Gobierno Autónomo Municipal y desde allí se daría paso a un proceso de potenciación de la transformación de la lógica tradicional de funcionar de la administración pública. Por ello la evaluación se considera momento potencial de cambio social.

El Sistema GAT $^{28}$ plantea inicialmente un momento inicial en el que se realizaría una exploración de la herramienta planteada como instrumento para la evaluación de políticas públicas y control social, de igual manera en este momento se realizaría un examen detallado del PTDI municipal con el objetivo de decantar los indicadores y ejes temáticos a partir de los que se ha organizado de manera inicial el sistema técnico de valoración. Cabe destacar, que en esta fase se inicia a la par la consolidación del proceso social necesario para encauzar la voluntad política de los actores en términos del desarrollo de toda la dinámica que se plantea, sería igualmente un escenario de aprendizaje colectivo para comprender los aspectos concernientes a esta propuesta de evaluación y control social.

Posteriormente, el primer momento se plantea la realización de una jornada de taller de análisis situacional dialógico de la realidad del municipio, en donde participen diversos actores sociales, instituciones públicas, GAMS, organizaciones sociales, ciudadanos, universidad entre otros en la que se realice conjuntamente un mapeo de las situaciones que se identifican como socialmente problemáticas, se pretende realizar una investigación participativa con finalidad diagnóstica.

Se realiza una exploración de condicionantes (deficiencias, riesgos, potencialidades y restricciones), una identificación de tendencias en los procesos -estructurales y no estructurales- en relación con la realidad, una lista de procesos positivos que se encuentran operando en dicha situación, y una identificación de actores pertinentes a la problemática. El análisis situacional se registra por escrito en carteles con los títulos de caracterización de la problemática; tendencias, procesos positivos, actores pertinentes, mientras se va avanzando en el plenario y en grupos, el registro dura todo el taller.

El momento de análisis situacional involucra también la construcción de la llamada problemática de gestión, esta actividad posibilita la organización del plenario en

\footnotetext{
${ }^{28}$ A continuación se explicarán los momentos de construcción del sistema GAT, para ello se retoman los planteamientos de Poggiese (2011) al respecto.
} 
subgrupos de trabajo a partir de la identificación de ejes problemáticos principales en la lista de caracterización general; luego de nuevo en el plenario se examinarán los análisis de los subgrupos y se consensuarán los problemas a trabajar. Una vez realizado este paso se llega al momento de elaboración del modelo integrado de procesos problemáticos, dicho modelo es un esquema en el que se intenta representar la complejidad de la realidad social, se elabora a manera de mapa que registra todos los procesos críticos y positivos. Se parte de los problemas que consensuadamente se definieron como centrales y a partir de allí se van estableciendo encadenamientos causales que los producen o los ligan. Es así que se construye el modelo integrado de procesamiento, se grafica a manera de mapa decisorio.

Una vez se construye el modelo se procede a la identificación de procesos críticos, puntos de ataque, procesos positivos para desarrollar la evaluación de alternativas y formulación de acciones estratégicas. Los procesos críticos serán aquellos a los que se refieran más problemas señalándolos como negativos. De igual manera, se definen los encadenamientos que representan puntos de ataque -sobre los que actuar, ajustar, corregir o transformar-.

El segundo momento del sistema, se fundamenta en el estudio a profundidad de la herramienta de evaluación y control social. Una vez trabajados los procesos críticos, puntos de ataque, procesos positivos y situaciones socialmente problemáticas, ahora se realizará un proceso de conocimiento profundo, socialización, apropiación así como contextualización del instrumento a la realidad municipal. En este sentido continúan avanzando paralelamente el proceso social y el técnico. Se da paso a un análisis juicioso y minucioso del PTDI para enriquecer los indicadores que se plantean.

El tercer momento busca el fortalecimiento de las experiencias locales de base que existen al respecto, bien se podría trabajar con el Consejo de Coordinación de la Participación y Control Social del municipio así como con otros actores sociales presentes en el territorio, o bien se podría pensar en un escenario más amplio de monitoreo y seguimiento más a manera de Observatorio Social, pero para ello tendría que haber un fuerte trabajo territorial de conformación de la instancia, al respecto principalmente frente a la convocatoria a actores sociales a participar de estos procesos.

El cuarto momento Gestión Asociada I. sería formalmente de instauración del Sistema GAT aplicado a evaluación y control social en el que gobierno local y sociedad logran establecer por acuerdo/consenso social la necesidad de contar con estos espacios de trabajo conjunto, colectivo y cogestivo. Así, también la administración local y la ciudadanía establecen pactos/acuerdos sobre los indicadores que se van a evaluar y las evidencias que darían cuenta del nivel de avance de dichos indicadores. Se pactan entonces tanto indicadores como evidencias.

El quinto momento Gestión Asociada II. Estaría dado por la sesión de evaluación propiamente dicha, contexto en el que se realizará una revisión de las evidencias presentadas por el GAMS para cada eje de gestión pública. La ciudadanía a través del Consejo o del Observatorio Social, revisará minuciosamente de acuerdo a aquellas 
consideraciones que se hayan pactado en el momento anterior. El resultado de la evaluación se presentará retomando la metodología de semáforo.

El sexto momento Gestión Asociada III. Se desarrolla a partir de la socialización de resultados de la evaluación, en esta instancia se realizará una presentación frente al grupo de trabajo que participó de la evaluación. En la fase posterior se realizan los diálogos públicos o socialización de la información con un mayor número de ciudadanos y actores sociales.

En el séptimo momento se realiza la socialización de los resultados de evaluación producidos por el sistema GAT. Dicha presentación se realizará a través de la metodología de audiencias públicas participativas "entendidas como mecanismo de información, esclarecimiento y opinión, localizado en un punto de la cadena decisoria que organiza un proyecto, siendo que su mecanismo es abierto a la intervención de diversos actores de la sociedad" (Poggiese, 2011; P. 79)

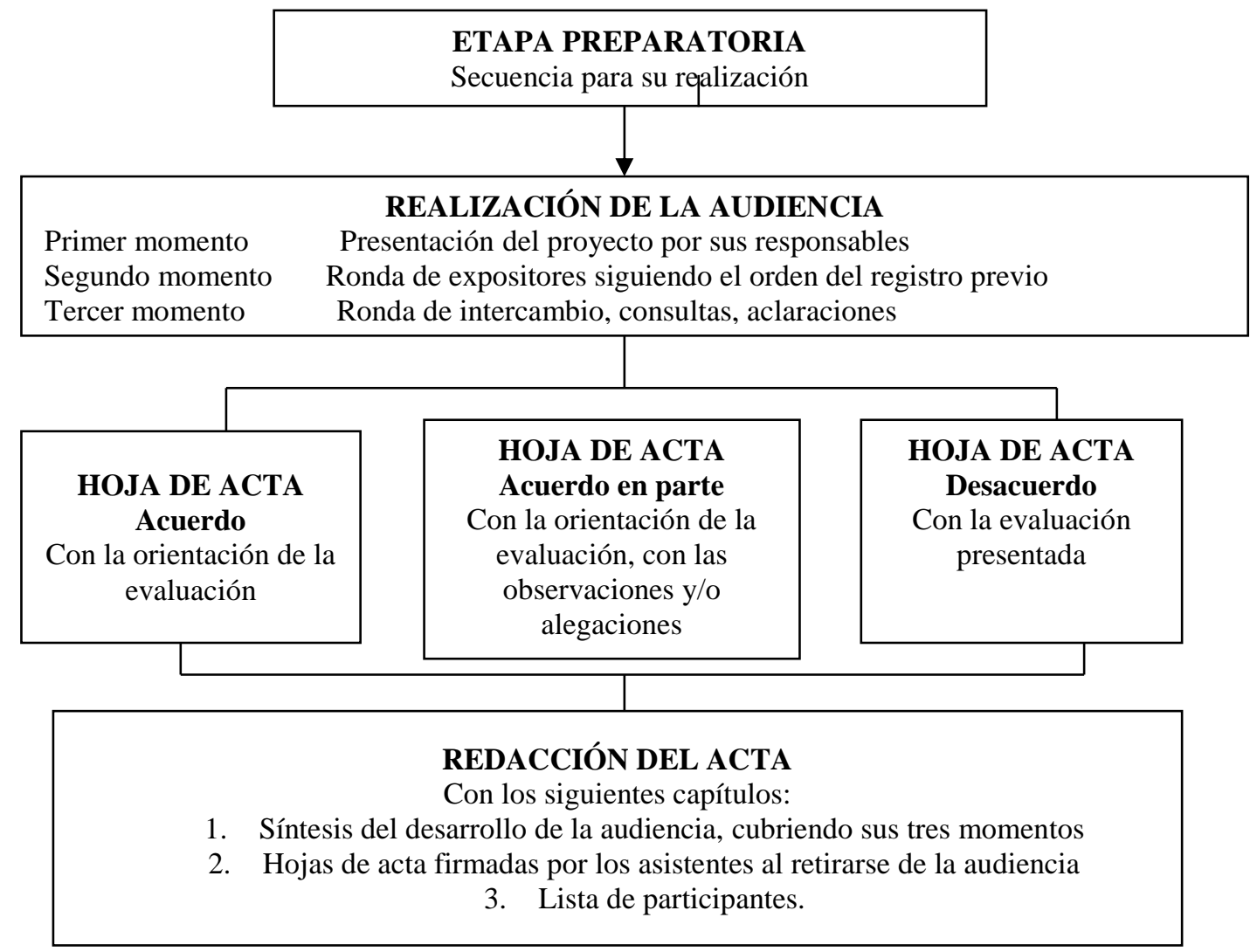

Fuente: Poggiese, 2011

Figura 72. Audiencia pública participativa, secuencia para su realización.

El octavo y final momento es el de continuidad del proceso y que asegura la sostenibilidad del mismo, se plantea para ello la técnica bandoneón incluida en la familia de Metodologías PPGA. Esta metodología se conoce también como consejos participativos de políticas públicas 
Resulta apropiada en aquellos contextos donde, por la agenda que se lleva y por el número de actores sociales que ésta involucra, se hace necesario garantizar la participación de un gran número de organizaciones con relación a problemáticas que varían en el tiempo. Cuando la política pública que se está llevando adelante, por su naturaleza, sostiene una agenda amplia, diversa y variable y además tiene un impacto amplio sobre diversos actores sociales, esta metodología parece ser el mejor instrumento para su éxito (Poggiese, 2011; P. 103)

Se trata entonces de un sistema que genera grupos de trabajo alternativos al sistema central GAT, ad hoc, que se constituyen con esas personas que cuenten con las capacidades específicas necesarias para el contexto dado. Este sistema posee un conjunto de reglas que pautan el trabajo colectivo de estos grupos de composición alterna, cuya demanda es de carácter esporádico, circunstancial, esporádico. Dichos grupos adicionales bien podrían estar conformados por profesionales o personal técnico que en sus reuniones trabajen con el grupo inicial/central del GAT sobre asuntos necesarios de la gestión pública, esos asuntos que en ocasiones tienen demasiados tecnicismos y que se ha visto generan dificultad en su comprensión para la población. El llamado bandoneón o consejos participativos tiene una dinámica interesante que se considera puede coadyuvar en el cumplimiento de los objetivos que se plantean para esta propuesta y que están encaminados a ampliar los escenarios de democratización social en el municipio a partir de los procesos de evaluación a la gestión pública.

Esta metodología tiene una particularidad y es que funciona con dinámicas de trabajo inicialmente del grupo central o permanente - en este caso del GAT- y posteriormente abre la posibilidad para opinión y participación de diversos actores en un espectro más amplio.

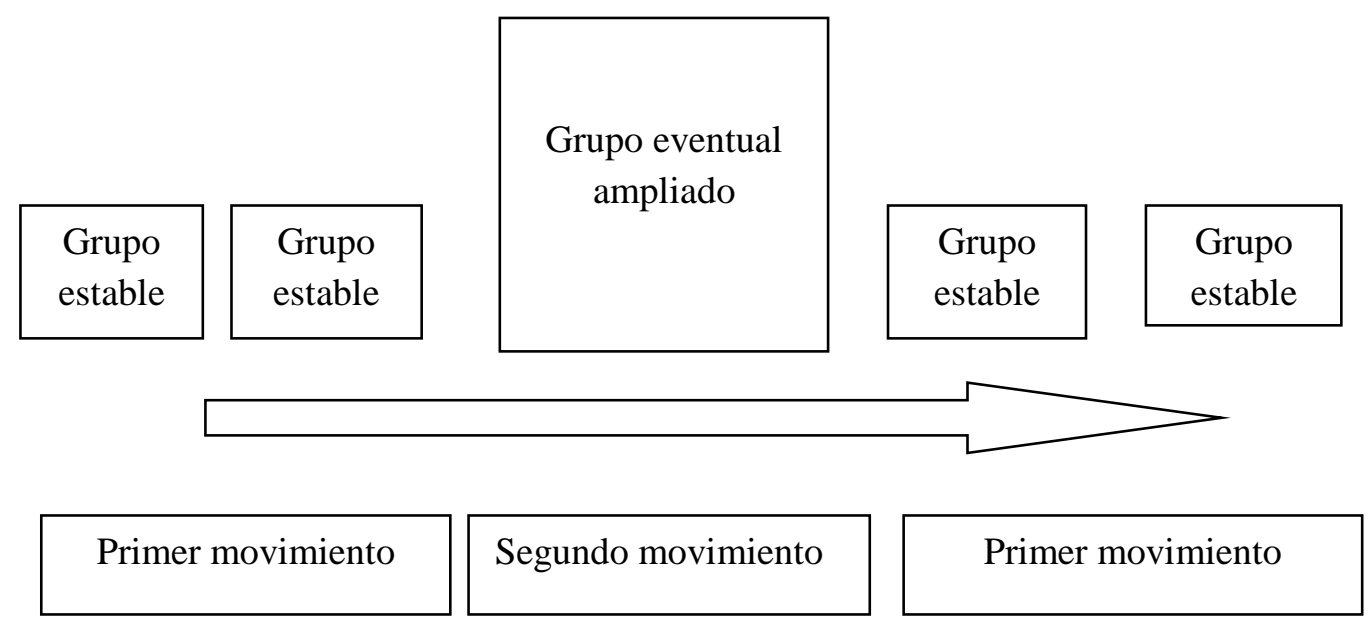

Fuente: Poggiese, 2011

Figura 73. Fuelle de bandoneón o Consejos Participativos de Políticas Públicas, secuencia para su realización. 


\subsection{Batería de indicadores propuesta}

El segundo punto nodal de la presente propuesta está constituido por una batería de indicadores que permitan orientar en alguna medida los procesos de evaluación a la gestión pública municipal. Se identificó que muchas veces ocurre que no se sabe qué evaluar y dicho desconocimiento del qué logra impactar negativamente el cómo. Como se mencionó en líneas anteriores resultaría ideal contar con la versión del PTDI recientemente construido para el municipio, pero desafortunadamente no se cuenta con dicho insumo, por tal razón se propondrán indicadores que se organizarán en torno a los ejes planteados en el Plan Departamental de Cochabamba para Vivir Bien, puesto que resulta ser la escala territorial que sigue a la municipal. En esta perspectiva, se encuentran siete ejes del plan a saber: dignidad y seguridad integral; identidades y culturas; saberes, ciencia y tecnología; producción e industria en economía plural; agua y seguridad alimentaria; madre tierra y político, autonómico e institucional.

Para el estudio de indicadores se consultaron varias experiencias de evaluación de política pública, entre ellas principalmente la experiencia del BID a partir de la iniciativa ciudades emergentes; la experiencia de Bogotá que se retoma en este documento, a partir del ISO-IWA 4 hoy norma ISO 18091; y la iniciativa de la Red de Ciudades Cómo Vamos. A partir de dicho estudio de las experiencias en mención sobre evaluación de políticas públicas, se construyen unas matrices analíticas para registrar sus especificidades -ver matrices más abajo-. Esta indagación permitió establecer cómo se organizan los indicadores (por ítems, sectores de política, ejes temáticos, entre otros) y en segunda medida ver cuáles son los indicadores que se trabajan y desde allí ver cuáles serían pertinentes para la realidad municipal en Sacaba en los ejes de planteamiento del Plan de Desarrollo Departamental.

En virtud de dicho análisis se identifica que la Iniciativa de Ciudades Emergentes y Sostenibles ICES-BID se organiza por dimensiones de la política pública, identificando como grandes áreas la sostenibilidad, medio ambiente y cambio climático; el desarrollo urbano sostenible y la sostenibilidad fiscal y gobierno; dichas grandes áreas se dividen a su vez en temas, en subtemas y finalmente de allí se plantean los indicadores evaluados. Ver tabla 30.

La iniciativa ISO 18091 identifica cuadrantes: desarrollo institucional para un buen gobierno; desarrollo económico sostenible; desarrollo social incluyente y desarrollo ambiental sustentable, de igual manera de estos cuadrantes surgen indicadores y sub indicadores a evaluar, a partir de ello se plantean las evidencias que debe tener cada uno de estos ítems para ser evaluados por los Observatorios Ciudadanos en las mesas de verificación.

La iniciativa de evaluación de la Red de Ciudades Cómo Vamos es una experiencia que busca generar información confiable, imparcial y comparable mediante indicadores veraces y periódicos en torno a temas de ciudad, calidad de vida y percepción ciudadana, para facilitar el conocimiento e intercambio de planes de desarrollo y 
programas específicos de interés entre los gobiernos locales. De igual manera, pretende utilizar la información disponible con el fin de enriquecer, fortalecer y potenciar las iniciativas de la Red y de cada ciudad, así como fomentar el intercambio de buenas prácticas de los diferentes programas Cómo Vamos. La organización de indicadores se organiza a nivel sectorial: en educación; en salud; en vivienda y servicios; en medio ambiente; en movilidad vial; en espacio público; en seguridad ciudadana; en responsabilidad ciudadana; en gestión pública; en finanzas públicas y en desarrollo económico, de allí plantea indicadores y el cómo se mide.

Tabla 44. Iniciativa de Ciudades Emergentes y Sostenibles ICES-BID

\begin{tabular}{|c|c|c|c|}
\hline \multicolumn{4}{|c|}{ INICIATIVA ICES BID } \\
\hline $\begin{array}{l}\text { DIMENS } \\
\text { IÓN }\end{array}$ & TEMA & subtema & INDICADOR EVALUADO \\
\hline \multirow{15}{*}{ 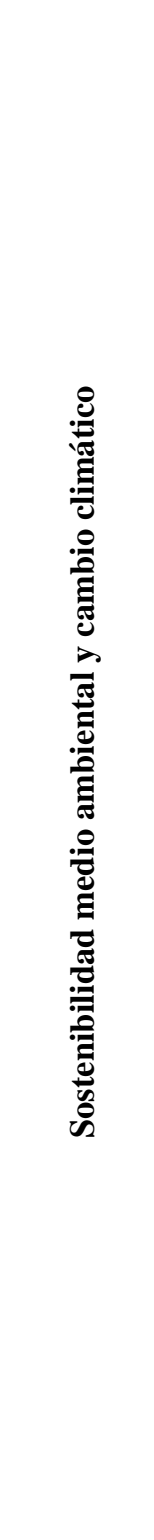 } & \multirow{6}{*}{ Agua } & cobertura agua & $\begin{array}{l}\text { Porcentaje de hogares con conexiones domiciliarias de agua } \\
\text { por red }\end{array}$ \\
\hline & & $\begin{array}{c}\text { Eficiencia en el } \\
\text { uso del agua }\end{array}$ & Consumo anual de agua per cápita \\
\hline & & \multirow{3}{*}{$\begin{array}{l}\text { Eficiencia en la } \\
\text { prestación de } \\
\text { servicios de } \\
\text { agua }\end{array}$} & Continuidad servicio de agua \\
\hline & & & calidad de agua \\
\hline & & & Agua no contabilizada \\
\hline & & $\begin{array}{l}\text { Disponibilidad } \\
\text { de recursos } \\
\text { hídricos } \\
\end{array}$ & Número de años remanente con balance de agua positivo \\
\hline & \multirow{3}{*}{$\begin{array}{l}\text { Saneamien } \\
\text { to y } \\
\text { drenaje }\end{array}$} & $\begin{array}{l}\text { Cobertura de } \\
\text { saneamiento }\end{array}$ & $\begin{array}{l}\text { Porcentaje de horas con acceso a servicios de saneamiento } \\
\text { por alcantarillado }\end{array}$ \\
\hline & & $\begin{array}{l}\text { Tratamiento de } \\
\text { aguas residuales }\end{array}$ & $\begin{array}{l}\text { Porcentaje de aguas residuales que reciben tratamiento de } \\
\text { acuerdo a normas nacionales }\end{array}$ \\
\hline & & $\begin{array}{l}\text { Eficiencia de } \\
\text { drenaje }\end{array}$ & $\begin{array}{l}\text { Porcentaje de hogares afectados durante precipitaciones con } \\
\text { frecuencia de ocurrencia igual a } 5 \text { años }\end{array}$ \\
\hline & \multirow{6}{*}{$\begin{array}{l}\text { Gestión de } \\
\text { residuos }\end{array}$} & $\begin{array}{l}\text { Cobertura de } \\
\text { recolección de } \\
\text { residuos sólidos }\end{array}$ & $\begin{array}{c}\text { Porcentaje de la población de la ciudad con recolección } \\
\text { regular de residuos sólidos }\end{array}$ \\
\hline & & \multirow{3}{*}{$\begin{array}{l}\text { Disposición } \\
\text { final adecuada } \\
\text { de residuos } \\
\text { sólidos }\end{array}$} & $\begin{array}{l}\text { Porcentaje de residuos sólidos de la ciudad dispuestos en } \\
\text { rellenos sanitarios }\end{array}$ \\
\hline & & & $\begin{array}{l}\text { vida remanente del predio en el cual está instalado el relleno } \\
\text { sanitario }\end{array}$ \\
\hline & & & $\begin{array}{c}\text { Porcentaje de residuos sólidos de la ciudad dispuestos en } \\
\text { rellenos sanitarios en la ciudad dispuestos en vertederos a } \\
\text { cielo abierto, vertederos controlados, cuerpos de agua y } \\
\text { quemados }\end{array}$ \\
\hline & & \multirow{2}{*}{$\begin{array}{l}\text { Tratamiento de } \\
\text { residuos sólidos }\end{array}$} & $\begin{array}{l}\text { Porcentaje de residuos sólidos de la ciudad que son } \\
\text { compostados }\end{array}$ \\
\hline & & & $\begin{array}{l}\text { Porcentaje de residuos sólidos de la ciudad que son separados } \\
\text { y clasificados para reciclado }\end{array}$ \\
\hline
\end{tabular}




\begin{tabular}{|c|c|c|c|}
\hline \multicolumn{4}{|c|}{ INICIATIVA ICES BID } \\
\hline $\begin{array}{l}\text { DIMENS } \\
\text { IÓN }\end{array}$ & TEMA & subtema & INDICADOR EVALUADO \\
\hline & & & $\begin{array}{l}\text { Porcentaje de residuos sólidos de la ciudad dispuestos que } \\
\text { son utilizados como recurso energético }\end{array}$ \\
\hline & \multirow{10}{*}{ Energía } & \multirow{5}{*}{$\begin{array}{l}\text { Cobertura } \\
\text { energética }\end{array}$} & $\begin{array}{c}\text { Porcentaje de la población de la ciudad con acceso autorizado } \\
\text { a energía eléctrica }\end{array}$ \\
\hline & & & $\begin{array}{l}\text { Porcentaje de la población de la ciudad con acceso a gas por } \\
\text { red domiciliaria }\end{array}$ \\
\hline & & & $\begin{array}{l}\text { Porcentaje de la población en viviendas con acceso a gas por } \\
\text { garrafas }\end{array}$ \\
\hline & & & $\begin{array}{l}\text { Número promedio de interrrupciones eléctricas al año por } \\
\text { cliente }\end{array}$ \\
\hline & & & Duración promedio de interrupciones eléctricas \\
\hline & & \multirow{3}{*}{$\begin{array}{l}\text { Eficiencia en el } \\
\text { uso de la energía }\end{array}$} & Consumo anual de energía per cápita \\
\hline & & & Intensidad energética de la economía \\
\hline & & & $\begin{array}{c}\text { Existencia, monitoreo y cumplimiento de regulaciones de } \\
\text { eficiencia energética }\end{array}$ \\
\hline & & \multirow{2}{*}{$\begin{array}{l}\text { Energías } \\
\text { alternativas y } \\
\text { renovables }\end{array}$} & $\begin{array}{c}\text { Porcentaje de energías renovables sobre el total del consumo } \\
\text { eléctrico }\end{array}$ \\
\hline & & & Uso de energía de fuentes renovables no convencionales \\
\hline & \multirow{4}{*}{$\begin{array}{l}\text { Calidad del } \\
\text { aire }\end{array}$} & $\begin{array}{l}\text { Control de la } \\
\text { calidad del aire }\end{array}$ & $\begin{array}{l}\text { Existencia, monitoreo y cumplimiento de regulaciones sobre } \\
\text { calidad del aire }\end{array}$ \\
\hline & & \multirow{3}{*}{$\begin{array}{l}\text { Concentración } \\
\text { de } \\
\text { contaminantes } \\
\text { en el aire }\end{array}$} & Air quality index \\
\hline & & & Concentración de PM 10 \\
\hline & & & Número de casos de infecciones respiratorias \\
\hline & \multirow{4}{*}{$\begin{array}{l}\text { Mitigación } \\
\text { del cambio } \\
\text { climático }\end{array}$} & $\begin{array}{l}\text { Sistemas de } \\
\text { medición de } \\
\text { emisiones GEI }\end{array}$ & Existencia y monitoreo de inventario GEI \\
\hline & & \multirow[t]{2}{*}{$\begin{array}{l}\text { Emisiones } \\
\text { totales de GEI }\end{array}$} & Emisiones GEI per cápita \\
\hline & & & Emisiones GEI/PIB \\
\hline & & $\begin{array}{l}\text { Planes y metas } \\
\text { de mitigación }\end{array}$ & $\begin{array}{l}\text { Existencia de planes de mitigación con metas de reducción } \\
\text { sectoriales y sistema de monitoreo }\end{array}$ \\
\hline & Ruido & $\begin{array}{l}\text { Control del } \\
\text { ruido }\end{array}$ & $\begin{array}{l}\text { Existencia, monitoreo y cumplimiento de regulaciones sobre } \\
\text { polución acústica }\end{array}$ \\
\hline & \multirow{4}{*}{$\begin{array}{l}\text { Vulnerabili } \\
\text { dad ante } \\
\text { desastres } \\
\text { naturales }\end{array}$} & \multirow{4}{*}{$\begin{array}{l}\text { Capacidad } \\
\text { adaptativa al } \\
\text { cambio } \\
\text { climático y } \\
\text { eventos } \\
\text { naturales } \\
\text { extremos }\end{array}$} & $\begin{array}{c}\text { Existencia de mapas de riesgo de la ciudad a escala de al } \\
\text { menos 1:10000 que incluyan información sobre amenazas } \\
\text { naturales (geofísicas e hidrometeorológicas) y análisis de } \\
\text { vulnerabilidad }\end{array}$ \\
\hline & & & $\begin{array}{l}\text { Existencia de mapas de amenazas hidroclimáticas, incluyendo } \\
\text { los efectos esperados del cambio climático, a } 2050 \text { y final de } \\
\text { siglo }\end{array}$ \\
\hline & & & $\begin{array}{l}\text { Existencia de planes de contingencia adecuados para } \\
\text { desastres naturales }\end{array}$ \\
\hline & & & Existencia de sistemas de alerta temprana efectivos \\
\hline
\end{tabular}




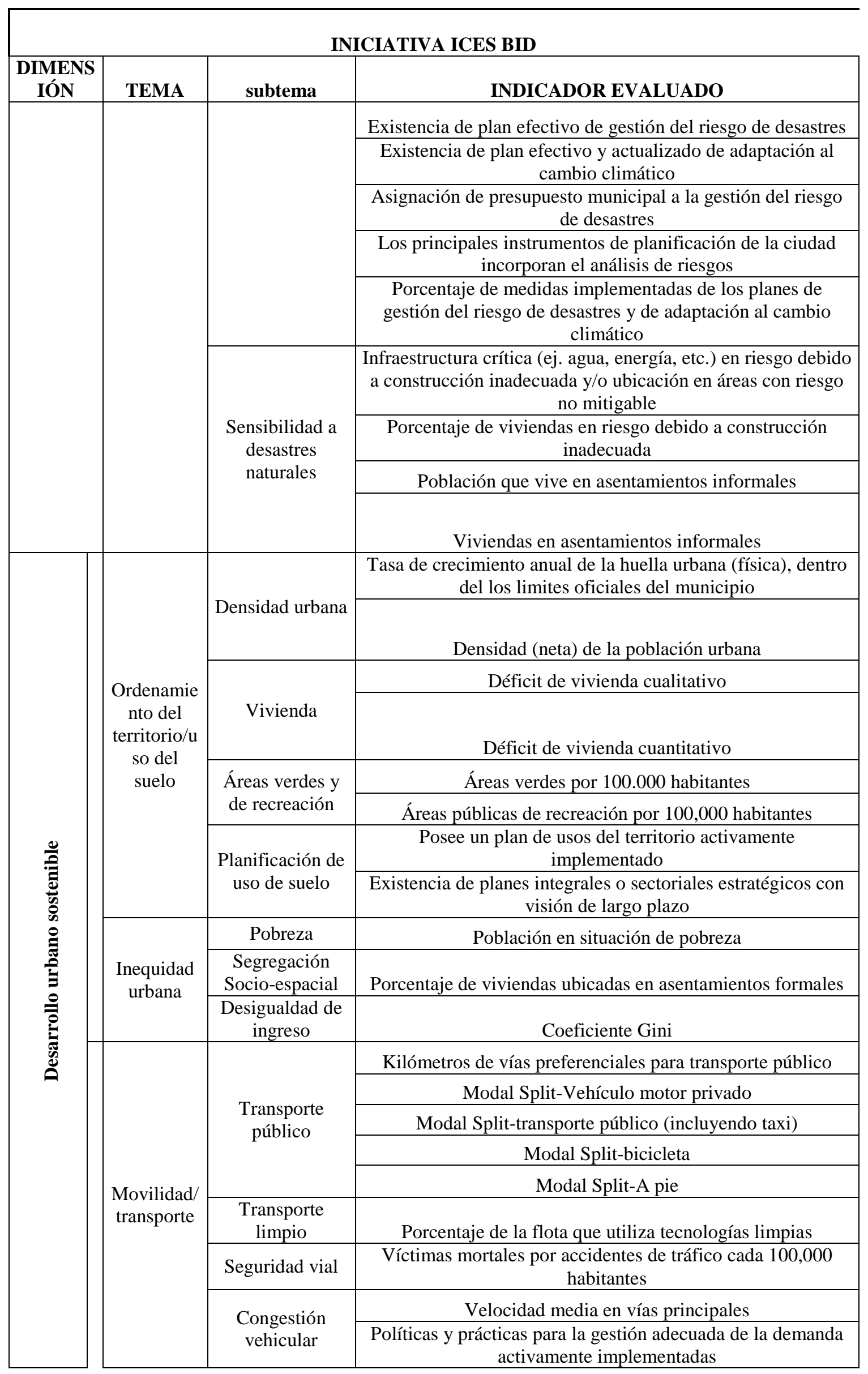




\begin{tabular}{|c|c|c|c|}
\hline \multicolumn{4}{|c|}{ INICIATIVA ICES BID } \\
\hline $\begin{array}{l}\text { DIMENS } \\
\text { IÓN }\end{array}$ & TEMA & subtema & INDICADOR EVALUADO \\
\hline & & & Travel time index privado \\
\hline & & & Travel time index público \\
\hline & & & Número de automóvles per cápita \\
\hline & \multirow{3}{*}{$\begin{array}{l}\text { Competitiv } \\
\text { idad de la } \\
\text { economía }\end{array}$} & $\begin{array}{l}\text { Regulación de } \\
\text { negocios e } \\
\text { inversión }\end{array}$ & Días para obtener licencia de funcionamiento \\
\hline & & \begin{tabular}{|c|} 
Manejo \\
estratégico de la \\
infraestructura \\
\end{tabular} & Existencia de plataforma logística \\
\hline & & Producto bruto & PIB per cápita de la ciudad \\
\hline & \multirow{2}{*}{ Empleo } & Desempleo & Tasa de desempleo (promedio anual) \\
\hline & & Empleo informal & Empleo informal como $\%$ del empleo total \\
\hline & \multirow{3}{*}{$\begin{array}{l}\text { Conectivid } \\
\text { ad }\end{array}$} & \multirow{2}{*}{ Internet } & $\begin{array}{l}\text { Subscripciones a internet de Banda Ancha Fija (para cada } 100 \\
\text { hab) }\end{array}$ \\
\hline & & & $\begin{array}{l}\text { Subscripciones a internet de Banda Ancha Móvil (para cada } \\
\qquad 100 \mathrm{hab})\end{array}$ \\
\hline & & Telefonía & $\begin{array}{l}\text { Número de subscripciones de teléfonos móviles (para cada } \\
\qquad 100 \mathrm{hab})\end{array}$ \\
\hline & \multirow{9}{*}{ Educación } & \multirow{4}{*}{$\begin{array}{l}\text { Calidad } \\
\text { educativa }\end{array}$} & Tasa de alfabetismo (15 años o más o definido por el país) \\
\hline & & & $\begin{array}{l}\text { Porcentaje de estudiantes de grado } \mathrm{x} \text { con un nivel } \\
\text { satisfactorio en pruebas estandarizadas nacionales (o locales) } \\
\text { de lectura, desagregado por género }\end{array}$ \\
\hline & & & $\begin{array}{c}\text { Porcentaje de estudiantes de grado x con un nivel } \\
\text { satisfactorio en pruebas estandarizadas nacionales (o locales) } \\
\text { de matemáticas, desagregado por género }\end{array}$ \\
\hline & & & Ratio estudiantes /docentes \\
\hline & & \multirow{4}{*}{$\begin{array}{l}\text { Asistencia } \\
\text { escolar }\end{array}$} & $\begin{array}{l}\text { Porcentaje de la población de } 3 \text { a } 5 \text { años de edad recibiendo } \\
\text { servicios integrales de Desarrollo Infantil Temprano }\end{array}$ \\
\hline & & & $\begin{array}{l}\text { Porcentaje de la población de } 6 \text { a } 11 \text { años de edad registrado } \\
\text { en escuela }\end{array}$ \\
\hline & & & $\begin{array}{l}\text { Porcentaje de la población de } 12 \text { a } 15 \text { años de edad registrado } \\
\text { en escuela }\end{array}$ \\
\hline & & & $\begin{array}{l}\text { Porcentaje de la población de } 16 \text { a } 18 \text { años de edad registrado } \\
\text { en escuela }\end{array}$ \\
\hline & & $\begin{array}{l}\text { Educación } \\
\text { superior }\end{array}$ & Vacantes universitarias cada 100.000 personas \\
\hline & \multirow{10}{*}{$\begin{array}{l}\text { Seguridad } \\
\text { ciudadana }\end{array}$} & \multirow{8}{*}{ Violencia } & Homicidios cada 100.000 habitantes \\
\hline & & & $\begin{array}{l}\text { Taza de victimización de homicidios de personas entre } 15 \text { y } \\
\qquad 24 \text { años de edad }\end{array}$ \\
\hline & & & $\begin{array}{l}\text { Homicidios perpetrados por población joven (entre } 15 \text { y } 24 \\
\text { años) }\end{array}$ \\
\hline & & & $\begin{array}{l}\text { Porcentaje de homicidios de mujeres debido a la violencia } \\
\text { doméstica }\end{array}$ \\
\hline & & & Robo con violencia (rapiña) cada 100.000 habitantes \\
\hline & & & $\begin{array}{l}\text { Robos con violencia (rapiña) por población joven (entre } 15 \text { y } \\
24 \text { años) }\end{array}$ \\
\hline & & & Hurto cada 100.000 habitantes \\
\hline & & & Hurtos perpetrados por población joven (entre 15 y 24 años) \\
\hline & & \multirow{2}{*}{$\begin{array}{l}\text { Confianza } \\
\text { ciudadana }\end{array}$} & Ciudadanos que se sienten seguros \\
\hline & & & Percepción ciudadana de la honestidad de la policía \\
\hline
\end{tabular}




\begin{tabular}{|c|c|c|c|}
\hline \multicolumn{4}{|c|}{ INICIATIVA ICES BID } \\
\hline $\begin{array}{l}\text { DIMENS } \\
\text { IÓN }\end{array}$ & TEMA & subtema & INDICADOR EVALUADO \\
\hline & & $\begin{array}{c}\text { Participación } \\
\text { ciudadana en la } \\
\text { seguridad }\end{array}$ & $\begin{array}{l}\text { Uso de la participación ciudadana en la definición de políticas } \\
\text { locales de seguridad }\end{array}$ \\
\hline & \multirow{6}{*}{ Salud } & \multirow{4}{*}{ Nivel de salud } & Esperanza de vida al nacer \\
\hline & & & Esperanza de vida masculina \\
\hline & & & Esperanza de vida femenina \\
\hline & & & Tasa de mortalidad de niños menores de 5 años \\
\hline & & \multirow{2}{*}{$\begin{array}{l}\text { Provisión de } \\
\text { servicios de } \\
\text { salud }\end{array}$} & Médicos cada 1.000 personas \\
\hline & & & Camas de hospital cada 100.000 personas \\
\hline \multirow{24}{*}{ 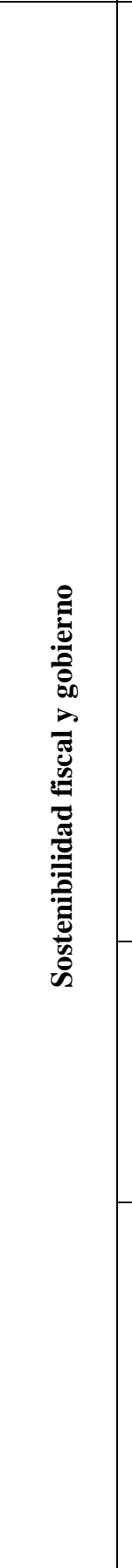 } & \multirow{3}{*}{$\begin{array}{c}\text { Gestión } \\
\text { pública } \\
\text { participativ } \\
\text { a }\end{array}$} & \multirow{2}{*}{$\begin{array}{c}\text { Participación } \\
\text { ciudadana en la } \\
\text { planeación de la } \\
\text { gestión pública } \\
\text { de gobierno }\end{array}$} & Existencia de proceso de planificación participativa \\
\hline & & & Existencia de presupuesto participativo \\
\hline & & $\begin{array}{c}\text { Rendición de } \\
\text { cuentas a la } \\
\text { ciudadanía }\end{array}$ & Sesiones públicas de rendición de cuentas por año \\
\hline & \multirow{4}{*}{$\begin{array}{l}\text { Gestión } \\
\text { pública } \\
\text { moderna }\end{array}$} & \multirow{2}{*}{$\begin{array}{c}\text { Procesos } \\
\text { modernos de } \\
\text { gestión pública } \\
\text { de presupuesto } \\
\text { municipal } \\
\end{array}$} & Existencia de presupuesto plurianual \\
\hline & & & $\begin{array}{c}\text { Remuneración del personal basado en un sistema de } \\
\text { indicadores de desempeño }\end{array}$ \\
\hline & & \multirow{2}{*}{$\begin{array}{c}\text { Sistemas } \\
\text { modernos de } \\
\text { gestión pública } \\
\text { de gobierno } \\
\text { municipal }\end{array}$} & $\begin{array}{c}\text { Existencia de sistemas electrónicos para el seguimiento de la } \\
\text { gestión de la municipalidad }\end{array}$ \\
\hline & & & Existencia de sistemas electrónicos de adquisiciones \\
\hline & \multirow{4}{*}{$\begin{array}{c}\text { Transparen } \\
\text { cia }\end{array}$} & \multirow{4}{*}{$\begin{array}{l}\text { Transparencia y } \\
\text { auditoría de la } \\
\text { gestión pública } \\
\text { de gobierno }\end{array}$} & Transparency Index \\
\hline & & & Cuentas de la municipalidad auditadas \\
\hline & & & Cuentas de empresas municipales auditadas por un tercero \\
\hline & & & $\begin{array}{c}\text { Existencia de sistemas electrónicos para el seguimiento de la } \\
\text { gestión de la municipalidad }\end{array}$ \\
\hline & \multirow{6}{*}{$\begin{array}{c}\text { Impuestos } \\
\text { y } \\
\text { autonomía } \\
\text { financiera }\end{array}$} & \multirow{5}{*}{$\begin{array}{l}\text { Ingresos e } \\
\text { impuestos } \\
\text { municipales }\end{array}$} & Ingresos propios como porcentaje de ingresos totales \\
\hline & & & Impuestos a la propiedad como porcentaje de ingresos totales \\
\hline & & & Transferencias totales como porcentaje del ingreso total \\
\hline & & & $\begin{array}{c}\text { Transferencias con uso específico asignado como porcentaje } \\
\text { del total de transferencias }\end{array}$ \\
\hline & & & $\begin{array}{c}\text { Ingresos de otras fuentes (donantes externos) como } \\
\text { porcentaje del ingreso total }\end{array}$ \\
\hline & & $\begin{array}{l}\text { Gestión de } \\
\text { cobranza }\end{array}$ & $\begin{array}{l}\text { Impuestos recaudados como porcentaje de los impuestos } \\
\text { facturados }\end{array}$ \\
\hline & \multirow{7}{*}{$\begin{array}{l}\text { Manejo del } \\
\text { gasto }\end{array}$} & \multirow{5}{*}{$\begin{array}{l}\text { Control del } \\
\text { gasto }\end{array}$} & $\begin{array}{l}\text { Existencia de indicadores de desempeño y metas para } \\
\text { seguimiento de ejecución del presupuesto }\end{array}$ \\
\hline & & & Presupuesto bruto operativo \\
\hline & & & Presupuesto bruto de capital \\
\hline & & & Tasa de crecimiento anual del gasto operativo \\
\hline & & & Tasa de crecimiento anual del gasto de capital \\
\hline & & \multirow{2}{*}{$\begin{array}{l}\text { Inversión } \\
\text { pública } \\
\text { municipal }\end{array}$} & Gasto de la inversión fija bruta como porcentaje del PIB local \\
\hline & & & El presupuesto está alineado con la planificación, sus \\
\hline
\end{tabular}




\begin{tabular}{|c|c|c|c|}
\hline \multicolumn{4}{|c|}{ INICIATIVA ICES BID } \\
\hline $\begin{array}{l}\text { DIMENS } \\
\text { IÓN }\end{array}$ & TEMA & subtema & INDICADOR EVALUADO \\
\hline & & & objetivos e indicadores \\
\hline & & \multirow{2}{*}{$\begin{array}{l}\text { Agencias y } \\
\text { empresas } \\
\text { públicas }\end{array}$} & $\begin{array}{c}\text { Recuperación de costos de empresas municipales de } \\
\text { provisión de servicios }\end{array}$ \\
\hline & & & $\begin{array}{l}\text { Agencias municipales cuyas cuentas son auditadas por } \\
\text { terceros }\end{array}$ \\
\hline & $\begin{array}{c}\text { Pasivos } \\
\text { contingent } \\
\text { es } \\
\end{array}$ & $\begin{array}{l}\text { Pensiones } \\
\text { municipales }\end{array}$ & $\begin{array}{c}\text { Activos acumulados de pensión / obligaciones } \\
\text { correspondientes a pensión }\end{array}$ \\
\hline & \multirow{4}{*}{ Deuda } & \multirow{4}{*}{$\begin{array}{l}\text { Sostenibilidad } \\
\text { de la deuda } \\
\text { municipal }\end{array}$} & Coeficiente del servicio de la deuda \\
\hline & & & Deuda total como porcentaje de ingresos totales \\
\hline & & & Crecimiento anual del servicio de la deuda \\
\hline & & & Crecimiento de la deuda \\
\hline
\end{tabular}

Tabla 45. Iniciativa ISO/IWA 4

\begin{tabular}{|c|c|c|}
\hline \multicolumn{3}{|c|}{ INICIATIVA ISO/IWA 4} \\
\hline $\begin{array}{c}\text { CUADRA } \\
\text { NTE }\end{array}$ & INDICADOR EVALUADO & Subindicador \\
\hline \multirow{12}{*}{ 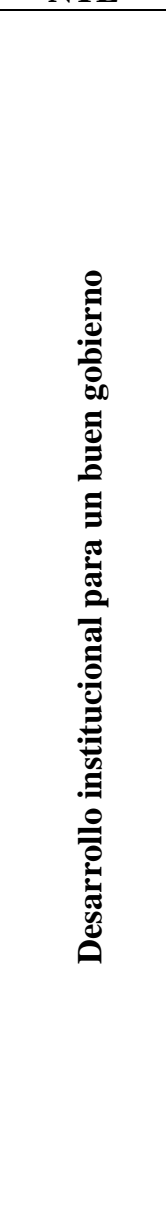 } & \multirow[t]{2}{*}{$\begin{array}{c}\text { 1.1 Gobernar responsablemente y } \\
\text { con una buena Gestión de la } \\
\text { Calidad }\end{array}$} & $\begin{array}{l}\text { 1.1.1 Eficacia respecto a las metas del Plan de } \\
\text { Desarrollo Local. }\end{array}$ \\
\hline & & $\begin{array}{l}\text { 1.1.2 Eficiencia de los recursos girados con relación al } \\
\text { avance programático. }\end{array}$ \\
\hline & 1,2 Asociado, vinculado y solidario & $\begin{array}{l}\text { 1.2.1 Capacidad de Articulación con las Entidades } \\
\text { Distritales }\end{array}$ \\
\hline & \multirow{2}{*}{$\begin{array}{c}1,3 \text { Competencia y continuidad de } \\
\text { los servidores públicos }\end{array}$} & 1.3.1 Suficiencia de los Servidores Públicos \\
\hline & & 1.3.2 Continuidad de los servidores públicos \\
\hline & \multirow[b]{2}{*}{$\begin{array}{l}\text { 1,4 Participación de la comunidad } \\
\text { en políticas públicas y programas }\end{array}$} & $\begin{array}{l}\text { 1.4.1 Consulta a la ciudadanía para la definición de } \\
\text { políticas y programas. }\end{array}$ \\
\hline & & $\begin{array}{c}\text { 1.4.2 Participación de la sociedad civil en el control y } \\
\text { seguimiento a la Gestión Pública. }\end{array}$ \\
\hline & 1,5 Fiscalmente responsable & $\begin{array}{l}\text { 1.5.1 Sistema de Seguimiento a la recaudación por } \\
\text { multas y sanciones }\end{array}$ \\
\hline & $\begin{array}{l}\text { 1,6 Promotor de la protección civil } \\
\text { y de los servicios de emergencia }\end{array}$ & 1.6.1 Sistema Local de Gestión del Riesgo. \\
\hline & $\begin{array}{l}1,7 \text { Uso de las tecnologías de la } \\
\text { información y comunicaciones }\end{array}$ & 1.7.1 Herramienta Tecnológica de Información \\
\hline & $\begin{array}{l}\text { 1,8 Marco legal transparente y } \\
\text { actulizado }\end{array}$ & 1.8.1 Atención y orientación al ciudadano. \\
\hline & $\begin{array}{c}1,9 \text { El estado de derecho prevalece } \\
\text { en el territorio local }\end{array}$ & 1.9.1 Facilidad en el acceso a las instancias de justicia. \\
\hline
\end{tabular}




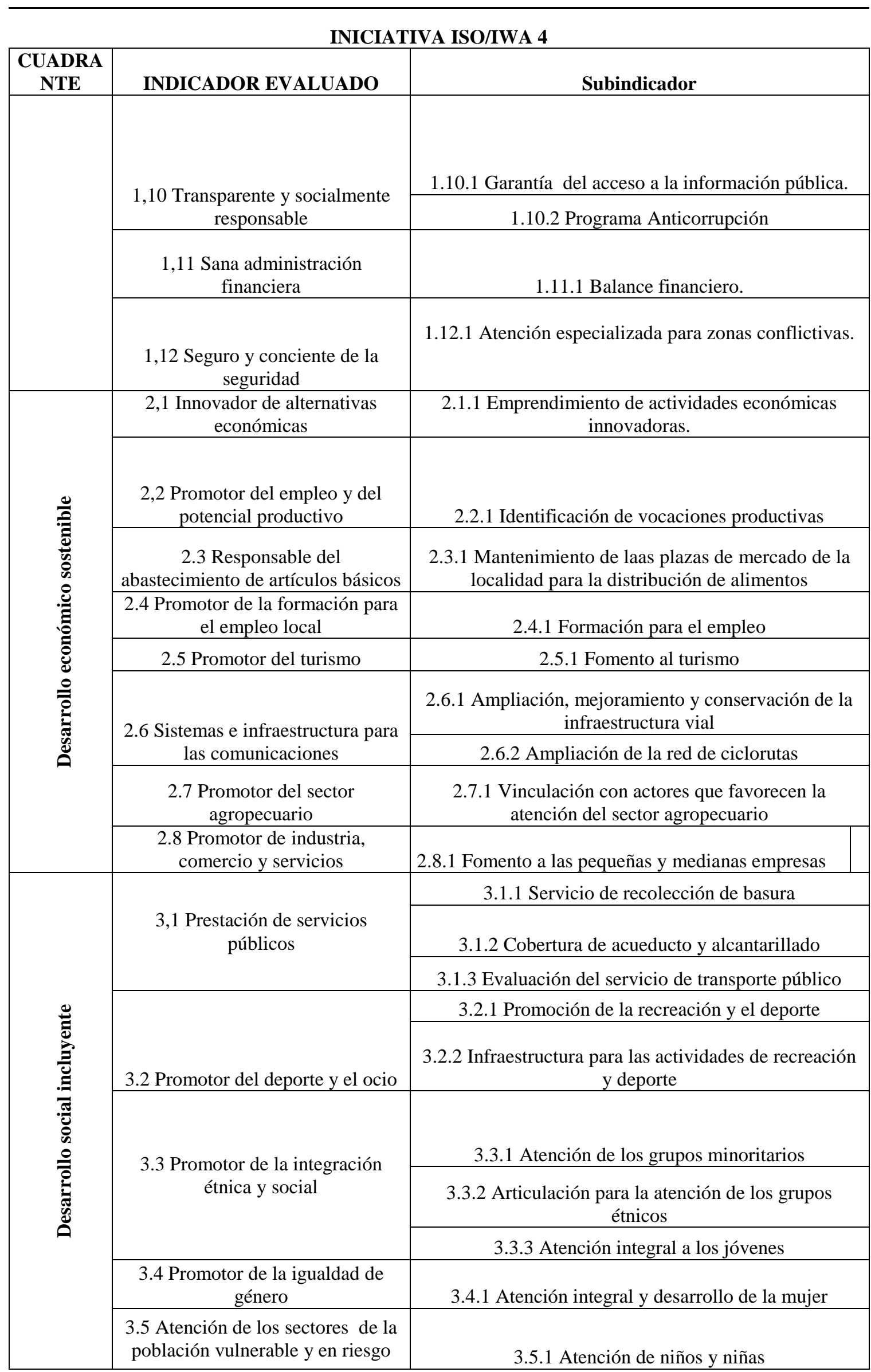




\begin{tabular}{|c|c|c|}
\hline \multicolumn{3}{|c|}{ INICIATIVA ISO/IWA 4} \\
\hline \multirow[t]{16}{*}{$\begin{array}{l}\text { CUADRA } \\
\text { NTE }\end{array}$} & \multirow[t]{6}{*}{ INDICADOR EVALUADO } & Subindicador \\
\hline & & 3.5.2 Atención de habitantes de y en calle \\
\hline & & 3.5.3 Atención de adultos mayores \\
\hline & & 3.5.4 Atención de personas con discapacidad \\
\hline & & 3.5.5 Atención de la violencia familiar \\
\hline & & $\begin{array}{l}\text { 3.5.6 Atención de familias instaladas en lugares de alto } \\
\text { riesgo }\end{array}$ \\
\hline & \multirow{2}{*}{ 3.6 Promotor de la salud pública } & 3.6.1 Programas de salud \\
\hline & & 3.6.2 Vinculación saludable \\
\hline & \multirow{2}{*}{$\begin{array}{l}\text { 3.7 Promotor de la educación } \\
\text { básica }\end{array}$} & 3.7.1 Situación educativa en las localidades \\
\hline & & $\begin{array}{l}\text { 3.7.2 Seguimiento al logro escolar mediante pruebas } \\
\text { estandarizadas }\end{array}$ \\
\hline & 3.8 Fomento de la vivienda digna & 3.8.1 Gestión de los programas en materia de vivienda \\
\hline & \multirow{2}{*}{$\begin{array}{l}\text { 3.9 Promotor de la responsabilidad } \\
\text { cívica }\end{array}$} & 3.9.1 Sana convivencia ciudadana \\
\hline & & 3.9.2 Derechos y obligaciones de los ciudadanos \\
\hline & $\begin{array}{l}\text { 3.10 Promotor de la cultura y el } \\
\text { patrimonio histórico }\end{array}$ & $\begin{array}{c}\text { 3.10.1 Actividades artísticas, culturales, de } \\
\text { conocimiento del patrimonio histórico y de divulgación } \\
\text { científica }\end{array}$ \\
\hline & \multirow{2}{*}{$\begin{array}{l}\text { 3.11 Responsable del combate } \\
\text { contra la pobreza }\end{array}$} & $\begin{array}{l}\text { 3.11.1 Apoyos económicos para personas en situación } \\
\text { de pobreza }\end{array}$ \\
\hline & & $\begin{array}{c}\text { 3.11.2 Coordinación intergubernamental para el } \\
\text { combate de la pobreza }\end{array}$ \\
\hline \multirow{8}{*}{ 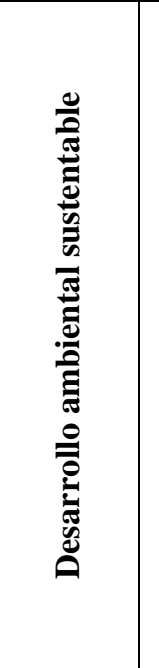 } & 4.1 cuidadoso de la calidad del aire & $\begin{array}{l}\text { 4.1.1 Difusión de resultados del monitoreo en la } \\
\text { calidad del aire }\end{array}$ \\
\hline & $\begin{array}{l}\text { 4.2 Responsable de la recolección } \\
\text { de residuos sólidos y su } \\
\text { disposición final }\end{array}$ & $\begin{array}{l}\text { 4.2.1 Separación, reutilización y reciclaje de residuos } \\
\text { sólidos urbanos }\end{array}$ \\
\hline & $\begin{array}{l}\text { 4.3 Atención de la imagen del } \\
\text { entorno del gobierno local }\end{array}$ & 4.3.1 Normatividad en materia de espacio público \\
\hline & $\begin{array}{l}\text { 4.4 Protector de sus recursos } \\
\text { naturales }\end{array}$ & $\begin{array}{l}\text { 4.4.1 cuidado, protección y mantenimiento de los } \\
\text { recursos naturales }\end{array}$ \\
\hline & $\begin{array}{l}\text { 4.5 Sistema de ordenamiento } \\
\text { territorial eficaz }\end{array}$ & 4.5.1 Plan de ordenamiento territorial \\
\hline & 4.6 Responsable del agua & 4.6.1 Promoción de cultura de cuidado del agua \\
\hline & $\begin{array}{l}\text { 4.7 Cuidadoso y responsable del } \\
\text { suelo }\end{array}$ & $\begin{array}{l}\text { 4.7.1 Vigilancia, inspección y sanción para el cuidado } \\
\text { del suelo }\end{array}$ \\
\hline & $\begin{array}{l}\text { 4.8 Promotor de la educación } \\
\text { ambiental }\end{array}$ & $\begin{array}{l}\text { 4.8.1 Sanciones por violación a la normatividad } \\
\text { ambiental }\end{array}$ \\
\hline
\end{tabular}


Tabla 46. Iniciativa de evaluación de la Red de Ciudades Cómo Vamos

\begin{tabular}{|c|c|c|}
\hline \multicolumn{3}{|c|}{ EJERCICIO BOGOTÁ CÓMO VAMOS } \\
\hline $\begin{array}{c}\text { INDICAD } \\
\text { OR } \\
\end{array}$ & VARIABLES & QUÉ MIDE \\
\hline \multirow[t]{3}{*}{$\begin{array}{c}\text { En } \\
\text { Educación }\end{array}$} & $\begin{array}{l}\text { Tasa de cobertura neta } \\
\text { Calificación promedio de pruebas de } \\
\text { logro educativo }\end{array}$ & \multirow{3}{*}{$\begin{array}{c}\text { Cambios en la cobertura, calidad y percepción } \\
\text { del servicio }\end{array}$} \\
\hline & Porcentaje de conocimiento de valores & \\
\hline & Calificación ciudadana al servicio & \\
\hline \multirow{4}{*}{ En salud } & Tasa de cobertura del régimen de salud & \multirow[b]{4}{*}{$\begin{array}{c}\text { Cambios en la cobertura, calidad y percepción } \\
\text { del servicio }\end{array}$} \\
\hline & Tasa de mortalidad materna & \\
\hline & $\begin{array}{l}\text { Tasa de mortalidad de menores de } 5 \text { años } \\
\text { por EDA e IRA }\end{array}$ & \\
\hline & Calificación ciudadana al servicio & \\
\hline \multirow{4}{*}{$\begin{array}{l}\text { En } \\
\text { vivienda y } \\
\text { servicios }\end{array}$} & Déficit de vivienda prioritaria & \multirow{4}{*}{$\begin{array}{c}\text { Cambios en el déficit de vivienda prioritaria y en } \\
\text { la cobertura de agua potable y saneamiento y } \\
\text { percepción }\end{array}$} \\
\hline & Tasa de cobertura de acueducto & \\
\hline & $\begin{array}{l}\text { Tasa de cobertura de alcantarillado } \\
\text { sanitario y pluvial }\end{array}$ & \\
\hline & Calificación ciudadana al servicio & \\
\hline \multirow{4}{*}{$\begin{array}{l}\text { En Medio } \\
\text { Ambiente }\end{array}$} & $\begin{array}{l}\text { No. Datos que sobrepasan los niveles de } \\
\text { Ley por cada contaminante del aire }\end{array}$ & \\
\hline & $\begin{array}{l}\text { Porcentaje de aguas tratadas por } \\
\text { industrias }\end{array}$ & \\
\hline & Nivel de arborización y áreas verdes & \multirow[b]{2}{*}{$\begin{array}{l}\text { Cambios en niveles de contaminación y } \\
\text { percepción }\end{array}$} \\
\hline & Percepción ciudadana de contaminación & \\
\hline \multirow[b]{2}{*}{$\begin{array}{l}\text { En } \\
\text { Movilidad } \\
\text { Vial }\end{array}$} & Tiempo promedio de movilidad vial & \multirow[b]{2}{*}{$\begin{array}{l}\text { Cambios en los tiempos de movilidad vial y } \\
\text { percepción }\end{array}$} \\
\hline & $\begin{array}{c}\text { Percepción ciudadana de cambios en la } \\
\text { movilidad, calidad del servicio, estado } \\
\text { de vías y manejo del tráfico }\end{array}$ & \\
\hline \multirow{3}{*}{$\begin{array}{l}\text { En Espacio } \\
\text { Público }\end{array}$} & Porcentaje de malla vial en buen estado & \multirow{3}{*}{$\begin{array}{l}\text { Cambios en la cantidad de espacio público } \\
\text { peatonal por habitante y en la cobertura de la } \\
\text { malla vial en buen estado y percepción }\end{array}$} \\
\hline & Tasa de cobertura troncales Transmilenio & \\
\hline & Tasa de cobertura Red de Ciclorutas & \\
\hline
\end{tabular}




\begin{tabular}{|c|c|c|}
\hline \multicolumn{3}{|c|}{ EJERCICIO BOGOTÁ CÓMO VAMOS } \\
\hline $\begin{array}{l}\text { INDICAD } \\
\text { OR }\end{array}$ & VARIABLES & QUÉ MIDE \\
\hline \multirow{4}{*}{$\begin{array}{c}\text { En } \\
\text { seguridad } \\
\text { ciudadana }\end{array}$} & Tasa de homicidios & \multirow{4}{*}{$\begin{array}{l}\text { Cambios en los índices de homicidio, } \\
\text { victimización y percepción sobre la inseguridad }\end{array}$} \\
\hline & Índice de victimización & \\
\hline & Tasa de no denuncia & \\
\hline & Percepción ciudadana de inseguridad & \\
\hline \multirow{5}{*}{$\begin{array}{c}\text { En } \\
\text { responsabil } \\
\text { idad } \\
\text { Ciudadana } \\
\end{array}$} & Tasa de accidentalidad & \multirow[b]{5}{*}{$\begin{array}{c}\text { Cambios en el comportamiento ciudadano según } \\
\text { niveles y consecuencias a desacato a la Ley }\end{array}$} \\
\hline & Número de comparendos & \\
\hline & Muertes por abusos de alcohol & \\
\hline & Nivel de evasión & \\
\hline & $\begin{array}{l}\text { Percepción ciudadana sobre } \\
\text { responsabilidad y solidaridad }\end{array}$ & \\
\hline $\begin{array}{l}\text { En Gestión } \\
\text { Pública }\end{array}$ & $\begin{array}{c}\text { Percepción ciudadana sobre imagen, } \\
\text { gestión, confianza en las entidades } \\
\text { públicas del Distrito }\end{array}$ & $\begin{array}{l}\text { Cambios en percepción sobre la administración } \\
\text { pública, sus funcionarios y las alcaldías locales }\end{array}$ \\
\hline \multirow{2}{*}{$\begin{array}{c}\text { En } \\
\text { Finanzas } \\
\text { Públicas } \\
\end{array}$} & $\begin{array}{c}\text { Índices de capacidad de pago y } \\
\text { sostenibilidad de la deuda }\end{array}$ & \multirow[b]{2}{*}{$\begin{array}{l}\text { Cambios en los índices de finanzas sanas y en las } \\
\text { calificaciones internacionales de riesgo crediticio }\end{array}$} \\
\hline & $\begin{array}{l}\text { Indicadores Duff and Phelps, Fitch y } \\
\text { Estándar\&Poor }\end{array}$ & \\
\hline \multirow{4}{*}{$\begin{array}{c}\text { En } \\
\text { Desarrollo } \\
\text { Económico }\end{array}$} & Tasa de crecimiento del PIB & \multirow[b]{4}{*}{$\begin{array}{l}\text { Cambios en productividad, competitividad y } \\
\text { mercado laboral }\end{array}$} \\
\hline & $\begin{array}{c}\text { Tasas de ocupación, subempleo y } \\
\text { desempleo }\end{array}$ & \\
\hline & Tasa de crecimiento de las exportaciones & \\
\hline & $\begin{array}{l}\text { Percepción ciudadana de situación } \\
\text { económica familiar }\end{array}$ & \\
\hline
\end{tabular}

Tomando en consideración los valiosos aportes que se realizan a partir de los anteriores insumos, construidos en el marco de importantes experiencias de evaluación de políticas públicas; se logró establecer un marco amplio de análisis que posibilitó la consecución de índices importantes e interesantes para ser valorados en la experiencia del municipio de Sacaba en Cochabamba. Como se mencionó en líneas anteriores, esta constituye una propuesta que deberá ser analizada por el grupo permanente de trabajo en la Gestión Asociada del Territorio GAT aplicada a evaluación de políticas públicas y control social en el municipio de Sacaba. A continuación, se muestra el mapeo de los siete ejes del Plan Departamental de Cochabamba para Vivir Bien y sus áreas de trabajo, posteriormente se presentarán los indicadores para cada área de trabajo. 


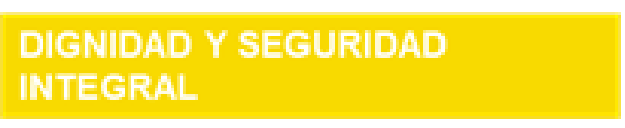

IDENTIDADES Y CULTURAS

SABERES,CIENCIA Y

TECNOLOGIA

PRODUCCIÓN E INDUSTRIA EN

ECONOMIA PLURAL

POLITICO, AUTONÓMICO E

INSTITUCIONAL

AGUA Y SEGURIDAD

ALIMENTARIA

\section{MADRE TIERRA}

Ejes del plan
Salud, Educación, Deportes, Vivienda,

Servicios básicos, seguridad

Saberes y lenguas en las comunidades

Ciencia, tecnologia

Industria, producción agropecuaria, turismo,
mineria, transporte, empleo, ingresos

Procesos autonómicos, gestión

pública, transparencia

Implementación proyectos agua, uso integral
y sostenible, para consumo, para riego

Preservación sistemas de vida,

componentes sustentables.

\section{Áreas de desarrollo de los ejes}

Fuente: Elaboración propia, 2016.

Figura 74. Estructura sistema de indicadores propuesta para evaluación y control social a la gestión pública municipal

A partir de la estructura de trabajo planteada se determinarán un conjunto de indicadores para desarrollar la evaluación a la gestión pública local en Sacaba. Se tomará en cuenta el planteamiento que se realiza en el plan en mención y desde allí en cada área de desarrollo se señalarán cuáles podrían llegar a ser indicadores de orientación para la evaluación. Sin embargo, destacar que dicha herramienta se ampliará una vez estudiada por la GAT y desde allí cobrará mucho más sentido en tanto terminará de plantearse como pertinente a la realidad actual del municipio en mención, se considera que este proceso enriquecerá el quehacer de la gestión local, así como el fortalecimiento del trabajo asociado, conjunto y cooperativo entre los actores locales, instituciones, sociedad civil, organizaciones sociales entre otros. 
Tabla 47. Propuesta indicadores

\section{INDICADORES EJE DIGNIDAD Y SEGURIDAD INTEGRAL}

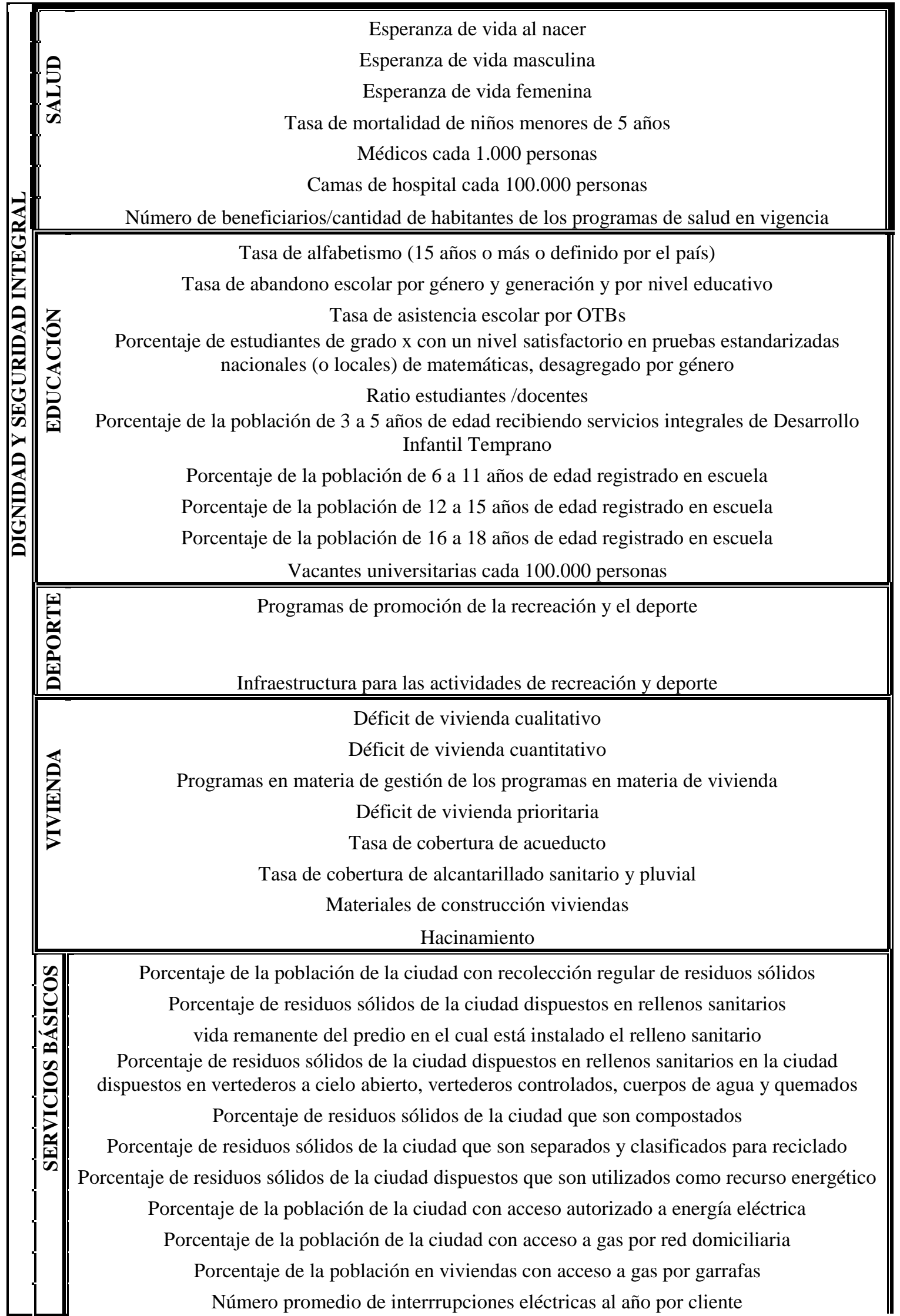


INDICADORES EJE DIGNIDAD Y SEGURIDAD INTEGRAL

\begin{tabular}{|c|c|}
\hline & $\begin{array}{c}\text { Duración promedio de interrupciones eléctricas } \\
\text { Consumo anual de energía per cápita } \\
\text { Intensidad energética de la economía } \\
\text { Existencia, monitoreo y cumplimiento de regulaciones de eficiencia energética } \\
\text { Porcentaje de energías renovables sobre el total del consumo eléctrico } \\
\text { Uso de energía de fuentes renovables no convencionales } \\
\text { Servicio de recolección de basura } \\
\text { Cobertura de acueducto y alcantarillado } \\
\text { Evaluación del servicio de transporte público }\end{array}$ \\
\hline 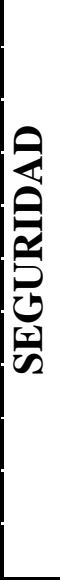 & $\begin{array}{l}\text { Tasa de homicidios } \\
\text { Taza de victimización de homicidios de personas entre } 15 \text { y } 24 \text { años de edad } \\
\text { Homicidios perpetrados por población joven (entre } 15 \text { y } 24 \text { años) } \\
\text { Porcentaje de homicidios de mujeres debido a la violencia doméstica } \\
\text { Robo con violencia (rapiña) cada } 100.000 \text { habitantes } \\
\text { Robos con violencia (rapiña) por población joven (entre } 15 \text { y } 24 \text { años) } \\
\text { Hurto cada } 100.000 \text { habitantes } \\
\text { Hurtos perpetrados por población joven (entre } 15 \text { y } 24 \text { años) } \\
\text { Ciudadanos que se sienten seguros } \\
\text { Percepción ciudadana de la honestidad de la policía } \\
\text { Uso de la participación ciudadana en la definición de políticas locales de seguridad }\end{array}$ \\
\hline
\end{tabular}

\begin{tabular}{|c|c|c|}
\hline & \multirow{4}{*}{$\begin{array}{c}\text { Atención diferencial y } \\
\text { generacional }\end{array}$} & Programas de articulación para la atención de los grupos étnicos \\
\hline & & Programas Atención de adultos mayores \\
\hline & & Programas de atención integral a los jóvenes \\
\hline & & Programas de atención de niños y niñas \\
\hline \multirow{7}{*}{ 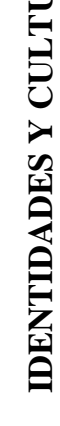 } & Enfoque de género & Programas de atención integral y desarrollo de la mujer \\
\hline & \multirow[b]{4}{*}{$\begin{array}{l}\text { Situaciones de vulnerabilidad } \\
\text { social }\end{array}$} & Programas de Atención de habitantes de y en calle \\
\hline & & Atención de personas con discapacidad \\
\hline & & Programas Atención de la violencia familiar \\
\hline & & $\begin{array}{l}\text { Programas Atención de familias instaladas en lugares de alto } \\
\text { riesgo }\end{array}$ \\
\hline & \multirow[b]{2}{*}{ Enfoque pluricultural } & porcentaje de auto identificación a comunidades étnicas \\
\hline & & Porcentaje de población que habla diversas lenguas \\
\hline
\end{tabular}

\begin{tabular}{|l|c|}
\hline & Subscripciones a internet de Banda Ancha Fija (para cada 100 hab) \\
\cline { 2 - 3 } SABERES; CYT & Subscripciones a internet de Banda Ancha Móvil (para cada 100 hab) \\
\cline { 2 - 2 } & Número de subscripciones de teléfonos móviles (para cada 100 hab) \\
\hline
\end{tabular}




\begin{tabular}{|c|c|}
\hline \multirow{14}{*}{ 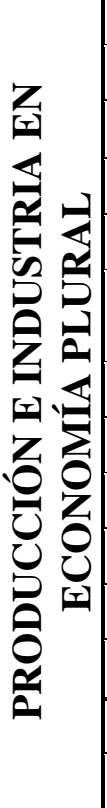 } & PIB per cápita de la ciudad \\
\hline & Tasa de desempleo (promedio anual) \\
\hline & Empleo informal como \% del empleo total \\
\hline & Emprendimiento de actividades económicas innovadoras. \\
\hline & Identificación de vocaciones productivas \\
\hline & Mantenimiento de las plazas de mercado de la localidad para la distribución de alimentos \\
\hline & Formación para el empleo \\
\hline & Vinculación con actores que favorecen la atención del sector agropecuario \\
\hline & Fomento a las pequeñas y medianas empresas \\
\hline & Tasa de crecimiento del PIB \\
\hline & Tasas de ocupación, subempleo y desempleo \\
\hline & Posee un plan de usos del territorio activamente implementado \\
\hline & Existencia de planes integrales o sectoriales estratégicos con visión de largo plazo \\
\hline & Fomento al turismo \\
\hline
\end{tabular}

\begin{tabular}{|c|c|}
\hline \multirow{19}{*}{ 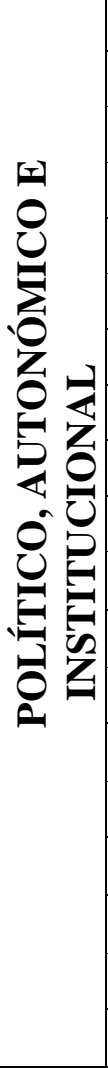 } & Existencia de proceso de planificación participativa \\
\hline & Existencia de presupuesto participativo \\
\hline & Sesiones públicas de rendición de cuentas por año \\
\hline & Existencia de presupuesto plurianual \\
\hline & Remuneración del personal basado en un sistema de indicadores de desempeño \\
\hline & Existencia de sistemas electrónicos para el seguimiento de la gestión de la municipalidad \\
\hline & Transparency Index \\
\hline & Cuentas de la municipalidad auditadas \\
\hline & Existencia de sistemas electrónicos para el seguimiento de la gestión de la municipalidad \\
\hline & Eficacia respecto a las metas del Plan de Desarrollo Local. \\
\hline & Eficiencia de los recursos girados con relación al avance programático. \\
\hline & Capacidad de Articulación con las Entidades Departamentales \\
\hline & Suficiencia de los Servidores Públicos \\
\hline & Continuidad de los servidores públicos \\
\hline & Consulta a la ciudadanía para la definición de políticas y programas. \\
\hline & Participación de la sociedad civil en el control y seguimiento a la Gestión Pública. \\
\hline & Atención y orientación al ciudadano. \\
\hline & Garantía del acceso a la información pública. \\
\hline & Programa Anticorrupción \\
\hline
\end{tabular}




\begin{tabular}{|c|c|}
\hline \multirow{12}{*}{ 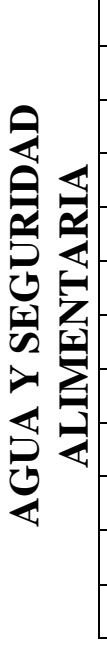 } & Porcentaje de hogares con conexiones domicialiarias de agua por red, por cañería \\
\hline & Consumo anual de agua per cápita \\
\hline & Continuidad servicio de agua \\
\hline & calidad de agua \\
\hline & Agua no contabilizada \\
\hline & Implementación de proyectos destinados a promover uso integral del agua \\
\hline & Rehuso del agua \\
\hline & Promoción de cultura del cuidado del agua \\
\hline & Cobertura SEMAPA \\
\hline & Cobertura de agua para riego \\
\hline & Iniciativas de agricultura familiar, campesina y urbana apoyados \\
\hline & Alternativas de sistemas de riego tecnificado implementados en el municipio \\
\hline
\end{tabular}

\begin{tabular}{|c|c|}
\hline & $\begin{array}{c}\text { Existencia de mapas de riesgo de la ciudad a escala de al menos 1:10000 que incluyan información } \\
\text { sobre amenazas naturales (geofísicas e hidrometeorológicas) y análisis de vulnerabilidad }\end{array}$ \\
\hline $\begin{array}{c}\text { Existencia de mapas de amenazas hidroclimáticas, incluyendo los efectos esperados del cambio } \\
\text { climático, a 2050 y final de siglo }\end{array}$ \\
\hline Existencia de planes de contingencia adecuados para desastres naturales \\
\hline Existencia de sistemas de alerta temprana efectivos \\
\hline Existencia de plan efectivo de gestión del riesgo de desastres \\
\hline Existencia de plan efectivo y actualizado de adaptación al cambio climático \\
\hline Asignación de presupuesto municipal a la gestión del riesgo de desastres \\
\hline \begin{tabular}{c} 
Los principales instrumentos de planificación de la ciudad incorporan el análisis de riesgos \\
\hline Infraestructura crítica (ej. agua, energía, etc.) en riesgo debido a construcción inadecuada y/o \\
ubicación en áreas con riesgo no mitigable
\end{tabular} \\
\hline Porcentaje de viviendas en riesgo debido a construcción inadecuada \\
\hline Población que vive en asentamientos informales \\
\hline Viviendas en asentamientos informales \\
\hline Tasa de crecimiento anual de la huella urbana (física), dentro de los limites oficiales del municipio \\
\hline Densidad (neta) de la población urbana \\
\hline Difusión de resultados del monitoreo en la calidad del aire \\
\hline Separación, reutilización y reciclaje de residuos sólidos urbanos \\
\hline Normatividad en materia de espacio público \\
\hline cuidado, protección y mantenimiento de los recursos naturales \\
\hline Plan de ordenamiento territorial \\
\hline Sanciones por violación a la normatividad ambiental \\
\hline
\end{tabular}




\subsection{Cronograma de trabajo tentativo}

Al constituirse ésta como una propuesta que entraña la construcción y fortalecimiento de procesos sociales territoriales en el nivel local, se considera que es importante aclarar que en ocasiones resulta difícil plantear los tiempos exactos en que dichas experiencias se consolidarán, sin embargo y tomando como referencia la experiencia de la ciudad de Bogotá se plantea un cronograma tentativo para dos años de trabajo.
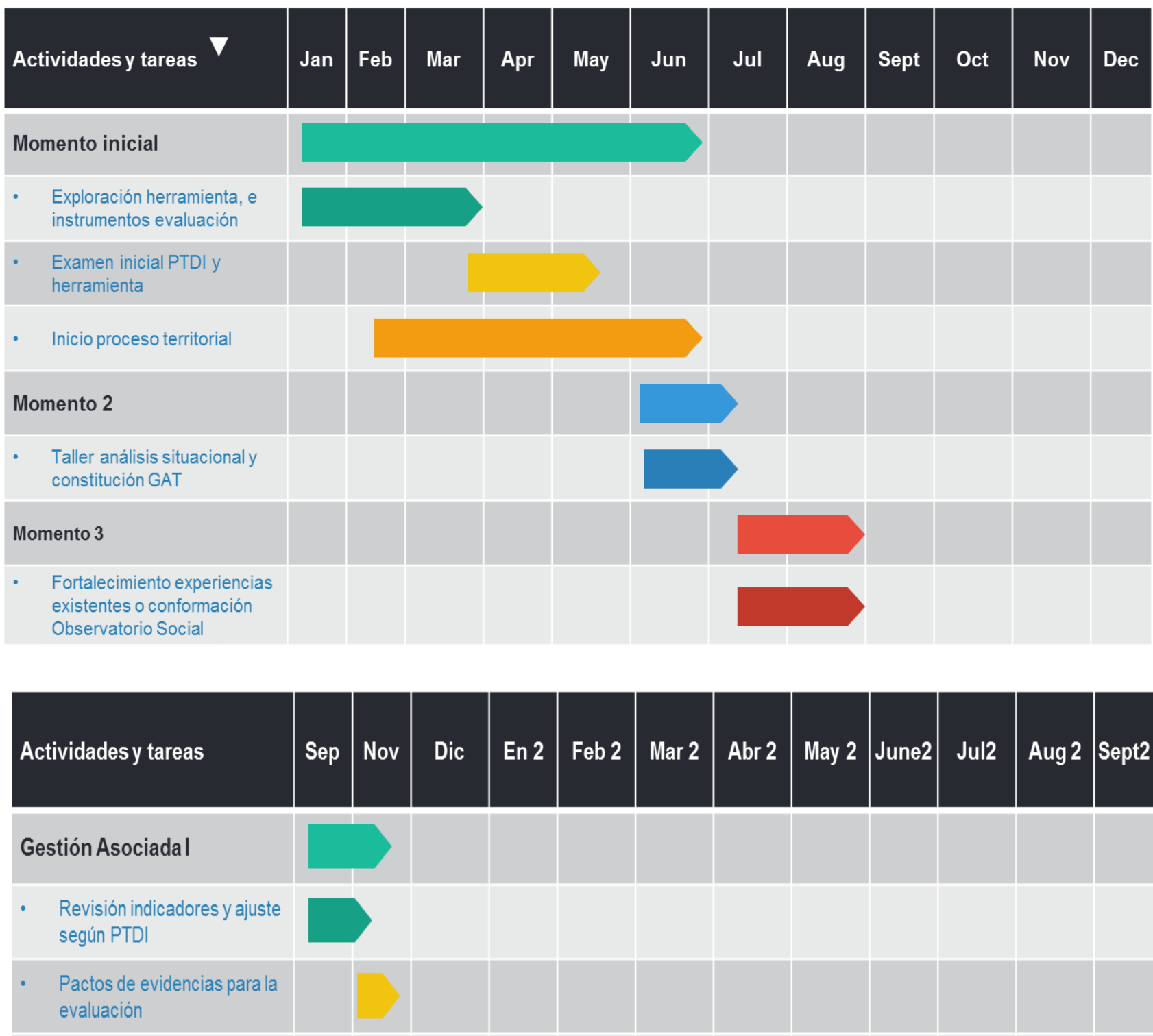

Gestión Asociada II

- Valoración de la gestión pública con evidencias

- Construcción documento resutlado de evaluación

Gestión Asociada III

- Presentación a la GAT de resultados 


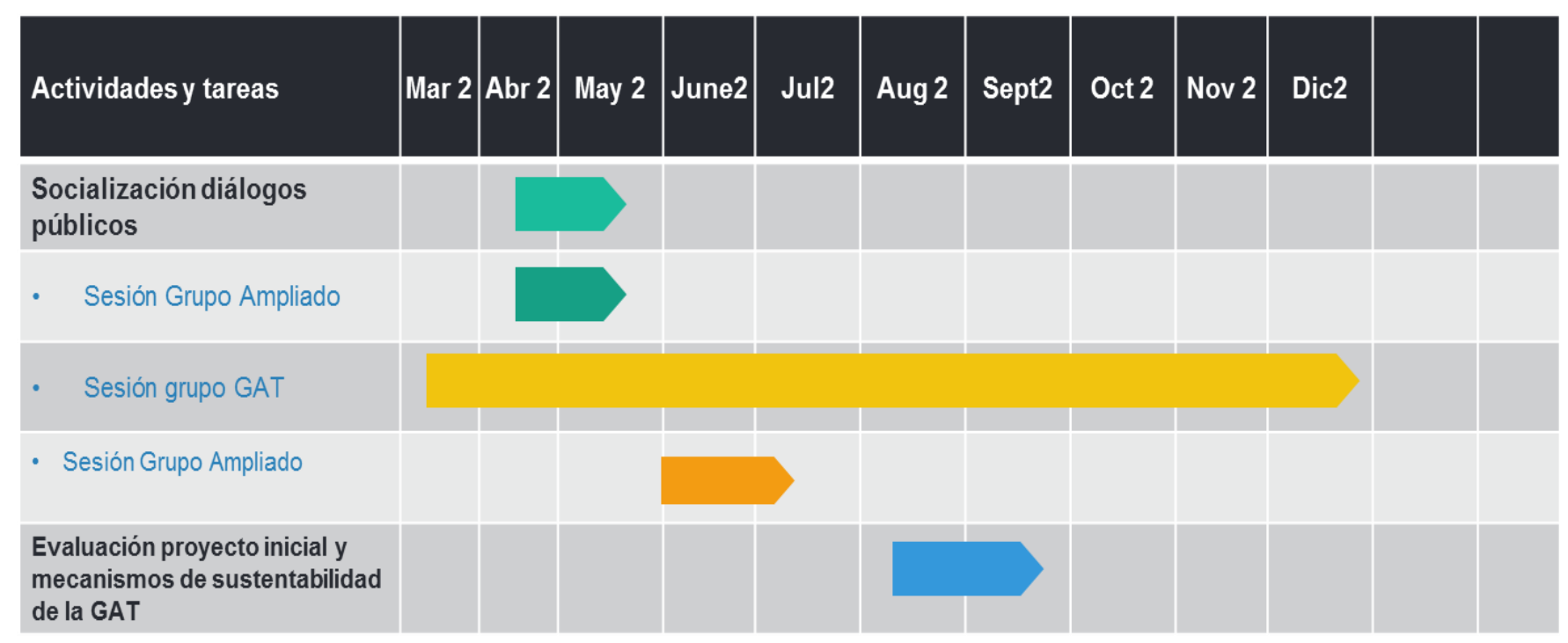

\subsection{Síntesis}

En este capítulo, se presentó una propuesta de fortalecimiento de la incidencia ciudadana a través del control social a la gestión pública en ámbitos locales, en este caso la escala municipal de Sacaba. Dicha propuesta surgió a partir del trabajo desarrollado desde 2013 en el tema de evaluación de políticas públicas y control social, la estrategia de acción se enriqueció entonces a partir de la experiencia de fortalecimiento del control social a la gestión pública de Bogotá adelantada 2013-2014, en donde la autora participó como investigadora principal y consultora.

La propuesta está conformada por dos ejes, el primero de ellos la construcción de un sistema de gestión y trabajo permanente de Gestión Asociada del Territorio para la cualificación de la evaluación y control social a políticas públicas locales y el segundo eje de trabajo lo constituye una propuesta tentativa de indicadores de valoración de la gestión pública municipal, para lo que se retomaron como antecedentes los resultados de ejercicios de análisis de iniciativas de evaluación tales como: la iniciativa ciudades emergentes del BID; la iniciativa de la Red de Ciudades Como Vamos y la herramienta IWA 4 O ISO 18091.

El escenario propuesto busca que los actores aúnen esfuerzos en torno a valorar la actualidad de la gestión pública en la escala municipal y a partir de allí, se logre consolidar un sistema de evaluación, planificación y gestión permanente de los asuntos públicos municipales en Sacaba. Sistema que evidentemente se plantea como objetivo el de lograr incidencia en la toma de decisiones y políticas públicas. De esta manera, se hace necesario que las instancias y experiencias existentes en la actualidad, se fortalezcan para potenciar las capacidades ciudadanas e institucionales, así como los escenarios de cambio social y la agencia social de los ciudadanos.

La propuesta que se plantea se enmarca en el enfoque de las Metodologías de Planificación Participativa y Gestión Asociada PPGA, cuyo fundamento teórico de 
soporte fue abordado en el capítulo II del presente documento. El proceso planteado constituye una dinámica social compleja, que requiere de unas condiciones y prerequisitos para su configuración; dentro de los requisitos están voluntad política para participar y poner en práctica la estrategia planteada, disponibilidad de metodologías específicas y disposición para participar.

Debe existir la disposición de los actores por la construcción colectiva, por el trabajo articulado y conjunto, de lo contrario no habría espacio para la generación de esfuerzos colectivos y la co-construcción. Se evidencia que éste es un escenario de trabajo que se relaciona mucho con el construccionismo social, se habla de lo común, el trabajo articulado, los esfuerzos comunales y comunes, para ello es condición sine qua non la voluntad política de los actores que se integran al sistema GAT. Es importante mencionar que este contexto, representa una forma diferente a la tradicional para trabajar la planificación y cualquier momento del ciclo de política pública, rehúye los cánones tradicionalistas para funcionar, trascendiendo a un espacio en el que se desea funcionar de una manera diferente, por lo cual la parte metodológica resulta indispensable, está claro que se quiere cambiar el paradigma de trabajo en el hacer y quehacer de las políticas, pero surge un interrogante por el ¿Cómo hacerlo? Dicho cuestionamiento entraña aspectos referentes a lo metodológico, para solventar esta inquietud la PPGA aporta un conjunto de metodologías susceptibles de combinarse para producir el efecto transformador y deseado.

La propuesta de fortalecimiento de capacidades ciudadanas para el control social debería estar alineada entonces con el recién -a 2017- formulado PTDI, la cuestión es que en la actualidad dicho documento todavía no está disponible para su circulación pública, puesto que a fines de 2016 se estaba culminando el proceso de su construcción a partir de los lineamientos de la Ley 777 dictados en enero de 2016. En este sentido, se plantearán indicadores que sean compatibles con la escala municipal en concordancia con los siete ejes del Plan Departamental de Cochabamba para Vivir Bien 2013-2017, considerando que se articularía entonces con lo planteado en el reciente PTDI.

Los ejes entonces de la propuesta y que articulan el Plan Departamental son: dignidad y seguridad integral; identidades y culturas; saberes, ciencia y tecnología; producción e industria en economía plural; agua y seguridad alimentaria; madre tierra y político, autonómico e institucional. Desde los mencionados ejes se desarrolló la propuesta de indicadores técnicos, claro está que cada eje tiene sub ejes temáticos que igualmente se plantearon en esta estrategia. Pero cabe destacar, que la principal propuesta de este apartado fue la de la estructuración de un sistema de trabajo permanente de Gestión Asociada del Territorio para la cualificación de la evaluación de políticas públicas y el control social a las políticas públicas locales, ello se resalta ya que es allí en donde finalmente debe establecerse la batería de indicadores finales a ser implementados en el proceso de valoración participativa y cogestiva. 



\section{CAPÍTULO 8. SÍNTESIS FINAL Y PROYECCIONES}

En desarrollo de la investigación social se re-descubren los caminos de indagación, recopilación y análisis de la información, develando con ello nuevas herramientas, conceptos y rutas metodológicas. Adentrarse en uno o varios temas implica establecer relación entre categorías, las nociones emergentes, así como los sentidos y significados de los términos que subyacen a un planteamiento inicial.

En este sentido, el abarcar toda la información existente sobre un tema determinado es una labor que requiere mucho tiempo, siempre van a existir nuevos conocimientos que incorporar al análisis. En este sentido una investigación se convierte en insumo para nuevos planteamientos y reflexiones sobre uno o varios ejes temáticos, se concibe como un aporte a la comunidad científica sobre uno y varios temas de indagación, susceptibles de ser estudiados desde diversas disciplinas y campos de conocimiento. Se visibilizan los vacíos en las teorías sociales, de la mano de las potencialidades en términos de rutas a seguir para continuar con una $\mathrm{u}$ otra indagación. En esta investigación sucedió lo mismo con el tema de la Gestepaz y dentro de ésta con la Gestión Asociada del Territorio, que en este estudio doctoral, vieron desarrollados sus elementos fundamentales, logrando dar cuenta de las implicaciones conceptuales, éticas, políticas, sociales, culturales y metodológicas de los mismos, en perspectiva de ampliar el conocimiento alrededor del tema que bien se podrían profundizar en otros escenarios académicos y sociales.

El mundo de la investigación es un campo con innumerables aristas, la episteme ancla su acción en diversidad de unidades de análisis, en este sentido y respecto a la reflexión sintética sobre la investigación desarrollada, empezaremos por mencionar que es importante acercarse a espacios, documentos y otras investigaciones que hayan abordado en alguna medida los temas que se desean investigar, ya que estos insumos constituyen un elemento fundamental en la tarea de develar los vacíos existentes en el conocimiento y elaborar la justificación del estudio que se emprende, dichas investigaciones que preexisten a la que se desea realizar, se conciben como líneas base que posibilitan y motivan la búsqueda sistemática de información y la proyección de nuevos caminos de investigación.

Como ejercicio responsable y sistemático de investigación el proceso materializado en las páginas de este documento, fue pensado para constituir y de hecho constituye un importante aporte a la comunidad científica, puesto que aúna esfuerzos en torno a la construcción de conocimiento sobre temas incipientemente estudiados en el campo de las Ciencias Humanas y Sociales a saber, la Gestepaz y la Gestión Asociada del Territorio aplicada a la evaluación de políticas públicas y el control social. A lo largo del proceso de investigación como en el proceso extensivo de escritura, reflexión, análisis y de-construcción permanente, que implicó la elaboración de esta tesis doctoral, se acotaron varios campos de conocimiento, logrando establecer conexiones y relaciones que vislumbran reflexiones retrospectivas desde lo conceptual, lo ético y lo 
metodológico de la acción y el discurso de la construcción de paz y la gestión asociada del territorio, desde una perspectiva democrática y competente, así como desde el quehacer de las organizaciones sociales y movimientos sociales de contextos urbanos, rurales y periurbanos como son Bogotá y Sacaba respectivamente.

Desde allí se evidenció que los participantes de la investigación no son grupos ni cuerpos teóricos homogéneos con lógicas empíricas y discursivas simples, constituyen por el contrario la complejidad de aquello que en el mundo social coexiste en una interacción dialéctica, que da cuenta de las múltiples relaciones de todo tipo que se desarrollan en el contexto, con unos actores determinados y determinantes y con unas características particulares que ponen en evidencia la necesidad y demanda de una atención detallada, un abordaje y trabajo que parta de considerar y recuperar las diferencias y similitudes en espacios caracterizados por la heterogeneidad.

Por ende, si analizamos los aportes en términos investigativos de este proceso encontraremos que se contribuye a afianzar la relación entre investigación sistemática y las prácticas y discursos que se desarrollan en campo (en escenarios locales, urbanos, ruales, barriales y comunitarios), en los que se articula un quehacer que da cuenta de relaciones que permiten "aterrizar" los entramados teóricos y conceptuales a las realidades sociales, observando que en la práctica se construye conocimiento, de manera que se constata con ello la construcción de conocimiento en la acción. En este contexto, varios aportes de esta investigación están vinculados con la creación de instrumentos tales como el diario de campo en clave de Gestepaz, analizado en el capítulo de recursos, que construye guías consideradas como fundamentales a la hora de realizar un estudio de identificación de capacidades locales para la construcción de paz, dicha herramienta no es un insumo inamovible, es presentado como susceptible de permanente enriquecimiento a partir de las experiencias de aquellos y aquellas que lo consideren en sus propios procesos, constituye una propuesta que como todas desde la perspectiva teórica, conceptual están en construcción y de-construcción permanente.

Igualmente se han mostrado rutas epistemológicas y metodológicas para realizar una investigación desde la perspectiva cualitativa y su conexión con datos duros o cuantitativos, que van desde el planteamiento de una base de datos bibliográfica hasta la creación y/o consolidación de instrumentos, métodos (como la lectura vertical y horizontal, individual y comparativa), la construcción de bases de datos en sistemas informáticos como SPSS y rutas de trabajo con el fin último de hacer una recolección sistemática de información, así como de aprovechar la misma para el enriquecimiento de la reflexión y los análisis resultantes.

Este estudio evidencia que el trabajo de las organizaciones sociales y los ciudadanos organizados tanto en el contexto bogotano como el cochabambino, desde la perspectiva de la agencia social y a través de los pilares del fortalecimiento de lo público desde lo público, la cualificación de procesos de valoración ciudadana y de la administración pública entre otros como los que se articulan con lógicas de aprendizaje-reflexión y 
acción, vehiculan las lógicas del conocer-intervenir-transformar, como fundamento del cambio social y como escenario reivindicativo de derechos y de ciudadanías. Esta acción es concebida como camino dirigido a la transformación de condiciones de exclusión, desigualdad e injusticia social hacia escenarios de convivencia pacífica, democracia y transparencia en el manejo de recursos.

Se puso un énfasis especial en el sentido y significado de la construcción y deconstrucción colectiva de conocimiento, logrando con ello trascender el mero ejercicio estadístico o descriptivo, para adentrarnos en el campo de las subjetividades, la acción colectiva, la intervención conjunta y la co-construcción de dinámicas sociales, como ejercicio que involucra a varios, otros y otras que como legítimos, son concebidos como sujetos de realizaciones, de reflexiones pero también de valiosas aportaciones. A nivel contextual podemos afirmar que los territorios bogotano y cochabambino, expresan tradiciones históricas de organización social, que se sitúan como corolario de luchas reivindicativas por la satisfacción de necesidades pero también por los Derechos, aquellas premisas universales de las que somos sujetos y de los cuales el Estado Social y Plurinacional de Derecho en teoría debería ser garante.

A causa de que dicha garantía de Derechos pasa de ser obligación constitucional a un deber ser (ideal a cumplir y no acción realizada), posicionándose así como correlato de la exclusión y desigualdad social en varios contextos nacionales, regionales y locales; resulta inaplazable que los discursos y prácticas transiten por la reflexión y redefinición de los planteamientos vinculados con la gestión democrática y competente del territorio, como una clave para la construcción de paz y la superación de inequidades sociales, a través del incentivo de culturas de paz que promuevan condiciones que permitan hacer frente y superar progresivamente las violencias directa, estructural y cultural mencionadas por Galtung en su amplia obra.

Las prácticas comunitarias desarrolladas por las organizaciones sociales son productoras de saber, de iniciativas, de estrategias y conquistadoras de caminos, que reclaman una mayor visibilización en el escenario social, ya que como experiencias locales en sí mismas son constructoras de pilares de paz. De ahí que la participación se conciba como fundamental en la gestión asociada del territorio para la paz, es un eje articulador en tanto permite la inclusión de diversidad de actores en la construcción de un desarrollo con visión compartida, un desarrollo que nace de las propias necesidades de las comunidades, y que debe materializarse en las acciones de políticas públicas, en las que también se deben dilucidar mecanismos que propendan por la inclusión social en razón del reconocimiento de la heterogeneidad en el marco de una perspectiva diferencial de género, generación y etnia.

Pensando en prospectiva y en clave de trabajo a futuro surgen varias posibilidades para nuevos estudios sobre la Gestepaz y la Gestión Asociada del territorio, que bien en primera instancia estarían vinculados con análisis específicos en términos: sectorial (educación, salud, ambiental), territorial (planeación, perspectiva de género, de 
Derechos), poblacional (infancia, juventud, adultos mayores, discapacidad). Se pueden escudriñar los fundamentos de estos conceptos expresados en discursos y prácticas, a través de identificar como se inscriben en cada uno de los aspectos mencionados, o cuáles son las contribuciones de cada elemento bien sea sectorial, territorial o poblacional a la construcción de paz y superación de inequidades y desigualdades sociales en los países, al ser aspectos diferentes se hallarán especificidades en trabajos, concepciones, metodologías y contribuciones.

Así, vemos que las posibles líneas de investigación que se abren a partir del recorrido realizado por esta tesis doctoral, podrían ser:

- Concepciones y perspectivas de desarrollo desde las prácticas y discursos de las comunidades barriales.

- Sistematización de las experiencias organizativas populares desde la GAT y su relación con la democratización de la política pública

- Construcción social en los territorios y su vínculo con prácticas de no violencia y transformación de conflictos

- Análisis poblacional de las experiencias organizativas de control social y evaluación de políticas públicas, desde un enfoque diferencial y de derechos

- Vicisitudes de la participación social en Colombia y Bolivia y nuevos mecanismos de re significación en la época contemporánea.

- El quehacer femenino como sustento empírico de las experiencias de organización social: un análisis en clave de paz y superación de inequidad y desigualdad social.

- Sujetos, subjetividades y acción colectiva en las experiencias organizativas de evaluación de políticas públicas, ¿Qué relación guardan con la construcción de paz y superación de inequidades y desigualdades sociales?

Como se observa, en realidad son bastantes amplias las opciones de investigación que se pueden llevar a cabo a partir de este estudio doctoral, ya que al ser una temática de desarrollo incipiente varios aspectos resultan ser ejes de desarrollo interesantes, por su innovación temática. Las proyecciones temáticas son amplias, y se recomienda siempre abordarlas teniendo como punto de referencia que oriente las disertaciones, el contacto permanente con las experiencias, como recortes de la realidad social que nos permiten tener una visión global del contexto ya sea en niveles nacional o regional o en los locales, comunitarios o barriales. La investigación sustentada en el objetivo de visibilizar buenas prácticas resulta enriquecedor puesto que permite dar cuenta de la estrecha relación entre la teoría y la práctica, rompiendo con el falso dilema o la falsa dicotomía de su contradicción. Partiendo de considerar siempre que "el conocimiento se construye en la acción".

De igual manera, campos de información tales como las palabras clave posibilitan la creación de otros insumos indispensables para la investigación sobre estos ámbitos de 
conocimiento, así encontramos la posibilidad de construcción de un glosario de términos que facilitará la referencia sobre temáticas comunes alrededor del tema general de interés investigativo la Gestepaz y su eje subyacente la Gestión Asociada del territorio. De acuerdo a lo mencionado anteriormente se observa la importancia de la construcción de esta herramienta que en el marco de la investigación cualitativa sobre la paz y superación de inequidades y desigualdades sociales, permitirá que aquellos investigadores interesados en el tema, puedan acceder a información organizada de forma sistemática sobre la producción bibliográfica de este tema.

Por otra parte, es importante mencionar que esta investigación fue posible gracias a las nuevas miradas que se abrieron con el trabajo de la autora en los grupos de investigación: En Educación Popular y Procesos Comunitarios "EnRaízAndo"; y Programa Interdisciplinario de Apoyo a la Comunidad PRIAC de la Universidad Nacional de Colombia. Así como en el Centro de Planificación y Gestión CEPLAG de la Universidad Mayor de San Simón en Cochabamba Bolivia. Estos fueron espacios en los que fue posible pensar la articulación temática de los temas educación popular, organización social, gestión del territorio; construcción de paz y Gestión Asociada del Territorio para la cualificación de la evaluación y el control social a políticas públicas, pensarlos, re-pensarlos y de-construirlos a la luz de la estructuración de propuestas de análisis, de reflexión y sistematización desde la perspectiva de la vinculación activa de comunidades y colectivos sociales. El convenio de codesarrollo entre la Universitat Jaume I y la Universidad Nacional-Programa PRIAC, hicieron posible este trabajo y la apertura de iniciativas de investigación a futuro, nuevos caminos por recorrer y nuevos retos por asumir. 



\section{BIBLIOGRAFÍA}

Abramovay, M. y Castro, M. (1998). Engendrando um novo feminismo, mulheres líderes de base. v. 1. Brasilia: UNESCO.

Abramovay, M. y Waiselfisz, J. J. (1998). Juventude, Violência e Cidadania. Cortez. v. 1. Brasilia: Gntez.

Agost, R. (2011). El modelo de potenciación empowerment (Material de clase e learning.). España: Universitat Jaume I.

Albert, G. M. (2004). El conflicto en Colombia ¿Es posible la paz? Alicante: Instituto Universitario de Desarrollo Social y paz.

Alburquerque, F. (1999). Identidad y Territorio Instituto de Economía y Geografía, Barcelona: Consejo Superior de Investigaciones Científicas.

Alcadía Mayor de Bogotá. (4 de Mayo de 2010). Decreto 166 de 2010. Política Pública de Mujeres y Equidad de Género en el Distrito Capital. Bogotá, Bogotá, Colombia.

Alcaldía Mayor de Bogotá D.C. (2005). Plan de Igualdad de Oportunidades para la Equidad de Género en el Distrito Capital 2004 - 2016. Bogotá D.C.: s.d.

Alcañiz, M. (2008). Globalización y desarrollo local. En: De la economía global al desarrollo local. El alcance de la intervención de los agentes de empleo y desarrollo local Valencia: Universitat de Valencia.

Aledo, A. (sf). Problemas socioambientalesII: Las ecoutopías. Recuperado el 8 de abril de 2012 de http://rua.ua.es/dspace/bitstream/10045/2725/4/cap4.pdf

Alvarez R. D. y Acevedo, J. A. (2010). El territorio como factor de desarrollo. Colombia: Semestre Económico.

Amezcua, M. (2009). El Trabajo de Campo Etnográfico en Salud. Una aproximación a la observación participante. Index Enferm.

Anderson, M. B. (2009). Acción sin daño. Cómo la ayuda humanitaria pude apoyar la paz o la guerra. Traducción del texto de Mary B. Anderson Do no harm: how aid can support peace or war. Realizada por Jacques Mérat. Colombia: Universidad Nacional de Colombia, Programa Piupc.

Ardaya, R. (1998). El comité de vigilancia al servicio de la democracia municipal. La Paz: ILDIS

Arroyabe, C. (2011). Retos de intervenir contextos urbanos en conflicto. Tesis de grado para optar al título de Especialista en Acción sin daño y construcción de paz. Universidad Nacional de Colombia, Colombia. 
Asociación de Vivienda Popular - Programa Ciudades Seguras sin violencia hacia las mujeres, ciudades seguras para todos y todas. (2011). Violencias basadas en género y ciudadanía de las mujeres: Abordajes sobre las violencias hacia las mujeres en Bogotá. Bogotá: ARFO Editores e Impresores.

Barbeito, C., Redondo, G. y Acebillo, M. (2009). Diagnóstico de construcción de paz. Análisis de la perspectiva de construcción de paz en la cooperación al desarrollo de las comunidades autónomas. Barcelona: Escola de cultura de pau.

Bello, M. (2005). Bojayá, memoria y río. Violencia política, daño y reparación. Colombia: Universidad Nacional de Colombia.

Bello, M. N. (2009). La acción sin daño en el contexto colombiano. Reflexiones sobre su sentido y pertinencia. Ponencia encuentro Internacional Retos y propuestas sobre acción sin daño y construcción de paz en Colombia. Universidad Nacional de Colombia, COSUDE-Embajada de Suiza GTZ, Ministerio Federal de Cooperación Económica y Desarrollo. PPT. Colombia: Universidad Nacional de Colombia.

Beltran, M. A. (2005). Cinco vías de acceso a la realidad social En: Análisis de la realidad social: métodos y técnicas de investigación. Madrid: Alianza editorial.

Beristain, C. (sf). Reconstruir el tejido social. Un enfoque crítico a la ayuda humanitaria Barcelona: Icaria Editorial.

Berzosa, C. (2006). Economía del subdesarrollo y subdesarrollo de la economía España: Universidad complutense de Madrid.

Boisier, S. (2005). Un ensayo epistemológico y axiológico sobre gestión del desarrollo territorial: conocimiento y valores. Santiago de Chile: S.E.

Bonilla, E. y Rodríguez, P. (1997). La investigación en ciencias sociales. Santafé de Bogotá: Ediciones Uniandes.

Bruner, J. S. (1993). Explaining and Interpreting: Two ways of using mind. In G. Harman (Ed.), Conceptions of the human mind: Essays in honor of George A. Miller (pp. 123-137). Hillsdale, NJ: Lawrence Erlbaum Associates.

Bustelo, P. (2003). Desarrollo económico: del Consenso al post consenso de Washington y más allá. España: Universidad complutense de Madrid.

Busticchi, M. y Rivero, M. (2005). Programa de Educación Equipo de Investigación Acción Educativa. Santa Fe.

Bustos, T. L. (s.f). Educación popular: Lo que va de ayer a hoy. Colombia.

Cabrera, J.E. (2011). Pensar e intervenir el territorio a través de la teoría actor-red. Barcelona: Universidad Autónoma de Barcelona.

Cachón, R. L. (2009). En la España inmigrante: entre la fragilidad de los inmigrantes y las políticas de integración. Papeles del CEIC N. 45. 
Calderón, F. y Jelin, E. (s.f). Clases y movimientos sociales en América Latina: perspectivas y realidades. Buenos Aires: Centro de Estudios Estado y Sociedad CEDES.

Callejo, J. (2001). El grupo de discusión: Introducción a una práctica de investigación. Barcelona: Ariel.

Cardarelli, G., \& Rosenfeld, M. (mayo de 2002). La gestión asociada: una utopía realista. Obtenido de Centro de Apoyo al Desarrollo Local: http://www.ceadel.org.ar/cuadernos.htm

Cáritas. (s.f). Participación en la construcción de paz. Protección de los derechos de las víctimas en Colombia. España: Cáritas Española Editores.

Carrillo, A. T. (2013). El retorno a la comunidad. Problemas debates y desafíos de vivir juntos. Bogotá: CINDE-El Búho Ltda.

Carrillo, G. (2009). Impactos y estrategias de resistencia en organizaciones que trabajan para la construcción de escenarios de paz. Ponencia encuentro Internacional Retos $y$ propuestas sobre acción sin daño y construcción de paz en Colombia. Colombia: Universidad Nacional de Colombia, COSUDE-Embajada de Suiza GTZ, Ministerio Federal de Cooperación Económica y Desarrollo.

Carrión, F. (2007). Interrogatorio a la descentralización latinoamericana. En: 20 años de la descentralización en Colombia: presente y futuro. Memorias del seminario 20 años de la descentralización en Colombia. Bogotá: Red de Iniciativas para la gobernabilidad, la democracia y el desarrollo territorial.

Cazzaniga, S. (2007). Hilos y nudos. La formación, la intervención y lo político en Trabajo Social. Buenos Aires: Editorial Espacio.

CEAAL (2009). Educación popular y paradigmas emancipatorios. Revista la Piragua $\mathrm{N}^{\mathrm{o}} 28$.

Cepal (2008). Panorama social de América Latina. CEPAL.

Cepeda, I. (2006). Genocidio político: El caso de la Unión Patriótica en Colombia. Colombia: S.E.

Chaparro, R. (2009). Acción sin daño y enfoque psicosocial. Colombia: Universidad Nacional de Colombia.

Clausewitz, K. V. (1999). De la guerra. Barcelona: Idea Books.

Codhes (2011). De la seguridad a la prosperidad democrática en medio del conflicto. Informe $\mathrm{n}^{\circ}$ 78. Bogotá: Quito. Recuperado el 9 de Septiembre de 2011 de www.codhes.org

Comisión de estudios sobre violencia (1997). Colombia: violencia y democracia. Bogotá: Colciencias. 
Concejo de Bogotá. (10 de Septiembre de 2013). Acuerdo 526 de 2013. Consejos Locales de Seguridad de Mujeres. Bogotá, Bogotá, Colombia.

Concejo de Bogotá. (28 de Junio de 2012). Acuerdo 490 de 2012. Sector Administrativo Mujeres y Secretaría Distrital de la Mujer. Bogotá, Bogotá, Colombia.

Consorcio Swisspeace (2010). Gestión efectiva para transformar conflictos y construir paz: Manual de conceptos y herramientas. Consorcio Swisspeace.

Contreras, Y. (2004). Estudio de caso: Experiencias comunitarias en la localidad de San Cristóbal -Avesol y Pepaso-. Tesis para optar al título de magíster en planificación y administración del desarrollo regional. Universidad de los Andes. Cider-Uniandes Colombia.

Cortina, A. (sf). Conferencia: ética, ciudadanía y modernidad. Valencia, España.

Coser, L. (1956). The functions of social conflicto. New York: Free Press.

Cunill, N. (1999) Balance de la participación ciudadana en las políticas sociales. Propuesta de un marco analítico. S.E.

De Souza Joao, F. (s.f). La vigencia de la Educación Popular. S.E

Delgado, R. (2007). Los marcos de acción colectiva y sus implicaciones culturales en la construcción de ciudadanía. Colombia: Pontificia Universidad Javeriana.

Deubel, A.-N. R. (2002). Políticas públicas. Formulación, implementación y evaluación. Bogotá: Ediciones Aurora.

Díaz, Á. (2006). Subjetividad y subjetividad política. Colombia: Universidad Pedagógica Nacional.

Dubet, F. (1989). De la sociología de la identidad a la sociología del sujeto.

Eizaguirre, M. (2006). Educación Popular. País Vasco: HEGOA.

Escobar, A. (1996). La invención del Tercer Mundo. Construcción y deconstrucción del desarrollo. Cap. 1-2. Bogotá: Norma.

Escola de cultura de pau (2007). La construcción de paz aplicada. Quaderns de construcció de pau, № 01 .

Estrada, R. F. (2009). Acción humanitaria y acción sin daño. Colombia: Universidad Nacional de Colombia.

Francioni, M.C. y Poggiese, H. (1993). Escenarios de gestión asociada y nuevas fronteras entre el Estado y la sociedad. Toluca: Conferencia Internacional de Ciencias Administrativas. 
Fals Borda, O. (2004). Pertinencia actual de la educación popular y proyección en los años venideros Brasil: S.E.

Federación Colombiana de Municipios, GTZ. (s.f). Construcción de paz, transformación de conflictos y reconciliación local. Colombia: Federación colombiana de municipios, GTZ.

Fisas, V. (1998). Una cultura de paz. Barcelona: Escola de cultura de pau.

Fisas, V. (1999). Una comunidad con una ética global. Barcelona: UNESCO.

Fisas, V. (2010). Cultura de paz en tiempos de crisis. Barcelona: Escola de cultura de pau.

Fisas, V. (2010). El proceso de paz en Colombia. Barcelona: Escola de cultura de pau.

Fisas, V. (2011). Educar para una cultura de Paz. Barcelona: Escola de cultura de pau.

Fisas, V. (s.f). Un poco de historia sobre la resolución de conflictos y la investigación sobre la paz. Barcelona: Escola de cultura de pau.

Flores, J. A. (2009). La acción sin daño y el enfoque étnico. Ponencia para el encuentro Internacional Retos y propuestas sobre acción sin daño y construcción de paz en Colombia. Colombia: Universidad Nacional de Colombia, COSUDE-Embajada de Suiza GTZ, Ministerio Federal de Cooperación Económica y Desarrollo. Universidad Nacional de Colombia.

Flores, M. (2007). La identidad cultural del territorio como base de una estrategia de desarrollo sostenible. Colombia: Universidad externado de Colombia.

Flores, R., Gil, J. M., Caballer, A. y Martínez, M. A. (2012). Base de datos de investigación en orientación vocacional: Enfoque centimétrico. Education \& psychology. Electronic Journal of Research in Educational Psychology. Recuperado el 20 de mayo de 2012 de www.investigacionpsicopedagogica.org/revista/new/ContadorArticulo.php?641

Francois J. J. (2005). Gobernabilidad territorial y descentralización en Colombia: $¿$ Regir el territorio o gobernar los territorios? Colombia.

Funtowicz, S. y Ravetz, J.R. (1993). Science for the Post-Normal Age. Futures, 25, 735-755.

Galeano, M. (2004). Estrategias de investigación social cualitativa. Medellín: La carretera editores.

Galtung, J. (1969). Violence. Peace and peace research. Journal of peace research. Vol. $6 \mathrm{~N}^{\circ} 3$.

Galtung, J. (1982). Active peaceful coexistence: is a new departure posible. Berlin. 
Galtung, J. (1986). Peace theory: an introduction. Berlin.

Galtung, J. (1987). Peace studies: a curriculum proposal. Princeton.

Galtung, J. (1987). The "peace process" twenty years later. Failure without alternative? Princeton.

Galtung, J. (1990). Cultural violence. Journal of peace research. vol 27. № 3

Galtung, J. (1998). Tras la violencia, 3R: reconstrucción, reconciliación, resolución. Afrontando los efectos visibles e invisibles de la guerra y la violencia. Bilbao: Gernika Gogoratuz, Bakeaz.

Galtung, J. (2003). Paz por medios pacíficos. Paz y conflicto, desarrollo y civilización Bilbao: Gernika Gogoratuz. Bakeaz.

Gandour, M. (1996). La evaluación de resultados en el contexto de un proceso de democratización. En: Hacia una gestión pública orientada a resultados. Bogotá: DNP, Lito Camargo, Ltda.

Garcés, M. (2010). Educación popular desde los actores. Diversos enfoques y movimientos sociales. CEEAL.

García, A. y Sarmiento, A. (2002). Programas regionales de desarrollo y paz: casos de capital social y desarrollo institucional. Colombia: Fundación Ideas para la Paz

García, K. (2011). Construcción de paz: una aproximación desde las capacidades locales. Tesis de grado para optar al título de Especialista en Acción sin daño y construcción de paz. Universidad Nacional de Colombia. Colombia.

García, R. X. (s.f). Mecanismos de exclusión y desarrollo comunitario. Universidad de Valencia. España.

Gault, D.A. y Blanco, F. (2013). Políticas públicas y democracia. México: Instituto Federal Electoral

Giddens, A. (1987). Social Theory and Modern Sociology. Stanford: Stanford University Press

Giménez, G. (1996). Territorio y cultura. Méjico: Universidad de Colima.

Gimenez, G. (1997). Materiales para una teoría de las identidades sociales. Frontera Norte. vol 9. $\mathrm{N}^{\circ} 18$ Julio-Diciembre.

Giménez, G. (1999). Territorio, cultura e identidades. La región socio-cultural. Méjico: S.E.

Gómez, A. (1971). Esencia de la acción comunal. Desarrollo de la comunidad. Primera Edición. Medellín: S.N. 
Gómez, L. M. (2009). Conflictos territoriales y gestión pública territorial en Colombia. Colombia: S.E.

Gonzáles, C., Herbolzheim, K. y Montaña, T. (2010). La vía ciudadana para construir la paz ¿Cómo terminar la guerra? Más allá de la derrota o la negociación? Colombia: Instituto de Estudios para el Desarrollo y la paz.

González, H. (2004). La planificación y gestión del desarrollo territorial en municipios con dificultades de gobernabilidad Colombia: Universidad Externado de Colombia.

González, P. Á. (s.f). Control territorial y gobernabilidad en zonas afectadas por la presencia de grupos armados ilegales en Colombia. Colombia: Departamento Nacional de Planeación.

González, V. B. y Martín, L. (2005). Cómo lograr la participación comunitaria Cuba: ENSAP (Escuela Nacional de salud pública)

Grewal, B. (2003). Johan Galtung: Positive and negative peace. S.E

Guba, E.G. y Lincoln, Y.S. (1989). Fourth generation evaluation. Newbury Park, CA: Sage.

Guerrero, O. (1993). Las políticas públicas como ámbito de concurrencia multidisciplinaria. Ciencia, 44, 29-40.

Gudynas, E. (2011). Buen vivir: Germinando alternativas al desarrollo. Ecuador: Agencia Latinoamericana de Información.

Hadad, M. G. y Gómez, C. (2007). Territorio e identidad. Reflexiones sobre la construcción de territorialidad en los movimientos sociales Latinoamericanos. Buenos Aires: Instituto de Investigaciones Gino Germani. UBA/CONICET.

Hernández, A. (2010). La participación ciudadana en Bogotá. Colombia Internacional, $71-85$.

Hernández, D. E. (2009). Paces desde abajo en Colombia. Colombia: Universidad Autónoma de Bucaramanga.

Hernandez, E. (2002). La paz y la no violencia adquieren significado propio en Colombia en las iniciativas de paz que construyen las bases desde lo local. Colombia: Referencia Política.

Hissong, R. (1996). Las teorías y las prácticas del desarrollo desde la perspectiva de la modernidad. Cuadernos ocasionales 10. Bogotá: CIDER, UNIANDES.

Hocker J.L y Wilmot W. W. (1953). Interpersonal conflict. Dubuque: W. C. Brown Co.

Hofman, A, y Torres, M. (2008). El pensamiento cepalino en la revista de la CEPAL (1976-2008). CEPAL 
Hoyos, B. C. (2000). Un modelo para la investigación documental: guía teóricopráctica sobre construcción de Estados del Arte: con importantes modelos sobre la investigación. Medellín: Librería Señal.

Ibañez, J. (1985). Análisis sociológico de textos y discursos. Revista internacional de sociología. $\mathrm{N}^{\mathrm{o}} .43$.

Ibañez, V. (s.f ). Efectos de la guerra y la violencia organizada en la salud mental.

Jara, O. (2010). Educación popular y cambio social en América Latina. Oxford University Press and Community Development Journal.

Jaramillo, L.G. (2006). Ser sujeto en la investigación: investigando desde nuestra subjetividad. Colombia: Universidad Pedagógica Nacional Colombia.

Jiménez, J. M. (2006). El modelo de reconciliación de Lederach: hacia la paz sostenible. TEM 217. Máster Universitario Internacional en estudios de paz, conflictos y desarrollo Universitat Jaume I. España.

Jiménez, W. G. (2007). Gestión pública y desarrollo territorial. Gobernanza para la gestión del desarrollo local. En: Descentralización, conflicto, participación y territorio. Bogotá: Universidad Nacional de Colombia.

Krueger, R.A. (1991) El grupo de discusión. Guía práctica para la investigación aplicada. Madrid: Pirámide.

Laguens, J., \& Rozenhauz, J. (s.f.). Planificación Estratégica Situacional. s.d.: Universidad Tecnológica Nacional.

Lederach, J. P. (2007). La imaginación moral. El arte y el alma de la construcción de la paz. Bilbao: Bakeas.

Lederach, J. P. (s.f) Preparing for peace. Conflict transformation across cultures. Syracuse: university press.

Lederach, J.P (2009). Perspectiva ética de la construcción de paz. Ponencia para el encuentro Internacional Retos y propuestas sobre acción sin daño y construcción de paz en Colombia. Colombia: Universidad Nacional de Colombia, COSUDEEmbajada de Suiza GTZ, Ministerio Federal de Cooperación Económica y Desarrollo.

López, M. A. (s.f) Territorios en construcción, actores, tramas y gobiernos: entre la cooperación y el conflicto.

López, M. M. (1998). Las ilusiones participativas de la planificación estratégica. Los dilemas históricos y Metropolitanos de Medellín tras la transmodernidad. Revista Interamericana de Planificación Vol.XXX. Nros. 117 y 118 (Ecuador), 167 - 197.

Lozano, A. (2008). Estilos de aprendizaje y enseñanza, un panorama de la estilística educativa ( $2^{a}$ Ed.). México, D.F.: Trillas. 
Majone, G. y Wildavsky, A. (1998). La implementación como evolución. Implementación, 12-58. Jeffrey Pressmann y Aaron Wildavsky (comps.). Ciudad de México: Fondo de Cultura Económica.

Maldonado, C. (2011). Descentralización territorial en Colombia: situación y perspectivas de política. Colombia. Colombia: Friedrich Ebert Stiftung en Colombia Fescol.

Mancini, M. (2009). Democracia, Ciudadanía y Desigualdad Social. Una aproximación desde Hobbes, Locke, Tocqueville y Marx. UNSAM.

Manzanal, M, Arzeno, M. y Nussbaume, B. (2009). Territorios en construcción, actores, tramas y gobiernos: entre la cooperación y el conflicto. Argentina: Universidad de la Plata.

Manzanal, M. (2004). Instituciones, territorio y gestión del desarrollo rural-local (teoría y praxis desde la realidad del norte argentino. Rio de Janeiro, Brasil: S.E

Martínez, G. V. (2008). El Papel de la sociedad civil en la construcción de la paz: un estudio introductorio. Barcelona: Icaria.

Martínez, G. V. (2009). Localismo cosmopolita para hacer las paces. Documentos de trabajo N. 16. XVIII Jornadas Internacionales de Cultura y Paz de Gernika. Gernika, Bilbao: Gernika Gogoratuz.

Martínez, L. (2011). Reflexiones para la construcción de políticas públicas para la paz. considerando el enfoque de acción sin daño y construcción de paz. Tesis de grado para optar al título de Especialista en Acción sin daño y construcción de paz. Universidad Nacional de Colombia. Colombia.

Martínez, M. (2007). Ciencia y arte en la metodología cualitativa. México: Editorial Trillas.

Martínez, M. C. (2006). Disquisiciones sobre el sujeto político. Pistas para pensar su reconfiguración.Colombia: Universidad Pedagógica Nacional.

Matus, C. (1988). Adiós, señor presidente. Planificación, antiplanificación y gobierno. Venezuela: Pomaire.

Max-Neef, M. (1998). Desarrollo a escala humana. Uruguay: Nordan Comunidad.

Max-Neef, M. A. (1993). Desarrollo a escala humana. Conceptos, aplicaciones y algunas reflexiones. s.d.: s.d.

Medellín, P. (2004). La política de las políticas públicas: propuesta teórica y metodológica para el estudio de las políticas públicas en países de frágil institucionalidad. CEPAL, División de Desarrollo Social 
Medrano, M. (2009). Programa de incorporación enfoque diferencial y acción sin daño en entidades y organizaciones. Ponencia encuentro Internacional. Retos y propuestas sobre acción sin daño y construcción de paz en Colombia. Colombia: Universidad Nacional de Colombia, COSUDE-Embajada de Suiza GTZ, Ministerio Federal de Cooperación Económica y Desarrollo. Universidad Nacional de Colombia.

Meertens, D. (s.f.). Género, desplazamiento y derechos. Recuperado el 8 de mayo de http://www.piupc.unal.edu.co/catedra01/pdfs/DonnyMeertens.pdf

Mejía, M. R. (2007). Educación(es) en la(s) globalización(es). Entre el pensamiento único y la nueva crítica. Colombia: Desde Abajo.

Mera, S. A. (2011). Experimentando con la sensibilidad al conflicto en un laboratorio de construcción de construcción de paz. Tesis de grado para optar al título de Especialista en Acción sin daño y construcción de paz. Colombia: Universidad Nacional de Colombia.

Mires, F. (1994). La reformulación de lo político. Nueva Sociedad No.134 nov-dic., 86 $-101$.

Mockus, C. A. (2009). Rol de la academia en educación y formación para la construcción de paz. Ponencia para el encuentro Internacional Retos y propuestas sobre acción sin daño y construcción de paz en Colombia. Colombia: Universidad Nacional de Colombia, COSUDE-Embajada de Suiza GTZ, Ministerio Federal de Cooperación Económica y Desarrollo. PPT. Universidad Nacional de Colombia.

Molano, O. L. (2006). La identidad cultural, uno de los detonantes del desarrollo territorial. Rimisp.

Monje, R. P. y Ferrer, L. M. (2007). Gobierno, región, gestión y territorio: el caso de la región bio-bio. Santiago de Chile: Universidad Central de Chile.

Montero, M. (2006). El fortalecimiento en la comunidad, la comunidad como ámbito de la ciudadanía. Buenos Aires: Paidós.

Moreno, L. (2003). Ciudadanía, desigualdad socialy Estado del bienestar. Recuperado el 8 de abril de 2012 de http: digital. Csic.es/bitstream/10251/1570/1/dt-038.pdf.

Morgan, D.L (1988). Focus group as qualitative research. London: Sage, Qualitative Research Methods. Series vol 16.

Morroni, W. F., \& Redín, M. E. (2002). Aportes metodológicos para la ampliación democrática de la toma de decisiones y la particpación social en la gestión sociourbana. En s.d., Gestao democratica das cidades, metodologías de participación, redes y movimientos sociales (pág. s.d.). Buenos Aires, Argentina: s.d.

Morse, J.M. (1994). Emerging from debate. The cognitive proceses of analysis in qualitative inquirí. En J.M Morse. Critical issues in qualitative research methods, Thousand Oaks: Sage. 
Mucchielli, A. (1969). La dinámica de grupos. Madrid: Ibérico Europea de Ediciones.

Múnevar, R. L. (1993). De los movimientos sociales al movimiento popular. Colombia: S.E.

Niño, B, Gómez de Mantilla, L. y Bello A. M. (2011). Extensión, docencia, investigación: contextos, procesos, reflexiones y perspectivas. Colombia: Universidad Nacional de Colombia.

Niño, B. J. (2007). Descentralización, conflicto, participación y territorio. Colombia: Universidad Nacional de Colombia.

Nioche, J.P. (1982). De l'evaluation a l'analyse des Politiques Publiques. Revue Française de Science Politique, 32, 33-61.

Ocampo, G. J. (2010). La paz como construcción ético-política de base. Revista NovaetVera. Políticas públicas y derechos humanos. Vol 19. № 63. CaliColombia.

O'Donnell, G. y Schmitter, P. (1988). Transiciones desde un gobierno autoritario. Conclusiones tentativas sobre las democracias inciertas, vol. 4, Buenos Aires: Paidós.

ONU. (2008). Los objetivos de desarrollo del Milenio. Nueva York: Organización de las Naciones Unidas.

Ortún, V. (1995). Gestión pública: Conceptos y métodos. Seminario del Departamento de Economía de la Universidad de Oviedo.

Oszlak, O. (1994). Estado y Sociedad: las nuevas fronteras, en B. Kliksberg (comp.). El Rediseño del Perfil del Estado. México: Fondo de Cultura Económica

Pabón E. C. y Riaño, G. (2006). Una aproximación a la atención jurídica y psicosocial a la población víctima del desplazamiento forzado. Bogotá: Universidad Nacional de Colombia, Acnur, Generalitat Valenciana.

Palmeira, P. (2008). El/la Trabajador/a Social como constructor/a de paz. TEM125. Máster Universitario Internacional en estudios de paz, conflictos y desarrollo. España: Universitat Jaume I.

Peña C. A. (2010). Capacidades para la paz: Participación de menores víctimas del desplazamiento forzado en la construcción de paz. Tesis de grado para optar al título de Especialista en Acción sin daño y construcción de paz. Universidad Nacional de Colombia. Colombia.

Pérez de Armiño, C. (2010). La acción humanitaria como instrumento para la construcción de paz. Herramientas, potencialidades y críticas. Bilbao: HEGOA 
Perez Sales, P, y Lucena, R. (2000). Duelo: Una perspectiva transcultural. Más allá del rito: la construcción social del sentimiento de dolor. S.E.

PNUD (2003). Informe Nacional de Desarrollo Humano: Conflicto callejón con salida. Colombia: PNUD.

PNUD (2010) Informe Regional sobre Desarrollo Humano para América Latina y el Caribe 2010. Actuar sobre el futuro: romper la transmisión intergeneracional de la desigualdad. Colombia: PNUD.

PNUD (2011). Informe nacional de desarrollo humano. (Colombia rural razones para la esperanza). Colombia: PNUD.

Poggiese, H. (2000). Desarrollo local y planificación intersectorial, participativa y estratégica. Breve revisión de conceptos, métodos y prácticas. Buenos Aires: FLACSO Argentina.

Poggiese, H. (2000). Movimientos sociales, formulación de políticas y redes mixtas socio-gubernamentales: para un nuevo "saber-hacer" en la gestión de la ciudad. En A. C. Compiladora, Repensando la experiencia urbana de América Latina: cuestiones, conceptos y valores (pág. s.d.). Buenos Aires: Grupo de Trabajo Desarrollo Urbano de CLACSO.

Poggiese, H. (2004). Alianzas transversales, reconfiguración de la política y desarrollo urbano: escenarios del presente y futuro. En A. T. Compiladora, El rostro urbano de América Latina (pág. s.d.). Buenos Aires: CLACSO/ASDI.

Poggiese, H., \& Redín, M. E. (1997). La región oeste de la ciudad de Buenos Aires. La gestión asociada en la red regional. Serie de Documentos e Informes de Investigación No. 220, s.d.

Poggiese, H., Redín, M. E., \& Alí, P. (1999). El papel de las redes en el desarrollo local como prácticas asociadas entre Estado y sociedad. En D. F. Compilador, Los noventa. Política, sociedad y cultura en América Latina y Argentina de fin de siglo (pág. s.d.). Buenos Aires: FLACSO Argentina y Eudeba.

Poveda, A. (1976). El Trabajo Social en la problemática socioeconómica colombiana en la época del Frente Nacional. Tesis para optar al título de Licenciatura en Trabajo Social, Bogotá: Universidad Nacional de Colombia.

Pressman, J. y Wildavsky, A. (1998). Implementación. Cómo las grandes expectativas concebidas en Wahington se frustan en Aokland. México: FCE

Raczynski, D. (s.f.). Focalización de programas sociales. Recuperado de http://cieplan.cl/media/publicaciones/archivos/15/Capitulo_10.pdf

Ramírez, A. C. (2011). El problema agrario en Colombia: causas y posibles soluciones. Colombia: Universidad Nacional de Colombia. 
Ramos, A. (2012). Material de cátedra. Asignatura Teorías y conceptos de Desarrollo. Máster Interuniversitario en Cooperación al Desarrollo. Castellón de la plana: Universitat Jaume I.

Red de Iniciativas para la Gobernabilidad, la Democracia y el Desarrollo Territorial RINDE. (2007). 20 años de la descentralización en Colombia: presente y futuro. Colombia: RINDE.

Rendón, A. J. (2009). Industrialización y dinámicas espaciales en Bogotá: las urgencias de la gestión territorial. Colombia: Universidad de Medellín.

Restrepo, C. A. (2010). Construcción de la acción colectiva. Colombia: Universidad de Antioquia.

Reverón, C. (2009). La cooperación al desarrollo desde un enfoque de ASD y como aporte a la construcción de paz. Ponencia para el encuentro Internacional Retos y propuestas sobre acción sin daño y construcción de paz en Colombia. Colombia: Universidad Nacional de Colombia, COSUDE-Embajada de Suiza GTZ, Ministerio Federal de Cooperación Económica y Desarrollo.

Reverón, C. A. (2009). Los daños en nombre del desarrollo: enfoques y perspectivas. Colombia: Universidad Nacional de Colombia.

Roth, A.N. (2002). Políticas públicas. Formulación, implementación y evaluación. Bogotá: Ediciones Aurora

Rodríguez, P. A. (2009). El enfoque de la acción sin daño. Colombia: Universidad Nacional de Colombia.

Saboyá, M. (1976). El Trabajo Social en la problemática socioeconómica colombiana en la época del Frente Nacional. Tesis de pregrado para optar al título de Licenciadas en Trabajo Social. Universidad Nacional de Colombia. Bogotá.

Sampieri, R, Collado, C. y Baptista, P. (1991). Metodología de la investigación. México: McGraw-Hill.

Sandoval, C. C. (1996). Investigación cualitativa. Bogotá: Instituto para el Fomento de la Educación Superior ICFES.

Sanjurjo, G. D. (2010). La sensibilidad al conflicto y su incorporación por parte de las ONG en el ámbito español. España: AECID.

Schneider, S. y Tartaruga, I. (2006). Territorio y enfoque territorial: de las referencias cognitivas a los aportes aplicados al análisis de los procesos sociales rurales. In M. Manzanal, G. Neiman, \& M. Lattuada (Orgs.), Desarrollo Rural. Organizaciones, Instituciones y Territorio (pp. 71- 102). Buenos Aires: CICCUS

Schirch, L. (2004). The Little book of strategic peacebuilding. Pensilvania: Buenos libros. 
Sen, A. (2000). Desarrollo y libertad. Barcelona: Planeta.

Sepulveda, S. (2008). Gestión del desarrollo sostenible en teritorios rurales: métodos para la planificación. Costa Rica.

Serpa, U. H. (2007). Balance y retos del proceso descentralizador en Colombia. En: 20 años de la descentralización en Colombia: presente y futuro. Memorias del seminario 20 años de la descentralización en Colombia. Bogotá: Red de Iniciativas para la gobernabilidad, la democracia y el desarrollo territorial.

Silveira, M. L. (2011). Territorio y ciudadanía: reflexiones en tiempos de la globalización. Medellín: Unipluriversidad.

Suárez, M. (2011). Dimensión personal: Educación para la paz y transformación de conflictos. TEM 326. Máster Universitario Internacional en estudios de paz, conflictos y desarrollo. España: Universitat Jaume I.

Torres, A. (2000). Identidades barriales y subjetividades colectivas en Santafé de Bogotá. Colombia: Universidad Pedagógica Nacional.

Torres, A. (2006). Organizaciones populares, construcción de identidad y acción política. Colombia: S.E.

Torres, A. (2006). Subjetividad y sujeto: perspectivas para abordar lo social y lo educativo. Colombia: Universidad Pedagógica Nacional

Torres, A. (2009). Acción colectiva y subjetivdad. Un balance desde los estudios sociales. Colombia: S.E.

Torres, A. (2011). Educación Popular. Trayectoria y actualidad. Venezuela: Universidad Bolivariana de Venezuela.

Torres, A. (2011). La interpretación de la sistematización de experiencias. Colombia: Revista edición.

Torres, A. (s.f). Investigar desde los márgenes de las ciencias sociales. Colombia.

Torres, A. (s.f). Las lógicas de la acción colectiva: Aportes para ampliar la comprensión de los movimientos sociales. Colombia

Torres, A. (s.f). Reconstruir memoria de procesos organizativos populares. Colombia

Torres, A. (s.f). Sistematización de experiencias de organización popular en Bogotá. Colombia: Dimensión Educativa.

Torres, A. y Torres, J.C. (s.f). Subjetividad y sujetos sociales en la obra de Hugo Zemelman. Colombia: Universidad Pedagógica Nacional. 
Torres, R.M. (2001). Repensando lo educativo desde el desarrollo local y desde el aprendizaje. Documento presentado en el Simposio Internacional sobre Comunidades de Aprendizaje. Barcelona.

Touraine, A. (2006). Los movimientos sociales. Colombia: Universidad Nacional de Colombia.

UNESCO (2008). Convivencia democrática, inclusión y cultura de paz. Santiago de Chile: Unesco.

Universidad de Alicante (2012). Apunte bibliográfico de Johan Galtung. Recuperado el 23 de abril de 2012 de www.ua.es/es/presentacion/doctores/galtung/biografia.htm

Universidad de Granada (2004). Enciclopedia de paz y conflictos. Universidad de Granada.

Uricoechea, F. (1968). Modernización y Desarrollo en Colombia: 1951-1964. Presente y futuro de América Latina N. 1. Departamento de Sociología, Universidad Nacional de Colombia, Bogotá.

Valbuena, N. (2010). El liderazgo de la mujer empresaria en Colombia, una mirada desde el saber, el poder y la sexualidad en las organizaciones privadas y mixtas.

Valenzuela, E. C. (2008). Coinvestigación: Organizaciones populares y nuevas prácticas de saber. Colombia: Universidad Central de Colombia. Bogotá: Pontificia Universidad Javeriana

Valles, M. S. (2000). Técnicas cualitativas de investigación social. Reflexión metodológica y práctica profesional. España: Editorial Síntesis Sociología.

Vargas, A. (1999). Notas sobre el Estado y las políticas Públicas. Bogotá: Almudena

Vásquez, O. (2009). Estrategias metodológicas para prevenir, monitorear y evaluar el daño. Colombia: Universidad Nacional de Colombia.

Vázquez, O. (2010). Sensibilidad al conflicto. Principios, estrategias metodológicas y herramientas. Módulo 6.1. Dentro del material escrito para la Especialización en acción sin daño y construcción de paz. En el marco del convenio entre Universidad Nacional de Colombia-PIUPC- y la GTZ. Colombia: PIUPC. GTZ.

Velásquez, F. (2008). El modelo de descentralización en Colombia: avances y retrocesos. En: Conflicto, descentralización, participación y territorio. Colombia: Universidad Nacional de Colombia.

Velásquez, F. y González, E. (2003). ¿Qué ha pasado con la participación ciudadana en Colombia? Colombia: Fundación Corona.

Velásquez, A. V. (1999). Notas sobre el Estado y las políticas públicas. Bogotá: Almudena Editores. 
Velásquez, F, Zuluaga, J. y Valencia, L. (2009). Las otras caras del poder. Territorio, conflicto y gestión pública en municipios colombianos. Colombia: Fundación Foro Nacional por Colombia.

Velásquez, F. (2010). Conflicto armado, gestión municipal y participación ciudadana en Colombia. Congreso de LASA. Toronto, Canadá, Colombia.

Velásquez, F. E. (2003). La participación ciudadana en Bogotá: ¿dónde estamos? ¿para dónde vamos? Bogotá: IDU.

Velásquez, F. E. \& González, E. (2003). ¿Qué ha pasado con la participación ciudadana en Colombia? Bogotá: Fundación Corona.

Velásquez, F. E., \& González, E. (2004). La planeación participativa en Bogotá D.C. Análisis y propuestas. Bogotá: s.d.

Vides, R, Villalobos, R, y Lobo, A. (2010). Documento de trabajo. Capacitación en gestión territorial: ¿Qué necesitamos en los bosques modelo? Colombia: S.E

Ware, C. (1954). Organización de la comunidad para el bienestar social. Washington: Unión Panamericana (División de Trabajo y asuntos sociales).

Webel, C. y Galtung J. (2007). Handbook of peace and conflict studies. Londres: Routledge.

Weiss, C.H. (1975). Investigación evaluativa. Métodos para determinar la eficiencia de los programas de acción. México: Trillas.

Widmaier, H.P. (1976). Sozialpolitik im Wohlfahrtsstaat. Reinbeck bei Hamburg: Rowohlt.

Zaltsman, A. (2006). Experience with Institutionalizing Monitoring and Evaluation Systems in Five Latin American Countries: Argentina, Chile, Colombia, Costa Rica and Uruguay. Washington DC: ECD Working papers series.

Zapata, M. L. (2009). Construcción de paz y transformación de conflictos. Colombia: Universidad Nacional de Colombia.

Zemelman, H. (1998). Sujeto: existencia y potencia. Barcelona: Anthropos Editorial.

Zemelman, H. (2006). Pensar la sociedad y a los sujetos sociales. Colombia: Universidad Pedagógica Nacional.

Zuluaga, J. (2008) Conflicto y territorio En: Conflicto, descentralización, participación y territorio. Colombia: Universidad Nacional de Colombia. 


\section{Webgrafía}

Alcaldía Mayor de Bogotá. (16 de Noviembre de 2011). Decreto 503 de 2011. Política Pública de Participación Incidente en el Distrito Capital. Obtenido de Secretaría General de la Alcadía Mayor de Bogotá: http://www.alcaldiabogota.gov.co/sisjur/normas/Norma1.jsp?i=44692

Alerta Internacional: www.international-alert.org

En esta página se encuentran documentos sobre Construcción de paz, ayuda humanitaria, desarrollo, género, seguridad, reconstrucción. Página en inglés con algunos materiales en español

Asamblea permanente de la Sociedad Civil por la paz: http://www.asambleaporlapaz.com/

Fortalece el movimiento social de paz para la construcción de un nuevo país. Tiene noticias y muestra documentos de sistematización construidos a partir de eventos realizados por la Asamblea, dichos documentos están clasificados por regiones colombianas.

Centro de Investigación y Educación Popular: http://www.cinep.org.co/

Se tiene el acceso a libros, revistas, material multimedia, la base de datos de la biblioteca presencial, artículos de prensa. Cuenta con un sistema de información y bases de datos sobre Derechos Humanos y violencia política.

Centro de memoria histórica: http://www.centrodememoriahistorica.gov.co/

Se encuentran los informes de memoria de hechos violentos ocurridos en Colombia, los documentos son de análisis y reflexión se pueden descargar en pdf; también hay links de contenido multimedia donde se pueden ver videos de memoria sobre el conflicto armado en Colombia. en la parte final de la página se encuentra un link de acceso al centro de documentación del Centro de Memoria donde se pueden buscar documentos por palabras clave. Se encuentran los informes desde 2008 construidos por el grupo de memoria histórica. Hay un link de iniciativas de memoria en donde se encuentra el mapa de iniciativas y el análisis de iniciativas por región.

Corporación Nuevo Arco Iris: http://www.arcoiris.com.co/

Se encuentran artículos, noticias y videos relacionados con los temas: conflicto armado, justicia, paz, política, territorio y desarrollo, víctimas y tierras. Tiene archivo audiovisual; en el enlace titulado "a profundidad" se encuentran documentos, informes, libros, e-books y resúmenes de prensa

Escola de cultura de pau: http://escolapau.uab.cat/

Se encuentra: base de datos de conflictos y construcción de paz, Ediciones de los Quaderns de construcció de pau, artículos de análisis. Publicaciones sobre temas conflictos y construcción de paz: boletín mensual, informe alerta, barómetro. Procesos de paz: colección HD Centre. Educación para la paz: banco de recursos de juegos y dinámicas, paz y convivencia en el centro educativo. Derechos Humanos: Índice de Derechos Humanos (INDH), justicia transicional. Además se encuentra un link de 
publicaciones en donde aparecen documentos periódicos, libros, informes. Así como un link de recursos sobre temas de paz.

Fundación Ideas para la paz: http://www.ideaspaz.org/

Promoción de ideas y propuestas para la paz con ayuda del sector empresarial. Hay publicaciones (libros, series, boletines, cronologías de los grupos armados, publicaciones ocasionales, textos de diferentes analistas sobre el conflicto armado colombiano, crónicas del conflicto armado. Se encuentra el link a la biblioteca de conflicto y paz. Las áreas temáticas de la fundación son: dinámicas del conflicto y negociaciones de paz; construcción de paz y postconflicto; sector empresarial, conflicto y construcción de paz y estudios de seguridad y defensa

HEGOA. Instituto de Estudios sobre Desarrollo y Cooperación Internacional. Diccionario de Acción Humanitaria y Cooperación al Desarrollo: http://www.dicc.hegoa.ehu.es

Diccionario que incluye todos los términos vinculados con la acción humanitaria y la cooperación al desarrollo.

Instituto de Estudios para el Desarrollo y la Paz: http://www.indepaz.org.co/ Cuenta con un centro de documentación que da acceso a la información sobre conflicto armado y paz en el país. Se pueden descargar los números de la Revista Punto de Encuentro, así como otros textos editados por la institución.

Laboratorio de paz y proyecto de paz y desarrollo: http://www.laboratoriodepaz.org/ Programa de Cooperación Internacional, suscrito entre el gobierno colombiano y la Comisión Europea. En la página web se pueden encontrar memorias de eventos realizados, sistematizaciones de procesos y programas de paz, boletín regional de la ecoregión del Macizo Colombiano y publicaciones institucionales.

Medios para la paz: http://www.mediosparalapaz.org/mpp/

Propicia el ejercicio de periodismo como instrumento de paz, con énfasis en el conflicto armado colombiano, cuenta con biblioteca virtual, hay un vínculo a talleres de formación, se pueden descargar artículos, se pueden ver las publicaciones (audiovisuales, de radio y libros) de la ONG.

Meertens Donny: Género, desplazamiento y derechos. Texto recuperado de: http://www.piupc.unal.edu.co/catedra01/pdfs/DonnyMeertens.pdf

MORENO Luis: Ciudadanía, desigualdad social y Estado del bienestar. Agosto de 2003. Texto recuperado de http://digital.csic.es/bitstream/10261/1570/1/dt-0308.pdf.

ONG Dimensión Educativa: http://www.dimensioneducativa.org.co/biblioteca.shtml Centro de documentación virtual sobre Educación Popular

Página Web de TRANSCEND International A Peace Development Environment Network: http://www.transcend.org/

Se encuentran papers, libros y documentos escritos por Johan Galtung experto en la teoría de la paz, transformación de conflictos. 
Poggiese, H. (s.d.). Escenarios del presente y del futuro en la gestión democrática de las ciudades: Metodología y modelos decisionales alternativos. Buenos Aires: s.d. Obtenido de Biblioteca virtual

CLACSO: http://bibliotecavirtual.clacso.org.ar/ar/libros/campus/poggiese/13poggi.pdf

Poggiese, H., \& Francioni, M. C. (1993). Escenarios de gestión asociada y nuevas fronteras entre el Estado y la sociedad. Buenos Aires: FLACSO Argentina. Obtenido de Biblioteca Virtual

CLACSO: http://bibliotecavirtual.clacso.org.ar/ar/libros/argentina/flacso/no18_Poggiese.pdf

Red Nacional de Iniciativas por la Paz y contra la guerra: http://www.redepaz.org.co/ Se encuentran noticias, el boletín informativo notiguacamaya, se encuentra el acceso a publicaciones de la Red los cuáles pueden leerse a través de la página de la entidad, noticias, eventos, artículos de opinión, la version digital del periódico de la red "TErritorios de paz"

Universidad de Granada España. Instituto de la Paz y los conflictos: http://www.ugr.es/ eirene/publicaciones/revista.html

Contiene libros que se pueden descargar en formato pdf, se encuentran las ediciones de la revista paz y conflictos una colección de monografías sobre la paz, la violencia y los conflictos que, con el nombre de EIRENE, intenta corregir la escasez de publicaciones en castellano que recojan resultados de investigación sobre estas temáticas. De hecho, se trata de la primera colección de estas características dentro de las Universidades españolas.

Universidad Nacional de Colombia. Biblioteca Digital en Violencia Sociopolítica Acción Sin Daño y Construcción de Paz BIVIPAS: http://bivipas.info/

Se pueden buscar documentos sobre temas vinculados con la construcción de paz, violencia sociopolítica y acción sin daño. También se encuentran libros completos sobre desplazamiento forzado, violencia sociopolítica y construcción de paz así como videos. La búsqueda se puede realizar por descriptores o por categorías generales.

Valbuena, D. R. (2010). Territorio y territorialidad. Nueva categoría de análisis y desarrollo didáctico de la geografía. Unipluriversidad. Obtenido de Unipluridiversidad. Revista Virtual Universidad de Antioquia: http://aprendeenlinea.udea.edu.co/revistas/index.php/unip/article/view/9582 

ANEXOS 



\section{ANEXO 1. FICHA DE REVISIÓN BIBLIOGRÁFICA}

FICHA DE REVISIÓN DE TEXTOS A PROFUNDIDAD.

\begin{tabular}{|c|c|c|c|}
\hline \multicolumn{4}{|c|}{ 1. TIPO DE DOCUMENTO REVISADO } \\
\hline $\begin{array}{l}\text { Libro } \\
\text { completo: }\end{array}$ & \multicolumn{2}{|c|}{$\begin{array}{l}\text { Memorias: } \\
\text { Nombre del } \\
\text { evento: }\end{array}$} & Capítulo de libro: \\
\hline $\begin{array}{l}\text { Revista o } \\
\text { Cartilla: } \\
\text { Nombre de la } \\
\text { revista: }\end{array}$ & \multicolumn{2}{|l|}{ Página web de donde se toma: } & \multirow{2}{*}{$\begin{array}{l}\text { En caso de que el } \\
\text { documento revisado sea } \\
\text { un capítulo, en este } \\
\text { espacio aparece el } \\
\text { nombre del libro: }\end{array}$} \\
\hline \multicolumn{3}{|c|}{$\begin{array}{l}\text { Sí el documento revisado es revista o cartilla, ¿Cuál es el título o } \\
\text { tema de esta edición?: }\end{array}$} & \\
\hline $\begin{array}{l}\text { Monografía o } \\
\text { tesis: _- }\end{array}$ & \multicolumn{2}{|l|}{$\begin{array}{l}\text { Universidad: } \\
\text { Título de la tesis:. } \\
\text { Fecha: }\end{array}$} & $\begin{array}{l}\text { Pregrado: }--\overline{1} \\
\text { Especialización:___ } \\
\text { Maestría:___ } \\
\text { Doctorado:__ }\end{array}$ \\
\hline $\begin{array}{l}\text { Documento o } \\
\text { investigación } \\
\text { sin publicar: }\end{array}$ & \multicolumn{3}{|c|}{$\begin{array}{l}\text { Título del documento: (En caso de ser capítulo aparece el número y nombre } \\
\text { completo del mismo): }\end{array}$} \\
\hline \multicolumn{3}{|c|}{ Autor (es) del documento revisado: } & $\begin{array}{l}\text { Año y país de } \\
\text { publicación: }\end{array}$ \\
\hline $\begin{array}{l}\text { Edición del } \\
\text { texto: }\end{array}$ & Editorial: & \multicolumn{2}{|c|}{$\begin{array}{l}\text { Organización (es) que apoya la } \\
\text { publicación: }\end{array}$} \\
\hline Artículo: _ & $\begin{array}{l}\text { Revista de donde se toma el } \\
\text { artículo }\end{array}$ & \multicolumn{2}{|c|}{ Tema de la revista: } \\
\hline \multicolumn{4}{|c|}{ 2. PALABRAS CLAVES } \\
\hline \multicolumn{4}{|c|}{$\begin{array}{l}\text { 3. RESUMEN DEL CONTENIDO DEL DOCUMENTO: (Realice un resumen de la } \\
\text { totalidad del documento en } 20 \text { lineas a espacio sencillo) }\end{array}$} \\
\hline \multicolumn{4}{|c|}{ Objetivos de la autora o autor: } \\
\hline \multicolumn{4}{|c|}{ Grupos poblacionales mencionados: } \\
\hline \multicolumn{4}{|c|}{ CATEGORÍAS DE LA INVESTIGACIÓN: } \\
\hline \multicolumn{4}{|c|}{ Evaluación de políticas públicas } \\
\hline Control soci & & & \\
\hline
\end{tabular}


Construcción de paz (incluye referencias a definiciones ligadas con la paz, los elementos, criterios $o$ aspectos de este proceso etc.).

\section{GESTEPAZ:}

PARTICIPACIÓN, ORGANIZACIÓN.

APORTES DESDE LO LOCAL A LA CONSTRUCCIÓN DE PAZ (Puede provenir de análisis de la investigadora o de los y las autoras consultadas)

Observaciones y otras alusiones importantes.

Citas importantes. (Aquellas que se consideren importantes para nutrir la elaboración del texto de investigación, teniendo en cuenta las categorías y objetivos de la investigación)

$$
\bullet
$$

Anexos...

En el texto se alude a mencionar tipos de violencia a partir de la exposición de la concepción de Urra, así: azul oscuro (del texto) azul claro ( mío =) ) 


\section{ANEXO 2. ENCUESTA DE CAPACIDADES ORGANIZACIONES SOCIALES ECOS 01}

\begin{tabular}{|c|c|c|c|c|c|c|c|}
\hline $\begin{array}{r}\text { FORTALECIMIEN } \\
\text { CIUDADANAS PARA EI } \\
\text { GESTIÓN PÚBLIC } \\
\text {-INTERESES, ACT } \\
\text { (Diagnós }\end{array}$ & $\begin{array}{l}\text { TO DE CAPACIDADI } \\
\text { CONTROL SOCIAL } \\
\text { DISTRITAL Y LOC } \\
\text { ORES Y ESCENARIOS } \\
\text { tico Perceptual) }\end{array}$ & $\begin{array}{l}\text { S } \\
\text { DE LA } \\
\text { L }\end{array}$ & & $(*$ Enc & a de ca & $\mathrm{COS}$ & -01 \\
\hline $\begin{array}{l}\text { Nombre de la organización a la } \\
\text { que representa }\end{array}$ & & & & & & & \\
\hline Rol - Cargo & & & & & & & \\
\hline Representante legal & & & & & & & \\
\hline Dirección & & Localid & & & & & \\
\hline & & Barrio & & & & & \\
\hline Teléfono: & e-mail & & & & & & \\
\hline Nombre del encuestado & & & & & & & \\
\hline Documento de Identidad & & & & & & & \\
\hline LA ORGANIZACIÓN & & & & & & & \\
\hline 1. Total miembros & Hombres & & & Iujeres & & & \\
\hline $\begin{array}{l}\text { 2. Total miembros } \\
\text { activos }\end{array}$ & Hombres & & & Iujeres & & & \\
\hline 3. De mayor a menor & PROBLEMAS & & & $\begin{array}{l}\text { Grupo } \\
\text { blacional } \\
\text { ue se diri }\end{array}$ & & $\begin{array}{r}\text { tor de po } \\
\text { que se a }\end{array}$ & $\begin{array}{l}\text { ica con el } \\
\text { icula }\end{array}$ \\
\hline $\begin{array}{l}\text { importancia senale los } \\
\text { problemas que concentran }\end{array}$ & a. & & & & & & \\
\hline las actividades de la & b. & & & & & & \\
\hline organización. & c. & & & & & & \\
\hline & d. & & & & & & \\
\hline & e. & & & & & & \\
\hline 4. Entidades distritales v/o & & & Local & Distr. & Nal. & \begin{tabular}{|l} 
Públic \\
a
\end{tabular} & Privada \\
\hline locales que apoyan el & a. & & & & & & \\
\hline trabajo de la organización. & b. & & & & & & \\
\hline & c. & & & & & & \\
\hline & d. & & & & & & \\
\hline & e. & & & & & & \\
\hline 5. Sectores de la política & Salud & E & & guridad & & & \\
\hline pública en los que se & Educación & $E$ & & dio $a m b$ & & & E \\
\hline concentra el trabajo de la & Movilidad & $\square$ & & vienda & & & L \\
\hline & Desarrollo Económico & $\square$ & & ancia & & & 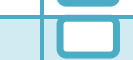 \\
\hline & Integración social & $\square$ & & $\mathrm{Cos}-i \mathrm{Cu}$ & & & 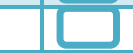 \\
\hline 6. Escenarios privilegiados de & Barrial & $\square$ & & tituciona & & & E \\
\hline trabajo & Local & $\square$ & Soc & & & & $\square$ \\
\hline & Distrital & $\square$ & & $\mathrm{OS}-i \mathrm{Cu}$ & & & $\square$ \\
\hline $\begin{array}{l}\text { 7. ¿ué tipo de proyectos de } \\
\text { control social ejerce en su } \\
\text { localidad? }\end{array}$ & & & & & & & \\
\hline
\end{tabular}




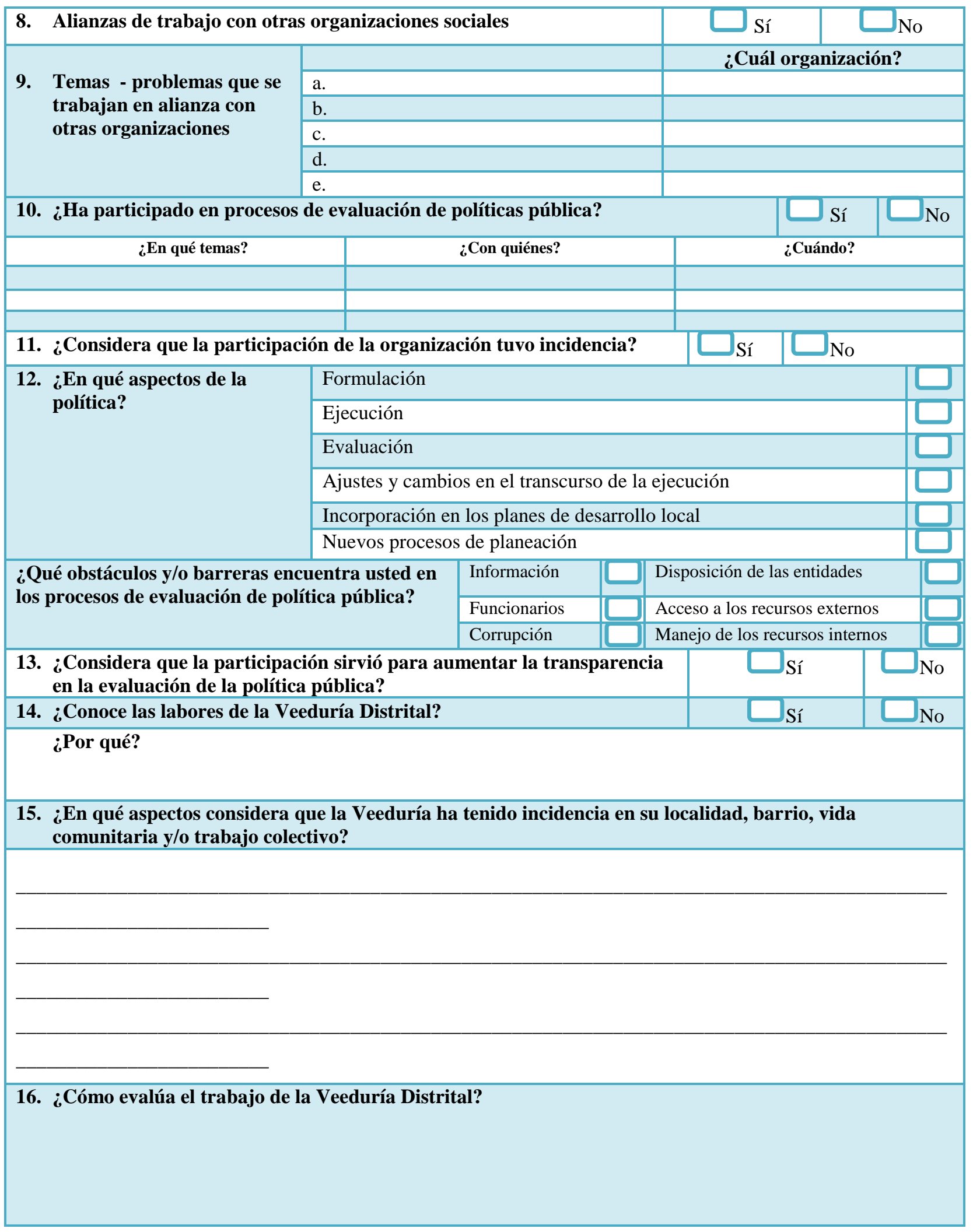




\section{ANEXO 3. ENCUESTA PARA LA EVALUACIÓN DE LA PARTICIPACIÓN CIUDADANA EVAPACI}

1. ОTB Distrito:

2. No. cuestionaric

\section{ENCUESTA PARA LA EVALUACIÓN DE LA PARTICIPACIÓN CIUDADANA} EVAPACI

Estimado(a) vecino(a): Agradeceríamos que respondiera algunas preguntas sobre el proceso de participación ciudadana que se ha dado en su municipio en relación con los planes, programas, proyectos y políticas públicas que se desarrollan en él.

No hay respuestas buenas ni malas y todas son absolutamente confidenciales.

\section{DATOS SOCIODEMOGRÁFICOS}

3. Sexo
\begin{tabular}{|l|l|l|l|}
\hline 1. Hombre & & & 4. Edad cumplida \\
\hline 2. Mujer & & & Principal: \\
\hline
\end{tabular}

6. Nivel de educación formal (Marcar con x el último grado aprobado)

\begin{tabular}{l}
$\begin{array}{l}\text { Sin educación } \\
\text { formal }\end{array}$ \\
\hline
\end{tabular}

7. Lugar de nacimiento
\begin{tabular}{|l|l|l|}
\hline Ciudad o comunidad: & Municipio: & Departamento: \\
\hline
\end{tabular}

8. Lugar de residencia actual

9. Duración última residencia

\begin{tabular}{|l|l|l|l|}
\hline Ciudad o comunidad: & Municipio: & Departamento: & \\
\hline
\end{tabular}

10. Su vivienda es:

\begin{tabular}{|l|l|l|l|}
\hline Propia & Alquilada: & Otro? & Cuál? \\
\hline
\end{tabular}




\section{BLOQUE I. Agencia social}

11. Pertenece a una organización social

11 a. ¿Cuál

\begin{tabular}{|l|l|l|l|l|l|l|}
\hline & & & & En el municipio & & \\
\cline { 4 - 6 } SI & & NO & & Fuera del municipio & & \\
\hline
\end{tabular}

12. ¿Conoce el Plan de Desarrollo o el PMOT de su municipio?

\begin{tabular}{|l|l|l|l|}
\hline SI & & NO & \\
\hline
\end{tabular}

13. ¿Cuál es su grado de acuerdo/desacuerdo con las siguientes afirmaciones? (Marca con una $X$ la alternativa que corresponda):

\begin{tabular}{|c|c|c|c|c|c|}
\hline & $\begin{array}{c}\text { Totalmente } \\
\text { en } \\
\text { desacuerdo }\end{array}$ & $\begin{array}{c}\text { Algo en } \\
\text { desacuerdo }\end{array}$ & $\begin{array}{l}\text { Algo de } \\
\text { acuerdo }\end{array}$ & $\begin{array}{l}\text { Totalmente de } \\
\text { acuerdo }\end{array}$ & $\begin{array}{l}\text { No } \\
\text { sabe }\end{array}$ \\
\hline $\begin{array}{l}\text { 1. Durante el proceso de elaboración del diagnóstico y planeación } \\
\text { municipal se respetó el punto de vista de vecinos y vecinas }\end{array}$ & & & & & \\
\hline $\begin{array}{l}\text { 2. Los vecinos y las vecinas participan activamente en actividades de } \\
\text { grupos u organizaciones del municipio }\end{array}$ & & & & & \\
\hline $\begin{array}{l}\text { 3. El proceso de diagnóstico generó mayor contacto y conocimiento entre } \\
\text { quienes habitan el municipio }\end{array}$ & & & & & \\
\hline
\end{tabular}

14. ¿Con qué frecuencia participaron los siguientes grupos de la comunidad en esta etapa (diagnóstico) del plan de desarrollo municipal? (Marca con una X la alternativa que corresponda para cada grupo):

\begin{tabular}{|c|c|c|c|c|c|c|}
\hline & $\begin{array}{c}\text { Siempre } \\
\text { (Todos los días } \\
\text { a }\end{array}$ & $\begin{array}{c}\text { Muy frecuentemente } \\
\text { (Dos o tres veces a la } \\
\text { semana) }\end{array}$ & $\begin{array}{c}\text { A veces } \\
\text { (Dos o tres } \\
\text { veces } \\
\text { al mes) }\end{array}$ & $\begin{array}{c}\text { Casi nunca } \\
\text { (Menos de una vez } \\
\text { al mes) }\end{array}$ & Nunca & No sabe \\
\hline 1 Jóvenes (16-24) & & & & & & \\
\hline 2. Adultos (24-58) & & & & & & \\
\hline $\begin{array}{ll}\text { 3. } & \text { Adultos } \\
\text { mayores (59 en } \\
\text { adelante) }\end{array}$ & & & & & & \\
\hline 4. Mujeres & & & & & & \\
\hline 5. Usted & & & & & & \\
\hline
\end{tabular}


15. ¿Cuál es su grado de acuerdo/desacuerdo con las siguientes afirmaciones? (Marca con una X la alternativa que corresponda):

\begin{tabular}{|c|c|c|c|c|c|}
\hline & $\begin{array}{l}\text { Totalmente en } \\
\text { desacuerdo }\end{array}$ & $\begin{array}{c}\text { Algo en } \\
\text { desacuerdo }\end{array}$ & $\begin{array}{l}\text { Algo de } \\
\text { acuerdo }\end{array}$ & $\begin{array}{l}\text { Totalmente de } \\
\text { acuerdo }\end{array}$ & $\begin{array}{l}\text { No } \\
\text { sabe }\end{array}$ \\
\hline $\begin{array}{l}\text { En la evaluación de PMOT, planes, políticas o gestión de la } \\
\text { alcaldía municipal se toma en cuenta el punto de vista de vecinos y } \\
\text { vecinas }\end{array}$ & & & & & \\
\hline $\begin{array}{l}2 \text { Hay organizaciones de la sociedad que hagan control social o } \\
\text { evalúen políticas públicas en el municipio }\end{array}$ & & & & & \\
\hline $\begin{array}{l}\text { 3 Los vecinos y las vecinas participan activamente la evaluación de } \\
\text { la gestión pública del municipio }\end{array}$ & & & & & \\
\hline
\end{tabular}

16. ¿Con qué frecuencia participaron los siguientes grupos de la comunidad en esta etapa (EVALUACIÓN) del plan de desarrollo municipal? (Marca con una X la alternativa que corresponda para cada grupo):

\begin{tabular}{|c|c|c|c|c|c|c|}
\hline & $\begin{array}{c}\text { Siempre } \\
\text { (Todos los días } \\
\text { a }\end{array}$ & $\begin{array}{c}\text { Muy frecuentemente } \\
\text { (Dos o tres veces a la } \\
\text { semana) }\end{array}$ & $\begin{array}{l}\text { A veces } \\
\text { (Dos o tres } \\
\text { veces } \\
\text { al mes) }\end{array}$ & $\begin{array}{c}\text { Casi nunca } \\
\text { (Menos de una vez } \\
\text { al mes) }\end{array}$ & Nunca & No sabe \\
\hline \multicolumn{7}{|l|}{1 Jóvenes (16-24) } \\
\hline 2. Adultos (24-58) & & & & & & \\
\hline $\begin{array}{ll}\text { 3. } & \text { Adultos } \\
& \begin{array}{l}\text { mayores (59 en } \\
\text { adelante) }\end{array}\end{array}$ & & & & & & \\
\hline 4. Mujeres & & & & & & \\
\hline 5. Usted & & & & & & \\
\hline
\end{tabular}

\section{BLOQUE II. Incidencia ciudadana}

Responda a las siguientes preguntas según su experiencia (Marca con una X la alternativa que corresponda):

17. ¿Considera que usted tiene influencia para hacer que su municipio sea un mejor lugar para vivir?

\begin{tabular}{|c|c|c|c|c|}
\hline 1. Sí, mucha & 2. No mucha & 3. Poca & 4. Muy poca & 5. Ninguna \\
\hline & & & & \\
\hline
\end{tabular}


18. ¿Considera que usted tuvo influencia en la elaboración del plan de desarrollo o PMOT de su municipio?

\begin{tabular}{|c|c|c|c|c|}
\hline 1. Sí, mucha & 2. No mucha & 3. Poca & 4. Muy poca & 5. Ninguna \\
\hline & & & & \\
\hline
\end{tabular}

19. ¿Cómo clasificaría la unidad social de su municipio? (Marca con una $\mathrm{X}$ la que corresponda):

\begin{tabular}{|c|c|c|c|c|}
\hline 1. Muy unida & 2. Unida en parte & $\begin{array}{c}\text { 3. Algunas disputas } \\
\text { y conflictos }\end{array}$ & $\begin{array}{c}4 . \text { Dividida por } \\
\text { muchas tensiones } \\
\text { y conflictos }\end{array}$ & $\begin{array}{c}5 . \text { Con gran } \\
\text { conflicto } \\
\text { y violencia }\end{array}$ \\
\hline & & & & \\
\hline
\end{tabular}

\section{BLOQUE III. Procesos participativos Política Pública}

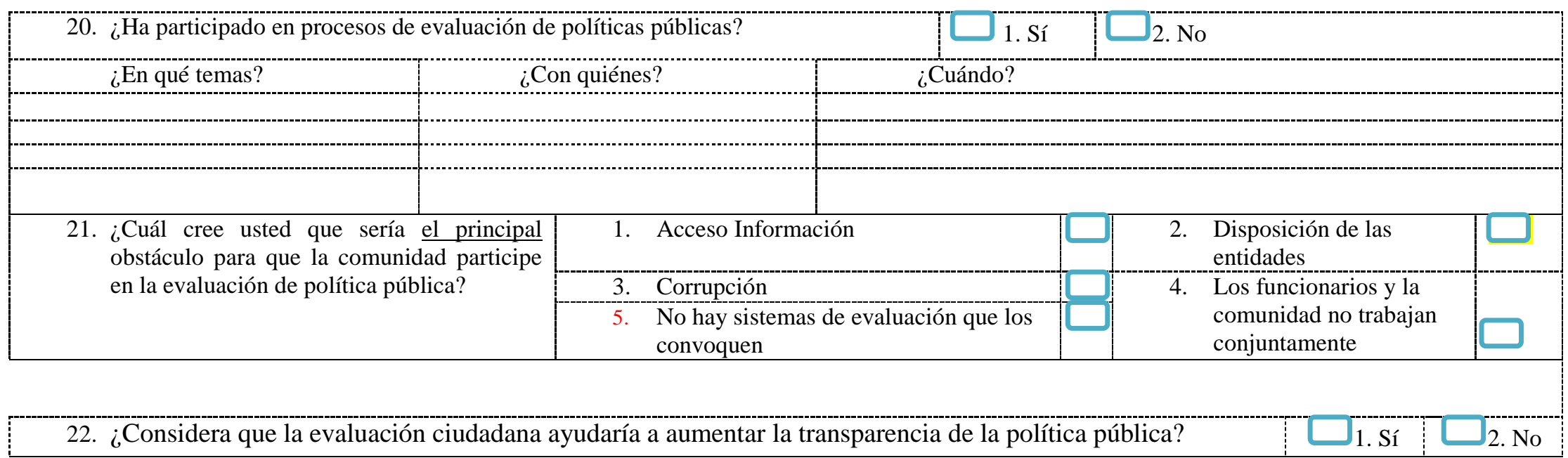

23. Conoce o ha escuchado algo del Observatorio Ciudadano "Cochabamba nos une"

1.Sí $\square \square 2$. No

24. ¿Ha participado en procesos que tengan que ver con políticas públicas? (sí su respuesta es afirmativa pase a la pregunta 25 , si no pase a la pregunta 26 )

1.Sí $\square \quad \square 2$. No




\begin{tabular}{|c|c|c|c|}
\hline \multicolumn{4}{|c|}{ 25. ¿Cuáles? (puede señalar varias opciones) } \\
\hline $\begin{array}{l}\text { 1. Diagnósticos de su } \\
\text { territorio }\end{array}$ & $\square$ & 2. Diseño de planes, programas o proyectos & $\square$ \\
\hline $\begin{array}{l}\text { 3. Ejecución de planes, } \\
\text { programas o proyectos }\end{array}$ & $\square$ & $\begin{array}{l}\text { 4. Control social o evaluación de planes, } \\
\text { programas, proyectos o políticas }\end{array}$ & $\square$ \\
\hline
\end{tabular}

\begin{tabular}{|c|c|c|c|c|c|c|}
\hline \multicolumn{7}{|c|}{$\begin{array}{l}\text { 26. ¿Cuáles serían las principales razones que lo (la) motivarían a participar en la gestión de su municipio? (Marque hasta tres indicando } \\
\text { orden de prioridad? }\end{array}$} \\
\hline 1. & $\begin{array}{l}\text { Garantizar una gestión } \\
\text { municipal transparente }\end{array}$ & $\square$ & $\begin{array}{l}\text { 2. Cumplimiento de derechos de } \\
\text { los ciudadanos }\end{array}$ & $\square$ & & Contribuir al cumplimiento de las Leyes \\
\hline 4. & $\begin{array}{l}\text { Mejorar la calidad de } \\
\text { vida de los habitantes del } \\
\text { municipio }\end{array}$ & $\square$ & $\begin{array}{l}\text { 5. Compensaciones sociales o } \\
\text { económicas. }\end{array}$ & $\square$ & & $\begin{array}{l}\text { Velar por la inversión de recursos en } \\
\text { necesidades prioritarias }\end{array}$ \\
\hline
\end{tabular}





\title{
ANEXO 4. ENTREVISTA A PERSONAS VINCULADAS CON EXPERIENCIA IWA 4 EN BOGOTÁ
}

\author{
UNIVERSITAT JAUME I \\ PROGRAMA INTERUNIVERSI TARIO DE COOPERACIÓN AL DESARROLLO \\ DOCTORADO EN COOPERACIÓN AL DESARROLLO \\ ENTREVISTA A PERSONAS VINCULADAS CON EXPERIENCIA IWA 4 EN \\ BOGOTÁ.
}

NOMBRE ENTREVISTADO:

Fecha entrevista

Lugar

1. ¿Qué es el IWA 4 y cuál es su importancia para la evaluación de políticas públicas?

2. ¿Cuál fue el proceso desarrollado para lograr que Bogotá contara con la herramienta ISO-IWA 4 para la experiencia de trabajo desarrollada?

3. ¿Cuál fue el proceso que se llevó a cabo para la construcción de Observatorios Ciudadanos de Control social?

4. ¿Qué asuntos pretende cambiar el IWA en cuanto a la gestión pública local?

5. ¿Por qué es necesario llevar a cabo procesos de evaluación de políticas públicas y control social? 


\title{
ANEXO 5. ENTREVISTA A PERSONAS QUE ACOMPAÑAN EL PROCESO DE IMPLEMENTACIÓN DE LA EVALUACIÓN EN BOGOTÁ
}

\author{
UNIVERSITAT JAUME I \\ PROGRAMA INTERUNIVERSI TARIO DE COOPERACIÓN AL DESARROLLO \\ DOCTORADO EN COOPERACIÓN AL DESARROLLO \\ ENTREVISTA A PERSONAS QUE ACOMPAÑAN EL PROCESO DE \\ IMPLEMENTACIÓN DE LA EVALUACIÓN EN BOGOTÁ.
}

NOMBRE ENTREVISTADO:

Fecha entrevista

Lugar

1. ¿Para usted qué es la herramienta ISO-IWA 4?

2. ¿Cómo se vincula con el proceso territorial de implementación de la herramienta de evaluación?

3. ¿Cuál fue el trabajo que desarrolló en el marco de este proceso?

4. ¿Por qué considera que esta herramienta es un insumo para cualificar la evaluación a la política pública y el control social?

5. ¿Cuáles fueron sus aportes para que el proceso social y territorial de implementación de la herramienta fuera exitoso en la localidad en la que participó?

6. ¿su participación en este tipo de procesos como cualifica su ejercicio profesional? 


\title{
ANEXO 6. ENTREVISTA A LÍDERES SOCIALES QUE PARTICIPAN EN EL PROCESO DE IMPLEMENTACIÓN DE LA EVALUACIÓN EN BOGOTÁ
}

\author{
UNIVERSITAT JAUME I \\ PROGRAMA INTERUNIVERSITARIO DE COOPERACIÓN AL DESARROLLO \\ DOCTORADO EN COOPERACIÓN AL DESARROLLO \\ ENTREVISTA A LÍDERES SOCIALES QUE PARTICIPAN EN EL PROCESO DE \\ IMPLEMENTACIÓN DE LA EVALUACIÓN EN BOGOTÁ.
}

NOMBRE ENTREVISTADO:

Fecha entrevista

Lugar

1. ¿Puede decirnos cuál era la tarea de quienes acompañaron el trabajo del Observatorio?

2. ¿Qué destaca del trabajo de acompañamiento para la implementación de la herramienta de evaluación?

3. ¿Qué papeles o funciones desempeñaron los actores sociales involucrados en el proceso?

4. ¿Se ha transformado su interés por la participación en los asuntos públicos?

5. ¿Respecto al inicio del proceso, cómo evidencia usted que se transformó el sentido de lo público en las y los ciudadanos? (¿De qué manera?)

6. ¿Cuál es la importancia de la participación en espacios como el Observatorio Ciudadano?

7. ¿Considera usted que hubo metodología de soporte de quienes acompañaron el proceso de implementación de la herramienta ISO/IWA 4? (¿Cuál fue?)

8. ¿Cuál cree que era la intención del acompañamiento al Observatorio?

9. ¿Qué cree que se quería lograr al acompañar al Observatorio, o sea, que esperaban ellas que pasara con el Observatorio a partir de su trabajo?

10. ¿Qué significó el trabajo de acompañamiento del estudiante? (Defina el antes y el después del acompañamiento)

11. ¿Considera usted que queda el Observatorio consolidado y en capacidad de agenciar sobre lo público de mejor manera? (¿Por qué?) 
Programa de Doctorado en Cooperación al Desarrollo Estudio sobre los procesos de construcción y fortalecimiento de capacidades ciudadanas para evaluación de política pública

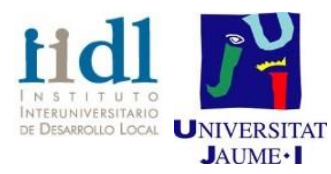

\section{ANEXO 7. ENTREVISTA LÍDERES SOCIALES CONTROL SOCIAL SACABA}

1. ¿Qué es el control social? Y ¿Qué es la evaluación de políticas públicas?

2. ¿Cómo funciona el control social en el Municipio?

3. ¿Cuál fue el proceso para hacer el reglamento de control social municipal?

4. ¿Cómo funciona el Consejo de coordinación de la participación y control social en sacaba? (qué hacen, cómo lo hacen, cómo participa la gente)

5. ¿Cuáles los aprendizajes de la experiencia de control social en el municipio?

6. ¿Qué impacto tiene el consejo en los procesos de rendición de cuentas en el municipio? ¿El Consejo tiene incidencia en los procesos que desarrolla la administración local (Municipal y/o Departamental)? ¿Por qué? ¿Cómo se logró?

7. ¿Cuáles han sido las principales dificultades del Consejo y cuáles son en la actualidad sus necesidades?

7. ¿Cómo contribuye el Consejo a fortalecer la participación ciudadana y el control social? 
Programa de Doctorado en Cooperación al Desarrollo Estudio sobre los procesos de construcción y fortalecimiento de capacidades ciudadanas para evaluación de política pública

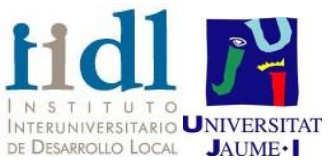

\section{ANEXO 8. ENTREVISTA UNIDAD DE TRANSPARENCIA SACABA}

1. ¿Qué es el control social? ¿Qué es la evaluación de políticas públicas?

2. ¿Cómo funciona el control social y la evaluación en el municipio?

3. ¿Cómo y cuáles son las metodologías para evaluar las políticas públicas en el municipio? (por ejemplo existen indicadores, cómo participa la ciudadanía, cada cuánto se hace)

4. ¿Hay organizaciones sociales que hagan control social en el municipio? ¿Qué trabajo desarrollan? (hay bases de datos que me puedan proporcionar con sus contactos)

5. ¿Cómo se realiza la rendición de cuentas en el municipio? ¿Cómo se evalua la gestión pública en el municipio?

6. ¿Qué acciones desarrolla la unidad de transparencia en el municipio? ¿Cómo desde allí promueven la participación social?

7. Las comunidades y organizaciones sociales deberían vincularse a los procesos de transparencia del GAMS ¿por qué?

8. ¿Cómo se construyó el reglamento del control social en el municipio?

9. ¿Cómo debería ser la evaluación de política pública en el municipio? (qué sectores se deberían evaluar, qué se debe priorizar en la evaluación, recomendaciones en caso de querer plantear una propuesta)

10. ¿Cómo contribuye la evaluación // control social // transparencia a la planificación del desarrollo municipal? 
Programa de Doctorado en Cooperación al Desarrollo Estudio sobre los procesos de construcción y fortalecimiento de capacidades ciudadanas para evaluación de política pública

\section{ANEXO 9. ENTREVISTA OBSERVATORIOS CIUDADANOS COCHАВАMBA}

1. ¿Qué es el control social? Y ¿Qué es la evaluación de políticas públicas?

2. ¿Qué son y por qué es importante que existan los Observatorios Ciudadanos?

3. El trabajo que desarrolla el Observatorio Cochabamba Nos Une ¿Es de control social o de evaluación de políticas públicas?

4. ¿Quiénes conforman el Observatorio actualmente?

5. ¿Cómo se desarrolla el trabajo en el Observatorio?

6. ¿Cómo y cuáles son las metodologías para evaluar las políticas públicas en Cochabamba? (por ejemplo, existen indicadores, cómo participa la ciudadanía, cada cuánto se hace)

7. ¿Cuáles los aprendizajes de la experiencia de evaluación más reciente? ¿Cómo la socializaron?

8. Actualmente ¿En qué proceso se encuentra el Observatorio?

9. ¿Cuáles son los principales logros que ha tenido el Observatorio?

10. ¿Qué impacto tiene el Observatorio en cuanto a los procesos de rendición de cuentas en el Departamento y en los municipios?

11. ¿El Observatorio tiene incidencia en los procesos que desarrolla la administración local (Municipal y/o Departamental)? ¿Por qué? ¿Cómo se logró?

12. ¿Cuáles han sido las principales dificultades del Observatorio y cuáles son en la actualidad sus necesidades?

13. ¿Cómo contribuiría el OCNU a fortalecer la participación ciudadana y el control social? 


\section{ANEXO 10. RECURSOS PÁGINAS WEB}

Se lleva a cabo un análisis de 26 páginas web, en el que se analiza la entidad y se hace una referencia sobre los contenidos que se van a encontrar.

\begin{tabular}{|c|c|c|}
\hline N. & Web & Institución \\
\hline 1 & http://www.dicc.hegoa.ehu.es & $\begin{array}{l}\text { HEGOA. Instituto de Estudios sobre } \\
\text { Desarrollo y Cooperación Internacional. } \\
\text { Diccionario de Acción Humanitaria y } \\
\text { Cooperación al Desarrollo }\end{array}$ \\
\hline 2 & http://www.dimensioneducativa.org.co/biblioteca.shtml & Dimensión Educativa \\
\hline 3 & http://escolapau.uab.cat/ & Escola de cultura de pau \\
\hline 4 & http://www.transcend.org/ & $\begin{array}{l}\text { Trascend Internacionational. A peace } \\
\text { development network }\end{array}$ \\
\hline 5 & $\underline{\text { http://bivipas.info/ }}$ & $\begin{array}{l}\text { Biblioteca digital en violencia sociopolítica, } \\
\text { acción sin daño y construcción de paz }\end{array}$ \\
\hline 6 & http://www.ugr.es/ eirene/publicaciones/revista.html & $\begin{array}{l}\text { Universidad de Granada. Instituto de la Paz y } \\
\text { los Conflictos }\end{array}$ \\
\hline 7 & http://www.laboratoriodepaz.org/ & $\begin{array}{l}\text { Laboratorio de paz y proyecto de paz y } \\
\text { desarrollo }\end{array}$ \\
\hline 8 & http://www.centrodememoriahistorica.gov.co/ & Centro de memoria histórica \\
\hline 9 & http://www.ideaspaz.org/ & Fundación Ideas para la paz \\
\hline 10 & http://www.mediosparalapaz.org/mpp/ & Medios para la paz \\
\hline 11 & http://www.asambleaporlapaz.com/ & $\begin{array}{l}\text { Asamblea permanente de la Sociedad Civil } \\
\text { por la paz }\end{array}$ \\
\hline 12 & http://www.cinep.org.co/ & Centro de Investigación y Educación Popular \\
\hline 13 & http://www.indepaz.org.co/ & $\begin{array}{l}\text { Instituto de Estudios para el Desarrollo y la } \\
\text { Paz }\end{array}$ \\
\hline 14 & http://www.arcoiris.com.co/ & Corporación Nuevo Arco Iris \\
\hline 15 & http://www.redepaz.org.co/ & $\begin{array}{l}\text { Red Nacional de Iniciativas por la Paz y } \\
\text { contra la guerra }\end{array}$ \\
\hline 16 & www.international-alert.org & Alerta Internacional \\
\hline 17 & http://www.cdainc.com/cdawww/default.php & Collaborative learning projects \\
\hline 18 & http://www.mediate.com/ & Mediate \\
\hline 19 & www.internationalpeaceandconflict.org & Peace and collaborative development network \\
\hline 20 & http://www.codhes.org/ & $\begin{array}{l}\text { Consultoría para los Derechos Humanos y el } \\
\text { desplazamiento. }\end{array}$ \\
\hline 21 & http://www.nocheyniebla.org/ & $\begin{array}{l}\text { Banco de datos Derechos Humanos y } \\
\text { violencia política del Cinep }\end{array}$ \\
\hline 22 & http://www.iecah.org/web/ & Instituto de Estudios sobre conflictos y acción \\
\hline
\end{tabular}




\begin{tabular}{|c|l|l|}
\hline $\mathbf{N}$. & \multicolumn{1}{|c|}{ Web } & \multicolumn{1}{|c|}{ Institución } \\
\hline 23 & $\underline{1}$ & \multicolumn{1}{|c|}{ humanitaria } \\
\hline 24 & $\underline{\text { http://wwww.ceaal.org/ }}$ & $\begin{array}{l}\text { Consejo de Educación de Adultos de América } \\
\text { Latina }\end{array}$ \\
\hline 25 & $\underline{\text { http://www.bakeaz.org/ }}$ & Centro de Investigación GernikaGogoratuz \\
\hline 26 & $\underline{\text { http://www.contravia.tv/espanol }}$ & $\begin{array}{l}\text { Centro de documentación y estudios para la } \\
\text { paz. }\end{array}$ \\
\hline
\end{tabular}




\section{ANEXO 11. GLOSARIO TIPO TESAURO}

\begin{tabular}{|c|c|c|}
\hline español & inglés & Francés \\
\hline acceso a la educación & access to education & accès à l'èducation \\
\hline América del sur & South America & Amérique du Sud \\
\hline América Latina & Latin America & Ameriqué Latine \\
\hline bienestar & well-being & bien-étre \\
\hline buenas prácticas & best practice & bonnes pratiques \\
\hline centralización & centralisation & Centralisation \\
\hline ciencias sociales & social sciences & sciences sociales \\
\hline ciudadano & citizen & Citoyen \\
\hline comunidad & community & Collectivité \\
\hline comunidad local & local community & collectivité locale \\
\hline conflicto & conflict & Conflit \\
\hline conocimiento & knowledge & Savoir \\
\hline contexto social & social background & situation sociale \\
\hline contexto sociocultural & socio-cultural background & environnement sociocultural \\
\hline cooperación & cooperation & Coopération \\
\hline creatividad & creativity & Créativité \\
\hline cultura & culture & Culture \\
\hline democracia & democracy & Demokratia \\
\hline $\begin{array}{l}\text { democratización de la } \\
\text { educación }\end{array}$ & democratisation of education & $\begin{array}{l}\text { démocratissation de } \\
\text { l'enseignement }\end{array}$ \\
\hline derecho a la educación & right to education & droit à l'éducation \\
\hline derechos & rights & Droits \\
\hline derechos humanos & human rights & droits de l'homme \\
\hline desarrollo & development & Développement \\
\hline descentralización & decentralisation & Décentralisation \\
\hline desigualdad social & social inequality & inégalité sociale \\
\hline discurso & speech & Discours \\
\hline educación & education & Éducation \\
\hline educación para la paz & education for peace & éducation à la paix \\
\hline educación pública & public education & enseignement public \\
\hline educación social & community studies & éducation sociale \\
\hline educador & educational childcare staff & Éducateur \\
\hline enfoque interdisciplinar & interdisciplinary approach & approche interdisciplinaire \\
\hline enseñanza & teaching & Enseignement \\
\hline estudiante & student & Étudiant \\
\hline exclusión social & social exclusion & exclusion sociale \\
\hline función pública & civil service & fonction publique \\
\hline gestión & management & Gestión \\
\hline globalización & globalisation & Globalisation \\
\hline
\end{tabular}




\begin{tabular}{|l|l|l|}
\hline \multicolumn{1}{|c|}{ español } & \multicolumn{1}{c|}{ Francés } \\
\hline gobernanza & governance & Gouvernance \\
\hline gobierno & government & Gouvernement \\
\hline identidad cultural & cultural identity & identité culturelle \\
\hline inclusión social & \multicolumn{1}{|c|}{ USE integración social } \\
\hline integración social & social integration & intégration sociale \\
\hline investigación & research & Recherche \\
\hline legislación & legislation & Legislation \\
\hline nivel local & local level & niveau local \\
\hline & non-governmental & \\
organización no gubernamental & organisation & organisation non-gouvernementale \\
\hline participación ciudadana & citizen participation & participation du citoyen \\
\hline población & population & Population \\
\hline pobreza & poverty & Pauvreté \\
\hline resultado de aprendizaje & learning outcome & résultats de l éducation \\
\hline resultados de la investigación & research results & résultats de recherche \\
\hline sitio web & website & site internet \\
\hline sociedad & society & Société \\
\hline violencia & violence & Violence \\
\hline zona urbana & urban area & zone urbaine \\
\hline
\end{tabular}




\section{ANEXO 12. DIARIO DE CAMPO EN CLAVE DE GESTEPAZ}

(Elaboración propia, 2012)
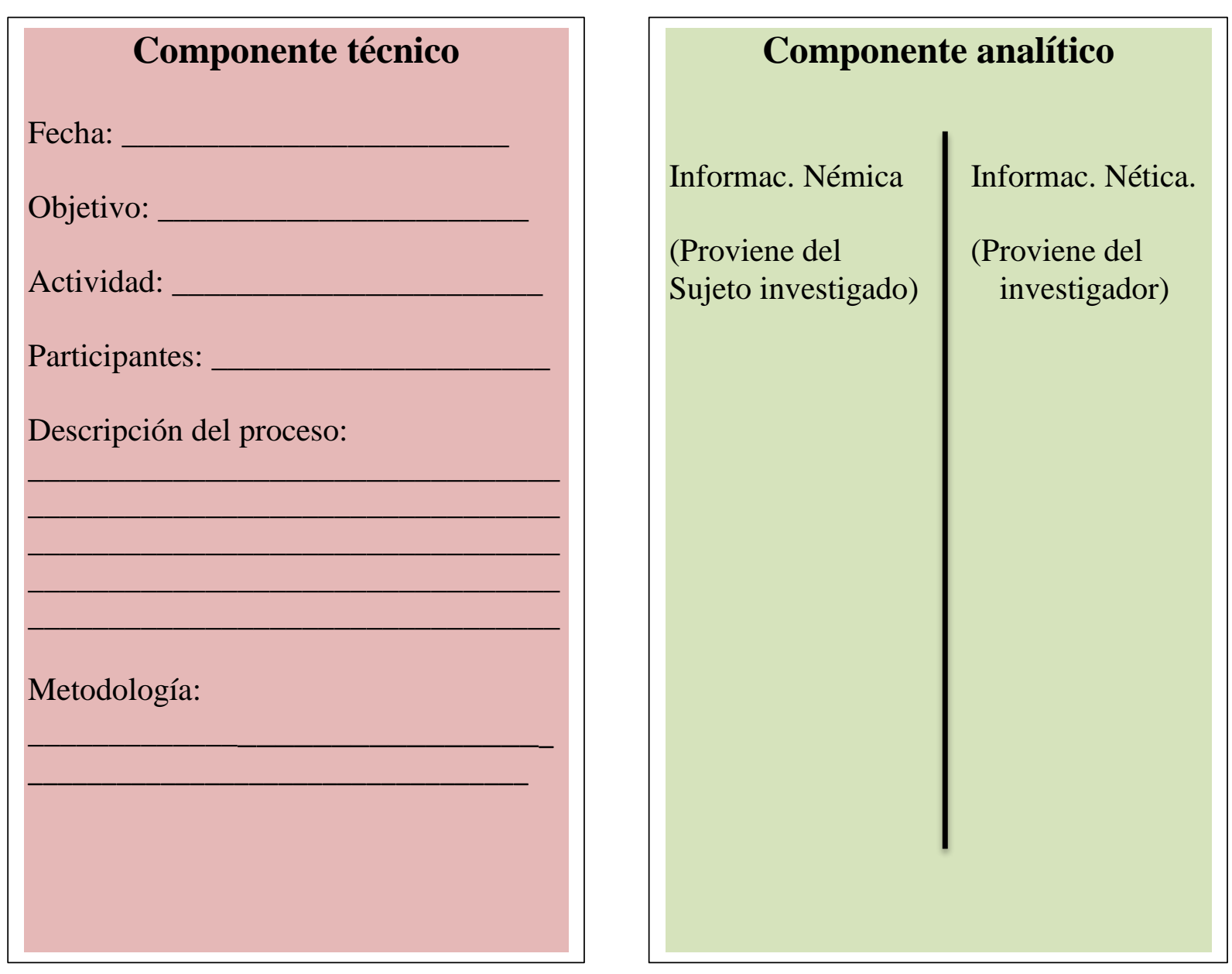

\section{Componente síntesis analítica en clave de paz.}

Imaginación moral: (Aquellas respuestas creadas desde lo real que dan a la luz lo que no existe. En clave de paz: capacidades para imaginar y crear respuestas e iniciativas que arraigadas en lo cotidiano del espacio territorial local, trascienden y rompen con pautas de violencia.

Cambio constructivo: Flujos de interacción que promueven la paz.

\begin{tabular}{|c|c|c|c|}
\hline $\begin{array}{l}\text { Tipos de } \\
\text { acciones }\end{array}$ & Actores & $\begin{array}{l}\text { Campo de } \\
\text { incidencia }\end{array}$ & $\begin{array}{c}\text { Nivel de } \\
\text { impacto } \\
\text { en paz }\end{array}$ \\
\hline $\begin{array}{l}\text { Capacidades } \\
\text { de paz a } \\
\text { nivel social, } \\
\text { local y } \\
\text { comunitario. }\end{array}$ & $\begin{array}{l}\text { Gobierno, } \\
\text { sociedad } \\
\text { civil, líderes } \\
\text { comunitarios, } \\
\text { comunidades } \\
\text { de base. }\end{array}$ & $\begin{array}{l}\text { Cultura de } \\
\text { paz. } \\
\text { Violencias: } \\
\text { cultural, } \\
\text { estructural, } \\
\text { directa. }\end{array}$ & $\begin{array}{l}\text { Paz } \\
\text { positiva. } \\
\text { Paz } \\
\text { negativa. }\end{array}$ \\
\hline
\end{tabular}





\section{ANEXO 13. GLOSARIO DE TÉRMINOS}

Bloque de constitucionalidad: Está compuesto por aquellas normas y principios, que sin aparecer formalmente en el articulado del texto constitucional, son utilizados como parámetros del control de constitucionalidad de las leyes, por cuanto han sido normativamente integrados a la constitución, por diversas vías y por mandato de la propia constitución. Son pues verdaderos principios y reglas de valor constitucional, esto es, son normas situadas en el nivel constitucional, a pesar de que puedan a veces contener mecanismos de reforma diversos al de las normas del articulado constitucional stricto sensu. Información retomada de: Corte constitucional, sentencia C-222 de 1995.

Cambio constructivo: la búsqueda del desplazamiento de las relaciones de unas definidas por el temor, la recriminación mutua y la violencia, a otras caracterizadas por el amor, el respeto mutuo y el compromiso proactivo. El cambio social constructivo pretende modificar el flujo de la interacción en el conflicto humano desde ciclos de modelos de relación destructivos hacia ciclos de dignidad relacional y compromiso respetuoso. Lederach (2007) La imaginación moral, el arte y el alma de la construcción de paz. Bakeaz, Gernika Gogoratuz. Bilbao.

Chulavitas o Policía Chulavita: a un grupo armado de élite en Colombia que existió durante los primeros años de La Violencia, conformado por campesinos conservadores procedentes de la vereda "Chulavita" del municipio de Boavita en el departamento de Boyacá. Información retomada de: artículos de la Biblioteca Luis Ángel Arango del Banco de la República de Colombia, en su página web de biblioteca virtual http://www.banrepcultural.org/blaavirtual/indice

Constitución política de Colombia 1991: Llamada también la constitución de los derechos ya que reconoce y consagra los fundamentales como tal; se reconocen los derechos civiles y políticos así como los económicos, sociales y culturales inherentes a un Estado Social de Derecho. Además crea los mecanismos necesarios para asegurar y proteger esos derechos, entre otros, la Acción de Tutela, la Acción de Cumplimiento, las Acciones Populares y de Grupo. Es importante destacar en este punto que es a partir de un movimiento estudiantil formado en 1989, que se convoca en 1990 una Asamblea Nacional Constituyente elegida por voto popular directo, la cual promulga en Bogotá en 1991 la Constitución Política de Colombia de 1991, como resultado de la movilización social.

Cooptación: "Se define como una captura del Estado que se asocia con una forma de corrupción a gran escala que debilita la estructura económica de un país porque distorsiona la formulación de leyes, normas, decretos, reglas y regulaciones. Usualmente se diferencia entre la captura del Estado y la corrupción administrativa, para referir el momento regulatorio en el que aparece el acto de corrupción, la primera se da en las primeras etapas del desarrollo normativo, legislativo y regulatorio de un Estado, mientras que la segunda se refiere a las distorsiones en las etapas de implementación y ejecución de leyes, reglas y regulaciones formuladas e instituidas” Banco Mundial, 2000. Citado en Garay Luis Jorge. De la captura a la reconfiguración cooptada del Estado, sf. 
Deconstruir: Deshacer analíticamente los elementos que constituyen una estructura conceptual. Definición retomada de diccionario de la Real Academia Española.

Descentralización: Es un proceso complejo tendiente a distribuir la centralidad (el poder) en el marco de la búsqueda del equilibrio democrático entre los poderes (la centralidad) existentes en el interior del Estado, con la finalidad de profundizar la democracia, potenciar el desarrollo y mejorar la calidad de vida de la población. Fernando Carrión. 2007. 20 años de la descentralización en Colombia: presente y futuro. Red de iniciativas para la gobernabilidad, la democracia y el desarrollo territorial. Bogotá, 2007

Imaginación moral: Imaginar respuestas e iniciativas que, estando enraizadas en los retos del mundo real, sean por naturaleza capaces de elevarse por encima de los patrones destructivos y de dar a luz aquello que aún no existe. En relación con la construcción de paz, es la capacidad de imaginar y generar respuestas e iniciativas constructivas que, arraigadas en los retos cotidianos de los escenarios violentos, trasciendan y finalmente rompan los grilletes de esos patrones y ciclos destructivos. Lederach (2007) La imaginación moral, el arte y el alma de la construcción de paz. Bakeaz, Gernika Gogoratuz. Bilbao.

Ley del llano: Durante la Revolución del Llano (1946-1953), se gestó un turbión de insurrección popular en donde los llaneros, en un escenario de confrontaciones sociales, políticas, militares y culturales, se vieron impelidos a declararse en rebelión e inventarse la lucha armada en forma concomitante con el surgimiento y maduración de un pensamiento táctico, estratégico y político que reconfigurara el sentido de sus luchas, y que quedó plasmado en las denominadas Leyes del Llano. Información retomada de: artículos de la Biblioteca Luis Ángel Arango del Banco de la República de Colombia, en su página web de biblioteca virtual http://www.banrepcultural.org/blaavirtual/indice

Pájaros: Grupos de hombres armados, protegidos por políticos conservadores, que actuaron entre las décadas de 1940 y 1950, en el departamento del Valle del Cauca. Estos grupos ejercían justicia de manera privada para adquirir el control sobre la población a través de la violencia y el miedo. Información retomada de: artículos de la Biblioteca Luis Ángel Arango del Banco de la República de Colombia, en su página web de biblioteca virtual http://www.banrepcultural.org/blaavirtual/indice

Paradigma: Se ha retomado la definición que plantea Ritzer (1993) rescatando los planteamientos de Kuhn. Imagen básica del objeto de una ciencia. Sirve para definir lo que debe estudiarse, las preguntas que es necesario responder cómo deben preguntarse y que reglas es preciso seguir para interpretar las respuestas obtenidas. Es la unidad general del consenso dentro de una ciencia, sirve para diferenciar una comunidad científica de otra. Subsume, define e interrelaciona los ejemplares, las teorías y los métodos e instrumentos disponibles. Está compuesto de teorías o perspectivas.

Pillaje: Robo, despojo saqueo hecho por los soldados en país enemigo.

Plataformas: Espacios sociales y de relaciones continuas; en otras palabras, personas con relaciones mutuas que generan procesos, iniciativas y soluciones creativas a los modelos destructivos más profundamente arraigados y al flujo y reflujo cotidiano del conflicto social 
como tal, una plataforma tiene una capacidad generadora continua de responder a pautas relacionales de largo plazo y de adaptarse a entornos cambiantes. El enfoque de una plataforma es crear y sostener unos cimientos capaces de generar procesos de cambio responsivos que aborden tanto la expresión inmediata del conflicto como el epicentro más profundo del contexto relacional conflictivo. Una plataforma es como una cinta transportadora de aeropuerto combinada con un trampolín. La cinta transportadora se mueve continuamente a través del tiempo, y el trampolín tiene la capacidad de lanzar nuevas ideas en respuesta a problemas inesperados emergentes, sosteniendo a la vez la visión a largo plazo del cambio constructivo. Lederach (2007) La imaginación moral, el arte y el alma de la construcción de paz. Bakeaz, Gernika Gogoratuz. Bilbao.

Reconfiguración cooptada del Estado: Para efectos de esta investigación se retomó el concepto expuesto por Luis Jorge Garay (2008). Proceso que consiste en la acción de organizaciones legales e ilegales que mediante prácticas ilegítimas, no necesariamente ilegales buscan modificar el régimen político de manera sostenible, así como a lograr que sus intereses sean válidos política y legalmente, y legitimados socialmente en el largo plazo, aunque éstos no obedezcan al interés rector del bienestar social.

Unión Patriótica: La Unión Patriótica surgió como una convergencia de fuerzas políticas a raíz del proceso de negociación adelantado a mediados de la década de 1980 entre el gobierno del presidente Belisario Betancur y el estado mayor de las Fuerzas Armadas Revolucionarias de Colombia, FARC.

Vacunas: También conocidas como pagos periódicos cobrados por los grupos insurgentes a cambio de "dejar trabajar". Es un seguro, a veces poco confiable, contra secuestro, decomiso, incendio u otro siniestro causado por el propio asegurador. Se cancela en efectivo, en especie o mediante triangulaciones. Definición tomada de: PNUD Informe Nacional de Desarrollo Humano Colombia 2003. Conflicto callejón con salida.

Violencia sociopolítica: Cuando se hable de violencia en este texto se está haciendo referencia al concepto que según la definición del Cinep se refiere a: "aquella ejercida como medio de lucha Político - Social, ya sea con el fin de mantener, modificar, sustituir o destruir un modelo de Estado o de sociedad, o también para destruir o reprimir a un grupo humano con identidad dentro de la sociedad por su afinidad social, política, gremial, étnica, racial, religiosa, cultural o ideológica, esté o no organizado". Centro de Investigación y Educación Popular CINEP. Revista Noche y Niebla N. 39. Bogotá, 2009. 